UNIVERSIDADE DE SÃO PAULO

FACULDADE DE FILOSOFIA, LETRAS E CIÊNCIAS HUMANAS DEPARTAMENTO DE LETRAS MODERNAS

PROGRAMA DE PÓS-GRADUAÇÃO EM ESTUDOS LINGUÍSTICOS,

LITERÁRIOS E TRADUTOLÓGICOS EM FRANCÊS

DIRCEU MAGRI

\title{
ASPECTOS DA PRESENCA DE AUTORES FRANCESES DO SÉCULO XVIII NAS CRÔNICAS MACHADIANAS E SUAS IMPLICAÇÕES INTERTEXTUAIS
}

(VERSÃO CORRIGIDA)

SÃO PAULO

2014 
UNIVERSIDADE DE SÃO PAULO

FACULDADE DE FILOSOFIA, LETRAS E CIÊNCIAS HUMANAS

DEPARTAMENTO DE LETRAS MODERNAS

PROGRAMA DE PÓS-GRADUAÇÃO EM ESTUDOS LINGUÍSTICOS,

LITERÁRIOS E TRADUTOLÓGICOS EM FRANCÊS

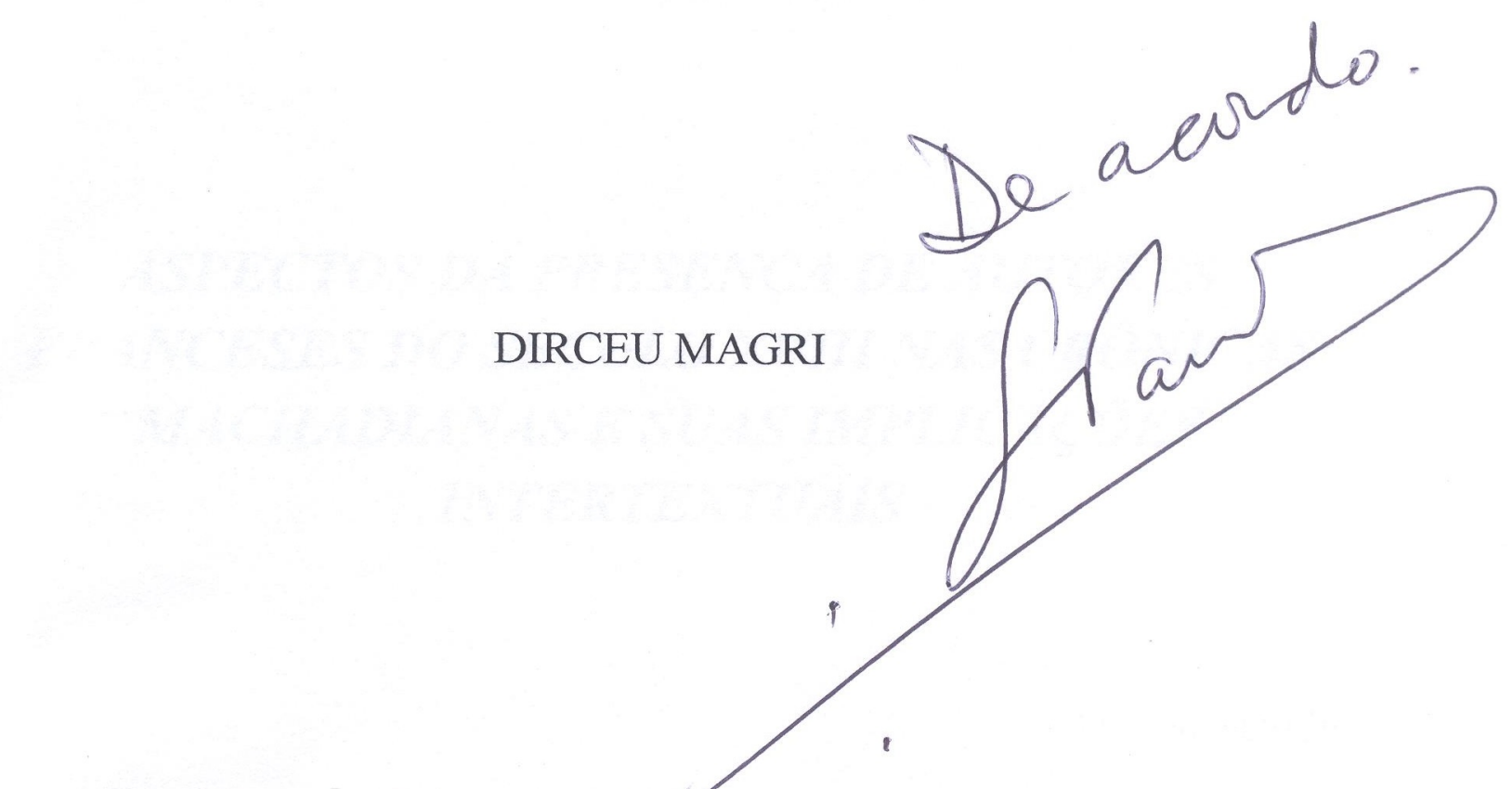

ASPECTOS DA PRESENÇA DE AUTORES

FRANCESES DO SÉCULO XVIII NAS CRÔNICAS

MACHADIANAS E SUAS IMPLICAÇÕES

INTERTEXTUAIS

(VERSÃO CORRIGIDA)

SÃO PAULO

2014 
Nome: MAGRI, Dirceu.

Título: Aspectos da presença de autores franceses nas crônicas machadianas e suas implicações intertextuais

Tese apresentada ao Programa de Pós-graduação em Estudos Linguísticos, Literários e Tradutológicos em Francês do Departamento de Letras Modernas, da Faculdade de Filosofia, Letras e Ciências Humanas da Universidade de São Paulo, para a obtenção do título de Doutor em Letras - Língua e Literatura Francesa.

Aprovado em:

Banca Examinadora

Prof. Dr.:

Instituição: Assinatura:

Prof. Dr.:

Instituição: Assinatura:

Prof. Dr.:

Instituição: Assinatura:

Prof. Dr.:

Instituição: Assinatura:

Prof. Dr.:

Instituição: Assinatura: 
Li tudo, misturei, digeri, e aqui estou. Machado de Assis, "Balas de Estado", 2/9/1883.

Les abeilles pillotent deçà delà les fleurs, mais elles en font après leur miel, qui est tout leur. Montaigne, Essais, Liv. I, chap. XXVI. 


\section{AGRADECIMENTOS}

Ao Altíssimo pela força, coragem, esperança e fé!

Aos meus pais e irmãs pela generosidade de sempre;

Ao Prof. Dr. Gilberto Pinheiro Passos, por sua paciência ao longo das minhas jornadas de mestrado e doutorado, seu apoio e confiança, e por seu elevado senso de excelência como professor e pesquisador, algo que sempre me inspirou;

Às Profas. Dras. Maria Cecília Queiroz de Moraes Pinto e Diva Barbaro Damato pelas valiosas sugestões e orientações, como membros da banca de Qualificação de Doutorado;

Ao Francisco, pelos muitos livros e pelo dedicado incentivo;

A Regina Krasovski, amiga de muitos livros e incansáveis conversas francesas;

A Denise Duran, minha mais fiel entusiasta;

A Edite Mendez Pi, do Departamento de Letras Modernas da USP, pela simpatia e eficiência;

Ao Prof. Dr. Michel Delon, responsável por minha orientação acadêmica na Université Paris Sorbonne-Paris IV, sobretudo, por seus cursos dedicados aos estudos huitièmistes e a oportunidade de participar de colóquios e seminários doutorais;

Ao Prof. Pierre Frantz, pelos animados cursos e seminários sobre Voltaire, Diderot, Rousseau e o teatro setecentista, as jornadas de estudo no Centre de recherche du Château de Versailles e por meu ingresso na SFEDS-Sociète française d'Étude du Dixhuitième siècle;

A Marie-Andrée Grandguillaume e Anne-Marie Pialloux pela amizade, inspiração e alegria ao me dessiner un parisien;

Ao CNPq pela concessão de uma bolsa de Doutorado-GD, que me permitiu dedicação integral aos meus estudos e pesquisas ao longo de meu doutorado na USP;

À Fundação CAPES pela concessão da bolsa PDSE, que possibilitou a extensão de minhas pesquisas sobre o século XVIII na França. 


\section{RESUMO}

Este estudo visa sondar a presença de autores franceses setecentistas ligados às Lumières no universo das crônicas de Machado de Assis. Popularizados, sobretudo, graças à imprensa, força motriz na disseminação do conhecimento no início do século XIX, Voltaire, Rousseau e Diderot, destituídos da aura de grandes filósofos, integram-se facilmente na esfera do folhetim. Ali, obras, temas e princípios criados por eles (já decantados pela cultura popular e tornados clichês, axiomas e ditos) agregam sentidos, ampliam a compreensão do elemento local, concorrem para a característica irônicochistosa do gênero e sedimentam a relação Brasil-França através da poética intertextual, traço profundo da escrita machadiana, cuja pluralidade de vozes fez da crônica um diálogo particular entre os dois países.

A crítica moderna nos adverte quanto ao maniqueísmo da esquematização, ressaltando o lado arbitrário de toda periodização. Nota-se, contudo, que ao olhar o passado recente na tentativa de "compreender" o século XVIII, os homens do XIX retomaram em parte imagens herdadas da autorrepresentação daquele que foi o século da audácia crítica, de maneira que se pode "isolar" o século XVIII, pois, mitificado, impõe-se ainda como identidade específica, irradiando a cultura francesa através de Voltaire, Rousseau e Diderot, seus exponenciais mitos mobilizadores.

Palavras-chave: Machado de Assis, crônica, intertextualidade, Lumières, Voltaire, Rousseau, Diderot, Brasil-França. 


\begin{abstract}
This study aims, above all, at scrutinizing the presence of French writers from the eighteenth century, related to the Lumières, in the universe of Machado de Assis's chronicles. Popular, especially due to the press - driving force in the dissemination of knowledge in the beginning of the nineteenth century - Voltaire, Rousseau and Diderot, destitute of the great philosopher's aura, easily fit into the universe of the broadsheet, where works, themes and principles created by them (which no longer enchanted the popular culture and had become clichés, axioms and sayings) were able to attribute meanings, broaden the understanding of the local element, compete for the mockingironic characteristic of the genre and strenghten the Brazil-French relationship through intertextual poetics - deep feature of Machado's writings, whose plurality of voices turned the chronicles into a particular dialogue between the two countries.

Modern criticism advises us about the manichaeism of scheming, by highlighting the arbitrarity side of periodization. However, by looking at the recent past while trying to "understand" the eighteenth century, it is possible to notice that those men from the nineteenth century resumed, in part, the images inherited from the selfrepresentation of the century which was the time for the critical audacity, so as that one can "isolate" the eighteenth century, since, mythified, it also imposes itself as a specific identity, irradiating the French culture through Voltaire, Rousseau and Diderot, its exponential moving myths.
\end{abstract}

Key words: Machado de Assis, chronicle, intertextuality, Lumières, Voltaire, Rousseau, Diderot, Brazil-France. 


\section{RÉSUMÉ}

Cette étude vise, avant tout, à scruter la présence d'autres auteurs français huitièmistes liés aux Lumières dans l'univers des chroniques de Machado de Assis. Popularisés notamment grâce à la presse, puissance dans la diffusion du savoir au début du XIX siècle, Voltaire, Rousseau et Diderot, dépourvus de l'aura de grands philosophes, s'intègrent facilement dans la sphère du feuilleton. Dans ce domaine, leurs oeuvres, thèmes et principes (déjà décantés par la culture populaire et devenus des clichés, des aphorismes et des dictons) acroissent des sens, élargissent la compréhension de l'élément local, en concourant à la caractéristique ironique-facétieuse du genre et en consolidant la relation Brésil-France moyennant la poétique de l'intertextualité, trace profonde de l'écriture machadiana, dont la pluralité des voix a fait de la chronique un dialogue particulier entre les deux pays.

La critique moderne nous met en garde contre la schématisation et le manichéisme, en soulignant le côté arbitraire de la périodisation. Il est à noter, cependant, que quand on regarde le passé récent dans une tentative de « comprendre »le dix-huitième siècle, on remarque que les hommes du $\mathrm{XIX}^{\mathrm{e}}$ ont repris en partie des images héritées de l'auto-représentation de celui qui a été le siècle de l'audace critique, de sorte qu'on peut «isoler» le dix-huitième siècle, car mythifié, il s'impose encore comme une identité spécifique, en rayonnant la culture française par le biais de Voltaire, Rousseau et Diderot, ses mythes mobilisateurs exponentiels.

Mots-clés: Machado de Assis, chroniques, intertextualité, Lumières, Voltaire, Rousseau, Diderot, Brésil-France. 


\section{NOTAS}

Neste trabalho foram observados os seguintes critérios:

Assim como Machado de Assis em seus escritos semanais, a palavra folhetim e crônica trazem a mesma sinonímia. Ora no intuito de se evitar a repetição de palavras, ora em proveito da estilística e da expressão, foram utilizadas uma pela outra;

Em itálico, aparecem palavras estrangeiras, expressões curtas e ou aquilo que se quis destacar ao longo da escritura;

Luzes, Iluminismo, Ilustração ou Lumières? Consultados os dicionários Houaiss e Aurélio, além de várias outras publicações, notei que não há consenso ao classificar o período das Lumières. O Houaiss, por exemplo, para o verbete "luz" (pl.) traz: "conhecimentos advindos do exercício da razão na filosofia iluminista", porém "iluminista" remete a "iluminismo", que por sua vez traduz a "doutrina dos que crêem na ação de uma intuição mística, luz sobrenatural ou iluminação divina no interior do ser humano, guiando-o para a verdade religiosa". Ao consultar a palavra "ilustração", o pesquisador encontra: "mesmo que iluminismo". "Iluminismo" apresenta ainda uma definição mais apropriada: "movimento intelectual do sXVIII, caracterizado pela centralidade da ciência e da racionalidade crítica no questionamento filosófico, o que implica recusa a todas as formas de dogmatismo", porém, em meio a uma enormidade de nominatas (Filosofia das Luzes, Ilustração, Esclarecimento, Século das Luzes), decidi-me por Lumières;

$\checkmark \quad$ Foi mantido o texto da publicação da Editora Jackson para os extratos de crônicas e o original de publicação para os periódicos.

Por fim, para as obras citadas, raramente me vali das primeiras edições, optando por publicações mais recentes, comentadas e de referência; no caso das obras referenciadas ao longo do texto, estas sempre vêm acompanhadas da data da primeira publicação, exceto para uma segunda menção, quando aparece bastante próxima, ou na mesma página. 


\section{SUMÁRIO}

\section{INTRODUÇÃO-13}

\section{CRÔNICA-20}

1. A crônica machadiana: especificidades de um gênero híbrido-20; 2. "O autor de si mesmo", a prática machadiana da inversão e Schopenhauer-22; Swift e a isotopia metafórica-27; 4. Os arredores do texto, a legibilidade literária e a intertextualidade autárquica-29; 5. O mundo narrado em função das obras literárias e "aberto às mutações associativas de ideias", a artimanha machadiana e a inversão-31; 6. Um cronista moralista, pintor de homens e sua percepção artística-34;

\section{A COSMOVISÃO ARTÍSTICO-LITERÁRIA MACHADIANA!-38}

1. A conjunção do imaginário (e da memória literária) ao real: contar histórias é só fantasiar-38; 2. "O Punhal de Martinha" e Lucrécia: um caso intertextual de mise en abyme e a fabulação da notícia-41; 3. A história "ficcionada": um "pássaro sem asas"46; 4. "As futuras edições": releitura e atualização de textos e o traço carnavalesco-49; 5. A imagem "artística" da história e a politonalidade da escrita ignoradas-50; 6. A realidade anedótica: se é para “imitar alguém, imita Mirabeau”!-52;

\section{A MEMÓRIA LITERÁRIA-58}

1. A memória literária: faculdade que inviabiliza o ineditismo-58; 2. A intertextualidade e a expressão pessoal como originalidade-58; 3. Enunciados ficcionais, a compreensão do mundo e a subversão do tempo cíclico-60; 4. O trânsito entre literaturas, a contaminação pelo contexto cultural e o leitor-62; 5. Os traços plurais, a atualização das obras e os connaisseurs-64; 6 . As expectativas estéticas, o esquecimento e a reabilitação das obras-67; 7. Aspectos da memória literária: clássicos e modernos-69; 8. A memória cultural - dos outros-73; 9. Dois polos na memória-75; 10. O núcleo estável da memória-76; 11. As obras de estudo e Machado-78; 12. Machado e os influxos franceses-81;

\section{O SÉCULO XVIII-84}

1. O século XVIII francês e a ruptura das ideias-84; 2. As primeiras críticas: "Écrasez l'infâme!" e as descobertas científicas-85; 3. O indivíduo como protagonista, a 
conquista de espaços e novas aspirações-86; 4. As Lumières e os ideais humanistas-88; 5. Mas, e a literatura?-89; 6. Machado digressivo e progressivo-96;

\section{VOLTAIRE-99}

\section{VOLTAIRE: OBSESSÃO MACHADIANA-99}

1. Linhagem irônica-99; 2. "Un louis d'or, [...] pour l'amour de l'humanité."-102; 3. Mélanges littéraires: “Où la vertu va-t-elle se nicher!”-102; 4. "Quanto pode a mecânica! ou "Où la mécanique va-t-elle se nicher!”-104; 5. "Où la direction d'une académie va-t-elle se nicher!"-110; 6. “Où la science et la pairie vont-elles se nicher!"$113 ;$ 7. "Tous les genres sont bons, hors le genre ennuyeux."-118; 8. "Voilà comme on écrit l'histoire."-124; 9. “Diz-se que o francês não tem la tête épique.”-129; 10. "Si Dieu n'existait pas, il faudrait l'inventer."-135;

\section{CANDIDE-144}

1. Candide-144; 2. Pangloss, uma obsessão machadiana-146; 3. "Um pouco de filosofia Pangloss"-148; 4. "Pangloss é o meu padre-santo"-151; 5. E "os narizes fizeram-se para os óculos"...-156; 6. "Os óculos é que se fizeram para os narizes"-160; 7. "Nas ruas de El-Dorado"-162; 8. Tudo se aproxima do otimismo de Pangloss-166; 9. Enfim, "no melhor dos mundos possíveis"-169;

III. VOLTAIRE: sua língua, seu espírito, seus contos e seu riso-172

1. A língua-173; 2. O conto-177; 3. O espírito-181; 4. O riso-188; 5. À guisa de conclusão-194 ;

\section{ROUSSEAU-196}

1. "Cinco odaliscas... Oh! meu doce leite romântico!"-196; 2. "O Oriente acabou e com ele a poesia"-199; 3. "Je devins polisson mais non un libertin."-204; 4. ... O Rio pode ser Constantinopla -206; 5. Na crônica: a notícia sob a fabulação-206; 6. Efeito de leitura-209; 7. Contextualizando: "Uma cova de Caco"-211; 8. Um novo escândalo: “juro por Deus Nosso Senhor que não estou inventando. A única coisa que faço é não entender nada.”-213; 9. “É preciso aceitar a teoria de Rousseau: o homem nasce puro. Para que corromper-nos?"-216; 10. “A cartomancia nasceu com a civilização, isto é, com a corrução, pela doutrina de Rousseau."-221; 11. "Nada há pior que oscilar entre dois assuntos.”-227; 12. “Entre Manaus e Jerusalém”-229; 13. Em Jerusalém-231; 14. À guisa de conclusão-235; 


\section{DIDEROT-238}

\section{A LETTRE-238}

1. As polêmicas-238; 2. O "problème de Molyneux"-241; 3. Lettre sur les aveugles à l'usage de ceux qui voient-243; 4. A Marmota, Paula Brito, “Os cegos” e Machado-246; 5. N'A Marmota, o passo a passo da polêmica-248; 6. A polêmica n'A Marmota: Machado e Jq. Sr.-249; 7. Machado e Diderot: a fatura machadiana-256; 7.1. A escuridão das trevas-256; 7.2. As "ideias adquiridas pelos sentidos"-258; 7.3. A natureza, "colorida e perfumada por uma mão suprema"-261; 7.4. Irreligião e materialismo-264; 7.5. À guisa de conclusão-267;

\section{O BOTÃO QUE NÃO É DE DIDEROT!-269}

1. As Origens de um "paradoxo"-269; 2. ... o botão pode ser pressionado no Rio de Janeiro-271; 2.1. A emblemática capital-271; 2.2. E Machado altera o "paradoxo"-273; 3. A Revolta da Armada e calor intenso: "bandeiras públicas" e "bandeiras particulares"-275; 3.1. "Eu bufo aqui e [...] morre alguém na Noruega"-276; 4. “Abitanti de Parigi..."-279; 4.1. “O problema de Diderot"-280;

\section{OLHARES SOBRE O SÉCULO XVIII E ANALOGIAS DE LEITURAS NAS CRÔNICAS MACHADIANAS-284}

1. Na França do século XIX, diferentes "regards en arrière"-284; 2. Piscadelas setecentistas nas crônicas machadianas-288; 2.1. Robespierre nas crônicas machadianas291; 2.2. Miscelânea: Buffon, Chénier... e os Luíses da França.-305;

\section{DE BORBOLETAS E COLIBRIS EM SOBREVOO, UM MEL TODO MACHADIANO-312}

XI. BIBLIOGRAFIA-318 


\section{INTRODUÇÃO}

"O nosso êrro é crer que inventamos, quando continuamos, ou simplesmente copiamos." Machado de Assis, “A Semana”, 5/2/1893.

A hipótese deste estudo constrói-se a partir de dois eixos fundamentais: de um lado, um cronista zeloso de seu público e preocupado em entretê-lo, de outro, o peso do século XVIII, intrometendo-se nos meios jornalístico e literário do XIX através da forte presença dos autores setecentistas. Visto que, em seus escritos semanais, Machado de Assis não escapou de se aliar a isso, em que medida desbastou os excessos da erudição, refinou indagações filosóficas e questionamentos científico-religioso-sociais, tornandoos palatáveis a ponto de satisfazer as exigências do jornal e distrair seus leitores?

A presença dos autores franceses setecentistas adquire status de premissa nas crônicas machadianas, fazendo delas um fascinante corpus para se verificar como foram decantados página à página, nas entrelinhas e em jogos de palavras e situações, até que se constituíssem em algo atraente ao leitor por meio do chiste e da galhofa, artimanhas caras a Machado. Assim, surge como hipótese o fato de as crônicas trabalharem para a decantação cultural e a popularização de autores exponenciais como Voltaire, Rousseau e Diderot. Estes, tanto quanto as questões com que se ocuparam, foram universalizados como esteios do século XVIII, mitificando-o como o século das rupturas.

Reminiscências e lembranças trazidas à luz permitem uma constante presença intertextual nas crônicas machadianas, constituindo-se a intertextualidade (e o dialogismo bakhtiniano) na vertente teórica deste estudo, que, por sua vez, privilegia a memória não só como fio d'Ariadne conduzindo à reflexão, mas, sobretudo, como algo que combina observações, provoca curiosidade, generaliza fatos e vincula-os por meio de analogias. Por essa razão, as considerações têm movimento integrador e pendular: ora o foco é histórico, com incursões frequentes no quotidiano prosaico ou pitoresco, iluminando-se o contexto em que fatos e obras foram produzidos, ora é atualizado, 
quando esse mesmo material é lido à luz dessas teorias, na tentativa de desvendar a expressão machadiana nesses escritos.

Análogos a uma colcha de retalhos, lembranças e fragmentos são combinados, comparados e agrupados à maneira do cronista em sua escrita-urdidura, de tal modo que se evidencia a impossibilidade de escrever o quotidiano sem lançar mão das opiniões disseminadas ao longo da circulação literária.

Nas crônicas, Machado, exímio "escrevinhador", malgrado a realidade dos fatos e em proveito do estilo e credibilidade de seu texto, relativiza acontecimentos, alegoriza, explora o pitoresco e faz uso de metáforas, a fim de construir uma "narrativa" que faculta uma visão se não nova, mas particular do mundo, onde a existência é redimensionada. Dessa forma, ao descrever seu meio social, imprime um tom que não só resulta de um desprendimento da escrita puramente jornalística - isenta de comentário, que registra o fato tout court -, mas, sobretudo, de uma indumentária galhofeira.

Em sua origem, a crônica, que, por definição, tratava da história na qual os fatos eram registrados em ordem cronológica, versando, em geral, sobre um acontecimento de ordem particular, sem qualquer preocupação analítica, produziu, na Idade Média, figuras como Villehardouin, Joinville, Froissart, Philippe de Commines, etc.

Porém, mais tarde, quando os acontecimentos passam a ser reconstituídos com o auxílio de documentos, a exegese entra em cena e esses mesmos fatos são interpretados à luz de um pensamento filosófico, político ou religioso (BROCA, 1969: 115). Com isso, a história toma configuração própria, tal como é vista hoje, dissociando-se da crônica, e esta se enternece: apresenta os fatos de maneira metafórica, ironiza, parodia, ressalta o cômico, comenta de forma divertida, com desembaraço e leveza, sem, contudo, deixar de tirar suas próprias conclusões.

Muito se tem escrito sobre livros que se explicam por si mesmos, perpetuando o gosto excessivo pela exegese na literatura contemporânea e fazendo com que alguns autores sejam "explicados demais", a exemplo de Machado de Assis. Por que então persistir em território machadiano? A resposta parece não vir pelo fato de as crônicas serem consideradas até muito recentemente uma parte "menor" da obra do grande romancista e contista; afinal, desde os anos 80, notas, introduções de teses e 
dissertações insistem no argumento do "gênero menor" e no descaso recebido por esses escritos. ${ }^{1}$

Hoje, passadas três décadas, durante as quais as crônicas têm sido objeto de diferentes olhares, longe do desmerecimento, a justa alegação para que se continue a estudá-las é, sem dúvida, sua irrefutável fertilidade, seja como documento "histórico"2, responsável por uma arqueologia sociocultural da capital do Império e suas extensões, seja em razão do matiz e da pujança do substrato literário, largamente disseminado ao longo dos relatos.

"Fusão admirável do útil e do fútil", a crônica machadiana reveste-se de um tom jocoso e, longe de parecer leviana, singela ou modesta, revela certa complexidade que reside justamente no fato de a notícia jamais ser apresentada de forma isolada, mas adquirir desdobramentos que envolvem não só a referência literária, mas, sobretudo, o tom galhofeiro como estratégia do articulista, algo que jaz como "a fruta dentro da casca", retomando a célebre metáfora machadiana.

Esse modo particular de escrever a crônica, que sabe refinar fatos e "personagens" à medida que se sucedem as colunas e série de relatos, ganha relevância por causa da forma e da linguagem. De fato, a linguagem é a grande personagem e, dentro dela, o intertexto, plasmado por meio de interconexões e analogias. No mais, esse "gênero" prima pelo entretenimento e Machado como jornalista - e seu grande representante -, deixa claro que para se chegar direto ao ponto não se pode ser muito profundo, mas é preciso exercitá-lo com a pena da galhofa. E, num singular trabalho de linguagem, confere vigor ao texto por meio da graça e da jocosidade; assim, não só respeita e entretém seu leitor, como atribui modernidade a seus escritos.

Efêmera, a crônica hoje respira ares eletrônicos e muito raramente se lembra da vida das gentes habituadas à lentidão das carroças e bondes puxados a burro, quando, há mais de um século foram produzidos esses alfarrábios, de maneira que cabe a pergunta: o que continua legível nesse apanhado de escritos? O matiz da escrita machadiana por si só já é razão para que se dê relevo e importância a essas crônicas, tanto é que muitos

\footnotetext{
${ }^{1}$ Veja-se, por exemplo: CALLIPO, Daniela Mantarro. Rimas de ouro e sândalo: a presença de Victor Hugo nas crônicas de Machado de Assis. São Paulo: Editora Unesp, 2010, p. 17, e a dissertação de Heloisa Helena Paiva de Luca (Propósito e fantasia: a presença francesa nas crônicas machadianas, 1996, 211f., p. 8. Dissertação, Mestrado em Letras - Faculdade de Filosofia, Letras e Ciências Humanas FFLCH, Universidade de São Paulo, São Paulo), entre outros.

2 Não se trata de História, mas do fato filtrado pela consciência crítica de um artista consumado e exímio observador. Sobre isso ver capítulo 2: "A Cosmovisão artístico-literária machadiana!".
} 
estudiosos $^{3}$ creditam a elas o engenho que Machado demonstraria em seus romances e contos, atribuindo caráter experimental à escritura dessas gazetilhas.

Enfim, vale destacar que ao inventariar esse material, conclui-se que sua legibilidade está intimamente ligada à ficcionalização da linguagem, pois ao mesmo tempo em que o cronista induz o leitor a uma leitura contrária àquela que privilegia os liames biográficos, em se tratando da forma artística, assegura a autonomia do texto, creditando-lhe relevo e sentido enquanto prática social (FACIOLI, 2002: 10). Não por outra razão, Machado reiterava: "Reproduzo, não moralizo." "Assim, ao reproduzir por meio da prática social da linguagem traz de arrasto uma infinidade de vozes mediadoras da "verdade" do cronista:

As vozes são recriadas e encenadas como opiniões sociais, que mais ou menos se equivalem, sem que nenhuma seja portadora de verdade positiva, definitiva ou dogmática. E se aparecem assim, a ironia estratégica trata de desqualificá-las, ou relativizá-las. São, enfim, discursos, falas, vozes, que pronunciam opiniões, interesses e pontos de vista, mas nunca chegam a formar um sistema de idéias, ou um conjunto aceitável de preconceitos, de compensações, de justificações, de legitimações. Há uma fragmentação que mimetiza a presença e a situação das vozes do mundo. A relativização generalizada, sempre mediada pela ironia, a sátira, o sarcasmo, se impõe como uma espécie de embate que impõe ao leitor a prática de uma atenção constante, uma astúcia que não pode baixar a guarda, pois só assim o sentido será questionado, bem como será questionado o seu modo de produzir-se. (FACIOLI, 2002: 10)

A intromissão dessas vozes no folhetim não só contribui para a pertinência dos comentários do cronista, mas também para a compreensão das relações entre discurso e fato (notícia), de tal arte que a vivacidade de seus escritos, o movimento e a diversidade neles impressos ressoam construindo sentidos, coadunando-se com a opinião do enunciador, tornando-se plenivalentes ${ }^{5}$. Desse modo, na esfera da crônica não se tem uma iteração de ideias, mas uma inter-relação de ideias e pensamentos provocada pela memória literária.

\footnotetext{
${ }^{3}$ Veja-se, por exemplo: GRANJA, Lúcia. Machado de Assis em formação: à roda dos jornais. Campinas: Mercado das Letras; São Paulo: FAPESP, 2000.

${ }^{4}$ O Espelho, 9/10/1859.

${ }^{5}$ No sentido atribuído ao termo por Bakhtin, qual seja, plenas de valor, mantendo com as outras vozes do discurso uma relação de absoluta igualdade.
} 
Verificar-se-á, ainda, que, ao longo da circulação literária, Machado se insere na tradição à proporção que age como literatos predecessores agiram em relação aos clássicos, isto é, como "modelos" dispostos para serem canibalizados, pilhados. Ao refletir sobre essas apropriações, as ideias de pronto ligam-se às lembranças, à mobilidade do espaço literário; suas dimensões e natureza comprovam indubitavelmente a memória literária como arcabouço intertextual a ponto de corroborar o dito de que a literatura, em muitos casos, se sustenta tanto de seus liames literários quanto de suas ligações com o real. ${ }^{6}$

Ora, o texto machadiano prova dessa hibridez, pois atenua as fronteiras entre o real e a ficção: nas crônicas, gênero marcado pela contingência, ora o articulador envereda visceralmente pelo literário retomando obras e autores, submergindo o real em meio a personagens e situações ficcionais de forma a minimizá-lo em importância com o risco de fazê-lo desaparecer aos olhos do leitor, ora caminha em sentido contrário, convergindo sua elocução para o fato (a notícia) simplesmente porque nele vê a possibilidade de criar um contraponto com algo ficcional, ativando, assim, sua memória literária. Nessa perspectiva - e porque o cronista trabalha com a consentaneidade entre um mundo possível e o mundo real, é possível afirmar a pertinência de enunciados ficcionais como mecanismos suscetíveis de possibilitar a compreensão do mundo.

Num pequeno sobrevoo sobre a produção machadiana, nota-se que os franceses, indiscutivelmente, oferecem embarras de richesse, tal a assiduidade com que Machado os frequentou. Mercê da avassaladora francofilia que campeava entre nós, surgem de suas páginas exemplos franceses que vão do século XVI ao XIX. Em razão disso, este trabalho visa sair ao encalço de nomes que contribuíram para a riqueza da cultura ao longo do século XVIII, sobretudo os que fizeram deste, o Siècle des Lumières.

Exemplos dessa contribuição podem ser vislumbrados já no início da obra machadiana quando o autor, ainda jovem, nos idos de 1858, participa da polêmica d' $O s$ Cegos, n'A Marmota ${ }^{7}$, jornal editado por Paula Brito, assecla de polêmicas e discussões.

\footnotetext{
${ }^{6}$ Samoyault (2005: 78) ao tratar das noções de "referência" e "referencialidade" afirma que « la littérature ne parle pas du monde, mais d'abord d'elle-même, mettant en évidence l'hétérogéneité fondamentale du réel et du texte ».

${ }^{7}$ Jornal de modas e variedades cuja publicação tem início em 1849; até 1852 recebe o nome de Marmota na Corte, de 1852 a 1857 é editado sob o nome de Marmota Fluminense e, de 1857 a 1864, quando encerra suas atividades, é chamado de Marmota.
} 
À maneira das academias francesas ${ }^{8}$, que propunham questões a serem respondidas por seus colaboradores e membros, Brito incitava seus leitores ao comentário através de motes.

A memória literária, que relativiza o ineditismo e coloca os textos em constante movimento, surge como ferramenta intertextual do artista no trato do circunstancial. Machado, levado pela admiração, exercitou-a incansavelmente em constantes visitas aos antigos e clássicos, inundando sua produção de referências, citações e alusões às obras da grande biblioteca.

Em suas lembranças, não só franceses, mas também ingleses, espanhóis, italianos, portugueses... Porém os gálicos são recorrentes e o Século de Voltaire perpassou suas crônicas ao longo dos quarenta anos em que tomou da pena para entreter seus leitores. O XVIII, século das grandes polêmicas, também trouxe à luz uma nova grande força: a opinião pública. A princípio restrita aos salões, ganhou as ruas com a difusão dos periódicos e logo depois obrigou filósofos e intelectuais a chamarem-na como árbitro. O ganho maior, porém, foi a democratização do conhecimento e a propagação de nomes como Voltaire, Rousseau e Diderot.

Estes, considerados esteios das Lumières, foram largamente comentados e popularizados nos periódicos oitocentistas a tal ponto que, banalizados, tornaram-se parte do chão cultural mais imediato, transformando-se, por vezes, em clichês, axiomas e ditos, aproveitados, na maioria das vezes, sem critério realmente integrativo.

Nas crônicas, as referências a personagens e eventos setecentistas constituem corpus volumoso, donde o recorte limitando este estudo àqueles que amiúde frequentaram o teatro das Lumières, tornando-se, por diferentes motivos, ícones do Século da Razão.

Voltaire, há muito idolatrado em terras brasileiras ${ }^{9}$, nas crônicas mantém a divisa de grande ironista e, assim como sua personagem Pangloss, surge, indiscutivelmente, como obsessão machadiana. Intertextualmente entrelaçado às situações locais, sob a

\footnotetext{
${ }^{8}$ Os Discours sur les sciences et les arts (1750) e Discours sur l'origine et les fondements de l'inégalité parmi les hommes (1755), de Rousseau, ambos, foram respostas às perguntas: «Si le rétablissement des sciences et des arts a contribué à épurer les moeurs ? » " Quelle est l'origine de l'inégalité parmi les hommes, et si elle est autorisée par la loi naturelle ? », respectivamente propostas pela Académie de Dijon.

9 "Voltaire possuía tudo quanto é necessário para a formação de um ente sem igual, e ele o foi, foi o primeiro dos seres pensantes." - Trecho extraído da Revista da Sociedade Filomática. In: (PASSOS, 1991: 55).
} 
forma de clichê ou por meio de textos relativamente esquecidos, ajuda a compreender nossa realidade, conferindo-lhe uma abrangência maior graças ao trabalho do cronista, hábil em sincronizar as sugestões do patriarca de Ferney ao Brasil oitocentista. Entre ambos, o jornalismo, veículo comum a partir do qual disseminavam conhecimento e combatiam a ignorância.

Comparada às presenças de Rousseau e Diderot, Voltaire tem participação preponderante nas crônicas, razão pela qual é objeto do mais extenso dos capítulos. Este, vale ressaltar, em parte é fruto de considerações mais antigas que resultaram em minha dissertação de mestrado, intitulada Aspectos da presença de Voltaire nas crônicas machadianas, defendida em 2009, na USP. Porém, agora, atualizadas e repensadas à luz de novas reflexões, lancei-me à releitura dos textos voltairianos e à reescritura de minhas análises, de modo que o alterar de meu juízo e observações configurou-se um exercício em que pesquisas passadas e novas se entrecruzaram. Assim, trouxe à luz um novo trabalho que, acredito, não anula em absoluto o anterior, mas, ao contrário, revela o trajeto ascendente das considerações, constituindo-se este estudo em um longo e largo fôlego para caminhadas voltairianas.

Os capítulos seguintes são dedicados a Rousseau e a Diderot, suas contribuições à crônica machadiana: Rousseau surge a partir de temas e princípios criados por ele; Diderot aparece não só por sua contribuição ao que de novo apareceu no campo da filosofia da percepção - o problème de Molyneux (mote da "polêmica dos cegos", cujo desenrolar contou com a participação de Machado nas páginas d'A Marmota), mas também em razão de um engano do cronista, que acreditou ser dele o botão capaz de acionar o móbil que mataria um mandarim na China, ou quiçá, um desconhecido na Noruega.

Por fim, os regards en arrière, a inconstância dos olhares oitocentistas ao século da audácia crítica e a reprodução dessas visadas por Machado de Assis - com destaque para Buffon, Chénier e Robespierre -, completam esse sobrevoo setecentista sobre o conjunto das crônicas machadianas. 


\section{A CRÔNICA}

“...as ilusões, ainda que pequenas, dão outra côr a êste mundo...”

\section{A crônica machadiana: especificidades de um gênero híbrido}

O fragmento acima, extraído de uma crônica publicada originalmente em 26/7/1896 na Gazeta de Notícias, poderia figurar como emblema do mundo retratado nas crônicas machadianas. Se por um lado traz em si algo poético que denuncia a origem ainda romântica do gênero (razão de ter sido incubado no seio do folhetim, espaço protéico, onde se publicavam romances capitulados, contos e poesias), por outro é uma pequena amostra de como essa categoria narrativa, sob a pena de Machado de Assis e seu refinamento estético, revela-se híbrida. Sua escrita é resultado do entrelaçamento de dois fios principais: a predisposição à oralidade estilizada (tom necessário ao gênero) e a tessitura literária, elementos capazes de paralisar o tempo, transformando o circunstancial, a notícia, em ficção.

$\mathrm{O}$ uso desses recursos, que atingem seu mais alto grau nas crônicas d'“A Semana" permite preservar a efemeridade do fato porque, justapostas, oralidade e tessitura literária, conciliam-se no enunciado e encerram o tempo em si mesmo. Dessa forma, o circunstancial, ainda que em caráter diminuto, adquire ressonância alegórica, desprende-se do contingente e se transforma em indicador do modus operandi do cronista.

A crônica machadiana, como é sabido, muito frequentemente trata de assuntos demasiadamente intelectivos. Talvez, por isso, Augusto Meyer tenha afirmado que Machado "não se integra muito bem no papel de conversador fiado" (MEYER, 2008: 139). Porém, a oralidade na condição de amálgama discursivo, conjugada à "acrobacia humorística" (paródia, ironia, sátira) característica da escrita machadiana, garante literariedade ao texto. $\mathrm{O}$ resultado é que esse texto extrapola para além da realidade histórica, pois, fatos e discursos se aproximam quando filtrados pela consciência crítica e lúdica do cronista. 
O fato é que desde sua origem o espaço da crônica figura como ponto de contato entre a amenidade (e vicissitude) do quotidiano e a fabulação, donde a coexistência da díade tempo-memória, especificidade do gênero. Relembrar e escrever: na tentativa de prolongar a ação humana, volta-se o cronista para as rosas de Malherbe ${ }^{10}$ e busca preservá-las através da memória escrita.

Ao elaborar seu relato, não obstante a realidade dos fatos, todas as vezes em que alegoriza, relativiza acontecimentos, explora o pitoresco e faz uso de metáforas, o cronista trabalha em proveito do estilo e credibilidade de seu texto. Assim constrói uma visão se não nova, mas particular do mundo, onde a existência é redimensionada. Afora isso, o desprendimento da escrita puramente jornalística (isenta de comentário, que registra o fato tout court) imprime ao texto um matiz ficcional. Dessa forma, a crônica, antes predestinada ao descarte, ganha fôlego, resiste ao tempo, é reproduzida, vira volume, resultado de um discurso onde o tempo é imobilizado e pode ser representado, por exemplo, na tradição, uma vez que é passível de leituras e releituras. O que está ali pode ser dito e redito e promover a ativação de sentidos.

Exímio manipulador desses artifícios e consciente de seu artesanato literário, Machado, no grande tablado que se configura o espaço da crônica, ao narrar os pequenos sucessos do quotidiano explora o lado pitoresco, humano e urbano das relações sociais do Rio de Janeiro (e do país); destaca aspectos psicológicos dos atores em ação, aponta e reinterpreta contrastes e tempera tudo a seu modo marcadamente irônico. No gênero, nota-se que desde seus primeiros escritos mostrou-se um "homem do seu tempo e do seu país" ${ }^{11}$ ao colocar em cena as questões em voga, que reelaboradas através de um discurso marcado pelo relativismo cético, traz à luz as farsas da classe dominante.

Dialético, hábil em garimpar entre os fatos da semana, ideias, princípios, situações, figuras díspares e contraditórias, traça um panorama da sociedade composto de material humano ordinário, comum. Destaca a vulgaridade da vida cotidiana e circunscreve o gênero:

\footnotetext{
${ }^{10}$ Referência a «Et, rose, elle a vécu ce qui vivent les roses, L'espace d‘un matin. », verso extraído do poema Consolation à Cléophon (1592) de François de Malherbe, reiteradamente retomado por Machado.

${ }^{11}$ O Novo Mundo, Nova York, $n^{\circ} 30,24 / 3 / 1873$.
} 
Eu gosto de catar o mínimo e o escondido. Onde ninguém mete o nariz aí entra o meu, com a curiosidade estreita e aguda que descobre o encoberto. [...] eu [aperto] os meus [olhos] para ver cousas miúdas, cousas de míopes. A vantagem dos míopes é enxergar onde as grandes vistas não pegam. ${ }^{12}$

Com a habilidade de pinçar a "coisa miúda", o "fútil", comenta o "útil” e revela principalmente as modificações em trânsito na sociedade de seu tempo nos campos social, político e econômico (ainda que se postule a moralidade individual como o principal arrazoado de suas crônicas). Desse modo evidencia a decomposição moral de um país que se debate entre prolongar sua estrutura patriarcal ou adotar a concepção de um modelo burguês de civilização, denunciando um sistema que se diz adepto das ideias liberais, embora só sobreviva porque ancorado na prática do escravismo, razão pela qual o representa sob a égide do relativismo, uma vez que nele a liberdade, a ordem e a justiça surgem como conceitos utópicos, quiméricos. Por fim, um país onde sequer o liberalismo era colocado em prática de maneira unívoca, dividindo-se entre liberalismo conservador e liberalismo democrático (BOSI, 2006: 46-47).

\section{2. “O autor de si mesmo", a prática machadiana da inversão e Schopenhauer}

Nessa dinâmica textual, uma constatação: o texto, ainda que evidencie todos esses contrastes, sofre uma regulação interna que induz o leitor desavisado a crer numa suposta normalidade das coisas, razão de o cronista tão somente expor a problemática de sua época e desobrigar-se de julgamentos. O controle e a regulação da escrita ficam por conta da práxis da inversão, vezo costumeiro ao longo de seu ofício como cronista.

Exemplo dessa manufatura é a crônica de $16 / 6 / 1895^{13}$, que versa inteiramente sobre assunto ainda comum em nossos dias: os maus-tratos à criança. Nela, o cronista reconta fato ocorrido em Porto Alegre com o casal Guimarães e Cristina que, cansados de maltratar o pequeno Abílio, resolvem colocar o filho em um caixote e deixá-lo em uma estrebaria. Abílio, do alto de seus dois anos, passados três dias sem comer nem beber, coberto de chagas e bicado pelas galinhas, vem a falecer.

\footnotetext{
12 "A Semana" - Gazeta de Notícias, 11/11/1900.

13 "A Semana", Gazeta de Notícias. Na edição organizada por Mário de Alencar esta crônica recebeu o título de "O autor de si mesmo".
} 
A priori, mais um caso de violência, cuja indubitável responsabilidade é atribuída aos pais. A história se resumiria a isto não tivesse o cronista recorrido à sua memória literária para amalgamar os fatos com matéria ficcional, procedimento que corresponde a 90\% da crônica. Machado retoma um capítulo de Schopenhauer, faz sua habitual cabriola pelos Evangelhos, traz de arrasto Shakespeare, envolve Swift e enreda Hegel, tal a extensão de suas evocações literárias.

O cronista prossegue comentando o encontro de Guimarães e Cristina, a troca de olhares, as primeiras emoções, a decisão pelo matrimônio, as formalidades e, enfim, as bodas. "Bem-aventurados os que se possuem, porque êles possuirão a terra", arrisca o narrador ao lançar mão do aforismo bíblico, ainda que alterado, para ilustrar a felicidade do casal e garantir a plausibilidade de uma história cujo protagonista inexiste, não obstante, de seu estado de não-ser, articule todo o entrecho - como se verá adiante. Assim, aplicada a teoria schopenhauriana ao caso de Abílio, este, antes mesmo de ter sido gerado, resolve se intrometer entre os dois e decide: "Guimarães há de ser meu pai, e Cristina há de ser minha mãe; não quero outro pai nem outra mãe; é preciso que nasça dêles, levando comigo, em resumo, as qualidades que estão separadas nos dous."14

Ainda que quisesse, neste instante da narrativa, o leitor já está para além do trágico, relativizou sua aversão inicial pelo casal e não mais reflete sobre a ação em si, mas sobre as causas que determinaram o episódio em razão da literariedade impressa à notícia. Na sequência, aparecem os estratagemas de Abílio no intuito de fazer o casal se juntar: apara as dificuldades, dita cartas de amor, infiltra-se no pensamento dos dois, cria ideias, faz-se duplo, vive por inteiro em ambos, Guimarães e Cristina, sem quebra de identidade nem integridade.

Ao dissociar o fato da contingência da crônica policial e fazê-lo mote de seu relato ficcional, o narrador intensifica os liames literários a ponto de induzir seu leitor a perfilhar a ideia de que Abílio teve seus momentos de Hamlet: "Ser ou não ser, eis a questão. Valerá a pena sair da espécie para o indivíduo, passar dêste mar infinito a uma simples gôta d'água apenas visível, ou não será melhor ficar aqui, como outros tantos que não se deram ao trabalho de nascer?"

\footnotetext{
${ }^{14}$ Para Schopenhauer, enamorando-se, dois indivíduos de sexos diferentes, acreditam que o amor e a atração que nutrem um pelo outro é uma determinação particular e individual de ambos, pois desconhecem que são movidos pela soberana Vontade da natureza, a Vontade em-si, que os obriga a agir em função da espécie, cujo fim principal é a procriação; a criança procriada terá do pai a vontade ou o caráter, da mãe o intelecto, e a corporificação dos dois.
} 
Aqui, embora o cronista informe a seu leitor de que "se não fôsse Schopenhauer, é provável que [eu] não tratasse dêste caso diminuto, simples notícia de gazetilha", talvez seja interessante retomar John Gledson quando, ao analisar a série "Bons Dias" (GLEDSON, 2008: 17), conclui que Machado, cada vez mais, se dava conta da distância que havia entre ele e seus interlocutores, uma vez que "a compreensão machadiana da história, ou do fluxo dos acontecimentos, era mais aguda que a dos seus leitores", razão pela qual, nesse e em muitos outros casos não se desobriga de citar a fonte, talvez porque se questionasse se seu leitor ideal trilhava em mesma sintonia.

O contexto no qual o crítico levanta tal hipótese, é evidente, pende para o político, face ao tenso biênio de 1888-1889, por claras razões históricas. Contudo, nas crônicas d'“A Semana”, esse hiato cronista-leitor, ocorre, não raro, por duas razões: as extensas reminiscências literárias do cronista e o fato de que nesses textos nada é explicitamente dito, o que obriga, muitas vezes, o leitor a partir em busca do significado cifrado nas entrelinhas.

Não se pode desconsiderar, contudo, que embora as crônicas fossem publicadas em jornais, é no século XIX, como bem demonstrou Walter Benjamin (WEINRICH, 1989: 48) que aparece um novo público: la foule, la masse. Se Benjamin destaca a modificação qualitativa quando relaciona o grande sucesso de Victor Hugo ao aumento do público leitor, no Brasil o problema é de outra ordem: a escassez de um público leitor $^{15}$, o que obriga o cronista, muitas vezes a dirigir-se a um círculo restrito de leitores - os happy few, ou ainda a um leitor póstumo que provavelmente saberá compreendê-lo. Logo, para os poucos leitores contemporâneos a Machado a busca pela total compreensão implicava estabelecer conexões alhures, ou seja, partir das fontes sugeridas; para o leitor atual, entretanto, ela vem acrescida de um complicador que é o levantamento de fatos, situações e vultos envolvidos - sejam eles históricos ou não.

O mundo como vontade e representação (1818) é a chave para desnudar o raciocínio do cronista e revelar a origem dos fios que empregou ao tecer sua "trama". Machado comenta o episódio à luz da teoria schopenhauriana relativa às causas transcendentes do amor, donde se conclui que os dois namorados não se escolheram um

\footnotetext{
${ }^{15}$ Machado, em crônica de 15/8/1876, comenta o recenseamento do Império que revelava um índice de $70 \%$ de analfabetos. Embora dissesse que a "a nação não sabe ler" e que "as instituições existem, mas por e para 30\% dos cidadãos", o retrato representado está aquém da verdade e era mais sombrio. Nas eleições de 1881, por exemplo, para uma população de provavelmente 12 milhões de habitantes, votaram apenas 96.411 eleitores, menos de 1\% (FAORO, 2010: 144).
} 
ao outro por motivos individuais, mas porque um ser - o pequeno Abílio -, os teria incitado.

Abílio, sempre à luz de Schopenhauer, representa a Vontade como coisa-em-si, já que para o filósofo, vida e morte, num jogo constante, são derivações dessa mesma e única Vontade, cujo mundo multifacetado que se apresenta diante de nós, não passa de mero espelho. Assim, filosoficamente, as metafísicas do amor e da morte, tratadas por Schopenhauer, de maneira conceitual, constituem parte da trama de um grande drama universal que é a existência, pois a Vontade é visceralmente uma discórdia em si mesma, o que, por vezes, faz com que o argumento desse drama seja trágico, donde a célebre frase schopenhauriana alles leben leiden ist (toda a vida é sofrimento).

Nota-se que sob o crivo dessa filosofia, o cronista faz com que dramaticidade e lamúria sejam mitigadas em lugar de uma descrição seca e ironicamente cruel, de maneira a conceber tragicamente a existência, levando o leitor a uma espécie de catarse diante dela em sentido semelhante ao empregado por Aristóteles ao definir o pensamento trágico. A tragédia de Abílio, ação de caráter elevado, exatamente por despertar terror e piedade, e por estas emoções serem ruins, leva o leitor à catarse.

O fato é que nasceu Abílio e a crônica, desfigurada enquanto gênero que dispõe e representa os eventos de forma temporal, ganha ares de conto, mostra-se concisa, densa, precisa, tem unidade de efeito, proporciona uma impressão do desenredo e é verossímil até mesmo quando traz à baila um "monólogo interior" para o inexistente Abílio. O final enigmático característico do conto, antecipado com as referências do narrador aos castigos que teria recebido a criança, atinge seu clímax com o monólogo transcendente da vítima. A tensão e densidade ficam por conta do possível sofrimento do pequenote ao longo dos três dias em que jazeu abandonado pelos pais à mercê dos animais.

Ao leitor resta a perplexidade do arremate tão logo corra os olhos pelas linhas seguintes ao reclamo de Abílio, que num solilóquio de cunho meio metafísico meio realista, questiona o sentido de sua breve existência:

Quem mandou aquêles dous casarem-se para me trazerem a êste mundo? Estava tão sossegado, tão fora dele, que bem podiam fazer-me o pequeno favor de me deixarem lá. Que mal lhes fiz eu antes, se não era nascido? Que banquete é êste em que a primeira cousa que negam ao convidado é pão e água? 
Abílio, "no mar infinito" vislumbrou ser "uma simples gota d'água apenas visível" e seguiu inexoravelmente a vontade cega da vida, sedenta por existência. Preferiu o ser ao não-ser e - vivo - se esqueceu de que o homem em vida é um ser para a morte e acreditou-se um ente análogo ao animal, que frui da imortalidade da espécie, sem o inelutável medo da morte.

Ao final, a culpabilidade dos pais, grande objeto de controvérsia da crônica, sofre reviravolta. Condenados, digamos, em duas instâncias - primeiro, a notícia que veicula o crime dá como certa a prisão dos progenitores, depois, pelo próprio leitor, induzido que fora a crer no clamor de Abílio: "Que mal lhes fiz eu antes, se não era nascido?” -, são absolvidos pela inversão, controle de regulação da escrita, que faz com que o narrador tome as rédeas de seu relato e redimensione os fatos à luz do filósofo de Dantzig. Outrora, algozes; hoje, vítimas. A sentença final vem por meio do próprio Schopenhauer, avalizando ao leitor que os pais de Abílio não passaram de peças manipuladas pela Vontade da natureza no jogo que constitui o grande drama cósmico que é a existência:

Nesse ponto do discurso é que o filósofo de Dantzig, se fôsse vivo e estivesse em Pôrto Alegre, bradaria com a sua velha irritação: "Cala a bôca, Abílio. Tu não só ignoras a verdade, mas até esqueces o passado. Que culpa podem ter essas duas criaturas humanas, se tu mesmo é que os ligaste? Não te lembras que, quando Guimarães passava e olhava para Cristina, e Cristina para êle, cada um cuidando de si, tu é que os fizeste atraídos e namorados? Foi a tua ânsia de vir a êste mundo que os ligou sob a forma de paixão e de escolha pessoal. Êles cuidaram fazer o seu negócio, e fizeram o teu. Se te saiu mal o negócio, a culpa não é dêles, mas tua, e não sei se tua sòmente... Sôbre isto, é melhor que aproveites o tempo que ainda te sobrar das galinhas, para ler o trecho da minha grande obra, em que explico as coisas pelo miúdo. É uma pérola. Está no tomo II, livro IV, capítulo XLIV... Anda, Abílio, a verdade é verdade ainda à hora da morte. Não creias nos professôres de filosofia, nem na peste de Hegel..."

Logo, vê-se que a urdidura da escrita machadiana se constrói em relação de estreita interdependência intertextual. A teia constitui-se do entrelaçar de fios principais e secundários. No exemplo acima, Schopenhauer contribui com o fio principal, porém, parodiado e diminuído. Machado não raro faz uso dos mesmos fios para levar a 
"verdade" a seu leitor. Acima, sarcasticamente, envolve o próprio Schopenhauer em mais um lance de inversão: “Anda, Abílio, a verdade é verdade ainda à hora da morte. Não creias nos professôres de filosofia, nem na peste de Hegel..."

Escrita capciosa que demonstra "o prazer do tiro certeiro, da flecha viva que ainda vibra, cravada no alvo" (MEYER, 1947: 37) e, aqui, diga-se, uma só flecha a atingir dois alvos: primeiro, o próprio Schopenhauer adverte Abílio (e o leitor) a não crer em professores de filosofia, a princípio crê-se que Machado aventou tal história para ilustrar as desinteligências entre o filósofo e Hegel, a quem combatia fortemente chegando a ponto de afirmar: "Non, non, il ne restera rien de Hegel, parce qu'il n'a pas pensé, mais jonglé avec des formules. (BARRÈRE; ROCHE, 1997: 60)".

Porém, num segundo instante, vê-se que o cronista refere-se ao próprio Schopenhauer e é como se alertasse o leitor de que também não se pode crer em Schopenhauer! Ou seja, Abílio está entregue à própria sorte. De fato, Machado denuncia de maneira irônica o grotesco e o absurdo a que poderia levar em termos humanos o sistema filosófico de Schopenhauer. No contexto intertextual, a rivalidade entre os dois filósofos e a decisão do cronista de zombar de ambos, remete a Luciano de Samósata e seu diálogo "Filosofias à venda" (SÁ REGO, 1989: 128) e denota sua intencionalidade explicitamente crítica, própria da sátira menipeia.

\section{Swift e a isotopia metafórica}

As múltiplas ligações intertextuais oferecidas pela escrita machadiana transbordam para além de alusões, referências e citações. Na crônica em questão, Swift não é contribuição direta, porém, dado o comportamento da narrativa, sua essência e humor, manifesta-se como parte integrante de um "feixe de virtualidades intertextuais combinatórias", na condição de isotopia metafórica, quando o fragmento textual é convocado por analogia semântica com o contexto (JENNY, 1979: 35).

O humor escorado em argumentação filosófica revela algo do sardônico irlandês: a estruturação da frase, a percepção da realidade e os influxos corrosivos colocam o cronista perto do satírico Swift, criando uma espécie de atração recíproca, assegurando coerência e sustentação ao universo semântico da crônica. Ao relembrar as bicadas de galinha em cima de chaga aberta, o cronista afirma: "tudo isto, com fome e 
sêde, fê-lo passar 'um mau quarto de hora' [...] donde se pode inferir que o organismo do menino Abílio era apropriado aos tormentos. Se chegasse a homem daria um lutador resistente; [...]"; como se vê, uma tirada à galhofa, uma espécie de travessura linguística que traz de arrasto o sarcasmo do grande humorista em seu panfleto Modest Proposal (1729).

Em Modest proposal, através de um humor cáustico e macabro, Swift sugere um meio de as famílias pobres irlandesas se livrarem de seus problemas econômicos: a venda de seus filhos como alimento aos senhores ricos; um exagero satírico, cheio de influxos corrosivos, que zomba das atitudes cruéis para com os pobres, assim como da política britânica na Irlanda.

Meses depois, em $1 / 9 / 1895^{16}$, o cronista volta a Swift ao relembrar um caso antropofágico ocorrido em Minas Gerais e, ao deslindar o percurso do lavrador que confessou ter comido seis pessoas (dentre as quais duas crianças) imprime viés literário à notícia e retoma o humorista irlandês ipsis litteris: "Afirmou-me um americano, disse êle, meu conhecido de Londres e pessoa capaz, que uma criança de boa saúde e bem nutrida, tendo um ano de idade, é um alimento delicioso, nutritivo e são, quer cozido, quer assado, de forno ou de fogão."

Involuntariamente, é provável que os influxos schopenhaurianos latentes em sua pena, tenham partido da mesma fonte, pois como afirma o filósofo: "a natureza abandona seus organismos mais engenhosos, não apenas à voracidade do mais forte, mas também ao acaso mais cego, e ao humor de cada louco, e ao capricho de cada criança, ela exprime que a aniquilação desses indivíduos lhe é indiferente, não lhe prejudica nada, e que, nesses casos, o efeito importa tão pouco quanto a causa" (SCHOPENHAUER, 2000: 78).

Afora a correspondência entre os discursos, pode-se contra-argumentar a presença de Swift como mera analogia figurada, dada a inexistência de sequer um fragmento de sua obra, logo, um evidente problema de identificação intertextual. Não obstante o risco de se incorrer no que Perrone-Moisés (1973: 84) classifica como “delírio de interpretação", passível de acometer todo intérprete no zelo em explicar "pormenores" ou o "maior número possível de movimentos" em busca da exatidão do percurso das fontes, cabe considerar que a menção a Swift vai além das semelhanças

16 “A Semana”, Gazeta de Notícias. 
semânticas, intensificando o intertexto schopenhauriano. Ademais, revela algo da estética machadiana: a memória literária contribuindo para dar o tom da crônica de maneira original, coadunando à matéria "crua" do jornal, a anedota e a paródia, onde até os ressaibos de grotesco trazem certo "ar" filosófico e de alta literatura.

Assim, muito embora a imagem de Modest Proposal (a dieta dos ricos à base de crianças pobres) não tenha qualquer relação com o drama de Abílio (no caso, os maustratos à criança), a intertextualidade pode ser recuperada pela aparição dos semas criança e morte - comuns aos dois textos. Este último, a morte, permite não só a reutilização da imagem numa outra construção temática ${ }^{17}$, como também favorece a presença da reminiscência schopenhauriana, sobretudo quando o filósofo trata do abandono e da aniquilação dos indivíduos pela natureza - como visto no parágrafo acima -, de maneira que "ao remodelar a representação a seu bel-prazer como um material transformável, a intertextualidade segue vias que evocam por vezes o trabalho do sonho sobre representação-lembranças" (JENNY, 1979: 16).

\section{Os arredores do texto, a legibilidade literária e a intertextualidade autárquica}

Já no início de sua vida de cronista, Machado sinaliza: "reproduzo, não moralizo" e "meu fim é o indivíduo, não um indivíduo"18. Logo, transpostas estas assertivas à escrita, seu texto apresenta unidade de conjunto e escritura "direcionada", cuja compreensão isolada oferece dificuldades, de modo que a crônica fechada em si mesma não se mantém, obrigando o leitor a uma intensa mobilidade pelos arredores do texto, sua periferia, quiçá extratexto, não só para constituir a "verdade", mas também para que haja condição mínima de legibilidade literária.

Da mesma forma que se pode buscar essa completude de sentido nas adjacências do texto, nota-se que as analogias intertextuais se estendem por sua própria produção e, se não provocam total interdependência entre as obras, mutatis mutandis, auxiliam na compreensão do uso e evolução das fontes em trânsito ao longo de seu exercício como cronista-romancista.

\footnotetext{
${ }^{17}$ No caso, o lexema contribui para o nível de estruturação e com uma unidade textual abstrata (a morte), extraída de seu contexto (Swift) e inserida em um novo sintagma textual (a crônica) a título de elemento paradigmático.

18 "O parasita", O Espelho, 18/9/1859.
} 
Essas correspondências "internas" podem ser explicadas através da isotopia metafórica, teorizada por Jenny (1979: 35). A convocação da "analogia semântica com o contexto" direciona a leitura e provoca uma equipolência de recordações associativas, de modo que a obra passa a ser lida em conjunto. À vista disso, essas relações intertextuais entre textos de um mesmo autor ora são definidas por intertextualidade restrita ora intertextualidade autárquica ou ainda autotextualidade ${ }^{19}$. Guimarães e Cristina, a ação subterrânea da Vontade em-si concorrendo para a aproximação do casal e o monólogo de Abílio, têm evidente aproximação com a história da alcoviteira D. Plácida, de Memórias póstumas (1881):

Assim, pois, o sacristão da Sé, um dia, ajudando à missa, viu entrar a dama, que devia ser sua colaboradora na vida de D. Plácida. Viu-a outros dias, durante semanas inteiras, gostou, disse-lhe alguma graça, pisou-lhe o pé, ao acender os altares, nos dias de festa. Ela gostou dele, acercaram-se, amaram-se. Dessa conjunção de luxúrias vadias brotou D. Plácida. É de crer que D. Plácida não falasse ainda quando nasceu, mas se falasse podia dizer aos autores de seus dias: - Aqui estou. Para que me chamastes? E o sacristão e a sacristã naturalmente lhe responderiam. - Chamamos-te para queimar os dedos nos tachos, os olhos na costura, comer mal, ou não comer, andar de um lado para outro, na faina, adoecendo e sarando, com o fim de tornar a adoecer e sarar outra vez, triste agora, logo desesperada, amanhã resignada, mas sempre com as mãos no tacho e os olhos na costura, até acabar um dia na lama ou no hospital; foi para isso que te chamamos, num momento de simpatia. (MACHADO DE ASSIS, 2008: 701, Vol. I)

Nota-se, no trecho acima, que anos antes Machado já buscara abrigo na doutrina de Schopenhauer, origem, segundo consenso geral da crítica, de sua visão algo cética. A "carência de sentido da vida no cosmo" perfilhada por este seu autor predileto em muito veio ao encontro do espírito do romancista, donde se destacam alguns pontos de contato: a compreensão de que "todas as coisas são magníficas de ver, mas temíveis de ser" e "a dor e o tédio como sendo os dois inimigos da felicidade humana", além da atração pelo problema do nada, a "lei geral das compensações" e a inexorabilidade do destino (REALE, 1982: 13).

\footnotetext{
${ }^{19}$ Ver artigo de Lucien Dällenbach, "Intertexto e autotexto" em que menciona os textos de Jean Ricardou, cunha o termo "intertextualidade autárquica" e retoma Gérad Genette, que define por "autotextualidade" o mesmo processo intertextual (In: Poétique - "Intertextualidades", 1979: 51-52).
} 
Embora as principais obras de Machado de Assis sejam governadas por uma ideia de inspiração schopenhauriana (GOMES, 1958: 91-98), Machado "não se dobra, servilmente, ao comando de Schopenhauer" (FAORO, 2010: 436), tanto é que suas maiores protagonistas, Virgínia, Capitu e Sofia, regidas pela intensa vontade de viver, não obedecem ao conceito da Vontade em-si naquilo que ele tem de metafísico. A realidade contraditória, os desvios tortuosos e desconcertantes da vida, o morrer em vida e a inelutável caminhada em direção ao abraço da morte, tudo isso, embora traga um eco da metafísica da morte do pensador germânico, de fato, desvela um pouco do ceticismo machadiano.

\section{O mundo narrado em função das obras literárias e "aberto às mutações associativas de ideias", a artimanha machadiana e a inversão}

Fundada no circunstancial, a crônica busca a simplicidade da linguagem e, para isso, coopta o leitor como constitutivo de seu discurso, porém, controlando-o, donde certa prevalência do “eu” em razão de o cronista prendre la balle au bond, já que seus comentários e impressões são emitidos no calor da hora. Muitas das marcas pessoais impressas ao relato não são fruto pura e simplesmente de sua habilidade em captar a realidade, mas sim resultado de sua destreza em concatenar reminiscências à notícia. Ainda que Machado se abstenha de julgamentos, isso concorre para a subjetividade comum ao gênero, de maneira que o leitor, ao interpretar os fatos, é obrigado a buscar pela coerência do narrador numa sorte de poética histórico-literária, que tutela seu discurso e imprime caráter literário à sua escrita jornalística.

Constituída dessa forma, a crônica rompe com o monolitismo do sentido e da escrita e mostra-se impregnada de textos anteriores, assim como a subjetividade, que se intensifica na expressão do mundo narrado em função dessas obras ${ }^{20}$, testemunha a incapacidade de se garantir um sentido absoluto. Dessa forma, por meio de um processo complexo, em que o leitor ora é introduzido na cena dos fatos graças ao comentário ora é afastado da narrativa em função de uma distância estética, realiza-se o trabalho de assimilação e transformação que caracteriza o processo intertextual.

\footnotetext{
${ }^{20}$ Aqui vale lembrar Tzvetan Todorov (2007: 72): "La littérature peut beaucoup. Elle peut [...] nous faire mieux comprendre le monde et nous aider à vivre."
} 
Ao delinear seus caminhos narrativos sob o jugo da recordação, Machado opta por um discurso leve e coloquial, "aberto às mutações associativas de ideias, que o tornam fluente enquanto temporalidade e registro estilístico” (BRAYNER, 1982: 427). Assim, expõe e reflete as ações cotidianas da cidade à distância com um "movimento ao canto da boca, [...] feição própria dos cépticos e desabusados" ${ }^{21}$ (como definia a ironia), faz-se narrador estimulante e dispõe seus pensamentos de maneira a criar uma escrita cujos movimentos num primeiro momento destacam os contrastes para, em seguida, ordená-los um à frente do outro de modo a provocar a reflexão sobre suas contradições, até que convirjam, mantendo assim o controle sobre o leitor, levando-o a assimilar aquilo que previra desde o início da crônica sem, contudo, dobrar-se às opiniões do momento, uma vez que essas normalmente são subjugadas por importantes artimanhas do narrador: a literariedade ao recontá-las e o destaque ao que elas trazem de histriônico e ridículo.

Essas artimanhas são próprias de um arguto observador. Sobre tal fato, afirma o cronista: "eu gosto de ver correr o tempo e as coisas; só isso". ${ }^{22}$ Deste seu observatório, esquadrinha o comportamento humano, suas ações, suas escolhas; analisa o que passou e, de modo ambíguo, sugere o que dessas escolhas poderá advir; relativiza os fatos chamando ao diálogo seu leitor ideal, mostra-lhe a pantomima que é a vida e ri nas entrelinhas, fazendo da crônica o espaço de uma escrita dialógica, "um campo experimental para um tipo de narrador não-convencional, espontâneo, intruso, a comentar suas próprias decisões retóricas” (BRAYNER, 1982: 429).

É comum afirmar a tonalidade desconcertante da escrita machadiana e a "inadequação" entre a ideia e a expressão de um narrador que afirma ao negar, provocando um descompasso entre "o significante apontado e a significação escondida, entre o mundo exterior e sua manifestação na subjetividade" (BRAYNER, 1982: 428), contudo, o que, em princípio, aparece como procedimento retórico expõe sua destreza ao desvelar a alma humana e toda sua constituição desarrazoada.

A constatação de que o amálgama do "barro humano", além das pitadas de ética, moral, bondade, nobreza e retidão, é em grande parte composto de vilania, estupidez, vaidade, ganância, hipocrisia, indiferença, violência, covardia, manias, fraquezas, taras e uma infinidade de posições ideológicas que se contradizem, leva o cronista à

\footnotetext{
${ }^{21}$ In: Teoria do Medalhão (1881).

22 "História de quinze dias", Gazeta de Notícias, 15/8/1876.
} 
impossibilidade de apreender a totalidade do discurso social, sobretudo, porque como afirma Bakhtin, esse diálogo é composto de "vozes do passado que se cruzam com vozes do presente e fazem seus ecos se propagarem no sentido do futuro" (BEZERRA, 2008: XII).

A impossibilidade de se colocar o ponto final é a principal característica do discurso polifônico. Porém, nota-se que o fato de se ter sempre um discurso em aberto e em constante correspondência intertextual não impede que o cronista entreveja uma

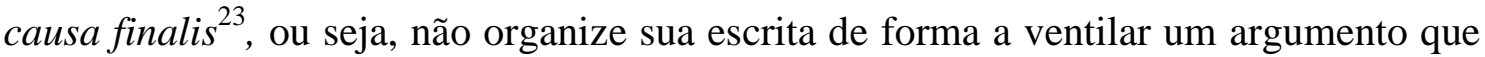
se não é conclusivo, ao menos redireciona seu interlocutor e o leva a questionar sobre as verdadeiras "causas".

A práxis da inversão, tutelada pela ironia, realça o ceticismo do cronista e mostra uma forma de expressão, donde se destacam as oposições entre o real e o fictício, o acontecimento e a fantasia. O cronista não julga, apenas apresenta. Assim, permeiam pelas crônicas situações que provocam desapontamento e estranheza ao leitor caso este insista em cravar os olhos no real que jaz ao rés da ficção: o gatuno que foge à banalidade e deposita o produto do roubo na caixa econômica é visto pelo cronista como "um fenômeno alta psicologia" e que "abre uma larga janela sobre a alma humana" 24 .

Embora fictício, o diálogo em que representantes da União dos Proprietários pedem a Louise Michel que interceda junto aos locatários a fim de que paguem seus aluguéis, dá-se sob o jugo da inversão: proprietários e não locatários se associam à comunista francesa. A casuística utilizada pelo cronista não só vincula os problemas locais ao grande acontecimento da semana (a notícia de que Louise Michel visitaria o Rio de Janeiro), como traz à tona, num golpe sarcástico, sua opinião via Louise Michel: “_ Mas então a anarquia está feita, o comunismo está feito.”,25

Ainda como exemplo de prática da inversão, temos que a culpabilidade de o carro fúnebre ter chegado atrasado à casa do defunto não é da funerária, pois a “impontualidade é antes dos que morrem em desproporção com o material da empresa". ${ }^{26}$ As recorrentes menções às mortes causadas por enganos nas farmácias de

\footnotetext{
${ }^{23}$ Adaptação livre da causa final, uma das quatro causas descritas por Aristóteles em Ética a Nicômaco, e considerada a mais determinante das causas, a finalidade para o qual algo foi construído. Também chamada de teleologia, o estudo filosófico dos fins.

24 "A Semana", Gazeta de Notícias, 13/10/1895.

25 "A Semana", Gazeta de Notícias, 20/10/1895.

26 "A Semana", Gazeta de Notícias, 05/4/1896.
} 
manipulação, por exemplo, são vistas pelo cronista como necessárias, pois "pode suceder que alguns envenenamentos se dêem a princípio; mas todo ofício tem uma aprendizagem, e não há benefício humano que não custe mais ou menos duras agonias". ${ }^{27}$ Enfim, são inúmeros os casos em que a inversão atua como instrumento de relativização em uma elocução irônica, chiste para destacar o ridículo, o oportunismo, o descaso e a desatenção. Essa relativização possibilita a alimentação progressiva de interpretação das crônicas.

Num gênero destituído dos privilégios que sustentam outras modalidades da prosa e com suposta ausência de elaboração narrativa - o desenvolvimento e aprimoramento de enredo e personagens (CANDIDO, 1992: 53-54), não bastasse o uso comum de lítotes, Machado utiliza a inversão como figura de linguagem para ancorar um humor às vezes sarcástico. Afora sua habitual ironia, faz uso deste mesmo instrumento não só para associar seu olhar pensativo ao espelho do mundo (que projeta nas crônicas), mas principalmente para sustentar, por antíteses, um discurso que destaca a vacuidade humana. Afinal, a inversão dá-se pelo contraponto entre o real (apresentado comumente em valor negativo) e a ficção, cuja função é redimensioná-lo, a partir de seu pretenso aspecto positivo.

\section{Um cronista moralista, pintor de homens e sua percepção artística}

Esse deslocamento do discurso em que o cronista parte de um fait divers de jornal, de um dado circunstancial, para explorar as deficiências da alma humana, assemelha-se à prática cultuada pelos moralistas, pois "no caso de Machado, o eixo da interpretação dos comportamentos é a análise das paixões que os motivam" e assim foi “desde Montaigne a La Rochefoucauld, desde Maquiavel a La Bruyère e a Schopenhauer" (BOSI, 2006: 121). A escolha dos fatos, seu agenciamento e comentários dependem de variáveis que destacam a ambivalência da escritura e ressaltam a dimensão moral da crônica, da história contada.

Dentre essas variáveis, destaca-se a capacidade de Machado em embaralhar as cartas, ou seja, materializar uma intersecção em que elementos do contexto social, personagens imaginárias e fictícias concorrem para afastar o automatismo comumente

\footnotetext{
27 “A Semana”, Gazeta de Notícias, 05/7/1896.
} 
lançado à visão da realidade, iluminando-a a partir de uma perspectiva artística, de modo que a percepção do real é singularizada e o mundo é apresentado sob o vinco das ideias de grandes escritores, filósofos, moralistas e outros.

A perspectiva é a da mimesis, liberta do copismo e da imitação dos fatos, representados passivamente no espelho, afirma Faoro (2010: 531) ao retomar o próprio Machado em crítica a Macedo em $O$ culto do dever: "Se a missão [...] fôsse copiar os fatos, tais quais eles se dão na vida, a arte era uma cousa inútil; a memória substituiria a imaginação..." (MACHADO DE ASSIS, 1952: 64, Vol. XXIX). Ademais, a leitura do conjunto das crônicas machadianas denuncia não só um cronista que, como os grandes moralistas, mostra-se observador, analista e pintor de homens ${ }^{28}$ (FRIEDRICH, 1991: 3), portanto, subtrai da aridez do real material necessário à literatura, mas, sobretudo, revela os questionamentos que vêm de arrasto sob essa tutela.

A célebre declaração de Montaigne segundo a qual "chaque homme porte la forme entière de l'humaine condition" (MONTAIGNE, 2009: 35, Vol. III) ressoa nas crônicas e traz o eco de uma das grandes questões presente nos Essais (1580): é possível fazer um inventário dos homens e do mundo e dali extrair algumas regras fundamentais? Machado perfilhava dessas mesmas dúvidas e a todo o momento parecia colocar à prova a ideia (bastante em voga até o século XVII e parte do século XVIII) de que a semelhança era suficiente para dar uma noção de lógica, de ordem oculta a tudo o que parecia, à primeira vista, contraditório (DESAN, 2008: 10). Contudo, como convicto moralista, esclarece: "Não mofeis de mim, se achais aí um ar de sermão ou filosofia. O meu fim não é só contar os atos ou comentá-los; onde houver uma lição útil é meu gôsto e dever tirá-la e divulgá-la como um presente aos leitores; é o que eu faço aqui". 29

A moralidade também enreda os questionamentos de José de Alencar que anos antes, ao refletir sobre a tensão "narrativa" da crônica despretensiosa, porém ligada às questões de seu tempo, conclui: "É uma arte difícil essa, de dizer tudo, não dizendo nada." ${ }^{30}$ Alencar, chega mesmo a comparar os textos publicados em jornais às cartas de

\footnotetext{
28 "Moralists are neither educators nor moral philosophers. They are observers, analysts, and describers of mankind. They find themselves facing an endless task. Their studies concern the contradictory nature and commonplace elements of mankind which only come to the fore when ethics recede and leave the field open for objective observation of what is real."

29 "A Semana", Gazeta de Notícias, 22/11/1896.

30 "Ao Correr da Pena", $O$ Globo, 14/10/1875.
} 
Horácio, cujas discussões filosóficas e morais tratavam de assuntos diversos. Nota-se, ao compará-lo ao cronista machadiano, que a estrutura (da crônica) não se altera, o fato não só se destaca como pré-requisito para armar a análise, como também a construção da cumplicidade (e a comunicação com o público) se faz através de fatos atuais, variados e compartilhados por ambos - cronista e público. Ao dissecar o fato na tentativa de inventariar a alma humana Machado traça um panorama extenso e crítico de um Brasil que persegue a todo custo a modernização e sua integração no concerto das nações ditas civilizadas.

A bem da verdade, ao tentar retratar essa alma humana e a vacuidade de seu caráter, o cronista revela uma compreensão arguta e original de acontecimentos históricos, do sistema político, suas transações e suas relações de força. As crônicas, modelos de sucessivas experiências ficcionais, revelam a visão artística de Machado, sobretudo porque figuram como instâncias de interlocução crítica entre o autor, seu tempo, seus contemporâneos e, não raro, figuras históricas de outrora que, rememoradas, se intrometem pelas páginas do folhetim, conferindo credibilidade às suas "verdades".

Com isso a crônica sustenta em sua escritura nesgas de um "realismo enganoso", em que o cronista, por um lado, transcreve a realidade através das "convenções doutrinárias da estética dominante", de outro lado, "solapa, suspende e compromete todas elas ao mesmo tempo" (GLEDSON, 2003: 15), de maneira a desafiar o leitor a encontrar nas fendas um substrato histórico, diferente do oficial, mas mais próximo de uma "verdade", ainda que relativa.

Essa maestria analítica só em parte revela o que está oculto sob o instante fugaz tomado como matéria da crônica, o que não é revelado cabe ao leitor buscar nas entrelinhas e decidir se concorda ou não com a "verdade" perfilhada pelo cronista. Ainda assim, é admirável o modo como Machado subverte o circunstancial, aborda episódios históricos e os transmuta em ficção. A interpretação desses eventos, em sua grande maioria, escapa à leitura convencional comum ao historiador. Este, leva em conta sobretudo as condições de enunciação e recepção, em que o texto dificilmente tira sua força das banalidades do quotidiano, e argumentos individuais jamais são tomados como modelo. Nas vezes em que utiliza reminiscências literárias como démarche de seu discurso, essas são pautadas por rapidez e síntese. 
Tudo isso porque o historiador está habituado a refletir sobre a representatividade dos fenômenos estudados, sobre o modelo, o exemplo, o índice; o que de fato busca é a investigação, análise e comprovação do fato, ao passo que o cronista quando não preenche os vazios deixados pela história com seu entendimento crítico, o faz sob a tutela da ficção num trabalho de assomo intertextual, evidenciando suposto conhecimento dos eventos. A presença do elemento histórico na narrativa não raro se sobressai mais como elo com o real e instrumento de expressão do cronista, que por sua própria importância na historiografia, razão pela qual se pode afirmar que Machado praticava jornalismo literário, ou ainda, que suas crônicas eram literatura de não ficção.

O fato é que na interseção da ficção com a história, nota-se, uma vez mais a vitalidade da obra machadiana e sua consentaneidade à releituras. Recentemente, da obra do escritor carioca tem-se dito que é integralmente construída sob o signo da representação histórica. Uma vez tomada essa trilha, o cronista cujos relatos transbordam referências literárias, padece de certo reducionismo. Taxá-lo historiador significa ignorar uma categoria fundamental de seus escritos: sua visão artística. Capcioso, Machado desenvolveu toda matéria da realidade (e semântica) que estava ao seu alcance e transformou-a em ideias. Estas, ambíguas e relativas, desorganizavam a representação oficial do sistema. Ao áspero relato da notícia, sobrepôs sua percepção artística do mundo.

Ainda que a relevância e a densidade dos acontecimentos históricos não alcancem o consenso almejado pela "nova" crítica, vale adentrar nesse ponto de vista e buscar sua evolução, desviando aqui e lá o olhar para momentos em que a crônica (essa conversa miúda de duas "vizinhas [que] entre o jantar e a merenda, sentaram-se à porta, para debicar os sucessos do dia", deixaram de "lastimar-se do calor" e de comentar "as tropelias amatórias" ${ }^{, 31}$ do morador fronteiro) ganhou foro de "alta prosápia" e acumulou dimensões sociais, com ares de "história".

\footnotetext{
31 “História de Quinze Dias”, Illustração Brazileira, 1/11/1877.
} 


\section{A COSMOVISÃO ARTÍSTICO-LITERÁRIA MACHADIANA!}

"Minha opinião é que a lenda é melhor do que a história autêntica.",32

\section{A conjunção do imaginário (e da memória literária) ao real: contar histórias é só} fantasiar

Quem conta um conto... O axioma, explorado de forma bastante lúdica por Machado em um conto homônimo, ${ }^{33}$ não só evidencia a errância dos textos, como também lhes garante sobrevida intertextual. Em se tratando da escrita, oralidade estilizada e tessitura literária garantem literariedade à crônica. Porém, no caso machadiano, quando se fala de conteúdo, os fatos não se explicam por si mesmos. Ao explicá-los (aumentar um ponto) Machado o faz sob a conjunção do imaginário e da memória literária e, ao espiar os fatos através da memória, confere tratamento artístico à matéria. Com isso, de pronto aparta-se do historiador (que se debruça de maneira criteriosa sobre suas fontes documentais) para observar e registrar o quotidiano sob a insígnia da fabulação.

As crônicas machadianas, singular exemplo de aglutinação de memória literária ao real, deixam rastros que denunciam o modo como o cronista atribuía ânimo aos acontecimentos pretéritos e interpretava eventos e fenômenos à guisa do que se propunha à época: a oposição racionalismo e idealismo, conhecimento científico e metafisicismo, etc. Esses mesmos "duplos" aparecem na conversa miúda como "parodiadores", tornando-a carnavalizada, ambivalente e relativizada. Assim o cronista reflete sobre sua condição de ficcionista doublé de historiador:

Mais dias menos dias, demito-me dêste lugar. Um historiador de quinzena, que passa os dias no fundo de um gabinete escuro e solitário, que não vai às touradas, às câmaras, à Rua do Ouvidor, um historiador assim é puro contador de histórias.

E repare o leitor como a língua portuguêsa é engenhosa. Um contador de histórias é justamente o contrário de historiador, não sendo um historiador, afinal de contas, mais do que um contador de histórias. Por que essa diferença? Simples, leitor, nada mais simples. O historiador foi inventado por ti, homem

\footnotetext{
32 "História de Quinze Dias", Illustração Brazileira, 15/9/1876.

33 "Quem conta um conto", Jornal das Famílias, fevereiro de 1873.
} 
culto, letrado, humanista; o contador de histórias foi inventado pelo povo, que nunca leu Tito Lívio, e entende que contar o que se passou é só fantasiar. ${ }^{34}$

A constituição textual da crônica é híbrida. Embora a discussão gire em torno de duas noções (história-contador de histórias) que ocasionalmente se misturam quando uma é tomada pela outra, algo da ideia criativa do artista vem à tona: a coadunação dos contrários. As relações contraditórias, combinadas de maneira original na escrita de jornal, abrem espaço para a reflexão e uma maior diversidade de temas, facilitando a compreensão dialética do Machado artista e a polifonia de sua escrita.

Ora, é preciso que se refine essa concepção em Machado: em se tratando da ideia, as opiniões (intertextos) aparecem na escrita machadiana como reforços, interferências combinadas, que robustecem seus argumentos. Não se tratam de teses e antíteses em constante jogo argumentativo. Ao contrário, o processo consiste em reunir substratos ficcionais diferentes (em contínuo diálogo) para que produzam uma síntese coerente (uma réplica que lance novo "olhar" à notícia), de modo que a ficção não reflita a realidade, mas apareça de forma crítica e combativa.

Essas "vozes" ficcionais também aparecem entremeadas ao discurso do cronista nas vezes em que faz apelo à historia ou imprime seu posicionamento face às forças políticas, sociais e ideológicas. Ao lançar luz aos problemas da vida quotidiana, a mediação dessas "consciências" literárias concorre para a constituição da voz inquieta do cronista. Seja por semelhança ou assimetria de julgamento, elas garantem sua liberdade de opinião e impedem que se "envolva" em polêmicas, afastando-o da linha de frente. Da correspondência entre Voltaire e o Duc de Richelieu, por exemplo, saem as críticas ao senador José Martins da Cruz Jobim ${ }^{35}$.

Nessa lógica (e só por isso) o cronista garante seu lugar como contador de histórias. Afinal, ao trabalhar os fragmentos crus da vida quotidiana, ousadamente os entrelaça à narrativas e personagens inspiradoras que se corporificam à sua escrita, fazendo com que um material heterogêneo (ficção e realidade) assuma o tom de suas crônicas. Anedota, paródia, sátira e inclusive o grotesco ganham verniz artístico. Assim, o fato, longe de se inscrever como relato histórico, vira prosa, fantasia, farsa, sem que o cronista abandone sua visada crítica.

\footnotetext{
34 "História de Quinze Dias", Illustração Brazileira, 15/3/1877.

35 "Badaladas do Dr. Semana", Semana Illustrada, 2/3/1873.
} 
Contador de histórias (cronista) e historiador: como distinguir um do outro? Afinal, apesar de seu enternecimento, da cena de rua e da conversa miúda, em seus primórdios a crônica versou sobre acontecimentos de ordem particular, atrelou-se ao desenvolvimento das nações e se destacou, sobretudo, por seu caráter documental. Com então separar um do outro? Hoje, com os desdobramentos do gênero ${ }^{36}$, nota-se que o que é passível de figurar nas linhas da crônica pode estar nas ruas.

Por outro lado, o cronista, casmurro e solitário, provavelmente em companhia dos livros, recorre à ficção e à fantasia como arrimos à sua escritura, tanto é que confessa nas entrelinhas valer-se parcialmente de conhecimento já há muito legitimado pela história e armazenado na grande biblioteca universal. Por isso se autodenomina historiador de quinzena? A resposta parece não vir pelo simples fato de o leitor estar frente a um autor que nos chama o tempo todo a uma definição embora ele, refratário, seja contrário a definições e, a fortiori, a resposta sequer existe, por tratar-se de um ficcionista da história que preza acima de tudo o mascaramento e o relativismo.

Assim, diante de mais uma sugestão da ideia pela negação, a fatura é repassada a seu leitor culto, que se vê responsabilizado pela invenção do historiador. Curiosamente e por via tortuosa -, Machado afirma ser a crônica o lugar teórico de fusão da escrita e da oralidade, da historiografia e da fabulação, do real e da fantasia, ratificando a crítica intertextual, a qual atesta que as "verdades" 37 histórica e literária só se constituem na multiplicidade dos textos e das escritas. Em suma: lendo Tito Lívio ou escrevendo a barafunda da Rua do Ouvidor, conta-se história.

Dessa forma, o que parece dúbio a princípio se esclarece à medida que o cronista desfaz o imbróglio do que vem a ser um contador de histórias, ou seja, aquele "que entende que contar o que se passou é só fantasiar". Quando não, seja para um contador de histórias seja para um historiador, os eventos se dividem entre protagonistas e coadjuvantes, e à crônica fica a obrigação de recolher o que não foi catalogado pela história oficial porque, ainda assim, "são migalhas da história" e "as migalhas da história devem ser contadas" ${ }^{38}$.

\footnotetext{
${ }^{36}$ Falam-se comumente em crônica esportiva, política, de entretenimento, da vida social, etc.

37 "Verdade" compreendida de maneira abstrata e sistêmica, haja vista a impossibilidade de se sustentar qualquer "verdade" na concepção de mundo atual.

38 "A Semana", Gazeta de Notícias, 11/8/1895.
} 
Machado tinha consciência da relevância dessas "migalhas da história" para sua narrativa. Ainda que as crônicas não fossem responsáveis pela produção de conhecimento histórico oficial, recontar o dia-a-dia implicava examinar o quotidiano das pessoas de maneira diferente, do ponto de vista delas, trazendo-as ao centro da narrativa de maneira a torná-la mais prazerosa (e despretensiosa) como requer o gênero, enfim, explorando as muitas possibilidades de explicação e especulação sobre o sentido muitas vezes oculto das coisas.

\section{2. "O Punhal de Martinha" e Lucrécia: um caso intertextual de mise en abyme e a fabulação da notícia}

As imbricações entre o especulativo e o conhecimento histórico podem ser vistas na crônica de 5/8/1894, intitulada $O$ Punhal de Martinha ${ }^{39}$ : nela, partindo do destino de dois punhais, um lendário e célebre, que servira ao suicídio de Lucrécia, ultrajada por Sexto Tarquínio; outro, vulgar, brasileiro, destinado à "ferrugem da obscuridade", Machado constrói uma narrativa cuja ligação fundamental é o fato local vs. história universal.

Assim como a tragédia do pequeno Abílio, o drama de Martinha foi pinçado de um fait-divers sertanejo, publicado originalmente no jornal A Ordem, de Cachoeira, interior da Bahia. "Martinha [diz o jornal] é uma rapariga franzina, moderna ainda, e muito conhecida nesta cidade, de onde é natural"; fora agredida e insultada por João Limeira, de "nenhum sangue régio", que se irritara com seus desdéns. A jovem recolheu-se a casa onde morava, na Rua do Pagão e, depois de "nova agressão, à porta", “indignada, mas ainda prudente, disse ao importuno: 'Não se aproxime, que eu lhe furo", "João Limeira aproximou-se, ela deu-lhe uma punhalada, que o matou instantaneamente".

Na crônica, o fait-divers tem como correspondente o célebre capítulo da História Romana (TITO LÍVIO, 1793: 59-64), que relata o ultraje sofrido por Lucrécia ${ }^{40}$. Como de hábito, à medida que deslinda a história, Machado enuncia os contrários, partindo do

\footnotetext{
${ }^{39}$ O título, de fato, foi atribuído por Mário de Alencar para a edição d'“A Semana", publicada pela Garnier, em 1914.

${ }^{40}$ De la Fundacion de Roma - Capitulo XXI - "De como Sexto, el hijo menor de Tarquino, forzó á Lucrecia, muger de Collatino, y como por este crimen abominable perdieron el Reyno, y él et su linage fueron lanzados de Roma"
} 
punhal, que, nas mãos de Lucrécia, soa algo lendário, ao passo que usado por Martinha se insere na categoria de objeto mal-afamado, de modo a construir um pastiche da história de Lucrécia. Vamos a ela, nas palavras do cronista:

\begin{abstract}
Quereis ver o que são destinos? Escutai.
Ultrajada por Sexto Tarquínio, uma noite, Lucrécia resolve não sobreviver à desonra, mas primeiro denuncia ao marido e ao pai a aleivosia daquele hóspede, e pedelhes que a vinguem. Êles juram vingá-la, e procuram tirá-la da aflição dizendo-lhe que só a alma é culpada, não o corpo, e que não há crime onde não houve aquiescência. A honesta moça fecha os ouvidos à consolação e ao raciocínio, e, sacando o punhal que trazia escondido, embebe-o no peito e morre.
\end{abstract}

Isto posto, o cronista transfere o punhal das mãos de Lucrécia às de Brutus, elevando-o à condição de clássico. Nesse contexto, exalta Roma e seus historiadores e relativiza Cachoeira e suas gazetas, unindo os dois punhais:

\begin{abstract}
Cachoeira não é Roma, mas o punhal de Lucrécia, por mais digno que seja dos encômios do mundo, não ocupa tanto lugar na história, que não fique um canto para o punhal de Martinha. Entretanto, vereis que esta pobre arma vai ser consumida pela ferrugem da obscuridade.
\end{abstract}

As comparações não terminam aí: Lucrécia se destaca pela honestidade e pureza, Martinha ganha o atributivo de "moderna", maledicência que a coloca distante da virtude conjugal da romana; seria desnecessário, porém, o cronista insiste em ressaltar a condição de João Limeira, moço de nenhum "sangue régio" em contraponto a Sexto Tarquínio, filho do último rei de Roma ${ }^{42}$. Vale considerar que em todas as comparações o elemento local é mitigado em face de seus modelos universais e insignes, o que leva a crer num olhar superior e cosmopolita do cronista diante da minúscula e esquecida cidade do sertão baiano, de modo que, ao emparelhar as duas histórias, reforça a supremacia de uma e o avassalamento da outra, desqualificando-a, irônica e

\footnotetext{
41 "Moderno", enquanto regionalismo da Bahia refere-se a moço, jovem, porém, considerada a ironia machadiana implícita no texto, à significação do adjetivo publicado na Ordem agrega-se novo sentido, que ratifica tal comparação entre as duas mulheres.

${ }^{42}$ Segundo Tito Lívio, a violência imposta a Lucrécia por Sexto Tarquínio, teria culminado no fim da monarquia, no banimento da família real e no nascimento da República Romana no ano de 509 a.C..
} 
divertidamente. A ironia, também aqui, é submetida à têmpera da inversão, com o cronista a avultar a bravura de Martinha:

Isto pôsto, em que é que o punhal de Martinha é inferior ao de Lucrécia? Nem é inferior, mas até certo ponto é superior. Martinha não profere uma frase de Tito Lívio, não vai a João de Barros, alcunhado o Tito Lívio português, nem ao nosso João Francisco Lisboa, grande escritor de igual valia. Não quer sanefas literárias, não ensaia atitudes de tragédia, não faz daqueles gestos oratórios que a história antiga põe nos seus personagens. Não; ela diz simplesmente e incorretamente: "Não se aproxime, que eu lhe furo."

Note-se que ironicamente Machado reforça a atitude de Martinha e relativiza a de Lucrécia, já que esta se volta ao pai e ao marido clamando por vingança e, digamos, num ato de covardia (ou de coragem?) dá cabo à própria vida, ao passo que Martinha, sequer violada, encarrega-se de punir o que de fato não passou de uma intenção, donde cabe a pergunta ao suposto leitor culto: qual o melhor modelo, aquele que desponta das páginas de Tito Lívio ou a sertaneja protagonista de um contador de histórias, que fantasia entre pausas e vírgulas?

É evidente que as comparações entre Roma e Cachoeira, Tito Lívio e A Ordem, Lucrécia e Martinha não passam de encontros fortuitos de perfis, acidentes geográficos e de escrita que visam, sobretudo, à sátira, ou seja, um jeito burlesco de o cronista rir ora de Martinha ora de Lucrécia, ora de Roma ora de Cachoeira, sem propósito algum. Dessa casuística, pode-se apreender certa "arrogância" 43 do cronista em face de seus compatriotas, habitantes de um lugar extremo, distante da Corte onde ele vive repleto de informações, de tradição e de todo um repertório cultural, literário e histórico vindo das grandes metrópoles europeias, portanto, uma espécie de happy few, que ri nas entrelinhas da sorte obscura de seus patrícios, sem jamais o fazer explicitamente.

Referindo-se ao aspecto intertextual, o aparecimento da Lucrécia de Tito Lívio no entrecho da crônica, seguramente trata-se de uma ocorrência de mise en abyme, aqui, no rastro da definição apontada por Gide (1948: 41) e retomada por Dällenbach, como um "redobramento especular, à escala das personagens e do próprio sujeito" da

\footnotetext{
${ }^{43}$ Em seu artigo $O$ artista e a sociedade, Eugenio Gomes observa que "o artista que criou Brás Cubas tinha um sentimento de superioridade espiritual e também moral ante a sociedade burguêsa, sentimento desenvolvido ou nutrido com o emprêgo da ironia, que não deixava de aplicar a si mesmo" (GOMES, 1958: 65).
} 
narrativa (DÄLLENBACH, 1979: 51-76). Vejamos: Machado, em situação de emergência e por meio de uma questão, desloca a atenção de seu leitor para uma narrativa intrometida e estranha ao que de fato tenciona narrar. O leitor é levado a refletir sobre a tragédia de Lucrécia e, só mais tarde desvia sua reflexão para um outro enunciado, sem contudo, abandonar o anterior que, de certa forma, intervém como elemento de meta-significação.

A história de Martinha só é redimensionada a partir das escoras impostas pelo relato de Lucrécia, que se impõe analogicamente como elo ao tema sugestionado - o destino dos punhais e por extensão de sentido, das protagonistas e também das pessoas. Dessa forma, a intromissão imposta pela mise en abyme permite que o leitor tenha um "resumo intratextual" da narrativa perpetuada por Tito Lívio, pois ao se condensar ou citar a matéria duma narrativa, ela passa a se constituir num "enunciado que se refere a outro enunciado - e, portanto, [n]uma marca do código metalinguístico; enquanto parte integrante da ficção que resume, torna-se o instrumento dum regresso e dá origem, por consequência, a uma repetição" (DÄLLENBACH, 1979: 54).

Dessa forma, o leitor machadiano se vê frente a uma acumulação de enunciados, uma iteração que, como vimos, sofre de espasmo: ora é Lucrécia que figura como modelo ora é Martinha, ora é o universal que aparece como representação ora é o local que o suprime, e, de fragmento, passa à condição de protótipo, relativizando a preponderância do cânone externo.

Não se pode desprezar, contudo, que a introdução da mise en abyme logo no início da narrativa, dota-a de forte poder de significação, o que permite, entre outras coisas, que o cronista se arvore dono de ares de cosmopolita fim de século e mostre um rastro de classe, munido da artificiosa historieta clássica, além do que, em nível de enunciação, a crônica de Lucrécia dialoga com a aventura de Martinha e vice-versa, corroborando o que Borges dissera sobre a capacidade de atualização e renovação das obras, de modo que ao correr os olhos pela crônica machadiana, o leitor invariavelmente acrescentará sentidos e significados ao episódio histórico de Lucrécia: o que teria impedido Lucrécia de ter agido como Martinha? Ademais, nesse exercício de reflexão por parte do leitor, abrem-se inúmeras possibilidades: afinal, embora dotados de estruturas semelhantes, os relatos de Lucrécia e Martinha, respondem às indagações de 
maneira relativa; como visto, dependendo de como se movimentam as peças no xadrez, o singular, o local equivale ao geral, ao universal.

Tudo depende também do grau de ironia do cronista: Martinha bem pode se distanciar da barbárie e alçar os degraus da elite histórica, porém, o fará sob a égide do caricato: Cachoeira é logo ali, pertinho de Roma e Martinha pode ser alguém próximo, tão afetuosa se mostra no diminutivo sugerido pelo nome, afora que - mais uma pilhéria! - o seu "eu lhe furo", se sobrepõe a "todas as belas frases de Lucrécia", a despeito de afrontar os gramáticos, partidários do mesmo verniz civilizatório do cronista.

Com tudo isso, arrôjo de ação, defesa própria, simplicidade de palavra, Martinha não verá seu punhal no mesmo feixe de armas que os tempos resguardam da ferrugem. $\mathrm{O}$ punhal de Carlota Corday, o de Ravaillac, o e Booth, todos esses e ainda outros farão cortejo ao punhal de Lucrécia, luzidios e prontos para a tribuna, para a dissertação, para a palestra. O de Martinha irá rio abaixo do esquecimento.

O parágrafo acima ilustra que o esforço do cronista em dar visibilidade a Martinha, de fato, é absolutamente em vão. As razões que envolvem a questão são especulativas, é claro, porém, devem-se considerar como dados exponenciais as condições espaciais e culturais em seu verso e reverso, isto é, vistas do ângulo da personagem e do sujeito da narração. Martinha está duas vezes distante: não bastasse viver em um país periférico, o arrabalde onde vive sequer é contíguo às influências da Corte.

No outro extremo, há o cronista, sujeito da narração. Este, embora nesse mesmo país periférico, não consegue escapar da tradição europeia largamente reproduzida na Corte, donde seu hábito em comentar o local a partir de representações, modelos e ideias, cujas raízes estão fincadas nas distantes metrópoles europeias. Nesse imbróglio todo, ao promover o encontro entre o local e o universal, o máximo que o cronista consegue é inscrever o punhal de Martinha na ficção da crônica. Por fim, à Martinha resta a prisão no interior das fronteiras brasileiras, com a agravante de que seu punhal jamais será listado no rol dos que fizeram sucumbir Lucrécia, César, Marat, Henri IV, Abraham Lincoln e outros. 
Se, ao menos, o punhal de Lucrécia tivesse existido, vá; mas tal arma, nem tal ação, nem tal injúria, existiram jamais, é tudo uma pura lenda, que a história meteu nos livros. A mentira usurpa assim a coroa da verdade, e o punhal de Martinha, que existiu e existe, não logrará ocupar um lugarzinho ao pé do de Lucrécia, pura ficção. Não quero mal às ficções, amo-as, acredito nelas, acho-as preferíveis às realidades; nem por isso deixo de filosofar sôbre o destino das cousas tangíveis em comparação com as imaginárias. Grande sabedoria é inventar um pássaro sem asas, descrevê-lo, fazê-lo ver a todos, e acabar acreditando que não há pássaros com asas... Mas não falemos de Martinha.

"Mas não falemos de Martinha", não falemos do real - a menos que seja metamorfoseado pela ficção. O cronista, que postulara um destino pujante para o punhal de Martinha, depois de certa indignação, perde-se em sua própria retórica e deixa de defendê-lo, levando a crer que o que talvez seja realmente digno de nota está na ficção; à fabulação está condenado o real, sem a qual não suportaríamos sua suposta "verdade". A história de Martinha, marginalizada, só ganha interesse (e graça) porque se escora nos ecos poéticos da Lucrécia de Tito Lívio e na parcialidade atribuída aos clássicos; dessa forma, toda a bagatela retórica e trágica, volatilizada, permite que o povo e seus dramas se perpetuem nas páginas da crônica. Ademais, nessa lógica, ser civilizado ou civilizarse implica relação de estreita dependência das convenções literárias, não se leva mais em conta o sujeito matéria da crônica, mas a própria crônica e os livros adquirem condição de sujeito, sujeito escrito, sujeito "escrevente", sujeito que permite vaguear pelas supostas "verdades" históricas.

\section{A história "ficcionada": um "pássaro sem asas"}

Para o cronista a "coroa da verdade" das "realidades" é usurpada pela lenda "que a história meteu nos livros", ou seja, a realidade pode muito bem figurar como história, contanto que modificada pela ficção, de modo a acomodar interesses. Não por outra razão o cronista afirma ser perfeitamente possível inventar "um pássaro sem asas, descrevê-lo, fazê-lo ver a todos" e, ao fazê-lo, acreditar "que não há pássaros com asas". Mas nem tudo está perdido. Nessa lógica, ao refletir sobre a história de maneira "ficcionada", é certo que o real sofre certa redução em sua complexidade original, porém, como esclarece Dällenbach (1979: 55), “a réplica de ficção converte o tempo em 
espaço, transforma a sucessividade em contemporaneidade e, por isso mesmo, aumenta a nossa capacidade de com-preender".

Mas a capacidade de compreensão, colocada dessa maneira, não compromete a "complexidade original" do fato histórico? Até que ponto é possível "captar" a "verdade"? E os bastidores que o determinaram, não acabam excluídos da cena em si? É certo que a escrita ficcional machadiana pode ser entendida como instância de interlocução crítica com seu tempo e seus concidadãos (SEVCENKO, 2003: 13), porém, creditar aos eventos históricos a total coerência, legibilidade e consistência da obra de arte, não é incorrer em riscos?

Ao responder a essa e outras questões, não se pode deixar de considerar que ao se aproximar da ficção a história entra em zona de litígio e, não raro, sofre certa hibridação. Afinal, se de um lado há um historiador em busca da comprovação do fato histórico, do outro, está o escritor munido de estratégias, artimanhas e subterfúgios ao transcrever episódios, submetendo-os, na maioria das vezes, a um processo fundado em certo psicologismo, arbitrando critérios a seu bel prazer, sonegando, exagerando e desconsiderando qualquer conhecimento normativo que possa avalizar a "verdade" ou a falsidade de determinado fato histórico. Tudo em prol de sua expressão literária.

Em se tratando de ficção, é natural a recorrência à imaginação com o objetivo de conferir dignidade a testemunhos de personagens ordinárias, sobretudo quando ligados a eventos históricos. Ao tratar das possíveis analogias entre história e literatura, também não se pode deixar de considerar - principalmente - a escritura, ponto natural e central de todo discurso: para que as opiniões prevaleçam e se perpetuem ao longo da circulação literária é preciso que tenham sido escritas. E, ao destacar esse ou aquele ponto de vista as produções discursivas devem ressaltar seu valor (implícita ou explicitamente) impondo-os a seu interlocutor (o leitor) de forma orientada.

Desse modo, busca-se interiorizar padrões e normas que façam da experiência da escritura, algo digno de credibilidade, embora muito das representações, lembranças e relatos históricos sejam contextuados de forma a se adaptarem à significação pretendida no ato da escrita. Também não se pode esquecer que muitos desses acontecimentos só foram (ou são) preservados para a posteridade porque ganharam visibilidade por intermédio da ficção. 
Na crônica de 15/9/1876 ${ }^{44}$, Machado defende a ideia de que testemunhos, eventos, episódios sociais e históricos sejam revestidos de indumentária ficcional, de sorte que possam ser redimensionados pela força da expressão literária. Embora um tanto extensa, vale retomar parte da crônica:

Grito do Ipiranga? Isso era bom antes de um nobre amigo, que veio reclamar pela Gazeta de Notícias contra essa lenda de meio século.

Segundo o ilustrado paulista não houve nem grito nem Ipiranga.

Houve algumas palavras, entre elas a Independência ou morte, - as quais tôdas foram proferidas em lugar diferente das margens do Ipiranga.

Pondera o meu amigo que não convém, a tão curta distância, desnaturar a verdade dos fatos.

Ninguém ignora a que estado reduziram a História Romana alguns autores alemães, cuja pena, semelhante a uma picareta, desbastou os inventos de dezoito séculos, não nos deixando mais que uma certa porção de sucessos exatos.

Vá feito! O tempo decorrido era longo e a tradição estava arraigada como uma idéia fixa.

Demais, que Numa Pompílio houvesse ou não existido é coisa que não altera sensivelmente a moderna civilização.

Certamente é belo que Lucrécia haja dado um exemplo de castidade às senhoras de todos os tempos; mas se os escavadores modernos me provarem que Lucrécia é uma ficção e Tarquínio uma hipótese, nem por isso deixa de haver castidade... e pretendentes.

Mas isso é história antiga.

O caso do Ipiranga data de ontem. Durante cinqüenta e quatro anos temos vindo a repetir uma coisa que o dito meu amigo declara não ter existido.

Houve resolução do Príncipe D. Pedro, independência e o mais; nem êle se deu nas margens do célebre ribeiro.

Lá se vão as páginas dos historiadores; e isso é o menos.

Emendam-se as futuras edições. Mas os versos? Os versos emendam-se com muito menos facilidade.

Minha opinião é que a lenda é melhor do que a história autêntica. A lenda resumia todo o fato da independência nacional, ao passo que a versão exata o reduz a uma coisa vaga e anônima. Tenha paciência o meu ilustrado amigo. Eu prefiro o grito do Ipiranga; é mais sumário, mais bonito e mais genérico.

\footnotetext{
44 "História de quinze dias", Gazeta de Notícias.
} 
"Lá se vão as páginas dos historiadores; e isso é o menos. Emendam-se as futuras edições". Ao cronista, que elege a lenda em substituição à história autêntica,

pouco importa se, nas futuras edições, ao conto venha aumentado um ponto. Ao recontar um fato do passado - o Grito do Ipiranga, por exemplo, é possível ao escritor realizar a absorção e dissolução de uma escritura em outra, do relato histórico na ficção, de modo a expandir ou reduzir a importância de um gesto passado submetendo-o ao ato da escrita, à escolha da expressão, subvertendo características e identidades sociais, a fim de que o fato histórico e o contingente possam ser transfigurados pelo poder da expressão literária. Em Machado, a paródia aparece como importante elemento intertextual desse processo.

\section{4. "As futuras edições": releitura e atualização de textos e o traço carnavalesco}

Nesse exercício de escrita em que se "emendam as futuras edições", misturam-se escrituras do passado e escrituras sobre o passado, efeito intertextual que provoca a releitura e atualização do texto primeiro que, em suma, mostra sua vulnerabilidade conjectural, pois se torna lugar de inspiração, elaboração e produção. De fato, o relato histórico em sua "suposta" origem não é visto apenas como depositário de episódios e eventos do passado, testemunhos da realidade que descreviam, mas, sobretudo, como lugar onde uma realidade se construiu ativamente, por isso, ainda hoje, passível de nos transmitir um movimento de tomada de posição sobre o real e sobre a experiência de construção do real pela escritura, donde a perspectiva de "futuras edições".

Boa parte do prazer e do conhecimento está no jeito de narrar e a narrativa é campo aberto para múltiplas possibilidades de especulação - e explicação -, sobre o sentido das coisas. Incertezas e interpretações variadas sobre determinado fenômeno histórico devem ser incorporadas à narrativa, jamais desprezadas, sob pena de, a exemplo de "alguns autores alemães", desbastar "os inventos" - e eventos -, e não deixar "mais que uma certa porção de sucessos exatos". Assim, longe de garantir veracidade, a rigidez do texto se justificaria somente àquele historiador que finge ter certezas; ao cronista, cabe relativizar, explorar o pitoresco, fazer apelo à metáfora e à alegoria.

Nota-se, dessa forma, que a relação com a história é sempre ambígua em Machado. A crônica não substitui a história, apenas registra (enviesadamente) a 
inserção do pequeno, do mínimo, do escondido, na "realidade" dos acontecimentos. Mais que relatar os fatos históricos como tais, a função do cronista é dar relevo às possibilidades "ficcionais" que qualquer evento (ou pessoas - inclusive aquelas como Martinha) propicia em termos de comentário jocoso. No caso, uma das fontes de jocosidade está na desproporção entre a Lucrécia romana e nossa moça do interior. A história surge não como ponto de partida (Martinha não é uma personalidade histórica), mas como ilustração cultural (Lucrécia) a realçar a minimização do fato e o apequenamento de Martinha.

$\mathrm{Na}$ crônica machadiana (de caráter jornalístico e folhetinesco e que se vale do quotidiano mordaz) a escritura se perfaz em constante simbiose entre fato e intertexto. Chamado à cena, este dá vazão ao pensamento artístico-literário do cronista. Em parte, o jocoso vem do aproveitamento de diversos elos mediadores (literários e históricos) que conferem à escritura traço carnavalesco. Tem-se então uma escritura característica do sério-cômico (sátira menipeia), onde as questões históricas aparecem predominantemente como elemento necessário à poética do gênero, sem qualquer apelo ou reconhecimento oficial, ou seja, não vai além de um fenômeno, uma peculiaridade no tratamento que se dá ao "recontar" a "realidade".

A escritura associa-se ao discurso do espetáculo. Heróis míticos ou históricos são atualizados, interpretados e apreciados à luz do dia-a-dia, entram em contato com a pluralidade de vozes que circundam o cronista. Não raro, ao comentar uma obra ou o discurso de um senador ou deputado, Machado retoma obras, personagens e personalidades históricas já referenciadas anteriormente, de maneira que a paródia, a ironia, enfim, o jocoso, vem da interpretação da interpretação.

Contudo, essa atualização é deliberada e acentuadamente intertextual e exatamente por isso soa como uma atualidade inacabada, ou seja, pode ser interpretada à exaustão. Só depende da visada valorativa-temporal, da associação interpretativa e da memória criativa. Conforme afirma Bakhtin (2008: 128), os gêneros do sério-cômico (e aqui incluímos a crônica machadiana) baseiam-se conscientemente na experiência e na fantasia livre e seu tratamento, na maioria dos casos, é profundamente crítico, às vezes, cínico-desmascarador.

\section{A imagem "artística" da história e a politonalidade da escrita ignoradas}


Mas não parece ter sido essa a leitura de parte da crítica à presença dos elementos históricos na obra machadiana. A imagem "artística" da história, nas quais vozes ficcionais (e históricas) se intercalam amplamente, parece ter sido ignorada. A politonalidade da escrita, a fusão entre o sublime e o vulgar, o sério e o cômico, a paródia, a ironia, etc., deixaram de ser disfarces de um discurso crítico e foram tomados ao "pé-da-letra", como "enfrentamento" do artista face ao sistema e à história.

Não por outra razão, tem-se afirmado que a maestria de Machado em Casa Velha $(1943)^{45}$ é reflexo de "verdades" históricas, onde "há paralelos entre a esfera da vida privada e pública, de maneira que se torna necessário procurar o significado político do relato" (GLEDSON, 2003: 47). De A Mão e a Luva (1874), Schwarz afirma que "a história de Guiomar reúne muito destiladamente os elementos de totalidade necessários a uma representação problematizada da vida do país, sem considerações de pitoresco" (SCHWARZ, 2003: 107). De Dom Casmurro (1899), ignorou-se sua problemática essencial, o ciúme, afirmando ser a obra "uma especulação, um exercício de interpretação dos sentidos da história [...] um momento de reflexão sobre a indeterminação da História". ${ }^{6}$

À mesma leitura, submeteu a crítica Memorial de Aires (1908), Quincas Borba (1891) e outros. A ironia, o pessimismo e o realismo psicológico, que fizeram de Memórias póstumas de Brás Cubas (1881) uma obra capital, embora continuem incólumes como campos que conferiram maestria a Machado e à obra, nessa perspectiva, parecem se debilitar face à busca de especulações políticas e históricas ocultas e implícitas. De fato, essas diferentes leituras não só mostram a vitalidade da obra machadiana como abrem espaço para questionamentos: em que medida seu olhar distanciado de observador aproximou-se daquele do cientista social ou vero historiador? Até que ponto sua escrita é embebida do discurso do espetáculo devido à presença da alegoria político-histórica? A "Paris dos trópicos", onde tudo era cenário, da arquitetura às relações sociais, certamente deixou rastros em sua escritura; qual a dimensão dessas marcas na carnavalização do discurso, aproximando-o do espetáculo? É certo que a

\footnotetext{
${ }^{45}$ Publicado pela primeira vez entre os anos de 1885 e 1886, na revista A Estação, em 25 capítulos. A primeira edição em volume só se tornou possível graça aos esforços de Lúcia Miguel Pereira.

${ }_{46}$ Sidney Chalhoub em entrevista a Revista de História.com.br. Disponível em http://www.revistadehistoria.com.br/secao/entrevista/sidney-chalhoub. Acesso em 15/9/2011, às 15h23m.
} 
fronteira entre literatura e história determina estruturas à obra machadiana; como essas estruturas se articulam?

Ora, diante de um experimentador de técnicas narrativas, sutil e movediço, as questões se multiplicam, dado que, muitas vezes, para transmitir uma "verdade", Machado nos obriga ir para além da consciência das personagens e, como vimos nas crônicas, para além do círculo do texto, obrigando-nos a reconstituir uma trama extramuros. Em suma, em Machado há a dubiedade da leitura: o que é visível e o que é obscuro; uma se adapta às normas da ficção realista, outra, secundária, desafia e leva à descobertas, reflexo na escrita de uma época que "em matéria de racionalidade, os papéis se embaralhavam e trocavam normalmente: a ciência era fantasia e moral, o obscurantismo era realismo e responsabilidade, a técnica não era prática, o altruísmo implantava a mais valia, etc.” (SCHWARZ, 2003: 15).

Mas e as crônicas, plenas de alusões e referências irônicas, humorísticas, cujos textos muito frequentemente beiram ao sarcasmo e, não raro, acusam de estúpido seu interlocutor ficcional; em que medida o leitor é desafiado? Como já visto, Machado prefere a ficção à história autêntica e nas crônicas é comum que um tema sirva de disfarce para outro, o principal, onde residiria a suposta "verdade", trazendo complexidade a um gênero que prima pela interlocução com o circunstancial. A duplicidade de significados e sentidos é tão elevada que induz o leitor à desatenção e para isto basta se habituar à ironia. Em que pese o mundo relativo de Machado e seu "pessimismo", vale destacar que nas crônicas a "história autêntica" é mitigada em prol da "lenda".

Embora o vigor da expressão machadiana seja campo aberto a diferentes abordagens, Machado aproxima-se da realidade de forma anedótica e pitoresca. Há casos em que leitor sente ausência de nitidez face à névoa que embaça o real filigranado sob a escrita e a apreensão fidedigna mostra-se então comprometida porque abordada pontual e ocasionalmente. Desta feita, reiteramos: para se entrevir o real sob o véu da escrita é indispensável sair em busca de contextos extramuros, pois, não raro, o que se deixou estar encoberto é para o leitor a razão máxima da curiosidade e da excitação.

\section{A realidade anedótica: se é para "imitar alguém, imita Mirabeau"!}


Vejamos um caso de abordagem pontual em que o tratamento artístico livre da matéria liberta quase que totalmente a crônica das referências históricas. Estas, na condição de intertexto (apesar de suas raízes), não só revelam o confronto da visão machadiana face à realidade, como também afastam a escritura do monologismo oficial. Tudo o que vem a ser dito depende das relações intertextuais e, no caso, a fonte francesa, concorre para a interpretação crítica de Machado. A crônica é de 9/4/1893 ${ }^{47}$ :

Que vemos no Rio Grande do Sul ${ }^{48}$ Combate-se e morre-se para derrocar e defender um govêrno. Venhamos a Niterói, mais próximo do teatro lírico. Trata-se de depor a intendência. Reúnem-se os autores e propugnadores da idéia, escrevem e assinam uma mensagem, nomeiam uma comissão, que sai a cumprir o mandato. A intendência, avisada a tempo, está reunida; talvez de casaca. A comissão sobe, entra, corteja, fala:

— Vimos pedir, em nome do povo, que a intendência deponha os seus poderes. A intendência, para imitar alguém, imita Mirabeau:

- Ide dizer ao povo, que estamos aqui pelos seus votos, e só sairemos pela força das baionetas!

A comissão corteja e vai levar a resposta ao povo. O povo, na sua qualidade de Luiz XVI, exclama:

—É pois uma rebelião?

- Não, real senhor, é uma conservação. Tudo isto limpo, correto, sem ódio nem teimosia, antes do jantar, antes do voltarete, antes do sono. Se alguém ficou sem pinga de sangue, não o perdeu na ponta de uma espada; foi só por metáfora, uma das mais belas metáforas da nossa língua, e ainda assim duvido que ninguém empalidecesse. Talvez houvesse programa combinado. Quantos fatos na história, que, parecendo espontâneos, são filhos de acordo entre as partes!

A crônica, uma consideração sobre a regulamentação do serviço doméstico pelo conselho municipal, detém-se por breve momento na indecisão em nomear os integrantes de tal conselho - se intendentes ou vereadores, como à época das câmaras municipais. Na sequência, volta-se o cronista à regulamentação, em seguida reflete sobre a conjuntura econômica, pondera sobre a possibilidade de vir a tornar-se jardineiro e expressa seu apoio à nova lei; porém, logo depois, ao voltar à "realidade" e

\footnotetext{
47 “A Semana”, Gazeta de Notícias.

${ }^{48} \mathrm{O}$ cronista refere-se ao movimento insurrecional conhecido por Revolta Federalista, ao qual se dá também o nome de Revolução Federalista, que durou entre os anos de fevereiro de 1893 a agosto de 1895, envolvendo as principais facções políticas do Rio Grande do Sul, quando o poder era disputado pelo Partido Republicano Rio-grandense e pelo Partido Federalista o Rio Grande do Sul.
} 
constatar que o regulamento beneficia muito mais a seu criado que a ele próprio, assegura que a lei não será cumprida, "porque eu [ele] não vim [veio] ao mundo para cumprir uma lei, só porque é lei”.

Nota-se na transposição do fato empírico, evidente ironia e desdobramento da escrita a ponto de o leitor desinformado tomar o comentário por suposta "verdade", quando, de fato, está à frente de duas inverdades. Veja-se que ao prever um leitor modelo, não significa de modo algum que o cronista tenha querido que ele existisse, porém, ao criá-lo, age sobre sua escrita em função dessa hipotética existência. Por outro lado, crê-se que o cronista e seu interlocutor irreal, ambos, têm um criado e não cumprirão a lei. Há um apelo à verossimilhança comunicativa, configurando sentido à realidade a partir de um ponto de vista infundado, porque ficcional.

Mas voltemos à realidade anedótica e pitoresca da qual falávamos acima e que nos desautoriza a ler a ficção machadiana como história. Ao justo, Machado passa ao largo da questão que se desenrolava no Rio Grande do Sul e o quiproquó entre a comissão e a intendência, algo teatral, bem "próximo do teatro lírico", que figura mais como mecanismo retórico que eco de uma realidade lastreada em episódios extraídos das notícias semanais, comumente retratada nas páginas d'“A Semana”. Na hipótese de ignorar os assuntos, o leitor contemporâneo ao cronista não fica sequer sabendo se ambos têm ligação entre si, e hoje, em face da escassez de referência histórica, pode-se até mesmo especular se esses eventos refletiram ou não na Revolta da Armanda ${ }^{49}$ que solapou Niterói cinco meses mais tarde.

Ocorre que o discurso tenta, sem sucesso, moldar-se a um real que, dissolvido na escritura, não tem função outra que servir de pretexto para as estruturas retóricas. A partir de um episódio compacto, o cronista volta-se às memórias, às reminiscências e harmoniza discursos que poderiam parecer equívocos à narrativa, criando uma rede de ficções organizadas a partir de sistemas de pensamento que se identificam, de modo que o texto deixa de ser uma representação do mundo exterior e se torna uma estrutura em mutação, ou seja, deixa de se constituir num simulacro do real para desenhar um relevo

\footnotetext{
${ }^{49}$ Movimento liderado pelo Almirante Custódio de Melo e segmentos da Marinha que se opunham à permanência no governo do Vice-presidente Floriano Peixoto, que desejava completar o mandato do presidente anterior. No dia 6 de setembro de 1893 um grupo de oficiais graduados da Marinha tentaria depor o presidente, a revolta ganhou apoio político e popular na cidade do Rio de Janeiro, onde a partir de 13 de setembro diversas unidades encouraçadas trocaram tiros com a artilharia dos fortes em poder do Exército. Houve sangrenta batalha na Ponta da Armação, em Niterói, área guarnecida por aproximadamente 3.000 governistas, na maioria compostos por batalhões da Guarda Nacional.
} 
mais profundo, algo como sua própria escrita. Nesse tipo de produção textual, a crônica abre espaço para a intertextualidade, ou melhor, para o dialogismo, ou a interdiscursividade, pois, de fato, não se trata da retomada de textos literários anteriores, mas da imitação de um discurso social perpetuado pela história - o de Mirabeau.

"A intendência, para imitar alguém, imita Mirabeau: _ Ide dizer ao povo, que estamos aqui pelos seus votos, e só sairemos pela fôrça das baionetas!” Ora, parágrafos antes, na mesma crônica, Machado afirma: "o espírito da imitação é altamente fecundo". A "fecundidade" provocada pelo impulso inspirador da citação sinaliza que o leitor estará, no mínimo, predestinado a uma dupla leitura: decifrar o modelo antigo, sua transformação, adaptação ou transgressão, como também, nesse vai-e-vem entre intertexto e hipertexto ${ }^{50}$, reler o que está à sua volta. De quebra, descobrirá que a retomada de um discurso, texto ou fragmento é, sobretudo, resultado da admiração, esta, constitutivo de grande importância na seleção, recorte e dissolução do empréstimo na escrita. Assim, nota-se :

Allez dire à votre maître que nous sommes ici par la volonté du peuple, et qu'on ne nous en arrachera que par la puissance des baïonnettes. ${ }^{51}$

\footnotetext{
${ }^{50}$ Aqui na definição de Gérard Genette (1982: 14): «J'appelle donc hipertexte tout texte dérivé d'un texte antérieur par transformation simple (nous dirons désormais transformation tout court) ou par transformation indirecte : nous dirons imitation. »

${ }^{51}$ Fala de Mirabeau a M. de Brézé, na sessão de 23/7/1789, da Assembleia Constituinte. A fala de Mirabeau tem sofrido pequenas alterações, dificultando mesmo saber o que literalmente teria sido dito, ou mesmo se algo foi dito. Sobre isso, embora um tanto longa, vale retomar a nota de Sauclières (1860 : 115116) em sua Histoire de la Révolution Française : «La version de Bailly est : 'Allez dire à ceux qui vous envoient que la force de baïonnettes ne peut rien contre la volonté de la nation.' On a beaucoup loué, ajoute Bailly, cette réponse, qui n'en est pas une, mais une apostrophe qu'il ne devait pas faire, qu'il n'avait pas droit de faire, puisque le président seul doit parler, et qui, en même temps que déplacée, était hors de toute mesure.

Plusieurs historiens rapportent la version suivante : 'Allez dire à votre maître que nous sommes ici par la volonté du peuple, et que nous n'en sortirons que par la force de baïonnettes.' Cette version fut même reproduite par M. Villemain, en pleine Chambre des pairs, dans sa séance du 9 mars 1833. M. le marquis de Brézé, fils de l'ancien grand maitre des cérémonies sous Louis XVI, lui répliqua avec feu, et rétabli les faits dans toute leur vérité et tels que nous venons de les rapporter. M. de Brézé invoqua le témoignage de plusieurs membres de la Chambre des pairs alors présents qui avaient fait partie de l'Assemblée Constituante, notamment M. de Montlosier, qui répondit à l'interpellation par des mots : C'est la vérité tout entière.

Voici maintenant ce qui dit l'abbé Monnet dans ses Mémoires: 'Je voudrais que ces mots sublimes eussent été prononcés ; mais je suis désespéré de détruire l'enthousiasme qu'ils inspirent encore au lecteur des récits de ces temps déjà si loin. Deux députés seulement me séparaient de Mirabeau, ma position me forçait d'avoir presque constamment les yeux sur lui, et je puis affirmer que ce n'est pas là le langage qu'il tint pendant la discussion élevée entre Bailly et le maître de cérémonies. Ma conviction est si forte à cet égard, que je défie les membres de l'Assemblée qui vivent encore, d'affirmer qu'ils ont entendu cette éloquente apostrophe, dont les éléments existent, il est vrai, dans la réponse du Démosthène français, mais qu'un député arrangea pendant la séance même, en y ajoutant les baïonnettes, et dont il fit ensuite
} 
A resposta de Mirabeau é dirigida ao mestre de cerimônias, escoltado por um pelotão de guardas franceses e um destacamento da Guarda Suíça; em seguida, Brézé transmite a informação ao rei que, em tom de desânimo, exprime sua impotência. "Eh, bien! s'ils ne veulent pas quitter leur salle, qu'on les y laisse" (POUJOULAT, 1866: 101). Machado, ao lançar mão da fala de Mirabeau, inverte a tribuna, altera os interlocutores, distorce a arenga do orador francês de modo que, transplantado para a pequena Niterói, é apequenado, parodiado, a ponto de o chamado l'orateur du peuple tutelar um desentendimento, ao que parece, entre pares: de fato, o cronista diz tratar-se de uma comissão que reivindica a saída da intendência, porém, não há qualquer indício de sua origem, ao contrário, a intendência faz apelo ao povo e à presumida legibilidade por ele garantida.

A inversão é hiperbólica: "O povo na qualidade de Luís XVI, exclama: É pois uma rebelião?" _ “Não, real senhor...", responde a comissão, fazendo rapapés. Sarcasticamente, o cronista brinca com o mito da "vontade geral" implícito na máxima rousseauniana de que "todo poder emana do povo" (ROUSSEAU, 1797: 26-33). Vejase: em um dos extremos, Mirabeau, orador na Assembleia, ainda que hipoteticamente, intitula-se representante do povo e resiste ao poder, ao rei; no outro extremo, na reduzida Niterói, não há extremos, ou melhor, se os há, estão unidos: a intendência, representante do povo, portanto, o poder, reporta-se ao povo, mas um povo na qualidade de Luís XVI, de "real senhor", ou seja, tão soberano quanto ela; é o poder falando consigo mesmo.

De fato, o cronista ironiza a capacidade de os políticos manipularem o populacho, empregando duplo sentido à palavra, pois, em se entendendo que todo poder emana do povo, conclui-se que também ele, o povo, é elemento inerente à soberania, uma vez que esta, manifestamente faz parte de sua essência.

Machado parece brincar com as definições, pois ao embaralhar povo e poder, soberania e populacho - o povo "real senhor", mostra o imbróglio que se pode criar quando teorias são subtraídas a serviço de uma classe política que concebe o absurdo de

honneur à l'orateur. Le public fut trompé : le caractère ardent et fougueux de Mirabeau la lui fit attribuer, et il aimait trop la gloire et le bruit pour démentir une circonstance d'importance, mais faite pour le flatter. Il n'en fallut d'avantage pour perpétuer une erreur qui, répétée jusqu'à nos jours, a acquis un tel poids par le crédit et l'autorité de mille écrivains, que mon assertion, je ne me le dissimule pas, paraîtra hasardée à beaucoup de monde, malgré ma qualité de témoin.' » 
colocar concomitantemente o povo governando a si mesmo e acima de si mesmo. Ou seja, o mito da "vontade geral", que não é uma simples vontade majoritária, mas uma vontade superior e indivisível, que emana do povo como entidade única, em Niterói, é trapaceado e fragmentado pela intendência diante da vontade da comissão que, supostamente, pleiteava seu afastamento. O fato é que a "verdade" aparece meio de lado, obscurecida num curto parágrafo: "Talvez houvesse programa combinado."

"Quantos fatos da história, que, parecendo espontâneos, são filhos de acôrdo entre as partes!" A bem dizer, essa é a crítica do cronista. E o intertexto, retomado em contexto estranho ao de sua origem, fecha-se no novo discurso. Em razão dos "lastros históricos" (indícios da engrenagem política, seus conchavos, conluios, intrigas, cabalas, etc.) sugeridos no corpo da crônica, por sua conta e risco, o historiador pode facilmente tomar um desvio estranho àquele trilhado pelo cronista que, definitivamente, não está preocupado com a comprovação do fato, simplesmente porque elabora de maneira livremente artística o quotidiano.

A exposição crítica do dia-a-dia é "literária", pois o cronista cede à ilusão e às lembranças. Com isso fatos e ideias são interpretados em estreita relação com as ideias dos outros, os acontecimentos ganham vida e a crítica exibe traço artístico, adquire outra tonalidade, reflete outros contextos, reproduz ecos de "vozes" anteriores e o quotidiano aparece na escrita de forma autenticamente pictórica, carnavalesca. A "realidade", para o cronista artista, não passa de uma "desculpa" que dialoga intertextualmente com a ficção. E, nessa "conversa" é como se o cronista reescrevesse um passado raspado do palimpsesto, cujos traços antigos são vistos e vêm à luz pela memória, de maneira que não se pode afirmar que a crônica constitui-se documento histórico; os fragmentos residuais ali encontrados, no máximo contribuem para a construção da cosmovisão artístico-literária machadiana! 


\section{A MEMÓRIA LITERÁRIA}

«... plus au moins, tous les livres, contiennent la fusion de quelque redite comptée...»

(MALLARMÉ, 1945: 367)

\section{A memória literária: faculdade que inviabiliza o ineditismo}

A epígrafe de Mallarmé provoca, move ideias, e talvez a principal delas seja a de que desde sua origem a literatura é um recontar ligado à memória. Nas sociedades ágrafas valorizava-se a oralidade, meio pelo qual se transmitia a cultura. Ao recontar a cultura dessa forma, através da repetição, ritmos e sonoridades se perpetuavam, inscrevendo-se por longo tempo no imaginário popular. Do mesmo modo, através da arte da mnemônica, reconhecia-se sobremaneira a importância da memória como instrumento capaz de sustentar o relato.

Isolado, não raro o relato é tomado como testemunho, porém, em sentido lato, coletivo, produz ecos, ganha densidade, propaga e registra o brilhantismo de ações e feitos memoráveis. À guisa da memória, torna-se procedimento da literatura, sempre que busca reconstituir um desses eventos, agenciar, explorar e trazer à luz episódios pretéritos e obscuros para re-contá-los por inteiro ou, ao menos, reproduzi-los de maneira lógica e organizada, via de regra, sempre à procura de um gesto fundador.

A origem está justamente nessa necessidade absoluta de querer buscar o porquê, a gênese, ainda que inverossímil e "ficciosa", para de alguma forma explicar a própria existência. A literatura segue caminho paralelo ao tentar perpetuar a memória do mundo e dos homens e com isso registra o movimento de sua própria memória. Ainda que hora ou outra tente se desvencilhar dessa espiral, transgredindo a si própria, seja negando evidências que alinhavam sua existência a uma literatura anterior, seja reivindicando sua própria originalidade, querendo ela própria estar na sua origem, o fato é que ao tentar afirmar sua pretensa concepção, acaba acionando o gatilho da memória, trazendo à tona todo um repertório constituído ao longo da circulação literária, inviabilizando, assim, todo e qualquer ineditismo.

\section{A intertextualidade e a expressão pessoal como originalidade}


A intertextualidade se caracteriza pela possibilidade de explicar e demonstrar como a literatura se escreve a partir das lembranças que tem de si mesma e, ao fazê-lo, aciona a memória através de uma infinidade de procedimentos - e elementos -, que surgem como constitutivos intertextuais. São traços como leituras, representações, símbolos, estilos, formas, epígrafes, alusões, metáforas, impressões, imagens, fisionomias, personagens, autores, etc. - e livros -, que, ativados pelas lembranças, se modificam, transgridem, adaptam, metamorfoseiam, completam, alteram cenários e intenções, trazendo à luz a questão da originalidade, porém negando e relativizando-a a ponto de hoje já se discutir seus efeitos nocivos:

La poursuite de l'originalité est mauvaise conseillère dans un temps où chacun s'accord à y voir la vertu principale de l'oeuvre de l'art. Elle n'aboutit pas du tout à marquer celle-ci d'un sceau reconnaissable. De nos jours, les gens qui s'efforcent d'être originaux sont si moutonniers qu'on se demande combien auraient songé à l'être si l'opinion nes les y avaient pas expressément invités. (CAILLOIS, 1958: 74)

É certo que opiniões semelhantes à de Caillois comportam certo grau de ambiguidade, uma vez que atingem de forma diferenciada a prática da escritura (e a literatura). A razão é simples: se por um lado o crítico relativiza a originalidade, considerando-a uma "busca pela busca" (portanto, fadada ao fracasso), por outro lado (algo que ele não considera), deve-se observar que muito dos aspectos "originais" de determinada obra resulta do entrecruzamento de ideias, fenômeno intertextual que configura estruturas inéditas e vigor à obra. No caso, o novo vem da genialidade do autor em retrabalhar elementos já disseminados ao longo da circulação das ideias, adaptando-os a diferentes contextos.

Assim, no desenrolar da história literária, em meio à crítica de fontes, citações, alusões, referências, paródias, pastiches, plágios, etc. (sem falar em paratextualidade, metatextualidade, arquitextualidade, hipertextualidade), seria mais atraente e imperativo sair em busca do inédito na feitura da expressão verbal, quiçá da expressão pessoal de cada autor, sondando sua coerência, eficácia e conformidade estética em contraponto às literaturas do passado.

Afinal, as ideias transbordam para além das convenções e a história, aos poucos, vai sendo recoberta pela pátina do tempo, preservando traços, riscos, restos de tinta, 
enfim, marcas do uso contínuo e muito provavelmente dos múltiplos usos, de modo que determinada obra, ao se inscrever no amontoado histórico das ideias, não só adquire densidade, mas, sobretudo, versatilidade, alimentando ideologias e argumentos díspares. Logo, com as ideias, umas se sobrepondo às outras, um ponto de vista original ou uma pureza teórica são, definitivamente, ilusórios.

Sempre que se reflete sobre a circulação das ideias, estas se vinculam de alguma forma à retomada de conceitos e relatos já ditos, enfim, à memória. A mobilidade desses princípios no espaço literário, suas dimensões e natureza ligam-se indubitavelmente à noção do intertextual a ponto de a literatura, em muitos casos, sustentar-se mais de seus liames literários que de suas ligações com o real. Samoyault (2005: 78) ao tratar das noções de referência e referencialidade, afirma que "la littérature ne parle pas du monde, mais d'abord d'elle-même, mettant en évidence l'hétérogéneité fondamentale du réel et du texte".

Ora, o texto machadiano prova dessa hibridez, pois atenua as fronteiras entre o real e a ficção: nas crônicas, gênero marcado pela contingência, ora o cronista envereda visceralmente pelo literário, retomando obras e autores, submergindo o real em meio a personagens e situações ficcionais de forma a minimizá-lo em importância com o risco de fazê-lo desaparecer aos olhos do leitor, ora caminha em sentido contrário, convergindo sua elocução para o dado real simplesmente porque nele vê a possibilidade de criar um contraponto com algo ficcional, ativando, assim, sua memória literária.

\section{Enunciados ficcionais, a compreensão do mundo e a subversão do tempo cíclico}

Nessa perspectiva - e porque o cronista trabalha com a consentaneidade entre um mundo possível e o mundo real ${ }_{-5}^{52}$, admite-se afirmar a pertinência de enunciados ficcionais como mecanismos suscetíveis de possibilitar a compreensão do mundo real. Diante de tal afirmativa, ouvem-se claramente ecos mallarmeanos sinalizando que "tout, au monde, existe pour aboutir à un livre" (MALLARMÉ, 1975: 378). Ora,

\footnotetext{
52 Eugenio Gomes em seu artigo "O testamento estético de Machado de Assis", ao tratar dos acontecimentos históricos em Esaú e Jacó, retoma Astrogildo Pereira ao observar que este destacara a "formidável transformação social operada no período abrangido pelo romance", porém, conclui que na obra "êste [período] transcende consideràvelmente o ângulo histórico por efeito da filosofia de vida implícita em sua esmerada qualificação estética", observando sobretudo "a poetização da realidade". (GOMES, 1958: 178).
} 
considerando-se o contradito do poeta francês, vale lembrar que, para ele, não existia literatura sem segredo, algo que de pronto sugere a impossibilidade desse livro (GODIN, 1997: 278).

Ademais, o assunto oferece um leque variado de abordagens críticas e, levandose em conta que, amiúde, o cronista machadiano usa da ficção para escarafunchar os segredos da alma humana, cabe lembrar Todorov que em La littérature en péril (2007: 89) afirma não só que a literatura é a melhor maneira de se conhecer o mundo, mas coteja a ideia de que um livro, para ser realmente um livro, deve compreender e conter o mais possível da humanidade ${ }^{53}$. Ora, Machado, enquanto cronista (e crítico) mostra-se profundo conhecedor da alma humana porque seu objeto de escrita não foi outro que a "condição humana". E, repetida vezes, esta vem à tona em suas páginas via ficção. Assim, torna-se duplamente conhecedor do homem: nas vezes em que o tem como objeto de sua escrita e quando interpreta a literatura, "ficcionalizando" artisticamente sua crítica.

Contudo, posto que para a literatura, o mundo é antes de qualquer coisa um livro (ou pode ser transformado em um), não se pode deixar de observar que o conjunto de ideias, formas, estilos, gêneros, etc., constitutivos da biblioteca universal, impõe-se como modelo, engendrando uma espécie de filtro entre o texto e o mundo:

Cette littérature "livresque", qui prend appui sur d'autres livres, serait l'instrument, ou le lieu, d'une perte de contact avec la «vraie » réalité, qui n'est pas dans les livres (GENETTE, 1982: 558).

Desse modo, é perfeitamente possível afirmar que embora a littérature livresque proporcione uma observação gazée (ou seja, alusiva, vista como através de uma gaze), ela contribui para a expressão artística do cronista, no sentido em que fatos da semana (sobre os quais Machado calcava suas opiniões e ironia) também não passavam de empréstimos do circunstancial que, ligados à sua memória literária, são amalgamados na escrita e, uma vez absorvidos, ganham foro de enunciados ficcionais, o que impede

\footnotetext{
${ }^{53}$ Entre outras questões, pergunta o critico: "L'objet de la littérature étant la condition humaine même, celui qui la lit et la comprend deviendra, non un spécialiste en analyse littéraire, mais un connaisseur de l'être humain. Quelle meilleure introduction à la compréhension des conduites et des passions humaines qu'une immersion dans l'oeuvre des grands écrivains qui s'imploient à cette tâche depuis des millénaires ? (TODOROV, 2007: 88-89)"
} 
que sejam vistos como "reais" os empréstimos feitos à realidade e preservados nas crônicas $^{54}$.

Exemplo dessa artimanha dá-se quando o cronista, à cata de ideias, retoma o ocorrido em São Fidélis ${ }^{55}$, onde o povo, revoltado, tomou a cadeia, destruiu-a e declarou não receber o subdelegado que para lá mandaram. Desta feita, o cronista conclui que “esta reprodução de 1789, em ponto pequeno, [...] é uma boa ideia", porém, deve-se observar: nem 1789, nem o apequenado episódio da "Bastilha" de São Fidélis adentram ou traduzem a importância do(s) acontecimento(s), cujo aproveitamento, na crônica, não é outro que auxiliar na construção retórica de um autor com o "carnaval à porta". Sem notícias, à espera dos "carros das idéias", o cronista combina eventos, indiferente à linearidade do tempo.

Pensar o universo como algo estático e repetitivo, regido por um tempo cíclico, ritualizado, em perfeita sincronia, parece não se aplicar na íntegra à memória literária, uma vez que à consciência e à criação artística acomodam-se alterações e iniciativas, na grande maioria, frutos do talento e do vigor da expressão individual. Ainda que essas manifestações, inconscientes e lacunosas, unam-se a concepções anteriores, alimentando a ideia de um mundo pleno, onde tudo já está lá, de maneira a confirmar os dizeres de Borges (1956: 28) que afirma que "todas as obras são obra de um só autor, que é intemporal e é anônimo",56, exatamente em razão do impulso criativo, há a possibilidade de se modificar o pecúlio pretérito, precisando, alterando, agregando ou adulterando sentidos. Nessa perspectiva intertextual a memória volta-se ao repertório literário não só para tutelar argumentos, mas também em busca de um provável ponto de partida.

\section{O trânsito entre literaturas, a contaminação pelo contexto cultural e o leitor}

Entretanto, nem todo autor dispõe de tudo ou está à distância de tudo, há certa complexidade ao se buscar por isso ou por aquilo; a seleção, com frequência dá-se em

\footnotetext{
${ }^{54}$ Sobre essa questão vale lembrar que Machado, não raro, dissimulava sua identidade, não só lançando mão de pseudônimos, mas também "brincando" com sua idade, ora envelhecendo ora remoçando (MAGALHÃES JR., 2008: 91, Vol. 1).

55 “Bons dias!", Gazeta de Notícias, 27/2/1889.

56 "todas las obras son obra de un solo autor, que es intemporal y es anónimo", in: "Tlön, Uqbar, Orbis Tertius".
} 
razão de admiração e oportunidade, que determinam a intimidade pessoal, a sedução por certa literatura, os limites e a abrangência das apropriações intertextuais. Machado, embora transite pelas literaturas italiana, espanhola e inglesa, é sabido, exercitou de maneira fecunda o mecanismo da intertextualidade, privilegiando a cultura francesa, fonte de suas inumeráveis leituras; idiossincrasia esta, muito provavelmente atribuída a ele em razão da irrefutável presença francesa na capital federal.

Enfim, algo que demonstra como a substância poética, a despeito da personalidade e do vigor da expressão pessoal, é contaminada pelo contexto cultural, de maneira que o idiossincrático responde pela personalidade, seleciona e destaca traços da experiência íntima dos sentidos e imprime textura específica à escrita, enquanto o envolvimento cultural determina um modo de organizar coletivamente o que se considera desejável, importante destacar ou mesmo excluir.

Desse modo, Machado, ao nutrir-se de seus contemporâneos e de seus predecessores em franco exercício de memória literária, engendrava a ideia de fecundidade futura, proporcionando ao leitor póstumo a possibilidade e satisfação do reencontro e da renovação através de uma escrita que se não pretexta algo de inaudito e original, ao menos atualiza em profundidade, revelando o que já estava lá, na grande biblioteca, e passara despercebido. Sem a preocupação do ineditismo, mas juntando os iguais e o que é essencial, Machado dá vazão à sua expressão pessoal e proporciona ao leitor a oportunidade de reencontrar aspectos que lhe são íntimos, porém distantes, cabendo à leitura a aproximação desejada pelo cronista.

Nessa poética de expressividade um tanto romântica, questionar se é factível escrever algo afastando de si tudo o que se leu e passando ao largo do cultural deixa de ser relevante, sobretudo porque, ao longo da circulação literária, é nítida a ostensiva recorrência aos antigos, de maneira que tão ou mais importante que o novo é a postura do leitor. Este, ao contrário, na maioria das vezes resiste a se deixar levar pelo desconhecido e quer reencontrar a si mesmo, atualizar um lado seu, ainda que obscuro, enfim, dar de cara com algo que, deixado na escrita, lhe é familiar e pode ser recuperado.

Assim como o autor, o leitor também compartilha de uma memória literária e é com base nesse seu repertório que ele pondera o inusitado, o novo, de modo a integrá-lo na genealogia das obras, considerando o que pode enriquecê-la sempre a partir de um 
conhecimento pretérito, alimentando dessa forma seu espírito crítico, que o autoriza qualificar o atual como excelente ou medíocre. De qualquer forma, é o consenso de um grupo - formado por autor, leitor, crítica - que determina no primeiro momento o que é possível, fecundo, interessante e, quiçá, genial.

\section{Os traços plurais, a atualização das obras e os connaisseurs}

Quer do ponto de vista do autor, do leitor, ou da crítica, tratando-se de memória literária, devem-se levar em conta os traços plurais das obras, o que, de certa forma caracterizam-nas como intertextuais. A pluralidade desses traços não pode ser reduzida a uma unidade, uma fonte, sequer um sistema homogêneo, uma vez que existem vários centros propulsores de ideias suscetíveis de garantir a pluralidade.

Em Machado, exemplos pululam: toda a série de crônicas com citações e referências a Candide (1759), de Voltaire, traz de arrasto Leibniz e a questão sobre a razão suficiente no sistema filosófico alemão; o riso voltairiano não pode ser comentado, sem que se observe o célebre discurso de Victor Hugo no Théâtre de la Gaité, Musset, com Rolla (1833), as assertivas de Petrarca e Plínio, o Velho, Cícero com seu De Oratore (55 a.C.), Aristóteles com Ética a Nicômaco, ou ainda os registros bíblicos, do Eclesiastes - todos versando sobre o riso, suas demonstrações, características e implicações. O plural, de caráter incontável, é definido pelas ocorrências, transforma-se, adquire formas exuberantes, díspares, ampliando a memória através de um sistema combinatório ad infinitum, sem que se torne enfadonho pelo uso, regendo-se tão somente pelo princípio de atualização.

Nessa lógica, qualquer nova realização literária vem de uma matéria global amealhada ao longo do tempo, e, se no esquema de cada obra, de cada episódio literário, suas múltiplas formas e seus aspectos essenciais são tutelados por obras predecessoras, a realização enquanto expressão que irrompe na escrita, o savoir-faire, este, cabe ao autor, à sua habilidade pessoal. Ainda que se afirme com isso a reiteração de ideias idênticas, não se quer aqui afirmar a impossibilidade de se produzir o novo. Inúmeros, como Pascal, nas Pensées (1837: 260), entreviram otimismo nessa prática:

Qu'on ne dise pas que je n'ai rien dit de nouveau: la disposition des matières est nouvelle. Quand on joue à la paume, c'est une même balle dont jouent l'un et l'autre, 
mais l'un la place mieux. J'aimerois autant qu'on me dit que je me suis servi des mots anciens, et comme si les mêmes pensées ne formoient pas un autre corps de discours par une disposition différente, aussi bien que les mêmes mots forment d'autres pensées par leur différente disposition.

Dessa forma, nota-se que o impulso criativo e sua apreciação coletiva são acionados a partir de um gesto precedente, um saber pretérito no qual o autor se apoia, algo já inscrito na tradição das obras e subtraído pela memória para o agenciamento de um novo discurso. Cabe, portanto, àquele que trouxe à luz a ideia adormecida, atualizála em consonância com seu tempo, reativando sentidos. O impulso criativo demonstra vigor literário na medida em que o autor procura triunfar do texto pressuposto, aproveitando sabiamente a ideia precedente, pois, à maneira de qualquer sintoma intertextual, essas apropriações comportam modificação do conteúdo, “forment d'autres pensées”, embora elas, as ideias "n'appartiennent à personne, elles circulent, volent, se dispersent et se posent, au gré d'un vent dont il faut mesurer l'orientation" (SAMOYAULT, 2005: 52).

Assim, a memória constitui-se mecanismo primordial para criar e inventar a partir da tradição; além do autor, a percepção do re-aproveitamento das ideias é reservado a uma parcela de leitores, um grupo reduzido de testemunhas, dentre as quais, os chamados connaisseurs, sensíveis às singularidades, que sabem apreciar e experimentar na identidade fundamental da ideia os sinais de diferença, as inovações operadas e manifestas no texto centralizador ${ }^{57}$, algo particular e excepcional que, malgrado as apropriações, inscreve a obra na tradição. Ainda que a fonte e apropriação sejam amplamente manifestas, cumpre ao connaisseur o ônus de determinar a fundo, ao longo da existência das ideias, seu percurso, suas mudanças e alterações estilísticas.

Mas não é essa a regra geral. Em parte, o público leitor é indiferente às singularidades da história literária, interessando-se pelo enredo e personagens sem, contudo, preocupar-se com a gênese e o parentesco dessas criaturas. Para esse grupo, em razão da importância que a nova obra adquire ao criar sua própria genealogia, notase certa "anulação" da origem e o "esquecimento" da fonte. Em muitos casos, a memória contribui para isso ao transplantar para o "novo" somente o conteúdo,

\footnotetext{
57 Aquele que detém o comando do sentido e acolhe em seu interior "vários textos" através de um trabalho de transformação e assimilação (JENNY, 1979: 14).
} 
convertendo de tal forma o substrato intertextual que, repetido à exaustão, passa à condição de primevo.

Para os connaisseurs, o percurso da memória é desafiador e desperta interesses. Circunscrevendo Machado, por exemplo, não se pode deixar de destacar o epíteto que remete aos olhos de Capitu, criando uma imagem intertextual que sinaliza uma história de ciúme. Se, superficialmente, os "olhos de cigana oblíqua e dissimulada" trazem de arrasto a Carmen, de Mérimée, com seus "yeux sensiblement obliques", mais a fundo, sob as pálpebras, desvela-se o topos presente na literatura da mulher como ser perigoso e sedutor.

Associado à cigana Carmen, a alcunha traz a essência desse topos como insígnia indelével das mulheres do demi-monde, que se destacam pela sedução como principal atributo feminino. Pertinentes a um mundo marginal, essas figuras, imortalizadas nas obras de Prévost, Dumas, Alencar, etc., contribuem para a construção do perfil de Capitu. O connaisseur, evidentemente, não se contenta com isso e descobre na menina de "quatorze anos, [que] tinha já idéias atrevidas", traços ancestrais de Judith, Salomé, Dalila, Circe, Eva, além de imbricações que ligam João Dias a Iago, de Shakespeare, coadjuvantes na história do ciúme, tal a extensão do percurso das ideias evocadas pela memória e retransmitidas em ponto pequeno. ${ }^{58}$

O fato é que a memória permite, ainda que de modo obscuro e fragmentado, que se continue a produzir e a re-lançar clichês largamente descritos, às vezes, de maneira persistente. Não se trata, evidentemente, de obras ou escritores específicos, mas de topos, do lugar comum, onde se encontra também a ideia de uma estrutura que promove e regula um número desconhecido - e ilimitado - de casos possíveis, alimentando a trama literária.

Ao connaisseur uma obra a mais, uma descrição a mais, proporciona ver o mesmo de outra forma, a variação dentro da conformidade, enfim, um prazer essencialmente lúdico que se estende ao leitor, induzido a apreciar a engenhosidade do autor, que soube inovar, valorizar a surpresa e imprimir à obra algo inesperado, embora manuseasse ideia redita. A inovação implica, quase sempre, jogar com os limites de identidade do lugar: o aproveitamento do topos em contexto diverso, possibilita a invenção e a criatividade na conformidade; com isso, a partir do oposto, o escritor

\footnotetext{
${ }^{58}$ Sobre a questão ver Capitu e a mulher fatal: análise da presença francesa em Dom Casmurro (PASSOS: 2003).
} 
possibilita, através do emprego de alusões, deslocamentos, aproximações e desvios, que o leitor aprofunde seu conhecimento sobre determinada matéria literária, a priori, difusa.

Assim, ainda hoje, pode-se reproduzir a ideia redita reformulando-a, em diferentes graus de maestria e sucesso, associando elementos, manipulando, combinando e restaurando-os. Nesse percurso das ideias literárias, três elementos permanecem: o autor, o leitor e a biblioteca universal. A retenção ou a coexistência das obras na memória dependem exclusivamente de como se organiza o dado poético/literário na escrita: alguns aspectos são supervalorizados, conferindo-lhes preponderância e status de origem, fundamento, referência e modelo - veja-se Les Fleurs du Mal (1857), de Baudelaire; algumas obras, como a Ilíada, de Homero, malgrado a distância no tempo, revelam-se tão atuais e pertinentes que sequer podem ser consideradas obras "datadas", tal o estoque de modelos e arquétipos que comporta.

À memória literária cabe cruzar o tempo, aparar os desníveis, interagir entre a idade e o status e imprimir ao canônico uma variante nova, suscetível de responder às questões atuais. Nessa lógica, a memória letrada tem justamente o efeito de isolar, impor e atualizar, a despeito do contexto histórico de origem, protótipos que pelo grau de correção, magistralidade e excelência, podem ser reproduzidos e adaptados à exaustão.

\section{As expectativas estéticas, o esquecimento e a reabilitação das obras}

Posto que leitores nutrem-se de expectativas estéticas em relação ao novo, este, ao vir à luz, é mais que um acontecimento estético isolado, pontual, pois se de um lado está incontestavelmente entrelaçado às obras ascendentes da grande biblioteca, por outro lado, repercute modificando e orientando o que vem a seguir. Ora, nem tudo o que vem à luz inscreve-se na memória, mas para se inscrever na memória é necessário que venha à luz, e nem sempre esse aparecimento coincide com a imediata valorização do trabalho.

A constatação de que a obra traz algo que a faz sobressair à grande massa, às vezes demanda tempo, e, se ao renascer em outro contexto provoca impacto, surpresa e admiração, não se compreende muito bem porque permaneceu esquecida. Contudo, há casos de reconhecimento imediato, se transitórios ou perenes, posteriormente, só a 
memória dirá. Exemplos insignes desse processo são o Mulato (1881), de Aluísio de Azevedo e Memórias póstumas de Brás Cubas (1881): o primeiro, enorme sucesso editorial à época, hoje, caiu no esquecimento.

Talvez porque já tivesse publicado Memórias de março a dezembro de 1880, na Revista Brazileira, quando o editou (1881), Machado, no célebre prólogo ao leitor aposta em cinco leitores, número muito aquém aos cem pretendidos por Stendhal. Falsa modéstia ou não, o fato é que a obra inscreveu-se na memória em processo de permanente difusão, sendo referenciada como "um desses livros arrebatadoramente originais" (SONTAG, 2005: 58-59), ou ainda como uma obra "que parece cavar um fosso entre dois mundos, [...] uma revolução ideológica e formal” (BOSI, 1994: 177). Memórias, por seu diferencial, inclui-se entre as obras que se propagam e suscitam palavras, textos e livros, por isso está sentenciada à difusão escrita, oral, pública e privada na voz das gerações futuras.

O livro revela-se um sortimento de possibilidades temáticas, retóricas, morais, etc., abre à atividade literária um mundo possível: nele a crítica traçou paralelos entre o romantismo e realismo, buscou elementos do romance impressionista, traços intertextuais e sociológicos, discutiu a ironia, o ceticismo, a sátira, o positivismo, o cientificismo, a filosofia, a psicanálise... Nota-se, contudo, que a obra impõe-se não como uma teoria, mas por estar lá, na biblioteca, como um acontecimento único, singular, às vezes, inacessível, incontornável, prevalece por ser uma fonte indefinida e contagiante de riqueza, enfim, uma obra-prima, cuja duração foi proporcionada pela lentidão do crescimento ao longo do tempo.

À época do aparecimento, a expectativa de ser um "acontecimento" é algo comum a todas as obras. Logo, submetidas a importante julgamento (apreciação do público e da crítica), algumas obtêm mudança de nível em razão de seu valor, o que faz com que se destaquem em meio à massa de livros. Outras, porém, sentenciadas ao esquecimento, nem sempre o são porque foram deglutidas pelo tempo, mas sim porque simplesmente foram ignoradas.

A história literária, tal como a conhecemos hoje, é repleta dessas lacunas ou mesmo elipses. No caso de obras antigas, tropeça-se muitas vezes nos obstáculos materiais que o tempo, providencial, encarrega-se em fazer desaparecer. Outras, no entanto, embora antigas e à disposição nas bibliotecas, por motivos diversos e obscuros, 
são ignoradas, prova de que o reconhecimento pela história literária nem sempre está disponível para produções não sem interesse. Por outro lado, alguns autores - talvez porque lutassem contra as crenças recebidas ou suas obras iam ao encontro das disposições dos homens, muito bem sucedidos em vida, passado o entusiasmo que as fizeram vir à luz, caíram no esquecimento. Outros (Ronsard, por exemplo), após a morte, desprezados pelos séculos seguintes, são reabilitados e contribuem com os ânimos do momento.

Porém, nem sempre as escolhas obedecem a esses "ânimos" e à complexa antecipação coletiva que rege a concepção e a recepção das obras, mas sim à memória, própria, pessoal. Assim como num movimento natural, as evidências ascendentes se deslocam da grande biblioteca em direção ao novo, e a memória pessoal contribui para a construção da história das letras a partir do gosto, da apreciação. É certo que muitas obras se inscrevem na memória a partir da avaliação de um grupo de connaisseurs que, portadores de certa jurisdição, organizam a cena literária atribuindo ou não valores às obras recém-chegadas, porém, matrizes podem ser criadas a partir de autores e leitores, que exprimem seu "gosto" de maneira pragmática. Além disso, ao longo do tempo, tais connaisseurs perdem sua influência.

\section{Aspectos da memória literária: clássicos e modernos}

A memória literária se fortalece de maneira circular no classicismo, quando a produção literária usufrui de certa estabilidade em virtude de sua regulação. Nesse contexto, autores e leitores compartilham, de forma geral, os mesmos valores e gostos, criação e crítica andam em consonância. As futuras gerações, espelhando-se em modelos e reproduzindo fragmentos, desvios, temas, tons e estilos se veem capazes de produzir variações lúdicas a partir de uma mesma biblioteca, alimentando com isso uma forma de apreciação que se constitui na própria fecundidade do classicismo.

A competência retórica se propaga sequencialmente e o que vem a seguir é uma produção moderna bastante distinta da precedente: essa produção posterior insta por liberdade e tem como principal característica o fato de que é igualmente apreciada pelo público leitor, que nela, influi ativamente. Inicia-se então a saída do círculo clássico e, com o romantismo - principalmente o romantismo alemão -, aspectos sobre a criação 
literária e a crítica cultural passam à discussão. Abre-se, em várias frentes, uma nova reflexão a propósito da apreciação estética, sobretudo de perspectiva histórica, provocando um "renversement de valeurs", como afirma Florence Lotterie (2006: 203) em "Le discours historique: une laïcisation ambiguë":

$\mathrm{Au} \mathrm{XVII}^{\mathrm{e}}$ siècle, le discours historique tend à mesurer le devenir humain en fonction d'écarts à la norme intellectuelle de la liberté critique et parvient ainsi difficilement à se répresenter une temporalité productrice de positivité continue.

Com isso, a memória sugere uma reavaliação cuidadosa da grande biblioteca, de modo que não se valorizam somente as obras, mas também a ideia de que a arte é a expressão de uma força interior. Funda-se, desse modo, um jeito romântico e novo de apreciar, próximo da criação: inspiração e experiência poética pessoal ganham impulso, a arte que se faz e a arte que se herdou, ambas, manifestam valores particulares na criação e apreciação.

Contudo, apesar desse jeito novo de conceber e ou avaliar a obra de arte, os clássicos são estáveis e em relação ao acesso à grande biblioteca, persistiu a ideia da imutabilidade dos modelos. Exemplo de resistência ao novo, a Querelle des Anciens et des Modernes, no final do século XVII, ilustra o enfrentamento de ideias entre os Anciens, que defendiam os clássicos como legítimos modelos de poesia, pleiteavam a vigência da arte antiga e rejeitavam sumariamente qualquer obra moderna, e, os Modernes, que defendiam o afastamento das regras clássicas. Era um período de transição no mundo das ideias e Kant (2006: 127), que parece ter se oposto aos Modernes, afirma:

Os modelos da bela arte são por isto os únicos meios de orientação para conduzir a arte à posteridade, o que não poderia ocorrer por simples descrições (principalmente no ramo das artes do discurso), e também nestas somente podem tornar-se clássicos os modelos em línguas antigas, mortas e agora conservadas apenas como línguas cultas.

Nessa lógica - e por extensão -, exatamente por estarem fora do alcance, distanciados da língua e da civilização, esses modelos podem ser canibalizados à medida que são reaproveitados ao longo da circulação das ideias, alimentando o conceito operatório da intertextualidade. 
Com o advento do romantismo, entretanto, as obras passam a ser vistas como resultado do talento, desse ou daquele escritor. Diferente dos clássicos, distanciados pela língua e a civilização (já mortas), essas obras-primas modernas reaparecem de tempos em tempos e não são compreendidas como modelos de perfeição à maneira de Homero, mas pela grandeza do gênio, portanto, algo único, extraordinário e que não se deixa pilhar à guisa dos clássicos perfeitos.

Ainda se pode, por exemplo, pilhar Homero de forma direta e sem entraves, embora isolado na aurora dos tempos, porém, no caso dos modernos em que o gênio substitui essa distância heróica, a relação com as suas obras é indireta e oblíqua. Os clássicos gregos, por exemplo, não só ensinavam como fazer, como também disponibilizaram um sortimento substancial de conteúdos dos quais, ainda hoje, a literatura se nutre, de modo que os antigos serviam como alimento, enquanto os modernos são enigmáticos sinalizadores.

Reproduzir Proust, repetindo suas ideias, seu modo de escrever, a temática de sua obra, seria a um só tempo estimulante e desencorajador, porque muito provavelmente uma experiência fadada ao malogro; especulação esta que comprova a valorização do gênio nos clássicos modernos e seu papel de guia e expoente no universo literário atual.

O fato é que houve uma mudança no universo das letras: mudou o relevo, os nomes, a história, as condutas, a distribuição, a recepção, o modo de subtrair (a pilhagem antes feita sem cerimônia, hoje, requer aspas e notas de rodapé, traveste-se de paráfrase). Enfim, os modernos ainda diferem dos antigos em relação à completude: estes, distanciados no tempo, à sombra de uma civilização e língua já extintas, não pedem acréscimos e se perpetuam, ao passo que os modernos em parte se alimentam do interesse, do prazer e da expectativa do leitor. Uma vez extinto o sentimento de interesse, reduz-se a importância da obra, algo como uma bolsa de valores, onde autores e obras sofrem com os revezes e as flutuações do câmbio apreciador.

"No princípio era o Verbo..."59, de modo que a partir deste versículo bíblico é possível perfilhar a ideia de que a palavra consubstanciada ao discurso é instrumento essencial do pensamento, ferramenta incontestável da reflexão e do espírito. E a memória literária? Mais où sont les neiges d'antan? É necessário que exista uma obra

\footnotetext{
${ }^{59}$ Evangelho segundo São João, 1:1.
} 
para que nasça a literatura. A memória literária, como é sabido, é um repositório de nomes e de obras. Em geral, busca-se nesse princípio algo identificado por sua excelência, uma obra-prima, portanto, tomemos simbolicamente Homero. A memória, no mundo ocidental, volta-se à "l'aurore aux doigts de rose" e lá encontra Homero: por isso ela é cultural, monumental e heroica e, na literatura, torna-se surpreendentemente nominativa. Esse ímpeto mnemônico que busca a facilidade de memorização organiza os eventos em gêneros, escolas, rubricas, noções, alusões, nomes coletivos, separa os acontecimentos literários geograficamente, em datas, períodos históricos, tudo para atender às necessidades da descrição, da análise, da polêmica.

Nota-se que a memória trabalha (não só!) com obras monumentais que, entre outros efeitos, acionam um processo reativo ao longo da circulação das ideias: um sucesso extraordinário, inesperado, estimula a admiração e suscetibilidade do possível. Machado, sob os efeitos provocados pelos sinos da igreja do Carmo, admite:

Quando um dia li o capítulo dos sinos em Chateaubriand, tocaram-me tanto as palavras daquele grande espírito, que me senti (desculpem a expressão) um Chateaubriand desencarnado e reencarnado. ${ }^{60}$

Sobre o mesmo Chateaubriand, Victor Hugo, no impulso de seus quatorze anos, teria escrito em seu diário, em 10/7/1816:

Je veux être Chateaubriand ou rien. (HUGO, 1867: 339)

Através da memória, Homero, Hugo, Chateaubriand e tantos outros suscitam em seus pósteros a aspiração, o anseio de fazer - igual -, de entrar na poética que revelam, e, tudo o que vem a seguir constrói-se à sombra ou à luz das lembranças de cânones, arquétipos, protótipos, os quais, despertados pela admiração ou oportunidade, instauram, através dessa retomada, uma repetição de contornos cada vez mais complexos à medida que se distanciam da origem, com o entrecruzamento das obras,

60 “A Semana”, Gazeta de Notícias, 3/7/1892. 
possibilitando ao intertexto engendrar novos sentidos, quando transposto ao "texto centralizador" ${ }^{\prime \prime}$.

\section{A memória cultural - dos outros}

Imitatio, pilhagem, intertextualidade - todos - princípios submetidos à memória. Machado desde muito cedo reconheceu a prioridade e os influxos da memória dos outros na literatura nacional. Leitor contumaz e sensível, logo despertou para os benefícios e danos dessa memória à literatura de seu país, sobretudo a francesa que, indiscutivelmente, à época, figurava como parâmetro e comparativo. Lugar comum é o artigo que publicou n' A Marmota, em 23/4/1858, intitulado “O passado, o presente e o futuro da literatura" (2008: 1002, Vol. III):

Tratemos das três formas essenciais: - o romance, o drama e a poesia.

Ninguém que for imparcial afirmará a existência das duas primeiras entre nós; pelo menos, a existência animada, a existência que vive, a existência que se desenvolve fecunda e progressiva. Raros, bem raros, se têm dado ao estudo de uma forma tão importante como o romance; apesar mesmo da conveniência perniciosa com os romances franceses, que discute, aplaude e endeusa a nossa mocidade, tão escrupulosa de ferir as susceptibilidades nacionais.

Nota-se a dificuldade que a memória cultural dos outros impõe àqueles que a têm secundária, obrigando-os a perpetuá-la através da discussão, da admiração e do "endeusamento", enquanto à recente e "nova" memória e ao que é "genuinamente" seu, restam melindres, desconfiança e suscetibilidades. É certo que cabe a cada época o direito de julgar seu presente e seu passado, aquilo que é e o que o precedeu. Machado, no referido artigo, aprecia o trajeto percorrido pela literatura nacional desde seu início, quando estava intimamente entrelaçada à portuguesa.

A princípio, em um parágrafo de tom hiperbólico, anuncia a literatura e a política como duas faces distintas da sociedade, que se misturaram à medida que “cingiram como uma dupla púrpura de glória e de martírio os vultos luminosos da nossa

\footnotetext{
${ }^{61}$ Em retomada à definição de Jenny (1979: 14) de que "a intertextualidade designa não uma soma confusa e misteriosa de influências, mas o trabalho de transformação e assimilação de vários textos, operado por um texto centralizador, que detém o comando do sentido".
} 
história de ontem", em seguida, proclama "uma raça heróica que lutava contra a indiferença de uma época", para depois trazer à luz "apóstolos do pensamento e da liberdade" e "novos Cristos da regeneração de um povo, cuja missão era a união do desinterêsse, do patriotismo e das virtudes humanitárias", fazendo crer com isso na existência de uma raça de homens autossuficientes, alheios à memória e à dependência de convenções literárias externas.

Logo, porém, constata que a poesia tinha "caráter essencialmente europeu" e Gonzaga trazia em si "a frase de Garrett", renunciando a cor local. No entanto, nem tudo estava perdido: apareceu Uruguai (1769), de Basílio da Gama, "se não puramente nacional, ao menos nada europeu”. A presença francesa alicia jovens e acantona o autóctone ainda "vacilante sob a ação de uma literatura ultramarina", e Machado parece aborrecido ao concluir que é muito mais fácil regenerar uma nação que uma literatura.

Mas o que vem a ser "regenerar"? Excluir ideias que não as concebidas em seu meio? Ser indiferente às tendências literárias irrompidas em solo estranho? Não, "regenerar" parece, definitivamente, imprimir vigor e fôlego a um universo apático, fatigado, que anuncia uma "decadência prematura", e Machado aponta o caminho a seguir: explorar a sociedade, esse "aluvião de tipos e caracteres de tôdas as categorias", algo que trabalharia eximiamente em seus romances. Porém, ciente da inexistência de uma "literatura convenientemente desenvolvida" conclui:

\footnotetext{
No estado atual das cousas, a literatura não pode ser perfeitamente um culto, um dogma intelectual, e o literato não pode aspirar a uma existência independente, mas sim tornarse um homem social, participando dos movimentos da sociedade em que vive e de que depende.
}

Ora, participar "dos movimentos da sociedade em que vive e de que depende" é nada mais que o embrião da célebre assertiva machadiana em "Instinto de Nacionalidade" 62 , quando afirma "que se deve exigir do escritor antes de tudo, certo sentimento íntimo, que o torne homem do seu tempo e do seu país, ainda quando trata de assuntos remotos no tempo e no espaço".

Nota-se com isso o amadurecimento do pensamento machadiano: se em 1858, ao exortar a participação em movimentos da sociedade e buscar uma regulação para a

\footnotetext{
${ }^{62}$ O Novo Mundo, Nova York, n $30,24 / 3 / 1873$.
} 
influência da memória externa parece não ter opinião definida, pois, ora considera perniciosa a conivência dos franceses ora admite a impossibilidade de o "literato não pode[r] aspirar a uma existência independente", em 1873, embora não afirme que essa conivência atenda ao gosto e às necessidades da literatura, reconhece que ser alguém de seu tempo é também tratar de "assuntos remotos no tempo e no espaço", aproximandose de uma problemática antiga às voltas da transferência da memória, na qual questões como fragilidade e imposição desta ou daquela literatura são trazidas à luz ${ }^{63}$.

\section{Dois polos na memória}

Diante disso, criam-se dois polos na memória: obras arcaicas e obras contemporâneas. Às obras arcaicas, reconhecidamente memoráveis pela tradição, nos apegamos quando não temos qualquer outra memória - próxima e mais íntima -, que preencha nosso espírito e proporcione fruição aos nossos gostos e sentimentos; contudo, como só o admirável é, de fato, memorável, as obras contemporâneas nos proporcionam verdadeira admiração, a ponto de nos interagirmos com obra e autor à maneira de Barthes, quando afirma que "vivre avec Sade, c'est à certains moments, parler sadien, vivre avec Fourier, c'est parler fouriériste" (1971:12).

$\mathrm{Na}$ França, a admiração pelas obras contemporâneas impôs nova problemática, discutida com a Querelle des Anciens et des Modernes: o que fazer com o século XVII impondo-se face aos antigos? O que fazer quando se têm dois núcleos geradores de modelos, produtores de obras-primas? Enfim, algo que se repetiria com o século XIX inundando os cérebros com obras admiráveis de Hugo, Stendhal, Flaubert, Zola, Proust e tantos outros; o que fazer quando o que é admirável não está mais distante, em segurança na aurora dos tempos, fora de alcance, mas à mão, passível de ser manipulado, questionado, submetido às ideias e teorias contemporâneas à obra?

Nas nações novas, a discussão ganhou novos contornos: como amalgamar o local às convenções literárias externas de modo a fundar uma literatura nacional? Invariavelmente a intenção de instituir uma memória coletiva futura, resvala em certo

\footnotetext{
${ }^{63}$ Sobre essa questão, vale retomar Horácio (1846: 135-167) - Livre II - Épîtres I (À Auguste), onde o autor reflete sobre o "novo", a idade das obras, sua apreciação e a "inferioridade" autóctone de Roma face aos gregos.
} 
voluntarismo nacionalista, o que suscita a criação de inúmeras obras (José de Alencar e seu projeto nacionalista figura como exemplo insigne na Literatura Brasileira).

Se as obras antigas despertaram uma admiração que permitiu, entre outras coisas, a imitação e a pilhagem como fenômenos constitutivos do que veio a seguir, revelando-se, sob este aspecto, provocadoras e estimulantes, as obras contemporâneas deixaram de responder a esse modelo "universal" a partir do momento em que começaram a versar sobre problemas, hábitos, costumes e sociedades específicas, absorvendo em sua estrutura dimensões político-nacionalistas; como modelos, angariaram a admiração dessas sociedades por representá-las e de tantas outras quando, em períodos específicos, mostraram efetiva influência político-cultural. Veja-se Junqueira Freire em seu Elementos de Rhetorica Nacional (1869: 50-51):

Depois da gloriosa época da nossa emancipação política, têm surgido muitos gênios, mas ainda não temos completa a nossa emancipação literária. Enquanto não a tivermos, e formos obrigados a seguir um norte, sigamos a França. Porque é ela o farol que ilumina todo o mundo civilizado.

As obras se acumulam, o dispositivo de transmissão de memória é fecundo, atribuindo às "novas" status de obras-primas, clássicos modernos ou clássicos da literatura nacional, que, integrados à grande biblioteca, mudam de significação e de alcance. Embora a seleção seja apurada, algumas ultrapassam o status representativo de memória coletiva específica, galgam consideração e prestígio global e alimentam um jogo combinatório e intertextual com inúmeras outras literaturas, até que futuramente adquiram dimensão temporal, tornando-se patrimônio comum - memória.

\section{O núcleo estável da memória}

Inserir-se na memória, integrar-se à grande biblioteca, permite o aparecimento de traços comuns em literaturas díspares, instituindo um corpus que se altera ao longo da circulação das ideias. Esse corpus memória submetido à reflexão crítica, à inspiração, às interferências históricas e ideológicas, às preocupações e julgamentos estéticos, é modificado e faz com que o memorável apresente zonas de instabilidade, nas quais a importância do texto sofre visível transformação, embora mantenha seu núcleo estável. 
Tome-se como exemplo Romeu e Julieta (1597), de Shakespeare, que adaptado à exaustão e submetido a diferentes tipos de mídia e contextos desiguais, ainda assim, preserva a ideia central de que o ódio entre os mais velhos pode sacrificar o amor dos jovens.

O fato é que apesar de a obra estar inserida entre as literaturas nacionais, algo que pertence a seu núcleo, à parte estável, é arbitrariamente calcado de um fundo de memória universal, sem o qual as obras não se reconheceriam e o leitor não se mostraria íntimo a ponto de intuir continuidade e correspondências entre umas e outras. A seu modo, em prefácio ao livro Harmonias Errantes (2008: 1257-1258, Vol. III) ${ }^{64}$, Machado teorizou a imutabilidade do núcleo da memória:

Que a evolução natural das coisas modifique as feições, a parte externa, ninguém jamais o negará; mas há alguma coisa que liga, através dos séculos, Homero e Lord Byron, alguma coisa inalterável, universal e comum, que fala a todos os homens e a todos os tempos.

Exemplos dessa imobilidade proliferam na literatura: amiúde, pela sua estatura, Shakespeare oferece exemplos: Otelo, cujo núcleo gira em torno da maldade e do ciúme infundado de Iago, traz de arrasto a ideia de que o homem sempre mata o que mais ama, incubada em visível alusão intertextual à passagem bíblica "le Seigneur châtie celui qu'il aime" (Hébreux, 12: 6), constituindo-se o texto bíblico, por sua tradição, no fundo de memória universal. Veja-se o intertexto transplantado para a tragédia shakespeariana:

\author{
OTHELLO: [...] \\ __ One more [kiss], ands this the last: \\ So sweet was ne'er so fatal. I must weep, \\ But they are cruel tears: this sorrow's heavenly; \\ It strikes, where it doth [does] love. ${ }^{65}$ \\ (SHAKESPEARE, 1837: 138, Act V, Scene II)
}

\footnotetext{
${ }^{64}$ Carta-prefácio a Harmonias Errantes, de Francisco de Castro, publicada em 4/8/1878; Tipografia Moreira, Rio de Janeiro.

65 "Outro beijo, o último. Nunca houve um assim, tão delicioso e tão fatal. Choremos. O meu pranto é feroz, a minha cólera é como a de Deus, que fere a quem mais ama."
} 
O ciúme permanece como núcleo estável da tragédia shakespeariana (assim como o caráter sacrificial da morte de Desdêmona) ${ }^{66}$. O que vem a seguir são contextualizações a partir de um intertexto que se perpetua ao longo da circulação das ideias como núcleo, ainda que dissolvido em discursos: Bentinho, receoso, diz um dia “_ Não fales em morrer, Capitu!" (Dom Casmurro, cap. XLIV), tempos depois, ainda no teatro, corroído pelo ciúme e sob claro influxo shakespeariano, sentencia: "O último ato mostrou-me que não eu, mas Capitu devia morrer" (cap. CXXXV). Desse modo, vêse o movimento das ideias a partir de um patrimônio comum composto não só da antiguidade compartilhada, mas principalmente de um apanhado bastante eclético de obras-primas da literatura mundial.

Nesse contexto, a dispersão das obras através de comentários e interpretações reflexivas é responsável não só pela proliferação e atualização dos antigos e dos clássicos, mas também pelo nascimento de produções que se consideradas secundárias quando comparadas à literatura, certamente não o são no universo das letras: são as obras críticas, que difundem e atualizam os grandes impulsos criativos da antiguidade e dos clássicos. O mundo das letras busca reconstituir traços deixados entre os eventos literários, analisar suas correlações com a grande biblioteca, inteirar-se do ambiente e das preocupações de determinada época e com isso investigar a lógica do discurso de um tempo e sua relação com as obras que produziu, enfim, busca entender a absorção do mundo nas letras, na ficção.

\section{As obras de estudo e Machado}

É comum as obras de estudo atingirem o mesmo grau de reputação das obras ficcionais, figurando como códigos de acesso a uma ficção que se pretende criptografada: são estudos, teses, monografias, tratados, ensaios, artigos, obras teóricas e históricas, volumes de estética, enfim, todo um aparato que se constitui ele próprio intertextual, resultado da memória coletiva, da literatura como tecido contínuo. Não raro, nota-se que a leitura das obras explicativas antecede à leitura das obras de origem. Michel

\footnotetext{
${ }^{66}$ Alfred de Vigny, por exemplo, em versão para o francês (Le More de Venise, Othello, 1829), vai além do texto shakespeariano em sua "interpretação bíblica" e traduz o verso acima por: "Il faut que je pleure! ah! C'est que ma fureur même/ Est le courroux du Ciel qui frappe ce qu'il aime.", algo que em tese poderia ter sido traduzido por: "Cette douleur tient du ciel, elle châtie qui elle aime.". Sobre isto consultar: (VIGNY, 1830: 169) e (JARRY, 1998: 239).
} 
Schneider, em Voleurs de mots (1985: 110), explica esse conhecimento instaurado pela "métalangage critique":

Si l'on dit - formule convenue: "Je relis Madame Bovary" qu'en fait on n'a jamais lu, ce n'est pas fondamentalement pour masquer les lacunes de sa culture mais parce que les classiques entrent en nous préfigurés par leur réputation, enveloppés d'un métalangage critique, précédés d'une rumeur. Ils ne sont déjà que l'écho de leurs noms.

Os ecos se propagam em vários sentidos e esta prefiguração da memória cultural se instala a partir da repetição, do redizer, da retomada, da reescritura, de modo que a intertextualidade não se limita à produção, mas também à recepção, seja sob o olhar prazeroso do leitor seja sob o olhar crítico do connaisseur; ambos, cada um a seu modo, contribuem para a sinapse e transmissão da memória literária. Ao longo da circulação das ideias, a realidade intelectual é uma só: a superpopulação e densidade das obras, de modo que, nesse universo, isolar momentos máximos, obras-primas e volumes de pureza teórica, torna-se algo ilusório, ineficaz.

Uma plêiade de escritores de primeira ordem não é suficiente para fomentar uma vida intelectual, alimentar a memória, movimentar as ideias: é preciso uma multidão de leitores, escritores admiradores e apaixonados, assim como não só de obras-primas vive a memória, mas também do rumor provocado pelas obras menores.

Machado, levado pela admiração, exercitou incansavelmente sua memória literária em constantes visitas aos antigos e clássicos, inundando sua produção com referências, citações e alusões às obras da grande biblioteca, privilegiando, inclusive, as chamadas obras "menores". Hoje considerados exercícios de experimentação intertextual, as referências e empréstimos machadianos foram objeto de reiteradas críticas, a exemplo de Cruz e Sousa que o rotulou de "plagiário de Gil Blas" (GRIECO, 1959: 23).

No Brasil, quando a compreensão das obras padecia sensivelmente com a ausência de instrumentos teóricos, impossibilitando maior alcance interpretativo, e a crítica, inconsciente de sua intertextualidade natural, preferia ver no diálogo entre textos ranço e falta de criatividade, Machado sofreu com as diatribes de alguns de seus leitores especializados. Nos idos em que conceitos como intertextualidade, interdiscursividade, dialogismo, polifonia, etc. jaziam adormecidos, Agrippino Grieco, por exemplo, ao 
confessar resmungando que o admirava, afirma que Machado "sabia tudo dos franceses", acrescentando a isso - ou por isso -, que "Machado de Assis dá antes idéia de um escritor de civilização cansada, de fimm de raça” (1959: XI).

Em seguida, Grieco elogia o cosmopolitismo da obra machadiana, aproxima-o de Balzac, Dickens e Eça de Queirós e entrevê nos franceses as razões de gosto e reticência do leitor em relação à obra machadiana:

\begin{abstract}
O leitor brasileiro, ainda quando não o perceba, gosta de ler Machado pela nítida forma francesa das suas narrações. Ora, os franceses poderão sentir grande prazer ao se reencontrarem aí a si próprios? Seria justo objetar que as notas afrancesadas de muitos tipos de Joaquim Maria resultam de uma idade em que era epidêmica a influência dos figurinos parisienses na vida social do Rio. Mas os patrícios dos livreiros, cabelereiros e perfumistas que encheram a antiga Rua do Ouvidor, êsses não querem saber de trabalhos que, lembrando Mérimée e Stendhal, não excedam Stendhal ou Mérimée. (1959: XI)
\end{abstract}

Mais à frente, Grieco, que desconhecia os conceitos intertextuais, retoma Afrânio Coutinho e afirma:

Quem tem razão é Afrânio Coutinho ao assegurar que Machado, ledor prodigioso, "uma verdadeira esponja", formava a sua liga através "de um processo de assimilação e transformação". Jamais se mostrou um decalcomaníaco. Apenas, cerebral como era, livresco por excelência, não poderia eximir-se a influxos encontráveis em todos os grandes escritores. (1959:4)

Coutinho (1960: 32-33), em análise da obra machadiana, destaca sua riqueza de princípios estéticos “à luz dos quais Machado estabelece seus juízos de valor”, observa a natureza aristotélica de sua crítica e finalmente comenta sua técnica de ficção e composição:

Aspecto importante é o das impregnações e reminiscências de outros escritores em sua obra. O estudo das influências em Machado revela a enorme dívida do escritor aos estrangeiros, antigos e modernos, dívida tão grande que dá idéia de uma verdadeira esponja, cujo processo era a assimilação e transformação de muito material de outrem recebido pela leitura. 
O que importa em arte não é o material, venha de onde vier. É o modo como é tratado. É o seu tratamento original, artístico. E êsse foi o sêgredo de Machado.

Ao buscar em fontes alheias inspiração, sugestões, imagens, moldes, fórmulas, soluções, jamais usava tais contribuições exatamente como estavam na origem, nem reproduzia literalmente.

Nota-se, ao comparar os dois entrechos, o trabalho de Grieco com a tesoura ao desenraizar Coutinho e transplantá-lo em contexto de significação adversa, ignorando exatamente algo que enaltece a escritura machadiana, "seu tratamento original [e] artístico", expressão de sua habilidade no trato intertextual, concorrendo assim, para a “desvalorização" dessa escritura. O esforço de acomodação cria uma problemática na qual a crítica degrada a si mesma, no intuito de contaminar o texto analisado: Grieco impõe ao texto um desvio de sentido que altera a unicidade do discurso de Coutinho, esfacelando sua integridade e induzindo o leitor a mitigar Machado, sobretudo depois da afirmativa de que seu leitor contemporâneo não queria "saber de trabalhos que, lembrando Mérimée e Stendhal, não excedam Stendhal ou Mérimée”.

\section{Machado e os influxos franceses}

O fato é que o Rio de Janeiro imperial tomava-se por réplica de uma Paris acantonada nos trópicos, uma cidade que abdicava de suas características próprias e se afrancesava em tudo. "A mocidade se intoxicava de Alfred de Musset e de Victor Hugo" (MAGALHÃES JR., 1957: 128), a Revue des deux mondes era uma "espécie de Bíblia contemporânea" e vivia-se "uma fase de bovarismo social e intelectual, sonhando modelar a vida do Rio de Janeiro pela vida de Paris".

Machado, inserido neste mundo afrancesado, ainda muito jovem, publica no Correio Mercantil, em 21/7/1859, uma poesia escrita em francês intitulada $A C h$. $F$., filho de um proscrito, dedicada ao filho de Charles Ribeyrolles, exibindo sua condição de escritor bilíngue. Aliás, a exemplo do mundo literário, o mundo jornalístico estava tomado pela língua, cultura e ideias francesas; não só alusões, mas também citações em língua estrangeira inundavam os jornais da época, algo corriqueiro e que não causava surpresa, até mesmo porque esses entrechos eram destinados a um público letrado, tão íntimo do teatro francês - e admirador de Sarah Bernhardt -, quanto do teatro italiano, 
afinal, dizia Machado, quem não se lembra da célebre Candiani, que teve seu carro puxado por homens, soprano que "não cantava, [mas] punha o céu na bôca, e a bôca no mundo" e que ao suspirar a Norma (1831), de Bellini, punha "a gente fora de si",67?

O Rio é francófono e muito dessa movimentação pode ser acompanhada nas crônicas machadianas: a vida político-cultural francesa frequentava essas páginas, imiscuíam-se também por elas $\mathrm{M}^{\text {lles }}$ La-grua, Charton, Risette e Aimée, provocando suspiros na plateia - e no cronista -, companhias francesas (de teatro e ópera) mereciam comentários, em geral, elogiosos; personagens, obras e autores franceses ilustravam fatos quotidianos e figuras políticas locais, enfim, crônicas ganhavam entrechos em francês, a exemplo de Gastilbeza, paródia do poema hugoano, inserida na crônica publicada no Diário do Rio de Janeiro, em 2/5/1865. O uso da língua francesa é reflexo do espírito coletivo de uma sociedade - especialmente de seu meio cultural e político, profundamente imergida e guiada pelo espírito francês -, não sendo, portanto, esnobismo ou particularidade machadiana rasgo como: "Pego na pena com bastante medo. Estarei falando francês ou português..." ${ }^{\circ 8}$.

Alterado aqui e ali, todo um estoque de imagens e expressões modificou sentidos e foi submetido à expressão de Machado, enriquecendo sua representação do mundo. De fato, tão importante quanto valorizar a originalidade de sua visão de mundo, é destacar que os elementos que caracterizam essa visão foram expandidos, amplificados, porque estimulados pela memória literária sob intenso exercício de leitura.

Nada é produzido no vácuo. Até mesmo a visão romântica que reivindica singularidade e originalidade, ao justo, está calcada na mitologia, pois, no plano temático, poetas românticos comumente utilizaram mitos gregos e romanos, de modo que a memória permite à literatura alimentar-se de si mesma, num perpétuo exercício de autofagia. Machado, embora tenha vivido o romantismo, ignora escolas e definições, colhe ideias de outrem, adapta velhos mitos, faz-se antropófago ao devorar livros, e, livros, como bem disse Murilo Mendes (2003: 27), não são homens, mas contêm a mesma substância, o próprio sangue do homem. Assim, Machado pillote deçà delà les fleurs, apropria-se do alheio, adapta, modifica, imprime sua marca inconfundível, constrói sua expressão pessoal e tempera tudo a seu modo, afinal, como ele mesmo

\footnotetext{
67 "História de quinze dias", Illustração Brazileira, 15/7/1877.

68 "Bons Dias", Gazeta de Notícias, 7/3/1889.
} 
disse, "pode[-se] ir buscar a especiaria alheia, mas há de ser para temperá-la com o môlho de sua fábrica"69 (MACHADO DE ASSIS, 2008: 699, Vol. II).

Numa espiral, a memória literária cria em torno de si mesma sociabilidade e admiração que acionam o mecanismo da leitura, e este provoca a memória suscitando a re-descoberta de extensões inteiras do mundo literário que o escritor, logo após tê-las redescoberto, passa a manipular como memória de empréstimo, tecendo liames intertextuais que possibilitam a continuidade das ideias, rejuvenescendo as obras toda vez que o "novo" recorre a elas em busca de inspiração, tutela, princípios de natureza estética, sugestões, imagens, soluções, aferições, etc..

Machado, ao traçar a história da sociedade carioca lança mão da memória ao fixar seus numerosos detalhes, analisar e dissecar seu espírito, ainda que para isso hora ou outra padeça com os entraves e os labirintos que a memória coloca à sua frente: "A minha memória compõe-se de muitas alcovas meio escuras e poucas salas claras; às vezes, para achar uma cousa, desço ao porão com a lanterna." ${ }^{\text {70 }}$ Mas, ainda assim, fazendo ou não uso da "lanterna", busca a tutela de figuras - e obras da grande biblioteca.

Em se tratando dos franceses, Machado de Assis, indiscutivelmente oferece embarras de richesse, tal a assiduidade com que os frequentou. Em razão disso, neste trabalho, pretende-se sair ao encalço daqueles que contribuíram para a riqueza da cultura ao longo do século XVIII. Exponenciais ou não em suas áreas de atuação, buscar-se-á como, intertextualmente, contribuíram para a compreensão de nossa realidade, através do trabalho incansável de um cronista que procurava sincronizar as ideias oriundas de um país visto como "farol" da civilização e aquelas em trânsito em nosso país - periférico. Diante de tal panorama, nada mais útil que trazer à luz a importância e irradiação do século XVIII francês, antes de adentrar nas intervenções intertextuais presentes nas crônicas machadianas.

\footnotetext{
69 “Antônio José e Molière”, Revista Brazileira, 15/7/1879.

70 "A Semana", Gazeta de Notícias, 1/3/1896.
} 


\section{O SÉCULO XVIII}

"Le dix-huitième siècle doit être mis au Panthéon. »

(SAINT-JUST, 1834: 392)

\section{O século XVIII francês e a ruptura das ideias}

Desde o final do século XVII, propagaram-se por toda a Europa novas ideias que, sob a metáfora de Lumières lembram a passagem do obscurantismo para a liberdade de pensamento e ações esclarecidos pela razão, faculdade esta, compartilhada por todos os homens. As Lumières, mais que se desenvolverem em âmbito europeu, foram um dos principais elementos de constituição desse contexto responsável pela cisão no mundo das ideias e das artes. A universalidade do pensamento - acreditava-se -, poderia romper as barreiras da tradição, modificar modos de vida e culturas, inclusive deitando abaixo as fronteiras, a ponto de Rousseau (1823: 260) afirmar: "Il n'y a plus aujourd'hui de Français, d'Allemands, d'Espagnols, d'Anglais même, quoi qu'on en dise; il n'y a que des Européens."

Novos princípios reguladores acompanharam essa emancipação da vontade: o direito natural, por exemplo, despontou como a grande divisa que garantia ao homem direitos inalienáveis, autêntico instrumento de busca para o bem-estar humano e a independência de espírito. Ora, pensar por si mesmo implicava total liberdade para examinar, questionar, criticar e duvidar de "verdades" há muito cristalizadas pela tradição. Nessa lógica, imperava o princípio de que nenhum dogma era sagrado, ainda que ao fim, nada fosse proposto em substituição ao que fora desmistificado, pois, de fato, o que importava era a busca da "verdade".

Essa busca de algo livre de todo preconceito imanente à religião estabelecida é resultado da visão crítica que marca a atitude do filósofo do século XVIII diante das crenças religiosas, não importando quais fossem. Ela constituiria, ironicamente, o espírito de personagens literárias representadas em obras como Lettres Persanes (1721), de Montesquieu, Candide (1759) e L'Ingénu (1767), de Voltaire.

A tutela sob a qual viviam os homens antes das Lumières era, sobretudo, de natureza religiosa, de maneira que nessa época em que a razão se torna uma "audace critique" (HAZARD, 1961: 8), a verdade deixa de ser a VERDADE, pois se instaura o relativismo. Vê-se o mundo sob outra perspectiva: conceitos anteriormente 
considerados transcendentes passam a depender da diversidade de lugares e de costumes locais, sobretudo após a "mania" das viagens, que se apoderou do homem setecentista.

\section{As primeiras críticas: "Écrasez l’infâme!" e as descobertas científicas}

Como falar de Deus depois de se ter conhecido um indígena sorridente, nu e feliz sob a luz dos trópicos, longe da escuridão dos monastérios e do peso imposto pela doutrina religiosa? Não por outra razão as primeiras críticas das Lumières ergueram-se contra as instituições religiosas, visando, principalmente, devolver à humanidade o controle de seu próprio destino. Embora ainda pairasse a sombra de Descartes, o homem setecentista conscientizava-se de que seu "problema" estava além da existência e da natureza de Deus, do ser e da aparência, do bem e do mal, enfim, descobria que não era mais a autoridade do passado que deveria orientar sua vida, mas um projeto de futuro, e isso implicava discutir a estrutura da sociedade mais que suas crenças, por isso, atacavase a igreja, não a fé. Por essa mesma razão, bradejava Voltaire: “Écrasez l'infâme!”

Segundo Launay e Mailhos (1968: 54), “l'esprit philosophique va donc dissocier la spiritualité de la religion" e "l’honnête homme, le sage, le philosophe" veem-se no direito de fundar suas vidas em um conhecimento positivo da humanidade e do universo. Desse modo, uma grande corrente das Lumières expressava não o ateísmo, mas a religião natural, o deísmo, ou alguma de suas variantes ${ }^{71}$. O homem setecentista o filósofo - observa e descreve todas as crenças: desde as religiões próximas ao cristianismo, como o judaísmo, até as mais distantes e algo exóticas, como as indianas, chinesas, da Oceania, África e América. Esses povos não só desconheciam o Deus dos cristãos, como também, segundo Bougainville ${ }^{72}$, viviam livres e felizes sem leis nem Igreja, e só uma moral natural organizava suas sociedades. Essa visada filosófica em

\footnotetext{
${ }^{71}$ Hazard (1961: 239-240), em retomada a Samuel Clarke, lista quatro categorias de deístas: "Ceux qui font semblant de croire à l'existence d'un Être éternel, infini, indépendent et intelligent ; mais qui nient la Providence. Ceux qui admettent Dieu, et la Providence, mais soutiennent que Dieu ne se met pas en peine des actions moralement bonnes ou moralement mauvaises; les actions ne sont bonnes ou mauvaises qu'en vertu de l'établissement arbitraire des lois humaines. Ceux qui admettent Dieu, la Providence, le caractère obligatoire de la morale, mais qui refusent d'admettre l'immortalité de l'âme et la vie à venir. [et] Il y a enfin une autre espèce de déistes, qui... ont à tous égards des idées saines et justes de Dieu et de tous ses attributs. Ils font profession de croire à l'existence d'un Être unique, Éternel, Infini, Intelligent, ToutPuissant, et Tout-Sâge, Créateur, Conservateur, et Monarque Souverain de l'Univers...

${ }^{72}$ Louis Antoine de Bougainville (1729-1811), navegador e explorador francês. Sobre isso ver o conto filosófico de Diderot: Supplément au Voyage de Bougainville (1796).
} 
relação à Igreja, não objetivava, contudo, a negação das religiões, mas, principalmente, disseminar uma nova atitude de tolerância e defesa à liberdade de consciência.

Ao questionar o saber tradicional, o homem setecentista pleiteava o avanço em direção ao conhecimento, sobretudo fundado na razão e na experiência, atitude que, de pronto, afastava do cenário a magia e a revelação, arcabouço da Igreja. À certeza da Luz divina, sobrepõe-se a pluralidade das Lumières. Liberado dos entraves religiosos, o conhecimento é caminho certo para o desenvolvimento da ciência. Émilie du Châtelet traduz Newton e Voltaire dá inicio aos princípios da nova física, que faz progressos espetaculares, seguida de ciências como a química, a biologia, e mesmo a psicologia e a sociologia.

Sabia-se, acima de tudo, que as descobertas científicas não deviam repousar entre muralhas, como acontecera com o conhecimento escolástico, mas estar ao alcance de todos. Assim, apareceram as publicações populares e as enciclopédias, cuja maior delas, a Enclyclopédie (1751-1772) ${ }^{73}$, com 35 volumes, dirigida por Diderot e d'Alembert, pretendia difundir o saber ao maior número possível de pessoas, ao mesmo tempo em que surgiram as sociedades científicas, as academias e os salões ${ }^{74}$, onde se vulgarizava o conhecimento científico e acadêmico.

\section{3. $O$ indivíduo como protagonista, a conquista de espaços e novas aspirações}

E foi no século XVIII que o homem, através do conhecimento, descobriu ser possível tornar-se senhor de si mesmo e de sua existência. A educação surge no âmbito setecentista como algo essencial, assim como a pedagogia desperta cada vez mais interesse. Em 1762, Rousseau publica sua obra-prima, Émile. O indivíduo ganha destaque e torna-se protagonista num contexto em que se reivindica total liberdade de consciência: busca-se não só a liberdade de escolher a própria religião, mas,

\footnotetext{
${ }^{73}$ O primeiro volume veio a público em $28 / 7 / 1751$.

74 Destacam-se os salões de $\mathbf{M}^{\text {me }}$ de Lambert (1710-1733), $\mathbf{M}^{\text {me }}$ de Tencin (1726-1749), mãe de d'Alembert, $M^{\text {me }}$ du Deffand (1740-1780), $\mathbf{M}^{\text {me }}$ Geoffrin (1749-1777) e $\mathbf{M}^{\text {lle }}$ de Lespinasse (1764-1776). Neles, escritores, cientistas e pensadores discutiam suas ideias e teorias em clima de admiração e entusiasmo, colocando em prática a revisão crítica de noções fundamentais sobre o homem e a organização da sociedade, principal intuito das Lumières.
} 
principalmente, o direito à expressão pessoal, à liberdade de opinião e, para os filósofos, sobretudo, a liberdade de publicação.

Protagonista, o homem não mais se debruça sobre o que deveria ser porque busca ser aceito tal como é: seu corpo, seu espírito, paixão e razão, sensualidade e meditação. $\mathrm{O}$ amor figura entre os prazeres da vida privada, assim como a fruição diante da arte e da natureza adquire nova dimensão, que se traduz na descoberta do mundo natural e numa maneira de vivenciá-lo.

Logo, o homem aparece infinitamente diverso, como evidenciam os novos gêneros literários que o colocam no centro da ação. A literatura, então, parte em direção ao romance realista e autobiográfico. $\mathrm{O}$ romance não aspira mais revelar as leis eternais que regulam as condutas humanas, nem as especificidades de cada gesto, mas mostra homens e mulheres em sua singularidade. O trágico, aos poucos, começa a ceder espaço ao drama, a epopeia às sagas pessoais e a poesia, sob severo código de escrita, acaba cedendo lugar à prosa. Por outro lado, a pintura se desvia dos temas mitológicos e religiosos e passa a mostrar os mais humildes, as ações comuns e os gestos quotidianos. Através da criação o artista ilustra o exercício da liberdade, e deixa de ser um mero artífice para incarnar uma forma de realização humana. A essência de construção de mundo não está mais vinculada à igreja, mas ao homem.

O homem ganha os espaços abertos e públicos, lugares onde se consolida o debate, a troca e a difusão do saber, evitando que as ideias das Lumières tornem-se letra morta. Esse deslocamento é acompanhado de ações que impulsionam o debate público com o suporte de uma crescente impressão de livros, almanaques, panfletos políticos e o aparecimento dos primeiros periódicos e revistas de opinião. A imprensa periódica, ainda reservada a uma minoria, se expande e dá lugar às leituras comentadas em grupo, favorecendo a ilustração dos espíritos. As cidades tornam-se o principal espaço da vida comunitária, concorrendo para o progresso da laicização e a proteção da liberdade individual em consonância ao que afirma Hume (1819: xii, v. 1): "the town [is] the true scene for a man of letters".

Ao afirmar a separação do temporal e do espiritual, o espírito das Lumières transforma profundamente a ordem política. As aspirações à justiça, à igualdade e à liberdade, exprimem-se, a princípio, através da ideia de uma nação governada por um déspota esclarecido a serviço dos interesses do povo, tal como foram Frédéric II, na 
Prússia e Catherine II, na Rússia. Contudo, a ideia evolui, e, se a fonte de todo o poder está no povo, é o povo, por intermédio de seus representantes, responsável por colocar o Estado a serviço do bem público. Nasce desse modo, a ideia de república. Sonhada pelos europeus, vem à luz nos Estados Unidos. Porém, entre o princípio de igualdade apregoado na carta americana (1787) e na posterior Declaração dos Direitos do Homem (1789) e a realidade, um longo caminho ainda terá que ser percorrido.

Os rastros do Ancien Régime persistem: o escravismo continua a mover a cultura da cana-de-açúcar, apesar das vozes importantes de Mirabeau e Condorcet combateremno com frequência. O mesmo Condorcet, ao lado de Laclos, clamaria pelo direito das mulheres à educação, algo que não viria naturalmente. Artistas e escritores não se demoram mais em descrever os hábitos e tipos da corte, mas se voltam para as personagens subalternas, servos, enfim, a pègre, o populacho. Contudo, a soberania popular não revoga a liberdade individual: Montesquieu, em De l'esprit des lois (1748), não só busca garantir a liberdade e a autonomia individual como lança as bases da democracia moderna, ao pregar a necessidade de separação dos poderes.

\section{As Lumières e os ideais humanistas}

"Tout ce qui tient intimement à la nature humaine se ressemble d'un bout de l'univers à l'autre" (VOLTAIRE, 1835: 609, Vol. 3). A frase voltairiana é o arcabouço de um dos grandes princípios dos pensadores e filósofos das Lumières: a universalidade. Todos os homens têm a mesma natureza, e a história e a geografia limitam-se a explicar as diferenças entre eles. Ora, essa "igualdade" desperta o interesse pela universalidade humana e exploradores aventuram-se pelo mundo buscando conhecê-la em sua multiplicidade de formas. Desses confrontos, advém um acúmulo de informações e análises que levariam o homem setecentista não só a mudar sua ideia de "humanidade", mas, sobretudo, olhar para si mesmo com um olhar mais crítico.

Mas o que ficou do século XVIII, que se caracterizou por seus ideais humanistas e apregoou a felicidade como bem-estar de todos? Passados mais de dois séculos, ao menos na Europa e no Ocidente, pode-se confirmar a vitória sobre o obscurantismo tão pleiteada nos idos das Lumières. A soberania popular, o respeito pelos direitos individuais e o reconhecimento dos Direitos Universais do Homem, são considerados o 
ideal comum, e respeitados nos estados democráticos. A democracia legítima tornou-se referência. Contudo, o alcance de algumas ideias formuladas à época das Lumières, parece estar distante do ideal: "humanismo", "emancipação", "progresso" e mesmo "razão" são palavras que hora ou outra soam desacreditadas.

A razão pode ser, em parte, explicada pelo próprio Machado que em crônica de $1865^{75}$, arriscava que "é a sorte de tôdas instituições humanas trazerem o gérmen de sua destruição", numa retomada de Billaud-Varenne ${ }^{76}$. Ocorreu que os adversários das Lumières provaram ser mais renitentes do que se pensava e o obscurantismo e a opressão se metamorfosearam, ganhando novas formas. O inimigo mais temível surgiu no seio das Lumières, uma vez que os excessos do cientificismo a serviço de regimes totalitários tornaram insustentável a afirmativa de que a razão necessariamente produz o bem. Notou-se que a soberania popular é melhor que a teocracia, porém, quando bem manipulada, pode vaguear à deriva.

\section{Mas, e a literatura?}

Não obstante as várias correntes que atravessaram o século XVII e as novas ideias em ebulição que agitariam o sistema, ao final do Grand Siècle, a França continuava cristã, monárquica e clássica. Se no começo do século a vida fora conturbada, com os seigneurs em conflito aberto contra a autoridade real, ao final, imposto o absolutismo, a impressão geral é de aparente estabilidade.

$\mathrm{O}$ homem setecentista endossou piamente as mudanças e o progresso ao expandir seus horizontes, interessar-se pela diversidade do mundo e descobrir que viajar era universalizar-se, ainda que em 1734, Marivaux (1868: 336) tenha afirmado: "Paris, c'est le monde; le reste de la terre n'en est que les faubourgs." Essa universalização, no horizonte literário, figura como uma das primeiras marcas de ruptura, haja vista que a única influência externa aceita pela literatura clássica eram os anciens - clássicos gregos

\footnotetext{
75 “Ao Acaso", Diário do Rio de Janeiro, 4/4/1865.

76 Trata-se de Jacques Nicolas Billaud, depois conhecido por Billaud-Varenne (1756-1819). Um dos principais responsáveis pelo Terror, Billaud-Varenne foi chamado por Alejo Carpentier de "Le Terrible" do século das Lumières (BRUNEL, Françoise, 1992: 13). Para F.-A. Aulard, célebre estudioso da Revolução, foi esse "Orateur de la Législative et de la Convention" quem matou Danton. O texto retomado por Machado está em Principes Régénérateurs du systême social (1795) : "Autrement les droits naturels de l'homme sont altérés dans leurs principes ; et l'institution sociale porte en elle-même le germe de sa destruction, quand elle n'est pas ordonnée de manière à ramener sans cesse l'équilibre dans toutes ses parties. (BILLAUD-VARENNE, 1992: 124)"
} 
e latinos, ao passo que o pensamento e a arte setecentistas abriram-se para os mais diversos influxos estrangeiros, ainda que exóticos para o gosto francês.

No universo literário, o classicismo, que substituíra o preciosismo barroco, aos poucos cede espaço ao pré-romantismo e se a literatura clássica era ao mesmo tempo moral e artística, a setecentista caracterizou-se pela ação: buscou-se, em várias frentes, reformar a sociedade, instituições e leis. A arte seguiu o fluxo das mudanças e paulatinamente deixou de representar a estabilidade de pensamento e dos modos, para tornar-se veículo de expansão - e vulgarização - da ciência. A literatura se despe da ortodoxia clássica e se torna prática, social e militante: procura-se, por exemplo, desvendar os mistérios da natureza (Buffon), almeja-se modernizar a legislação (Montesquieu). Contudo, a França não deixa de ser conservadora de um momento para outro e as mudanças, embora cada vez mais ousadas, são duramente criticadas.

Tornou-se senso comum, por exemplo, desqualificar esse ou aquele gênero, e o romance, desde muito cedo, foi o alvo escolhido. Riou (2006: 664), ao tratar do nascimento do romance moderno no século XVII, menciona a blasfêmia de Pierre Nicole, nos idos de 1667: "Le faiseur de romans et le poète de théâtre est un empoisonneur public, non des corps, mais des âmes des fidèles, [...] coupable d'une infinité d'homicides spirituels." Décadas depois, ainda em linha de mira, o romance, assim como o conto, é depreciado não mais pela força de seu caráter "degenerativo", mas em razão de uma suposta debilidade expressiva. Tomados por inferiores, romance e conto continuam a ser criticados, sobretudo por transmitirem facilmente sentimentos e ideias, ainda que frequentemente servissem para "déguiser la critique dirigée contre le christianisme autoritaire et contre 'le bon plaisir' royal, l'arbitraire du gouvernement despotique"(KOHLER, 1948: 278).

O fato é que o rompimento na literatura do século XVIII, sobretudo em relação ao discurso clássico, dá-se na condição de transfiguração do real, ou seja, estrutura e discurso literários alteram-se em consonância à mutação de saberes e a redefinição de papéis. A emancipação em relação à influência teológica e a valorização do homem, da razão e de sua atividade no mundo recusam-se terminantemente submeter-se à paralisia que caracterizava o padrão clássico, em que temas religiosos e mitológicos eram recorrentes e retrabalhados de modo a acrescentar mais um elo à corrente. Contudo, vale observar que o homem não se desvencilhou de Deus tão facilmente como às vezes se 
afirma: o pecado original, por exemplo, se populariza nos discursos filosóficos e tornase um de seus constitutivos.

De qualquer forma, essa reorientação do saber em torno do material, do terrestre, provoca mudanças e a produção literária atesta essa importância terrena na vida humana. Diderot, em 1745, cunha o neologismo "sociabilité” que, segundo, Lotterie (2006: 199) contribui para expandir o conceito clássico de "civilité". Voltaire, em sua poesia, emprega slogans carregados de afetividade e de uma moral hedonista, algo provocante. Privilegia-se tudo o que se refere à comunicação entre os homens de maneira a constituir verdadeiro espaço público onde o diálogo com o divino já não influi tanto. Valoriza-se sobremaneira o indivíduo e seu bem-estar, de tal arte que o sensualismo lockiano aclimata-se com facilidade na França (LOTTERIE, 2006: 200).

Ora, para Locke o homem é um ser constituído por suas experiências, que por sua vez foram apreendidas pelos sentidos, portanto, sob esse raciocínio o homem escapa das concepções dualistas que o colocam sob a influência das paixões sobre o espírito. Diderot, um dos mais ardentes promotores da reabilitação das paixões, aliadas à afirmação da liberdade criativa do indivíduo, traz à luz La Religieuse (1796) ${ }^{77}$, ode à liberdade de escolha e crítica ao obscuro e fechado mundo religioso que levava à degradação da natureza humana. Nesse mundo de ação, o ócio, a inutilidade social e a opressão vivida pela heroína, contrariam não só as aspirações à felicidade e ao bemestar apregoado pela razão, como também o desejo, impulso natural do homem.

A ruptura com o discurso clássico abre espaço para deslocamentos: o local e o estrangeiro, o real e o imaginário, de maneira que, reais ou fictícios, os relatos de viagem contribuem para a modificação das representações anteriores. Segundo Paul Hazard, em La crise de la conscience européenne (1961), antes mesmo que isso ocorresse, valores filosóficos, religiosos, sociais e políticos já eram questionados, porém, ao lançar os olhos para além das fronteiras do continente, os europeus substituem uma "verdade universal" circunscrita, de feitio local, por uma visão relativista e de aceitação, da diversidade de modos, crenças, governos e leis, explicada

\footnotetext{
${ }^{77} \mathrm{O}$ romance La Religieuse começou a ser redigido em primeira pessoa, sob a forma de cartas. Acreditase que as primeiras tenham sido escritas por volta de 1760. A obra, contudo, só aparece como romance constituído e com esse título entre outubro de 1780 e março de 1782. Em 1796, doze anos após a morte de Diderot, La Religieuse foi publicada pela primeira vez em formato impresso.
} 
pela consciência de um determinismo de ordem demográfica, econômica e climática, a exemplo da teoria dos climas em De l'esprit de lois (1748).

Enfim, adota-se uma postura crítica na confrontação entre o local e o sistêmico, entre o eu e o outro, e, à época, o olhar do viajante ocidental representou a norma de referência para o leitor. A literatura de viagem e o romance de imaginação são representativos dessa época e vêm a calhar, pois são "genre[s] littéraire[s] aux frontières indécises, commode parce qu'on y pouvait tout verser, [...] le Voyage triomphait" (HAZARD, 1961: 19).

Exemplo claro dessa nova postura de ver o mundo e principalmente a si mesmo, são as Lettres Persanes (1721), de Montesquieu, onde ocorre o que Roger Caillois (GALAND, 2003: 46) classificou de "révolution sociologique":

\begin{abstract}
J'appelle ici révolution sociologique la démarche de l'esprit qui consiste à se feindre étranger à la société où l'on vit, à la regarder du dehors et comme si on la voyait pour la première fois. L'examinant alors comme on ferait d'une société d'Indiens ou de Papous, il faut se retenir sans cesse d'en trouver naturels les usages et les lois. Il s'agit d'oser considérer comme extraordinaires et difficiles à entendre ces institutions, ces habitudes, ces mœurs, auxquelles on est si bien accoutumé dès sa naissance et qu'on respecte si fort et si spontanément qu'on n'imagine pas la plupart du temps qu'elles pourraient être autrement. Il faut une puissante imagination pour tenter une telle conversion et beaucoup de ténacité pour s'y maintenir. ${ }^{78}$
\end{abstract}

Ora, nas Lettres Persanes Montesquieu provoca uma cisão ao inverter o habitual polo de observação europeu - a saber -, a partir de si e de seu contexto, com isso o olhar estrangeiro explicitado de forma eloquente desloca o conceito de "exótico". Se para o leitor ocidental a sociedade persa em suas especificidades (religiosa - o Islã, política - o despotismo e sexual - o harém) é sinonímia de exotismo, ao deslocá-la (a sociedade persa, os persas) para uma visita a Paris, Montesquieu sobrepõe ao estrangeiro o inverso exótico da sociedade francesa, de maneira que o eu torna-se um outro, sob o olhar persa, revelando assim uma "verdade" que passara despercebida.

A técnica narrativa adotada por Montesquieu permite desvendar a relatividade cultural, seus modos e crenças e constitui-se no elemento que sustenta a sátira da obra.

\footnotetext{
${ }^{78} \mathrm{O}$ texto de Roger Caillois, retomado por David Galand, foi originalmente publicado no prefácio às Oeuvres Complètes de Montesquieu, Gallimard, 1949.
} 
O procedimento de observar a sociedade francesa a partir do olhar estrangeiro, obriga o leitor a certo distanciamento. Essa artimanha da escrita conduz o leitor a um recuo em suas crenças e comportamentos, nos quais está habitualmente imerso e que considera naturais. Esse artifício

[...] dévoile le caractère faussement naturel des moeurs et des idées qui nous entourent. Ce qui nous semble donnée, toujours déjà là, et donc sans alternative possible (sans qu'un autre système puisse être envisagé), apparaît dès lors comme artificiel et conventionnel. Le système de nos moeurs et de nos croyances n'est pas une nature, mas un code (GALAND, $2003:$ 47).

Se esse distanciamento provoca uma reflexão crítica, cabe questionar: se crenças e modos são uma convenção, quem os determinou? Em que foram fundados? Quais suas origens? Uma vez que se podem estabelecer diferentes "códigos" ou maneiras de pensar, por que não foram escolhidos outros? Tal abordagem contribuiu para aprofundar ainda mais a fenda já instaurada entre as literaturas do século XVII e XVIII.

Avez-vous jamais été en France, monsieur Martin? dit Candide.

- Oui, dit Martin, j'ai parcouru plusieurs provinces. Il y en a où la moitié des habitants est folle, quelques-unes où l'on est trop rusé, d'autres ou l'on est communément assez doux et assez bête, d'autres où l'on fait le bel esprit; et, dans toutes, la principale occupation est l'amour ; la seconde, de médire ; et la troisième, de dire des sottises.

- Mais, monsieur Martin, avez-vous vu Paris ?

- Oui, j'ai vu Paris ; il tient de toutes ces espèces-là ; c'est un chaos, c'est une presse dans laquelle tout le monde cherche le plaisir, et où presque personne ne le trouve, du moins à ce qu'il m'a paru. [...] On dit qu'il y a des gens fort polis dans cette ville-là : je veux le croire. (VOLTAIRE, 1989: 106-107)

Em Candide ou l'Optimisme (1759), conto filosófico de Voltaire, a ficção aparece como uma realidade objetiva, reivindicando veracidade e trazendo à luz características que, de forma estereotipada, satirizam e criticam a sociedade francesa. Em meio às peripécias da personagem voltairiana, repete-se a fórmula de Montesquieu: a relatividade de modos, discursos e ideias e a ambiguidade de opiniões, através da fala de um estrangeiro, iluminando aqui e ali, os vícios de uma cultura que só são vistos a partir do outro. Num estilo que exige do leitor disponibilidade - e mobilidade -, a 
alacridade do espírito voltairiano coloca em jogo um duplo realismo: o dos fatos reais alguns incontestáveis, tal o terremoto de Lisboa, e o envolvimento das personagens com esses fatos. A isso, soma-se a ironia, arma predileta das Lumières e manipulada com incomparável maestria por Voltaire. No texto, o irônico se sustenta parcialmente dos pequenos insultos aos amigos de Candide, que, de fato, tinham endereço certo e cujas correspondências eram facilmente elaboradas pelos contemporâneos à obra.

Por ter contribuído para a fissura provocada na literatura clássica, por trazer em sua escritura influxos de The life and opinions of Tristam Shandy, Gentleman (1759), de Laurence Sterne, e por sua extensão intertextual na escrita machadiana, deter-nos-emos em Jacques le Fataliste et son maître (1796), obra de evidente jogo paródico: paródia do romance picaresco, do romance realista e do romance filosófico. Uma obra cuja estrutura se aproxima de todos os gêneros sem, contudo, curvar-se a nenhum deles, exibindo uma liberdade tão paradoxal que se supõe, nega a si mesma.

Ao considerar o longo tempo que "se escreveu", de 1765 a 1778, Andrau (2006: 21), considera Jacques, uma obra "polype" (pólipo), algo como uma membrana ou uma estrutura que, hipertrofiada, desenvolve-se espontaneamente. Calcula-se que o início de sua redação tenha sido por volta de 1765 , pois se sabe que Diderot já havia lido Tristam Shandy na casa de d'Holbach, entre os anos de 1759 e 1764. Notam-se em alguns episódios relacionados a Jacques - sua desventura inicial e o ferimento no joelho referências à obra de Sterne. O fato é que Diderot não escondia seu apreço pelo livro; em carta a Sophie Volland" (26/9-7/10/1762) afirma: "le plus fou, le plus sage, le plus gai de tous les livres", obra que, sem dúvida, é o gérmen de Jacques le Fataliste.

Jacques, romance polimorfo, durante vários anos circulou através de cópias, e era modificado por Diderot, para que se adaptasse ao gosto de seus diferentes leitores ${ }^{80}$, algo que afasta sobremaneira a obra do espírito e conduta clássicos. Ora, no século XVIII o romance já atingira outro estágio, não padecia mais com a virulência de críticos

\footnotetext{
79 Trata-se de Louise Henriette Volland (1725-1784), epistológrafa francesa, amiga, amante e correspondente de Diderot entre os anos de 1755 e 1769. Não se encontrou nenhuma de suas cartas.

${ }^{80}$ Episódios foram cortados ou acrescentados, antes que se optasse pelo manuscrito de Saint-Pétersbourg, corrigido por Diderot e que deu forma ao romance tal como é conhecido hoje, algo que denuncia seu processo de criação. Assim como La Religieuse, a obra só viria a público após a morte de Diderot.
} 
como Pierre Nicole e, em oposição ao romance sério e nobre, desenvolve-se um romance que recusa o idealismo e se inscreve numa tradição popular ${ }^{81}$.

Assim como em Candide, em Jacques o tema da viagem se impõe e a viagem de Jacques e seu mestre é recheada de ladrões e malfeitores, "monstros" de uma época fértil em traições e crueldade. Se Voltaire ironiza o otimismo leibniziano, Diderot destaca as variantes que ressaltam as falsas paixões, a mentira amorosa e venalidade de seu mestre. Do ponto de vista narrativo, o diálogo entre Diderot autor-narrador e seu leitor, que subjacente ao desenvolvimento da narrativa, especula sobre as possibilidades narrativas e as escolhas do narrador, é algo que se aproxima bastante do feitio machadiano. Outra aproximação é o fato de que o pitoresco não reside nos lugares, no geográfico, mas, sobretudo, nos relatos e nas etapas desenvolvidas ao longo da escrita.

Jacques le Fataliste aprofunda o rompimento com o clássico, não só por apresentar uma escrita repleta de rupturas e retomadas, mas, principalmente, pela presença de um narrador que afirma incessantemente sua onipresença na narrativa, impulso arbitrário que a inscreve como marco de modernidade no percurso das ideias literárias.

Os influxos de Sterne são tão eloquentes em Jacques que, ao final da obra, ao concluir a leitura das memórias, o editor comenta que dos três parágrafos que se encontram no manuscrito que possui, dois parecem originais (o primeiro e o último), entretanto, o segundo é "évidemment interpolé”:

\begin{abstract}
Voici le second paragrafe, copié de la vie de Tristam Shandy, à moins que l'entretien de Jacques le Fataliste et de son maître ne soit antérieur à cet ouvrage, et que le ministre Sterne ne soit le plagiaire, ce que je ne crois pas, mais par une estime toute particulière de M. Sterne, que je distingue de la plupart des littérateurs de sa nation, dont l'usage assez fréquent est de nous voler et de nous dire des injures (DIDEROT, 1989 : 369).
\end{abstract}

Ora, Diderot desestabiliza seu leitor em duas frentes ao introduzir esse suposto editor: no relato em si, ao propor diversos fins para a aventura de Jacques e Denise, e ao jogar com a convecção da escritura, através da qual o editor sugere os meandros pelos quais os romancistas tentam autenticar suas ficções. O estratagema, a bem da verdade,

\footnotetext{
${ }^{81}$ De fato, Histoire de Gil Blas de Santillane (1715-1735), de Lesage, de veia satírica e picaresca, já era um exemplo de como a observação da realidade atribui a esses romances uma aparência de autenticidade, sobretudo pelo emprego do foco narrativo em primeira pessoa.
} 
vai além, constituindo-se numa crítica às conveções do romance, ainda que lúdica e provocante. Com isso, a paródia, de fato, torna-se uma negaça, pois o narrador denuncia o artificialismo da invenção literária e a arbitrariedade de qualquer técnica ficcional, conforme afirma Mauzi:

Les impertinences de l'auteur envers son lecteur, apparaissent comme la contrepartie symbolique de la désinvolture du destin envers les hommes, et le destin mène le monde avec ce même mélange de liberté, d'indifférence et de malice dont s'inspire le conteur pour conduire ou plutôt pour brouiller les fils multiples de son récit (1964: 90).

Percebe-se, dessa forma, que o narrador em Diderot se coloca no centro da trama, como principal ator da história, da qual também é seu enunciador basilar. Algo, que está na essência da escritura de Sterne, mas que Diderot reordena de modo a fazer da técnica a grande responsável pela economia narrativa da escritura, rompendo assim, com o romance clássico, que faz apelo a uma multiplicidade sem fim de relatos para contar a história. A mesma economia narrativa seria reproduzida com maestria em Memórias póstumas de Brás Cubas (1881), obra machadiana de reconhecida relevância.

\section{Machado digressivo e progressivo}

Sainte-Beuve, em Chateaubriand et son groupe littéraire sous l'Empire (1861) ao tratar do sucesso de Génie du christianisme (1802) começa por analisar como a religião foi abordada literariamente ao longo dos séculos XVII, XVIII e XIX, e, ao comentar o mal do século ${ }^{82}$, traça rápido comparativo entre Voltaire e Chateaubriand, afirmando sobre este último (1861 : 340): "René est le fils d'un siècle qui a tout examiné, tout mis en question [...] [une] intelligence avancée, consommée, [qui] se trouve en désaccord flagrant avec une imagination réveillée et puissante, avec un coeur avide et inassouvi.”

\footnotetext{
${ }^{82}$ Segundo Hélène Potelet (1990: 152), o mal do século é o estado em que "l'âme, avide d'infini, assoiffée d'absolu, souffre des limites que lui impose la destinée terrestre. Le coeur est empli de passions violentes que rien sur cette terre ne saurait combler. C'est le 'vague des passions', tel que le décrit Chateaubriand: «L'imagination est riche, abondante et merveilleuse, l'existence pauvre, sèche, désenchantée. On habite avec un coeur plein un monde vide. (CHATEAUBRIAND, s/d: 111» Ainda segundo o autora, "toute une génération, déçue dans ses rêves de grandeur après la chute de l'Empire, se reconnaît dans le René (1802), de Chateaubriand. Le mal de René deviendra le mal du siècle".
} 
Considerando-se o "tamanho da sociedade carioca", Machado vai além: tributário dos séculos de Voltaire e Chateaubriand (XVIII e XIX) ${ }^{83}$, integra-os ao contexto local (social, político e literário), conciliando-os em sua escrita, e desse diálogo retira substrato que contribui para sua expressão pessoal. Ateve-se mais à ficção que às personalidades, pois afirmava: "Quando a gente não pode imitar os grandes homens, imite ao menos as grandes ficções." ${ }^{~} 84$ Contudo, mirar-se nas obras e ou pessoas que considerava inspiradoras, não lhe fora um problema, pois acreditava que "o espírito da imitação é altamente fecundo". ${ }^{85}$ Porém, vale ressaltar: o intertextual em Machado equivale a verdadeiro trabalho de (re)criação literária, chegando ao refinamento. Ora, a transposição efetuada pelo autor - é sabido - integra-se ao texto centralizador, produz sentidos, estala a linearidade da leitura e, para o leitor brasileiro, atualiza as obras pretéritas, que serão relidas à luz da fatura machadiana. Não por outra razão, Jenny (1979: 21) afirma que uma das características da intertextualidade é provocar uma volta "ao texto-origem, procedendo a uma espécie de anamnese intelectual em que a referência intertextual aparece como um elemento paradigmático 'deslocado' [...] semeando o texto de bifurcações que lhe abrem, aos poucos, o espaço semântico".

Considere-se a ironia machadiana: o tom irônico, distanciado de fatos e personagens, o narrador altivo que ao esmiuçar as vilanias e vicissitudes humanas esboça um sorriso no canto da boca, impassível, sem pena nem horror, apenas observando o vai-e-vem periclitante das personagens que compõem a comédia humana; qualquer reminiscência a Voltaire não é mera coincidência. Esse estilo, "que consiste essencialmente em sugerir as coisas mais tremendas da maneira mais cândida (como os cronistas do século XVIII); ou em estabelecer um contraste entre a normalidade social dos fatos e sua anormalidade essencial" (CANDIDO, 1977: 23) hoje é visto como puramente machadiano.

No campo literário, Diderot representa o novo, que Machado visita incessantemente. O enciclopedismo filosófico-literário, aforismos e máximas morais das Lumières figuram em romances, contos e crônicas e dão conta de um universalismo letrado, que vem à luz no espaço da narrativa, na polifonia e no embate narrador-autor.

\footnotetext{
${ }^{83}$ No caso, aqui, circunscrevemos, pois em suas crônicas Machado lança mão inclusive dos clássicos gregos e latinos.

84 “A Semana", Gazeta de Notícias, 19/11/1893.

85 "A Semana", Gazeta de Notícias, 9/4/1893.
} 
Seja a ruptura da narrativa linear, seja a organização do discurso ou o envolvimento do leitor como entidade opinativa, muito dessas experiências já havia sido colocado em prática no século XVIII: "Dites-moi, lecteur, ce que vous eussiez fait à la place de Jacques? Rien. Eh bien! c'est ce qu'il fit (DIDEROT, 1989: 369).” Um narrador intrometido que busca o leitor para rejeitá-lo no mesmo instante.

Sterne por sua vez, usa da mesma desenvoltura: "Dites-moi, je vous prie, si vous ne devinez pas pourquoi la troupe entière de nos fabricants de Drames a pris pour modèle l'exemple de trim et de mon oncle Tobie ? - Ariston et Pacavins, le Bossu et Riccoboni, Did... et tant d'autres graves précepteurs du Théâtre, sont des Messieurs, grâce à Dieu, que je n'ai jamais lus et je m'inquiète peu de ce qu'ils disent ou ne disent pas (STERNE, 1777 : 125, Seconde Partie, ch. XLV)." Mais uma vez o leitor é chamado a opinar e é rechaçado pelo narrador.

Em Memórias póstumas (1881), assediado desde o prólogo, o leitor corre o risco, inclusive, de receber uns piparotes: "A obra em si mesma é tudo: se te agradar, fino leitor, pago-me da tarefa; se te não agradar, pago-te com um piparote, e adeus." Reiteradamente esse mesmo leitor é chamado à conversa e, com frequência, é objeto das "rabugens" do narrador: "Já meditaste alguma vez no destino do nariz, amado leitor?" (XLIX); "Leitor obtuso, isso prova que nunca entraste no cérebro de um chapeleiro." (XLIX); “Não serias capaz de lá entrar hoje, curioso leitor;”(LXX); “o maior defeito deste livro és tu, leitor." (LXXI); "Eis aí um mistério; deixemos ao leitor o tempo de decifrar este mistério."(LXXXVI); "Sinto que o leitor estremeceu, - ou devia estremecer."(XCVII); "Mas enfim eu escrevo as minhas memórias e não as tuas, leitor pacato.”(XCVIII); "Não se irrite o leitor com esta confissão (CXV).” Nota-se na ficção machadiana a frequente interrupção da narrativa, quando narrador e leitor refletem sobre o enredo e comentam a estrutura do romance e outros assuntos.

Ao assumir o duplo daquele que escreve e ao mesmo tempo se vê escrevendo, Machado se inscreve na genealogia das obras setecentistas, reflete sobre a memória da literatura e funda o romance moderno na literatura brasileira. Digressivo, divaga e volta ao século XVIII, progressivo, mostra-se contemporâneo, original, e cria sua própria genealogia, de maneira que se pode afirmar categoricamente que Machado é "le fils qui a tout examiné, qui a tout mis en question". 


\section{VOLTAIRE}

«Quand on combattait le vice chez ce diable d'homme, on finissait toujours par blesser la vertu.» (KOHLER, citando o dito de um crítico sobre Voltaire, 1948: 308)

\section{VOLTAIRE: OBSESSÃO MACHADIANA}

\section{Linhagem irônica}

Dentre os estudos cujo objeto é a constituição da escrita machadiana, destacam-se aqueles que valorizam a expressão pessoal do artista, tornando-o tributário de uma linhagem de ironistas hábeis em ressaltar o excêntrico revestido por uma camada de normalidade. Se por um lado Machado trilha por esse mesmo caminho, por outro, sua indiferença em se filiar a uma escola literária contribui para o equilíbrio, a concisão e a contenção lírica de sua expressão. Assim, quando seus procedimentos impressionistas entram em ação, não só segmentos do real são submetidos à têmpera de sua economia narrativa, mas, também fragmentos ficcionais vêm à tona, contribuindo para a elaboração de seu juízo crítico.

Se, nos romances, o elíptico e o alusivo permitem diferentes interpretações, nas crônicas, o não querer explicar tudo contribui sobremaneira para a leitura crítica do circunstancial. A apreensão do mundo é contraditória; em geral privilegia-se o olhar de míope, porém, nas vezes em que o cronista contempla até onde a vista alcança, identifica com precisão o detalhe a contradizer a visão panorâmica. Desse modo, alerta seu leitor sobre o caráter ilusório da realidade, o senso comum e o equívoco que reside no superficial, dimensão onde a compreensão objetiva dos fatos é distorcida, comprometendo a percepção plena da "verdade". Assim, através do detalhe, desnuda a alma humana.

Em virtude das recorrentes idas e vindas à grande biblioteca, diz-se que o estilo de Machado é culto; graças aos reiterados diálogos mantidos com toda uma plêiade de clássicos e contemporâneos ingleses, espanhóis, italianos e, sobretudo, franceses, credita-se sua virtuose na arte da intertextualidade; e, do colóquio com esses mestres, atribui-se a força de um dos mais refinados traços de sua escrita: a ironia. 
A ironia, arte da persuasão, mas também da denúncia, desperta a percepção do interlocutor exigindo atitude de observador em face do objeto da crítica, em consonância ao que afirma Schoentjes ao retomar Burke (2001: 70): “en effet, l'ironie n'est pas un phénomène statique, c'est un processus qui aboutit à une 'perspective des perspectives"”.

Ora, para que o leitor construa sua própria perspectiva, o cronista desvela a constituição do fato, expõe sua problemática e contrasta os diferentes pontos de vista em litígio. Não bastasse isto, como se quisesse ter certeza de que seu interlocutor não ficará passível e silencioso em seu papel de leitor, agrega à notícia material ficcional, instigando-o à reflexão, enlaçando-o em uma teia de natureza intertextual que, de certa forma, força-o a um posicionamento crítico.

Contudo, esse mecanismo que se revela altamente eficiente na crônica e à primeira vista surge como singularidade da escrita machadiana, é conhecido de longa data e faz parte da dinâmica da ironia, cuja realização plena só ocorre quando o leitor participa ativamente de seu significado. Machado faz apelo ao seu leitor culto, e, não por outra razão Fernando Pessoa (2012: 150) assevera que "o homem superior difere do homem inferior, e dos animais irmãos deste, pela simples qualidade da ironia. A ironia é o primeiro indício de que a consciência se tornou consciente".

Nessa perspectiva, a ironia se situa no leitor, e, se por um lado ambos, cronista e leitor tornam-se cúmplices diante da constatação de que a "verdade" dos fatos nem sempre confirma a visão otimista da história da humanidade, por outro, a ironia em si, torna-se modo de escritura e de leitura. Esse pacto faz do cronista um moralista ${ }^{86}$ no sentido de que ao exprimir as vilanias e o ordinário do "barro humano", desenha uma sociedade utópica, busca a perfeição no homem (embora certo de não encontrá-la), enfim, adere a um mundo meio nostálgico, onde a realidade "ideal" surge nas palavras por meio de intertextos que, ironicamente, produzem efeito contrário, destruindo a fé "no melhor dos mundos possíveis".

O intertexto, como esteio, reforça uma crítica que se constrói a partir de ideias anteriores e a ironia se enquadra numa estratégia retórica, cujo objetivo, mais que

\footnotetext{
${ }^{86}$ Segundo Schoentjes (2001: 85) "l'ironiste est un moraliste qui, constatant que les faits qui se présentent à ses yeux ne correspondent pas au monde parfait qu'il a à l'esprit, désigne les imperfections qu'il entend épingler par des termes qui ne conviennent qu’à son idéal”.
} 
procurar a "verdade" é, acima de tudo, convencer o leitor de que se deve estar ciente do jogo irônico entre o ser e o parecer.

Em sua manufatura, Machado faz da ironia o principal traço de sua escrita, tornando-a ambígua e relativista, e, ao fazê-lo, trilha pelas diferentes etapas do gênero: dos antigos, sobretudo Sócrates, nota-se que o cronista incorpora a maiêutica nas vezes em que demonstra desconhecimento e ingenuidade diante do dissimulado sob os fatos, de modo a ressaltá-los depois, ao longo do relato; também dos clássicos, pinça a ideia retórica dos contrários e faz da antífrase irônica importante mecanismo que o auxilia nas vezes em que nega aquilo que, de fato, pretende afirmar.

Ao se aproximar da alegoria, coligindo definições ${ }^{87}$, o cronista replica a ironia socrática de cunho dialético e, nessa perspectiva, sai à procura de um saber mais autêntico, de uma sabedoria mais intensa (e extensa), que em geral se abriga em páginas da grande biblioteca: tutelado por esses saberes anteriores ressalta as características da condição humana, contrapondo-as e as alegorizando.

Mas a ironia, essencialmente retórica, reconcilia-se ${ }^{88}$ com a literatura e a filosofia e, no início do século XIX, adquire nuance ligada à renovação, liberta-se, aparece como instrumento de crítica e nutre-se de grandes autores. Não por outra razão Machado, leitor contumaz que "bebeu do leite romântico", alimenta-se da leitura de grandes ironistas como Cervantes, Sterne, Diderot, Shakespeare, Swift, Montaigne, La Fontaine, etc. - e Voltaire.

"En France, au milieu du XIX" siècle, on considérait toujours l'ironie dans le prolongement d'un siècle de Lumières marqué par l'ironie flagellatrice de Voltaire." (SCHOENTJES, 2001: 245), depois, mais para o final do XIX, surge certo ceticismo que se alia ao positivismo e, nas crônicas, ambos os matizes estão presentes: ora corrosiva ora cômica, é ali que a crítica machadiana toma corpo e, se não fustiga como Voltaire, só não o faz em respeito às dimensões e natureza do gênero que, afinal, "no banquete dos acontecimentos, [é] a mesa dos meninos". 89

\footnotetext{
${ }^{87}$ Nos moldes pensados por Quintiliano (Institutio oratória, VIII, 6, 44) e expostos por Schoentjes (2001: 81): "L'allégorie, en latin inversio, présente sens autre que celui des mots [aut aliud verbis, aliud sensu ostendit], et même parfois le contraire [contrarium]."

${ }^{88}$ Segundo Schoentjes (2001: 100), após Platão, a ironia abandonara a esfera literário-filosófica, tornando-se preceito retórico.

89 “A Semana”, Gazeta de Notícias, 18/11/1894.
} 


\section{2. "Un louis d'or, [...] pour l'amour de l'humanité."}

Em 12/5/1664, foram representados ao público os três primeiros atos de Tartuffe, logo denominada L'Hypocrite pelos espectadores. Proibida de ser encenada para o grande público até que fosse terminada, sua estreia ocorreu em Raincy, aos 29 de novembro, na casa do prince de Condé, amigo e protetor de Molière. Segundo D'Hoefer (1866: 859), desde sua representação parcial, embora tivesse agradado bastante a Corte, a censura debruçou-se dia e noite sobre a peça. Nos meses que se seguiram, segundo relatos de M. Bazin, reproduzidos por D'Hoefer, ímpio, ateu e libertino foram adjetivos comumente associados ao grande dramaturgo.

E é nesse estado de espírito que Molière dispõe-se a escrever Don Juan, ou le festin de Pierre, cuja estreia deu-se em 15/2/1665. Embora Le festin de Pierre, seja uma reflexão sobre a libertinagem e seus excessos, o tema é complexo (D’HOEFER, 1866: 860): “C'est que le libertin amuse, qu'il met le spectateur de son parti, tant que dure son peché en action, et que le châtiment surnaturel, qui arrive à la fin pour terminer la pièce, n'épouvante et ne corrige personne."

Ainda que em suas comédias Molière reiteradamente lance mão do riso em sua crítica à hipocrisia religiosa, seu D. Juan, sedutor e libertin pareceu agravar o que tentara remediar, uma vez que os devotos viram na peça um novo ultraje, considerandoa uma apologia à incredulidade. $\mathrm{O}$ fato é que o sieur de Richemont escreve um violento libelo contra a peça, impedindo-a de ser publicada.

Afora isso, desde sua segunda representação, algumas cenas mais "ousadas" foram censuradas, e dentre elas a do pobre: nela, enquanto perambula por uma floresta em companhia de seu fiel criado Sganarelle, D. Juan confessa sua descrença na medicina e, ao compará-la a Deus, afirma realmente não saber em qual dois dos mais

acredita. À frente, deparam-se com um pobre e ao se informarem sobre o caminho a tomar em direção à cidade, este lhes pede uma esmola; D. Juan promete-lhe então uma moeda de ouro à condição de um juramento, algo que o pobre prontamente se nega a fazer, evitando pecar caso jure em vão. Testado à exaustão a abandonar seus princípios, o pobre resiste e ganha a moeda "pour l'amour de l'humanité".

\section{Mélanges littéraires : "Où la vertu va-t-elle se nicher!"}


Recontada de forma anedótica pelos biógrafos, a origem da cena, afirmam, reside em algo que acontecera ao próprio Molière: certo dia, voltando de Auteuil a Paris, en voiture, o dramaturgo joga uma moeda a um pobre e logo o percebe tentando alcançá-lo. Este, ao se aproximar, diz: “Monsieur, [...] vous n'aviez probablement pas l'intention de me donner un louis d'or. Je viens vous le rendre. _ Tiens, mon ami, répondit Molière, en voilà un autre pour ton honnêteté." E exclamou: "Où la vertu va-t-elle se nicher?" (D'HOEFER, 1866: 861)

Voltaire, na curta biografia que escreveu sobre o dramaturgo (Vie de Molière, 1739), ressalta o caráter benevolente do artista, referindo-se, inclusive, a algumas de suas ações complacentes. Após mencionar a ajuda que Molière teria dado a Baron (comediante que considerava como seu próprio filho) e a Mondorge (ator, cuja troupe estava em dificuldades), Voltaire reconta a historieta do pobre:

Un autre trait mérite plus d'être rapporté. Il venait de donner l'aumône à un pauvre ; un instant après le pauvre court après lui, et lui dit : «Monsieur, vous n'aviez peut-être pas dessein de me donner un louis d'or, je viens vous le rendre. - Tiens, mon ami, dit Molière, en voilà un autre. »; et il s'écria : «Où la vertu va-t-elle se nicher ! » Exclamation qui peut faire voir qu'il réfléchissait sur tout ce qui se présentait à lui, et qu'il étudiait partout la nature en homme qui la voulait peindre. (VOLTAIRE, 1879: 95, Tome XXIII)

Curiosamente, assim como o cronista se debruça sobre a natureza humana a partir da "coisa miúda", Voltaire ressalta a perspicácia do dramaturgo em dispor das mesmas situações ordinárias, transformando-as em metáforas representativas dos movimentos e da expressão do espírito humano.

Em tempos de fanatismo e intolerância exacerbados, quando se acreditava que as virtudes tinham morada certa entre o clero e a nobreza, pregar sua volubilidade e demonstrar seu florescimento em solo abjeto, surge como enfrentamento: primeiro, do próprio Molière ao replicar a cena em Le festin de Pierre, constituindo-se o entrecho num exórdio em defesa própria, haja vista o patrulhamento que enfrentara desde Tartuffe (1664); depois surge Voltaire que, simultaneamente, não só exalta as qualidades morais e a compreensão do dramaturgo em manusear os vícios e desvios da 
humanidade, mas também reforça sua luta pessoal contra os desmandos eclesiásticos, contribuindo para a vulgarização do espírito crítico.

O encontro entre o filósofo e o cronista ocorre neste instante, exatamente quando Machado apropria-se da célebre expressão voltairiana, parodiando-a, num contexto medíocre, porém exemplar, ao mostrar o homem despido de suas virtudes, concorrendo para o triunfo perene da morte, em escala industrial. Tudo isso no grande matadouro de Cincinnati, nos Estados Unidos.

\section{4. “Quanto pode a mecânica! ou "Où la mécanique va-t-elle se nicher!”.}

Em 8/5/1860 vem à luz nas páginas d'A Marmota “Carniceira a Vapor”, crônica que, de fato, surge como adaptação de parte da obra ${ }^{90}$ de Oscar Comettant (1858: 141-143). Nela, o cronista retoma passo a passo a descrição feita pelo francês de um matadouro em Cincinatti, nos Estados Unidos:

O estabelecimento de M. Roviello ${ }^{91}$, situado nas proximidades da cidade do Brooklyn, nos Estados Unidos, é um matadouro de porcos, onde se empregam os aparelhos mecânicos a vapor para o tríplice processo de - sangrar ou matar, esquartejar e salgar êsses animais. [...]

O estabelecimento, de que vamos tratar, vasto, como deve o ser para estrangular diàriamente centenas de porcos, compõe-se de quatro extensas casas, que se comunicam entre si por pontes pênseis. Ao redor, e em todos os sentidos, se distinguem diversos cercados, fechados, onde formigam inumeráveis porcadas pertencentes a diferentes criadores.

Longe nos levaria a descrição do maquinismo, peça por peça, o que só interessaria a quem quisesse organizar uma Companhia de - açougues monstros - de carne de porco; assim, vamos ser simplesmente espectadores, para o que não basta sòmente - presenciar - é preciso também ter ânimo sòmente para - ver -

A matança vai começar.

O engenheiro em chefe faz um sinal; abre-se logo a comunicação do exterior para o primeiro compartimento da máquina chamada degoladouro.

\footnotetext{
90 Trata-se de Trois ans aux États-Unis.

91 Aqui vale atualizar certas imprecisões que ao cronista certamente se fizeram irrelevantes: o estabelecimento era de propriedade dos Srs. Borello e Hinglinton e situava-se em Cincinnati, cidade próxima ao rio Ohio, e não na cidade do Brooklyn, como citado.
} 
O ingresso para este compartimento é feito por um estreito corredor, que se afunila, e só podem (sic) chegar ao compartimento de que se trata um porco por sua vez. Ao têrmo deste corredor são os porcos obrigados a parar, e logo, com rapidez de raio, enormes facões manejados por um punho tão forte, como o do vapor os traspassem certeiramente a sangrar pelo coração.

Quanto pode a mecânica!

Isto feito, sem demora, cada um porco é agarrado pelos quartos traseiros por grampos, e assim violentamente levantados e conduzidos em enfiada, como um rosário, para serem mergulhados em um vasto reservatório de água fervendo, donde saem para sofrerem o processo final de pelação entre grandes escôvas.

$\mathrm{O}$ vapor ainda não terminou aqui sua missão. O porco ou porca (que neste estado é sempre - porco - nos açougues) é ainda agarrado convenientemente pelos grampos, e em um movimento brutal é arremessado para um lugar apropriado, onde a máquina leva as suas afiadas facas, e de uma só vez abre desde o focinho até a cauda.

Neste estado, saltam logo alguns operários para arrancar os intestinos, ou quaisquer outras partes não aproveitáveis do porco, e os lançam em uma vala que atravessa o estabelecimento, que é constantemente lavada pelas águas do rio Ohio.

A máquina ainda continua a trabalhar, levando o porco ao horrível compartimento do talho; aí se espedaça o animal com aquela regularidade e simetria que lhe é devida, e passa por montões de sal.

Os encarregados do recebimento da carne reúnem os pedaços e os põem no fumeiro ou os embarrilam na salmoura.

Eis a carniceira feita, e com tão grande presteza, que perde-se de vista os múltiplos processos porque passam os pobres animais!

Os porcos sucedem aos porcos, como os cavalinhos de pau da Maxambomba ${ }^{92}$, que mal são percebidos no rápido circular em tôrno do mastro! E juntai a êste movimento o grunhido rouco e sinistro das vítimas que são degoladas ou sangradas, e dos que semi-vivos seguem em rosários para a terrível caldeira d'água em ebulição! Esta lúgubre e horrível música não tem fim, porque, enquanto alguns porcos morrem na água fervendo, já outros são esfaqueados, e assim não cessa de haver sempre um contingente de lamentações!!!

Terminemos a nossa missão de levar o leitor a visitar o estabelecimento de M. Roviello, nos Estados-Unidos.

Agora resta-nos entregá-lo à liberdade de seu pensar, para que julguem até onde se tem empregado as máquinas movidas a vapor.

A este respeito diz um mecânico francês:

“Où la mécanique va-t-elle se nicher!”.

\footnotetext{
${ }^{92}$ Denominação popular dada aos trens.
} 
No retomada a Commetant, Machado já ensaia seus passos de "escriba de coisas miúdas" "93, debruçando-se sobre o detalhe, método que utilizaria ao longo de toda sua vida de cronista. Da obra do francês, repleta em assuntos passíveis de reflexão sobre o espírito humano ("L'esprit de liberté", "Religions", "Beaux-Arts", etc.), pinça três páginas que tratam do funcionamento de um matadouro de porcos. $\mathrm{O}$ texto francês tem caráter informativo; nele a expressão máxima de emoção humana diante da vida que se acaba é o incômodo que a morte provoca aos ouvidos: "Cette lúgubre et horrible musique n'a pas de fin, car au fur et à mesure que les cris d'un cochon disparaissent étouffés dans les puits de vapeur, la mécanique sans cesse en mouvement égorge un autre cochon qui apporte son contingent de sourdes lamentations. (1858: 143)” No mais, o texto atém-se a seu objeto, a eficácia da "mécanique moderne à vapeur".

Se para o francês a morte é extensiva à eficiência da máquina, não oferecendo às suscetibilidades humanas nada além do estorvo dos lamentos, para o cronista o canto fúnebre que embala o sistema capaz de produzir uma "mort aussi prompte qu'extraordinaire", soa paródico, até mesmo porque Comettant já tivera seu rasgo de inspiração irônica ao classificar de "véritables gentlemen" os então proprietários do matadouro pelo fato de "galamment tuer [...] une trentaine de cochons" só para demonstrar o funcionamento da máquina a um turista francês.

Referindo-se a eles logo após o relato da morte de trinta porcos por pura exibição, Comettant joga com a ironia e dispara: “On ne saurait être plus aimable.” E, uma vez que a dissimulação da ironia joga com os limites entre o ser e o parecer, entre a realidade e a aparência, o cronista persiste na mesma trilha, porém, envereda pelo paródico, abandonando momentaneamente a ironia que brota do cinismo das palavras para ressaltar o pragmatismo (e seriedade) com que o autor descreve o funcionamento da máquina.

Contudo, sob viés paródico, a ironia persiste e se instala a partir das ligações assimétricas que emergem da contraposição entre máquina e homem, suposto progresso para a vida e a constatação de que tal progresso contribui para a extinção dela, de forma que o matadouro é elevado à categoria de metáfora irônica. Assim, ao anunciar "a matança vai começar", o cronista o faz como se estivesse convidando o leitor a

93 “A Semana”, Gazeta de Notícias, 28/8/1892. 
participar de um espetáculo onde ambos presenciam com espanto o desenvolvimento de uma ciência, cuja técnica abriga a destruição. Porcos sempre foram mortos, argumentase, porém, o que surge de forma paródica é a decepção reinante quanto a um progresso que produz maravilhas, mas é incapaz de frear a miséria que se alastra.

Cotejando-se os diversos entrechos das crônicas machadianas, nota-se que o fervor e o entusiasmo dispensados ao progresso em idade madura, contrastam radicalmente com as observações de juventude do cronista, quando via com perplexidade o desenvolvimento que se impunha, indiferente à vida, aos modos e costumes. ${ }^{94}$ Levando-se em conta o hiato que se produzia entre a veiculação da ideia na Europa e sua disseminação no Rio de Janeiro, é provável que essa postura reflita as discussões literárias do velho continente, quando o classicismo cedia espaço para o romantismo.

O movimento romântico, é sabido, refuta o avanço da modernidade no que se refere à intensa racionalização e mecanização, produtos da razão universal propagados intensamente pelas Lumières $^{95}$, trazendo à cena o lirismo e a subjetividade. No mais, sempre que se dispuseram a expressar a sensibilidade atormentada do ser, os românticos mitigaram os valores clássicos em beneficio da emoção.

Desse modo, cronista e leitor tornam-se espectadores de um espetáculo dantesco, uma espécie de ópera de horrores, mimeses do matadouro de Cincinnati. O texto lança mão de um léxico que acentua a dramaticidade (sangrar, matar, esfaquear, etc.), cujo intuito não é outro que acentuar a posição ocupada pelo homem nos dois polos de produção, ou seja, a de propulsor no início e na finalização do "produto", com a justa aferição do lucro, ideia subjacente desde a idealização da máquina.

Quanto pode a mecânica! A exclamação é dúbia: ao mesmo tempo em que sugere o espanto do cronista em face da eficiência da ciência e da razão, portanto, emitida no domínio do narrativo, no teatral, tem seu sentido justaposto às sensações do espectador o qual, nesse segundo ato, será exposto à vileza humana, sobretudo quando

\footnotetext{
${ }^{94}$ Reflexão circunscrita às crônicas.

${ }^{95}$ Mal começara o século XVIII e Fontenelle já elevava a ciência a um patamar que faria da terra um paraíso: "voici un vaste champ de connaissances propres à l'usage et à l'avantage des hommes ici-bas: à savoir inventer des machines nouvelles et rapides qui abrègent ou facilitent notre travail, combiner l'application sagace de plusieurs agents ou matériaux qui nous assurent des produits nouveaux et bienfaisants dont nous puissions nous servir, et accroître par là l'ensemble de nos richesses, c'est-à-dire des choses utiles aux commodités de notre existence... (Préface à l'Histoire du renouvellement de l'Académie royale des sciences (1702), in : HAZARD, 1961: 300)"
} 
se destacam os muitos "semi-vivos [que] seguem em rosários para a terrível caldeira d'água em ebulição!", acentuando, assim, o horror do cronista diante da frieza e imparcialidade com que a técnica subjuga a vida, ironia machadiana à ciência, cuja razão de existir reside justamente no oposto, em facilitá-la e preservá-la.

Daí um cronista enternecido pelos "múltiplos processos porque passam os pobres animais", a convidar o espectador à reflexão e ao julgamento. Em discussão a disseminação e o intrometimento atingido pelas máquinas a vapor; nas entrelinhas, o preço que a vida haverá de pagar para obter o progresso. Sob essa lógica há o cronista preocupado com o futuro, cioso da necessidade de esclarecer ao seu leitor a origem e o custo empregados no simétrico pedaço de carne que consome. Proteção à vida animal avant la lettre? Muito provavelmente não, haja vista ser esta uma interpretação à luz de nossos dias que certamente passou ao largo do leitor oitocentista, embevecido a cada instante face aos saltos do progresso, além do que a reflexão de Machado paira no plano das ideias, nada de concreto é proposto, nada se altera, cronista e leitor se mantêm na postura de origem, ou seja, simplesmente espectadores.

Por conseguinte, o diálogo que se estabelece com Voltaire também se dá no plano das ideias, só que então, para, através da paródia, destacar o caráter no mínimo duplo da natureza humana. Discretamente, la vertu cede lugar à mécanique, sai a poesia, entram a frialdade e a inexpressão da máquina. O mais importante sinal do diálogo com Voltaire se faz pela ausência. O nome do francês é apagado e substituído por um qualquer mecânico francês, numa adequação de referência incorporada que se aclimata, perde a asserção filosófica, para se inserir numa instância mais popular, na qual o nome do autor não mais é necessário, embora a ele sempre se volta por associação de ideias, uma vez que o que disse é agora adágio de domínio público.

A rigidez clássica da forma que encerra as qualidades humanas inerentes à vertu, que na expressão do francês nos remete às vicissitudes e às boas surpresas que a alma humana pode encerrar, ironicamente, nestes tempos de ares românticos, mostra-se inadequada, o que faz com que o cronista lance mão de algo destituído de qualquer sentimento - la mécanique -, indício e denúncia de ideias que despontam em época na qual as emoções já podem aflorar, contudo, sacolejam entre o que emociona e o que leva à indiferença, entre o terno e o prático, as emoções de um lado, o estático, porque destituído delas, de outro. 
Entretanto é preciso atentar para o fato de que embora a crônica se constitua num espaço para o efêmero, a anedota e o cômico, em Machado, justamente por ela, em princípio ser vista como material produzido para a alegria e o divertimento dos leitores, pode encerrar armadilhas, já que a realidade é volatilizada, se desvanece, e é transformada em ficção. De tal processo de escrita se desprende a ambigüidade, a relativização e a convivência de opostos. Assim, o lado prático - ciência e progresso -, embora justapostos, necessariamente não se equivalem no sentido de que a primeira determinará o segundo, isto é, de que a técnica - la mécanique, seja porventura resultado da ciência. Machado intervém constantemente por meio de uma polifonia, na qual vozes claramente identificáveis e perceptíveis - Molière e Voltaire - contribuem para a ideia de que sob um processo pretensamente científico jaz uma prática perversa e sádica.

Ao ser convidado a interlocutor do cronista, a primeira pista que o leitor recebe é a de que deve enveredar pelo risível, pelo cômico. Afinal, é em Molière que nosso autor busca respaldo ao ironizar os benefícios da mecânica, tão demolidores quanto a comicidade do francês. $\mathrm{O}$ aforismo de Molière, no entanto, é de segunda mão, é dito pelo mecânico francês - Voltaire -, indicação de que embora a reflexão deva começar pelo risível, para sua total realização - e também do diálogo que a precedeu -, o leitor não deve ignorar a mordacidade e a ironia do trágico de Ferney. É a conjunção do sempre combativo e desconfiado Voltaire, sobretudo das leis e das ideias, com o caráter demolidor do cômico, que reforça a ideia veiculada pelo cronista, a do perigo existente em acreditar-se unilateralmente na ciência como a solução para muito dos problemas do mundo, algo, a essa época, bastante em voga.

Assim, Machado alerta, a grosso modo, para o pensamento aí incluso, porém, elíptico - e invertido -, de o que o fim justificaria os meios, ou seja, para a materialização do progresso como resultado da ciência e do desenvolvimento da razão, são necessários meios que, embora contribuam para o bem estar humano, em algum momento, interrompem a cadeia natural da vida em benefício do progresso. Tal a justaposição do cosmopolita Voltaire, entusiasta da ciência e do progresso, e Molière, representante por excelência do gênero cuja característica principal é o engano, uma vez que em geral o cômico tem sua origem no fato de uma ou mais personagens serem trapaceadas ao longo de um enredo, um aviso ao leitor de que, embora necessária, a 
ciência esconde sob suas asas, caminhos tortuosos e nada admiráveis, antes de se converter em progresso.

Entenda-se, porém, que o alerta do cronista não é um convite para que o leitor rejeite a chegada e as qualidades das máquinas a vapor, mas principalmente, que desconfie, com ele, da bondade unilateral e da unicidade de um pensamento, porque seja ele qual for, este só se constitui pela ambivalência e pela ambigüidade, isto é, há sempre dois lados a considerar.

\section{5. "Où la direction d'une académie va-t-elle se nicher!"}

"Nesse anno entrara eu para a imprensa." $96 \mathrm{O}$ ano de 1860 parece ter sido significativo para Machado de Assis. Embora já tivesse contribuído para diversos periódicos ${ }^{97}$, sua entrada para o Diário do Rio de Janeiro, a convite de Quintino Bocaiúva, define-o como profissional de imprensa ${ }^{98}$. Ali, gozava de relativa liberdade ao produzir seus "Comentários", crônicas que ditavam a tendência do jornal, uma vez que ocasionalmente substituíam o editorial.

A série, onde o cronista supostamente trataria das novidades teatrais e literárias (logo relegadas a status secundário) revela-se de um matiz político contundente, trampolim para que Machado exiba postura combativa e liberal em consonância com a linha editorial do jornal. Nesses relatos, a prudência, apontada pela crítica como seu principal traço (MIGUEL-PEREIRA, 1988: 77), contrasta com as atitudes ousadas e destemidas do jovem jornalista. Talvez por excesso de engajamento ou porque o contexto político invertera-se radicalmente ${ }^{99}$, a série começa a se espaçar e seu autor, ativo e idealista, mostra-se "desgostoso da política, da qual se afastou ou da qual foi afastado" (MASSA, 1971: 308).

A crônica publicada em 25/11/1861 trata substancialmente de dois assuntos: na primeira parte, a unificação da Itália e o rápido reconhecimento do novo reino

\footnotetext{
96 "O Velho Senado", in Revista Brazileira. Tomo XIV, Abril-Junho. Rio de Janeiro: Sociedade - Revista Brazileira, 1898, pp. 257-271.

${ }^{97}$ Marmota Fluminense, Correio Mercantil, O Espelho, etc.

98 Jean-Michel Massa (1971: 292) especula sobre o fato de as experiências anteriores ao Diário terem sido colaborações "gratuita[s], ou quase, [pois Machado] era ainda um diletante no jornalismo".

${ }^{99} \mathrm{Em} 1861$ os liberais aproximam-se dos conservadores moderados, formando a Liga Progressista e, em maio de 1862, o governo é posto é minoria por um voto (Annaes do Parlamento Brazileiro, 1862: 92 Sessão de 27/5/1862).
} 
justapõem-se à descortesia do governo brasileiro em não enviar um representante à coroação de Guilherme I, da Prússia. Em ambos os casos o cronista tece duras críticas à diplomacia, seja pela agilidade com que se considerou a questão italiana (algo visto com ceticismo pelo cronista, habituado a ver o governo contrariar a opinião), seja pela ausência brasileira no país onde procurávamos "colonos [...] para lavrar nossas terras". Em análise rigorosa, destacam-se não só a incoerência e o despreparo do governo no trato de questões externas, como a inconsistência das explicativas.

$\mathrm{Na}$ segunda parte, as "ocorrências da semana" (o drama de Valentim Lopes, em cartaz no Theatro Gymnasio Dramatico, o lançamento do livro de Moreira de Azevedo e comentários sobre Theresa Parodi, a prima-dona da companhia italiana que trouxera aos palcos cariocas a Norma de Bellini e Ernani de Verdi) são precedidas de artilharia de grosso calibre endereçada ao diretor da Faculdade de Medicina:

Outro tanto pudesse eu opor à negação da ciência em favor do empirismo, que no meio de uma corporação fêz o diretor da academia de medicina ${ }^{100}$. Ouvi bem, o vindouros, o diretor de uma academia de medicina! Où la direction d'une académie va-t-elle se nicher!

Mas não pasmemos, leitor amigo. Negar a ciência é negar a espôsa, com que se contraiu, depois de longo estudo, o consórcio íntimo do espírito e dos princípios. Mas negar a publicidade, negar a discussão, que são a alma do sistema representativo, equivale a negar a liberdade, a negar a própria mãe.

$[\ldots]$

Felizmente o senso comum faz ouvidos de mercador, e o senador-diretor prega debalde aos peixinhos.

Enviesado, o sarcasmo destinado ao senador do Império revela como o cronista desde muito cedo se contaminara do espírito das Lumières, de modo a reforçar em contexto adverso ao da origem o conceito de que a ciência não é um simples jogo de ideias, mas um saber suscetível de subjugar a natureza para proporcionar ao homem bem estar e felicidade.

\footnotetext{
100 Trata-se de José Martins Cruz Jobim (1802-1878) que, de fato, era diretor (de 1842 a 1872) da Faculdade de Medicina, e não da Academia de Medicina; a correção será feira por Machado na crônica de 1/12/1861. O discurso ao qual se refere o cronista foi proferido por Cruz Jobim na cerimônia de colação de grau dos alunos de medicina, conforme noticia o Diário, de 21/11/1861, p. 1.
} 
Para o cronista, o contrassenso de Cruz Jobim soa ofensivo: habituado a beber nas fontes francesas e, supondo-se que o diretor da faculdade fizesse o mesmo ${ }^{101}$, como poderia ele orientar-se pela experiência, com desprezo pela metodologia científica? Negar a ciência significava perpetuar a visão rígida e escolástica do mundo medieval, quando o sentido da ordem visível estava diretamente ligado à intuição.

O posicionamento de Cruz Jobim abre espaço para críticas em duas frentes: circunscrevendo-as à medicina, abraçar o empirismo significava reforçar uma prática arraigada em crendices populares, e, sobretudo, o exercício de uma medicina canhestra, desprovida de comprovações científicas, quando a farmacologia, por exemplo, constituía-se em parte de substâncias tóxicas (arsênico, mercúrio, antimônio, etc.); por outro lado, com a intromissão do intertexto, não se criticam só as ideias do médico, do diretor da faculdade de medicina, mas, principalmente a instituição que ele representa, fragilizando-a.

“Où la direction d'une académie va-t-elle se nicher!" O aforismo, ao mesmo tempo em que denuncia Cruz Jobim, acusando-o de relativizar a razão (conceito caro ao cronista), contribui para o desmerecimento do status da faculdade, uma vez que o leitor tem a tendência de subscrever o enunciado irônico, conforme afirma Théodore Reik (The secret of life, 1952) ${ }^{102}$ : "le processus émotionnel chez l'auditeur (ou le lecteur) doit être le reflet direct ou indirect de quelque chose qui s'est déroulé lors de la production de la phrase ou de la représentation ironique."

Nessa perspectiva, o mecanismo responsável pela memória literária é rapidamente disparado tão logo o leitor culto machadiano corra os olhos pela frase de Molière. Se na origem, ao ser reproduzida por Voltaire, trazia uma assonância positiva, na crônica a situação se inverte, pois contribui para questionar a competência profissional de Jobim. Se, no passado, a virtude se acomodara em lugar onde se acreditava ser impossível vê-la florescer (o pobre que devolve a moeda a Molière), validando aos incrédulos certa pureza inata ao espírito humano, agora, através do paralelismo entre a produção e a recepção irônica da citação, o leitor se dá conta da outra face desse espírito, contraditória por natureza e incoerente em suas crenças e atitudes.

\footnotetext{
${ }^{101}$ Cruz Jobim graduou-se em medicina pela Universidade de Paris em 1828.

${ }^{102}$ Citado in: Poétique de l'ironie (SCHOENTJES, 2001: 88).
} 
Enquanto prática intertextual, a presença da expressão no espaço da crônica concorre para a originalidade do texto que se constrói; referência e referencialidade ${ }^{103}$ se justapõem: a primeira, aleatória ou consentida, surge na trama da escritura através de uma citação e leva o leitor até Voltaire que, por sua vez, acompanha-o até Molière, depois, esbravejada contra Cruz Jobim, entrelaça-se ao real e, não só agrega sentidos à crônica, revigorando a própria citação, mas, em esfera maior, no contexto da circulação das ideias, contribui para sua banalização, reforçando sua estereotipagem e transformando-a em clichê.

Toda essa "maquinaria textual" atualiza o texto voltairiano, trazendo à luz a expressão pessoal do cronista: se na crônica de 8/5/1860, quando perdeu a palavra "vertu" e ganhou "mécanique", a citação sustentara seu espanto (e de seu leitor) diante do progresso e da ciência, agora sua perplexidade é maior, pois a "bobagem humana" permanece, tem nome, endereço e pode facilmente ser localizada na faculdade de medicina e na pessoa do senador Cruz Jobim, referencial que mimetiza a desilusão do cronista.

De fato, em ponto pequeno, o cronista parece reprisar o espanto vivido pelos europeus do século XVIII, quando a razão tornou-se uma audácia crítica e a curiosidade dos espíritos ameaçou a estabilidade do Grand Siècle. Na Paris dos trópicos, após grande interlúdio, algo ameaça mudar, falta coerência e os modos se alteram, levando, inclusive a ciência e a nobreza para "lugares" suspeitos.

\section{6. "Où la science et la pairie vont-elles se nicher!"}

A crônica da semana subsequente (1/12/1861) é uma colcha urdida com retalhos pinçados aqui e acolá: a morte de um general, os preparativos da exposição nacional e suas prévias, as provinciais, a comissão do teatro, Resignação, um drama de Miranda Varejão, La Dame Blanche, ópera de Boieldieu e seus intérpretes, além da questão italiana e o senador Cruz Jobim, já mencionados na semana anterior. Esses dois últimos ditam o tom do texto.

As considerações diplomáticas sobre o reconhecimento da Itália desvelam uma reflexão mais extensa sobre o direito divino.

\footnotetext{
${ }^{103}$ Compreendendo-se referência como o olhar da literatura sobre si mesma e referencialidade como o olhar da literatura sobre o real (SAMOYAULT, 2005: 77).
} 
Está acabada a questão do reconhecimento da Itália. [...]

Supunha que o gabinete tivesse olhado as coisas políticas da Europa de um ponto de vista justo, e portanto elevado. Era caluniá-lo; e para não haver dúvida veio êle próprio declarar que faz a sua apreciação do movimento do espírito humano do alto da varanda do palácio imperial.

Qualquer que seja o respeito que mereça aquêle ponto de vista, palpita-me que o mundo é alguma coisa de mais largo, e que as idéias pairam um pouco acima dos augustos telhados da monarquia.

Se o governo é dos que, como o rei Guilherme I, ainda andam embebidos pela idéia de que Deus se ocupa em fazer coroas para constituir direitos que têm outra fonte real, bem pode renunciar a querer fazer do império uma coisa que preste, e desde já fica habilitado a tirar diploma de imbecilidade ou de especulação.

Para isso tem amplo e indisputável direito.

Será mais um episódio de sua biografia, já opulenta dêstes e quejandos.

Contudo, nada é discutido em profundidade! A crítica, indireta, como convém ao gênero, revela-se um estratagema: primeiro, o cronista, ocultando-se sob o pseudônimo de Gil, depois, a censura à monarquia. Esta, a priori estranha, sugere a complexidade de sua escolha, tratando-se de um possível militante do liberalismo-monarquista como Machado (MAGALHÃES JR., 2008: 308; 322, Vol. I). Observando-a sob o viés da especulação, podem-se intuir suas restrições ao absolutismo e, nessa lógica, ao poder moderador. Visto ora como a "válvula pela qual [podíamos] escapar à anarquia parlamentarista" ora como um mecanismo de sustentação da chamada "ditadura ${ }^{104}$ da honestidade" (GALVÃO DE SOUSA, 1962: 125-127), o certo é que esse quarto poder alimentava ideias anacrônicas.

Na primeira página, ao lado da crônica machadiana, temos a publicação de uma coluna intitulada "Noticiario", que se inicia com o seguinte entrecho:

O novo reino de Italia não devia ser reconhecido pelo Brasil, porque (diz o Scoevola) ${ }^{105}$ A REALEZA VEM POR GRAÇA DE DEOS, isto é, o poder dos reais vem de Deos. Já se vê, pois, que o reconhecimento lisongeiro e ostentado pelo nosso ministro de

\footnotetext{
${ }^{104} \mathrm{O}$ termo surge como exemplificação da força e da moralidade de D. Pedro II enquanto monarca constitucional e não no sentido pejorativo recente.

${ }^{105}$ Trata-se de um articulista que publicava em vários periódicos sob o pseudônimo de Scoevola, na seção intitulada "A Pedidos". A edição de 2/12/1861 menciona que Scoevola teria escrito sobre o mesmo tema no Correio Mercantil e no Jornal do Commercio.
} 
estrangeiros, em nome, e estamos certos que de accordo com Sua Magestade o Imperador, importa a negação de tão falso principio.

O Sr. Taques, comnosco, reconhece sómente o poder da soberania do povo. Isto nos honra muito, e tanto quanto o Sr. Taques, secretario de estado, não obrou em seu proprio nome, e sim no do illustrado monarcha do Brasil.

Nessa perspectiva, parece claro que a monarquia constitucional ${ }^{106}$ surja como o sistema que mais responde às convicções do cronista, uma vez que ele deplora categoricamente aqueles que "andam embebidos pela idéia de que Deus se ocupa em fazer coroas para constituir direitos que têm outra fonte real". Talvez, já receoso do "pugilato das idéias"107, seja sintomático que sua crítica não se restrinja ao local, mas às "idéias que pairam um pouco acima dos augustos telhados da monarquia" e Guilherme I figure como representação e metáfora daqueles (ou dos regimes) "habilitado[s] a tirar diploma de imbecilidade ou de especulação”.

Ainda assim, o cronista assegura "amplo e indisputável direito" aos "imbecis", algo que não só mostra sua grandeza de espírito, mas soa tentador a qualquer estudioso que busca uma aproximação entre o "Bruxo de Cosme Velho" e o "Patriarca de Ferney", tivesse este último pronunciado o célebre aforismo que reiteradamente lhe tem sido atribuído, ${ }^{108}$ notando-se de qualquer modo o espírito liberal do cronista, seu cosmopolitismo e sua consonância com as Lumières.

Diretor de academia sem nunca ter sido (engano do cronista, claro!), cientista que abjura a ciência, o senador Cruz Jobim surge como uma figura caricatural e burlesca na sociedade de então. Veja-se:

\footnotetext{
106 Em crônica publicada em 10/10/1864 (“Ao Acaso", Diário do Rio de Janeiro) Machado vê com desconfiança o casamento do grão-duque Nicoláo, da Rússia e da princesa Marie Dagmar, filha do rei da Dinamarca. Sobre isso, afirma: "a notícia [...] que muita gente olha como um prenúncio da formação do reino escandinavo, mas que eu não sei se dará em resultado exatamente o contrário disso, isto é, a supressão de uma monarquia constitucional em favor de uma monarquia autocrática".

107 "Crônicas", O Futuro, 15/9/1862. Nesta crônica Machado aconselha sua pena: "Não te envolvas em polêmicas de nenhum gênero, nem políticas, nem literárias, nem quaisquer outras; de outro modo verás que passas de honrada a desonesta, de modesta a pretenciosa, e em um abrir e fechar de olhos perdes o que tinhas e o que eu te fiz ganhar." Muito provavelmente, resultado de sua "experiência" liberal nas páginas do Diário.

${ }^{108}$ Trata-se do aforismo apócrifo "Je ne suis pas d'accord avec ce que vous dites, mais je me battrai jusqu'au bout pour que vous puissiez le dire." A citação ("I disapprove of what you say, but I will defend to the death your right to say it."), cunhada por Evelyn Beatrice Hall, aparece em The friends of Voltaire (1906) e tem sido exaustivamente atribuída a Voltaire, em geral, como sinônimo da plena liberdade de expressão, em razão de o filósofo ter defendido Helvétius, embora tenha deplorado De l'esprit (1758).
} 
Antes de pingar o ponto final, permita-me o leitor que eu retifique um êrro que me escapou nos Comentários últimos. Quando falei de um personagem que preferia a ciência dos selvagens à ciência das academias, o que prova bem que lhe assiste o direito de ser colocado entre os primeiros, disse __ diretor da academia de medicina __ em vez de __ diretor de faculdade.

E, já que falo no diretor, lembra-me (sic) êsse trecho de um discurso de S. Ex. (sic), em que a palavra cloaca era repetida, sem embargo da presença das augustas personagens, em sessão pública e solene. Nem ao menos o sexo delicado, que ali tinha um régio representante, mereceu de S. Ex. uma consideração de deferência e atenção.

Se o bom do homem é retrógrado em ciência, em cortesia mostra uma simplicidade rústica, digna dos primeiros tempos da humanidade.

E é senador, e é diretor de uma faculdade!

Où la science et la pairie vont-elles se nicher!

Ao corrigir o próprio texto, o cronista não deixa passar ao largo a oportunidade de criticar o senador, como faria inúmeras outras vezes (MAGRI, 2009: 93-94). A um senador afeito às honrarias, a correção soa como peça de artilharia, desautorizando-o não só profissionalmente por preferir "a ciência dos selvagens à ciência das academias", mas socialmente, ao destacar o caráter tosco e grosseiro de sua aparição na sociedade mundana.

Assim como na crônica precedente, o caráter irônico surge via intertexto, de modo que um pecúlio literário comum entre interlocutor e leitor é essencial, sobretudo para este último que, perspicaz, além do contexto, deverá manipular os indícios deixados pelo cronista, ou seja, "inverter" o julgamento de valor implícito e reconhecer se se trata de um elogio ou de uma crítica, para que a ironia se consuma.

Où la science et la pairie vont-elles se nicher! Afora os acréscimos ("la pairie", surge por conta de uma ironia de situação), o leitor machadiano facilmente identificará a inversão de sentido produzida desde a origem da citação, quando a ação do pobre (vista de forma positiva) fizera com que a virtude buscasse morada entre os mendigos. Ainda que a ironia enquanto mecanismo linguístico consista em dizer pouco para significar muito, em geral há um agenciamento verbal que desvia o sentido de modo a afirmar direta ou mesmo indiretamente o oposto de uma sugestão manifesta. Nessa lógica "se nicher" funciona como propulsor que dispara a memória literária do leitor, colocando-o na mesma sintonia do interlocutor e criando espaço para a ironia. 
O compartilhamento de um mesmo universo permite que o cronista exprima em potencial sua perplexidade, pois seu leitor culto de pronto especula sobre o contraste entre a fonte francesa e o modelo brasileiro, no caso, extremos contrários: Voltaire, cosmopolita e afeito à vida mundana versus um senador que apesar da indiscutível ascensão, mostra-se de uma "simplicidade rústica" e "selvagem".

A rigidez das críticas endereçadas ao parlamentar tem origem em uma ironia de situação, contudo, o que o cronista busca destacar é a falha moral de Cruz Jobim e, nesse caso particular opta pelo sarcasmo. Essa ironia cáustica surge como crítica suplementar, ou seja, ultrapassa a ironia corretiva. Na medida em que dispensa o leitor como elemento constitutivo, evita desvios, ignora a arte do fingimento e vai direto ao insulto, à invectiva. De certo modo, como afirma Schoentjes (2001: 229), "le sarcasme sera toujours plus grossier que l'ironie parce qu'il est à la fois plus visible et plus malveillant".

Nessa perspectiva, a tutela de Voltaire distancia o cronista da esfera de Cruz Jobim, diferenciando-o enquanto espírito crítico e pertinente, e autorizando sua intromissão em uma esfera social superior, uma vez que não compartilha da frivolidade grosseira e característica do senador, mas surge como depositário de uma pena que denuncia sua razão esclarecedora, indigna-se com a vaidade obtusa que corrompe os espíritos e revela sensatez, bons modos, prudência e discrição. Ademais, imprime certo "verniz", do qual padece Cruz Jobim.

A ironia é plena de riscos, mas como nada é estranho ao cronista (e a ela, a ironia), no instante em que Cruz Jobim é ridicularizado por sua atuação em sessão solene, o leitor já escolheu de que lado vai ficar, lê o sarcasmo como sátira e ri com o interlocutor vendo nisso uma intenção moralizadora, afinal toda preocupação de um satírico é ridicularizar a sociedade e seus representantes.

Assim, se o intertexto sustenta a severidade da crítica, sua alusão pontual a Voltaire confere dinâmica e amplitude à citação, enriquecendo a interpretação. Às observações reprovadoras do cronista, soma-se a voz tonitruante e devastadora, quando não - debochada -, de Voltaire, cujo eco traz, ainda que de longe, o escárnio do cômico representado, na origem, pela ascendência de Molière.

Ao lançar mão do aforismo voltairiano, não se pode conjecturar uma escolha aleatória, mas refletida, sob a lógica do dialogismo: ao popular senador, a quem assiste 
o direito de ser colocado entre os selvagens, o cronista toma atitude responsiva e o faz sob o reflexo da fonte, mostrando o embate de Voltaire em favor da ciência, de forma a destacar não só o anacronismo das ideias do parlamentar, mas sua estupidez.

Seja como divulgador das ideias de Newton na França, seja na luta contra o fanatismo, considerado pelo gênio francês um baluarte contra a ignorância, Voltaire, na condição de intertexto, surge como contraponto ao senador, aprofundando seu caráter retrógrado e "ennuyeux".

\title{
7. "Tous les genres sont bons, hors le genre ennuyeux."
}

O cenário político já era outro. Em meados de 1862, quando Machado interrompe seus "Comentários" nas páginas do Diário, os liberais, que vislumbravam participar do governo, moderam seus ataques por ordem tática. Nota-se, já em 22/2/1862, seu desencanto com a política quando, ao finalizar a crônica, faz apelo a algo que

\begin{abstract}
satisfaça e entretenha o espirito publico, desgostoso e enjoado com as miserias politicas de que nos dão espectaculo os homens que a aura da fortuna ou o máo genio das nações, collocou na direção, patente ou clandestina, das cousas do paiz.

Causa tédio ver como se calumniam os caracteres, como se deturpam as opiniões, como se invertem as idéias, a favor de ínteresses transitorios e materiaes, e da exclusão de toda a opinião que não comunga com a dominante. Para este resultado nem os mais altos escapam, e é tecendo defesas ao principe que se procura provar a má fé alheia e os proprios fervores. ${ }^{109}$
\end{abstract}

Nota-se que à época o cronista já pressentia a perda da tribuna, privando-o de lançar suas catilinárias contra o governo, seu corporativismo e ineficácia. Embora não seja excluído em definitivo do Diário, é afastado da grande cena (a política), restandolhe as "notícias anódinas" e um papel de coadjuvante no proscênio mundano das artes e da literatura. É nesse espírito que Machado volta às crônicas em $1864^{110}$, agora assinando a coluna “Ao Acaso", que seria publicada até o ano de 1867.

A crônica de 10/10/1864 emana certo cansaço! De pronto, surge um cronista "reclamão", incomodado com o clima, a falta de notícia ao longo da semana ("sete dias

\footnotetext{
109 "Comentários da Semana", Diário do Rio de Janeiro.

${ }^{110}$ Embora as crônicas de "Ao Acaso" apresentem dados políticos, estes, porém, não mais figuram como mote principal dos textos.
} 
chochos") e o atraso do paquete, seguido de uma profunda decepção com as novas do velho continente. Para o cronista, exceto a notícia de um casamento real ${ }^{111}$, algo que o estimula a ler as entrelinhas e, de maneira capciosa, entrever o princípio de uma autocracia em meio ao idílio das bodas, nada de novo acontecera. A saída é comentar o matrimônio, porém, mal dá vazão aos pensamentos, vem a autocensura: "Aí vou eu entrando pelo terreno da política tôrva e sanhuda. Ponto final ao acidente."

Nessa perspectiva (e considerando-se a atual conjuntura vivida pelo Diário) é perfeitamente factível a observação de Jean-Michel Massa (1971: 299) sobre a série "Ao Acaso": "Estas crônicas, bastante vivas, são excelentes; como se sentisse algum ressentimento em ser privado do licor político, dirigia sua violência aos escritores de quem comentava as obras." O fato é que em 10 de outubro o cronista mira o vazio, o nada, na tentativa de transparecer sua angústia pelo impedimento em tratar do único assunto que realmente lhe interessava. Nessa toada, relembra Alphonse Karr, contrapondo os jornais franceses ao marasmo e ao "silêncio desolador" que habitam o Rio de Janeiro, implora à "musa faceira e gentil do folhetim" alguma inspiração (ainda que seja quimérica qual o poema de Ossian) até que, por fim, encontra o "Éden baiano".

Porém, nova desilusão! Nada de notícias, sequer um fait divers, um Abílio, uma Martinha, um punhal, nada! A última sessão do júri baiano não apontou um só crime, fosse ele morte, furto, adultério, falsificação..., o que leva o cronista a indagar: "O pecado sacudiu as sandálias às vossas portas e jurou não voltar aos vossos lares?” Na impossibilidade de uma crítica ácida ao poder jurídico baiano (algo que, evidentemente, obrigá-lo-ia a uma ponderação política), o cronista enreda-se pelo literário.

Éden, Eva, uma espiadela em Tartuffe (1664) e é o suficiente para que os problemas locais venham à tona. $\mathrm{O}$ descaso da câmara municipal com o caminho do Catete, a poeira, os boqueirões e a imundície afastam-no da rápida crítica à administração municipal e fazem-no mergulhar na imundície moral do homem. As peripécias de Lucrécia Borgia, pinçadas da obra de Hugo, sugerem ao bom entendedor algo podre numa política que submete as opiniões à mordaça, obrigando-o, por exemplo, a saltar de um assunto a outro, do real à fantasia e vice-versa, enfim, forçandoo a perpetuar estereótipos dignos da "sabedoria popular", ou seja, algo "que os

\footnotetext{
${ }^{111}$ Veja nota 106.
} 
tipógrafos de todos os países já estão cansados de compor, e os leitores de todos os livros e jornais cansados de ler".

E, mais uma vez o cronista chama a atenção de seu leitor para o aspecto caricatural das relações sociais e políticas que constituem a sociedade carioca do dezenove. O casamento da princesa imperial surge como alegoria, cenário e representação do teatro que se encena comumente na capital federal, onde "constroemse arcos e coretos em vários pontos da cidade [...] mas essas construções [sequer são] precedidas de alguns melhoramentos", de modo que o cronista lança mão da velha cantiga popular: "Por cima muita farofa, etc.".

Como parece discorrer sobre o óbvio, algo que seu leitor está "cansado" de ver, mas que o discurso oficial teima em não enxergar, o cronista procura não mais entediar seu leitor, e para isso busca a tutela de Voltaire (não sem antes anunciar que, enfim, tem uma notícia que "há de alegrar seus leitores") ${ }^{112}$ :

Demorar-me neste assunto seria aborrecer os leitores. A primeira condição de quem escreve é não aborrecer:

Tous les genres sont bons, hors le genre ennuyeux. ${ }^{113}$

Ora, a introdução do intertexto interrompe uma sucessão de não fatos: tratou-se daquelas "semanas pobres" quando nada de novo e inusitado acontecera, e o pouco sobre o qual o cronista poderia tecer algum comentário ou crítica, provavelmente era assunto protegido pelo impedimento que recaía sobre ele, de modo que nada sobrara além das notícias de longa data, ordinárias e cansadas. Tanto é que entre o pouco que poderia alegrar seu leitor está uma tradução de Ariosto, poeta italiano da Renascença.

Esse mesmo leitor, acostumado a uma pena ágil, belicosa, que se alimentava da política, suas ideias, acertos e entreveros, achá-lo-ia, no mínimo, entediante e se

\footnotetext{
${ }^{112} \mathrm{O}$ cronista finaliza a crônica informando sobre a impressão das obras completas de Odorico Mendes, anunciada pelo Imperador D. Pedro II, a publicação de dois livros do escritor português Alexandre Herculano (Contos do Vale dos Lôbos e uma tradução de Ariosto) e, como a confirmar que não tem mais nada a dizer, transcreve um trecho do jornal Despertador, de Santa Catarina, sobre um sermão feito pelo jesuíta Razzini.

${ }_{113}$ A frase aparece no prefácio de L'Enfant Prodigue, intitulado de "Préface de l'éditeur de l'édition de 1738", contudo, já em 1742, nas Oeuvres de Voltaire, o texto que aparece no quarto volume vem com a seguinte advertência: "La Préface qu'on trouve à la tête de la comédie de l'Enfant Prodigue est certainement du même auteur. On voit qu'il ne voulait pas alors que cette pièce parût sous son nom. Je n'en puis deviner le motif, car cette pièce est toujours rejouée avec succès : il est vrai que plusieurs personnes, mais particulièrement l'abbé Desfontaines, ennemi personnel de l'auteur, se déchainèrent contre elle dans sa nouveauté. (VOLTAIRE, 1877: 442, Tome III)"
} 
espantaria em face de uma novidade de aproximadamente 350 anos! ${ }^{114}$ Assim, diante do risco de alimentar o desinteresse e o tédio, busca caminhos que confiram "verdade" ao texto e agreguem importância ao relato. A solução (e respaldo) surge do aforismo voltairiano:

Les bons ouvrages que nous avons depuis les Corneille, les Molière, les Racine, les Quinault, les Lulli, les Le Brun, me paraissent tous avoir quelquer chose de neuf et d'original qui les a sauvé du naufrage. Encore une fois : tous les genres sont bons, hors le genre ennuyeux (VOLTAIRE, 1877 : 445, Tome III).

O entrecho acima faz parte de um prefácio em que Voltaire defende sua comédia como "la première comédie qui soit écrite en vers de cinq pieds", afirmando tratar-se de uma obra que produzirá variedade no teatro francês. Ademais - afirma -, "on y voit un mélange de sérieux et de plaisanteire, de comique et de touchant", afinal "la vie des hommes est bigarrée; souvent même une seule aventure produit tous ces contrastes".

Ao buscar a tutela de Voltaire, o cronista faz uso de sua espingarda de dois $\operatorname{canos}^{115}$ : primeiro mira seu próprio relato, como se se desculpasse com seu leitor pelo fato de tê-lo obrigado a saltar de um assunto a outro sem se demorar em nenhum deles, forçando-o a seguir suas peripécias quando não tinha muito o que dizer; depois, ressentido, alveja um inimigo invisível, institucional, que faz do real espetáculo, cenário, e das ideias e opiniões, fantasia (vide a crônica de 22/2/1862), afinal, o "tédio" não surge do relato, mas do fato de que "caluniam o caracteres" e "deturpam as opiniões, invertem as idéias", transformando o que poderia ser sério em comédia (no sentido crítico e pejorativo do termo), um simulacro!

Nessa lógica, as figuras tutelares indiciadas (Eva, Lucrécia Bórgia, Tartuffe), justapostas, evidenciam as vicissitudes e fraquezas humanas: o descaso, a hipocrisia e a degeneração do homem (sobretudo a dubiedade do homem político) são trazidos à crônica pela assertiva de Lucrécia: "Messeigneurs, vous êtes tous empoisonnés."

Exemplar no aproveitamento intertextual, a crônica desvela como o material literário preenche as lacunas deixadas pelo real na construção do relato: fórmulas já há muito em circulação, fixas no imaginário, disparam outras, entrelaçando-se entre elas e

\footnotetext{
114 Orlando furioso, poema épico de Ludovico Ariosto data de 1516.

${ }^{115}$ Permitindo-se aqui o uso da expressão cunhada por Jean Starobinski (1989: 123): "Le fusil à deux coups de Voltaire".
} 
formando uma teia onde as citações e referências, sobretudo a voltairiana, adequam-se à problemática do cronista em seu momento de criação. Exposto à ausência de notícias, ao cerceamento de suas ideias e à modorra social, as possibilidades de um texto "ennuyeux" são várias, donde a fonte francesa, balaustrada que alerta o cronista sobre o risco de se incorrer em um erro capital: aborrecer seus leitores.

Evitar aborrecimento surge das entrelinhas como a grande preocupação do cronista e o escape parece vir dessas fórmulas (comumente encontradas nos periódicos oitocentistas), que se volatilizam e aderem facilmente a inúmeras outras situações e sistemas ao longo da circulação das ideias. Nesse processo, adquirem vida própria, exibem força e flexibilidade, ajustam-se a outros campos do conhecimento e, sobretudo, guardam possibilidades e traços do sentido com que foram concebidas. De forma genérica, transformam-se em axiomas, adágios, enfim, máximas que adentram a cultura popular, onde são disseminadas e vulgarizadas.

Não por outra razão, o cronista dá início a seu texto parodiando o Baron Louis:

Dai-me boas semanas e eu vos darei bons folhetins. ${ }^{116}$

Mas, que se pode fazer no fim de sete dias chochos, passados a ver chover, sem acontecimentos de natureza alguma, ao menos dêstes que tenham para o folhetim o direito de cidade?

Gastou-se os primeiros dias da semana a esperar o paquête _ e o paquête, como para punir tão legítima curiosidade, nada trouxe que estivesse na medida do desejo e da ansiedade. Veio apenas a notícia de um casamento real ${ }^{117}$ no norte da Europa, que muita gente olha como um prenúncio da formação do reino escandinavo, mas que eu não sei se dará em resultado exatamente o contrário disso, isto é, a supressão de uma monarquia constitucional em favor de uma monarquia autocrática.

Ao parodiar o aforismo de Louis, de modo jocoso o cronista transfere ao leitor a responsabilidade pelo vácuo de notícias então existente. Contudo, ao correr os olhos

\footnotetext{
${ }^{116}$ A frase remete à máxima de Joseph Dominique, baron Louis (1755-1837), ministro de Napoleão e da Restauração francesa, conhecido por seu bom desempenho em assuntos financeiros: « Faites-moi de bonne politique, je vous ferai de bonnes finances. »(GUIZOT, 1858: 44, Vol. I). Contudo, segundo Guizot, de fato, teria dito: "Gouvernez bien, me dit le baron Louis, vous ne dépenserez jamais autant d'argent que je pourrai vous en donner. » $\mathrm{O}$ aforismo torna-se chavão e é glosado por Machado numa das crônicas de "Bons Dias", de 4/5/1888, com fins humorísticos, mas que no fundo traduz uma verdade quase proverbial, ou pelo menos muito corrente. Naquela ocasião ele escreve: 'Daí-me boa educação, e eu vos darei boa política, dizia o Barão Louis.' (PAIVA DE LUCA, 1996: 102)"

${ }^{117} \mathrm{O}$ cronista refere-se ao casamento do grão-duque Nicoláo da Russia, herdeiro do trono, com a princesa Marie Dagmar, filha do rei da Dinamarca (Diário do Rio de Janeiro, 6/10/1864, p. 1).
} 
pelo próximo parágrafo, nota-se que o fez humoradamente, pois sabe que "seu" leitor habitual é curioso ${ }^{118}$, malicioso ${ }^{119}$, indiscreto ${ }^{120}$ e que só o procura por desfastio. ${ }^{121}$ Desse modo, consoante o ar domingueiro e álacre do gênero, o cronista aposta na capciosidade desse seu leitor.

Capcioso a ponto de extrair as intenções do cronista forjadas graças ao intertexto? Sim, uma vez que o autor supõe estar diante de alguém com "alta dose de penetração"122, portanto, um espírito esclarecido cuja única saída para "espantar seu ócio" está na leitura da crônica, agora vinculada à chegada do paquete, ou seja, às notícias europeias: no subtexto, uma crítica à sonolência e à prostração que imperam na capital, onde sequer a corte consegue patrocinar algo festivo e animado.

Assim, sub-repticiamente, o cronista, sem mostrar arrogância e menosprezo ao local, sinaliza ao leitor que o único meio de se distanciar do tédio é o cultural e o literário, razão pela qual o "juste retour des choses d'ici bas"123 ilustra uma descida vertiginosa às notícias e surge como crítica ao sistema jurídico de um vilarejo baiano em que o júri foi dissolvido em razão de o promotor não apresentar sequer um processo, enquanto os jornais noticiavam uma sucessão de delitos, roubos e crimes.

Por fim, vem à luz a fala de Lucrécia Bórgia: “__ Messeigneurs, vous êtes tous empoisonnés." ${ }^{124}$, uma tirada irônica em que o cronista eleva e amplifica a imundície do caminho do Catete, comparando-a àquela da política reinante entre os Borgias, de maneira que a "sujeira" retratada pelo literário respinga no real, ressaltando a indolência e o descuido presentes no serviço municipal. Dessa forma, graças à força do

\footnotetext{
118 "Aquarelas - Os fanqueiros literários", O Espelho, 11/9/1859.

119 "Crônicas", O Futuro, 30/11/1862.

120 "A Semana”, Gazeta de Notícias, 5/11/1893.

121 “Comentários da Semana”, Diário do Rio de Janeiro, 14/1/1862.

122 "História de quinze dias", Illustração Brazileira, 15/6/1877.

${ }^{123}$ Le Tartuffe (1799: 97) - Ato V, cena III: Mme Pernelle, mãe de Orgon, não acredita no caráter hipócrita de Tartuffe, como pensa seu filho. Este, acabara de presenciar a cena em que o impostor tenta seduzir sua esposa. Quando a mãe insiste em que é preciso provas para acusar alguém, Orgon não se contém e esbraveja todo seu rancor em uma cena de diálogo contundente, quando Dorine intervém: "Juste retour, monsieur, des choses d'ici bas: Vous ne voulez point croire, et l'on ne vous croit pas."

${ }^{124}$ Lucrécia Bórgia (1840-1519), filha ilegítima de Rodrigo Bórgia, importante personagem espanhol do Renascimento, que viria a se tornar o papa Alexandre VI. O irmão de Lucrécia foi o conhecido déspota César Bórgia. A família Bórgia acabou por representar na história a política maquiavélica e a corrupção sexual, características dos papados à época do Renascimento. A fonte da citação é Lucrêce Borgia (HUGO, 1853: 78) Na cena II, do Ato III, Jeppo, Maffio, Olofermo, Apostolo, Ascanio, amigos de Gennaro, se divertem, brindam e riem em festa na casa de Lucrécia quando esta entra e os surpreende ao dizer: "Je viens de vous annoncer une nouvelle, c'est que vous êtes tous empoisonnés, messeigneurs, et qu'il n'y en a pas un de vous qui ait une heure à vivre.", para, em seguida, mostrar-lhes seus caixões, não sem antes deslindar a lista daqueles que matara antes.
} 
intertextual, da pretendida capciosidade do leitor e da natureza mordaz e galhofeira do gênero, se escreve a crônica.

\section{8. "Voilà comme on écrit l'histoire."}

Enfim, fala-se - um pouco - de política! Mas evita-se o embate direto, não mais se nomeia este ou aquele, a crítica é generalizada e, no caso da crônica de 7/3/1865, o alvo escolhido está além das fronteiras: a imprensa europeia (francesa e belga) contrária à política expansionista brasileira (afirmam os europeus). Mas antes o cronista não se contém e dá sua habitual escorregadela por assuntos "proibidos".

Tudo começa com os festejos da capitulação de Montevidéu celebrados pela população como a "festa da paz", porém, logo se descobriu (e publicou-se) que o acordo assinado com o Uruguai não contemplava os interesses brasileiros e a "dignidade do império". A apreciação do convênio de 20 de fevereiro "é matéria exclusiva das colunas editoriais" e "não cabe nos limites do folhetim", assegura o cronista; contudo, ao reiterar que a opinião do folhetim não pode ser duvidosa, embrenha-se pelos labirintos da política, pede a condenação dos culpados pela assinatura do tal acordo e ao se dar conta de que está em terreno que lhe fora proibido, rende-se: "Examine o caso quem tem o direito e o dever de fazê-lo, e previna-se dêste modo tão graves abusos para o futuro."

O acordo com o Uruguai não só é dura e amplamente criticado pela imprensa e por especialistas que consideram ter o país saído em desvantagem, como adquire eco popular, propagando-se na "praça do mercado". O cronista, capciosamente, explora o efeito simultâneo desse coro de mil vozes, algo que lhe confere respaldo e sustentação crítica e, a um só tempo, volatiliza sua voz, tornando-a difusa em meio à multidão. Desse modo, entoa o mesmo refrão sem ser visto como um formador de opinião (embora o seja) e com isso ganha autonomia para intrometer-se em assunto "proibido" ao "seu" folhetim.

Tamanha visibilidade autoriza-o a escolher alvos, afinal, trata-se de um cronista belicoso, que tem dificuldade em largar a presa: por essa razão, antes de atacar os jornais europeus, volta sua artilharia à ineficiente diplomacia brasileira, acusando-a de anular a "obra produzida com o fuzil e a espada" e, sobretudo, silenciar-se em 
continente europeu, onde deveria esclarecer os interesses e as ações do império. Assim, credita a ignorância dos europeus acerca dos negócios americanos, em parte, aos “nossos agentes na Europa, que não trazem à luz da imprensa a narração fiel dos acontecimentos".

A desinteligência com a imprensa europeia transforma o cronista liberal e crítico severo do governo, em um seu grande arauto no teatro das tensões e diferenças que marcaram as relações do Brasil com seus vizinhos ao longo dos séculos XIX e início do século XX. À medida que o país ia definindo suas fronteiras, as diferenças ideológicas se aprofundavam: de um lado os brasileiros, em defesa de uma "civilização" imperial e escravista, de outro, a política republicana e antiescravista já formalmente praticada pelas outras nações americanas.

Ao refutar os jornalistas europeus Machado endossa a política do império, desvelando a alma complexa (e dividida) de tantos intelectuais brasileiros do século dezenove, partidários das ideias das Lumières, mas conservadores em essência; personagem de uma corte europeizada, essa intelligentsia desloca-se por uma capital, simulacro de Paris, acreditando-se superior a seus vizinhos bárbaros, autoritários e não civilizados ${ }^{125}$, de modo que a guerra surgia como uma justificativa civilizatória.

Nessa perspectiva e em relação aos desentendimentos brasileiros com seus vizinhos (sobretudo à época da Guerra do Paraguai, entre os anos 1864 e 1870) o cronista adota uma atitude cuja linguagem apela para valores pátrios, é irônica e indignada, incita o leitor ao confronto e prepara-o para o combate, assim como a linguagem que credita a López, por exemplo.

Em 26/1/1865 (p. 1) ${ }^{126}$ o La Presse publica um artigo de autoria de Eugène Chatard sobre o conflito envolvendo o Uruguai, o Paraguai e o Brasil como protagonista e grande vilão. O autor destaca que "la plupart des gouvernements au delà de l'équateur (sic) semble prendre plaisir à méconnaître les premiers éléments d'une politique sensée

\footnotetext{
${ }^{125}$ Machado dá amplo respaldo ao Império mesmo após o conflito ("Notas Semanais", O Cruzeiro, 2/6/1878) e em 8/5/1865, com a Guerra do Paraguai em pleno curso, Furtado Coelho declama A Cólera do Império, poema de Machado de Assis, em um espetáculo organizado em benefício da Sociedade União e Perseverança. Nele Machado canta a nação que se levanta para defender o pérfido inimigo que subjuga a liberdade: "[...] Se o império é fogo,/ Também é luz: abrasa, mas aclara./ Onde levar a flama da justiça,/ Deixa um raio de nova liberdade./ Não lhe basta escrever uma vitória,/ Lá, onde a tirania oprime um povo;/ Outra, tão grande, lhe desperta os brios;/ Vença uma vez no campo, outra nas almas;/ Quebre as duras algemas que roxeiam/ Pulsos de escravos. Faça-os homens. [...]"

${ }^{126}$ Nota-se aqui o hiato entre as notícias publicadas na França e seus respectivos comentários na imprensa brasileira.
} 
et modérée", relembra a "mésintelligence" brasileira com a Inglaterra, insiste, sobretudo, na invasão (e saque) de Paissandu por soldados brasileiros e ao analisar o cenário político, diz que o Brasil "paraît décidé à s'aventurer dans les dangers d'une intervention étrangère".

Machado, ao criticar duramente o articulista francês, afirma: "Se o Sr. Chatard soubesse uma polegada dos negócios desta parte da América, queremos crer que outra seria a sua linguagem. Preferimos crê-lo ignorante, a crê-lo de má fé, posto que ambas as coisas se possam dar, e se dão em geral, quando se trata da política brasileira." Mas de má fé mesmo, reitera o cronista, são as publicações do L'Indépendance Belge e do Le Nord, jornais belgas que seguem a mesma toada do La Presse, ou seja, criticam o Brasil e tratam o ditador Solano López como a "providência do Rio da Prata", "um presidente que obra com espírito político, energia e resolução". ${ }^{127}$

As opiniões são divergentes: o cronista, por razões óbvias, antevê as críticas externas como uma nódoa que futuramente poderá macular a "transparente" imagem da história imperial. Diante disso, sua preocupação é deixar claro ao leitor quem é o inimigo e qual é seu objetivo no teatro da guerra. Ademais, ao mal-estar provocado pela crítica estrangeira, soma-se a constatação de que se vê em desvantagem, haja vista ao alcance relativamente reduzido de suas opiniões, algo nada comparado aos ditos “jornais internacionais".

Em meio a uma multiplicidade de opiniões, urge esclarecer o leitor, tirá-lo da confusão a que provavelmente foi induzido, e eis que surge o ferino Voltaire, de universalidade imensurável, autor de um aforismo tão ou mais destruidor que as críticas de seus patrícios:

Tal é o Nord. Os correspondentes desta fôlha são do mesmo gênero que os das outras. É inútil resumir as asserções e as opiniões dêle: são as mesmas. Mudam as palavras, é certo; ali é a política invasora do Brasil, aqui é o Brasil que tira a máscara. Lá como aqui, os soldados brasileiros saquearam Paissandu; aqui como lá, Leandro Gomes é um herói. As barbaridades, as violências, os roubos, praticados pelos heróis daquela medida, tanto orientais como paraguaios, ficam no escuro. As nossas legítimas queixas, os justos motivos que nos levaram à guerra, são substituídos por um desejo de anexar o Uruguai, por uma política ambiciosa, por uma intervenção mal compreendida. Voilà comme on écrit l'histoire.

127 “Ao Acaso", Diário do Rio de Janeiro, 7/3/1865. 
Como relativizar o discurso do "inimigo"? Interpretando-o ironicamente; afinal, se para o estudioso a compreensão da ironia revela-se um instrumento eficaz e revelador, permitindo desvendar os estratagemas do cronista, este, por sua vez, através de seu uso contumaz, revela o que muitas vezes jaz escondido sob o verniz da retórica oficial e de um pretendido estilo (no caso, do jornalista). Afora isso, essa mesma ironia contribui para sinalizar as distorções comumente introduzidas por meio de expressões inseridas no discurso, cuja função não é outra que o desejo de o enunciador induzir seu leitor a um caminho, não raro, incerto.

Mas, se à ironia, acrescenta-se uma pitada de humor, tanto melhor! Não por outra razão, Machado recorre a Charlot ou la comtesse de Givry (1767). Na comédia ${ }^{128}$, a comtesse de Givry, viúva e ligada ao partido de Henri IV, aguarda ansiosamente a chegada do rei à região da Champagne. O clima é de expectativa e todos se movimentam em função dos preparativos para a chegada do rei. Ao fim do primeiro ato, cena VII, o grupo de empregados que representa a multidão, espalha a nova de que o rei acabara de chegar, verbalizada nos gritos de Guillot: “C'est le roi, c'est le roi." A euforia é rapidamente desfeita por uma notícia trazida pelo intendente:

Ils se sont tous trompés selon leur ordinaire.

Madame, un postillon que j'avais fait partir

Pour s'informer au juste, et pour vous avertir,

Vous ramenait en hâte une troupe altérée,

Moitié déguenillée, et moitié surdorée,

D'excellents pâtissiers, d'acteurs italiens,

Et des danseurs de corde, et des musiciens,

Des flûtes, des hautbois, des cors, et des trompettes,

Des faiseurs d'acrostiche, et des marionnettes.

Tout le monde a crié le roi sur les chemins :

On le crie au village, et chez tous les voisins ;

Dans votre basse-cour on s'obstine à le croire ;

Et voilà justement comme on écrit l'histoire (VOLTAIRE, 1877: 360, Tome VI).

\footnotetext{
${ }^{128} \mathrm{Em} 12 / 7 / 1767$, Voltaire escreve a Damilaville: "Malgré mes maux, je m’égaye à voir embellir, par des acteurs qui valent mieux que moi, une comédie qui ne mérite pas leurs peines. (VOLTAIRE, 1877: 341, Tome VI)"
} 
Se na origem o verso completa uma estrofe satírica à corte, deslocada para contexto diverso, por um lado imprime caráter cômico à atuação diplomática brasileira, relativizando seu desempenho que, vulgarizado, ganha como foro de discussão a praça do comércio, por outro, chama a atenção do leitor para o fato de que a história também pode ser escrita por espíritos medíocres, passíveis de uma sepultura política qual a Rocha Tarpéia, destino apropriado aos traidores do Estado. Ademais, o cômico trazido pelo intertexto protege, sobretudo, o cronista, suavizando sua crítica contundente.

Mas a história também pode ser escrita por mal-entendidos, por desconhecimento e pelo reforço e transmissão de estereótipos. Desse modo, o intertexto guarda em síntese a ideia que o traduz, ou seja, a de que a "verdade" não raro, sucumbe à inverdade, que reproduzida à exaustão, boca-a-boca, repetidas vezes, ocupa o lugar daquela, condenando-a ao descrédito. Na visão do cronista, a imprensa europeia, sem qualquer verificação, sistematiza uma exegese do teatro da guerra a partir de lugarescomuns e boatos comprovadamente discutíveis, haja vista à evidente parcialidade dos relatos publicados.

Nessa perspectiva, ao contrapor os relatos da imprensa europeia ao texto voltairiano, de pronto, o cronista busca neutralizar a boataria, desacreditando as notícias d'além-mar e pulverizando as ideias oposicionistas em solo pátrio; para isso, induzir seu leitor a uma leitura regressiva é de fundamental importância, dada a ressonância que as notícias externas adquirem quando justapostas ao intertexto, depositário de uma ironia ferina que, uma vez evocada, imprime ambiguidade aos relatos exteriores e respalda os argumentos do cronista, auxiliando-o na construção de seu discurso.

Por fim, ao articular seus comentários em torno da citação voltairiana, o cronista não só dá fôlego à poética intertextual como se coloca em patamar superior, creditando a si mesmo a possível "verdade", em razão da dúvida que a citação imprime ao discurso de seus "adversários". Desse modo, seu argumento ganha destaque e seu texto densidade e pluralidade semântica através do diálogo com o gênio francês.

O clichê, fortalecido ao longo da circulação literária, torna-se um núcleo de sentidos capaz de envolver o leitor como elemento estrutural da crônica, gênero prolixo que "afirma não gostar tragédias, epopeias e lembranças tristes, por mais heroicas que 
elas sejam", mas que hora ou outra, ganha foro de "alta prosápia" e dá suas piscadelas ao “épico’ enquanto “debica os sucessos do dia”. ${ }^{129}$

\section{9. "Diz-se que o francês não tem la tête épique."}

Pelos idos de 1878, o cronista combativo que bebericava na política e produzia crônicas contundentes à moda dos "Comentários", já há muito se transformara. Neste ano, Machado publica seu quarto romance, Iaiá Garcia (1878), e parte para Nova Friburgo, onde conceberia Memórias póstumas de Brás Cubas (1881), marco na literatura brasileira.

À distância do confronto direto ${ }^{130}$, seu discurso reveste-se de um matiz puramente literário, não raro metafórico e, como de hábito, de forte apelo intertextual, haja vista à quantidade de empréstimos, evidenciados ou não. $\mathrm{O}$ real indiciado passa obrigatoriamente pelo filtro ficcional: a crônica preocupada em preservar o circunstancial, distancia-se do relato do fato tout court, para se inscrever em instância em que a notícia se articula com a tradição literária.

À medida que justapõe fato e substrato literário (clichês, alusões, citações, referências) o cronista amplia seu ângulo de associações e ganha maior envergadura para explorar diferentes aspectos psicológicos, aprofundando a prática intertextual, algo como se a escritura trouxesse em si uma memória capaz de reproduzir ecos e sinais dos que a precederam e presságios dos que estarão por vir.

A crônica publicada n'O Cruzeiro, em 18/8/1878, é modelo desse hibridismo jornalístico-literário:

(I) A vida humana oferece singulares mutações à vista. Não há imaginação de dramaturgo nem arte de maquinista que as faça mais súbitas nem mais completas. $\mathrm{O}$ grande mestre é exímio nesses saltos violentos; passa de uma tenda na Síria à galera de Pompeu, e do jardim de Capuleto à cela do pio frade. Não é êle o asno ordeiro e

\footnotetext{
${ }^{129}$ Os trechos entre aspas, extraídos de "A Semana”, Gazeta de Notícias, 1/1/1894 e "História de Quinze Dias", Illustração Brazileira, 1/11/1877, foram ligeiramente parafraseados para se adaptarem ao contexto. ${ }^{130}$ De fato Machado coloca em prática agora o que previra nas páginas d' $O$ Futuro, em conselho à sua pena: "Não te envolvas em polêmicas de nenhum gênero, nem políticas, nem literárias, nem quaisquer outras, de outro modo verás que passas de honrada a desonesta, de modesta a pretensiosa, e em um abrir e fechar de olhos perdes o que tinhas e o que eu te fiz ganhar. (15/9/1862)"
} 
regrado, que obedece às posturas e ao chicote; é o cavalo de Jó, impetuoso como o vento. Pois nem Shakespeare era capaz de imaginar coisa análoga ao caso Macaúbas.

Com efeito, um homem, um capitão, o capitão Porfírio, era ali há meses delegado de polícia; hoje investe as fazendas à frente de um grupo de homens armados. Têm-se visto naufrágios de virtudes; mas o caso do capitão Porfírio é diferente de um naufrágio; é o pescador que passa a fazer ofício de tubarão. O relatório oficial, agora publicado, é positivo, claro, minucioso; conta as aventuras do capitão com a sêca singeleza de um relatório. Vê-se o ex-delegado opondo-se a ceder lugar ao sucessor, ajuntando gente, abrindo a cadeia, voltando a Macaúbas, sitiando as casas, travando combates, ferindo, ensangüentando, fugindo enfim para iniciar outra profissão, que é justamente o contrário da que exercera até há pouco.

O romantismo deu-nos alguns casos de homens que se desligavam da sociedade por motivo de amor; mas, por motivo de uma vara policial, só a realidade era capaz do invento. Defender o código em novembro e desfeiteá-lo em março, abraçar a lei na quinta-feira e mandá-la à tábua no domingo, e isto sem gradação, mas de um salto, como se muda de sobrecasaca, é um fenômeno curioso, digno de meditação do filósofo.

Porquanto, não consta que o capitão, durante o exercício da delegacia, deixasse de cumprir os seus deveres policiais, perseguindo os malfeitores; donde se poderia inferir que não era uma vocação subjugada. O ex-delegado aterrava os gatunos e faquistas, devassava as casas de jôgo, encarcerava os criminosos, punia os maus, salvava os bons, tal qual um quinto ato de melodrama. Nunca jamais lhe descobriram tendência de talar os quintais alheios ou pôr em risco a vida do próximo. Comia os seus próprios cambucás. Pode ser que devastasse algum coração e matasse muitas saudades; mas fora êsses pecados veniais, não previstos no código, o capitão Porfírio foi sempre um modêlo de virtudes policiais e humanas. Macaúbas vivia à sombra de uma administração pacífica; o seu nome era inteiramente desconhecido nos conselhos da Europa. Que importavam a Macaúbas as convulsões do século? Vivia como um rebanho, aos pés do seu pastor, único e bom, que, se jogava, era o gamão, com o padre vigário ou o farmacêutico da vila, para matar as horas e nada mais. Tal era o distrito; tal era o delegado.

Vai senão quando, chega a Macaúbas a notícia da mudança política de janeiro último. Naturalmente houve regozijo de um lado e consternação de outro; é a ordem das coisas humanas. $\mathrm{O}$ capitão Porfírio, que era sòmente delegado, não filósofo, e menos ainda político, não soube cair com sisudez e graça; sentiu morder-lhe no coração alguma coisa semelhante à cólera romana; e disse consigo que não entregaria o poder nem ao anjo Gabriel. Daí a complicação, a batalha e a recente vocação do capitão Porfírio.

Ora, o que não disse o relatório submetido ao govêrno, o que talvez escapou e escapará a mais de um leitor desatento ou incrédulo, é que a alma do capitão Porfírio é 
nem mais nem menos a alma de Coriolano, transmigrada; descoberta que explica o procedimento do herói de Macaúbas. Coteje o leitor o relatório com o livro de Plutarco; verá as semelhanças dos dois capitães. Porfírio irrita-se com a ameaça de perder a delegacia, Coriolano por não ser eleito cônsul; ambos inflexíveis e ásperos, não podem suportar friamente a injúria. Um é demitido, outro banido; um e outro vão armar gente e invadem Roma e Macaúbas.

Isto pôsto, tudo se explica; e o que nos parecia absurdo, é simplesmente natural. Desde que Porfírio não é Porfírio, mas sim a alma do famoso herói, que transmigrou de corpo em corpo, até meter-se na pele do ex-delegado, cessa todo o motivo do ódio e tôda a causa do pasmo. Um delegado, que depois de ensangüentar o seu distrito, para não entregar a vara policial, vai entreter os ócios em talar as fazendas alheias, é tão absurdo, que passa de cruel a ridículo; mas se o delegado não faz mais do que repetir Plutarco, _ acomodá-lo ao menos aos nossos costumes; se êle não é êle, mas outro, que já não é outro, então demos graças aos deuses, que nestes tempos de vida pacata nos consentem uma nesga do céu heróico, uma ressurreição do antigo brio.

A única diferença entre as duas formas do célebre herói é que a segunda acaba um pouco menos heròicamente do que a primeira, e, se fôr capturada, achará, em vez de um Plutarco, um escrivão. Coisas do tempo. O Coriolano de Macaúbas sabe que não achará prontamente um aliado estrangeiro, como o de Roma, e sabe mais que em um século industrial, atacar a fazenda é ferir o coração da sociedade; daí, essa diversão pelos estabelecimentos agrícolas, levado de um sentimento vingativo, romano e gastronômico.

[...] (VI) Não é meu costume falar de livros nesta crônica; abro uma exceção, aliás três. $[\ldots]$

Vem igualmente de S. Paulo o outro livro, o Marido da Doida ${ }^{131}$, drama de um distinto escritor, o Dr. Carlos Ferreira ${ }^{132}$, já representado nesta côrte, com aplauso do público e da imprensa. Não obstante as incertezas próprias de um talento, que não chegou ainda à inteira maturidade, é trabalho de merecimento e de esperanças... De esperanças, para quê? O Dr. Carlos Ferreira cultiva um gênero que pouco tem vivido, e ora parece morto. Diz-se que o francês não tem la tête épique; pode dizer-se que o brasileiro não tem a cabeça dramática; nem a cabeça nem o coração. Tempo houve em que puderam aparecer e ser louvados alguns dramas e comédias; mas, a espaços, por motivos de ocasião. Por agora, a ocasião passou.

${ }^{131}$ Em 1/12/1877, na Illustração Brazileira, Machado tece rápida crítica ao texto dramático, que à época fora representado na Corte, no Teatro S. Luís. Não há qualquer referência ou depósito do livro na Biblioteca Nacional.

${ }^{132}$ Também sobre o dramaturgo, o que se pode afirmar é o que Machado cita na crônica de 1/12/1897: "Como poeta e jornalista era já conhecido do nosso público o nome do jovem rio-grandense." 
A aridez da notícia ganha verniz literário, único recurso capaz de se sobrepor à crueldade do real que em suas "singulares mutações" supera em largo a imaginação, tal a deliciosa crônica em questão. A conjugação com o literário é evidente: de pronto a pendenga que por muito tempo afastou os franceses do gênio shakespeariano, na medida em que se recusavam a abandonar o conjunto de regras imposto pelo classicismo francês; opção, segundo o cronista, que obriga o poeta ao papel do "asno ordeiro e regrado, que obedece às posturas e ao chicote".

Embora Voltaire tenha em algum momento afirmado haver na obra do gênio inglês "tant de fautes grossières", ou dito ainda que "on ne peut prononcer au Louvre ce que Shakespeare prononçait si familièrement devant la reine Elisabeth", acabou por admitir que no bardo "il avait entrevu des beautés" (LEPAPE, 1994: 396). Ora, no Essai sur la poésie épique (1733), em que afirmou tratar-se de uma introdução ao seu pretendido poema épico La Henriade (1723), Voltaire discursa sobre a epopeia, elenca poemas e poetas épicos e adentra a circulação literária do gênero, que em diferentes países adquire características múltiplas, oriundas do matiz e saga locais.

Na sequência, volta-se para o rigor do classicismo francês, contrapondo-o à liberdade reinante nas letras inglesas e comenta as peças de Shakespeare:

\footnotetext{
Ces pièces sont des monstres en tragédie. Il y en a qui durent plusieurs années; on y baptise au premier acte le héros, qui meurt de vieillesse au cinquième; on y voit des sorciers, des paysans, des ivrognes, des bouffons, des fossoyeurs qui creusent une fosse, et qui chantent des airs à boire en jouant avec des têtes de mort. Enfin imaginez ce que vous pourrez de plus monstrueux et de plus absurde, vous le trouverez dans Shakespeare (VOLTAIRE, 1877: 318, Tome VIII).
}

Descoberto o conteúdo do Essai, entrevê-se no início da crônica a retomada do argumento voltairiano em que Shakespeare introduz o rústico delegado Porfírio em sua "absurda" aventura, especulação que ganha força na aferição do intertexto (o aforismo "les Français n'ont pas la tête épique") extraído do ensaio. Em tom paródico, Machado parte da Síria, singra os mares na galera de Pompeu (referência a Antony and Cleopatra (1606) ${ }^{133}$ de Shakespeare), desembarca no jardim dos Capuletos, para em seguida, num roteiro tão rocambolesco quanto o de Candide (1759), navegar rumo a Macaúbas a

${ }^{133}$ Trata-se do Ato II, cena VII: “On board Pompey’s galley, off Misenum”. 
tempo de presenciar o naufrágio do capitão Porfírio. A viagem exemplifica a tese anteriormente proposta em que o real dilui-se na ficção.

E é assim que num claro exemplo de circulação literária o relato do cronista desprende-se da notícia (o real capitão Porfírio e suas ações ilegais na cidade de Macaúbas, Bahia) e se infiltra em domínio ficcional ao se aproximar do repertório shakespeariano, enredando o capitão Coriolano, outro rebelde eternizado nas páginas de Plutarco. Metaforicamente, a alma de Coriolano "transmigra[da] de corpo em corpo, até meter-se na pele do ex-delegado".

Dessa forma o real é volatilizado pela ficção em duas estâncias: primeiro na consentaneidade de "saltos violentos": contraposição das peripécias do ex-delegado à habilidade dramática de Shakespeare em deslocar personagens e ações de modo a constituir um universo ficcional; depois, porque a aventura de Porfírio, relativizada, deixa de ser absurda, uma vez que destituída de ilicitude e acomodada à saga do general romano, através do conluio da tradição literária com o circunstancial, não só é plausível, como ganha uma nesga heroica.

A vertente poética do intertexto também se desenvolve a partir da ficção (a referência a Shakespeare), pois ao indiciar o teatro como o campo da representação, dá lugar para que a literatura atraia a literatura, numa flutuação entre gêneros, no caso, o dramático e o épico. Explica-se: é como se por alguns instantes o cronista acenasse para o simulacro do real na narrativa, o drama, gênero capaz de pontuar a degenerescência moral do ex-delegado Porfírio.

Contudo, a mudança de Porfírio foi abrupta e, haja vista sua vida pregressa, sua rebeldia não foi "uma vocação subjugada", isto é, não seguiu o curso natural do drama em que uma ação provoca e determina outra. Ademais, o drama não conseguiria dar conta da "nesga de céu heroico" entrevista nas ações do delegado, qual arrebanhar homens e invadir a cidade, ainda que a causa fosse (como parece ser) um princípio, uma razão individual; isto porque as consequências se estendem para além do espaço particular do drama, para o espaço ampliado e público do épico.

Ora, ao justapor Porfírio a Coriolano pela similitude de suas ações, o cronista destitui dos feitos do primeiro qualquer natureza policialesca ou marginal, alçando-os, parodicamente, à condição de feitos heroicos, transformação possível graças ao efeito que a tradição literária confere ao real imediato, quando a ela associada. 
Nessa transposição do épico para o drama, atua a minimização, conforme teorizada por Passos (1996: 37-40-[1]), de maneira a incorporar e ajustar a fonte à sociedade fluminense, na esteira do que dissera Alencar. Tem-se então o apequenamento do épico na figura do capitão Porfírio. A grandiosidade histórica de Pompeu e Coriolano (alimentada pelo imaginário e solidificada pelas narrativas de Shakespeare e Plutarco) degenera-se e é reduzida a melodrama quando transmigrada para a pessoa de Porfírio e suas peripécias.

A recuperação (e aproveitamento) do intertexto voltairiano ulterior - "les Français n'ont pas la tête épique" - num primeiro momento lança o ex-delegado à condição de herói para, em seguida, destituí-lo de seu posto, uma vez que Porfírio está inserido em um meio que não privilegia a presença do épico. No entanto, "desde que Porfírio não é Porfírio, mas sim a alma do famoso herói”, terá o leitor o seu herói, ainda que em ponto diminuto e em correspondência com a fonte, que soa infinitamente e multiplica ecos em sua consciência literária.

A crônica que fez da notícia ficção também se alimenta da ficção, e é assim que O Marido da Doida (1874), drama do Dr. Carlos [Augusto] Ferreira, hoje completamente esquecido, volta às páginas do folhetim. À época de sua representação na cidade do Rio de Janeiro, Machado já comentara a obra em uma crônica repleta de ironia. ${ }^{134}$ Lá, como aqui, Machado não encoraja muito o autor: em 1877 foi morno no entusiasmo, valeu-se das reservas publicadas na imprensa e ventiladas pelo público para afirmar que "a tese do drama é um pouco escabrosa", porém, aconselhava o autor a perseverar, uma vez que "é ainda moço, [e] tem talento". Aqui, diante do texto publicado, reitera os conselhos a Carlos Ferreira, embora desconfie da esperança, tal qual Voltaire desconfiara do sucesso de sua Henriade (1723) ao ouvir o veredicto de M. de Malézieux.

A constatação de que "o Dr. Carlos Ferreira cultiva um gênero que pouco tem vivido, e ora parece morto", surge como um desestímulo cuja sonoridade traz no eco o intertexto voltairiano, demonstrando como o elemento intertextual se acomoda a um idioma estranho e ainda assim mantém seu vigor e força. Machado não poderia citar

\footnotetext{
${ }^{134}$ Na crônica de 15/11/1877, na Illustração Brazileira, escreve Machado: "Notou-se que na semana passada foram representadas três peças nacionais. Três peças! Já uma era de fazer pasmar. Em matéria teatral, orçamos pela alfaiataria, é de Paris que nos chegam as modas. Paris teatral é como os seus grandes depósitos de roupas; tem de tudo, para todos os paladares, desde o mimoso até o sangrento, passando pela tramóia."
} 
Voltaire como autor do aforismo, mesmo porque ele não o foi, no entanto, manteve "la tête épique", o que nos remete diretamente ao gênio francês, ou ao menos, à "tête épique" que ele pretendia.

Voltaire conhecia os gregos, os italianos e os ingleses e recomendava a leitura destes, sem desconhecer que a ocorrência do épico exige, sobretudo, condições históricas que o gênio não pode superar por si mesmo, ou seja, a verdadeira epopeia nasce de um trabalho onde a imaginação popular conta tal qual o talento do autor que a redigiu.

Embora pretendesse dar à França sua epopeia, Voltaire sabia da reserva de seus contemporâneos em relação ao gênero já em vias de desaparecimento. Ao concluir o Essai sur la poésie épique (1733), comenta:

Je me souviens que lorsque je consultai, il y a plus de douze ans, sur ma Henriade feu M. Malézieux, homme qui joignait une grande imagination à une littérature immense, il me dit: "Vous entreprenez un ouvrage qui n'est pas fait pour notre nation : les Français n'ont pas la tête épique." Ce furent ses propres paroles, et il ajouta: "Quand vous écririez aussi bien que MM. Racine et Despréaux, ce sera beaucoup si on vous lit. (VOLTAIRE, 1877: 363, Tome VIII)"

Ora, o conselho ao Dr. Carlos Ferreira segue na mesma direção: se o francês não tem "la tête épique", o brasileiro não a tem sequer dramática; e mais, tampouco seu coração padece do mesmo mal, o que equivale dizer que sem emoção, inútil querer o drama, pois este reduzir-se-á ao real que, ainda assim, é capaz de surpreender - donde os fatos na crônica representados qual um simulacro.

O diálogo intertextual, circunscrito ao círculo de atuação de Machado, adquire vigor extraordinário e soa como um desconcertante auto-encorajamento ao cronista no cenário combalido das artes teatrais no país (seja como dramaturgo, censor, espectador, ou, sobretudo, entusiasta), propagando-se até a esfera do leitor, alertando-o de que não se deve esperar pelo épico, tampouco pelo drama, mas interpretar o real, ainda que parodicamente, como se fosse qualquer um deles, pois na falta disso, "il faudrait l'inventer".

\section{0. "Si Dieu n'existait pas, il faudrait l'inventer."}


Considerando-se que as crônicas d"“A Semana" "se servem dos fatos do tempo como pretextos para as divagações que escapam à ordem dos tempos” (CORÇÃO, 1973: 328), o texto de 21/10/1894 surge como modelo da produção machadiana no gênero. Ali estão todos os fatos da semana, porém, nenhum deles adquire relevância a ponto de obstruir as digressões do cronista, misto de notícia e literatura.

A vanidade com que a notícia é apresentada (enquanto acontecimento e ação que se produziu) encaminha a "narrativa" para o literário; vã também soa a imoralidade e os vícios presentes na origem do relato, algo que destoa do procedimento comumente adotado pelo cronista na maioria dos textos da série, em que uma notícia qualquer (a arraia-miúda) surge como pretexto para o cronista desbravar a essência e a sutilezas da alma humana.

Subterfúgio também é a série de fait divers pinçada ao longo da semana e deslocada para a esfera da crônica. Temas ainda atuais como a violência à mulher, a bigamia e a prostituição são o núcleo dessas historietas que têm função meramente ilustrativa e figuram no texto como coadjuvantes na medida em que confabulam para a construção de uma "narrativa" cujo fim é a análise do discurso de um tal Dr. Capelli, integrante do $1^{\circ}$ Conselho Municipal.

Não se trata exatamente de uma crítica ao intendente, embora o cronista reconheça na natureza didática e imaginosa de sua alocução qualidades bem superiores à produção da classe política, já à época, destituída do amor às letras e praticante do "falar chão e natural".

Alheio às notícias da semana, o cronista envereda pelo desenvolvimento do discurso, transformando-o no contraponto que sustenta sua crítica à classe política então em voga no parlamento. O resultado é a constatação de uma câmara repleta de parlamentares presos a uma pseudomoralidade destituída de qualquer cunho científico, impregnados de uma compreensão teológica da realidade e indiferentes às questões práticas propostas pelo intendente Dr. Capelli.

Amor! assunto eterno e fecundo! Primeiro vagido da terra, último estertor da criação! Quem, falando de amor, não sentir agitar-se-lhe a alma e reverdecer a natureza, pode crer que desconhece a mais profunda sensação da vida e o mais belo espetáculo do universo. Mas, por isso mesmo que o amor é assim, cumpre que não seja de outro modo, 
não permitir que se corrompa, que se desvirtue, que se acanalhe. Onde e quando não fôr possível tolher o mal, é necessário acudir-lhe com a lei, e obstar à inundação pela canalização. Creio ser esta a tese do discurso do Sr. Capelli. Não a pode haver mais alta nem mais oportuna.

Direi de passagem que apareceram ontem alguns protestos contra dous ou três períodos do discurso, vinte e quatro horas depois dêste publicado, por parte de intendentes que declaram não os ter ouvido. Não conheço a acústica da sala das sessões municipais; não juro que seja má, visto que o texto impresso do discurso está cheio de aplausos, e houve um ponto em que os apartes foram muitos e calorosos. Um dos intendentes que ora protestam atribui as injustiças de tais trechos à revisão do manuscrito. Assim pode ser; em todo caso, as intenções estão salvas.

O que fica do discurso, excluídos êsses trechos, e mais um que não cito para não alongar a crônica, é digno de aprêço e consideração. Não há monografia no amor, digna de tal nome, que não comece pelo reino vegetal. O Sr. Capelli principia por aí, antes de passar ao animal; chegando a êste, explica a divisão dos sexos e o seu destino. Num período vibrante, mostra o nosso físico alcançando a divinização, isto é, vindo da promiscuidade até Epaminondas, que defende Tebas, até Coriolano, que cede aos rogos da mãe, até Sócrates, que bebe a cicuta. Todos os nomes simbólicos do amor espiritual são assim atados no ramilhete dos séculos, Colombo, Gutenberg, Joana D'Arc, Wether, Julieta, Romeu, Dante e Jesus Cristo. Feito isso, como o principal do discurso era a prostituição, o orador entra neste vasto capítulo.

O histórico da prostituição é naturalmente extenso, mas completo. Vem do mundo primitivo, Caldéia, Egito, Pérsia, etc., com larga cópia de nomes e ações, mitos e costumes. Daí passa à Grécia e a Roma. As mulheres públicas da Grécia são estudadas e nomeadas com esmêro, os seus usos descritos minuciosamente, as anedotas lembradas lembradas igualmente as comédias de Aristófanes, e todos quantos, homens ou mulheres, estão ligados a tal assunto. Roma oferece campo vasto, desde a lôba até Heliogábalo. Não transcrevo os nomes; teria de contar a própria história romana. Nenhum escapou dos que valiam a pena, porém, de imperadores ou poetas, de deusas ou matronas, as instituições com os seus títulos, as depravações com as suas origens e conseqüências. Chegando a Heliogábalo, mostrou o orador que a degeneração humana tocara o zênite. "O momento histórico era solene, disse êle, foi então que apareceu Cristo."

Cristo trouxe naturalmente à memória a Madalena, e depois dela algumas santas, cuja vida impura se regenerou pelo batismo e pela penitência. A apoteose cristã é brilhante; mas história é história, e fôrça foi dizer que a prostituição voltou ao mundo. Na descrição dessa recrudescência do mal, nada é poupado nem escondido, seja a hediondez dos vícios, seja a grandeza da consternação. Aqui ocorreu um incidente que 
perturbou a serenidade do discurso. O orador apelou para um novo Cristo, que viesse fazer a obra do primeiro, e disse que êsse Cristo novo era Augusto Comte...

Muitos intendentes interromperam com protestos, e estavam no seu direito, uma vez que têm opinião contrária; mas podiam ficar no protesto. Não sucedeu assim. $\mathrm{O}$ Sr. Maia de Lacerda bradou: Oh! oh! e retirou-se da sala. O Sr. Capelli insistiu, os protestos continuaram...

O Sr. Barcelos afirmou que o positivismo era doutrina subversiva. Defendeu-se o orador, pedindo que lhe respeitassem a liberdade de pensamento. Travou-se diálogo. Cresceram os não-apoiados. O Sr. Capelli parodiou Voltaire, dizendo que, se Augusto Comte não tivesse existido, era preciso inventá-lo. O Sr. Pinheiro bradou: "Chega de malucos!" Enfim, o orador, compreendendo que iria fugindo ao assunto, limitou-se a protestar em defesa das suas idéias e continuou.

A crônica machadiana é constituída de forma a valorizar o conhecimento literário transversal evidenciado por Capelli, donde desponta uma enormidade de escritores e vultos históricos, dentre eles os franceses Jeanne D’Arc, Auguste Comte e Voltaire $^{135}$. O intertexto voltairiano (referência que adquire forma de impli-citation ${ }^{136}$, porém, outrora uma citação) é absorvido pelo texto receptor e eclode parodicamente na elocução de Dr. Capelli contribuindo para a continuidade da narrativa sem que o leitor se dê conta de que está frente a uma apropriação.

“Chega de malucos!” bradou o Sr. Pinheiro ao ouvir de Capelli que se Auguste Comte não tivesse existido era preciso inventá-lo. Ora, a interferência do intertexto dáse nos moldes do que ocorrera a Voltaire tempos atrás. À época, Voltaire - tido como o maior dos ímpios (CAMBACÉRÈS, 1787: 4) ${ }^{137}$, escreve uma carta na qual condena o autor do livro Les Trois imposteurs ou Traité des trois imposteurs (séc. XVIII) ${ }^{138}$, numa

\footnotetext{
${ }^{135}$ Há ainda Jules Verne e Victor Hugo, presentes em trecho não reproduzido.

${ }^{136}$ SAMOYAULT, por exemplo, refere-se ao termo ao tratar da obra de Georges Perec, designando a impli-citation como a citação inteiramente fundida ao texto, diluída e então absolutamente enigmática (2005: 44). Aqui preferimos tratá-la simplesmente por referência.

${ }^{137}$ Sobre a questão, afirma Cambacérès : «Écoutons les incrédules, les impies mêmes, tous ceux qui se piquent le moins de la religion, écoutez-les parler sur la Divinité : plus éloquents souvent que les hommes les plus religieux, ils affectent de parler magnifiquement de Dieu : 'Si Dieu n'existait pas, il faudrait l'inventer, a dit le plus fier impie de nos jours.' »

${ }^{138}$ A existência de blasfemadores que teriam acusado de impostura deliberada os profetas judeu (Moisés) e muçulmano (Maomé), assim como Jesus, o messias cristão, parece ter sido recorrente entre os eclesiásticos da Idade Média. No entanto, no século XVIII o tema entrou em voga com a publicação do livro Les Trois imposteurs, que circulou clandestinamente. $\mathrm{O}$ autor permanece desconhecido, no entanto, vários foram aqueles a quem se atribuiu a autoria, entre eles: Averroès, Frederico II, Boccacio, Pompanazzi, Maquiavel, Aretino, Bernardino Ochino, Michel Servet, Jérôme Cardan. Giordano Bruno,
} 
mostra de que de fato não era ateu, mas deísta. A paródia ao aforismo de Voltaire, no qual o Cristo é substituído por Auguste Comte, demonstra não só a extensão da influência do filósofo francês (e do positivismo) no meio cultural e político brasileiro, mas, sobretudo, a resistência que provocava, principalmente entre os conservadores. Compará-lo ao Cristo soava como duplo sacrilégio.

Heresia, aliás, que perdurava desde o século de Voltaire quando o direito natural e a religião revelada ganharam ardorosos combatentes. À época, dentre muitas perguntas, questiona-se se a ordem social seria possível sem Deus, algo que de certa forma ampliava a discussão: seria possível a moral sem Deus? Ou ainda: poder-se-ia fazer uso da crença em Deus para introduzir as alterações que se julgavam necessárias para a ordem social? Indo ainda mais longe: aquele que, de uma forma ou outra, acreditasse em Deus, poderia se valer dessa crença para a salvaguarda da ordem política ou social, ou mesmo destruir qualquer outra fé que não fosse a sua? Inversamente, num outro extremo, poderia um ateu ou um deísta, com os mesmos fins, tentar inculcar em outros uma fé que ele nega em si mesma? Enfim, poderia a fé religiosa ser vista como uma forma de governo ou ser evocada para sustentar um meio qualquer de governo? Todas essas questões suscitavam discussões infinitas.

Diante da negativa (parcial, evidentemente) que se impunha a essas questões, e acreditando-se que o homem não deveria se servir de Deus como um mero instrumento, Voltaire, tivesse sido ele um católico fervoroso, teria abusado da religião, colocando-a a serviço de fins terrenos, tais como a política, a moral ou o simples interesse particular? Impossível afirmar. Contudo, o célebre aforismo, ganhou status de foro universal, foi infinitamente repetido ${ }^{139}$ e, para muitos de seus críticos, soou como a afirmativa de que Deus é um ser fictício, criado para o conforto da raça humana; para outros, no entanto, foi o reconhecimento pelo maior dos críticos da religião, da inegável existência de Deus (LA HARPE, 1834: 85 , Tome I). ${ }^{140}$

Marc-Antoine Muret, Vanini, Hobbes, Spinoza, Mathias Knutzen e o barão d'Holbach, entre os mais célebres.

${ }^{139}$ Flaubert, por exemplo, inclui-o em seu Dictionnaire des idées reçues

140 Afirma La Harpe : «Voltaire fut du moins un des plus constants adorateurs de la Divinité. 'Si Dieu n'existait pas, il faudrait l'inventer.' Ce beau vers fut une des pensées de sa vieillesse, et c'est le vers d'un philosophe. Quand on ira visiter le séjour qu'il a long-temps embelli et vivifié, on lira son nom sur le frontspice d'un temple simple et rustique, élevé, par son ordre et sous ses yeux, au Dieu qu'il avait chanté. » (Voltaire construíra uma igreja em sua propriedade e pedira para nela gravar esta inscrição: DEO EREXIT VOLTAIRE). 
O fato é que a declaração apareceu pela primeira vez, em 1768, em um dos versos da epístola escrita pelo filósofo e dirigida ao anônimo autor do polêmico livro Trois imposteurs, considerado um texto de virulento ateísmo. Voltaire parece ter engrossado o coro de que a obra figurava como um trabalho perigoso, pois colocava em cheque uma noção muito útil até então para as sociedades: a de que os criminosos seriam punidos em outra vida por um poder supremo, o que provocava forte dissuasão do crime, mesmo quando as forças policiais eram deficientes. Eis a estrofe em que o verso aparece na Épître à l'auteur du livre des Trois imposteurs (1769):

\author{
Consulte Zoroastre, et Minos, et Solon, \\ Et le martyr Socrate, et le grand Cicéron: \\ Ils ont adoré tous un maître, un juge, un père. \\ Ce système sublime à l'homme est nécessaire. \\ C'est le sacré lien de la société, \\ Le premier fondement de la sainte équité, \\ Le frein du scélérat, l'espérance du juste. \\ Si les cieux, dépouillés de son empreinte auguste, \\ Pouvaient cesser jamais de le manifester, \\ Si Dieu n'existait pas, il faudrait l'inventer. \\ Que le sage l'annonce, et que les rois le craignent \\ (VOLTAIRE, 1817: 487, Tome X) ${ }^{141}$
}

No poema Voltaire desenvolve a ideia de que a existência de Deus ou a crença nele ajuda a estabelecer a ordem social (ironicamente, considerando-se que talvez estivesse se referindo ao "seu" deus, o deus dos deístas, já que Zoroastro, Sócrates, Cícero [...] "ils ont tous adoré un maître, un juge, un père.”). Em seguida, afirma ter

\footnotetext{
${ }^{141}$ Voltaire trataria do assunto ainda outras vezes. Em correspondência ao Duc de Richelieu em 1/11/1770 afirma: “Au reste, je pense qu'il est toujours très bon de soutenir la doctrine de l'existence d'un Dieu rémunerateur et vengeur ; la société a besoin de cette opinion. Je ne sais pas si vous connaissez ce vers : 'Si Dieu n'existait pas, il faudrait l'inventer.' (VOLTAIRE, 1830: 482, Tome VIII)" Ao Prince Royal de Prusse, em 28/11/1770, diz : "Ce qui révolte plus dans Le Système de la nature (1770) - (après la façon de faire des anguilles avec la farine), c'est l'audace avec laquelle il décide qu'il n'y a point de Dieu, sans avoir seulement tenté d'en prouver l'impossibilité. Il y a quelque éloquence dans ce livre; mais beaucoup de déclamation, et nulle preuve. L'ouvrage est pernicieux pour les princes et pour les peuples. Si Dieu n'existait pas, il faudrait l'inventer. Mais toute la nature nous crie qu'il existe : qu'il y a une intelligence suprême, un pouvoir immense, un ordre admirable, et tout nous instruit de notre dépendance. (VOLTAIRE, 1839: 406, Tome III)" - * Le Système de la nature, ou Des Loix du monde physique et du monde moral (1770), trata-se da obra filosófica de Paul Henri Thiry, o Barão d'Holbach; afirma-se que obra foi escrita com a ajuda de Diderot e descreve o universo segundo as leis do materialismo filosófico.
} 
contribuído para minimizar os preconceitos e injustiças perenes ao longo do século XVIII em versos como: “Je distinguai toujours de la religion/Les malheurs qu'apporta la superstition." Ou ainda: "J'ai fait plus en mon temps que Luther et Calvin." Ao final, o poema ganha tons de sátira com os ataques de Voltaire aos seus inimigos. O texto em si revela muito das complexidades do autor, tanto de sua filosofia quanto de sua personalidade.

Ora, mas qual é enfim a inferência do intertexto como parte de um sistema operatório a alterar sentidos no interior da crônica? Em que a máxima voltairiana se aproxima da elocução paródica de Capelli? Voltaire frente à impossibilidade de erradicar a inelutável presença divina disseminada entre os mais diferentes estratos sociais (e seguramente não objetivava isso) capitula e confirma a onipotência de Deus intrometendo-se na vida humana, ainda que isso vá de encontro à razão, 'alma' das Lumières. A assertiva voltairiana é móvel na boca de seus críticos, pois ora proclamam ter ele afirmado ser Deus um ser fictício, ora demonstram ter ele se rendido ao divino, algo que denuncia falhas nas ideias racionalistas das Lumières. Ao fim da polêmica afirmou-se que Voltaire reconhece ou também se vale de Deus.

Capelli, no entanto, apropria-se da essência contida na ideia de Voltaire, subvertendo-a: enquanto o francês diante de uma situação hipotética, um suposto mundo "ateu", completamente destituído da onipresença de Deus (ou deuses), se vê compelido a recriá-lo em face de problemas de ordem moral e social, concluindo pela iminente invenção (e intervenção) de um "ser supremo", em cuja crença residiria a provável organização da sociedade, Capelli, ao afirmar a necessidade de um novo Cristo, destitui-o de seus traços espirituais.

Embora Capelli reconheça o Cristo, pois vê Comte como aquele capaz de realizar a obra do predecessor, não clama por sua volta (ou sua invenção), mas por sua substituição, algo equivalente à eliminação do Cristo predecessor. Veja-se: Comte ao redigir seu Système de politique positive (1854) destaca algumas das principais consequências de sua concepção não-teológica e não-metafísica do mundo, propõe para a sociedade sua interpretação pura e plenamente humana e sugere soluções para os problemas sociais.

Esse compêndio de ideias, conhecido por filosofia positivista, nega que a explicação dos fenômenos naturais e sociais provenha de um só princípio (no caso, 
divino). Essa visão positivista erradica Deus ou a natureza como origem, criação e ou causa dos fenômenos e parte em direção à pesquisa de suas leis, a partir de então vistas como relações abstratas e constantes entre fenômenos observáveis. A observação, a experimentação, a comparação e a classificação são elevadas à categoria de métodos para a compreensão da realidade social.

Em suma, se na origem o aforismo veicula a existência de Deus (ainda que fictício, como queriam alguns dos críticos de Voltaire), ao ser transposto para a crônica, na condição de paródia, o intertexto ganha sentido inverso e a nova dimensão na qual se insere é inteiramente destituída de qualquer aura religiosa. Não se discute mais a ingerência, ou não, da divindade nos atos humanos, mas sim, a transferência dessa ingerência: nos domínios do político e do social - como assinala Comte -, o estágio positivo do espírito humano denota a transferência, a passagem, do poder espiritual para a esfera e as mãos dos sábios e cientistas e, dando continuidade às ideias racionalistas de Voltaire, do poder material para o controle dos empreendedores, algo preconizado por Candide ao fundar a máxima "il faut cultiver notre jardin".

Nessa perspectiva, o que desperta a ira dos parlamentares (para o Sr. Barcelos, por exemplo, o positivismo é uma doutrina subversiva) é, de fato, a modernidade implícita (regulamentar a prostituição pública é, por si só algo destoante na conservadora sociedade carioca) no discurso do Dr. Capelli, algo que demonstra o lado prático de se governar e cujos resultados afastam-se da conduta religiosa e não são pressupostos de ajuda divina, mas sim, planejados, fundamentados e calculados. É o espírito positivo que instaura as ciências como investigação do real, do indubitável, do útil, do certo, enfim, do agir de maneira precisamente determinada.

À luz de nossos dias essas querelas de ordem religiosa (tanto a levantada pelos parlamentares a partir da afirmação de Capelli, quanto a que outrora envolvera Voltaire) circunscrevem-se ao plano das ideias, porém, à época em que vieram à baila, adquiriram força argumentativa, extrapolaram a retórica e interferiram na vida prática. Explica-se: se na Europa do século XVIII a religiosidade ainda se mostrava robusta, malgrado as investidas das Lumières, no Brasil do século XIX, a situação não era muito diferente. No país, o cenário que se apresentava era o de um ambiente extremamente místico: a Igreja intrometia-se nos negócios do Estado e nos afazeres dos cidadãos e as crenças, principalmente entre a população iletrada, sustentavam-se em dogmas da Igreja. Mesmo 
entre a elite, hábitos e ritos religiosos faziam parte da vida cotidiana e marcavam momentos do desenvolvimento da vida pessoal. A literatura é pródiga em demonstrar isso: Brás Cubas e Bentinho são exemplos, em Machado, de personagens que tiveram a expectativa de pertencer ao clero. Em tal ambiente, nota-se a extensão e o rumor gerado pelas ideias positivistas que ora ganhavam terreno entre os intelectuais.

A filosofia positiva de Comte fundamenta-se na lei dos três estados: teológico, metafísico e positivo, através dos quais todas as ciências e o espírito humano se desenvolvem como um todo. Não por outra razão, tais ideias anunciavam uma mudança radical no ambiente místico do brasileiro do século XIX. Veja-se: no estado teológico (fetichista, politeísta e monoteísta) a imaginação desempenha papel relevante e o processo de observação dos fenômenos - como mencionado acima -, reduz-se a poucos casos.

A explicação da natureza, pelo homem, só é possível mediante a crença na intervenção de seres e forças sobrenaturais. O mundo se explica pelo divino e, para além de Deus - ou deuses e espíritos -, o homem não coloca qualquer problema. Além de explicar a natureza, a mentalidade teológica, desempenha a função de coesão social e fundamenta a vida moral.

O problema não se coloca nem mesmo na transição para o estado metafísico, já que para os positivistas o país ainda vivia em um estado primitivo, ou seja, teológico e metafísico (MOTA, 2000: 56). Nesse estado, a concepção de forças através das quais se podem explicar os diferentes grupos de fenômenos, em substituição aos deuses da fase teológica, são tímidas. Em linhas gerais, forças físicas e químicas (sobretudo no estado positivo), que propusessem à existência valores completamente humanos, afastando-a radicalmente da teologia e da metafísica, ainda que incorporadas a uma filosofia da história, eram mínimas. Tal era a questão que se colocava: o abandono da religião em prol de uma interpretação das ciências e uma classificação do conhecimento sob a ética humana.

Questões políticas (e religiosas) trazidas pelo Positivismo à parte, o fato é que o cronista dá continuidade à circulação das ideias ao valer-se do aforismo voltariano parodiado por Capelli; tutelado por Voltaire, destitui Deus de sua divindade, tornando-o personagem literária em um discurso mesclado por bígamos, prostitutas e assassinos, reservando-lhe, assim, exclusiva dimensão histórico-literária. 
Por fim, Deus e Voltaire se inscrevem como personagens de uma polêmica pontual ocorrida no universo literário francês. À época, correspondiam-se como personagens: tratava-se de Voltaire reconhecer ou não a existência de Deus, algo que, dada a representatividade do filósofo, equivalia as Lumières admitirem a divindade como constitutivo para a resolução das questões terrenas.

O cronista não se adentra as questões religiosas, porém, apropria-se da polêmica e opta por aquilo que maneja com eficiência - o literário -, e é a partir dele que constrói sua "narrativa", integrando-a à circulação das ideias literárias e atualizando seu leitor sobre um pouco de memória que se perpetua ao longo desse trajeto sem rumo definido, pois ora personagens e autores deslocam-se por Paris ou pelo Rio ora tomam o caminho da paradisíaca terra de Eldorado, nos passos de Candide.

\section{CANDIDE}

\section{Candide}

Tratando-se do romancista, tornou-se senso comum dividir a obra machadiana em duas fases distintas, preceito que se adapta perfeitamente ao cronista. O "frondeur" (MIGUEL-PEREIRA, 1988: 82-83) ousado e ferino em suas opiniões à época do Diário, contrasta com o prudente articulista da Gazeta que busca salvaguardar sua intimidade, embora "resguardando sempre seu ponto de vista pessoal, liberal e livrepensador".

A segunda fase do cronista é menos belicosa: de um modo geral os alvos são difusos e, fatos, notícias, personalidades e ações são relegados à condição de coadjuvantes, já que o grande protagonista é o espírito humano. Dessas páginas em que a alma humana é debatida, analisada e revirada à exaustão, surge um cronista irônico, relativista e duvidoso, porém, sereno, ainda que a serenidade seja de superfície.

Ao se tratar do espírito humano, sobretudo em sociedades cujas posições não são nitidamente definidas ${ }^{142}$, involuntariamente corre-se o risco de se tornar tão disperso quanto elas, de modo que a filosofia surge como guia, instrumento de análise e referência, afinal, o "esprit, ce mot, en tant qu'il signifie une qualité de l'ame, est un de

\footnotetext{
${ }^{142}$ Ver cap. II. A crônica - Item 1, em que Bosi (2006: 46-47) reflete sobre as duas formas de liberalismo vigentes à época do Império.
} 
ces termes vagues, auxquels tous ceux qui les prononcent attachent presque toûjours des sens différens" (Encyclopédie, art. "Philos. \& Belles-Lettr.", 1755: 973, Tome V), consonante ao que afirma Voltaire.

Machado volta-se à filosofia e rende tributo ao século XVIII: Leibniz surge das páginas satíricas de Candide e o otimismo de Pangloss ridiculariza a vida nos trópicos. A "razão suficiente" - sistema filosófico alemão -, segundo o qual nada acontece sem que haja uma causa ou, ao menos, uma razão determinante - migra das páginas de Candide (1759) para romances e crônicas machadianos.

Em seu conto filosófico, Voltaire acaba por vulgarizar a Théodicée (1710), obra em que Leibniz funda a doutrina de que o mundo atual é o melhor dos mundos possíveis. A assertiva, elevada à condição de aforismo, sustenta um otimismo exacerbado que minimiza a miséria humana e o mal reinantes no mundo. Nessa perspectiva, cada acontecimento, situação e condição se justificam como o que há de melhor, simplesmente porque Deus assim o quis. Desse modo, o mal (seja metafísico, moral ou físico) $)^{143}$ é relativizado e surge como algo inadequado, de aparência relativa. Certo, a filosofia otimista de Leibniz não só é uma justificativa racional do mal que permite, sobretudo, inocentar Deus, mas satisfazia plenamente o modelo de sociedade da época, em razão de seu caráter imobilista.

Em Candide, pode-se afirmar livremente que o princípio leibniziano preconizado por Pangloss surge como protagonista através do aforismo "le meilleur des mondes possibles", algo que conferiu ao texto status moderno, uma vez que o otimismo e as teses providencialistas estavam em voga. A ironia e o sarcasmo presentes no texto evidenciam as ideias antagônicas de Voltaire ao pensamento de Leibniz, haja vista a sua grande admiração pelas ciências em geral e particularmente pelas teorias de Newton, que o tiveram como grande divulgador na França.

Fatos simultâneos ao que se discutia na época foram o terremoto de Lisboa (1755) e a Guerra dos Sete Anos, que eclode em 1756; ambos perturbam Voltaire e fazem com que ele se insurja contra a indiferença e a insensibilidade da filosofia face aos fenômenos naturais que, de forma trágica, tumultuavam o espírito e a vida dos homens. Em correspondência à duquesa de Saxe-Gotha (22/1/1757), Voltaire não se

\footnotetext{
${ }^{143}$ Ao refletir sobre a origem do mal, Leibniz apresenta as seguintes definições: "On peut prendre le mal métaphysiquement, physiquement, et moralement. Le mal métaphysique consiste dans la simple imperfection, le mal physique dans la souffrance, et le mal moral dans le péché. (§21)”
} 
contém e alfineta: “Que d'horreurs, madame, et que le meilleur des mondes possibles est affreux. (VOLTAIRE, 1860: 167)"

Após os acontecimentos, Voltaire reconsidera sua visão de mundo, indigna-se, questiona e se revolta. Não lhe concebe a ideia de que crimes e tragédias sejam necessários à busca da perfeição e à moral, porque delas resultariam um bem maior. ${ }^{144}$ Candide é fruto desse momento de ruptura e desilusões. O ceticismo do gênio de Ferney, em face de um mundo pleno de ideias imobilistas, tal qual as de Leibniz, é direcionado para a literatura, espaço em que, de forma paródica, luta contra todas as expressões de obscurantismo, opressão, intolerância, barbárie e fanatismo - e de maneira não tão otimista quanto Pangloss.

\section{Pangloss, uma obsessão machadiana}

Observador crítico, e não raro cínico, da alma humana, Machado focaliza os tormentos do homem e os absurdos do mundo por meio de um humor reflexivo. Ora divertido, ora amargo, uma nota de debique aqui, uma brincadeira envolvendo o leitor acolá, e a vida social é apresentada através de um jogo feroz em que os mais ambiciosos esmagam os fracos e miseráveis. A exemplo dos moralistas franceses, o cronista vê no egoísmo uma das emoções fundamentais do homem e, das crônicas, sobressaem fatos, situações e figuras movidas pelo interesse, cujos valores sociais repousam em conveniências e mentiras, sobretudo, tratando-se da classe política.

Não bastassem os moralistas, estimulado por grandes ironistas do século XVIII como Sterne, Swift e, sobretudo, Voltaire, o cronista coloca em prática uma técnica que consiste em estabelecer um vínculo entre a normalidade dos fatos e sua aparência essencial. Desse modo, através de uma crítica irônica, o mais absurdo denota candura e é sugerido em tons de pureza, induzindo o leitor ao contrário, o que faz com que esse absurdo pareça o normal, e este algo excepcional.

\footnotetext{
${ }^{144}$ Vale lembrar que para Leibniz os sofrimentos suportados pelo homem (o mal físico) são explicados de duas formas: ora atuam como castigos pelos pecados cometidos (Deus permitiu que acontecessem como consequência do mal moral), e, assim interpretados, teriam significado positivo, pois contribuiriam para o desenvolvimento moral; ora, sob outro ponto de vista, os sofrimentos são vistos como mecanismos e estratégias do bem, isto é, a ocorrência de um mal pequeno, frequentemente abriria caminho para um "plus grand bien".
} 
Nessa perspectiva, Pangloss surge como figura tutelar e de obsessão machadiana, pois contribui para a sedimentação desse tipo de expressão. A personagem voltairiana movimenta-se não só entre as crônicas, mas também em importantes romances como Memórias póstumas de Brás Cubas (1881) e Quincas Borba (1891). Em Memórias póstumas, a razão suficiente, princípio das teorias finalistas, surge das digressões filosofantes do narrador (PASSOS, 1996: 70-79-[1]). Na obra, Brás Cubas, o "bon vivant" culto e requintado, num jogo intertextual promovido pelo narrador, confere ao leitor o papel do fiel e ingênuo discípulo de Pangloss. Assim, segundo Passos, ao justapor o duplo Brás Cubas-Pangloss, Machado insiste no "absurdo da generalização e no despropósito do caráter inútil das explicações monolíticas”, de modo que o saber totalizante torna-se produto do cômico.

Por outro lado, Quincas Borba (personagem da mesma obra) é apresentado como fundador do Humanitismo, caricatura da religião da humanidade preconizada pelos positivistas, colocando em cena o diálogo que envolve as teorias e muito do conhecimento produzido em parte dos séculos XVIII e XIX. Assim, para o símile Pangloss-Candide, há Quincas Borba-Brás Cubas, fina ironia do narrador que justapõe o 'filósofo'-preceptor da fonte ao 'filósofo'-narrador que, estupefato, vê seu mestre explicar sob o viés do Humanitismo o funcionamento da engenhoca que se constituía a realidade sócio-econômica brasileira (cap. CXVII - O Humanitismo).

Por fim, diante de um cientificismo ainda ingênuo da década de 1880, que acreditava mandar à cova a filosofia, Quincas Borba, assim como Pangloss, surge como um otimista ridículo e o Humanitismo soa como sátira às teorias finalistas, algo que em Quincas Borba (a obra) aparece sob o lema darwiniano de "ao vencedor as batatas".

Em Quincas Borba, Rubião, ao sair de Barbacena para o Rio de Janeiro, leva consigo muito da ingenuidade de seu símile, à época que iniciara seu périplo em Thunder-ten-tronckh. E, uma vez na capital federal, o primeiro contato de Rubião com Pangloss dá-se através dos jornais da corte (cap. XI), justamente ao ler a nota de falecimento do Sr. Joaquim Barbosa dos Santos que, ao morrer, afirmara ser a dor uma ilusão “e que Pangloss não era tão tolo como o inculcou Voltaire”. Porém, Barbosa dos Santos “já então delirava”, e nessa "gag” reside muito da genialidade machadiana.

De fato, na série de crônicas em que referências e citações têm origem em Candide, Pangloss surge como personagem de eleição a ridicularizar as teorias de 
Leibniz, de modo que ora o intertexto recai de maneira obsedante na figura do preceptor e no finalismo dos óculos, ora sobre seu otimismo; com exceção de uma delas em que Candide, já distante do mestre e em companhia de Cacambo, surge na paradisíaca terra de Eldorado.

\section{3. "Um pouco de filosofia Pangloss"}

Experiência isolada, segundo Paiva De Luca (1998: 21), as "Balas de Estalo", resultantes de uma parceria jornalística, compreendem textos de vários articulistas, dentre os quais, Machado de Assis, que assinou 126 deles sob o pseudônimo de Lelio. As crônicas, pretendendo-se agressivas, prefaciavam que as "balas" deveriam repercutir como verdadeira artilharia, provocar os leitores, e quiçá, criar polêmica. A opção por pseudônimos não foi outra senão uma proteção contra prováveis represálias. ${ }^{145}$

O objetivo deve ter se cumprido a contento, pois o caráter combativo inicial foi logo alterado. Diante das reações, as "balas" semanticamente guerreiras, edulcoraramse, ganharam tom ameno, voltaram-se para o cômico e privilegiaram o irônico na tentativa de atingir os mesmos alvos, porém, sob a técnica da dissimulação, característica primeira da ironia.

De guerreiros a confeiteiros, não importa! O que vale é que as crônicas machadianas de "Balas de Estalo", escritas ao longo dos anos que antecedem a Abolição, ultrapassam o momento, alçam voo imaginativo, absorvem fontes variadas e imprimem tez literária ao material jornalístico. À mesa do leitor, a notícia tem seu sabor acentuado e a crônica, mais que informar, diverte, tornando-se pura iguaria!

Em 23/8/1884 ${ }^{146}$, o cronista trata da questão da falsificação dos vinhos, que chega às mãos do ministro dos Negócios Estrangeiros. Alguns atacadistas, sentindo-se lesados, saem a público contra os falsificadores e para isso alegam que "os progressos da química permitem obter as composições mais ilusórias, com dano da saúde pública”. O cronista, guiado por seu olhar de míope, vê nisso a tentativa de se impedir "certa ordem de produtos", a despeito da pretendida preocupação com a saúde pública.

\footnotetext{
${ }^{145}$ Na série, colaboraram: Zig-Zag (Henrique Chaves), Lulu Sênior (Ferreira de Araújo), José do Egito (Valentim Magalhães), Blick (Capistrano de Abreu), João Tesourinha (Francisco Ramos Paz), Lelio (Machado de Assis), Décio e Publicola (que podem ser Alfonso Montaury e Dermeval da Fonseca), Ly, Confúcio, João Bigode, João Minhoca, Carolus (DE LUCA, 1998: 22).

${ }^{146}$ Gazeta de Notícias.
} 
E, como de praxe, ocupa-se do pormenor, do aspecto aparentemente superficial em relação ao fato jornalístico para sondar a alma humana. De pronto, reúne os homens em sociedade, discorre sobre a obrigatoriedade de obedecer às leis que eles próprios formulam, justapondo-as àquelas não impostas. Estas, afirma o cronista, advêm de uma "necessidade divina e eterna", algo como a luta pela vida, a lei da sobrevivência, referindo-se às leis naturais. ${ }^{147}$

Desse modo, alia a luta pela vida dos molhadistas: parodicamente, o amor por si mesmo (instinto de conservação) se expande e responde pela necessidade de conservação de toda uma classe que, de fato, usa de estratagema para a manutenção do monopólio no comércio de vinho. Levando-se em conta a lei da oferta e procura, o cronista conclui haver um excesso de molhadistas, o que impede ganhos maiores, e uma vez que se tem de pagar por tudo (aluguel, impostos, funcionários, etc.) o melhor é entrar pela pura fisiologia universal. Para isso - acrescenta - nada melhor que a química!

Em seguida, após conjecturar sobre casos em que, defendendo-se um homem a si próprio, as leis sociais admitem a legitimidade do crime, propõe ao leitor um pouco de filosofia:

Depois, façamos um pouco de filosofia Pangloss, penetremos nas intenções da providência. Se com drogas químicas se pode chegar a uma aparência de vinho, não parece que este resultado é legítimo, lógico e natural? Acaso a natureza é uma escola de crimes? E dado mesmo que um tal vinho seja danoso à saúde pública, não pode acontecer que seja útil à virtude pública, levando os homens a abster-se? E, porventura, a virtude merece menos que a saúde? Não são ambas a mesma coisa, com a diferença que a virtude é ainda superior? Não entrará tudo isso nos cálculos do céu?

Mas de que natureza e virtude fala o cronista? A natureza, afirma Hazard (1963: 280) "est trop riche dans son contenu, trop complexe dans son être, trop puissante dans ses effets, pour qu'on pût l'enfermer dans une formule : la formule éclatait sous son effort", e a virtude, considerando-se o artigo "Vertu" da Encyclopédie (Tome XVII,

\footnotetext{
${ }^{147}$ Sobre a questão ver o artigo "Loi naturelle" da Encyclopédie (1765 : 46, Tome XI): NATURELLE, loi, s. f. (Droit naturel.) on définit la loi naturelle, une loi que Dieu impose à tous les hommes, \& qu'ils peuvent découvrir par les lumières de leur raison, en considérant attentivement leur nature \& leur état. [...] Les lois naturelles sont ainsi nommées parce qu'elles dérivent uniquement de la constitution de notre être avant l'établissement des sociétés. [...] Il est clair que ses premieres idées ne seroient point ses idées spéculatives, il songeroit à la conservation de son être avant que de chercher l'origine de son être[...]. Assim, segundo HAZARD (1963: 148), realiza-se o "effort pour enlever à la divinité la Loi, organisatrice du monde".
} 
1765 : 176), é algo “abstrait, qui n'offre pas d'abord à ceux qui l'entendent, une idée également précise \& déterminée ; il désigne en général tous les devoirs de l’homme, tout ce qui est du ressort de la morale; un sens si vague laisse beaucoup d'arbitraire dans les jugemens".

Ora, pergunta-se o leitor, a impureza do vinho comporta reflexão tão extensa, a ponto de o cronista enveredar pela esfera das ideias, criando uma espécie de querela, qual nas grandes discussões filosófico-retóricas? Ora, a crônica deveria ser divertimento e iguaria para esse leitor. Ademais, se o tom pedante (palavras do cronista) não cabe no espaço do folhetim, por que então optar pelo excesso? Afora o gosto pessoal pelo exagero, comumente a escolha se explica pelo fato de que os ruídos e respingos dessas grandes questões na massa medíocre de fatos quotidianos caem como fermento, amplificando as discussões, conferindo-lhes densidade e complexidade intelectual, elevando-as, enfim, à condição de controvérsia. No mais, surgem como sustentação ao discurso do cronista - o que já é senso comum.

E é nessa perspectiva que o determinismo e o finalismo panglossiano são introduzidos como elemento paródico. Associados à impureza do vinho fariam rir não só o próprio Voltaire, mas também Quincas Borba, às voltas com seu humanitismo ao explicar a morte da avó defronte da Capela Imperial. Ora, mais importante que a saúde, é o fato de que o vinho adulterado contribui para a virtude pública, levando os homens à abstenção, ainda que para isso algumas almas sejam ceifadas.

Por fim, tratando-se do cronista-enunciador, o exagero contribui para que se instale um diálogo, via memória literária. Dessa conversa, dois pontos se sobressaem: primeiro há a valorização do cânone: revisitado e inserido em novo contexto, contribui para a ambivalência do conteúdo, altera e potencializa sentidos; depois, surge algo inconfessado pelo cronista (e que explicaria o dito exagero): o prazer e a satisfação de pertencer a uma elite que conhece os "clássicos" e comprovadamente vê o que os outros não veem.

Assim, sorrateiramente e para além da impureza do vinho, ao convidar o leitor para "um pouco de filosofia Pangloss", o cronista está mesmo à busca de um cúmplice com quem possa compartilhar o prazer da leitura - e do texto. Se isso tudo entrará nos cálculos do céu? Só depende do leitor, uma vez que em face da incerteza do vinho, 
talvez o melhor seja deixar-se alimentar da certeza da crônica, regada ao poder de fabulação do cronista.

\section{4. "Pangloss é o meu padre-santo"}

Entre 1/11/1886 e 24/2/1888, Machado publica na Gazeta de Notícias, uma série de 48 crônicas versificadas, em que demonstra não só sua habitual destreza no trato de temas variados, mas também grande habilidade formal e estrutural. Na série, aborda temas políticos e econômicos, imprimindo caráter cômico, o que faz com que essas crônicas sejam vistas como um momento leve e de distração entre as "Balas de Estalo" e "Bons Dias".

As versiprosa, intituladas "Gazeta de Holanda" não fogem à identidade do gênero, ou seja, constituem-se, enquanto texto, num apanhado de fatos circunstanciais que ilustram a sociedade da época, tais como a queda de ações na bolsa, falências e mazelas financeiras caracterizadoras do fim do Império e a aurora da República. Tudo é revisto sob viés acentuadamente satírico - e sarcástico -, donde um matiz de sátira menipeia, uma mistura de sério e cômico, enfim, uma abordagem humorística das questões "sérias" que incomodavam o cronista e seus coetâneos no Rio de Janeiro finissecular. Rimadas e em redondilhas maiores, foram escritas sob o pseudônimo de Malvólio, homônimo da personagem shakespeariana de Twelfth Night (1599-1601datas presumidas).

Na crônica de 1/1/1886, exatamente a primeira da série, o articulista anuncia sua nova coluna na Gazeta de Notícias como se se tratasse de um jornal, a "Gazeta de Holanda". Para isso inspira-se na ópera bufa de Jacques Offenbach, La Grandeduchesse de Gérolstein (1867), cujo enredo relata a vida no imaginário país de Gérolstein, onde há tempos a Grande Duquesa protela seu casamento com o príncipe Paul. Os sucessivos adiamentos fazem do príncipe motivo de chacota na imprensa, sobretudo, na Gazette de Hollande. O nobre, aborrecido, queixa-se: "il a paru quelque temps une race d'hommes qui s'est donné pour mission de parler de tout, d'écrire sur tout, afin d'amuser le public [...] on les appelle gazetiers [...] ils osent entrer dans la vie privée, ce qui est monstrueux, et ce qui est plus monstrueux, c'est qu'ils osent entrer dans ma vie privée, à moi !" (MEILHAC ; HALÉVY, 1867: 37). 
Outro não é o objetivo do cronista na "Gazeta de Holanda": ali, falar-se-á de tudo, e se fará uso tanto da "muleta da inocência" quanto da "muleta da loucura", até mesmo porque, segundo o cronista, "se uma não pega, outra pega". A tendência é liberal e o que importa é espalhar as ideias, sejam elas quais forem. Não por outra razão o mote "voilà ce qu'on dit de moi dans la Gazette de Hollande", aparece como epígrafe nas crônicas e se confirma à medida que o cronista envereda pelo privado (no caso desta crônica, ao anunciar as moléstias de Joaninha e Eduarda):

\author{
$[\ldots]$ \\ Não traz idéias modernas, \\ Nem antigas: não traz nada. \\ Traz as duas pernas, \\ Uma sã, outra quebrada. \\ E vem, como é de ciência, \\ Entre muletas segura, \\ A muleta da inocência, \\ E a muleta da loucura. \\ Se uma não pega, outra pega, \\ E fica o corpo amparado; \\ Se para um lado escorrega, \\ Fica-lhe sempre o outro lado. \\ De modo que, quando diga, \\ Seja ou não o que a lei manda, \\ Há de achar entrada amiga, \\ Esta Gazeta de Holanda. \\ Que traga idéias a fôlha \\ Liberal que se anuncia, \\ Que as espalhe, que as escolha, \\ Como a Reforma ${ }^{148}$ fazia. \\ $[\ldots]$ \\ Exemplo: ao ler que se trata \\ De fazer um edifício \\ Para o júri: __ colunata. \\ Vasto e grego frontispício. \\ E que esta idéia bizarra \\ Nasceu mesmo agora, agora, \\ Quando foi ali à barra \\ Uma distinta senhora; \\ Quando a afluência de gente
}

\footnotetext{
148 A Reforma, dirigida por Joaquim Serra com a ajuda de Francisco Otaviano, apareceu na Corte em 12/5/1869 e circulou até 1879. Defendia um programa liberal, a abolição da escravatura, reformas eleitoral e judiciária, além da abolição do recrutamento militar e da Guarda Nacional.
} 
Era tal, que o magistrado

Teve de ir incontinenti

Pedir sabão emprestado;

Comigo disse: ___ Bem feito

Que a Joaninha expirasse

De uma moléstia do peito,

E que a Eduarda cegasse.

Só assim tínhamos prédio

Para um tribunal sem nada;

Não foi morte, foi remédio;

Foi vida, não foi pancada.

Pangloss, o doutor profundo,

Mostra que há grande harmonia

Entre as coisas dêste mundo,

Entre um dia e outro dia;

Que os narizes foram dados

Para os óculos; portanto,

Trazem óculos pousados...

Pangloss é o meu padre-santo.

Logo, se uma e outra escrava

Brigaram sem sentimento,

A razão de ação tão brava

Foi têrmos um monumento.

Afora a ligação intertextual com a ópera de Offenbach, que ocorre não só pela forma, mas sobretudo pela presença constante da epígrafe (repetida em forma de estribilho ao fim de cada verso no texto de Meilhac e Halévy), o intertexto voltairiano soa algo paródico, uma vez que Pangloss é evocado na condição de "doutor profundo", com o intuito de justificar as mortes de Joaninha e Eduarda. As teorias deterministas e fatalistas surgem na crônica a partir da morte das escravas, causalidade necessária para que o novo edifício para o júri fosse, enfim, construído.

Em Candide a história se desenvolve em episódios breves em que uma causalidade de curta duração opõe-se aos intermináveis elos propostos por Pangloss. Neles, Voltaire considera tão somente a causa imediata e seu posterior feito, de maneira que a razão suficiente é reduzida a uma causalidade eficiente. $O$ uso consciente da causalidade, em geral introduzido pela conjunção "car", mostra-se apropriado para questionar a razão suficiente. Veja-se o entrecho do capítulo V:

Il est vrai que le repas était triste; les convives arrosaient leur pain de leurs larmes; mais Pangloss les consola en les assurant que les choses ne pouvaient être autrement : «Car, 
dit-il, tout ceci est ce qu'il y a de mieux. Car, s'il y a un volcan à Lisbonne, il ne pouvait être ailleurs. Car il est impossible que les choses ne soient pas où elle sont. Car tout est bien. »

Para enfatizar o efeito crítico da fragmentação de uma cadeia causal, Voltaire utiliza esporadicamente vocábulos da filosofia sistemática e, ao introduzi-los no relato, é como se os estivesse testando, colocando-os à prova para ver como se comportam diante de uma realidade limitada. Dessa forma, em meio a situações desconcertadas e contextos estranhos e distantes de conexões sistemáticas, surgem conceitos como “causas e efeitos", "razão suficiente", "mundo melhor", etc., que, de fato, contribuem para desqualificar as teorias deterministas implícitas, haja vista que se mostram inconsistentes em face das limitações impostas pela realidade.

Machado segue o mesmo raciocínio e para chegar a seus fins, introduz o determinismo e o fatalismo no contexto vulgar do folhetim, inclusive valendo-se de um meio próprio (e à disposição) de todo satírico, que é apresentar ao leitor uma personagem ridícula que encarna de maneira desfavorável as opiniões a serem ridicularizadas. Assim, Pangloss retoma (e reforça) seu papel de Candide, que não era outro senão defender a teoria leibniziana do otimismo, mas também ridicularizar a razão suficiente. Conclui-se dessa forma que a morte das escravas surge como algo providencial e necessário para que se construa o prédio que sediará o tribunal:

\footnotetext{
Comigo disse: ___ Bem feito

Que a Joaninha expirasse

De uma moléstia do peito,

E que a Eduarda cegasse.

Só assim tínhamos prédio

Para um tribunal sem nada;

Não foi morte, foi remédio;

Foi vida, não foi pancada.
}

Se em Voltaire a conjunção "car" introduz a razão suficiente e os absurdos destacam-se pela adição de subordinadas, em Machado o contrassenso surge por meio da locução "bem feito", como expressão de um castigo merecido, trazendo consigo a informalidade que se ajusta ao gênero. Porém, subjacente à crítica contra o injusto sistema judiciário brasileiro, célebre pela inércia e cujas ações dependem de perecer 
alguns de seus cidadãos, o cronista sai pela tangente como se o "bem feito" que dissera a si mesmo, só o fizera por culpa de Pangloss, seu padre-santo.

Ao clamar por Pangloss, expõe ao ridículo o sistema judiciário ao mesmo tempo em que satiriza a superficialidade da filosofia dogmática e finalista. "Pangloss, o doutor profundo", ser que vê a "grande harmonia entre as coisas deste mundo", contribui para a expressão do cronista na medida em que surge como elemento de caráter dissimulatório em sua escrita, subterfúgio de significados ocultos. No universo ameno da crônica as articulações dentro do texto (ou de texto para texto) desafiam o enunciador e leitor a uma compreensão circular para entender o todo.

Nessa perspectiva, a compreensão total passa pela sátira em duas instâncias: no domínio da fonte, célebre por relativizar a teoria de Leibniz, e na esfera da crônica, que se apropria do episódio dos óculos e atualiza-o junto aos seus leitores, na condição de clichê, dada sua circulação literária. Assim, minimizado, Pangloss é ridicularizado via o finalismo estreito e menor dos óculos:

\footnotetext{
Que os narizes foram dados

Para os óculos; portanto,

Trazem óculos pousados..
}

Nota-se dessa forma a completa vulgarização da asserção filosófica em face da frivolidade e da futilidade características da crônica, gênero que refuta as densas discussões teóricas. Com isso, o ridículo se impõe e o aforismo ganha tom rasteiro e popular, de modo a fazer crer que o que se diz é de difícil ou nenhuma comprovação científica. Desse modo o cronista completa o círculo iniciado com as teses providencialistas, sistema cujo eixo, a razão suficiente, explicaria o porquê das coisas a partir da causa primeira - Deus.

Assim, Leibniz populariza os finalismos através da Théodicée (1710), numa tentativa retórica de agregar credibilidade e fundamentação científica às ideias de origem puramente metafísica; Voltaire lança mão de Pangloss para ridicularizá-las e destitui-las de qualquer verdade, tornando-as simples produto de retórica; e Machado, que não adentra as discussões, indicia-as nas crônicas, tornando-as superficiais e reduzindo-as a máximas, em que narizes e óculos e Pangloss tornam-se sintagmas de um mesmo refrão, pronto a ser repetido pelos leitores. 


\section{E “os narizes fizeram-se para os óculos”...}

A crônica de 6/11/1892, publicada na Gazeta de Notícias, não versa sobre um fato qualquer que tenha ocupado os espíritos, despertado polêmica e dividido opiniões ao longo da semana, sequer enquadra-se entre aqueles que provocam a curiosidade do míope, tal a sua insignificância, mas surge das observações visuais do cronista e de seu senso estético.

"Vou contar às pressas o que me acaba de acontecer" introduz um enunciador que perambula pelo Largo do Machado e, de repente, ao observar a igreja matriz da Glória, começa a refletir sobre sua arquitetura eclética que em parte privilegia o neoclassicismo, algo que para o cronista é uma imitação de "coisa nenhuma", um "singular conúbio", nem cristão, nem pagão - uma comédia! O leitor pode livremente associar esse ecletismo à mistura, que na origem, constitui a sociedade que o representa.

A Matriz da Glória surge como um símbolo que reúne todo o sincretismo de um povo, emblema de seu caráter híbrido, e conteúdo imagístico-simbólico de um imaginário coletivo, já que o cronista a vê como "uma página de psicologia social e política”. E assim, pensando sobre o caráter de suas ideias, pondera:

Vou contar às pressas o que me acaba de acontecer.

Domingo passado, enquanto esperava a chamada dos eleitores, saí à praça do Duque de Caxias (vulgarmente largo do Machado) e comecei a passear defronte da igreja matriz da Glória. Quem não conhece esse templo grego, imitado da Madalena, com uma tôrre no meio, imitada de cousa nenhuma? A impressão que se tem diante daquele singular conúbio, não é cristã nem pagã; faz lembrar, como na comédia, “o casamento do Grão-Turco com a república de Veneza". Quando ali passo, desvio sempre os olhos e o pensamento. Tenho mêdo de pecar duas vêzes, contra a tôrre e contra o templo, mandando-os ambos ao diabo, com escândalo da minha consciência e dos ouvidos das outras pessoas. [...]

Sempre que entrevejo uma idéia, uma significação oculta em qualquer objeto, fico a tal ponto absorto, que sou capaz de passar uma semana sem comer. Aqui, há anos, estando sentado à porta de casa, a meditar no célebre axioma do Dr. Pangloss que

os narizes fizeram-se para os óculos, e que é por isso que usamos óculos, sucedeu cair-me a vista ao chão, exatamente no lugar em que estava uma ferradura velha. Que haveria naquele sapato de cavalo, tão comido de dias e de ferrugem? 
Pensei muito, não posso dizer se uma ou duas horas, até que um clarão súbito espancou as trevas do meu espírito. A figura é velha, mas não tenho tempo de procurar outra. Cresci diante de Pangloss. O grande filósofo, achando a razão dos narizes, não advertiu que, ainda sem êles, podíamos trazer óculos. Bastava um pequeno aparelho de barbantes, que fôsse por cima das orelhas até à nuca. Outro era o caso da ferradura. Só o duro casco do animal podia destinar-se à ferradura, uma vez que não há meio de fazê-la aderir sem pregos. Aqui a finalidade era evidente. De conclusão em conclusão, cheguei às ave-marias; tinham-me já chamado para jantar três vêzes; comi mal, digeri mal. E acordei doente. Mas tinha descoberto alguma cousa.

Fica assim explicada a minha longa meditação diante da tôrre e do templo, e o mais que me aconteceu. Cruzei os braços nas costas, com a bengala entre as mãos, apoiando-me nela. Algumas pessoas que iam passando, ao darem, comigo, paravam também e buscavam descobrir por si o que é que chamava assim a atenção de um homem tão grave. Foram-se deixando estar; outras vieram também e foram ficando, até formarem um grupo numeroso, que observava tenazmente alguma cousa digníssima da atenção dos homens. [...]

Nem por isso interrompi as reflexões que ia fazendo. Sim, aquela junção da tôrre e do templo não era sòmente uma opinião da irmandade.

Não tenho aqui papel para notar todos os fenômenos históricos, políticos e sociais que me pareceram explicar o edifício do largo do Machado; mas, ainda que o tivesse de sobra, calar-me-ia pela incerteza em que ainda estou acêrca das minhas conclusões. Dous exemplos estremes bastam para justificação da dúvida. A nossa independência política, que os poetas e oradores, até 1864, chamavam grito de Ipiranga, não se pode negar que era um belo templo grego. $\mathrm{O}$ tratado que veio depois, com algumas de suas cláusulas, e o seu imperador honorário, além do efetivo, poderá ser comparado à tôrre da matriz da Glória? Não ouso afirmá-lo. O mesmo digo do quiosque. O quiosque, apesar da origem chinesa, pode ser comparado a um templo grego, copiado de Paris; mas o charuto, o bom café barato e o bilhete de loteria que ali se vendem, serão acaso equivalentes daquela tôrre? Não sei; nem também sei se os foguetes que ali estouram, quando anda a roda e êles tiram prêmios, representam os repiques de sinos em dias de festa. Há hesitações grandes e nobres; minha pobre alma as conhece. $[\ldots]$

Nesse ponto das minhas reflexões, o sino da tôrre bateu uma pancada, logo depois outra... Estremeço, acordo, eram ave-marias. Sem saber o que fazia, corro à igreja para votar.

___ Para quê? Diz-me o sacristão.

Para votar.

Mas eleição foi domingo passado.

Que dia é hoje? 
_ Hoje é sábado.

Deus de misericórdia!

Senti-me fraco, fui comer alguma cousa. Sete dias para achar a explicação da tôrre da Glória, uma semana perdida. Escrevo êste artigo a trouxe-mouxe, em cima dos joelhos, servindo-me de mesa um exemplar da Bíblia, outro de Camões, outro de Gonçalves Dias, outro da Constituição de 1824 e outro da Constituição de 1889, dous templos gregos, com a tôrre do meu nariz em cima.

A díade de princípios coexistentes, traço característico da escrita machadiana, em que um conceito ou teoria geralmente vinculado a seu contrário, cujo sentido se completa por estratégia de correspondência, aqui ganha força e se generaliza na crônica. O aspecto híbrido surge desde o início quando o cronista menciona o Largo do Marchado e sua denominação oficial, Praça Duque de Caxias. Seguida de uma série de duplos, como templo grego e sinagoga, pagãos e cristãos, etc., a observação é rapidamente interrompida em razão da lembrança de uma reflexão anacrônica, digressão que evoca Pangloss e seu axioma finalista.

A explicação para essa mistura surge em tom de paródia e, como característica de todo patrimônio parodiado, o intertexto é facilmente reconhecido pelo leitor. A dimensão lúdica é plena e chega mesmo à condição de variante satírica e popular. Popular porque tanto Pangloss quanto o nariz como criação finalista para suporte dos óculos já é uma "premissa evidente e universalmente verdadeira", satírica, porque o cronista vai além e afirma desnecessária e existência dos narizes, uma vez que um simples barbante amarrado acima das orelhas à nuca teria finalidade similar, dado que por si só destrói a teoria ridicularizada por Voltaire. Contudo, o elemento paródico é reiterado com o finalismo dos pregos necessários à fixação das ferraduras, algo que sustenta a dúvida. Assim, como explicar a existência da torre encimada ao templo?

A construção dualística continua e se num primeiro momento a torre e o templo remetem à cristandade e ao paganismo à força de um ecletismo estético, após "longa" reflexão, ambos ganham sentidos "históricos, políticos e sociais". Ao templo agrega-se a orientação e o sonho liberal-democrático que movia a maioria absoluta dos constituintes desejosos de uma monarquia que respeitasse os direitos individuais; à torre, o poder moderador, pairando sobre todos os demais e exercido pelo Imperador por meio do "tratado que veio depois", a Constituição de 1824. A igreja fica por conta de seu papel como religião oficial, porém, também ela, submetida à torre. 
O finalismo anunciado pela interação intertextual introduz a dúvida e a hesitação na alma do cronista, que perde seu rumo e a data das eleições. Os sinos repicam, batem uma pancada, depois outra, e conturbam as ideias do cronista, a ordem e a moral das coisas. Não deveriam eles, os sinos, em época de eleição repicar pelas liberdades individuais e pelos ideais liberais?

A resposta à questão, assim como as observações histórico-político-sociais do cronista sugerem uma reflexão que se complica não pela erudição, mas sobretudo pelo conhecimento político que exige do leitor, afastando-o da esfera da crônica. No mais, o aforismo de Pangloss exerce função outra que é a de manter o cronista às voltas com a dimensão do gênero, volúvel por natureza.

A visão dos "óculos” de Pangloss padece de horizontes, é oblíqua e em direção ao chão, portanto, rasteira. Com isso o cronista se exime de qualquer partidarismo ao tecer seus comentários. As reflexões não ganham o foro das altas discussões, uma vez que têm seu fim antecipado à medida que são aproximadas da ferradura velha, já comida de dias e de ferrugem, interpretação confirmada pela crítica a Pangloss, que se esqueceu de advertir que ainda sem os narizes é possível trazer os óculos por intermédio de um simples barbante.

Porém, nem tudo é o que parece: a díade de princípios coexistentes (mencionada acima) e o caráter borboleteante do gênero permitem que o cronista aprofunde sua crítica num texto cuja natureza é o entretenimento. O leitor machadiano, já habituado a esse movimento dissimulatório do texto, de pronto há de notar que as observações endereçadas a Pangloss, justapostas aos comentários sobre a torre, de modo sub-reptício ressaltam o imobilismo que ela representa.

De fato, o "singular conúbio" do templo grego (as ideias novas) e a torre (seu caráter social, ou seja, os interesses pessoais, o conservadorismo) ressaltam a esquizofrenia que caracterizaria o sistema político brasileiro: de um lado, o belo edifício que representava o grito de Ipiranga, a emancipação, o progresso, as ideias liberais, enfim, a possibilidade "esquecida" por Pangloss de que à força de um barbante, mesmo sem os narizes, podem-se trazer os óculos e vislumbrar a modernidade; de outro, a torre, obrigando o cronista a deitar a vista ao chão, onde jaz a ferradura.

Desse modo, da torre e ferradura contrapostas emerge todo o simbolismo que traduzem: a primeira, eleveda em direção às estrelas, impõe-se como eixo primordial, 
apagando a diversidade, indicando as direções e regulando a vida dos cidadãos, além, é claro, de servir como posto de observação de onde se pode espreitar o inimigo em segurança; já a ferradura é subjugada, padece de qualquer elevação do espírito e, submetida ao olhar vigilante da torre, está condenada à sua "finalidade evidente", misturar-se ao pó. E, padecendo dos óculos, é impedida de vislumbrar qualquer horizonte.

Assim, confundindo-se com o chão, a ferradura representaria o imobilismo político-social imposto ao povo pelo Estado brasileiro. Não à toa, o cronista nela vê a melhor tradução da teoria de Leibniz que, plasmada à crônica, mostra (e critica) o sistema e seus representantes, acusando-os de mascarar uma ideologia, perpetuar as imperfeições da sociedade, justificar misérias e desigualdades fazendo, por exemplo, da injustiça social, algo inevitável, portanto, aceitável. Nessa toada, de sugestão em sugestão, desvenda-se o âmago da crônica, uma crítica contundente às mudanças políticas no Brasil do século XIX quando, de fato, as rupturas entre Independência, Monarquia e República, soam teatrais e meramente superficiais.

\section{6. "Os óculos é que se fizeram para os narizes"}

No prólogo de Memórias póstumas (1881), ao confessar que metera algumas "rabugens de pessimismo" em meio à obra difusa, Brás Cubas o faz sob a tinta da melancolia, sentimento de vaga que deixa entrever aspectos de seu caráter. A mesma disposição emocional apodera-se do cronista em vias de abandonar seu leitor.

Em 28/2/1897, depois de um período de cinco anos assinando "A Semana" na Gazeta de Notícias, Machado de Assis escreve ali sua última crônica. ${ }^{149}$ Os fatos da semana são deixados de lado e o destaque é a persona do cronista, de modo que a imprescindível e intensa presença do narrador é direcionada ao homem Machado. Cabe ao enunciador, enfim, explicar as sensações do velho cronista que ao longo de meia década, aos domingos, submeteu sua pena às suas impressões.

Embora tente explicar ao leitor as razões da confusão pela qual passa sua alma (e confiante de que este o entenderá e o aplaudirá), ao "germer baixinho" em seu exame de consciência, o cronista permite entrever um instante de pessimismo pessoal.

\footnotetext{
${ }^{149}$ De fato, anos depois, em 1900, Machado escreveria ainda duas outras crônicas para a Gazeta: em 4 e 11 de novembro.
} 
Ao se ausentar das conversas semanais que mantinha com seu leitor, reconhece sua importância, suas qualidades e seu talento. Porém, admite a dificuldade de "pingar o dito ponto" final no texto e revela o lado despótico de todo autor ao confessar que "não há nada como falar com uma pessoa que não interrompe", a quem se pode dizer "tudo o que se quer, o que vale e o que não vale", enfim, repetir-lhe "as coisas e os modos, as frases e as ideias, contradizer-lhe as opiniões", com a certeza de que jamais será interrompido, uma vez que o máximo que essa pessoa pode fazer é lançar a folha para o lado e adormecer. ${ }^{150}$

Contudo, ao sair de modo discreto e sem muito alarde, desculpando-se pelas muitas explicações e já certo de que sentirá saudades desse leitor que não esboça qualquer gesto de desagrado, o cronista reitera seu otimismo, e o faz via Voltaire:

\section{$[\ldots]$}

Antes gemer, com esta cláusula de gemer baixinho, e confessar os pecados, mas com discrição e cautela. Pecados são ações, intenções ou omissões graves; não se devem contar tôdas, nem integralmente, mas só a parte que menos pesa à alma e não faz desmerecer uma pessoa no conceito dos homens. Não especifico, por não perder tempo, e quem se despede, mal pode dizer o essencial. O essencial aqui é dizer que não faço confissão alguma, nem do mal, nem do bem. Que mal me saiu da pena ou do coração? Fui antes pio e eqüitativo que rigoroso e injusto. Cheguei à elegia e à lágrima, e se não bebi todos os Cambarás e Jataís dêste mundo, é porque espero encontrá-los no outro, onde já nos aguardam os xaropes do Bosque e de outras partes. Lá irá ter o grande Kneipp, e anos depois o Kneippismo, pela regra de que primeiro morrem os autores que as invenções. Há mais de um exemplo na filosofia e na farmácia.

Não tireis da última frase a conclusão de cepticismo. Não achareis linha céptica nestas minhas conversações dominicais. Se destes com alguma que se possa dizer pessimista, adverte que nada há mais oposto ao cepticismo. Achar que uma cousa é ruim, não é duvidar dela, mas afirmá-la. O verdadeiro céptico não crê, como o Dr. Pangloss, que os narizes se fizeram para os óculos, nem, como eu, que os óculos é que se fizeram para os narizes; o céptico verdadeiro descrê de uns e de outros. Que economia de vidros e de defluxos, se eu pudesse ter esta opinião! [...]

E como não poderia deixar de ser, Pangloss intervém para fazer valer o otimismo do cronista. Afinal, ele próprio afirma: “achar uma coisa ruim, não é duvidar

${ }^{150}$ Parágrafo ligeiramente parafraseado para se adaptar ao contexto. 
dela, mas afirmá-la!”. Nessa perspectiva revela seu estratagema: afirmar para negar! E é nessa mesma lógica que afirmara "política não é assunto de crônica", embora tenha se indignado com os golpes do estado, o Encilhamento e suas consequências, a dissimulação, a corrupção e outras manifestações fisiologistas e endêmicas entre os políticos, algo que lhe valeu a pecha de pessimista.

Assim, num momento de adeus, eis que surge o Dr. Pangloss, ajudando-o a provar que ceticismo não é pessimismo, ainda que sua teoria aponte para o oposto, o desenfreado otimismo. $\mathrm{O}$ intertexto sustenta os argumentos do cronista em um momento de melancolia (quase pessimismo pessoal) como a incentivá-lo ao otimismo, afinal, não é dizendo não, que se diz sim? Para o cronista, ser crítico é ironizar o aforismo otimista de Pangloss, de modo a relativizar as "verdades" impostas, privilegiando a dúvida e instigando seu leitor a duvidar mesmo de que sejam os narizes responsáveis pelos óculos. O que vale mesmo é a reflexão sobre as ideias "prontas".

Distante do pessimista que caminha pela doutrina da negação absoluta, nosso autor desponta como um relativista contingencial que desconfiava, duvidava e mostrava-se incerto quanto a aspectos pontuais de sua existência e de seu meio social.

É evidente que muito de sua descrença veio de influências literárias e filosóficas, contudo, ele mesmo afirma: "o céptico verdadeiro descrê de uns e de outros. [...] se eu pudesse ser dessa opinião!", ou seja, em algo acreditava, embora pudesse duvidar em algum instante, acreditava! No entanto, sempre que o homem vem à tona, raras são as vezes em que Machado não o relativiza, descrendo de uns e de outros, submetendo seu espírito a uma têmpera duvidosa, testando-o infinitamente.

\section{7. "Nas ruas de El-Dorado"}

Basta um rápido sobrevoo por suas obras, e o leitor observa a frequência com que o cronista concentra seus esforços em reproduzir (e ou esboçar) situações que ressaltam as vicissitudes de caráter, onde figuras tutelares ajudam-no a ilustrar e avaliar as condutas morais do indivíduo. Contudo, muitas vezes essas figuras - tal qual Pangloss -, impõemse pela repetição, de modo que sua presença intertextual explica-se, sobretudo, como elemento de ironia e ridicularização a evidenciar as fraquezas humanas. 
Desse modo, a teoria finalista de Leibniz emerge via Candide na crônica de 26/2/1893, publicada na Gazeta de Notícias:

O que mais me encanta na humanidade, é a perfeição. Há um imenso conflito de lealdade debaixo do sol. O concêrto de louvores entre os homens pode dizer-se que é já música clássica. A maledicência, que foi antigamente uma das pestes da terra, serve hoje de assunto a comédias fósseis, a romances arcaicos. A dedicação, a generosidade, a justiça, a fidelidade, a bondade, andam a rôdo, como aquelas moedas de ouro com que o herói de Voltaire viu os meninos brincarem nas ruas de El-Dorado.

A organização social podia ser dispensada. Entretanto, é prudente conservá-la por algum tempo, como um recreio útil. A invenção de crimes, para serem publicados à maneira de romances, vale bem o dinheiro que se gasta com a segurança e a justiça públicas. Algumas dessas narrativas são demasiado longas e enfadonhas, como a Maria de Macedo ${ }^{151}$, cujo sétimo volume vai adiantado; mas isso mesmo é um benefício. Mostrando aos homens os efeitos de um grande enfado, prova-se-lhes que o tipo do maçante, ___ ou cacête, como se dizia outrora __ é dos piores dêste mundo, e impedese a volta de semelhante flagelo. Uma das boas instituições do século é a falange das cousas perdidas, composta dos antigos gatunos e incumbida de apanhar os relógios e carteiras que os descuidados deixam cair, e restituí-los a seus donos. Tudo efeito de discursos morais. [...]

Mas a paz não basta. Falta dizer da alegria. Oh! doce alegria dos corações! Um só exemplo, e dou fim a isto. Aqui está o parecer dos síndicos da Geral, publicado sexta-feira. Diz que entre os nomes da proposta de concordata há alguns jocosos e outros obscenos. O parecer censura esse gênero de literatura concordatária. Escrito com a melancolia que a natureza, para realçar a alegria do século, pôs na alma de todos os síndicos, o parecer não compreende a vida e as suas belas flores. Isto quanto aos nomes jocosos. Pelo que toca aos obscenos, é preciso admitir que, assim como há bôcas recatadas, também as há lúbricas. A alegria tem tôdas as formas, não se há de excluir uma, por não ser igual às outras. A monotonia é a morte. A vida está na variedade.

Demais, que se há de fazer com acionistas que ainda devem de entradas oitenta e cinco mil oitocentos e quarenta e seis contos cento e sessenta mil e duzentos réis (85.846:160\$200)? Rir um pouco, e bater-lhes na barriga. Ora, cada um ri com a bôca que tem. Mas a prova de que a obscenidade, com a jocosidade, formas de alegria, são de

\footnotetext{
${ }^{151}$ Referência ao célebre caso de Maria de Macedo, crime macabro que rendeu notícia de primeira página na Gazeta de Notícias em 21/9/1892, sob o título de "Singular crime!". À época, a notícia agitou a imprensa, deliciando os leitores do gênero e décadas mais tarde seria relembrada pela Folha, do Rio, de 9/9/1920 (p. 4), que anunciava: "Amanhã os leitores terão aqui o célebre caso Maria de Macedo - a mulher que foi esquartejada nos açougues como carne fresca." A Revista Ilustrada 650, de outubro de 1892, traz ilustração dos envolvidos, do corpo decapitado e recomposto.
} 
origem legítima e autêntica, é que tôdas as firmas foram legalmente reconhecidas. Quando a alegria entra nos cartórios, é que a tristeza fugiu inteiramente dêste mundo.

Se a fonte construiu-se sobre alicerce irônico, diferente não é o viés adotado pelo cronista ao se "encantar" com a perfeição da humanidade. A partir de um discurso antifrástico e de dissimulação, a ironia surge não só como máscara a ser retirada pelo leitor, mas também como principal elemento relacional entre os textos, solidificando-se a ponto de a maledicência, relegada às comédias e aos romances, ganhar status puramente ilusório e ser convertida em técnica de escrita.

O melhor dos mundos possíveis, encantador pela perfeição, é sistematicamente demolido por Voltaire, não só em suas correspondências e libelos, mas, sobretudo, em Candide, afinal, como bem afirma Chauí (1981: 119), esse mundo "não é apenas uma fábula de mau gosto, nem mais um erro de filosofia, mas superstição e burrice”. Se, a dimensão de Candide é a comédia, na relação transformacional, o debique e a veia satírica se mantêm plasmados ao novo contexto, uma vez que a referência se integra à crônica, preservando a ironia mordaz do de Voltaire.

Não por outra razão, dedicação, generosidade, justiça, fidelidade e bondade surgem no texto como atributos exponenciais do homem, que assomam em duas esferas da vida social: os crimes (que ora saltam às páginas literárias) e as especulações financeiras características do início da República. Em ambas, algo em comum: o mal moral. Este, se por um lado engendra o mal físico, indo de encontro ao desejo que define a instância real do homem (fugir da morte, o mal supremo), por outro, subjuga-o à miséria, instalando, em muitos casos, a dor física.

Nessa perspectiva, o cronista arma um jogo irônico cuja existência de "um imenso conflito de lealdade debaixo do sol", de pronto, invalida a anunciada perfeição da humanidade, em mais uma situação de inversão. Partindo de um juízo esquematizado, sua crítica só será compreendida à menção do herói de Voltaire nas ruas de Eldorado, afinal, consoante Candide (em resposta a Cacambo) o otimismo “c'est la rage de soutenir que tout est bien quando on est mal (cap. XIX)", de modo que nada vai bem e no Rio de Janeiro finissecular as moedas de ouro se revelam de nenhum valor e não passam de "seixos das estradas" (PASSOS, 1996: 123-[2]).

Se Candide surge da pena voltairiana como clara objeção ao otimismo, o cronista repisa a mesma trilha ao trazer à luz a história de Maria de Macedo. Embora 
volatilizada pela ficção, comentar sua morte é insistir na refutação à teodiceia e ressaltar a duplicidade do homem, uma mescla visível do bem e do mal. Nessa lógica, ainda que de forma implícita, surge $\operatorname{Martin}^{152}$ que, consoante Chauí (1981: 135) é figura privilegiada na sátira, pois "é a única a admitir a irredutibilidade sem disfarces do mal”.

No mais, se os atributos que andam a rodo, a priori, induzem o leitor a crer no desprendimento material, na indulgência e na benevolência do espírito humano, de sorte a fazer ressoar das entrelinhas ecos do célebre aforismo "le meilleur de mondes possibles", isto só ocorre porque estamos à frente de mais uma cilada do cronista, que de forma sub-reptícia, reproduz ironicamente Voltaire, afastando o mal da esfera metafísica para introduzi-lo na social, aprofundando sua crítica.

Se, ao plantar Eldorado como a sociedade perfeita, espécie de mundo paradisíaco onde a vida caminha livre e tranquila, em paz e sabedoria, Voltaire já enfraquecera o dogma filosófico,

"Voilà pourtant, dit Candide, un pays qui vaut mieux que la Westphalie." Il mit pied à terre avec Cacambo auprès du premier village qu'il rencontra. Quelques enfants du village, couverts de brocarts d'or tout déchirés, jouaient au palet à l'entrée du bourg; nos deux hommes de l'autre monde s'amusèrent à les regarder: leurs palets étaient d'assez larges pièces rondes, jaunes, rouges, vertes, qui jetaient un éclat singulier. Il prit envie aux voyageurs d'en ramasser quelques-uns; c'était de l'or, c'était des émeraudes, des rubis, dont le moindre aurait été le plus grand ornement du trône du Mogol. (VOLTAIRE, 1989: 84)

o cronista, não só destitui o princípio finalista de qualquer asserção filosófica, como recrudesce a ironia, ressaltando a visão relativista que traz do homem. Afinal, como afirma Chauí (1981: 132-133), “Eldorado é a alteridade radical”, “um experimentum crucis", compreendê-lo requer apagar "tudo o que se sabia antes" e, diante dessa inelutável [im]possibilidade, nada mais resta que conviver com o bem e o mal como essências isoladas governando as consciências. Por isso, às vezes nem tudo vai bem, e a vida oscila entre um e outro. Ora, ri-se com a boca que tem, ainda que à prova da obscenidade, legitimando e autenticando firmas, quando supostamente não deveriam sê-las.

152 Martin em suas reflexões conclui “que l'homme était né pour vivre dans les convulsions de l'inquiétude, ou dans la léthargie de l'ennui »(Candide, VOLTAIRE, 1989: 159). 
"No Eldorado não há especulação" (CHAUÍ, 1981: 133), e, se ali a alteridade é tamanha a ponto de inverter os papéis, relativizar a identidade e forçar a interdependência entre o individual e o coletivo através da dinâmica das relações sociais a ponto de esmeraldas e rubis pavimentarem o caminho e o ouro empoeirar as sandálias, na sociedade carioca finissecular o mal prospera nas consciências que, isoladas, entregam-se licenciosamente à especulação que marcou o Encilhamento ${ }^{153}$.

Nessa toada o cronista busca correspondência na obra voltairiana e, se no folhetim as vicissitudes, a maledicência, a cobiça e outros "atributos" humanos, erradicados do mundo real, não mais figuram como simulacro deste, mas são deslocados para as páginas literárias, isto só ocorre como artimanha de um articulador meticuloso, irrepreensível em sua arte de descobrir e encobrir, tal seu célebre Conselheiro, hábil numa espécie de "pacto com a convenção protetora" (BOSI, 1999: 128-148).

Nessa perspectiva, é como se o cronista reforçasse o uso da máscara como elemento irônico, uma vez que a literatura vai nutrir-se então do pior do homem para produzir obras equivalentes: romances insossos e arcaicos e comédias fósseis. Ali florescem os crimes que, a exemplo da terrível história de Maria de Macedo, ganham fôlego e preenchem de um matiz colorido as páginas dos livros, num grande exercício de ficção. Retirada a máscara, resta a vida real destituída de cores, plena de paz, tranquilidade, justiça e bondade. Tudo, é claro, para se ler ao contrário e nada tão otimista como queria Pangloss.

\section{Tudo se aproxima do otimismo de Pangloss}

Transcorridos pouco mais de dois anos, em 9/6/1895 ${ }^{154}$, Pangloss e seu otimismo surgem como mote principal de um folhetim cujo texto exibe uma trama repleta do característico relativismo machadiano. Este, algo potente e dotado do "demônio da

\footnotetext{
${ }^{153}$ A questão econômica é uma constante nas crônicas d'“A Semana": na crônica de 18/12/1892, por exemplo, Machado trata do "célebre Encilhamento". A essa época a bolha financeira ainda não havia estourado, mas logo viria a "caças às bruxas", quando seus idealizadores e maiores expoentes, como Ruy Barbosa, teriam seus bens congelados, confiscados, e sofreriam processos público e administrativo. Em Esaú e Jacó, no cap. LXXII, intiluado "Um Eldorado", Machado afirma: "Certo, não lhe esqueceste o nome, Encilhamento, a grande quadra das empresas e companhias de toda espécie. Quem não viu aquilo não viu nada." (2008: 1171, Vol. I).

154 "A Semana", Gazeta de Notícias.
} 
análise" (BOSI, 2006: 31), permite uma visão sempre movente e cambiante da realidade, onde a ironia ganha relevo:

Não estudei Pangloss; não creio que tudo vá pelo melhor no melhor dos mundos possíveis. Por isso, quando acho que censurar na nossa terra, digo com os meus botões: Há de haver males nas terras alheias, olhemos para a França, para a Itália, para a Rússia, para a Inglaterra, e acharemos defeitos iguais, e alguma vez maiores. Não costumo dizer: "Olhemos para o Japão", porque é o único país onde parece que tudo se aproxima do otimismo de Pangloss. Vêde êste pedacinho da proclamação do micado ao povo, depois de vencida a China: "Regozijemo-nos pelas nossas recentes vitórias, mas é ainda longo o caminho da civilização que temos que percorrer... Não nos deixemos guiar por sentimentos de amor-próprio excessivo, caminhemos modesta e esforçadamente para a perfeição das nossas defesas militares, sem cair no extremo... O govêrno opor-se-á a todos quantos, desvanecidos pelas nossas recentes vitórias, buscarem ofender as potências amigas do Japão, e principalmente a China..." Que diferença entre esta e as proclamações dos outros grandes Estados! Em verdade, essa linguagem prova que o Japão é alguém; mas, ainda assim, impossível que lá não haja tratantes. Notemos uma cousa: nós não lemos os jornais da oposição de Tóquio.

A que propósito isto? A propósito da eleição da Bahia. Li que na apuração dos votos apareceram agora centenas de eleitores inventados, contando várias paróquias três e quatro vêzes mais do que tinham há um ano. O espanto e a indignação que êste fato causou a algumas pessoas, foram grandes, mas a falta de memória dos nossos concidadãos não é menor. Quem pode ignorar que essa multiplicação de eleitores não é cousa nova, nem baiana? Sabe-se muito bem que a urna é um útero. Peço licença para recordar uma frase, não delicada, não cortês, mas vigorosa, que antigamente se aplicava aos casos em que era preciso aumentar as cédulas; dizia-se: emprenhar a urna. Que admira, com tal fôrça de natalidade, que os eleitores cresçam e apareçam?

É um mal, concordo; mas não haverá males análogos em outras terras? Olhemos para a Itália. As urnas italianas não são fecundas; aí vai, porém, um extraordinário fenômeno eleitoral.

Sabemos telegràficamente o resultado total da eleição da câmara. Há uns deputados governistas, uns tantos radicais, uns tantos socialistas, finalmente, um pequeno grupo de indecisos. [...]

Dei um exemplo de defeitos que achem análogos em outras terras, sem diminuí-los da grandeza, como nos não diminuem os nossos. Nem por isso deixamos de caminhar todos na estrada da civilização, uns mais acelerados, outros mais moderados. Não vamos crer que a civilização é só êste desenvolvimento da história, esta perfeição do espírito e dos costumes. Nem por ser uma galera magnífica, deixa de ter os seus 
mariscos no fundo, que é preciso limpar de tempos a tempos, e assim se explicam as guerras e outros fenômenos.

De pronto, surge o relativista de circunstâncias divergindo de Pangloss, ao refutar sua célebre divisa. Nessa perspectiva, descrer de que tudo vá pelo melhor dos mundos possíveis soa mais como constatação que aposição cética, haja vista que "por mais magnífica que seja a galera, não deixa de ter seus mariscos ao fundo" ${ }^{\text {"155 }}$.

Mostrar-se contrário às ideias de Pangloss, fingir desconhecê-lo ${ }^{156}$, de fato, não passa de um estratagema do cronista que, diante da fraude eleitoral que tencionara comentar logo em seguida, preferiu não ratificar o mal como produto ou característica endêmica do Brasil oitocentista. Fazê-lo, no caso, seria relativizar-se a Pangloss e seu otimismo. Melhor então é afirmar não conhecê-lo muito bem e discordar dele ipsis litteris em negativa.

$\mathrm{Na}$ tentativa de mitigar uma prática contumaz que campeia pelo país ${ }^{157}$, o cronista tenta generalizar as mazelas nacionais ao confrontá-las com as de outras nações, universalizando-as, de maneira que talvez umas se distingam das outras em razão da cor local. A referência, ligeiramente alterada, mal se integra ao texto e o cronista vê-se obrigado a se dobrar à fonte, afinal, o Japão sustenta o otimismo panglossiano.

Nessa perspectiva, e também porque em Machado a escrita está intimamente ligada a uma ironia que consiste em dizer algo aparentando não estar dizendo, a referência ao Japão, “o único país onde tudo se aproxima do otimismo de Pangloss" é, de fato, mais um embuste. Assim, ao reproduzir a diplomática nota emitida pelo governo japonês logo após ter vencido a guerra contra a China, não só soa algo hipócrita, evocando o adágio popular do morder e depois assoprar, mas, sobretudo, restitui ao cronista sua atitude, devolvendo-lhe o relativismo, a independência e a ironia que postula. Afinal, quem lê os jornais oposicionistas japoneses? Desse modo, desvincula-se da obrigação de se dobrar à fonte.

\footnotetext{
${ }^{155} \mathrm{O}$ último trecho aspado está ligeiramente parafraseado para se adaptar ao contexto.

${ }^{156}$ Ao evocar a falta de memória de seus concidadãos, o cronista parece brincar com seu leitor, sobretudo ao afirmar que não estudara Pangloss, a quem já chamara de "meu padre-santo" e "grande filósofo", afora as menções às suas peripécias em Candide.

${ }^{157}$ Ao longo de quarenta anos, foram inúmeras as vezes em que o cronista tratou da fraude e violência nas eleições.
} 
O descrédito à filosofia finalista acompanha o cronista pela volta ao mundo até dizer a que veio: “A que propósito isso?" E, se a dúvida fingida segue-o por outras paragens, ao chegar à Bahia ela deixa de existir. Ali o cronista mostra seu espanto e indignação em face das tramoias eleitorais e na busca por correspondentes em outras terras, volta-se para a Itália.

E, se as urnas brasileiras, férteis, geram eleitores que se multiplicam à exaustão, a Itália padece de indecisão, uma vez que lá se elegeu um pequeno grupo sem identidade partidário-ideológica. Ao tratar da indecisão na deputação italiana, o cronista traz de arrasto Dante e Hamlet, indeciso entre o ser ou não-ser, até resvalar na perfeição do espírito e dos costumes. Ao fazê-lo, sub-reptícia e metaforicamente, as teorias finalistas adquirem equivalência (e eco) nos mariscos que grudam no fundo da magnífica galera da civilização.

Por meio de um total relativismo - e malgrado a magnificência da embarcação -, o cronista reitera a necessidade de que os mariscos de seu casco sejam removidos de tempos em tempos, o que explicaria as guerras e outros fenômenos. Nessa lógica, pragas e flagelos surgem como agentes destruidores e necessários à renovação da humanidade, portanto, um discurso metafísico à guisa dos dilúvios e que não oferece explicação outra que satirizar o otimismo leibniziano e sua razão suficiente.

\section{Enfim, "no melhor dos mundos possíveis"}

Em maio de $1896^{158}$, um fait divers ganha destaque nas páginas dos jornais: a fuga dos doidos do hospício. Certo, não se trata de uma daquelas notícias anódinas e esquecidas que tanto aguçam seu olhar de míope, mas levado pelo hábito, o cronista aperta as pálpebras e encontra na historieta algo que o deixa confuso, a ponto de perder as "escoras da alma".

\footnotetext{
A fuga dos doudos do Hospício é mais grave do que pode parecer à primeira vista. Não me envergonho de confessar que aprendi algo com ela, assim como que perdi uma das escoras da minha alma. Êste resto de frase é obscuro, mas eu não estou agora para emendar frases nem palavras. O que fôr saindo saiu, e tanto melhor se entrar na cabeça do leitor.
}

158 “A Semana”, Gazeta de Notícias, 31/5/1896. 
Ou confiança nas leis, ou confiança nos homens, era convicção minha de que se podia viver tranqüilo fora do Hospício dos Alienados. No bonde, na sala, na rua, onde quer que me deparasse pessoa disposta a dizer histórias extravagantes e opiniões extraordinárias, era meu costume ouvi-la quieto. Uma ou outra vez sucedia-me arregalar os olhos, involuntàriamente, e o interlocutor, supondo que era admiração, arregalava também os seus, e aumentava o desconcêrto do discurso. Nunca me passou pela cabeça que fôsse um demente. Tôdas as histórias são possíveis, tôdas as opiniões respeitáveis. $[\ldots]$

A fuga em massa ocorrida no Hospício D. Pedro II, empreendimento que exigiu arte, cálculo, raciocínio e ordem, desconcerta-o na medida em que "diminui em grande parte a vantagem de [se] ter juízo". Assim, revelando ter perdido todas as suas convicções, coloca-se a divagar e a rememorar situações, lugares, e pessoas com quem trocou ideias: gestos abruptos e opiniões excêntricas, que considerara "simples loucura transitória", mudam de proporção e, com seu aspecto significativo alterado, são vistos como sintomas de loucura crônica.

Tão logo a dúvida se instala, o cronista desconfia de tudo e de todos: agora sua existência divide-se entre o antes e o depois da fuga dos doidos. Nostálgico, recorda-se do tempo em que a certeza e a antiga confiança permitiam-no ouvir tranquilamente discursos e notícias. Depois da fuga, pergunta-se: "acharei método para distinguir um louco de um homem de juízo?”. Desse modo, questionando o tênue limite entre sanidade e loucura, e, ilustrando seu discurso com casos de loucos que pareceram mais lúcidos que os lúcidos, deixa vacilante a alma do leitor.

Afinal, quem seriam os loucos, os despossuídos de razão? Aqueles que lá estavam trancafiados, incapazes de responder aos estímulos da sociedade, ou esta, que mal sabia distinguir o movimento e o encadeamento daqueles? Gestos, cacoetes, ideias e histórias fantásticas de seus interlocutores são relativizados em face das ações precisas e lógicas dos loucos encarcerados.

Nessa lógica, o cronista prova da mesma hesitação de seu leitor e uma vez que não mais é possível conviver com as [in]certezas do real, volta-se para a ficção. Ao recontar um poema não escrito, relembra a saga de um desses loucos, farto material de inspiração romântica: mar, navio, céu, a alegria a bordo e a confiança; depois, uma 
noite, a lua em todo o seu esplendor, uma batalha, versos, gritos, tumultos, sangue e o mais fica por conta do Deus inspirasse ao poeta. ${ }^{159} \mathrm{E} .$.

\section{$[\ldots]$}

De resto, tôda esta semana foi de sangue, ou por política, ou por desastre, ou por desfôrço pessoal. $\mathrm{O}$ acaso luta com o homem para fazer sangrar a gente pacata e temente a Deus. No caso de Santa Teresa, o cocheiro evadiu-se e começou o inquérito. Como os feridos não pedem indenização à companhia, tudo irá pelo melhor no melhor dos mundos possíveis. No caso da Copacabana, deu-se a mesma fuga, com a diferença que o autor do crime não é cocheiro; mas a fuga não é privilégio de ofício, e, ademais, o criminoso já está prêso. Em Manhuaçu continua a chover sangue, tanto que marchou para lá um batalhão daqui. O comendador Ferreira Barbosa, (a esta hora assassinado) em carta que escreveu ao diretor da Gazeta e foi ontem publicada, conta minuciosamente o estado daquelas paragens. Os combates têm sido medonhos. Chegou a haver barricadas. Um anônimo declarou pelo Jornal do Comércio que, se a comarca de S. Francisco tornar à antiga província de Pernambuco, segundo propôs o Sr. Senador João Barbalho, não irá sem sangue. Sangue não tarda a escorrer do jovem Estado (peruano) do Loreto...

Enxuguemos a alma. Ouçamos, em vez de gemidos, notas de música. Um grupo de homens de boa vontade vai dar-nos música velha e nova, em concertos populares, a preço cômodo. [...]

No jogo literário precedente, em que a relativização da sanidade (e da loucura) reflete (e constrói-se) no mundo real, nos fatos, o cronista lista uma série de acontecimentos (e indícios) que denotam a perda da razão de homens que se misturam àqueles ditos normais. Fugas, crimes, levantes, rebeliões, acidentes, desrespeito às leis vêm à tona como exemplos das mazelas do homem. Cotejá-las às desventuras de Candide, à força da significação, em princípio pode parecer algo exagerado, porém, à menção do aforismo voltairiano o matiz irônico se instala.

Se em Candide as personagens oscilam entre o mundo real do conto de fadas (o castelo de Thunder-ten-tronckh) e "o melhor dos mundos possíveis", na esfera do folhetim (que se pretende leve e bem humorado) o cronista experimenta certo paroxismo ao tentar desvendar os limites entre a sanidade e a loucura, e ironicamente vê

${ }^{159}$ Entrecho ligeiramente parafraseado para se adaptar ao contexto. 
loucos por todos os lados, assim como um dia Voltaire, ao se opor a Rousseau, afirmara existir selvagens em toda a Europa ${ }^{160}$.

E os loucos, espalhados pela cidade, ocupam cargos, e uma vez dirigindo companhias, alimentam não só o fatalismo indiciado pelo cronista de modo sardônico ("O acaso luta com o homem para fazer sangrar a gente pacata e temente a Deus."), mas, sobretudo o determinismo, cuja causalidade era amplamente discutida na época.

Nessa lógica, os acidentes provocados pelas companhias adaptam-se perfeitamente à determinação dos eventos condicionais no âmbito do princípio da causalidade, com resultados amplamente eficazes: se A (a causa) é produzido, B (o efeito) é $100 \%$ realizado. Assim, a despeito do descumprimento da lei que determina um número x de passageiros em cada vagão (causa), os frequentes atropelamentos, acidentes, descarrilamentos e mortes eram absolutamente esquecidos pelas companhias e pelo poder público (efeito).

O intertexto, mais que elemento de sustentação crítica, introduz ambiguidade ao discurso e auxilia o cronista em seu exercício de provocar o poder público a repensar a constituição de um sistema que, indubitavelmente, tem na loucura um de seus principais ingredientes. Assim, a loucura e tudo o mais mostram que muita coisa é possível no mundo, mas não obrigatoriamente no "melhor" dos mundos possíveis. Por fim, não se trata de um jogo do real vs ideal, mas, no caso, da oposição entre fatos e versões dos mesmos, algo que Pangloss fez inúmeras outras vezes.

\section{VOLTAIRE: sua língua, seu espírito, seus contos e seu riso}

Nas crônicas, são várias as referências diretamente ligadas à persona de Voltaire. Dessa visada despontam características como a língua, o espírito, o riso e o conto. Este último, extraído da generalidade dos gêneros literários, nos textos machadianos se particulariza e ganha predicados restritos. Isto, por tratar-se do conto filosófico, cuja forma exemplar está em Voltaire.

A língua, o espírito e o riso surgem como atributos do grande autor francês e, se evocados pelo cronista, só o foram porque consolidados ao longo da circulação literária. Comparando-os aos textos anteriores, em que referências textuais e citações ganham

160 "Il y a des sauvages-là dans toute l'Europe. (VOLTAIRE, 1878: 19, Tome XI)" 
status de linha de força, irradiam sentidos e deflagram interpretações, esses têm dimensão intertextual relativamente restrita. Contudo, vale lembrá-los em razão do caráter universal e flexível de cada um deles.

\section{A língua}

Afirmar a marca francesa como um dos principais constitutivos para a formação da cultura brasileira ao longo do século XIX tornou-se senso comum. Contudo, vale reiterar que a compreensão de muito do que pensávamos - e pensamos -, deve-se à cultura francesa, um "misto de tradição e modernidade" (PASSOS, 2000: 11), para o qual nos voltamos em tentativa de acesso ao concerto das nações civilizadas. Ora Paris Tropical, ora Belle Époque Tropical ${ }^{161}$, a capital do Império, cenário de uma corte afrancesada acantonada nos trópicos, falava francês, lia filosofia e romances no idioma de Voltaire e por meio dela recebia contribuições nos mais diversos campos das ciências e das artes.

A moda fez da Rua do Ouvidor, no centro do Rio, lugar de "flânerie" e ponto de convergência da elite brasileira, em razão da grande quantidade de produtos franceses ali disponíveis. As maison-de-nouveautés, os haut couturiers e as lojas que tinham um cachet europeu consagrado atraiam consumidores e faziam do francês língua franca. Se a moda cooperava para a expansão da língua entre os altos círculos sociais, com as artes (o teatro principalmente) não era diferente: o vai-e-vem de atrizes, cantoras e espetáculos disseminavam o uso da língua. Mas não era só isso: na alcova, o fetichismo que envolvia a prostituição carioca fazia da francesa "mercadoria [cara] para a elite", tanto é que Needell (1993: 202) questiona se tamanha atração não seria em razão do exotismo das mulheres de fala não-portuguesa.

Antônio Cândido é mais enfático e afirma que "foi graças ao francês que pudemos ver o mundo, que adquirimos o senso da História, que lemos os clássicos de todos os países, inclusive os gregos e romanos" (1977: 12). A despeito das eventuais "lacunas francesas", afirma Cândido, lemos Goethe, Byron, Schiller, Hegel, Poe, etc., todos em versões francesas, às vezes - acrescenta - em "traduções e interpretações [...]

\footnotetext{
${ }^{161}$ Termo cunhado por Jeffrey Needell e título de sua obra publicada em 1993, que trata da sociedade brasileira e do Rio de Janeiro na virada do século XIX para o XX.
} 
deformantes e até empobrecedoras" (caso, sobretudo, do romance russo, a partir de 1880).

Assim, a língua francesa, que adquiriu caráter universal em fins do século XVIII e ao longo do século XIX, chega às nações sul-americanas numa época em que a era industrial começa a tomar forma, relativizando, portanto, as línguas clássicas que não respondiam pela compreensão das novas formas de cultura e conhecimento.

Com a ampliação do idioma, autores como Rousseau, Montesquieu e Voltaire adquirem foro de "profetas do novo mundo" (PASSOS, 2000: 29), bibliotecas particulares e públicas, a despeito das interdições da Real Mesa Censória, ficam repletas de obras em francês e academias, qual a Academia dos Guardas-Marinha, cuja biblioteca era "predominantemente francesa, quer pelos autores, quer pelos tradutores" (NIZZA DA SILVA, 1978: 181), revelam a língua francesa como importante instrumento na aquisição de conhecimento técnico.

A universalidade da língua francesa e sua flexibilidade, já que também respondia aos anseios das classes inferiores, após o evento da Revolução, tornou-a constitutivo de nosso desenvolvimento, a partir de seu ensino obrigatório na escola secundária brasileira. Em colégios como o D. Pedro II e o Collège de Sion, grande parte dos textos e o paradigma pedagógico adotado eram todos franceses. "Havia, sem dúvida, obras indispensáveis sobre gramática portuguesa e livros brasileiros [...], mas em geral adotavam-se autores franceses, ou clássicos comentados por franceses" (NEEDELL, 1993: 82).

Ao longo do século XIX a França manteve-se como importante pólo irradiador de ideias, de modo que a língua propiciou a integração do elemento francês ao brasileiro; seja pelo hábito de ler romances, seja em razão de leituras técnicas ou de cunho político-filosófico, surgiram correspondências em vários domínios, sobretudo o literário.

A crônica de 19/7/1988 ${ }^{162}$ faz parte de um grupo de textos que desafiam o leitor por seu caráter enigmático. Certo, nada de esfinges, oráculos ou pitonisas, mas o enunciador convida o leitor a tomá-lo pelo bei de Túnis, tal é seu desejo de viver ali; o fato de não entender ninguém e sequer ser compreendido, vê como algo positivo e

162 “Bons Dias”, Gazeta de Notícias. 
desculpa para estabelecer relações cordiais. À guisa de exemplo, comenta sobre um tal sr. Von Stein, que fez-se amigo do índios do Xingu, recitando versos de Goethe.

Ao leitor, uma única pista: a interlocução entre dois grupos de línguas diferentes, mas nenhuma relação com os fatos da semana. Somente no quarto parágrafo é que o cronista começa a se situar no tempo e espaço, elementos que direcionam todo um conjunto de intenções. Ao fazê-lo, pinça uma frase do discurso do senador Leão Veloso, cujo sentido, afirma, jamais se perderia mesmo se estivesse em Túnis. Em seguida, ironiza-a, assegurando que talvez fosse mais bem explicada se tivesse sido escrita em idioma arábico.

Ora, as intenções do cronista se evidenciam ao tratar dos espiritualistas brasileiros, quando se explicam os tons de ficcionalidade impressos nos entrechos anteriores do texto: primeiro, denota-se sua crença evidente no privilégio e excelência da ficção como discurso e modelo de escrita; depois, só a ficção enquanto puro e simples fingimento (ou simulação do real) dá conta de relativizar e expressar sua descrença no acrobatismo mediúnico do espiritismo.

Quem me não fez bei de Túnis cometeu um desses erros imperdoáveis, que bradam os céus.

Suponhamos por um instante que eu era bei de Túnis. Antes de mais nada, tinha prazer de viver em Túnis, que é um dos meus mais desenfreados desejos. Depois, não entendia nada do que me dissessem, nem os outros me entendiam, e para estabelecer relações cordiais, não há melhor caminho. [...]

Os espiritistas brasileiros acabam de dar um golpe de mestre. Apareceu por aqui um médium, dr. Slade é o seu nome, com fama de prodigioso. A Federação Espírita Brasileira nomeou uma comissão para estudar os fenômenos da escritura direta sobre ardósias e outros efeitos físicos produzidos com o médium. Pois, senhores, não achou que o homem valesse a fama; declarou que os trabalhos ficaram muito abaixo do que esse mesmo médium conseguiu na Inglaterra, França, Alemanha, Estados Unidos e Austrália. É verdade que a própria Federação explica a diferença. "Todos os que estudam os fenômenos espiríticos (diz ela) conhecem que as mediunidades estão sujeitas a esses eclipses." E noutro lugar: "Sabem todos que os invisíveis não estão servilmente à nossa disposição."

Ora, tudo isso, que parece algaravia, sendo lido por um espiritista, é como a língua de Voltaire: pura, límpida, nítida e fácil. "Os invisíveis não estão servilmente à nossa disposição!” Não falo do enriquecimento da língua com a palavra mediunidade, que é nova, sem ser esbelta. 
Nessa perspectiva, o leitor, que estivera por alguns segundos frente a um “enigma”, através da ficcionalidade é encaminhado à sátira, onde se revela o mistério do cronista. A intromissão da expressão língua de Voltaire só contribui para a ridicularização das explicações da Federação Espírita, uma vez que a elas são atribuídas clareza e compreensão inexistentes. Justapondo-as ao devaneio do cronista "bei de Túnis", a alusão contribui para "superdimensionar" os aspectos fantasioso e imaginário como constitutivos da crença espírita, além de descreditar as experiências do médium dr. Slade.

Atribuídas às explicações da Federação Espírita, a pureza e a nitidez características da língua de Voltaire, mais que relativizar, parecem mesmo responder à preocupação de todo satirista, ou seja, ridicularizar os abusos de pessoas ou grupos que tentam negar o óbvio: no caso, a tentativa de se explicar a prática do charlatanismo, associando o malogro da experiência mediúnica à compleição dos "seres invisíveis".

Em 13/12/1896, ${ }^{163}$ ao tratar da questão tributária envolvendo as companhias de teatro estrangeiras e nacionais, o cronista produz um daqueles textos "demasiados cerebrais", que padecem de certa "crepitação de alegria", levando-se em conta os comentários de Grieco (1959: 109-110).

Embora se trate de um assunto árido, o cronista busca um atalho e, nessa tentativa, declara-se esteticamente adepto do princípio da universalidade das artes, porém vê-se obrigado a comentar a legislação que rege a vida dificultosa dos teatros cariocas e, ao fazê-lo, discorre sobre a imbricação a que chegou as culturas francesa e brasileira e vê a língua como elemento de destaque.

Pôsto não frequente teatros há muito tempo, sei que há aí uma arte especial, que eu já deixei em botão. Essa arte (salvo alguns esforços louváveis) não é propriamente brasileira, nem estritamente francesa; é o que podemos chamar, por um vocábulo composto, a arte franco-brasileira. A língua de que usa dizem-me que não se pode atribuir exclusivamente a Voltaire, nem inteiramente a Alencar; é uma língua feita com parte de ambas, formando um terceiro organismo, em que a polidez de uma e o mimo de outra produzem nova e não menos doce prosódia.

163 "A Semana”, Gazeta de Notícias. 
Desse modo - e acima dessas imbricações linguísticas -, surge Voltaire, na condição de magister dixit, marco incostentável de referência da cultura francesa a orientar os olhares do brasileiro oitocentista em direção a França. Divinizado, ora suas tragédias o mitificam, ora suas posições ideológicas (a luta contra o fanatismo e o despotismo) o tornam autoridade inconsteste, ora sua universalidade, pensamento crítico e habilidade no trânsito por diferentes gêneros literários, fazem-no figura de proa a inspirar autores (e o cronista), proporcionando o entrelaçamento das culturas brasileira e francesa. De forma genérica, tão importante quanto a língua francesa na justaposição das culturas, é a "língua" de Voltaire: leve, paradoxal, sintética; e sua frase: curta, simplificada, marcada pela clareza, o agenciamento e a variação constante das palavras, confirmando-o como figura tutelar no meio cultural oitocentista brasileiro. ${ }^{164}$

\section{O conto}

Em 1743, com a morte do cardinal de Fleury, Mme de Pompadour torna-se a primeira em influência na corte de Louis XV. E é por intermédio dessa velha amiga e confidente que Voltaire consegue o cargo de historiógrafo do rei; também nessa mesma época dá forma a um novo gênero literário: o conto filosófico.

Em seu relevante estudo "Le fusil à deux coups de Voltaire" (1989: 123-163), Starobinski percorre o estilo filosófico dos contos voltairianos, definindo-os como simulacro de narrativas ao destacar o caráter díspar desses relatos, cujos acontecimentos desafiam toda verossimilhança, sobretudo pela maneira como se sucedem. O crítico ressalta ainda o fato de que em nenhum momento fazem apelo à confiança do leitor, deixando-o completamente livre.

Através do uso sistemático do escárnio e principalmente pela invencibilidade dos heróis, que escapam a toda sorte de perigo, a evocação da violência surge como estratégia de denúncia. Starobinski destaca, por exemplo, que em Candide "rien de ce qui est atroce n'est inventé: Voltaire livre un documentaire, quelque peu simplifié et stylisé, mais qui constitue l'anthologie des atrocités que les gazettes portaient à la connaissance de tout Européen attentif” (STAROBINSKI, 1989 : 125).

\footnotetext{
${ }^{164}$ Sobre a "divinização" de Voltaire ver: "A Miragem Gálica: presença literária francesa na Revista da Sociedade Filomática". In: Cintilações Francesas: Revista da Sociedade Filomática, Machado de Assis e José de Alencar. PASSOS, Gilberto Pinheiro. São Paulo: Nankin, 2006.
} 
Os contos, talvez a parte mais viva de sua obra, apresentam uma escritura notável. Nada é supérfluo. A escrita se constrói por cortes, elipses, lítotes e por todas as formas de subtração, eliminando qualquer expressão de emoção que poderia inflar a frase, alongando-a, o que faz com que a narrativa se atenha em expressar a "verdade", fazendo-se curta e ágil.

A ironia, a sátira, a paródia, aliados à denúncia da violência ancorada em uma investigação filosófica, são elementos que compõem a narrativa do conto filosófico, tornando-o um "texte sans précédent". Sobre Candide, Starobinski afirma: "La littérature paraît être arrivée à son terme.” E ao fazê-lo ressalta o fato de que a obra faz o inventário do passado, afirmando tratar-se de um livro "hors littérature, hors philosophie, qui se moque de la littérature et de la philosophie" (STAROBINSKI, 1989: 126).

Enfim, no conto filosófico, o procedimento da crítica voltairiana consiste em suprimir o encadeamento das causas alegadas pelo uso frequente do sarcasmo. $\mathrm{O}$ emprego das palavras em sentido oposto objetiva o que se quer fazer entender, de modo que a ironia faz-se cúmplice da réplica do mundo, algo que nas palavras de Starobinski, traduz-se pela agudeza e pelo tom cortante de uma dicção irônica que age sobre a crueldade do real e lhe confere uma ferocidade hiperbólica.

O conto filosófico traz implícita uma argumentação indireta: é um “ouvrage qui dit plus qu'il ne semble dire" (VOLTAIRE, 1879: 32, Tome XXI) ${ }^{165}$, afora que são obras curtas bem à maneira de Voltaire. ${ }^{166}$ De certo modo pode-se afirmar que o conto filosófico nasceu dos apólogos, historietas leves mais ou menos longas, que trazem uma lição de sabedoria e cuja moralidade é expressa como conclusão, além de as personagens serem mais simplificadas e encarnarem uma virtude ou um vício.

Por fim, vale destacar que o conto voltairiano é um exemplo representativo não só dos debates que tiveram como palco o século das Lumières, mas, sobretudo da produção do próprio autor, como representante eletivo dos combates que travou pelo respeito aos direitos individuais, a tolerância, a justiça e a liberdade.

\footnotetext{
165 Introdução ao conto Zadig, ou la Destinée.

${ }^{166}$ Voltaire em correspondência a M. Moultou, afirma: “... il faut être très court, et un peu salé, sans quoi les ministres et Madame de Pompadour, les Commis et les femmes de Chambre, font des papillotes du livre" (D10885, à Paul Claude Moulton, le 5 janvier 1763). Dado extraído de: Revue des Deux Mondes, XXXII ${ }^{\mathrm{e}}$ Année. Seconde Période. Tome XXXI. Paris: Bureau de la Revue des Deux Mondes, 1862, p. 440.
} 
Nas crônicas machadianas o conto de Voltaire aparece em duas delas: em $31 / 3 / 1895^{167}$, o conto do vigário, tradicional protótipo da malandragem popular, vem à luz em decorrência de um fait-divers, caso em que um larápio surrupia quatro contos de réis de um fazendeiro que tentara ajudá-lo a entregar outros vinte contos à Ordem Terceira, numa transação que se assemelha ao conhecido golpe do bilhete premiado de loteria com que muitas pessoas se deixam enganar nos dias atuais.

Ao debruçar-se sobre a notícia, o cronista ressalta a falha moral, conferindo-lhe genealogia. Nessa perspectiva, a gênese textual do conto teria sido o discurso da serpente, induzindo Eva a provar do fruto proibido. Uma vez na esfera bíblico-literária, a vilania do "barro humano" ganha representação e vem à luz a história de Jacó que, premeditadamente, enganou seu sogro Labão, no episódio das cabras malhadas. Para o cronista, o estranhamento dá-se pelo fato de não saber o "que há na alma humana que Labão é que faz sorrir, ao passo que Jacó passa por um varão arguto e hábil”.

Dito isto, o cronista sugere o estudo da genealogia do conto do vigário:

\begin{abstract}
Aos sapientes e pacientes recomendo a bela monografia que podem escrever estudando o conto do vigário pelos séculos atrás, as suas modificações segundo o tempo, a raça e o clima. A obra, para ser completa, deve ser imensa. É seguramente maior o número das tragédias, tanta é a gente que se tem estripado, esfaqueado, degolado, queimado, enforcado, debaixo dêste belo sol, desde as batalhas de Josué [...] O conto é menos numeroso, e, seguramente, menos sublime; mas ainda assim ocupa lugar eminente nas obras de ficção. Nem é o tamanho que dá primazia à obra, é a feitura dela. $\mathbf{O}$ conto do vigário não é pròpriamente o de Voltaire, Boccaccio ou Andersen, mas é conto, um conto especial, tão célebre como os outros, e mais lucrativo que nenhum.
\end{abstract}

"A obra para ser completa, deve ser imensa." Mesmo as recomendações para o estudo soam irônicas, sobretudo se se levar em conta o modo como o cronista aborda as historietas bíblicas. Ali, do núcleo que rege as paixões, extraiu tão somente a essência torpe e ardilosa da alma humana. Suscitados pelo caso do larápio, o oportunismo e a astúcia são ilustrados por meio dos relatos bíblicos. Ao fazê-lo, é como se, ironicamente, advertisse seu leitor a não se deixar enganar, uma vez que sob a aparente bondade natural, esconde-se o homem lobo do homem - homo homini lupus est, numa clara alusão a Plauto.

167 “A Semana”, Gazeta de Notícias. 
Desse modo, em face da acintosa violência do mundo real, volta-se para o literário e comenta o gênero, seu caráter e, sobretudo sua extensão. O desvio abrupto indica que ao menos nos relatos curtos, a vilania e a degradação moral são elementos para a transmissão de valores culturais, de bondade, honestidade e virtude.

O conto de Voltaire, Boccacio e Andersen, por exemplo, mais que relato de intenção moralizadora - sugere o cronista -, permite que o leitor se situe em relação ao grotesco e o absurdo das ações humanas, sobretudo porque traz a ironia como constitutivo de interrogação, questionando as causas e as "verdades" e, ato contínuo, introduzindo simultaneamente um relativismo satírico às questões apresentadas.

Em 17/12/1896 ${ }^{168}$, num texto repleto de referências literárias, meio crônica, meio crítica, deslinda parte de seu repertório literário num trajeto que vai de Petrarca, passando por Shakespeare, Harlowe, Elliot, os franceses Molière, Musset, Taine, Mérimée, Flaubert e Benjamin Constant, até chegar a Valentim Magalhães, que afirmara ter produzido uma "obra de fôlego" ao condicioná-la à extensão.

Ao defender o gênero, o cronista evoca Voltaire:

Não insisto; aí fica o bastante para mostrar o aprêço em que tenho o talento de Valentim Magalhães, dizendo-lhe alguma cousa do que me parece bom e menos bom na Flor de sangue. Que há no livro certo movimento, é fora de dúvida; e esta qualidade em romancista vale muito. Verdadeiramente os defeitos principais dêste romance são dos que a vontade do autor pode corrigir nas outras obras que nos der, e que lhe peço sejam feitas sem nenhuma idéia de grande fôlego. Cada concepção traz virtualmente as proporções devidas; não se porá Mme. Bovary nas cem páginas de Adolfo, nem um conto do Voltaire nos volumes compactados de George Elliot.

Depois de um longo comentário a respeito de Flor de Sangue, obra de Valentim Magalhães, o cronista traz à luz o conto de Voltaire justamente porque em seu prefácio, referindo-se ao romance e ao poema como as duas principais formas literárias, Magalhães afirma: "Tudo o mais, contos, odes, sonetos, peças teatrais são matizes, variações, gradações; motivos musicais, apenas, porque as óperas são só eles.”

Ao assegurar que Flor de Sangue (1897) fora prejudicada exatamente por seu autor ter querido fazê-la longa e depressa, o cronista evoca o conto voltairiano, de brevidade mordaz, cuja escritura, de caráter claro e preciso, simultaneamente confere

168 “A Semana”, Gazeta de Notícias. 
liberdade ao leitor e o desperta para uma multiplicidade de sentidos e interpretações. Tão importante quanto a clareza, para que a escrita sugestione o leitor, é preciso não só imaginação, mas também força e habilidade de concisão.

Essa mesma concisão como forma de expressão leva o cronista a Voltaire, mas também a Benjamin Constant e seu Adolphe (1816), marca indelével de brevidade e, como contraponto, a Madame Bovary (1857). A referência a obra de Flaubert, surge como uma crítica educada ao amigo Magalhães, talvez na tentativa de dizer-lhe que tudo bem, nem só do laconismo se criam boas narrativas, também da loquacidade se fazem obras-primas, mas para isso é preciso genialidade. Desse modo, o conto de Voltaire, na condição de referência estigmatiza positivamente todo um gênero, e surge como ferramenta didática ao autor de Flor de Sangue.

\section{O espírito}

Considerando-se a Literatura Francesa, sua circulação e, de maneira mais extensa, o gosto francês, Voltaire surge como ícone da genialidade de uma nação e de sua língua. A universalidade de sua obra é exemplar, a despeito de ao longo dos séculos as opiniões sobre o autor terem sofrido constantes variações. De fato, nada diferente do que lhe ocorrera em vida: ora homenageado e considerado árbitro das letras, ora acusado de corromper mentes e espíritos e vice-versa, ileso, manteve o reconhecimento de seu talento como escritor, polemista e pensador, a ponto de tornar-se objeto de culto.

Intacta também permaneceu uma das mais importantes características de seu espírito: seu traço provocador. Como ninguém ele soube instigar a mente humana, provocando-a a se posicionar diante da intolerância, da tirania, do fanatismo e da [in]justiça. Suas reflexões induziam a tomadas de posição: aceitar e aprovar ou negar e rejeitar. Talvez por isso tenha assegurado uma glória durável que extrapolou sua nação e seu tempo, sendo cultuado na posteridade.

Ao defender Calas, já próximo dos 70 anos, Voltaire sonda os abismos da alma humana, enfrenta com espírito desafiador a intolerância e, nesse momento, do alto de uma constituição física já fragilizada, ganha o coração de todo um continente. Ao fazêlo, mostrou que não é suficiente a um escritor ater-se aos modos e ao tempo de seu país, mas ultrapassá-los e atingir não só o espírito, mas também o coração humano. 
Frédéric II, rei da Prússia, grande admirador de Voltaire em elogio (In : VOLTAIRE, 1833: 131-145, Tome I) ${ }^{169}$ ao escritor afirma: "son goût acquit ce tact fin, cette politesse, et cette urbanité à laquelle n'atteignent jamais ces savants érudits et solitaires [...], ce vernis a répandu dans les ouvrages de M. de Voltaire” (Idem, p. 133) e acrescenta: "Quoique M. de Voltaire fût sensible à des marques d'approbation aussi éclatantes, il était portant davantage à l'amitié. (Ibidem, p. 135)" O monarca destaca ainda sua imaginação brilhante e variada, seu espírito ágil e a efervescência de seu talento.

Profeta das Lumières em uma época em que grande parte da humanidade vivia alheia às ideias libertárias e sob a sombra da ignorância, levantou-se ferozmente contra o fanatismo religioso, inimigo que, não por acaso, nomeou de L'Infâme. E é esse Voltaire combativo e enciclopedista que surge discretamente no espaço do folhetim.

Nous l'avons échappé belle! Digo isto em francês porque as revoluções são produtos essencialmente franceses, e nós escapamos de uma revolução. [...]

Pela minha parte, se alguma vez morrer, espero ocupar também a atenção dos meus sobreviventes com muitos legados singulares, dos quais posso desde já dar uma pequena amostra. Espero deixar as seguintes coisas:

$1^{\circ}$ As tripas ao sol.

$2^{\circ} \mathrm{A}$ calva à mostra.

$3^{\circ} \mathrm{A}$ cara à banda.

$4^{\circ} \mathrm{O}$ coração à larga.

$5^{\circ}$ Os cabelos à Luís XV.

$6^{\circ}$ Os colarinhos ao alto.

Isto é só uma pequena amostra do pano; o resto é simplesmente espantoso. O caso é que eu morra, do que duvido. Quando muito, morrerei tarde, tão tarde como aquela senhora que expirou no mês passado, em Cachoeira, na Bahia.

Tinha a referida senhora nada menos de 128 anos, isto é cinco quartos de século e mais uns de quebra. Se isto é vida, não sei o que se deve chamar uma indigestão. Que os cedros do Líbano, os carvalhos e outros indivíduos da mesma gente vivam tanto ou mais, compreende-se; nenhum desgôsto os consome; [...]

Muda o caso de figura, tratando-se de uma senhora que, tendo nascido em 1747, é nada menos que contemporânea do terremoto de Lisboa; alcançou Voltaire e os enciclopedistas; viu morrer Tiradentes tendo já passado aos quarenta anos; era velha de

\footnotetext{
${ }^{169}$ Trata-se do «Éloge de Voltaire lu à l'Académie Royale des Sciences et Belles-Lettres de Berlin, dans une assemblée publique extraordinaire convoquée pour cet objet le 26 novembre 1778 ».
} 
setenta quando rompeu o grito do Ipiranga. O Centenário, que o Ginásio vai representar daqui a dias, é uma bagatela, à vista de tal prodígio de decrepitude. ${ }^{170}$

Ao lado da citação, a referência ocupa lugar central no estudo da poética intertextual, sobretudo porque ao surgir no espaço do texto, provoca um desvio de leitura e redireciona o leitor para dados que extrapolam o contexto e universo daquilo que se lê. Na crônica, a recorrência ao nome de Voltaire se inscreve como pálido intertexto, porém, o suficiente para que o leitor mergulhe na memória da literatura.

Ao mencioná-lo, aliado ao Terremoto de Lisboa e à palavra "enciclopedistas", o cronista revela muito de seu repertório literário e, das entrelinhas, faz emergir Candide (1759), as peripécias e os acontecimentos da obra. A menção à passagem do tempo pode conduzir o leitor até Cunégonde: de início, descrita como "extrêmement belle", no final aparece "rembrunie, les yeux éraillés, la gorge sèche [les seins tombant], les joues ridées, les bras rouges et écaillés", numa visão apavorante que faz Candide "recula, trois pas, saisi d'horreur" (VOLTAIRE, 1989: caps. I e XXIX).

A sucessão dos acontecimentos, a decrepitude física como medidor da passagem do tempo e da finitude da vida, adquirem completude na obra francesa, sobretudo porque ao ecoar na crônica o Terremoto de Lisboa relembra a morte de milhares. Assim o "nous avons échappé belle!", adquire sentido, provoca alento (a válvula por onde escapou a senhora de 128 anos) e serve de caminho para que o cronista e seu leitor, não, evidentemente, pleiteiem a eternidade, mas revivam longos dias e se consolem através da lembrança.

O recontar aprisiona o tempo e permite dias melhores, a exemplo do que ocorre no conto voltairiano Les deux consolés (1756). Na narrativa, o filósofo Citiophile, ao tentar consolar uma dama que chora seus próprios infortúnios, enumera a crueldade sofrida por grandes personagens como Marie Stuart, Hécubé, Nyobé e outras. Entretanto, no dia seguinte o filósofo perde seu único filho e a dama, para consolá-lo, relembra inúmeros reis que perderam seus filhos.

Três meses depois, os dois se encontram e decidem erigir uma estátua ao tempo com a seguinte inscrição: "A celui qui console". Da mesma forma, através do jogo literário o cronista trabalha a ideia do tempo que se desvanece e se dissipa, não só através da velhice física, mas também dos fatos históricos que se perdem na noite dos

170 "História de quinze dias", Illustração Brazileira, 15/11/1876. 
tempos. A única saída para ludibriar o tempo, no caso, é a literatura, por onde se pode “échapper belle".

Em 3/4/1885 ${ }^{171}$, o cronista começa citando o senador João Alfredo:

Há alguém, disse o Sr. senador João Alfredo, citando um velho dito conhecido, há alguém que tem mais espírito que Voltaire, é todo o mundo."

Não sei se já alguma vez disse ao leitor que as idéias, para mim, são como as nozes, e que até hoje não descobri melhor processo para saber o que está dentro de umas e de outras, - senão quebrá-las. [...]

Não escapou a êste processo a idéia de que todo o mundo tem mais espírito do que Voltaire, inventada por um homem ilustre, o que foi bastante para lhe dar circulação. E, palavra, no caso desta, senti profundamente o que me aconteceu.

Com efeito, a idéia de que todo o mundo tem mais espírito do que Voltaire, é consoladora, compensadora e remuneradora. Em primeiro lugar, consola a cada um de nós de não ser Voltaire. Em segundo lugar, permite-nos ser mais que Voltaire, um Voltaire coletivo, superior ao Voltaire pessoal. Às vêzes éramos vinte ou trinta amigos; não era ainda todo o mundo, mas podíamos fazer um oitavo de Voltaire, ou um décimo. Vamos ser um décimo de Voltaire? Juntávamo-nos; cada um punha na panela comum o espírito que Deus lhe deu, e divertíamo-nos muito. Saíamos dali para a cama, e o sono era um regalo.

Perdi tudo isto. Peguei desta compensação tão cômoda e barata, e deitei-a fora. Funesta curiosidade! O que achei dentro, foi que todo o mundo não tem mais espírito que Voltaire, nem mais gênio que Napoleão. Cito êstes dois grandes homens, porque o segundo lá está citado na frase do eminente senador.

Sim, meus amigos. Choro lágrimas de sangue com a minha descoberta; mas que lhes hei de fazer? Consolemo-nos com o ser simplesmente Macário ou Pantaleão. $[\ldots]$

Nem me retruque o leitor com o fato de ter de um lado a opinião do autor da idéia, e as gerações que a têm repetido e acreditado, enquanto do outro estou apenas eu. Faça de conta que sou aquêle menino que, quanto tôda a gente admirava o manto invisível do rei, quebrou o encanto geral, exclamando: El-rei vai nu! Não se dirá que, ao menos nesse caso, tôda a gente tinha mais espírito que Voltaire. Está-me parecendo que fiz agora um elogio a mim mesmo. Tanto melhor; é minha doutrina.

Ora fatos da semana, ora crítica literária ou teatral, ora textos que se aproximam de artigos de cunho filosófico, mas também reminiscências pessoais: assim, compõem-

171 “A Semana”, Gazeta de Notícias. 
se as crônicas d'“A Semana". Nesta, ao rememorar sua juventude, o cronista destaca seu percurso intelectual e trato com as ideias.

A referência a Voltaire, num processo de mise en abyme (a partir da citação do senador) replica o dito do "velho conhecido", Talleyrand, que em célebre discurso na Assembleia Nacional em 24/7/1821, pronuncia-se a favor da liberdade de imprensa, cuja existência, afirma, é uma necessidade dos tempos, uma vez que o espírito humano jamais foi completamente acomodado.

Ao ilustrar seu raciocínio, reitera o século XVIII, o século de Voltaire, como um dos mais afortunados da história em face de seu desenvolvimento intelectual. Ao fazêlo, o diplomata reforça a ideia de que a sociedade, em sua marcha progressiva, está destinada a novas necessidades que não devem ser impedidas, colocando governos e opiniões em campos opostos: “De nos jours, il n'est pas facile de tromper longtemps. Il y a quelqu'un qui a plus d'esprit que Voltaire, plus d'esprit que Bonaparte, plus d'esprit que chacun des directeurs, que chacun des ministres passés, présents, à venir, c'est tout le monde. S'engager, ou du moins persister dans une lutte ou tout le monde se croit intéressé, c'est une faute, et aujourd'hui toutes les fautes politiques sont dangereuses. (BULWER, 1868: 295, Tome I)"

O cronista, entretanto, desconfia das ideias prontas que são distribuídas aleatoriamente, desprendidas dos contextos nos quais foram concebidas. Para tanto, julga necessário descobrir o que "está dentro de umas e de outras". Embora acredite no aforismo de que todo mundo tem mais espírito que Voltaire (leia-se, no caso, "todo mundo" como um conceito - opinião coletiva), acaba por concluir ser esta uma ideia simplista, pois afinal, "não se chega nunca a ser todo mundo".

Discordar do aforismo, contudo, surge como reforço das ideias pessoais, sobretudo se se levar em conta Talleyrand, que afirma: "S'engager, ou du moins persister dans une lutte ou tout le monde se croit intéressé, c'est une faute[...]". Assim o cronista alerta sobre o perigo que a unanimidade pode esconder, ou seja, uma ideia, apesar de amplamente aceita, pode não ser a melhor ideia, não traduzir a "verdade" e mais, pode figurar como armadilha. Desse modo, acertadamente conclui seu pensamento ao se colocar no lugar do menino - o único -, a vislumbrar a nudez do rei, algo que a coletividade, por interesse e razões diversas, preferia não ver. 
Por fim, ao apropriar-se de Voltaire para se expressar, confere ao autor função diferente daquela sustentada por Talleyrand, em que Voltaire é minimizado em prol do espírito coletivo; em Machado, o ícone francês opera em sentido contrário, eleva-se, e surge como modelo de opinião pessoal. Nessa perspectiva, o cronista busca respaldo no próprio Voltaire para ir de encontro a um aforismo cuja construção tem como mote seu próprio nome: "todo o mundo não tem mais espírito que Voltaire", descontruindo uma locução que se tornara adágio e reafirmando a força do gênio.

Em 12/6/1896 $6^{172}$, Voltaire e sua notória incredulidade voltam à cena:

A bomba do Eldorado durou o espaço de uma manhã, tal qual a rosa de Malherbe. Esta velha rosa é que parece querer durar a eternidade. E aqui faço uma pequena crítica ao Sr. Conselheiro Ângelo do Amaral. S. Ex. escreveu no Jornal do Comércio um artigo contra o remédio que o Sr. senador Leite e Oiticica publicou na Revista Brasileira para extirpar o mal das nossas finanças. A revisão deixou passar esta frase: "a rosa do Sr. senador pelas Alagoas teria a sorte da de Malherbe". O Sr. Ângelo corrigiu-a no dia seguinte, restaurando o que escrevera: "o projeto do Sr. senador pelas Alagoas teria a sorte da rosa de Malherbe". Ah! por que não imitou o próprio poeta Malherbe, a quem a revisão atribuiu o verso que ficou? Francamente, a primeira forma era melhor; completava o seu pensamento dando ao projeto o nome da cousa perecível, uma vez que o acha perecível. Não me diga desdenhosamente que seria poético; poesia não deve entrar só por citação nas matérias áridas; pode muito bem tratar do próprio chão duro em que se pisa.

A rosa do Eldorado... Veja como eu dou execução ao meu conselho, sem que aliás uma bomba se pareça com flor. A rosa do Eldorado viveu tão pouco que nem se chegou a saber se foi dinamite, se pólvora; mas parece que foi pólvora. A incredulidade, que não morreu com Voltaire, abanou as orelhas à dinamite, o que diminuiu muito o horror à bomba. Mas fôsse isto ou aquilo, o que é certo é que houve faca e revólver, um morto (Deus lhe fale n'alma!) e alguns feridos; entrando-se em dúvida tão-sòmente se o ataque veio de fora ou de dentro, ou se de ambos os lados. Fezse autópsia; e enterrou-se o cadáver. Quia pulvis es. Segundo li ontem, vai aparecer um incidente extraordinário neste negócio que lhe dará nova face. Não há de ser a ressurreição do defunto.

Ao traçar o perfil de Voltaire, o arcebispo de Auch afirma : "Quel ennemi de la Religion la France a-t-elle élevé et nourri dans son sein dans la personne du Poëte de

172 “A Semana”, Gazeta de Notícias. 
nos jours! Combien d'aveugles disciples se sont mis à la suite de ce trop fameux maître de l'incredulité ? [...] Ingrat envers son bienfaiteur et envers sa Patrie, Philosophe orgueilleux, Apostat méprisable, né pour le malheur de son siècle et pour la perte d'une infinité d'âmes, [...]" (HAREL, 1781: 60). Divulgada pela Igreja, a opinião do arcebispo ilustra muito do que pensavam de Voltaire aqueles que não partilhavam das Lumières, sobretudo, quando o assunto em pauta era a religião.

Numa metáfora livre, pode-se afirmar que ao longo dos séculos XVII e XVIII cara e coroa da moeda foram a religião e a filosofia, de modo que o saber não raro surgia como produto da incredulidade. A filosofia de Voltaire, empenhada em fazer prevalecer a razão e o bom senso, solapou as superstições e de certo modo atuou como ferrugem nos pilares da religião, desarraigando as ideias pré-concebidas de Deus de entre os crédulos.

Em Le philosophe ignorant (1766) Voltaire destrói a filosofia cartesiana ao tratar da incredulidade: "Aristote commence par dire que l'incrédulité est la source de la sagesse; Descartes a délayé cette pensée, et tous deux m'ont appris à ne rien croire de ce qu'ils me disent. Ce Descartes, surtout, après avoir fait semblant de douter, parle d'un ton si affirmatif de ce qu'il n'entend point [...] (VOLTAIRE, 1879: 50, Tome XXVI)." Não por outra razão, Voltaire recebeu atributos de maître, apôtre e de le plus ardent propagateur de l'incredulité.

Machado, de ordinário, atém-se às "coisas miúdas", negligencia o atentado a bomba no Rio de Janeiro e coloca em discussão a revisão de um artigo que em sua opinião não merecia tal correção. Explica-se: a frase atribuída ao senador Leite e Oiticica, devido a uma falha de revisão, guardou intacta parte do intertexto, destoando do contexto em que fora inserida. Para o cronista a alteração providenciada pelo conselheiro Ângelo do Amaral, destituía o artigo de seu intuito principal: a incredulidade, e a recorrência a Voltaire não faz nada mais que restituir a incredulidade ao projeto de saneamento das finanças criticado pelo senador Leite e Oiticica.

$\mathrm{O}$ verso de Malherbe ${ }^{173}$ (proposto pelo senador) em cuja essência destaca-se a efemeridade e Voltaire (proposto pelo cronista) como modelo representativo da incredulidade, uma vez justapostos, não só reiteram a ideia de que o projeto realmente

\footnotetext{
173 Trata-se do verso "Et, rose, elle a vécu ce qui vivent les roses,/ L'espace d'un matin.”, extraído do poema Consolation à Cléophon (1592) de François de Malherbe.
} 
oferece motivos para ser desacreditado como também, traz à baila a descrença do cronista na dita empreitada.

Assim, ao longo da circulação literária, vêm à luz Malherbe e Voltaire, já agora na condição de clichês. É certo que o clichê é uma faca de dois gumes: muitas vezes, isolado, ou como parte de um agrupamento de expressões lugares-comuns, vazias de sentido, acaba por empobrecer o texto; no entanto, malgrado a repetição abusiva que pode fazê-lo se desgastar e se afastar da ideia original em que foi concebido, muitas vezes o clichê literário enriquece, dá expressividade ao texto e, sobretudo, contribui para sua compreensão. Usual nas crônicas machadianas, esse mecanismo surge em sua escrita como plena ferramenta intertextual.

Desse modo, a incredulidade de Voltaire e a rosa de Malherbe surgem como duas marcas francesas que servem de mote ao cronista, qual seja, dar suporte e apoio a digressões e impressões várias. No mais, esta é uma das funções do elemento estrangeiro: dar ao texto novo a possibilidade de crescer, se desenvolver. Assim, ao mesmo tempo em que atua na cultura literária, funciona como componente desencadeador do trabalho discursivo.

\section{O riso}

Nas muitas vezes em que Machado voltou-se para Voltaire, não só buscou entrechos de obras, princípios teóricos, ideias e aspectos de seu caráter e atuação, mas também o riso. Mas por que o riso, uma vez que desde os clássicos essa característica humana despertou, no mundo ocidental, certa cautela no trato social? Aristóteles em sua Poética (cap. 5) ao tratar do risível, justapõe tragédia e comédia, e afirma que esta última seria a imitação de "homens inferiores". Cícero, em De Oratore (Livro II), assegura que convém a um orador provocar o riso para angariar simpatia: dito assim, de qual ordem seria o riso de Voltaire?

O riso voltairiano era o riso da razão, filosófico, que muitos viam como incrédulo e demolidor, mas que, de fato, espantava a ignorância e o fanatismo incrustados no seio dos homens. Era também o riso que os convidava às Lumières, à felicidade, à prosperidade e ao progresso das ideias. 


\section{Em 30/5/1878, por ocasião do centenário de Voltaire, Victor Hugo discursa no} Théâtre de la Gaité ${ }^{174}$ e em seu célebre discurso menciona o riso ${ }^{175}$ de Voltaire:

[...] Il a vaincu la violence par le sourire, le despotisme par le sarcasme, l'infaillibilité par l'ironie, l'opiniâtreté par la persévérance, l'ignorance par la vérité.

Je viens de prononcer ce mot, le sourire, je m'y arrête. Le sourire, c'est Voltaire.

Disons-le, messieurs, car l'apaisement est le grand côté du philosophe, dans Voltaire l'équilibre finit toujours par se rétablir. Quelle que soit sa juste colère, elle passe, et le Voltaire irrité fait toujours place au Voltaire calmé. Alors, dans cet oeil profond, le sourire apparaît.

Ce sourire, c'est la sagesse. Ce sourire, je le répète, c'est Voltaire. Ce sourire va parfois jusqu'au rire, mais la tristesse philosophique le tempère. Du côté des forts, ils est moqueur; du côté des faibles, il est caressant. Il inquiète l'oppresseur et rassure l'opprimé. Contre les grands, la raillerie ; pour les petits, la pitié. Ah! soyons émus de ce sourire. Il a eu des clartés d'aurore. Il a iluminé le vrai, le juste, le bon, et ce qu'il y a d'honnête dans l'utile ; il a éclairé l'intérieur des superstitions ; ces laideurs sont bonnes à voir, il les a montrées. Étant lumineux, il a été fécond. La société nouvelle, le désir d'égalité et de concession et ce commencement de fraternité qui s'appelle la tolérance, la bonne volonté réciproque, la mise en proportion des hommes et des droits, la raison reconnue loi suprême, l'effacement des préjugés et des partis pris, la sérénité des âmes, l'esprit d'indulgence et de pardon, l'harmonie, la paix, voilà ce qui est sorti de ce grand sourire.

Le jour, prochain sans nul doute, où sera reconnue l'indentité de la sagesse et de la clémence, le jour où l'amnistie sera proclamée, je l'affirme, là-haut, dans les étoiles, Voltaire sourira. (Triple salve d'applaudissements. Cris: Vive l'amnistie!)

Messieurs, Il y a entre deux serviteurs de l'humanité qui ont apparu à dix-huit cents ans d'intervalle un rapport mystérieux.

Combattre le pharisaïsme, démasquer l'imposture, terraser les tyrannies, les usurpations, les préjugés, les mensonges, les superstitions, démolir le temple, quitte à le rebâtir, c'est à dire à remplacer le faux par le vrai, attaquer la magistrature féroce, attaquer le sacerdoce sanguinaire, prendre un fouet et chasser les vendeurs du sanctuaire, réclamer l'héritage des déshérités, protéger les faibles, les pauvres, les

\footnotetext{
174 Discurso intitulado Le Centenaire de Voltaire. Disponível no "site": www.voltaireintegral.com/Html/01/17Hugo.html. Acesso em 28/7/2009.

${ }^{175}$ Embora muitos autores estabeleçam nuances de significado entre as palavras "rire" e "sourire", aqui são entendidas como sinônimos. O riso normalmente é visto como a principal característica do ser humano a exprimir o prazer e a alegria, enquanto o sorriso, de gradação menos intensa, psicologicamente, envolveria outras emoções e denunciaria também a intensidade gradual de nossa dimensão espiritual.
} 
souffrants, les accablés, lutter pour les persécutés et les opprimés ; c'est la guerre de Jésus-Christ ; et quel est l'homme qui fait cette guerre ? c'est Voltaire. (Bravos)

L'oeuvre évangélique a pour complément l'oeuvre philosophique ; l'esprit de mansuétude a commencé, l'esprit de tolérance a continué ; disons-le avec un sentiment de respect profond, Jésus a pleuré, Voltaire a souri ; c'est de cette larme divine et de ce sourire humain qu'est faite la douceur de la civilisation actuelle. (Applaudissements prolongés.)

Voltaire a-t-il souri toujours? Non. Il s'est indigne souvent. Vous l'avez vu dans mes premières paroles. [...]

Victor Hugo vê sabedoria no sorriso de Voltaire, a sabedoria que reside e emana do próprio autor (“ce sourire, c'est la sagesse et ce sourire, c'est Voltaire”). Porém, não obstante certo cuidado ("un sentiment de respect profond"), o surpreendente em seu discurso é a relativização de Jesus Cristo. Ao fazê-lo, desqualifica completamente a querela patrocinada pela Igreja contra a filosofia, unindo-as em comum intenção: a busca da tolerância, respeito, justiça e liberdade para o bem estar do homem.

Os meios pelos quais esses objetivos foram perseguidos é que diferem: Jesus chorou pela paz, pelo perdão e pela indulgência dos pecados do homem, Voltaire fez o mesmo, porém, sorrindo. Desse modo, via Hugo, o homem anteriormente visto como o mais célebre dos ímpios e profeta da incredulidade é alçado à condição de divindade.

Entretanto, nem mesmo o riso de Voltaire recebeu tratamento unânime. Musset, poeta romântico, responsabiliza Voltaire pela Revolução Francesa e pelo que a ela se seguiu, ou seja, a irreligiosidade, o desespero, o desregramento, os crimes e o tédio que sobreveio à geração seguinte.

Em seu poema Rolla (1833), Musset plasma a impressionante imagem de um Voltaire morto no túmulo, ostentando o mesmo "sorriso repugnante" que exibira em vida (Dors-tu contente, Voltaire, et ton hideux sourire/ Voltige-t-il encor sur tes os décharnés?). Segue-se uma dura crítica ao filósofo, acusado de ter destruído a religião que ora desabava como um edifício enorme sobre as gerações posteriores. Rolla (personagem homônima ao poema) sofre as consequências das alegres destruições provocadas pelas Lumières, de modo a indiciar que a razão voltairiana não só era destruidora, mas também sorridente (MUSSET, 1963: 143-144, Tome I). No poema, essa mesma razão é acusada de dissecar minuciosamente objetos e sentimentos. 
De fato, Musset antecipa o que faria Victor Hugo anos depois, ao identificar e unir os dois opostos: Cristo e Voltaire. Explica-se: o poeta contrapõe um Voltaire morto, sorrindo e com os ossos descarnados (Rolla - parte IV) a um outro cadáver (Ta gloire est morte, ô Christ! Et sur nos croix d'ébène/Ton cadavre céleste en poussière est tombé ! - parte I) - o cadáver do Cristo dissecado -, atribuindo duplo sentido a mesma imagem que ora refere-se a Cristo, ora a Voltaire.

$\mathrm{Na}$ troca de cadáveres, inacreditavelmente, embora Musset condene Voltaire, quem morre é Cristo - transformado em poeira -; Voltaire, permanece, demolindo sobre nós o edifício imenso. Da questão religiosa envolvendo os três ícones franceses, o que resta de fato é a insistência de Voltaire e seu riso - ou sorriso - irradiando-se como intertexto ao longo da circulação literária. Machado, leitor de Hugo e Musset, não ficou indiferente a esta característica voltairiana, que emerge nas crônicas.

Tempos do papa! Tempos dos cardeais! Não falo do papa católico, nem dos cardeais da santa igreja romana, mas do nosso papa e dos nossos cardeais. F. Otaviano, então jornalista, foi quem achou aquelas designações para o senador Eusébio e o estado-maior do partido conservador. Era eu pouco mais que menino...

Fica entendido que, quando eu tratar de fatos ou pessoas antigas, estava sempre na infância, se é que seria nascido. [...] Realmente, os anos nada valem por si mesmos. A questão é saber agüentá-los, escová-los bem, todos os dias, para tirar a poeira da estrada, trazê-los lavados com água de higiene e sabão de filosofia.

Repito, era pouco mais que menino, mas já admirava aquêle escritor fino e sóbrio, destro no seu ofício. A atual mocidade não conheceu Otaviano; viu apenas um homem avelhantado e enfraquecido pela doença, com um resto pálido daquele riso que Voltaire lhe mandou do outro mundo. Nem resto, uma sombra de resto, talvez uma simples reminiscência deixada no cérebro das pessoas que o conheceram entre trinta e quarenta anos.

Nesta crônica ${ }^{176}$ cujo assunto gira em torno das eleições para o primeiro conselho municipal do Distrito Federal, o cronista mostra-se saudosista ao rememorar eleições e forças políticas de outrora. Com as lembranças, recorda o talento de Francisco Otaviano, desconhecido das novas gerações, e ao compará-lo a Voltaire, ressalta não só a estima que tem pelo jornalista, mas notabiliza sobretudo seu caráter crítico, ao destacar o riso como característica comum entre os dois homens.

176 “A Semana”, Gazeta de Notícias, 30/10/1892. 
Considerando-se que Machado era leitor de Musset, é provável que pela mente do narrador cruzasse lembranças literárias qual como o poema Rolla - já citado na introdução deste tópico. O léxico escolhido pelo cronista orienta-se nesta direção, vejase: primeiro, têm-se o papa e os cardeais, que remetem à religião, muito embora se trate de políticos; depois, o uso diário do sabão da filosofia condição sine qua non para que o homem possa suportar o passar dos anos; e, por fim, um resto de riso pálido de Voltaire a estampar no rosto de Otaviano.

A interpretação de que o intertexto surge na crônica via Musset se reforça, sobretudo pelo fato de que o cronista descreve o jornalista como "apenas um homem avelhantado e enfraquecido pela doença, com um resto pálido daquele riso que Voltaire lhe mandou de outro mundo". Ora, de pronto ecoa a dúvida que o poeta dirigira ao Voltaire d'além-túmulo: "Dors-tu content, Voltaire, et ton hideux sourire/ Voltige-t-til encor sur tes os décharnés?", que parece ser respondida pelo cronista ao ver no rosto pálido do jornalista a imposição da força e da lucidez do riso voltairiano. Ademais - e nessa lógica -, a palidez de Otaviano tem origem na de Voltaire, conforme sinaliza Musset: "Pour t'en aller tout seul promener ton front pâle...".

A escolha lexical que evoca Musset como o condutor do intertexto, por extensão, também recupera a doxa reproduzida pelo poeta, isto é, a censura ao filósofo, sob acusação de destruidor da religião e demolidor das crenças que sustentavam os homens, condenando-os a padecer dos males criados pelas Lumières; isto, sobretudo, como consequência da razão voltairiana, sorridente e destruidora, que contribuíra para deixar o homem livre, à mercê de sua razão, sem o amparo divino. Daí "papa" e outros.

Mas o riso de Voltaire já havia frequentado o folhetim: em $5 / 1 / 1888^{177}$, por ocasião da morte do jornalista Joaquim Serra, Machado publica uma espécie de crônica em que destaca as qualidades do amigo.

Quando há dias fui enterrar o meu querido Serra, vi que naquele féretro ia também uma parte da minha juventude. Logo de manhã relembrei-a toda. Enquanto a vida chamava ao combate diurno todas as suas legiões infinitas, tão alegre e indiferente, como se não acabasse de perder na véspera um dos mais robustos legionários, recolhi-me às memórias de outro tempo, fui reler algumas cartas do meu amado amigo. [...]

${ }^{177}$ Gazeta de Notícias. 
Era modesto até à reclusão absoluta. Suas idéias saíam todas endossadas por pseudônimos. Eram como moedas de ouro, sem efígie, com o próprio e único valor do metal. Daí o fenômeno observado ainda este ano. Quando chegou o dia da vitória abolicionista, todos os seus valentes companheiros de batalha citaram gloriosamente o nome de Joaquim Serra entre os discípulos da primeira hora, entre os mais estrênuos, fortes e devotados; mas a multidão não o repetiu não o conhecia. Ela, que nunca desaprendeu de aclamar e agradecer os benefícios, não sabia nada do homem que, no momento em que a nação inteira celebrava o grande ato, recolhia-se satisfeito ao seio da família. Tendo ajudado a soletrar a liberdade, Joaquim Serra ia continuar a ler o amor aos que lhe ensinavam todos os dias a consolação.

Mas eu vou além. Creio que Joaquim Serra era principalmente um artista. Amava a justiça e a liberdade, pela razão de amar também o arquitrave e a coluna, por uma necessidade de estética social. Onde outros podiam ver artigos de programa, intuitos partidários, revolução econômica, Joaquim Serra via uma retificação e um complemento; e, porque era bom e punha em tudo a sua alma inteira, pugnou pela correção da ordem pública, cheio daquela tenacidade silenciosa, se assim se pode dizer, de um escritor de todos os dias, intrépido e generoso, sem pavor e sem reproche.

Não importa, pois, que os destinos políticos de Joaquim Serra hajam desmentido dos seus méritos pessoais. A história destes últimos anos lhe dará um couto luminoso. Outrossim, recolherá mais de uma amostra daquele estilo tão dele, feito de simplicidade, e sagacidade, correntio, franco, fácil, jovial, sem afetação nem reticências. Não era o humour de Swift, que não sorri, sequer. Ao contrário, o nosso querido morto ria largamente, ria como Voltaire, com a mesma graça transparente e fina, e sem o fel de umas frases nem a vingança cruel de outras, que compõem a ironia do velho filósofo.

Sob o impacto da perda do amigo, numa prosa elegíaca o cronista ressalta o espírito vivaz de Joaquim Serra, seu amor à justiça e à liberdade, sua tenacidade de apóstolo. A multiplicidade de gêneros aos quais se dedicou durante sua vida de jornalista, ganha nova dimensão à menção de Voltaire no parágrafo em que Machado o associa ao gênio francês. Entretanto, Joaquim Serra não atinge a estatura de Voltaire, algo que o cronista esclarece em dois momentos: primeiro, ao afirmar ser a tenacidade de Serra "silenciosa", malgrado ter sido ele "um escritor de todos os dias, intrépido e generoso, sem pavor e sem reproche".

Ora, é sabido que os escritos de Voltaire produziam verdadeiras explosões; uma vez publicada uma crítica, um artigo, um libelo, em qualquer gazeta, sucedia-se uma enormidade de réplicas de seus adversários. Foi assim, por exemplo, com a Lettre au 
Docteur Jean-Jacques Pansophe (1766) e a Épître à l'auteur du livre des Trois Imposteurs (1769). O segundo momento fica por conta do riso de Voltaire: "O nosso querido morto ria largamente, ria como Voltaire." Impossível aqui não ouvir os ecos de Musset com seu "Dors-tu content, Voltaire, et ton hideux sourire/ Voltige-t-il encor sur tes os décharnés?" Entretanto, o riso relembrado de Serra, embora "com a mesma graça transparente e fina", padecia "do fel, da vingança cruel e da ironia do velho filósofo".

Essas características que o cronista sinaliza ausentes no riso gracioso de Serra são exatamente aquelas evocadas por Musset ao longo do poema e reunidas na expressão "hideux sourire" (de Voltaire), portanto, indiciadas como marcas indeléveis do escritor francês. Não por outra razão, por essas mesmas características foi Voltaire temido enquanto vivo e, na voz de Musset, odiado post mortem. Machado, por sua vez, recorre à figura tutelar de Voltaire para destacar as qualidades humanitárias de Joaquim Serra, este, também sorridente, porém, dono de um sorriso manso e nada repugnante. No mais, vale ressaltar o fato de que Voltaire representa não apenas a filosofia das Lumières, mas também certa atitude diante da vida: rir para atacar, provocar o riso para convencer. No texto, minimizada, essa atitude adere à imagem de Serra.

\section{5. À guisa de conclusão}

Certo, de ordinário Machado recorria à tradição, contudo, em face da vultosa obra voltairiana, Machado se vê frente a verdadeiro embarras de richesse e vai além das obras experimentadas ao longo da circulação literária. Vie de Molière (1739), por exemplo, hoje sequer poderia ser associada ao nome de Voltaire, e é de se crer que também não o fora à época de Machado, já que não há qualquer registro de tradução, algo visto como possível indicador de popularidade da obra. Nota-se, portanto, que a escolha não obedeceu ao binômio obra-prima/autor, a exemplo do que ocorre com Carmen (1847), de Mérimée, ou La Dame aux camélias (1848), de Dumas, mas recaiu sobre uma obra de valor menor e raramente lembrada quando se trata da fortuna crítica do autor.

Desse modo, presentes nas crônicas machadianas estão o teatro com Vie de Molière, Charlot ou la Comtesse de Givry (1767) e L'enfant prodigue (1736); a história com Le Siècle de Louis XIV (1751); a filosofia com Dictionnaire Philosophique (1764); 
a crítica poética com Essai sur la poésie épique (1733); a correspondência com Lettre au docteur Jean-Jacques Pansophe e Lettre à Louis-François du Plessis, Duc de Richelieu (1771), além do romance Candide (1759), a mais popular das obras.

Candide ou L'Optimisme, obra de eleição machadiana, difere dos textos citados acima. O mais célebre dos contos de Voltaire, modelo de sátira e ironia, instrumento de ridicularização da ignorância e da hipocrisia é submetido à rigorosa têmpera do cronista e surge nas crônicas fomentando reflexões, distendendo o gênero e atuando como operador de sentidos. Desse modo, os princípios deterministas e finalistas invadem o espaço lúdico, prazeroso e ridente do folhetim.

Enfim, vale ressaltar o universo jornalístico comum aos dois autores, fronte a partir do qual disseminavam conhecimento e combatiam a ignorância. As crônicas machadianas tiveram no jornal seu veículo de publicidade. Nelas, nosso cronista contou histórias, relatou fatos e opiniões e, nas entrelinhas, desconfiou, duvidou, revelou o que se escondia e publicou sua opinião.

Voltaire, já à sua época, foi inovador e num lance moderno preconizou a publicidade como arma capaz de aniquilar o obscurantismo, a superstição, o fanatismo e a intolerância. Muito do que escreveu foi publicado em jornal, levando-o a manipular já naquela época elemento ainda de central importância na imprensa moderna: a informação. Esta, como ingrediente de sua produção literária, elevou-o à condição de jornalista respeitado em seu tempo. Porém, à época de Machado, as polêmicas religiosas já não eram tão ruidosas e as ideias difundidas pelas Lumières já haviam sido discutidas e interpretadas à exaustão, razão pela qual Voltaire resistiu, sobretudo, como referência cultural.

Portanto, dois séculos - e seus problemas - dialogam, em países diferentes, mas irmanados pela cultura literária. O Brasil e a França se encontram na lembrança voltairiana presente na crônica de um autor atento não só ao fato bruto, mas à possibilidade de expressão do mesmo por meio do recurso ao maior polemista do século anterior.

Voltaire, sob a forma de clichê ou por meio de textos relativamente esquecidos, ajuda a compreender nossa realidade e a lhe dar um caráter mais abrangente, graças ao trabalho incansável de um cronista que busca sincronizar as sugestões do autor francês ao nosso Brasil. 


\section{ROUSSEAU}

\section{1. "Cinco odaliscas... Oh! meu doce leite romântico!"}

As crônicas machadianas figuram como extratos textuais representativos, "símbolos" através dos quais a notícia, via-de-regra, é interpretada a partir de um filtro artístico. $\mathrm{O}$ intertexto, na maioria dos casos, é a chave para se chegar a essa compreensão, uma vez que esses relatos são lugares de fusão, das pulsões entre o real e a ficção. Diante disso, vale recuperar não só o que de real foi submetido à ficção, mas sondar em que medida a presença de Rousseau revela sentidos (ocultos) nas entrelinhas.

A crônica, por se tratar de um gênero congênito ao circunstancial, propicia leitura pendular "obrigando" o leitor a se deslocar de modo intermitente do texto ao fato, condição, na maioria das vezes, necessária para seu amplo entendimento. Contudo, sempre que o relato encontra seus argumentos em outro texto a contraposição se faz texto a texto, confluência que favorece não só o entendimento da relação entre si, mas também entre gêneros e movimentos literários, facultando, assim, o estudo de influxos cujas significações se modificam através das sucessivas gerações de leitores.

Circunscrevendo a observação às crônicas machadianas, não se pode deixar de questionar em que medida a assertiva sustenta a reflexão desse gênero marcado pela polifonia, cujos extratos não só primam pela paródia, noção fundamental para a intertextualidade, como promovem um constante ir e vir do texto a outros textos do sistema literário.

Nessa lógica (e sob viés diacrônico) a crônica publicada em 1/7/1876 ${ }^{178}$ é mais bem compreendida se cotejada a um texto escrito 16 anos depois, quando sentido e leitura se atualizam em fluxo reverso. A exemplo de inúmeras outras vezes, em 25/12/1892, um telegrama dispara a memória literária do cronista, confirmando a presença de um arrière-texte que "procède, non de la théorie pure, mais de l'intuition d'écrivains nourris de deux cultures" (TROUVÉ, 2010: 7).

No cotejo entre o telegrama (de linguagem jornalística ordinária) e a crônica (impregnada de literariedade) é flagrante um processo de escrita que se constrói sob duas vertentes: a autoral e de leitura (leitoral), algo que materializa no texto uma rede de

178 "História de Quinze Dias", Illustração Brazileira. 
associações e se plasma enquanto fenômeno literário, nutrindo-se também das relações e afinidades que mantém com a realidade exterior ao texto. Veja-se o telegrama publicado na segunda-feira, 19/12/1892, n'O Paiz

Constantinopla, 18.

[...] - Cinco odaliscas do serralho do sultão da Turquia, que lhe haviam sido enviadas pelo rei do Egypto, foram envenenadas por suas companheiras, instigadas por ciumes dos eunucos.

As criminosas foram submetidas aos mais atrozes e barbaros tormentos.

e o texto machadiano:

"Cinco odaliscas..." Parei; lidas essas primeiras palavras, senti-me necessitado de tomar fôlego. Cinco odaliscas! Murmura esse nome, leitor: faze escorrer da boca essas quatro sílabas de mel, e lambe depois os beiços, ladrão. Pela minha parte, achei-me, em espírito, diante de cinco mulheres, com o véu transparente no rosto, as calças largas e os pés metidos nas chinelas de marroquim amarelo, babuchas, que é o próprio nome. Todas as orientais de Hugo vieram chover sobre mim as rimas de ouro e sândalo. Cinco odaliscas! Mas que é que fizeram essas cinco odaliscas? Não fizeram nada. Tinham sido mandadas de presente ao sultão. Pobres moças! Entraram no harém, lá estiveram não sei quanto tempo, até que foram assassinadas... Sim, leitor compassivo, assassinadas por mando das outras mulheres que já lá estavam, e por ciúmes...

Não, aqui é força interromper o capítulo, por um instante. Não continuo sem advertir que o ano é bissexto, ano de espantos. Míseras odaliscas! Assassinadas por ciúmes, não do sultão, que tem mais que fazer com o grande urso eslavo, por ciúmes dos eunucos. Singulares eunucos! Eunucos de ano bissexto! ${ }^{179}$ Todo o harém posto em ódio, em tumulto, em sangue, por causa de meia dúzia de guardas, que o sultão tinha o direito de supor fiéis ao trono e à cirurgia! ${ }^{180}$

À menção de odaliscas, nota-se um enunciador extasiado, às voltas com o lirismo de um mundo imaginário, lúdico e voluptuoso, cantado ao longo dos séculos por viajantes, exploradores, artistas e escritores. O êxtase do cronista não só atesta a perene polarização entre os mundos oriental e ocidental, como revela algo de seu pecúlio

\footnotetext{
179 Parecia ser senso comum atribuir ao ano bissexto a ocorrência de desgraças. Ao noticiar atropelamentos, o Diário do Rio de Janeiro (11/6/1876, p. 2) comenta: "Desgraças não faltam. O anno vai máo, e bem parece bissexto."

180 "A Semana", Gazeta de Notícias, 25/12/1892.
} 
literário $^{181}$, o "doce leite romântico". O curto trecho da crônica remete à evolução do gênero: o leitor, provocado em sua libido, uma vez lambendo os beiços, é tomado por "ladrão". O enunciador, na condição de herói romântico, tampouco chega a tocar sua(s) musa(s), e assim ilustra-se a primeira geração de românticos, quando a mulher era amada, desejada, porém, quase nunca tocada.

Logo, acha-se o cronista diante das cinco lindas mulheres. Se o "véu transparente no rosto" por um lado provoca a libido, por outro o distancia das odaliscas, impedindo sua "felicidade" na escrita. Contudo, antes que o ciúme e as intrigas de bastidores instalem certo gosto de morte, a memória o transporta para as rimas de Les Orientales (1829) e o cheiro de sândalo invade seus sentidos.

O que hoje talvez exija certa erudição, à época não oferecia qualquer dificuldade ao leitor machadiano: associações verbais, sensoriais, cognitivas e, sobretudo, literárias, de pronto deslocavam-no para o universo dos haréns. A alteridade que se instala entre a crueza da notícia e a dimensão lírica da crônica redireciona a leitura. $\mathrm{O}$ caráter singular do "barro humano" (intrigas, ciúmes, traição, morte, etc.) contraposto ao universo das Orientales $^{182}$ ganha relevo e se inscreve em esfera puramente literária. A notícia, destituída de seu traço informativo, é lida como ficção.

Certo que a técnica do cronista é simples, mas produz efeitos: inserir esteticamente elementos exóticos comuns ao romantismo (odaliscas, sultão, harém, eunucos) ${ }^{183}$, ainda latentes no imaginário de seu leitor, não só faculta a transposição fato/escrita literária, como afasta o prosaísmo da notícia. Aliás, algo anunciado por Machado logo no início da crônica, quando manifesta seus ímpetos românticos:

\footnotetext{
${ }^{181}$ Como exemplo, vale lembrar que esse pecúlio constitui-se da tradução d'As Mil e uma Noites, Les Lettres persanes, Les Bijoux indiscrets, Zaïre e muitos outros contos de Voltaire, todos do século XVIII.

${ }^{182}$ Veja-se, no caso, os poemas III (Les têtes du sérail), IX (La captive) e X (Clair de Lune) cujo mote é a violência nos haréns (Du sang... c'est le sérail! - p. 65; Ses eunuques impurs, ses muets homicides - p. 69) e o sujeito lírico, uma cativa ( $\mathrm{Si} \mathrm{je} \mathrm{n'étais} \mathrm{pas} \mathrm{captive} \mathrm{-} \mathrm{p.} \mathrm{121)} \mathrm{no} \mathrm{espaço} \mathrm{fechado} \mathrm{e} \mathrm{vigiado} \mathrm{dos} \mathrm{haréns} \mathrm{(} \mathrm{Si}$ le long du mur sombre/ N'étincelait dans l'ombre/ le sabre des spahis - p. 121). Aos leitores machadianos é provável que a crônica também os remetesse ao sultão Ali-Pacha, célebre, à época, pelo afogamento de 12 mulheres em seu harém, algo retomado por Byron (Le Giaour) e Dumas (Les Crimes célèbres).

$183 \mathrm{O}$ exotismo é elevado aos seus mais altos níveis à época do Romantismo, resultado, sobretudo, da profusão de histórias que provinham de todas as partes do mundo e alimentavam o imaginário europeu. Sobre isso ver: Le Romantisme dans la littérature europeénne (VAN TIEGHEM, 1969: 258-263). Ressalta-se, inclusive, que muitas dessas figuras não são exclusivas do movimento romântico, mas estão presentes no orientalismo e na natureza. Veja-se, por exemplo, os contos de Voltaire e as grandes discussões à época das Lumières que versavam sobre a natureza (sobretudo Buffon e Maupertuis, com seu Essai sur la formation des corps organisés).
} 
É desenganar. Gente que mamou leite romântico pode meter o dente no rosbife naturalista; mas em lhe cheirando a teta gótica e oriental, deixa o melhor pedaço de carne para correr à bebida da infância. Oh! Meu doce leite romântico! Meu licor de Granada!

Assim, da mesma forma que a poesia se inscreve na realidade mais prosaica e determinados poetas a concebem como evasão a mundos desconhecidos, Machado a utiliza como constituinte na transformação da linguagem "inexpressiva" que sustenta a contingência da notícia e se perpetuará na ficção. Logo, compreende-se a referência à poesia na crônica de 1/7/1876.

\section{2. "O Oriente acabou e com ele a poesia"}

Dou começo à crônica no momento em que o Oriente se esboroa e a poesia parece expirar às mãos grossas do vulgacho. Pobre Oriente! Mísera poesia!

Um profeta surgiu em uma tribo árabe, fundou uma religião, e lançou as bases de um Império; Império e religião têm uma só doutrina, uma só, mas forte como o granito, implacável como a cimitarra, infalível como o Alcorão.

Passam os séculos, os homens, as repúblicas, as paixões; a história faz-se dia por dia, folha a folha; as obras humanas alteram-se, corrompem-se, modificam-se, transformam-se. Toda a superfície civilizada da terra é um vasto renascer de coisas e idéias. Só a idéia muçulmana estava de pé; a política do Alcorão vivia com os paxás, o harém, a cimitarra e o resto.

Um dia, meia dúzia de rapazes libertinos iscados de João Jacques e de Benjamim Constant, ainda quentes do último discurso de Gladstone ou do mais recente artigo do Courrier de l'Europe ${ }^{184}$; meia dúzia de rapazes, digo eu, resolveram dar com o monumento bizantino em terra, abrir o ventre ao fatalismo e arrancar de lá uma carta constitucional.

Pelas barbas do Profeta! Há nada menos maometano do que isto? Abdul-Aziz, o último sultão ortodoxo, quis resistir ao 89 turco; mas não tinha sequer o exército, e caiu; e, uma vez caído, deitou-se da janela da vida à rua da eternidade.

\footnotetext{
${ }^{184}$ Fundado na Inglaterra, em 1776, por Swinton, editor inglês, e Serre de Latour, refugiado francês, era um periódico popular especializado em política destinado aos públicos inglês e francês. Redigido por Brissot Warville, le comte de Montbasier e Morande Théveneau, desde sua aparição enfrentou problemas com os governos dos respectivos países. Popular entre os leitores por sua liberdade de expressão, na Europa atingiu a marca 50.000 assinantes, sendo 4.000 deles na corte de Versailles. Foi suprimido pelos Montagnards em 13 de maio de 1793 (foi editado em Londres, Bologne-sur-Mer e Paris), mas o título foi retomado pela folha monarquista Messager du Soir durante o ano V. Desapareceu definitivamente em 1811.
} 
O Alcorão fala de dois anjos negros de olhos azuis, que descem a interrogar os mortos. O ex-padixá foi naturalmente inquirido como os outros:

— Quem é teu senhor?

- Alá.

— Tua religião?

- Islã.

- Teu profeta?

- Maomé.

— Há um só deus e um só profeta?

— Um só. La illah il Allah, ve Muhameden ressul Allah. ${ }^{185}$

— Perfeito. Acompanha-nos.

O pobre sultão obedeceu.

Chegando à porta das delícias eternas achou o profeta sentado em coxins espirituais, resguardado por um guarda-sol metafísico.

— Que vens cá fazer? - perguntou ele.

Abdul explicou-se, referiu o seu infortúnio; mas o profeta atalhou-o, clamando:

— Cala-te! És mais do que isso, és o destruidor da lei, o inimigo do Islã. Tu fizeste possível o gérmen corruptor das minhas grandes instituições, pior que a fé de Cristo, pior que a inveja dos russos, pior que a neve dos tempos; tu fizeste o gérmen constitucional. A Turquia vai ter uma câmara, um ministério responsável, uma eleição, uma tribuna, interpelações, crises, orçamentos, discussões, a lepra toda do parlamentarismo e do constitucionalismo. Ah! quem me dera $\operatorname{Omar}^{186}$ ! ah! quem me dera Omar!

Naturalmente Abdul, se o profeta chorou naquele ponto, ofereceu-lhe o seu lenço de assoar - o mesmo que na mitologia do serralho substitui as setas de Cupido; ofereceu-lho, mas é provável que o profeta lhe desse em troco o mais divino dos pontapés. Se assim foi, Abdul desceu de novo à terra, e há de estar aí por algum canto...

Talvez aqui na cidade.

Se cá viesse, é possível que a vista de alguns becos e certa quantidade de cães lhe fizessem crer que voltara a Constantinopla; ilusão que aumentaria se ouvisse falar no divã em que estou sentado e em várias mesquitas do meu conhecimento.

Mas o que eu apuro de tudo o que nos vem pelo cabo submarino e vapores transatlânticos é que o Oriente acabou e com ele a poesia.

Só a abolição do serralho é uma das revoluções maiores do século. Aquele bazar de belezas de toda a casta e origem, umas baixinhas, outras altas, as loiras ao pé

\footnotetext{
${ }^{185}$ La ilaha ila Allah, Mohamed rassoul Allah. = Não há Deus senão Alá, e Maomé é mensageiro de Deus.

${ }^{186}$ Provável referência a Omar ibn al-Kathâbb (c. 584-644), ou Omar I, companheiro e amigo de Maomé, foi o segundo e mais influente dos califas muçulmanos.
} 
das morenas, os olhos negros a conversar os olhos azuis, e os cetins, os damascos, as escumilhas, os narguilés, os eunucos...

Oh! sobretudo os eunucos! Tudo isso é poesia que o vento do parlamentarismo dissolveu em um minuto de cólera e num acesso de eloqüência.

Vão-se os deuses e com eles as instituições. Dá vontade de exclamar com certo cardeal: Il mondo casca! ${ }^{187}$

O oriente surge como fonte de inspiração poética e é objeto da primeira parte dessa conversa quinzenal com o leitor da Illustração Brazileira. O universo semânticolexical move-se em torno do exótico, assim como na crônica ulterior, privilegiando, inclusive, o mesmo espaço geográfico (Turquia, Constantinopla). Cotejando ${ }^{188}$, nota-se que esses registros machadianos permitem leitura em série ${ }^{189}$; e o fato de um texto posterior contribuir para o entendimento de um outro escrito anos antes, revela algo de sua constituição intertextual, ou seja, um "sistema" que escapa à lógica causal (de linearidade temporal). Assim, cada novo texto adicionado a esse "sistema" não é simplesmente resultado de seus precedentes porque ora ele é passado ora é futuro (se é que essas noções em si de fato ainda agregam sentido à experiência intertextual).

Nessa lógica, sob indiferença da linearidade, às Orientales (e Hugo), explícitas em 1892, destinaram-se as entrelinhas. Desorganizadas em sua cronologia, as crônicas estabelecem correspondência entre si e facilitam a compreensão, sobretudo ao leitor culto machadiano, fornecendo-lhe pistas para interpretar os intertextos absorvidos pela escritura. No caso, identificar e certificar-se de que a "mísera poesia" que expira "às mãos grossas do vulgacho" é a romântica, requer leitura pendular e recomposição dos textos (dialogismo).

Num rasgo de pura galhofa, próprio de seus textos plenos de verve e fantasia, o cronista, ironicamente, coloca lado a lado Rousseau e Benjamin Constant. Pura provocação. Crítico tenaz do autor do Contrat social (1762), Constant afirma que a obra "si souvent invoqué en faveur de la liberté" transformou-se no "le plus terrible auxiliaire

\footnotetext{
${ }^{187}$ Dito do Cardeal Antonelli, que Machado retoma na crônica de 24/12/1883 - "Balas de Estalo".

188 "História de Quinze Dias", Illustração Brazileira, 1/7/1876 e "A Semana", Gazeta de Notícias, 25/12/1892.

${ }^{189}$ Em 1/9/1876 (“Histórias de Quinze Dias”, Illustração Brazileira), Machado voltaria a comentar a instabilidade política da Turquia e o risco de deposição do novo sultão (Mourad V), quando anuncia o fracasso do projeto de Constituição "por fortuna do Alcorão".
} 
de tous les genres de despotisme" (1957: 1105). ${ }^{190}$ Sem que essa polêmica ganhe ressonância maior na esfera do folhetim, uma vez mais o humor crítico machadiano, comumente direcionado a costumes políticos e sociais, funda lastro na esfera das ideias, irmanando os dois adversários em torno de um juízo comum.

Desse modo, tornam-se partidários e libertinos. Numa retomada a Starobinski, o chiste lembra Voltaire com seu "fusil à deux coups", pois tanto um quanto o outro persistem como adversários e são ridicularizados pelo cronista. Rousseau, que em vida afirmara preferir ser canalha a libertino (veja item 3) é relativizado a ponto de não se ajustar a nenhuma das duas categorias. Ao ser chamado por João Jacques é apequenado, perde a identidade e, aclimatado, continua a vaguear como fizera em vida. Se antes, oscilara entre a Suiça e a França, na crônica vê-se destituído dos atributos que o elegem como referência (embora o seja), passa a um João qualquer (tal a ocorrência do nome), de maneira que Jacques, justaposto a João, longe de acrescentar algo, confirma a despersonalização, anonimizando-o.

Constant, se não padece com o anonimato, é submetido a uma hipertrofia irônica, humor que ganha ressonância à medida que se invertem os polos, qual seja, republicano, liberal, e envolvido (ou simpatizante) em dois golpes de estado durante a Revolução (18 fructidor an $V$ e 18 Brumaire); justaposto a Rousseau, emerge conservador, como provável lembrança do cronista ao fato de que, sob a Revolução de Juillet, apoiou a coroação de Louis-Philippe ao trono francês. Nessa lógica, instala-se a chacota, uma vez que Constant pode ser tomado por conservador-libertino (no sentido vago atribuído à palavra "libertino" pelo cronista, permite-se inferir "liberal" por sinonímia de "libertino", donde um Constant conservador-liberal). E, de quebra, uma alfinetada nos liberais conservadores que povoavam o Império brasileiro.

De fato, ecos intertextuais ressoam e antes que surja João Jacques, certo rumor voltairiano se impõe, ainda que à força de especulação. "Tu viens donner la paix, et m'annoncer un dieu?" À pergunta de Zopire, Mahomet responde :

\footnotetext{
${ }^{190} \mathrm{O}$ entrecho é extraido do texto Principes de politique applicables à tous les gouvernements (1815). Constant afirma ainda: «Je ne connais aucun système de servitude qui ait consacré des erreurs plus funestes que l'éternelle métaphysique du Contrat social. » (CONSTANT, 1957: 1216). Sobre a questão ver também : «Benjamin critique de Jean-Jacques Rousseau », de Paul Hoffmann. In: Revue d'histoire littéraire de la France. $82^{\mathrm{e}}$ année, n ${ }^{\mathrm{o}} 1$ (Jan.-Fév. 1982), pp. 23-40. Paris : Presses Universitaires de France, 1982.
} 
Je ne ferais parler que le dieu qui m'inspire.

Le glaive et l'alcoran, dans mes sainglaintes mains,

Imposeraient silence au reste des humains. [...]

Vois quel est Mahomet : nous sommes seuls; écoute :

Je suis ambitieux ; tout homme l'est, sans doute ;

Mais jamais roi, pontife, ou chef, ou citoyen,

$\mathrm{Ne}$ conçut un projet aussi grand que le mien.

(Le Fanatisme, ou Mahomet le Prophète, 1742, Acte II, Scène 5)

Paródico e diminuto é o contraponto machadiano ao referir-se à teocracia muçulmana:

Um profeta surgiu em uma tribo árabe, fundou uma religião, e lançou as bases de um Império; Império e religião têm uma só doutrina, uma só, mas forte como o granito, implacável como a cimitarra, infalível como o Alcorão.

Destituída da célebre elocução "Era uma vez...", a deposição do sultão de Constantinopla surge em tom de fábula, contudo, a leveza aparente da narrativa ao mesmo tempo em que se acomoda à crônica, deixa pistas sob a fabulação: o vínculo religioso que tutela o estado exclui o direito à consciência individual à força da “cimitarra" e do "infalível Alcorão". Ora, a crítica embutida nos remete a Mahomet, onde o profeta é apresentado como um conquistador fanático, maquiavélico e cínico.

Os liames continuam e o contraponto entre o constante "renascer de coisas e idéias" na "superfície civilizada da terra" e o imobilismo do pensamento muçulmano, reproduz as transformações ocorridas no mundo das ideias, com Rousseau representando o movimento, o [re]começo de um novo tempo.

Não que Voltaire traduzisse o cansaço da tradição muçulmana, em absoluto, mas no mundo ocidental o deísta das Lumières simboliza o fim de uma era: "Avec Voltaire, c'est un monde qui finit. Avec Rousseau, c'en est un qui commence."191 E se o cronista reproduz parodicamente as críticas voltairianas ao profeta (e ao mundo) do Alcorão,

\footnotetext{
${ }^{191}$ A frase teria sido dita por Goethe. In: Une autre histoire de la littérature française. (D’ORMESSON, 1997: 75, Tome II).
} 
Rousseau é chamado à discussão, cercado por clichês ${ }^{192}$, perpetuando inclusive o lugarcomum que desde as origens associou o filósofo ao libertino.

\section{3. "Je devins polisson mais non un libertin." 193}

A crise que se opera na consciência europeia entre a Renascença e a Revolução Francesa é sem dúvida a mais importante já ocorrida na história do pensamento ocidental. Muito do que se considerou revolucionário entre os anos de 1760 e 1789, já era veiculado por volta dos anos de 1680 (HAZARD, 1961: 9). Nesse fim de século XVII, a França, sobretudo, presencia intensa transformação de modos e ideias. À palavra "filósofo" acrescentam-se nuances: os sentidos próprio e moral já não comportam as variações no vocabulário, e ao verbete a Academia Francesa incorpora: "Il se dit quelquefois absolument d'un homme qui, par libertinage d'esprit, se met audessus des devoirs et des obligations ordinaires de la vie civile [...]" (1762: 365), formalizando a conjunção dos termos libertino e filósofo.

Ora, ao buscar razões para a deposição do sultão de Constantinopla, Machado perpetua a união desses dois termos, afinal, os rapazes libertinos foram iscados (contaminados, contagiados) de João Jacques, induzindo o leitor a tomá-lo por libertino:

\footnotetext{
Um dia, meia dúzia de rapazes libertinos iscados de João Jacques e de Benjamim Constant, ainda quentes do último discurso de Gladstone ou do mais recente artigo do Courrier de l'Europe; meia dúzia de rapazes, digo eu, resolveram dar com o monumento bizantino em terra, abrir o ventre ao fatalismo e arrancar de lá uma carta constitucional.
}

Rousseau libertino? A questão, de fato, é se se pode atrelar tal aposto ao nome do filósofo, afinal, de qual libertino falava Machado? Em Le savoir vivre-libertin (2000: 13-14) M. Delon reflete sobre as transformações do termo:

\footnotetext{
${ }^{192}$ Machado cita o 89 turco, e segundo Catherine Golliau : « Mais non, tout n'est pas 'la faute à Voltaire', tout n'est pas la 'la faute à Rousseau' : ils n'ont pas inventé la Déclaration des droits de l'homme ; ils n'ont pas voulu la Révolution française (2010, nr. 26: 3). » Contudo, é inquestionável que suas ideias foram aproveitadas pela Revolução; a essa época, por exemplo, Du Contrat social (1762) e seu autor ficaram célebres.

193 (ROUSSEAU, 2011: 67).
} 
Terme de dénonciation et de rejet, le libertinage se caractérise le plus souvent de l'extérieur et les efforts pour distinguer des libertinages d'idées ou de moeurs des textes licencieux ou obscènes montrent qu'il s'agit moins d'une réalité fixe que d'une tension. Le libertin s'installe dans l'entre-deux, entre l'interdit et la transgression, entre la réalité et l'imaginaire. Il résiste à une loi dominante et, selon le lieu et le moment de son action, il peut être érudit ou séducteur, philosophe ou mondain.

Contudo, ao distender suas ideias, acrescenta:

Le libertinage peut donc être appréhendé comme un ensemble d'idées subversives ou un réseau de connivences, comme une thématique littéraire ou un style de vie.

Levando-se em conta a definição moral da Academia (“On appelle aussi philosophe, un homme sage, qui mène une vie tranquille et retirée, hors de l'embarras des affaires."), o style de vie e o caráter ${ }^{194}$ de Rousseau, é provável que rotulem-no libertino, porém, ao se referir aos rapazes libertinos, Machado envolve Benjamin Constant, o que de certa forma esclarece a questão.

$\mathrm{O}$ fato é que num primeiro momento as Lumières veem em Rousseau um libertário; depois, ora associam-no à Garde nationale ${ }^{195}$ ora tomam-no por apóstolo da igualdade, o que leva a burguesia progressista (1848) ligá-lo ao Terror e à guerra social. Porém, se a referência a Rousseau "s'inscrit dans une lignée qui mène à Robespierre, aux socialismes utopiques et au marxisme" (DELON, 2012: 9), isso se deve mais ao fato de correntes ideológicas terem-no como protótipo de caráter cívico e de combate particular, afinal, Rousseau, avesso à "sociabilité de cour" e aos salões parisienses, "ne cesse de nous mettre en garde contre une aliénation de soi sous la pression de la mode, de l'opinion commune, du qu'en-dira-t-on (TODOROV, 2006 :47).

Republicano engajado que apoiou dois golpes de Estado ${ }^{196}$, líder dos liberais e orador de destaque na Assembleia, Benjamin Constant ${ }^{197}$ auxilia na compreensão do

\footnotetext{
194 “Il est l'individualisme, la rébellion, la révolte. Et il est l'étatisme absolu, où le souverain est maître de biens, de la personne et même de la conscience. Il est la nature et la sincerité. Il est la contradiction et la dissimulation. Il est le talent et la folie.(D'ORMESSON, 1997: 89, Tome II)"

${ }^{195}$ À época da Revolução Francesa, nome atribuído a uma milícia de cidadãos formada em cada cidade, a exemplo da Garde nationale criada em Paris, e que atravessou vários regimes, sendo extinta somente em julho de 1871, logo após a Comuna.

${ }^{196} \mathrm{O}$ golpe de 18 de Fructidor (Ano V, 4 de Setembro de 1797), que ocorreu sob o Diretório, com o apoio do exército contra jacobinos e monarquistas (majoritários nos Conseil des Cinq-Cents e Conseil des Anciens) marca o fortalecimento do Executivo em detrimento do Legislativo, e o de 18 de Brumário (Ano
} 
"Rousseau libertino" na medida em que aparece como referência de autoridade, haja vista seu perfil ideológico e político. Associados à deposição do sultão de Constantinopla na condição de inspiradores do movimento, são relativizados, tomados por provocadores e responsabilizados pelas mudanças em curso no estático regime teocrático muçulmano, a despeito de Rousseau ter afirmado preferir ser "un polisson mais non un libertin" (2011: 67). Mas o movimento da crônica é outro e ...

\section{4. ... O Rio pode ser Constantinopla}

A exemplo da cena teatral em que um adereço, um figurino ou uma imagem projetada permitem a ilusão do deslocamento geográfico e temporal, assim, o leitor é induzido a mirar os olhos para o proscêncio, onde Rousseau e Constant, unidos pelo cronista (e responsabilizados pela demolição da poesia) contracenam como duas personagens tragicômicas sustentando um quadro irônico, cujas falas do diálogo foram suprimidas, mas que se mantém em razão da galhofa atribuída pelo enunciador às didascálias também inexistentes - estas -, por sinal, compreendidas e assimiladas pelo leitor.

Num movimento constante, entre uma cena e outra, bastidores e palco se confundem. O leitor/espectador toma então novo percurso e é levado pelo cronista a percorrer os becos cariocas frequentados por cães, acreditando estar em Constantinopla. No caminho, não só o risco de cruzar Abdul, que descera à terra depois dos divinos pontapés, mas, sobretudo, a desilusão de caminhar por uma cidade onde, assim como Constantinopla, não há mais poesia. Porém, ambas, Rio e Constantinopla existem, e produzem notícia.

\section{Na crônica: a notícia sob a fabulação}

Desde meados de junho de 1876, os jornais brasileiros publicam semanalmente sobre "a famosa questão do oriente" 198 , de maneira que Machado pôde acompanhar a evolução da crise turca, ainda que com um lapso de aproximadamente um mês: o envolvimento (e

VIII, 9 de novembro de 1799), protagonizado por Napoleão Bonaparte, põe fim ao Diretório e à Revolução Francesa e dá início do Consulado.

${ }^{197}$ Benjamin Constant de Rebecque (1767-1830).

${ }^{198}$ Diário do Rio de Janeiro, 17/6/1876. 
interesses) das grandes potências (Áustria e Rússia, acusadas de subvencionar os revoltosos), as críticas à Inglaterra, em face da negativa de intervir no conflito, o boato de uma sedição oficial, em que o sultão vendo-se forçado a ceder espaço político, provocara ele próprio sua condenação e o fato de serem os softas estudantes oriundos da "aristocracia" turca, tudo isso praticamente desaparece sob a têmpera machadiana.

Machado não só está ciente de que "na política não há imaginação, há lógica, e lógica de ferro", sanhuda" em matéria alheia, afinal, busca o congraçamento do leitor tão logo este salte da aridez política à crônica; e não é por outra razão que aprecia "ver a política entrar pela literatura; [pois esta] anima a literatura a entrar na política, e dessa troca de visitas é que saem as amizades. ${ }^{200}$ Desse modo, os estudantes revoltosos, representantes de uma facção do poder, perdem status e na condição de "rapazes libertinos" engrossam o coro do populacho a clamar por mudanças.

A crônica condensa, sobretudo, o que fora divulgado ao longo da quinzena anterior à sua publicação: "os dois anjos negros de olhos azuis, que descem a interrogar os mortos", extraídos do Alcorão ecoam em matéria publicada em 17/6/1876 ${ }^{201}$, que os evoca por terem combatido ao lado da sagrada bandeira. Desse modo o cronista traz à luz o fanatismo maometano - e o direito divino -, algo refutado por essa "meia-dúzia de rapazes libertinos iscados por João Jacques".

No entanto, ainda que em âmbito especulativo, $O$ Globo de $28 / 6 / 1876^{202}$ traz algo que esclarece a presença de Rousseau: o novo sultão (Mourad V), através de um halt imperial, declara que "subiu ao throno pela graça de Deus e vontade da nação". O fato de Constantinopla inserir em documento oficial a "vontade da nação" revela não só uma nova configuração política local, mas, sobretudo, a irradiação e as mudanças provocadas pelas Lumières em nações tradicionalmente totalitárias.

Ora, Machado, homem de imprensa, muito provavelmente não deixou de ler a edição de 24/6/1876 quando, em breve artigo ${ }^{203}$, seu autor critica o marasmo na política brasileira. O fato de o país estar "sans parlement", à espera de uma "loi nouvelle et

\footnotetext{
199 "Balas de Estalo", Gazeta de Notícias, 20/7/1884.

200 "A Semana", Gazeta de Notícias, 13/5/1894.

${ }^{201}$ Diário do Rio de Janeiro, p. 1. - coluna: EXTERIOR, Europa.

${ }^{202}$ Republica franceza (Carta do nosso correspondente), Pariz, 2 de Junho de 1876 (p. 2).

${ }^{203}$ O Globo; trata-se de matéria de primeira página, redigida em francês e não assinada, cujo título é "Revue pour l'extérieur". Na sequência, vem a coluna "Mala da Europa" tratando da questão turca.
} 
mixte, qui n'est qu'un prélude d'une réforme" compromete seu desenvolvimento, com sérios danos para as finanças e economia. “Qu'a-t-on fait?”, questiona o autor, antes de voltar-se contra a classe política, cujos interesses demoram-se nas "listes électorales".

Diante da paralisia institucionalizada pelo parlamento, os eleitores são conclamados a votar naqueles que representam "la force des choses", ou seja, candidatos comprometidos em inserir o país no grupo das "nations directrices", algo natural quando se tem "le gouvernement et l'assemblée éclairée par la voix même du peuple, aidés de leurs propres lumières". Não é por outra razão que o profeta externa toda sua decepção contra Abdul e sua inaptidão, que levou às mudanças na totalitarista Constantinopla.

Desse modo, através de uma escrita (e leitura) pendular, o cronista elabora sua crítica ao sistema parlamentarista brasileiro, e o leitor (trata-se aqui do leitor ideal machadiano, pleno de compreensão, que se movimenta da notícia à crônica e viceversa), estimulado por um senso perspicaz, constrói inflexões a partir do relato, ou seja, o texto (ou a percepção dele) figura como espelho, refletindo a notícia, já descaracterizada como tal. As prováveis distorções da imagem (do fato), longe de levar à incompreensão, encaminham-no a engendrar uma teia de conexões entre crônica, notícia e obras já lidas, o que leva a um estalo do texto, incorporando-lhe sentidos.

Machado não foge à regra e, afora os livros, os jornais, universo no qual estava inserido, incluem-se nessa fatura, demarcando seus passos de cronista-leitor. Nos periódicos da época, artes e espetáculos, intrigas políticas, a vida literária e mundana francesas, tudo está lá; o leitor carioca acompanha o desenredo de Constantinopla (que chega via Paris), lê tiradas de Mirabeau e, assim como Paris, excita-se com a visita do nababo indiano Mooktar de Hyderadab, emociona-se com o translado do corpo de Michelet e as mortes de Alphonse Esquiros e Georges Sand. Proudhon, Descartes, Leibniz, Voltaire, Victor Hugo, Benjamin Constant, etc., aparecem desordenadamente à medida que se produzem fatos e notícias, e, uma vez chamados à cena, redirecionam e ou completam pensamentos, opiniões e informações. E é nesse contexto que as negativas do profeta evocam Rousseau.

Por fim, a crônica é conversa de salão; leve, deve ser comentada entre um batepapo e outro. Assim como o leitor comum dos periódicos passa rapidamente os olhos por essas conversas semanais e - ato contínuo -, vale-se das gazetas para embrulhar um 
objeto qualquer, a filosofia que o cronista embute no relato é vista como emblema. A ideia moral engastada ao nome de Rousseau surge como símbolo da atividade filosofante e suas consequências em contraposição à ignorância, ao primarismo e ao reacionarismo dos países muçulmanos e seus haréns. Assim, apesar de terrível, espantoso e atrasado, o Oriente mostra-se na literatura um lugar envolvente e pleno de atração. $^{204}$

\section{Efeito de leitura}

Nas "Balas de Estalo" de 15/7/1884, Machado comenta o feito de um tal sr. Ferreira, inventor de um processo para escrever tão veloz quanto a fala ou o pensamento. $\mathrm{O}$ feito, evidentemente, salta às páginas do cronista não só pelo que traz de fantasioso, mas, sobretudo, em razão do privilégio governamental concedido ao seu autor.

Ao desaprovar o contrato entre inventor e governo, ironicamente, Machado toma um súbito desvio que o leva a Simônides de Céos, poeta grego a quem se atribui a invenção da mnemônica, técnica de memorização através da associação de ideias. A inutilidade do novo invento, porém, surge com a intromissão dos versos camonianos ${ }^{205}$ que, simultânea e intertextualmente alicerçam a crítica do cronista e desqualificam o processo de escrita.

Em suma, o cronista não vê préstimo algum no processo do sr. Ferreira, afinal, argumenta, "há muita coisa que se salva, que se escreve, que se imprime, que se lê, que entra na economia, que mata, que esfola:...", mas "nesta vida tão cheia de amarguras, se há alguma coisa que pode consolar a gente é a quantidade enorme de pensamentos e palavras que ficam pelo chão".

Assim, segue descrevendo o martírio que sofre nos bondes quando ora ou outra encontra este ou aquele sujeito que, com "duas ou três idéias na cabeça e um oceano de palavras nos gorgomilos" faz dele um receptáculo. Nessas horas nem mesmo o bonde o ajuda: o entra e sai de passageiros e o atraso dos bondes prologam seu castigo,

\footnotetext{
${ }^{204}$ Afinal, isso está em Chateaubriand, Gautier e Hugo - entre outros.

${ }^{205}$ Os versos fazem parte das Elegias (Elegia III, 1834: 165, v. 3), contudo, vale pequena correção: nas páginas da Gazeta de Notícias (p. 2) o verso "Que mostras à memória nova via;" talvez por erro de impressão foi grafado "Que mostras à memória nova ira;", erro conservado em todas as publicações posteriores. Ademais, o verso "Me não lembrasse nada do passado,", na crônica machadiana aparece como "Me não lembrasse as cousas do passado,".
} 
tornando-o "lento, bárbaro, sem uma esperança de trégua". "Até aqui, porém, restava uma consolação; a consolação ou a ilusão do inédito." Algo que o invento do sr. Ferreira extingue em definitivo.

Porém, antes de declarar que "Governo e Ferreira são inimigos públicos, dignos da fogueira" e reiterar a inutilidade da tal máquina, Machado direciona suas farpas à política e ao que se diz nas câmaras, provando que a taquigrafia já é um processo excessivo. Um perigo para o comércio, uma inutilidade para a diplomacia e as páginas dos jornais infestadas pelas asneiras que se dizem nas câmaras, tudo isso faz com que o cronista bradeje contra o sr. Ferreira:

Não, Ferreira! Não, governo imperial! Nada de tal processo; nada de dar mais asas à asneira. Basta as que tem. A asneira anda de bonde, de carro, a cavalo, a pé, tem as asas da fama, e vós ainda lhe quereis dar as do privilégio! Odioso privilégio, Ferreira.

Escuta, patrício. Olha uma coisa: Lopes de $\operatorname{Vega~}^{206}$ escreveu as suas mil e tantas peças sem o teu processo; Voltaire $^{207}$ e Rousseau ${ }^{208}$ não precisaram dele. Nem Shakespeare, nem o João de Barros, nem o nosso jornalista C. B. de Moura, que há trinta e três anos ou mais acompanha assiduamente as evoluções de uma política bastarda e os protestos mais intencionais que eficientes dos nossos partidos.

Embora o comentário se restrinja a um fato episódico, a referência a Rousseau (e outros) não só sublinha em que medida a leitura, ligada à memória, mantém a reflexão do cronista às voltas do literário, como também denuncia seu empenho em incorporar o universo dos textos, ou, como afirma Barthes (1973: 59), demonstra sua “impossibilité de vivre hors du texte infini - que se soit Proust [Rousseau], ou le jornal quotidien...".

Circunscrevendo-se à referência, nota-se a perspicácia do cronista ao contrapor os dois maiores antagonistas das Lumières. É fato que ao longo ao século XIX ainda ressoam os ecos da grande querela que marcou o século XVIII: de um lado, Voltaire,

\footnotetext{
${ }^{206}$ Lope de Vega foi um autor extremamente profícuo: teria escrito cerca de 3000 sonetos, 9 epopeias, 1800 peças profanas, 400 dramas religiosos, romances e inúmeros intermédios (cf. Larousse). No entanto, a crítica diverge sobre esses números.

${ }^{207}$ A produção literária de Voltaire é imensa. Ainda vivo, vieram à luz suas Oeuvres Complètes em 40 volumes in- $8^{\circ}$ (édition de Genève, 1775). A edição Kehl (1783-1790), de Beaumarchais, totaliza 70 volumes in- $8^{\circ}$; a edição Garnier (1877) soma 50 volumes. Na Pléiade, só sua correspondência (cerca de 21000 cartas) perfaz 13 volumes.

${ }^{208} \mathrm{Na}$ Pléiade, edição de referência, as Oeuvres Complètes de Rousseau compreendem 5 volumes. Sua Correspondance Générale (Armand-Colin, édition de Théophile Dufour et Pierre-Paul Plan, 1926) comporta 20 volumes.
} 
sarcástico, brilhante polemista, símbolo do requinte aristocrático do Ancien Régime; de outro, Rousseau, arredio à "société de cour", mente atormentada e sensível. O primeiro adapta as desigualdades sociais ao absolutismo monárquico, é anticlerical, e embora lute arduamente contra o fanatismo e a intolerância, é particularmente violento contra inimigos como o próprio Rousseau e Fréron; o último, suscetível à injustiça social, aspira a "verdade", encontra dificuldades em viver na sociedade dos homens e concebe uma doutrina política que terá grande influência sobre as gerações seguintes. Arquiinimigos, irmanam-se num único ponto: são considerados dois grandes escritores, cujas penas elevaram a escrita a seu ápice, tornando-se modelos de clareza e concisão.

A referência, mais que alterar ou imprimir novo sentido às argumentações do cronista, aparece como status de recepção literária: uma dicotomia em que a literatura surge de dois extremos: escritura (o texto, a crônica) e leitura. De fato, nada que uma análise panorâmica das crônicas não permita reconhecer, ou seja, um modelo retórico de leitura fundado em fatos, os quais, referenciados por um corpus literário, orientam a interpretação a partir de indícios, traços e reminiscências (sejam eles citações, alusões, etc.) que provocam o leitor, induzindo-o a remexer seu próprio baú à busca de um anacronismo: personagens, obras, ideias, costumes e hábitos de uma época, enfim, um entrecho qualquer, adquire novo sentido, "reescreve" a leitura, atualiza o texto presente - e os futuros -, tudo em razão do "efeito de leitura" disparado pelo intertexto.

\section{Contextualizando: "Uma cova de Caco"209}

Em 1881, à época de sua inauguração por D. Pedro II, o matadouro Santa Cruz foi considerado um dos mais modernos do mundo. Importante centro industrial para abastecimento de carne na cidade do Rio de Janeiro, funcionou até a segunda metade do século XX. Em razão das portarias que impediam o abate do gado em povoações, à vista de toda a gente, para ali afluíam não só produtores e negociantes de gado dos Estados do Rio de Janeiro e Minas Gerais, mas também políticos.

Sólido, o edifício trazia inovações: o gerador ali instalado fez com que Santa Cruz fosse o primeiro bairro do subúrbio do Rio a ter energia elétrica. Porém, desde seu

\footnotetext{
${ }^{209}$ Em 20/2/1885, em sessão da Câmara Municipal, o vereador Sr. Costa Ferraz termina sua intervenção afirmando que o "matadouro é uma cova de Caco", em referência à caverna sob o Monte Aventino, onde o mitológico bandido Caco guardava o produto de seus roubos (Gazeta de Notícias, 21/2/1885, p. 2).
} 
início, estrutura e administração não se harmonizavam: insígnia de progresso e modernidade, a grande edificação nascera com alma insalubre. Em se considerando as publicações da Gazeta de Notícias ${ }^{210}$, o matadouro parece ter sido daquelas instituições públicas cuja administração era altamente permissiva, moralmente comprometida. Tudo ali exalava o odor da corrupção.

No princípio imperava a liberdade de matança, contudo, em 1/3/1884, o sr. Nobre, presidente da Câmara Municipal, ordena ao diretor do matadouro que estabeleça dias para invernistas e boiadeiros. Aparecem os atravessadores, que compram a carne verde a preço reduzido e impõem valor bem mais alto aos marchantes e açougueiros. $\mathrm{O}$ custo da carne sobe para o consumidor. A Câmara discute a "preferência" para o abate no matadouro público e o sr. Nobre é acusado de transformá-lo em negócio particular. Os jornais insinuam que o ministro do Império (agricultura), amigo do sr. Nobre, mantém em seu poder papéis que, uma vez despachados, poriam fim à crise.

Nos jornais, aparecem anúncios e artigos irônicos à administração do sr. Nobre, todos sugerindo sua participação nos negócios do matadouro. Criadores, invernistas, boiadeiros, açougueiros e marchantes fazem coro contra o sr. Nobre e o denunciam por cobrança de propina, $2 \$ 00^{211}$ por rês. Instala-se uma comissão de averiguação. A imprensa publica cartas de particulares endereçadas ao ministro do Império e ao Imperador pedindo providências.

Em 30/5/1884, o sr. Chaves Faria, presidente da comissão propõe a liberação da matança (divisão entre açougueiros, marchantes, boiadeiros e outros), a Câmara recusa e Chaves Faria pede exoneração da comissão. No mês seguinte o assunto é pauta no Parlamento, onde será exaustivamente debatido ao longo de dois meses. Logo, vem a público que o sr. Nobre recebe de um consórcio de empresas, no qual tem participação, a quantia de $3 \$ 00$ por rês abatida. O ministro resolve a questão, definindo a matança entre as partes.

Na sequência, os desdobramentos do fato: aparecimento dos chamados "testas de ferro" que se passam por açougueiros; paralisação iminente dos funcionários do matadouro por falta de pagamento dos salários; denúncia do médico (veterinário) da

\footnotetext{
${ }^{210}$ Quase que diariamente a Gazeta de Notícias publicava uma coluna intitulada "Câmara Municipal"; ali, desde o início de 1884 (período pesquisado), o matadouro é pauta das sessões.

${ }^{211}$ Em valores aproximados um real equivale $\mathrm{R} \$ 0,056$ e um conto de réis a $\mathrm{R} \$ 56,00$ (GOMES, 2007: $352)$.
} 
instituição por participação no esquema e por fazer cobranças à parte; boicote da sessão da Câmara cuja pauta era votar a liberação irrestrita do abate; acusação da comissão de averiguação por ter emitido portarias contrárias ao regulamento da Câmara; volta das "preferências"; redução do abate, aumento de preço e, por fim, um novo escândalo: o diretor do matadouro é denunciado por vender subprodutos (sebo, chifres) que não the pertencem. Enfim, um ano e meio depois, à época em que Machado decide tomar da pena e comentar o último dos escândalos, o matadouro figura nos jornais como incontestável "cova de Caco".

\section{Um novo escândalo: "juro por Deus Nosso Senhor que não estou inventando. A única coisa que faço é não entender nada."}

A instituição continua sendo palco de todo tipo de contravenção e isso vem à tona nas sessões da Câmara, em geral, pela voz dos opositores. A comissão responsável pela averiguação dos episódios do matadouro é desacreditada perante a opinião pública. Questionam-se o fornecimento de sal e toda sorte de concessões, inclusive aquela que responde pela limpeza do matadouro. O caso ganha foro de imprensa quando se descobre que um oficial do ministro do Império pede um conto de réis para não "aprovar" um forno de cremação, algo que poria fim ao sistema vigente de limpeza, fonte de rendimentos escusos.

Em 3/6/1885, a Gazeta de Notícias (p. 2) publica relato do que ocorrera na sessão da Câmara do dia anterior:

O Sr. Dr. Lopes pergunta á commissão de matadouro qual o motivo porque tirou o serviço da limpeza do matadouro ao Sr. Capitão Silva, para dar ao Sr. Victor Dumas, desautorando d'esta maneira uma resolução da camara, para proteger um afilhado.

O Sr. Dr. Chavantes, membro da commissão de matadouro, justifica o procedimento da comissão, e termina declarando que o actual emprezario entra com a quantia de $100 \$$ para os cofres municipaes.

No correr da discussão trava-se uma questão de ordem entre o orador e o Sr. Dr. Lopes, que diz que a cousa é tão boa, que ainda em cima o emprezario paga á câmara. 
O esquema corruptivo desvela-se das entrelinhas e Machado o explicita na crônica de 14/6/1885 ${ }^{212}$ (veja item 8): sob crivo jocoso "Fuão Silva" (que limpava o matadouro gratuitamente) é afastado de suas funções para que "Fuão Dumas" assuma o cargo pela quantia de $400 \$ 000$ mensais. Subtraído, o erário será parcialmente reembolsado. O cronista revela o estratagema, ironiza, jura por Deus Nosso Senhor que não está inventando nada e conclui: "A única coisa que faço é não entender nada." Antes, porém, trata do "barro humano" e para isso refere-se ao "estado social de Rousseau".

Na crônica, um procedimento de comparação implícita que combina alusão, subentendido e ironia apresenta ao interlocutor machadiano um pressuposto que, de pronto, o leva a entender o oposto do que se afirma:

A razão que me faz amar, sobre todas as coisas deste mundo, a nossa Ilma. Câmara municipal é que ali a gente pode dizer o que tem no coração.

Cá fora tudo são restrições e cortesias. Um homem crê que o outro é tratante e dá-lhe um abraço, e raramente um pateta morre com a persuasão de que o é. Obra das conveniências, costumes da civilização, que corrompe tudo.

Na ilustríssima é o contrário.

Tudo ali parece respirar o estado social de Rousseau, é a pura delícia da natureza em primeira mão. Não há sedas rasgadas, nem outras bugigangas e convenções.

Se nem todos observam a regra da casa, que é, logo à porta, desabotoar o colete e tirar os sapatos, não só para estar à fresca como para meter os pés nas algibeiras dos outros, é porque não se perdem facilmente os hábitos corruptos, mas basta que a regra exista, para crer que a reforma total se fará.

A última sessão (para não ir mais longe) deu-nos um desses espetáculos em que a natureza rude e ingênua vinga os seus foros. Tratava-se da limpeza do matadouro.

Ao que parece, êste serviço estava a cargo de Fuão Silva, que o fazia de graça, e foi dado a outro por $400 \$ 000$ mensais. Um dos vereadores pegou o ato, e começou por dizer que o presidente não tinha culpa do que fizera, visto que foi mal informado por outro vereador, e caiu em cima dêste. Não estêve com uma nem duas; disse-lhe claramente que estava perseguindo o Silva, e protegendo a alguém à custa dos cofres municipais; que era um escândalo e já não era o primeiro; que o dito vereador é uma potência do matadouro, onde prefere a quem quer; que prorroga contratos sem conhecimento da causa; que protege também um certo Marinho, e muitas outras coisas,

212 "Balas de Estalo", Gazeta de Notícias. 
concluindo por dizer irônicamente que esperava que o outro, com a eloqüência que todos lhe reconhecem, viria explicar o ato.

Tudo isso foi dito sem barulho, e respondido sem barulho. A resposta do outro foi que o novo empresário Fuão Dumas, que faz a limpeza por 400\$000, dá 200\$000 mensais ao primeiro, que a fazia de graça. Juro por Deus Nosso Senhor que não estou inventando. A única coisa que faço é não entender nada. Nem isso, nem a proposta com que o orador terminou, para que se faça o contrato definitivo com o dito Fuão Dumas, pagando êste à câmara $100 \$ 000$ mensais, em vez de receber os 400\$000. Mas, repito, tudo isto sem barulho.

Se o cronista domina com maestria a arte do "descobrir e encobrir", na crônica em questão, age de modo inverso, qual seja, numa só frase revela a seu leitor o estado social de Rousseau: a primeira condição do homem, ainda não corrompido: "Tudo ali parece respirar o estado social de Rousseau, é a pura delícia da natureza em primeira mão.” De fato, esse homem natural, ao garantir seu espaço na esfera do folhetim, já é moeda de troca há muito negociada no mercado das ideias filosófico-literárias.

"Interessava-lhe, artista que era, o estilo dos atores políticos; atraíam-no suas aparições efêmeras, ora risíveis, ora patéticas, mas não algum possível sentido da Política e da História, que não cabe nas suas crônicas como dificilmente se depreende de seus romances e contos." (BOSI, 2006: 55). Ora, se o sério não é matéria de folhetim, por que se aprofundar nos contratos e pactos rousseaunianos? A desnecessidade parece óbvia. Diante disso, para que o riso do leitor se estenda para além do canto da boca, extrapole a ironia e alcance o jocoso, o cronista lança mão de um clichê que traz em si algo banalizado à exaustão. E assim, na crônica, permite que a "natureza rude e ingênua" ainda produza espetáculos, e, na "Ilma. Câmara municipal", espetáculos pautados pelo ridículo, escancarando os abismos da vacuidade humana.

A crítica machadiana é duplamente indireta: "Fuão Silva" e "Fuão Dumas" são chamados à cena já desfigurados de suas identidades. $\mathrm{O}$ apelo à palavra fuão (fulano) por um lado indetermina, despersonaliza e, por outro, insinua tratar-se de algo sem importância, rasteiro, bem ao estilo do folhetim. Contudo, a recorrência a nomes como "vereador" e "presidente" e a intromissão da matemática, que esclarece ao leitor o passo a passo da mancomunação entre os envolvidos, não só afasta do relato qualquer banalização, como intensifica a gravidade da "denúncia", sugerindo que os tais "fuões" 
não passam de joguetes em mãos muito mais poderosas que, a exemplo do que se discutiu na sessão da Câmara, trabalham "sem barulho".

Por outro lado impõe-se dirigir àqueles que manipulam, tramam contra o bem público e fraudam a liberdade; para isso o cronista adota um ponto de vista imanente às condições sociológicas que regem o dia-a-dia dos cidadãos cariocas envolvidos com o comércio do gado e seus respectivos representantes.

Através da inversão, o cronista chama seu leitor à cena, subverte os papéis, avilta-o na medida em que exalta as "virtudes" da Câmara e o coloca na condição de farsante, afinal, seu interlocutor compactua de todas as "restrições e cortesias" que contribuem para a construção da "máscara" exigida pelo simulacro social. Dessa forma, emerge uma Câmara acima de qualquer suspeita, muito embora não se percam "facilmente os hábitos corruptos", saída paródica e estratégica, cujo objetivo não é outro senão a caricatura e a ridicularização da instituição, uma vez que lá seus integrantes não padecem com "conveniências, costumes da civilização, que corrompe tudo", mas respiram "o estado social de Rousseau", a "pura delícia da natureza em primeira mão".

\section{9. "É preciso aceitar a teoria de Rousseau: o homem nasce puro. Para que corromper-nos?"}

O outono de 1892 é atípico e os dias que comumente são curtos e frescos ganham a chuva como elemento extra. Deixada pelo verão, ela não só alaga a cidade, mas adentra as páginas da crônica. $\mathrm{O}$ cronista, incomodado, lança mão de sua memória literária e exibe sua poética intertextual ao tratar da frivolidade que preenche o dia-a-dia da cidade. Assim, desdobra-se sua habitual escritura híbrida de notícia e ficção, mescla de discurso crítico e discurso ficcional.

A chuva, que poderia escorrer pelas ladeiras e virar mar, ganha contornos expressivos, vira lágrima nos olhos do Senhor: 
O velho Dumas ou Dumas I, em uma daquelas deliciosas fantasias, escreveu esta frase: "Um dia, os anjos viram uma lágrima nos olhos do senhor; essa lágrima foi o dilúvio., 213

Uma lágrima! ai, uma lágrima! Quem nos dera essa lágrima única! Mas o mundo cresceu do dilúvio para cá, a tal ponto que uma lágrima apenas chegaria a alagar Sergipe ou a Bélgica. Agora, quando os anjos vêem alguma cousa nos olhos do Senhor, já não é aquela gôta solitária, que tombou e alagou um mundo nascente e mal povoado. Caem as lágrimas às quatro e quatro, às vinte e vinte, às cem e cem, é um pranto desfeito, uma lamentação contínua, um gemer que se desfaz em ventos impetuosos, contra os quais nada podem os homens, nem as minhas árvores, que se estorcem com desespêro.

Maio fêz-se abril. Diz-se que de um a outro não há muito que rir. Há que rir, mas é abril que se riu de maio, êste ano, êle que era o mês das águas, enquanto o outro era chamado das flores. Abril não quis ir buscar as lágrimas do Senhor, certo de que esse ofício caberia a outro, e não seria junho, mês dos santos folgazões, das fogueiras, dos balões, que no meu tempo eram chamados máquinas. Lá vai a máquina! Olha a máquina! [...]

Cresci, mudou tudo. [...] Ao tempo em que perdíamos o Solimões, o presidente da República Argentina anunciava em sua mensagem ao Congresso: "A marinha aumenta, e a esquadra possui torpedeiras, de modo a ser ela a primeira da América." Mudo de assunto, para obedecer ao poeta: “Glissez, mortels, n'appuyez pas."

Que outro assunto? O primeiro que se oferece é a câmara dos deputados, que, após longos dias de ausência e interrupções, começou a trabalhar, e parece que com fôrça, calor, verdadeira guerra. Alguns jornais tinham notado as faltas de sessões, infligindo à câmara uma censura, que a rigor não lhe cabe. É certo que a eleição da mesa arrastou-se por dias, e a da comissão do orçamento durou uma sessão inteira. Mas não basta censurar, é preciso explicar. Se bastassem críticas, já eu tinha carro, porque uma das tristezas dos meus amigos é êste espetáculo que dou, todos os dias, calcante pede. Não se pode julgar uma instituição, sem estudar o meio em que ela funciona.

Ora, é certo que nós não damos para reuniões. Não me repliquem com teatros nem bailes; a gente pode ir ou não a êles, e se vai é porque quer, e quando quer sair, sai. Há os ajuntamentos de rua, quando alguém mostra um assobio de dous sopros, ou um frango de quatro cristas. Uma facada reúne gente em tôrno do ferido, para ouvir a narração do crime, como foi que a vítima vinha andando, como recebeu o empurrão, e se sentiu logo o golpe. Quando algum bonde pisa uma pessoa, só não acode o cocheiro, porque tem de evadir-se; mas todos cercam a vítima. Há dias, na rua do Ouvidor, um

\footnotetext{
${ }^{213}$ Machado extraiu (e alterou) a citação de Une âme à naître (DUMAS, 1868: 267): "Un jour, les anges, courbés devant le trône éternel, virent, non pas de colère, mais une larme dans les yeux du Seigneur, et cette larme fît le déluge."
} 
gatuno agarrou os pulsos de uma senhora, abriu-lhe as pulseiras, meteu-as em si e fêz como os cocheiros. Mas não faltaram pessoas que rodeassem a senhora, apitando muito.

Tudo por quê? Porque são atos voluntários, não há calendário, nem relógio, nem ordem do dia; não há regimentos. O que não podemos tolerar é a obrigação. Obrigação é eufemismo de cativeiro: tanto que os antigos escravos diziam sempre que iam à sua obrigação, para significar que iam para a casa de seus senhores.

Nós fazemos tudo por vontade, por escolha, por gôsto; e, de duas uma: ou isto é a perfeição final do homem, ou não passsa das verduras. Não é preciso desenvolver a primeira hipótese; é clara em si mesma. A segunda é a nossa virgindade, e, quando menos em matéria de amofinações, políticas ou municipais, é preciso aceitar a teoria de Rousseau: o homem nasce puro. Para que corromper-nos? ${ }^{214}$

Assim como Dumas, o cronista entra pela fabulação e à medida que o texto avança, a lágrima divina deixa de ser solitária e se transforma em "um pranto desfeito, uma lamentação contínua", os meses se confundem e sua memória relembra a infância, quando, em junho, os balões eram chamados de máquinas: "Lá vai a máquina! Olha a máquina!”

No entanto, o texto folhetinesco e descomprometido que embala as lembranças e oscila entre a chuva intensa e os períodos da infância (época em que havia "riso no céu" e tudo era "perpetuamente azul"), logo depois se descuida do passado e das considerações meteorológicas para tratar da notícia crua, afinal, já quebrara o gelo ${ }^{215}$. Os assuntos "sérios" se sucedem (o naufrágio do Solimões ${ }^{216}$, por exemplo) e o cronista desvia o olhar para a alma humana.

Logo, porém, muda o rumo da prosa abrigado pelos versos de Pierre-Charles $\operatorname{Roy}^{217}$ e, dessa vez é a Câmara e seus deputados ausentes que vêm à tona,

\footnotetext{
214 “A Semana”, Gazeta de Notícias, 29/5/1892.

${ }^{215}$ Em 1/11/1877, na Illustração Brazileira - "História de Quinze Dias", o cronista graceja com seu interlocutor e esclarece-o sobre como se deve iniciar uma crônica: "Há um meio certo de começar a crônica por uma trivialidade. É dizer: Que calor! que desenfreado calor! Diz-se isto, agitando as pontas do lenço, bufando como um touro, ou simplesmente sacudindo a sobrecasaca. Resvala-se do calor aos fenômenos atmosféricos, fazem-se algumas conjeturas acerca do sol e da lua, outras sobre a febre amarela, manda-se um suspiro a Petrópolis, e la glace est rompue; está começada a crônica."

${ }^{216}$ Encouraçado brasileiro que naufragou em 19/5/1892 próximo ao Cabo de Polonio (Uruguai) a caminho de Corumbá, onde se juntaria a outros navios para sufocar uma rebelião na cidade. Segundo a Gazeta de Notícias de 22/5/1892, de um total de 151 pessoas (21 entre oficialato e tripulação, e 130 praças), apenas 5 se salvaram por terem saído em um bote à procura de socorro momentos antes da explosão da caldeira.

${ }^{217}$ Homem de letras francês, Pierre-Charles Roy (1683-1764) destacou-se por suas colaborações com compositores como François Francoeur e André Cardinal Destouches, quando produziu libretos para várias opéra-ballets. Também ganhou notoriedade por sua rivalidade com o jovem Voltaire, que em 1719
} 
compreendidos, estranhamente, por um crítico que sentencia: "Mas não basta censurar, é preciso explicar." Não por outra razão, sob a pena de um cronista despretensioso, a "cólera", presente no intertexto de Dumas desaparece, concorrendo para a "materialização" da candura no folhetim.

Assim, na tentativa de esclarecer o funcionamento da instituição, o cronista relaciona uma série de ajuntamentos de rua, o que soa algo satírico. As inexistentes reuniões da Câmara ganham eco e equivalência vulgares, e o leitor pode tomar uma sessão parlamentar por uma aglomeração de populares às voltas de um ferido a facadas, cujo intuito não é outro que se inteirar da narração do crime. Desse modo, evidencia-se o aparente apoio aos parlamentares e a ironia transforma a ausência em presença.

A ironia que se desenvolve através de uma suposta prudência e apoio aos parlamentares tem como certa a compreensão acertada de um leitor que sabiamente decifrará o avesso do que lhe é proposto. Se por um lado essa prudência egoísta imuniza o enunciador contra qualquer comprometimento, por outro, graças a ela, o texto caminha para o jocoso e convida o leitor a raciocinar a partir de outro ângulo, a fugir da percepção linear, o que permite uma análise irreverente do fato.

Contudo, afastado o olhar habitual, responsável pela multiplicação dos automatismos, a ironia submete o leitor à visão do cronista: qualquer independência (se houver) será extratexto (efeito de leitura) e, ainda assim, maculada pelo ponto de vista do enunciador. Este, mesmo que não quisesse ter sido profundo, erudito, mas apenas iluminar o detalhe, o fútil, compromete a visão de seu leitor. Desse modo, ainda que discorde de seus argumentos, o leitor é convidado a indignar-se com um sorriso no canto da boca. $^{218}$

teria escrito a Rousseau: "J'ai été si malheureux sous le nom d'Arouet que j'en ai pris un autre surtout pour n'être plus confondu avec le poète Roy" (POMEAU, 1995: 87, Tome I). O verso utilizado pelo cronista é o último da seguinte estrofe que compõe um poema intitulado "Sur une gravure de patinage": Sur un mince cristal le fer conduit leurs pas :/ Le précipice est sous la glace ;/ Telle est de nos plaisirs la légère surface./Glissez, mortels, n'appuyez pas !

${ }^{218}$ Machado frequentemente ligava a ironia a um movimento facial. Em Teoria do medalhão (2008: 275, Vol. II) uma das personagens do diálogo comenta: “ Somente não deves empregar a ironia, esse movimento ao canto da boca, cheio de mistérios, inventado por algum grego da decadência, contraído por Luciano, transmitido a Swift e Voltaire, feição própria dos cépticos e desabusados."; em Galeria Póstuma (2008: 372, Vol. II) "Benjamim ficou atordoado. Não podia acabar de crer na morte do tio. Correu ao quarto, achou o cadáver na cama, frio, olhos abertos, e um leve arregaço irônico ao canto esquerdo da boca.", mais à frente, o mesmo Benjamin evoca a figura do tio e "não podendo rejeitá-la, [...] tenta fecharlhe os olhos e concertar-lhe a boca; mas tão depressa o fazia, como a pálpebra tornava a levantar-se, e a ironia arregaçava o beiço. (2008: 376, Vol. II)" 
“A obrigação é eufemismo de cativeiro": assim justificam-se as ausências dos deputados. "Ora, é certo que nós não damos para reuniões." E, numa canetada, o cronista enreda seu leitor e o toma como cúmplice torcendo as ideias:

Nós fazemos tudo por vontade, por escolha, por gosto; e, de duas uma: ou isto é a perfeição final do homem, ou não passa das primeiras verduras. Não é preciso desenvolver a primeira hipótese; é clara em si mesma. A segunda é a nossa virgindade, e, quando menos em matéria de amofinações, políticas ou municipais, é preciso aceitar a teoria de Rousseau: o homem nasce puro. Para que corrompernos?

Ora, levando-se em conta a obrigatoriedade de os deputados estarem presentes às reuniões da Câmara e o fato de lá não aparecerem, é de se crer que o cronista de fato afirme: não, nós não fazemos tudo por vontade, por escolha e por gosto e, sobretudo, não padecemos de qualquer perfeição. Até mesmo porque, essa "perfeição final" inexiste e soa incoerente face ao que afirma Rousseau.

Por outro lado a "perfeição" talvez resida em "nossa virgindade" (porque tudo em Machado é relativo); nessa lógica, os deputados, vistos como homens em estado natural, portanto, governados por instinto, trazem em si esta "perfeição" ainda adormecida, em estado virtual (mas que pode ser atingida!). A ironia (que beira à sátira) é tratar os deputados como seres primitivos, virginais, cuja razão ainda não está em funcionamento, simplesmente porque ainda não precisaram dela. Assim, neste estado natural, reina a harmonia entre o homem (os deputados) e seu meio (a natureza, que, no caso, subtraída pelo cronista, pode ser lida como 'sociedade'), num retorno à teoria do bon sauvage aventada por Rousseau.

Isto posto, o "mas não basta censurar, é preciso explicar" lançado pelo cronista em favor dos deputados, soa algo paródico e ganha sentido oposto, sobretudo, se justaposto à ideia de Rousseau de que a perfeição pode tornar o indivíduo plenamente homem ou inferior ao animal, afinal: "l'homme reperdant par la vieillesse ou d'autres accidents, tout ce que sa perfectibilité lui avait fait acquérir, retombe ainsi plus bas que la Bête même" (ROUSSEAU, 2008: 80).

Entretanto, não se pode deixar de considerar que Rousseau enquanto base para a crítica aos políticos é visto a partir de um lugar comum filosófico. Fazendo-se de 
ingênuo, o cronista finge apoio à classe política. Porém, ao aventar Rousseau, a filosofia do francês é filtrada pela imaginação e fantasia literária de modo que temas (o bon sauvage, por exemplo) e clichês filosóficos (a pureza do homem e sua perfeição final, a corrupção pela sociedade e, mesmo a locução “teoria de Rousseau”) permanecem como resquícios de doutrinas filosóficas que, sintetizadas, surgem banalizadas, frutos da sabedoria popular na argumentação do cronista.

Por outro lado, considerando-se a ficção como um veículo que não prima pela transparência das ideias, estas, de certa forma, distanciam-se da realidade imediata e podem adquirir resultados aparentes. No caso, o leitor pode se enganar quanto ao objeto do cronista, pois ao introduzir Rousseau em sua argumentação, o cronista supostamente justifica o desleixo dos deputados. Isso, não só porque a ficção absorve filosofias, recombinando-as sob intenções diferentes das que possuem em seus discursos de origem, mas principalmente porque as ideias, interpretadas em conjunto e justapostas ao contexto, são "contaminadas", ou seja, permitem-se ser "distorcidas" a ponto de ratificar opiniões estranhas ao contexto de origem. É por isso que Machado, não sendo filósofo, ri da filosofia e, com um riso zombeteiro, chama Rousseau de João Jacques.

\section{0. "A cartomancia nasceu com a civilização, isto é, com a corrução, pela doutrina de Rousseau."}

A política está na ordem do dia, afinal, acontecem as eleições municipais e a discussão, como comumente ocorre nesses períodos, alvoroça os espíritos não só nas agremiações, clubes e botequins, mas, sobretudo, na imprensa. Também por razões políticas, ao longo da semana que antecede a crônica de $10 / 3 / 1895^{219}$, a atenção de todos se volta para o Recife, que é manchete de primeira página dos jornais.

Em 5/3/1895, a Gazeta de Notícias divulga o assassinato do Dr. José Maria de Albuquerque Mello, chefe do partido autonomista, que pleiteava contra o governo a eleição municipal na capital pernambucana. Tudo leva a crer tratar-se de um crime político: Albuquerque Mello é alvejado pelas costas por policiais em plena seção eleitoral, à vista de eleitores e mesários. Em ato contínuo, jogam a vítima ainda agonizando em um monturo e impedem-na de receber socorro médico. Instala-se o

219 “A Semana”, Gazeta de Notícias. 
pânico na cidade, a consternação é geral, e a população é aterrorizada por tropas da força estadual.

$\mathrm{Na}$ crônica ${ }^{220}$, o drama de Albuquerque Mello, que divide espaço na imprensa com o julgamento de José Valentim Sol Posto (envolvido no célebre assassinato de Maria de Macedo) $)^{221}$, é completamente ignorado. A razão pode ser explicada pelo próprio cronista que, míope, à vista de uma "semana rica", aperta os olhos para ver as coisas miúdas, e, com a curiosidade estreita, vai atrás do mínimo, do escondido e mete o nariz naquilo que ninguém vê. ${ }^{222} \mathrm{Em}$ suma, essa escolha por assuntos encobertos revela a técnica machadiana na seleção da notícia. Para o cronista, as manchetes do dia necessariamente não revelam os meandros da alma humana; é nos atalhos, nos pormenores que penetra em suas profundezas, tenta captar as sutilezas do espírito, nuances enternecidas, contrastes, dissimulações, enfim, a finura e a complexidade do ser.

E é desse modo que deslinda seu jeito de "ler" os fatos, personifica a notícia e determina a carpintaria de sua escritura:

$\mathrm{Eu}$, quando vejo um ou dois assuntos puxarem para si todo o cobertor da atenção pública, deixando os outros ao relento, dá-me vontade de os meter nos bastidores, trazendo à cena tão-somente a arraia-miúda, as pobres ocorrências de nada, a velha anedota, o sopapo casual, o furto, a facada anônima, a estatística mortuária, as tentativas de suicídio, o cocheiro que foge, o noticiário, em suma.

É que eu sou justo, e não posso ver o fraco esmagado pelo forte. Além disso, nasci com certo orgulho, que já agora há de morrer comigo. Não gosto que os fatos nem os homens se me imponham por si mesmos. Tenho horror a toda superioridade. Eu é que os hei de enfeitar com dois ou três adjetivos, uma reminiscência clássica, e os mais

\footnotetext{
${ }^{220}$ É sabido que de modo geral Machado privilegia em suas crônicas os "casos miúdos da semana" ("A Semana", Gazeta de Notícias, 30/8/1896).

221 Veja-se, por exemplo, a Gazeta de Notícias, de 9/3/1895 (p. 2). O assassinato de Maria de Macedo rendeu notícia de primeira página na Gazeta de Notícias, de 21/9/1892, sob o título de Singular crime! À época a notícia agitou a imprensa e deliciou os leitores do gênero e décadas mais tarde seria relembrada pela Folha, do Rio, de 9/9/1920 (p. 4): “Amanhã os leitores terão aqui o célebre caso Maria de Macedo a mulher que foi esquartejada nos açougues como carne fresca." A Revista Illustrada (nr. 650), outubro de 1892, traz ilustração dos envolvidos, do corpo decapitado e recomposto. Machado faz referência a Maria de Macedo nas crônicas de 25/9/1892, 15/1/1893, 26/2/1893 e 2/7/1893.

${ }^{222}$ Sobre isso ver "A Semana", Gazeta de Notícias, 11/11/1900. Frase ligeiramente parafraseada para se adaptar ao contexto.
} 
galões de estilo. Os fatos, eu é que os hei de declarar transcendentes; os homens, eu é que os hei de aclamar extraordinários. 223

Em síntese, nota-se a partir do entrecho acima como o cronista maneja esse gênero que transita pela história, jornalismo e literatura. Essas esferas de representação do mundo, sob a pena machadiana, desvinculam-se do tempo histórico em curso e se elevam em relação ao circunstancial para enriquecê-lo, transformando-o através de uma dinâmica atrelada ao conhecimento.

"A arraia-miúda, as pobres ocorrências de nada, a velha anedota, o sopapo casual, o furto, a facada anônima, etc.”, submetidos à fabulação, erguem-se do rasteiro, são discutidos de maneira subjetiva e conceitual e, ficcionalizados, ganham visão artística, equilibrando-se entre forma e conteúdo.

Submetido à apreciação, à memória literária e ao gosto estético do cronista, o prosaísmo da notícia, como dito acima, não só desponta pleno de literariedade, mas, enquanto percurso de reflexão, cuja dimensão essencial e ontológica do mundo real, ultrapassa a mera opinião irrefletida do senso comum, abre-se tal uma janela a partir da qual se pode escapar da cativa realidade empírica e mergulhar nos abismos da alma.

Porém, antes de deslindar sua manufatura, o cronista impõe-se como sujeito que pensa: o "tenho horror a toda superioridade" e ou "não posso ver o fraco esmagado pelo forte" são arrufos de um escritor sensível às injustiças que, embora não tenha provado das bastonadas sentidas por Voltaire, contempla seus patrícios que sentem o gosto amargo do cativeiro.

A imposição de "não posso ver", "não gosto", "não suporto", "tenho horror", não é só parte dos resmungos do cronista em face de uma sociedade desigual, mas, sobretudo, deixa entrever suas relações com a literatura, uma vez que a crônica machadiana surge como "narrativa" cuja estrutura do relato referencial é simétrica a do relato ficcional. Nesse sentido, no espaço próprio do texto jornalístico emergem ora a expressão pessoal ora a artística, que se modulam e se completam à medida que o enunciador restringe a notícia em benefício da ficção. Esta, numa acepção estendida (intromissões intertextuais) permite que o cronista negocie sua relação com o mundo.

Veja-se mais de perto, por exemplo, o noticiário de 4/3/1895:

223 “A Semana”, Gazeta de Notícias, 10/7/1892. 
Hontem, ás oito horas da noite, foram accomcodadas no xadrez da $1^{\mathrm{a}}$ estação policial duas feiticeiras de nome Maria Umbelina e Maria José, por serem encontradas com uma cesta de vime que pretendiam abandonar no armazem da rua do Ouvidor n. 2, contendo pombos, frangos e outras aves mortas, diversos saquinhos contendo sal, arroz, cangica, feijão e outros generos alimenticios, moedas de 10 e 20 rs, uma perna de ceroula velha e outras bugigangas.

Em poder de Umbelina encontrou-se a quantia de $413 \$ 000 .^{224}$

e sua relação a crônica de 10/3/1895:

A autoridade recolheu esta semana à detenção duas feiticeiras e uma cartomante, levando as ferramentas de ambos os ofícios. Achando-se estes incluídos no código como delitos, não fez mais que sua obrigação, ainda que incompletamente.

A minha questão é outra. As feiticeiras tinham consigo uma cesta de bugigangas, aves mortas, moedas de dez e vinte réis, uma perna de ceroula velha, saquinhos contendo feijão, arroz, farinha, sal, açúcar, canjica, penas e cabeças de frangos. Uma delas, porém, chamada Umbelina, trazia no bolso não menos de quatrocentos e treze mil-réis. Eis o ponto. Peço a atenção das pessoas cultas.

O cronista começa suas considerações semanais justamente comentando a prisão das feiticeiras. Afora o fato de referir-se a "duas feiticeiras e uma cartomante" (talvez porque evocasse o assunto de memória), em suma, o texto machadiano não difere da notícia publicada em 4 de março.

E é nessa toada, jogando com os conhecimentos geral e pessoal que o cronista tece suas observações: começa pela natureza do negócio que, em si, não pode ser considerado um delito como quer o código ${ }^{225}$, haja vista a sua rentabilidade; argumenta, inclusive, sobre a falibilidade do código diante dos mandamentos bíblicos, pois lá, proíbe-se o furto, mas não a feitiçaria, demonstrando com isso que o delito é uma invenção humana, portanto, se os homens erram, condená-lo seria incorrer duas vezes num mesmo erro.

Ao questionar o código, o cronista examina, sobretudo, o fato de seu autor desconhecer o que é a ilusão, arrolando Poe, que embora não tivesse sido um

\footnotetext{
224 “Policia da Cidade", Gazeta de Notícias, 4/3/1895 (p. 2).

${ }^{225}$ Provável referência ao Código Penal de 1890.
} 
jurisconsulto, manifestou-se como bom juiz formador de culpa: “O nariz do povo é a sua imaginação; por ele é que a gente pode levá-lo, em qualquer tempo. Aonde quiser." 226 Desse modo, critica o código que impede a ilusão do povo e faz vistas grossas a uma série de outras promessas, tais quais as apregoadas ao longo do "ano terrível". ${ }^{227}$ E assim o cronista constrói sua ironia ao aproximar um assunto de Estado à feitiçaria, prática marginalizada pela sociedade dominante.

Afinal, "foi a feiticeira que mais ódio gerou, porque corporificou, de maneira exemplar, o embate entre dois mundos: o da cultura popular, da tradição popular, da tradição oral e iletrada [...] e o da cultura erudita, letrada, escrita, exclusiva a um número restrito de intelectuais (SOUZA, 1995: 291-292). Como não poderia deixar de ser, o cronista aproxima-se de seu leitor sempre cheio de artimanhas. Primeiro, chama-o de lado, como se lhe fosse segredar algo muito particular, pedindo sua atenção, tratando-o por "pessoa culta"; depois embaralha os extremos ao sugerir o Encilhamento tão ou mais falho que a feiticeira, que promete "um verdadeiro amor com dois pés de galinha”.

Predominantemente feminino, o universo da feitiçaria incomoda não só porque relativiza o masculino, mas, sobretudo, porque abriga a mulher independente e uma cultura popular, sincrética, de forte apelo africano. Além de transgredir as leis e colocar à prova seus pilares constitutivos (a medicina, por exemplo, com seu suposto controle absoluto sobre a cura), na crônica as feiticeiras revelam-se mais "confiáveis" que os sistemas oficiais ou patrocinados pelo Estado, pautados pela aceitação social que engendrou o Encilhamento.

O leitor culto também não escapa à ironia do cronista, haja vista seu duplo sentido: o que pode muito bem ser lido como elogio à sua suposta ortodoxia, já que é

\footnotetext{
${ }^{226}$ No original: "The nose of a mob is its imagination. By this, at any time, it can be quietly led." A frase faz parte das Marginalia, notas escritas por Edgard Allan Poe às margens de livros e que foram publicadas em revistas americanas entre os anos de 1844 e 1849. Em geral são notas que transitam do elogio ao sarcasmo e contemplam a arte da ficção, filosofia, moral, ciência, linguagem e as dificuldades encontradas por um gênio, que se adapta mal à sociedade e à existência.

${ }^{227}$ Trata-se do período entre 1890 e 1891, que marca a crise do Encilhamento. Época de grande expansão dos capitais industrial e financeiro, especulação desenfreada, lançamento de ações sem lastro, forte alta inflacionária e dúvidas quantos aos procedimentos do mercado financeiro, o plano idealizado por Ruy Barbosa, destacou-se como a grande bolha econômica que estourou no início da República. O resultado de um deslumbre disseminado com a possibilidade de enriquecimento rápido foi a falência generalizada e o dinheiro trocando de mãos. Machado menciona o "ano terrível" nas "Páginas recolhidas", 3/7/1894, e nas crônicas d'“A Semana”, 30/6/1895 e 1/9/1895. Nesta última, esclarece: "Hão de lembrar-se que esse foi o ano terrível (1890-91) em que se perdeu e ganhou tanto dinheiro que não pude ler mais nada."
} 
um intelectual, formador de opinião, que compactua com o sistema, interpreta-se também como crítica ácida, uma vez que essa sua pretensa sabedoria não apreende que a cesta da feiticeira, plena de "bugigangas, aves mortas, moedas de dez e vinte réis, uma perna de ceroula velha, saquinhos contendo feijão, arroz, farinha, sal, açúcar, canjica, penas e cabeças de frangos" não só é a metáfora potencial de uma cultura mestiça, mas, sobretudo, prenúncio de mudança na ordem social que minará, sem dúvida, o status quo desse homem impregnado da cultura europeia e impassível em seus preconceitos.

Ao destrinchar a crítica ao código, que pensa que fora dele não há outras verdades, e desconhece a existência de "trocos miúdos para a circulação moral dos homens", o cronista chega às cartomantes:

Tudo isto, porém, me levaria longe; limitemo-nos ao que fica; e não falemos da cartomante, em que se não achou dinheiro, provavelmente porque o tem na caixa econômica. $^{228}$ Relativamente às cartomantes, confesso que não as considero como as feiticeiras. A cartomancia nasceu com a civilização, isto é, com a corrução, pela doutrina de Rousseau. A feitiçaria é natural do homem; vede as tribos primitivas. Que também o é da mulher, confessá-lo-á o leitor.

Desse modo, Rousseau afirmar que a cartomancia é produto da corrupção dos modos e a feitiçaria embalou o berço do homem, soa no mínimo, irônico, pois relativiza o código, mina a confiança de sua intencionalidade, minimiza os tentáculos da lei que quer alcançar a todos, sugere a existência de preocupações maiores (vide o Encilhamento) e restabelece ao leitor os seus direitos de intérprete: cabe a ele, portanto, compactuar ou não, crer ou não, no poder das bugigangas e nas cartas.

Alegoricamente, feiticeiras e cartomantes, livres do código e à mercê do leitor (como quer o cronista), aparecem como a ilusão de uma sociedade livre (ainda que corrompida, como quer Rousseau) da mão forte do Estado, de modo a confirmar o que Pierre Schoentjes (2001: 286) diz sobre a estrutura sincrônica da ironia quando ligada à experiência (no caso, o circunstancial, alimento da crônica): bipartida, de um lado, a interpretação da alegoria fica a critério do leitor; de outro, a ironia, como modo de criação, reside no autor.

\footnotetext{
${ }^{228}$ Vale lembrar que segundo a Gazeta de Notícias, foram presas "duas feiticeiras", portanto, a terceira, que o cronista nomeia cartomante é inteiramente produto da ficção.
} 
E assim, como é da natureza da crônica, o enunciador entra pelo despretensioso, brinca, chama a mulher feiticeira, diz-se doente e afirma estar inclinado recorrer à feitiçaria para, em seguida, destilar mais uma provocação: "Sim, creio na feitiçaria, como creio nos bichos de Vila Isabel ${ }^{229}$, outra feitiçaria, sem sacos de feijão." O leitor, que não deveria levá-lo a sério, se o fez, saiu ludibriado. Uma vez que atacara a política por acreditá-la corrompida, ao voltar-se ao júri, titubeia e lança a dúvida: talvez as instituições ainda possam ser credíveis, afinal, o júri "exprime a grande idéia do julgamento pelos pares, examina-se o fato sem prevenção de magistrados", embora muitos afirmem tratar-se de uma "instituição feiticeira". Mas, para afirmar isso, conclui: "Ser-me-ia preciso examinar este ponto, longamente, profundamente, independentemente, e não há em mim agora profundeza, nem independência, nem me sobra tempo para tais estudos."

E aí está a prudência e a arte do cronista: não querer ir além da borboleta de que fala Alencar ${ }^{230}$. É preciso manter a leveza, o rés-do-chão (segundo Antonio Candido) do gênero e alfinetar, criticar, mas sem nocautear, pois o público pode ter opinião variada sobre os temas. Não se trata apenas de buscar o mínimo, o escondido, mas também de tratá-lo quase tangencialmente, fazendo referência a elementos literários, sem carregar demais nas tintas e, para isso, o tom irônico e a literatura, com todos os seus matizes, servem bem.

\section{1. "Nada há pior que oscilar entre dois assuntos."}

É sabido que as características estilísticas dos textos jornalísticos machadianos se pautam pelo fato de o cronista segredar ao leitor seu gosto pela "arraia-miúda" e a

\footnotetext{
${ }^{229}$ O jogo do bicho foi inventado em 1892, pelo barão João Batista Viana Drummond, fundador e proprietário do jardim zoológico do Rio de Janeiro, em Vila Isabel, RJ.

${ }^{230}$ Em "Ao Correr da Pena" Correio Mercantil (24/9/1854 - p. 1) Alencar reflete sobre a condição do folhetinista: "Obrigar um homem a percorrer todos os acontecimentos, a passar do gracejo ao assunto sério, do riso e do prazer às misérias e às chagas da sociedade; e isto com a mesma graça e a mesma nonchalance com que uma senhora volta as páginas douradas do seu álbum, com toda a finura e delicadeza com que uma mocinha loureira dá sota e basto a três dúzias de adoradores! Fazerem do escritor uma espécie de colibri a esvoaçar em ziguezague, e a sugar, como o mel das flores, a graça, o sal e o espírito que deve necessariamente descobrir no fato o mais comezinho!"; mais à frente, no mesmo texto é a metáfora da borboleta que vem à tona: "Ainda isto não é tudo. Depois que o mísero folhetinista por força de vontade conseguiu atingir a este último esforço da volubilidade, quando à custa de magia e de encanto fez que a pena se lembrasse dos tempos em que voava, deixa finalmente o pensamento lançarse sobre o papel, livre como o espaço. Cuida que é uma borboleta que quebrou a crisálida para ostentar o brilho fascinador de suas cores; mas engana-se: é apenas uma formiga que criou asas para perder-se.”
} 
pouca importância que outorga aos assuntos que puxam "para si todo o cobertor da atenção pública". 231

Contudo, 14/4/1895 232 parece não responder por aquelas "semanas ricas", haja vista ao esvaziamento de notícias pós-quaresma. A edição do dia anterior à crônica, além dos anúncios habituais (Publicações a Pedido, Telegrammas, Avisos, etc), ocupouse da Semana Santa (relatos sobre as procissões do dia anterior, Sexta-feira Santa, e as missas do domingo da ressurreição) e anúncios dos bailes e espetáculos do dia, o Sábado de Aleluia.

Ao correr os olhos pelas páginas 3 e 6 da edição de 13/4/1895 (sábado), a impressão que se tem é de desafogo, um grande alívio, pelo fim das interdições impostas pela religião ${ }^{233}$. O Theatro Apollo apresenta A Pera de Satanaz, opereta com música de Offenbach, Lecocq, Furtado Coelho e outros; o Theatro Sant'Anna traz A Loteria do Diabo, além de um "Baile á Fantasia", e o Theatro Recreio Dramatico dá espaço para o Espectaculo e Baile á Fantasia - Festa Pariziense.

Nos clubes, o clima não era diferente: o C.U.F. Conde d'Eu, o Club Riachuelo, S. Christovão, dos Fenianos e o Pantheon Recreativo divulgaram seus bailes através de grandes anúncios, cujo maior deles, o do T.D.S.E. Commercial, anunciava os Tenentes do Diabo e prometia um Sabbado de Alleluia Judaico e ressurreicorico (sic) com a "Final apotheose das... batalhas da folia: Lucias mephistophelicas!! Ruidosos sorrisos de Momo!!! Revelações ironicas de Platão e... ultimos sonhos fantasticos de Satanaz." E é nesse contexto, entre o sacro e profano, que o cronista toma da pena em tom de desabafo:

\footnotetext{
Nada há pior que oscilar entre dois assuntos. A semana santa chama-me para as cousas sagradas, mas uma idéia que me veio do Amazonas chama-me para as profanas, e eu fico sem saber para onde me volte primeiro. Estou entre Jerusalém e Manaus; posso começar pela cidade mais remota, e ir depois à mais próxima; posso também fazer o contrário.
}

\footnotetext{
231 "A semana”, Gazeta de Notícias, 10/7/1892.

232 "A Semana", Gazeta de Notícias.

${ }^{233}$ Durante a quaresma e em noites de chuva os teatros eram fechados. Nas "Crônicas do Dr. Semana", publicadas na Semana Illustrada, em 27/3/1864, discutia-se sobre a lei que impedia os teatros de abrirem às sextas-feiras da quaresma e na véspera do Dia de Ramos (Vale lembrar que essas crônicas creditadas a Machado na publicação da Jackson, foram excluídas na Obra Completa da Aguilar). Magalhães Jr., em Machado de Assis Desconhecido (1957: 210-222), comenta, sobretudo as "Preleções Gramaticais", atribuídas a Machado; a seu ver, levianamente, pois não condizem em absoluto com o feitio intelectual do escritor.
} 
Havia um meio de combiná-las: era meter-me em uma das montarias ou igarités do Amazonas, com o meu amigo Dr. J. Veríssimo, e deixar-me ir com êle, rio abaixo ou acima, ou pelos confluentes, à pesca do pirarucu, do peixe-boi, da tartaruga ou da infinidade de peixes que há no grande rio e na costa marítima. Não podia ter melhor companheiro; pitoresco e exato, erudito e imaginoso, dá-nos na monografia que acaba de publicar, sob o título A Pesca na Amazônia, um excelente livro para consulta e deleite. Como se trata do pescado amazônico e acabamos a semana santa, iria eu assim a Jerusalém e a Manaus, sem sair do meu gabinete. Mas o bom cristão acharia que não basta pescar, como S. Pedro, para ser bom cristão, e os amigos de idéias novas diriam que não há idéia nem novidade em moquear o peixe à maneira dos habitantes de Óbidos ou Rio Branco. Fôrça é ir a Manaus e a Jerusalém. ${ }^{234}$

\section{2. "Entre Manaus e Jerusalém"}

A discrepância entre os assuntos marca a dificuldade experimentada pelo cronista em oscilar entre as "coisas sagradas" e "as profanas". Ainda que tente enfeitá-las "com dois ou três adjetivos, uma reminiscência clássica, e os mais galões de estilo",235, a dicotomia sobrepõe-se como marca de escritura forçando o crônica dobrar-se a ela.

A dualidade, como eixo central, regula ora a alternância entre os extremos ora seu paralelismo. Primeiro, a indecisão: qual deles privilegiar? O sagrado, que supostamente "sufocou" o cronista ao longo da quaresma com suas mostras abusivas de beatice, ou a vida quotidiana, poço de ideias que fustiga os espíritos, provoca a razão e alimenta o talento, o gosto e a graça pela vida?

Certo que as mudanças são paulatinas e as leis, embora recentes ${ }^{236}$, tornam-se letra morta em face de dogmas e de uma Igreja acostumada a se intrometer não só nos negócios de Estado, mas, sobretudo, na vida privada das pessoas, onde a regulação do calendário é um mal menor. À força de um Rio devoto, o cronista combina suas ideias e J. Veríssimo é seu elo entre os opostos.

J. Veríssimo acabara de publicar A pesca na Amazônia (1895), e levado rio acima, rio abaixo, o cronista oscila entre a fartura do grande rio e a costa marítima, o pitoresco e o erudito, o exato e o imaginoso, completando um salto que vai da pesca do pirarucu a Pedro, pescador de almas, de Manaus a Jerusalém.

\footnotetext{
234 “A Semana”, Gazeta de Notícias, 14/4/1895.

235 "A Semana”, Gazeta de Notícias, 10/7/1892.

${ }^{236}$ A separação entre a Igreja e o Estado é decretada em 7/1/1890, logo após a Proclamação da República.
} 
Ou vice-versa, pois pontuada a frase, repentinamente, acomoda o sagrado entre as muralhas de Jerusalém e o profano adentra as páginas da crônica, com a notícia de que a Câmara de deputados dividiu-se em duas, algo que, segundo o cronista, "tende a repetir-se, a multiplicar-se, a fixar-se nos vários Estados deste país". ${ }^{237}$ A desinteligência política não passa despercebida ao cronista que pressiona as pálpebras, afina seu olhar de míope e afirma: "Os olhos de pouca vista alcançam nisto um defeito e um mal, e não falta quem peça o conserto de um e a extirpação de outro."

À medida que o cronista avança em seus argumentos, a dualidade e a contraposição de elementos persiste como característica de escrita. Neste instante, recolhido no universo dos livros, onde busca conforto e respaldo para suas escolhas, o enunciador amplia seu discurso, afasta de si o campo de observação e transfere a palavra para vozes indeterminadas quaisquer, a partir de então responsáveis por confrontar pontos de vista, escolhas e decisões.

A morfologia das frases destaca os contrários, a multiplicidade de elementos, e a indefinição do sujeito prevalece: ora são "as oposições que não gostam dos governos" ora alguns que tentam acordos, algo que se estende até que o cronista chama para perto de si seu leitor ideal, confessor e cúmplice, ressaltando a importância deste como parte integrante da escritura, afinal, "l'opération d'écrire implique celle de lire comme son corrélactif dialectique" (SARTRE, 2011: 50). Desse modo, cria-se um jogo entre cronista e leitor que faz do objeto da crônica uma “étrange toupie, qui n'existe qu'en mouvement". 238

"Sim, leitor atento,...", é nesse tom de cumplicidade que o cronista estrutura seu texto e apresenta a problemática política valorizando a diversidade das ideias e a dualidade das opiniões que provocam, lentamente, mudanças no sistema político. As oposições assimétricas surgem como marca estilística através da qual é apresentado um

\footnotetext{
${ }^{237}$ Machado, ao comentar o cisma em Manaus, fala sobre "as folhas que chegaram ontem", no entanto, foi impossível apurar a origem da notícia: os periódicos cariocas de maior circulação (Gazeta de Notícias, O Paiz, Diário de Notícias) sequer mencionam o assunto; os jornais do Amazonas tampouco (os únicos registros digitalizados disponíveis na Biblioteca Nacional d'A Federação do Amazonas são de dezembro de 1895 e do Commercio do Amazonas não se preservou nenhuma edição do respectivo ano). A única referência à notícia comentada por Machado vem do The Rio News, April 16" $6^{\text {th }}$ 1895, p. 4: "There are duplicate state legislatures not only in Bahia and Sergipe, but also in Amazonas."

${ }^{238}$ Adaptação livre do que Sartre dissera sobre o objeto literário (2011: 48).
} 
duplo cenário político virtual, porque fundamentado em reminiscências livrescas (Sócrates, Taine, a Bíblia).

Desse modo, escora-se no universo dos livros para elaborar sua crítica e, capciosamente, desvela a seu leitor que ambos os segmentos, de fato, são perfis de um mesmo ser o qual, dissimulado, move-se à medida que alteram seus interesses, e o visto nada mais "é [que] a impressão em dois exemplares da mesma gramática".

\section{Em Jerusalém}

Ao constatar a dissimulação, o interesse e a fragilidade do espírito como amálgamas do "barro humano", o cronista volta-se para o sagrado: em tom profético, parafraseia o Cristo e admoesta seu leitor para que não se deixe seduzir, prevenindo-o para tempos difíceis em que lobos virão em pele de cordeiro:

Virão breve os tempos messiânicos, melhores ainda que os de Israel, porque lá os lobos deviam dormir com os cordeiros, mas aqui os cordeiros dormirão com os cordeiros, à falta de lobos.

O entrecho acima demonstra a fina ironia machadiana. Ao embaralhar os contrários, o cronista faz com que o lobo surja travestido de cordeiro, tornando-se seu oposto. Uma vez extinta uma das partes, a dificuldade estará em identificar o adversário, pois, com os opostos aparentemente unificados, o cordeiro sair-se-á tão ou mais perigoso que o lobo e aniquilará seus símiles. Essa consciência dos contrários que se eleva ao absoluto traz algo de bufoneria e se a ironia por um lado surge como princípio subjacente que guia o cronista em sua criação, por outro, dá conta das contradições do espírito, surgindo como paradoxo.

E assim, oscilando entre um assunto e outro, aporta a Jerusalém:

Há meia dúzia de assuntos que não envelhecem nunca; mas há um só em que se pode ser banal, sem parecê-lo, é a tragédia do Gólgota. Tão divina é ela que a simples repetição é novidade. Essa cousa eterna e sublime não cansa de ser sublime e eterna. Os séculos passam sem esgotá-la, as línguas sem confundi-la, os homens sem corrompê-la.

“O Evangelho fala ao meu coração", escrevia Rousseau; é bom que cada homem sinta êste pedaço de Rousseau em si mesmo... 
Entretanto, se eu admiro o belo sermão da Montanha, as parábolas de Jesus, os duros lances da semana divina, desde a entrada em Jerusalém até à morte no Calvário, e as mulheres que se abraçaram à cruz, e cuja distinção foi tão finamente tratada por Lulu Sênior, quinta-feira, se tudo isso me faz sentir e pasmar, ainda me fica espaço na alma para ver e pasmar de outras cousas. Perdoe-me a grandeza do assunto uma reminiscência, aliás incompleta, pois não me lembra o nome do moralista, mas foi um moralista que disse ser a fidelidade dos namorados uma espécie de infidelidade relativa, que vai dos olhos aos cabelos, dos cabelos à bôca, da bôca aos braços, e assim passeia por tôdas as belezas da pessoa amada. Espiritualizemos a observação, e apliquemo-la ao Evangelho.

Assim é que, no meio das sublimidades do livro santo, há lances que me prendem a alma e despertam a atenção dos meus olhos terrenos. Não é amá-lo menos; é amá-lo em certas páginas. Grande é a morte de Jesus, divina é sua paciência, infinito é seu perdão. A fraqueza de Pilatos é enorme, a ferocidade dos algozes inexcedível...

Mas, não sendo primoroso o último ato dos discípulos, não deixa de ser instrutivo. Um, por trinta dinheiros, vendeu o Mestre; os outros, no momento da prisão, desapareceram, ninguém mais os viu. Um só dêles, sem se declarar, meteu-se entre a multidão, e penetrou no pretório entre os soldados. Três vêzes lhe perguntaram se também não andava com os discípulos de Cristo; respondeu que não, que nem o conhecia, e, à terceira vez, cantando o galo, lembrou-se da profecia de Cristo, e chorou. S. Mateus, contando o ato dêste discípulo, diz que ele entrara no pretório, com os soldados, 'a ver em que parava o caso'. Hoje diríamos, se o Evangelho fosse de hoje, ‘a ver em que paravam as modas'. Tal é a mudança das línguas e dos tempos!

Este versículo do evangelista não vale o sermão da Montanha, mas, usando da teoria do moralista a que há pouco aludi, esta é a pontinha da orelha do Evangelho. ${ }^{239}$

Antífrase, relativização, inversão: mais uma vez, o que se apresenta como um brusco desvio para o sagrado revela-se puro engodo: o artifício é simples, falar do profano, mas envolto pelo sagrado. Ao afirmar admiração e estima pelos trechos do Evangelho que relatam a tragédia do Gólgota, considerando-a "divina”, de fato, o cronista reflete sobre a estrutura do texto e não sobre sua religiosidade.

Nesse sentido, nota-se que os aspectos textuais pontuados pelo cronista demonstram que a tragédia do Gólgota reúne os mesmos requisitos dos clássicos profanos, portanto, aproximá-la das tragédias seculares equivale a relativizar o caráter divino do texto. Em sua reflexão sobre o Gólgota (entrecho acima), encontram-se

239 “A Semana”, Gazeta de Notícias, 14/4/1895. 
parâmetros que delimitam ou explicam o porquê de se considerar clássico um determinado texto. ${ }^{240}$

"Há meia dúzia de assuntos que não envelhecem nunca, mas há um só em que se pode ser banal, sem parecê-lo, é a tragédia do Gólgota. [...] Os séculos passam sem esgotá-la, as línguas sem confundi-la, os homens sem corrompê-la." A partir disso o cronista introduz seu leitor no universo dos clássicos que atravessam o tempo, permanecem na biblioteca coletiva, são submetidos a frequentes leituras (veja-se a referência a Lulu Sênior) e atualizados ao longo da história.

E “o belo sermão da Montanha, as parábolas de Jesus, os duros lances da semana divina, desde a entrada em Jerusalém até à morte no calvário, e as mulheres que se abraçaram à cruz, [...] tudo isso [...] faz sentir e pasmar" o cronista, de modo a indiciar a seu leitor que ler um clássico não é só relembrar sua leitura de juventude, mas, sobretudo, apreciar sua re-leitura já em idade madura quando experiências, modelos, escala de valores, paradigmas de beleza, etc., podem ser comparados, revistos e modificados à luz do "novo" clássico que se reescreve.

A morte de Jesus, sua divina paciência e seu infinito perdão, a fraqueza de Pilatos e a inexcedível ferocidade dos algozes não só alertam seu leitor de que os clássicos tratam essencialmente das paixões humanas, expostas de maneira intensa, múltipla e original à luz da história, como também o adverte de que exatamente por isso não se pode deixar de questionar em que medida os significados implícitos no texto foram deformados ou expandidos, diante da complexidade do tempo. ${ }^{241}$

E assim o cronista "ressuscita" (e ressalta) através do relato bíblico, aspectos da natureza humana nada louváveis como a traição, a mentira e a vilania, encobertas nas “dobras" da fábula, como se estivesse a segredar que a historieta do galo mostra-se menos sagrada que humana, afinal, ali está muito das vicissitudes do espírito desse homem que vive entre Manaus e Jerusalém, ou seja, sua história é escrita não só de "lances que prendem a alma, mas, sobretudo, de episódios que despertam a atenção para os olhos terrenos". 242

\footnotetext{
${ }^{240}$ Os parâmetros e essa reflexão sobre o "clássico" foram extraídos da obra de Ítalo Calvino, Perché leggere i classici (2012: 5-13).

${ }^{241}$ Sobre essa questão Calvino menciona a Odisseia de Homero, e o que as aventuras de Ulisses passaram a significar ao longo dos séculos.

${ }^{242}$ Trecho ligeiramente parafraseado para se adequar ao contexto.
} 
"Este versículo do evangelista não vale o sermão da Montanha, mas, usando da teoria do moralista a que há pouco aludi ${ }^{243}$, esta é a pontinha da orelha do Evangelho.” A partir da alusão ao moralista vê-se que também o cronista tem sua leitura particular do Evangelho, indiciando (e reforçando) a existência de uma relação pessoal do leitor ${ }^{244}$ para com o clássico, algo como uma "infidelidade relativa", através da qual constrói "seu” próprio livro.

Ora, uma vez que o clássico exerce uma atração tão forte a ponto de preencher (representar ou estimular) os questionamentos de seu leitor, esse fascínio pode ser tão dúbio quanto Manaus e Jerusalém, despertar sedução ou repulsa. Segundo Calvino um clássico pode despertar um relacionamento de oposição, de antítese ${ }^{245}$. Tudo o que Rousseau pensa pode falar ao coração, mas tudo isso pode inspirar um desejo incontrolável de contradizê-lo, criticá-lo. Porém, isso não quer dizer que o leitor deixa de considerá-lo um de seus autores eleitos.

Desse modo, depois de uma sufocante Semana Santa, Machado evoca Rousseau:

[...]a tragédia do Gólgota. Tão divina é ela que a simples repetição é novidade. Essa cousa eterna e sublime não cansa de ser sublime e eterna. Os séculos passam sem esgotá-la, as línguas sem confundi-la, os homens sem corrompê-la. "O Evangelho fala ao meu coração", escrevia Rousseau; é bom que cada homem sinta êste pedaço de Rousseau em si mesmo...

Considerando-se a "religiosidade" 246 de Rousseau, o leitor machadiano (e o público cristão) pode tomá-lo como importante sectário ${ }^{247}$, afinal, o cronista o introduz

\footnotetext{
${ }^{243}$ Relembrando: no antepenúltimo parágrafo o cronista mencionara o tal moralista "que disse ser a fidelidade dos namorados uma espécie de infidelidade relativa, que vai dos olhos aos cabelos, dos cabelos à boca, da boca aos braços, e assim passeia por todas as belezas da pessoa amada".

${ }^{244}$ Sobre isso, diz Calvino (2012: 9): "I classici sono libri che quanto più si crede di conoscerli per sentito dire, tanto più quando si leggono davvero si trovano nuovi, inaspettati, inediti." (Os clássicos são livros que quanto mais pensamos conhecê-los por ouvir dizer, quanto mais os lemos, mais verdadeiramente se mostram novos, inesperados, inusitados.)

245 "Ma un classico può stabilire un rapporto altrettanto forte d'opposizione, d'antitesi (2012: 10)." - (Mas um clássico pode estabelecer um forte relacionamento de oposição, de antítese.)

${ }^{246}$ Rousseau era bastante cético quanto à religião revelada como era disseminada pela Igreja e por seus livros, todos traduzidos (questionava as traduções). Nascido em Genebra, educado no protestantismo calvinista, aos 17 anos, de passagem por Turim, converte-se ao catolicismo; depois, aos 42 anos, abjura o catolicismo e volta ao protestantismo. Na Lettre à Christophe de Beaumont (1835: 772) Rousseau afirma: "Monseigneur, je suis chrétien, et sincèrement chrétien, selon la doctrine de l'Évangile. Je suis chrétien, non comme un disciple des prêtres, mais comme un disciple de Jésus-Christ." A fórmula revela um cristianismo singular, despido de toda teologia (fé necessária, milagres, pecado original, etc.) e faz de sua fé um deísmo racionalista a exemplo de Malebranche (GOUHIER, 1970: 139).
} 
como respeitável referência de autoridade. Porém, na esfera do folhetim, o filósofo perde influência e status, uma vez que suas palavras, destituídas do tom filosófico e justapostas à coisa miúda, ganham como constituinte o efeito relativista pertinente à ironia. Não por outra razão o Rousseau presente nas crônicas é um Rousseau depurado, escoado pela cultura popular, restando nada mais que uma essência cujas gotas, volatilizadas, dissipam-se por entre a matéria chã que compõe o ordinário da vida.

Desse modo, a partir de uma cultura incontestavelmente operante, mas apenas indiciada por meio de clichês, máximas, aforismos, etc., o cronista reflete sobre o quotidiano. E uma vez que começara por Veríssimo, preparado o anzol, pescar um pirarucu, olhar para Pedro e pinçar uma alma, foi tão simples como ir de Manaus a Jerusalém.

\section{4. À guisa de conclusão}

Avesso ao culto do progresso, levado por seus argumentos e imbuído da vontade de realizar um "reforma moral", Rousseau afasta-se da mundanidade fervilhante das cidades e, não sem contradição, das artes e das letras. Prefere o campo e, em Montmorency, condado de Luxembourg, escreve suas três grandes obras: La Nouvelle Héloïse (1761), Émile (1762) e Du Contrat social (1762). Com Émile condenado pelo Parlamento de Paris, sobretudo pelas ideias religiosas disseminadas em Profession de foi, Rousseau tem sua prisão decretada e começa, aos 50 anos, uma vida de errante solitário.

Afastado, defende-se com as Lettres écrites de la montagne (1764), e, em meio a natureza, talvez refletisse sobre o homem americano, acreditando que de alguma forma este pudesse estar mais próximo de seu homem natural. Porém, o que talvez jamais tenha imaginado é que suas ideias e seu nome agregariam sentido às palavras de um capcioso cronista tupiniquim, hábil em manusear a ironia tal qual Voltaire, seu arquiinimigo, que a ela se voltou inúmeras vezes até mesmo para ridicularizá-lo.

Nas crônicas, o palco é menor; porém, a lógica de suas ideias, pulverizada em meio a assuntos tão ou mais mundanos do que imaginara (golpes de estado, invenções fraudulentas, escândalos de corrupção, prisões, feitiçaria, etc.), mantém-se intacta e

${ }^{247}$ No sentido de fiel, que segue os princípios e professa determinada religião. 
contribui para revelar o escondido, não só porque o folhetim pede graça e elegância, mas, sobretudo porque o cronista machadiano não se dobra ao "peso" rousseauniano, e sim, faz dele contrapeso para revelar a dissimulação.

Nessa perspectiva, Rousseau contribui para revelar uma ironia já implícita, pois, segundo Schaerer

[...] la dissimulation est la cactéristique première de l'ironie: c'est un masque, mais qui demande à être arraché. Ce seconde mouvement ramène l'ironie vers la sincérité ; il révèle aussi le mécanisme de l'ironie, qui est celui d'un dédoublement : pour qu'il y ait ironie, il faut qu'un même objet suscite deux opinions contraires (2001: 43).

Assim, expressões como "o homem natural", "a doutrina de Rousseau", o "Estado social de Rousseau”, etc., uma vez vulgarizadas, tornadas clichês, redirecionam sentidos, ampliam o universo de significação das crônicas e na esfera filosófico-literária contribui para a sedimentação da integração Brasil-França numa época em que a literatura brasileira permitia-se inundar de galicismos, teorias, autores, histórias e personagens franceses para construir seus próprios alicerces. Digeridos, os intertextos não só revelam a integração do elemento estrangeiro no texto brasileiro, mas, circunscritos à esfera das crônicas, estofam a ironia machadiana.

No mais, ressalta-se que o século XIX viu-se indiscutivelmente como tributário do Siècle des Lumières, período em que a humanidade luta contra a injustiça e a opressão, e começa a afrontar toda sorte de preconceitos e fanatismos. A literatura, que, por sua vez, torna-se em alguns casos, expressão da voz do povo, também veicula ideias filosófico-científicas e culturais, encontrando ali espaço ideal para disseminação e vulgarização.

O mesmo ocorre com o jornal, que floresce e se moderniza a partir do início do século XIX, prosseguindo com a popularização de conteúdos pautados por eruditismo e ilustração. Por essa razão, pode-se afirmar que Rousseau é visto, sobretudo, não a partir de seus próprios textos, mas de referências a seu nome ou de temas abordados por ele, algo tratado em maior grau como uma fortuna crítica e, em ponto menor, através de comentários em revistas e periódicos semanais. Jornais oitocentistas como a Gazeta de Notícias, O Paiz, Diário do Rio de Janeiro, Correio Mercantil, etc.,(afora os franceses Le Siècle, Le Monde, Le Figaro Chroniquer, La Revue des deux mondes, comumente 
lidos no Rio) eram literalmente recheados de citações, adaptações, comentários e trechos de autores como Rousseau, Voltaire, Montesquieu, Diderot - e inúmeros outros.

Por fim, não é de se crer que Machado tenha lido Rousseau em profundidade, mas, a exemplo da crônica borboleteante, Machado, como o colibri que esvoaça em ziguezague, suga um mel já depurado pela cultura geral, ou seja, ao submeter o fato bruto à têmpera do folhetim, resume, evoca e dá continuidade à circulação das grandes ideias, tais quais as rousseaunianas.

Nessa lógica, não é Rousseau, o grande filósofo que se "materializa" nas páginas da crônica, mas princípios e temas criados por ele, decantados pela cultura popular, filtrados pela interpretação de segunda mão do cronista, subordinando-os à crônica, cujo texto mantém a liderança de sentido. Dessa forma, Rousseau aclimata-se plenamente ao comezinho pinçado por um cronista em voo de colibri a sugar o mel, a graça e o espírito da notícia. 


\section{DIDEROT}

"La plus haute efficacité de l'esprit est d'éveiller l'esprit."

(Goethe, em declaração a respeito de Diderot)

\section{A LETTRE}

\section{As polêmicas}

O século XVIII foi acima de tudo uma época de confronto de ideias. A ordem clássica, sustentáculo da tradição, parecia imutável; materializada, afigurava-se permanente, afastava contradições, alicerçava sociedades e "estagnava" o pensamento. Não por outra razão, Bossuet era visto, no começo do século, como o representante do espírito francês por excelência. Seu Discours sur l'Histoire Universelle (1681), desenvolvido sob a filosofia da revelação, sequencia as eras históricas como bastiões majestosos que conduzem ao Messias. Era o império da fé. Porém, ainda no final do século XVII, tudo parece se mover. As ideias se metamorfoseiam, os espíritos tornam-se mais audaciosos, forças intelectuais e morais questionam a religião, o progresso atropela a tradição e a ciência questiona a fé.

O espírito da dúvida reina em todas as esferas: discute-se a autenticidade dos textos sagrados assim como se acalenta o sonho de uma era de felicidade terrestre fundada na razão e na ciência. Seja no domínio das ciências, da filosofia, das instituições acadêmicas, seja no mundo artístico e literário, nas ciências sociais e históricas, em todos os lugares, explodem polêmicas e desencadeiam-se controvérsias intelectuais que, não raro, do seio dos especialistas saltam para a arena pública ganhando foro de verdadeiros acontecimentos sociais e políticos.

A polêmica, em suas diversas modalidades - ficção, panfletos, libelos, manifestos, sátiras, ficção, etc. -, constituiu-se, talvez, no mais importante dos vórtices que movimentaram a voragem do espírito francês ao longo do século XVIII. Ancorada na retórica, sob a rubrica de essai, a polêmica não só respondeu pela polarização das ideias, como também promoveu entre estudiosos e pesquisadores, a violência verbal: insultos, injúrias e invectivas. 
Muitas vezes, a dinâmica que se imprimiu ao debate passou ao largo do confronto de ideias e o afrontamento teve como sustentáculo o argumentum ad hominem. Que o diga Voltaire: em 9/8/1742, após o escândalo provocado pela estreia de Mahomet, em Paris, clero e magistrados protestam e o procurador-geral obriga Voltaire a retirar sua peça de cartaz. Este, furioso, obedece, porém, logo sua indignação se transforma em sofrimento; humilhado, suplica ao chefe de polícia que "ordene que o abade Desfontaines ${ }^{248}$ não derrame seu veneno nesta ferida" (BADINTER, 2007: 160, Vol. I).

O principal palco das forças em confronto, na maioria das vezes, foi a Academia de Ciências: lá, travou-se o embate entre cartesianos e newtonianos, afinal, quem estaria com a razão? Em Paris, a Terra era vista com os pólos alongados; em Londres, achatada dos dois lados: a polêmica ficou por conta de Maupertuis, o newtoniano, e Cassini, que, ao lado de Réaumur, Bignon e Fontenelle, todos, homens do século XVII, estavam convencidos de que o universo cartesiano era o que mais se aproximava da "verdade". Ali também, Madame du Châtelet é oficialmente reconhecida como erudita depois de uma polêmica científica ${ }^{249}$ (1740-1741) com o secretário perpétuo da Academia, Dortous de Mairan.

Mas, ao longo do século XVIII, polêmicas e paixões intelectuais são atropeladas por uma força desconhecida do Grand Siècle: a opinião pública. O confronto de ideias e opiniões, antes restrito a pequenos círculos de ilustrados, ganha os salões. Eruditos e estudiosos (além de seus adversários) ficam expostos à apreciação de professores, leitores de periódicos e amadores esclarecidos, todos, ávidos pela disseminação da palavra e por fazer valer seus pontos de vista.

\footnotetext{
${ }^{248}$ Esse abade libertino, conhecido autor de La Voltairomanie (1738) fez sua conturbada carreira no jornalismo. De 1723 a 1727, ele dirige o Journal des Savants, do qual vem a ser expulso. Funda posteriormente as Observações sobre os escritos modernos (1735-1743). Quando este é suspenso, ele funda com Fréron, em 1744, a Jugements sur quelques ouvrages nouveaux, morrendo em dezembro de 1745. Seu tom agressivo e suas polêmicas sem conta contribuíram em grande parte para o sucesso de seus jornais. Conforme nota In: BADINTER, Elisabeth. As paixões intelectuais, v. 1: Desejo de glória (17351751). Rio de Janeiro: Civilização Brasileira, 2007, p. 464, nota 127.

${ }^{249}$ A polêmica remonta ao ano 1738, com a primeira publicação de Madame du Châtelet (Dissertation sur la nature et la propagation du feu), porém, em 1741, está no auge: Mme du Châtelet que havia se tornado autêntica leibniziana, coloca em cheque Mairan ao publicar Institutions de Physique (1740), questionando pontos da Dissertation sur l'estimation et la mesure des forces motrices des corps, apresentada à Academia em 1728 e publicada em 1741. Na sequencia, a polêmica ganharia ainda as peças: Lettre de $M$. de Mairan à Madame la Marquise du Chastellet sur la question des forces vives, en réponse aux objections qu'elle lui fait sur ce sujet dans ses Institutions de physique (1741) e a réplica de Mme du Châtelet : Réponse à la lettre de Mairan sur la question des forces (1741).
} 
A imprensa ganha força a ponto de D'Alembert, em 1765, confessar que o que mais o "irrita e impacienta é a impertinência de certas gazetas", referindo-se, em seguida, aos “impertinentes jornalistas” (BADINTER, 2009: 81, Vol. III). Contudo, é através da publicação de libelos na imprensa que muitas polêmicas irradiam-se para além das fronteiras francesas, envolvendo adversários em toda a Europa. Voltaire, grande propagandista, de quem dizia-se «Quand on combattait le vice chez le diable d'homme, on finissait toujours pas blesser la vertu. » (KOHLER, 1948: 308) protagonizou polêmicas que entraram para a história da contensão do espírito, tal o célebre Affaire Calas.

Voltaire contendeu-se a partir de um caso prático; mas qual o espírito do homem do século XVIII, que se indignava, tomava posições e demarcava territórios no espaço da retórica e das ideias? De fato, as ideias viviam numa encruzilhada incerta: dogmas, princípios cristãos, o direito divino, hierarquia, opressão e desigualdade desenham o universo do homem do século XVII, embora logo depois, não obstante a persistência de certo ranço do Grand Siècle, o homem setecentista começasse a vislumbrar mudanças. Consoante Hazard (1961: 8-11), a heresia deixa de ser solitária e a razão, de sabedoria equilibrada, torna-se uma audácia crítica.

O homem do século XVIII vê o mundo em convulsão: Deus é colocado em dúvida e o divino é acantonado em céus desconhecidos e impenetráveis, o homem torna-se o parâmetro para todas as coisas, sua razão de existir e seu fim. Destarte, era preciso construir um novo mundo e uma nova filosofia que renunciasse aos sonhos metafísicos, ao direito divino e buscasse o direito natural, uma religião sem mistério e uma moral sem dogmas. A ciência, longe de ser um simples jogo de espírito, deveria subjugar a natureza, pois só assim, o homem conquistaria a felicidade, o bem-estar.

Nesse contexto, em que cada vez mais se anunciava a falência de uma civilização esvaziada de direitos e fundada sobre o jugo da obrigação ao príncipe e em relação a Deus, filósofos acenam com a possibilidade de se criar uma nova civilização, cujo arcabouço é a ideia de direito: direito individual, direito à razão, à crítica, ao homem e ao cidadão. ${ }^{250}$ Assim, face às indecisões, cultivou-se no século XVIII a arte das antinomias: acreditar ou não acreditar (em Deus), obedecer à tradição ou revoltar-se contra ela, seguir antigos líderes e seus princípios ou voltar-se contra eles e sair em

\footnotetext{
${ }^{250}$ Este parágrafo traz em substância informações colhidas em La crise de la conscience européenne (HAZARD, 1961) - op. cit.
} 
busca de novas ideias e de uma nova - e racional - "terra prometida"? Ser empirista ou racionalista? Não raro, em proveito de uma inteligência estratégica, num sentido puramente oratório, alimentou-se por décadas polêmicas como La querelle des Anciens et des Modernes, e controvérsias como La querelle sur la poésie e La querelle sur Racine foram objeto de inúmeros debates e injetaram ânimo às discussões. Há casos em que centenas de páginas foram escritas a partir de uma simples indagação, à guisa das questões propostas por academias francesas, que resultaram em alguns dos célebres textos de Rousseau. Assim também, de uma indagação, veio à luz o "problème de Molyneux".

\section{O "problème de Molyneux"}

De fato, a questão, que ficaria conhecida por "problème de Molyneux"251, agitou o mundo filosófico por mais de um século a tal ponto que, afirma-se, depois dela pouco ou quase nada de novo apareceu ou foi desenvolvido no campo da filosofia da percepção.

A história toda tem origem na afirmação de que todo conhecimento humano provém ou da experiência com objetos externos, através da sensação, ou de operações intelectuais internas, por meio da reflexão, assertiva feita por Locke, em seu Essai sur l'entendement humain (1689), onde trata da percepção. Dito isto, William Molyneux (1656-1698), homem de letras, irlandês, interpela o inglês com a seguinte questão: "Um homem cego de nascença, que tivesse aprendido a distinguir um cubo de uma esfera através do tato, saberia distingui-los, sem os tocar, se tivesse sua visão restaurada?" 252 O filósofo inglês responde que "não" e reitera que o cego deve aprender pela experiência a coordenar suas sensações da vista e do tato.

\footnotetext{
${ }^{251}$ Diderot, na Lettre, afirma: «Ce fut M. Molyneux qui proposa le premier cette question, et qui tenta de la résoudre : [...]» (2000: 66). Contudo, foi através de Voltaire que o problema ganhou repercussão em toda a Europa (2000: 183 - nota 75).

${ }^{252}$ Locke incorpora a questão de Molyneux à segunda edição de seu ensaio: “À cette occasion, j'insérerai ici un problème du savant $M$. Molyneux, qui emploie si utilement son beau génie à l'avancement des sciences. Le voici tel qu'il me l'a communiqué lui-même dans une lettre qu'il m'a fait l'honneur de m'écrire il y a quelque temps : supposez un aveugle de naissance, qui soit présentement homme fait, auquel on ait appris à distinguer par l'attouchement un cube et un globe, du même métal, et à peu près de la même grosseur, en sorte que lorsqu'il touche l'un ou l'autre, il puisse dire quel est le cube et quel est le globe. Supposez que le cube et le globe étant posés sur une table, cet aveugle vienne à jouir de la vie. On demande si, en les voyant sans les toucher, il pourrait les discerner, et dire quel est le globe et quel est le cube » (LOCKE, 2009 : 271, livre II, chap. 9, § 8).
} 
Mas o que está por trás desta questão que suscitou tanta controvérsia e fascinou o século XVIII? Se o pensamento não tem outra origem que a sensação, pode-se perguntar, por exemplo, se diferentes maneiras de sentir determinam pensamentos diferentes sobre um mesmo dado. Pode-se ir além: há um mundo tátil e um mundo visual? É possível deslocar-se de um para outro? Um cego de nascença que recuperasse a visão poderia conciliar suas concepções primeiras com aquelas que ele acabasse de descobrir? Os sentidos (tato e visão) são autossuficientes à consciência para a construção de uma forma de ver o mundo, ou seriam necessários outros: a linguagem, por exemplo? Para que se construa uma concepção do que quer que seja, é necessário que fenômenos de percepção sigam uma ordem fixa?

Para responder a estas e outras questões, e, uma vez que o mundo se nos apresenta sempre como algo já constituído, era necessário lançar mão de procedimentos experimentais, aliás, só a experiência, essa grande arma comprobatória da ciência, aniquiladora de dogmas, poderia dar conta da infinidade de percalços advindos da questão: dados que levariam às ideias de posição, tamanho e distância. Disso, nota-se a necessidade da representação: a representação resultante dos vários dados sensíveis e da capacidade da consciência se deslocar de um para o outro, donde advém a ideia de espaço, diga-se, de maneira puramente empírica, sem a necessidade de qualquer conexão lógica ou raciocínio.

Um erudito, a necessidade de satisfazer sua curiosidade pessoal e uma questão de cunho marcadamente psicológico que promove toda uma discussão teórica e embala o raciocínio às voltas com um autêntico problema: saber qual é a relação entre os diferentes sentidos: ofereceriam todos a mesma informação ou nossa experiência sensorial é qualitativamente diferenciada de acordo com o sentido com que é transmitida? O debate em torno da questão proposta mobiliza grande parte das cabeças pensantes da época. Leibniz em seu Nouveaux Essais sur l'entendement humain (1765) e Condillac em Essai sur l'origine des connaissances humaines (1746), ambos, responderam "sim" à questão: o primeiro, ao afirmar que o cego pode perfeitamente aprender geometria pelo toque, caso contrário, haveria duas geometrias, uma para os paralíticos e outra para os cegos, quando, de fato, a geometria é única para ambos, porque fundada nas ideias exatas; já Condillac, busca mostrar a ausência de qualquer julgamento em nível de percepção, ou seja, acredita que a visão imediata pode 
proporcionar a ideia de figura e grandeza sem as sensações motoras e táteis que o movimento de "ir ver", "ir tocar", nos proporciona (HOBSON; HARVEY, 2000: 227).

O fato é que o problema de Molyneux mostrou-se verdadeiro exercício de reflexão da filosofia empírica, tanto é que, nem a primeira cirurgia de catarata realizada pelo cirurgião e anatomista William Cheselden (1728) pôs fim ao debate. Outros ainda se envolveriam na questão: Berkely, Voltaire e Diderot. Dentre eles, Diderot destacouse com sua Lettre sur les aveugles à l'usage de ceux qui voient (1749).

\section{Lettre sur les aveugles à l'usage de ceux qui voient}

O aparecimento da Lettre sur les aveugles em meio a toda essa discussão filosófica traz algo, no mínimo, curioso, sobretudo, ao se dar crédito à filha de $\operatorname{Diderot}^{253}$ : segundo ela, a Lettre estaria entre os livros pelos quais Diderot não recebera mais que 50 luíses, repassados imediatamente a sua amante, Mme de Puisieux, para satisfazer as exigências dela. Verdade seja dita, o fato é que dentre os livros citados ${ }^{254}$ por Mme. de Vandeul (1992: 26-27) em três deles nota-se claramente a evolução do pensamento filosófico do autor. Das Pensées (1746), que segundo o Parlamento de Paris, contém o "veneno" do ceticismo e do deísmo (BADINTER, 2007: 270,444, Vol. I) à Lettre, Diderot flerta com o materialismo ateu ao longo das etapas que caracterizam a filosofia do iluminismo.

A origem da Lettre é uma "estreia" científica: tratava-se de uma operação de catarata patrocinada por Réaumur e que seria realizada pelo oculista prussiano Hilmer, sendo a paciente em questão Mlle Simoneau, cega de nascença. A cirurgia colocou metafísicos, filósofos e médicos em polvorosa. Afinal, como uma pessoa privada de um dos sentidos concebia o mundo? Como lhe vinham as ideias e como elas se modificariam após sua primeira confrontação com a natureza? Diderot queria estar presente no instante em que a venda fosse retirada dos olhos de Mlle Simoneau, queria interrogá-la tão logo recuperasse a visão, pretendia saber se sua percepção e ideias eram as mesmas que as das pessoas que enxergam, contudo, Réaumur não autorizou sua presença. Diderot, evidentemente, não gostou dizendo que Réaumur “n’a voulu laisser

\footnotetext{
${ }^{253}$ Trata-se de Marie-Angélique de Vandeul, filha de Diderot, autora de Diderot, mon père.

${ }^{254}$ Essai sur le mérite et la vertu, de Shafestesbury, traduzido e anotado por Diderot (1745), Pensées philosophiques (1746), Les bijoux indiscrets (1748) e Lettre sur les aveugles à l'usage de ceux qui voient (1749).
} 
tomber le voile que devant quelques yeux sans conséquences", afinal, a paciente ofereceria uma oportunidade única de verificar experimentalmente a precisão - ou não -, de concepções há muito largamente discutidas por moralistas de todos os confins.

Na impossibilidade de "experimentar" com Mlle Simoneau, Diderot funda suas reflexões a partir de uma visita que fizera a um cego de nascença de Puiseaux (perto de Pithiviers), na leitura do matemático inglês - também cego -, Saunderson, no Traité sur les systèmes (1749), de Condillac e em sua própria imaginação (BADINTER, 2007: 271, Vol. I). De fato, o propósito de seu livro não é nada prosaico; do tom, denota-se o trabalho de um erudito, de um psicólogo, jamais de um panfletário, e chega ser surpreendente a precisão e a extensão das reflexões que Diderot faz sobre os cegos. Tem-se a impressão de que leu tudo sobre tratados de óptica, tal a perspicácia de suas considerações, inclusive com intuições pedagógicas para a educação dos cegos. Segundo Lepape (1991: 84), Diderot leu e entendeu muito bem Condillac e seu Essai sur l'origine des connaissances humaines (1746), porém, na Lettre essa compreensão vem acrescida da vivacidade de seu olhar, da riqueza de sua imaginação e da originalidade de sua abordagem metodológica dos problemas.

No intuito de entender o funcionamento da normalidade (da visão), Diderot se propõe a estudar o que é anormal. Com isso, envolve o leitor conduzindo-o pelos meandros e volteios que sua abordagem suscita a ponto de tocar em algo polêmico e suscetível de toda sorte de melindres: nossas ideias sobre Deus, sobre o bem e o mal são absolutas ou dependem de uma relação estreita com nossos sentidos? O que, no caso, determinaria a relatividade de nossas "verdades"? Se a maior prova da existência de Deus, segundo a teologia natural amplamente apregoada, reside na beleza e na harmonia da Criação, o que significa esse espetáculo para um cego? E mais: quem é este Deus que priva algumas de suas inocentes criaturas da possibilidade de acreditar em sua existência?

De fato, o núcleo da argumentação de Diderot, reside na narrativa da morte do matemático inglês (Saunderson), quando imagina um diálogo que este poderia ter tido com um pastor sobre a existência de Deus. Na conversa, o pastor evoca as maravilhas da natureza, sabidamente, a prova da existência de Deus mais difundida no século XVIII. Porém Saunderson, incrédulo, a recusa: 
Eh! Monsieur, lui disait le philosophe aveugle, laissez-là tout ce beau spectacle qui n'a jamais été fait pour moi. J'ai été condamné à passer ma vie dans les ténèbres, et vous me citez des prodiges que je n'entends point, et qui ne prouvent que pour vous et que pour ceux qui voient comme vous. Si vous voulez que je croie en Dieu, il faut que vous me le fassiez toucher (DIDEROT, 2000: 59).

Para muitos, uma heresia, mas a fala de Diderot via Saunderson, mostra a maneira que encontrou para expressar suas ideias a respeito de Deus e da moral, sugerindo que, longe de serem absolutas como se fazia crer, ao contrário, estavam subjugadas à condição física e aos sentidos. Nas palavras de Badinter (2007: 271, Vol. I): "Fim do Deus tradicional, das idéias inatas de bem e de mal etc.! Triunfo do sensualismo e do materialismo [...]" Afinal, o cego revela ao pastor as "verdades" que ele se recusa a ver, calando-o!

Por meio de observações, considerações algébricas e médicas, Diderot resvala em algo ousado e perigoso. Com isso transpõe uma importante etapa de seu desenvolvimento intelectual: do deísta das Pensées philosophiques (1746), na Lettre, traz à luz suas primeiras ideias de pensador materialista. No mais, Diderot retoma em profundidade o sensualismo preconizado por Locke em seu Essai sur l'entendement humain (1689), onde afirma que não se pode conhecer nada que não seja fundado na experiência de nossos sentidos não havendo "verdade" se não vier da experiência.

O caráter subversivo da Lettre pode ser atribuído ao salto de raciocínio impresso por Diderot à questão: se Locke, prudentemente, circunscreve suas ideias à esfera epistemológica, Diderot estende suas considerações para os domínios da moral e da metafísica. Ao disparar, Diderot empunha arma de grosso calibre: se não há mais ideias inatas $^{255}$, não há mais verdade revelada, não há mais sistema político fundado na tradição e no direito divino.

Repensar essas ideias sobre base radicalmente nova é pôr em xeque todo o sistema de saber, de poder e de valores que se constituíam no arcabouço do pensamento das sociedades do século XVII e parte do século XVIII. O fato é que a Lettre,

\footnotetext{
${ }^{255}$ Em Méditations Métaphysiques (1641), Descartes distingue três tipos de ideias: as ideias inatas (les idées innées) - (verdades reveladas por Deus a nós), as ideias adventícias (les idées adventices) - e as ideias fictícias (les idées factices) - (as ideias imanentes, que eu crio).
} 
segundo Lepape (1991: 85), é "sous une forme décousue, déconcertante et encore allusive, le premier manifeste de la révolution encyclopédique".

Embora, pouco depois, a Lettre se constituísse num manifesto ruidoso, para alguns, Diderot não era adepto do sensualismo, da necessidade científica de experimentação e do materialismo ${ }^{256}$. Ainda nas palavras de Lepape, suas ideias eram resultado de sua própria experiência intelectual, de uma evolução sem grandes explosões de inspiração ou descobertas, enfim, produto de uma maturação do espírito, observação da natureza e prática das ciências, de maneira que por meio de abordagens sucessivas, estudos, reflexões, tentativas e erros, Diderot forjou os conceitos que se adaptavam melhor à sua tarefa de se aproximar da "verdade", de tal arte que não se interrogava sobre a validade do método científico ou crítico, mas sobre a melhor maneira de empregá-lo face aos desafios impostos pela sociedade.

Por fim, a reação: as investidas vieram não só contra a obra, ao autor também coube parte da fatura. Na manhã de 24/7/1749, após busca e interrogatório em sua casa, na rue de la Vieille-Estrapade, Diderot, autor da Lettre sur les aveugles à l'usage de ceux qui voient (1749), é conduzido ao calabouço da prisão de Vincennes. Depois de quatorze dias em uma cela, deixa de rebater as acusações. Tratado como prisioneiro comum, confinado entre as muralhas da prisão, pôde receber visitas, especialmente as de Rousseau. Em três de novembro, é liberado. Diderot, jamais saberia, mas sua Lettre sur les aveugles, seria objeto de nova polêmica em uma nação distante, sob a pena de um jovem iniciado no mundo das letras - e das polêmicas.

\section{A Marmota, Paula Brito, "Os cegos" e Machado}

No Brasil do século XIX, a participação do leitor já era prática comum nos periódicos. Essa contribuição, impossível de ser rastreada dentro das publicações que faziam parte

\footnotetext{
${ }^{256}$ Aqui vale confrontar as afirmações de BADINTER e LEPAPE: ambos insistem na evolução gradativa das ideias intelectuais de Diderot, porém, na visão de Lepape, o caminho percorrido por Diderot, do deísmo ao materialismo, é solitário, fruto das experiências pessoais do autor; já Badinter, sustenta a tese mais plausível - de que Diderot está inserido no contexto onde essas ideias aparecem e tomam corpo, portanto, sofre influxos diretos dessa inter-relação. Tanto é que por volta do ano de 1765, já se trava uma guerra subterrânea que opõe Voltaire aos adeptos do materialismo. À época, há verdadeira cisão entre os filósofos: Voltaire, deísta, embora invoque Spinoza e aceite boa parte da metafísica dos ateus, mantém-se inflexível quanto à existência do Criador, já Diderot, faz parte do clã adverso, ao lado de d'Holbach, Naigeron e Grimm (ver: BADINTER, 2009: 137-142, Vol. III).
} 
do corpo do periódico, é facilmente encontrada nas colunas identificadas ${ }^{257}$ por "Publicações a pedidos" ou simplesmente "A pedidos", de fato, um eufemismo para muita matéria paga. Neste espaço publicavam-se escritos de toda ordem: pequenas peças literárias, produções poéticas de gosto duvidoso e, entre outros, reclamos e opiniões sobre assuntos de cunho geral, que eventualmente despertavam contendedores ansiosos por exporem seus pontos de vista. Entretanto, às vezes, eram convocados à tribuna impressa. No entender de Massa (1971: 189), essas discussões, por vezes estéreis, serviam para animar a vida ainda provinciana da capital, "romper a monotonia", de maneira que a polêmica constituía-se numa espécie de jogo, "uma segunda natureza" no âmbito da imprensa.

Polemistas - e polêmicas -, sem se dar conta, imitavam Alencar quanto ao "tamanho da sociedade fluminense", contudo, assim como na metrópole cultural, os ataques ad hominem eram habituais, algo que pode ser notado, sobretudo, nos discursos parlamentares de deputados e senadores, muitas vezes reproduzidos nos periódicos. Os ânimos eram acirrados e, não raro, extrapolavam o bom senso. A Marmota, em contexto redimensionado, buscava entrar nesse jogo e “animar as discussões”. É assim que, em 12/2/1858, Paula Brito, a exemplo das academias francesas que levantavam questões para serem respondidas por seus membros e colaboradores, ao mirar-se no hábito de glosar herdado da tradição lírica portuguesa (MASSA, 1971: 189), moderniza ao propor o tema através de um mote:

\section{Qual dos dois cegos mais sente \\ O penoso estado seu: \\ O que cegou por desgraça, \\ O que cego já nasceu?}

De pronto, pode-se inferir: ou o assunto é por demais importante, uma vez que, atravessado um século, ainda suscita questionamentos, ou, ecos do século XVIII francês ecoavam em terras tupiniquins, fruto de leituras ainda atuais e costumeiras à época da proposição de Paula Brito, ratificando um habitual descompasso entre o que ocorria na França e os ecos que por aqui repercutiam. Certo é que Paula Brito começa por fazer referência às "muitas e valiosas opiniões" já pronunciadas a respeito, indicando que chegara o momento de dar "nossa" contribuição.

${ }^{257}$ No Diário do Rio de Janeiro, por exemplo, recebia o nome de "Comunicações”. 
Paula Brito, ao propor a questão, lança os argumentos sobre os quais os participantes poderiam sustentar suas teses: o cego de nascença - afirma -, dizem uns "que é mais feliz, porque vivendo na ignorância de tudo, não pode ter pesar de não ver, de não comparar aquilo que nunca viu, aquilo que nunca comparou; e que só aquêle que já gozou o mundo, que tudo viu, que tudo admirou, é que, no estado de cegueira, por desgraça, sente mais a falta de vista”.

Dizem outros - continua Paula Brito -, "que o cego de nascença, sem nada ter visto, sem nada ter admirado, seria, sim, mais feliz se vivesse na ignorância de tudo, e não em uma sociedade onde a cada instante está ouvindo fazer-se pintura de cousas, de que êle, não pode formar uma idéia; entretanto que, o cego por desgraça, forma uma idéia de qualquer cousa em que se lhe fala, por isso que, no seu tempo, tudo vira, e a idéia que de tudo ainda tem o satisfaz comparando o velho com o nôvo, o feio com o bonito, etc etc.".

Tão logo sugere os pontos de vista, o editor d'A Marmota, informa: "Como existem já muitos escritos a êste respeito, aquêles dos nossos leitores que souberem de algum artigo ou artigos, que disso tratem, nos obsequiarão também remetendo-nos, traduzidos, por traduzir, ou copiadas mesmo de obras em Português, uma vez que não ocultem o nome do autor, do livro, ou do jornal de que os extraírem." E finaliza: "A questão, bem que muito filosófica, pode ser tratada segundo o sentir de cada um, uma vez que não se apresente edifício sem base.” Ora, o que Paula Brito, não traz à luz é que a "base" para o "edifício" que propunha fosse construído, estava em Diderot, algo que Massa (1971: 190), de pronto, percebe: "Desde a Carta sôbre os Cegos (1749) de Diderot, o problema foi várias vêzes levantado e provocou inúmeras discussões."

\section{N'A Marmota, o passo a passo da polêmica ${ }^{258}$}

1. N 925, 12/2/1858 - proposição de Paula Brito, sob o título de "Os Cegos";

2. N ${ }^{\circ} 929,26 / 2 / 1858$ - participação de Jq. Sr., sob o título de "Resolução filosófica a Demócrito;

3. $\mathrm{N}^{\mathrm{o}} 931$, 5/3/1858 - participação de Machado de Assis (As.), sob o título de "Os Cegos";

4. $\mathrm{N}^{\mathrm{o}}$ 932, 9/3/1858 - réplica de Jq. Sr., sob o título de "Réplica ao Sr. As.”;

5. No 934, 6/3/1858 - tréplica de Machado de Assis, sob o título de “Tréplica ao Sr. Jq. Sr.”;

6. N ${ }^{o}$ 935, 19/3/1858 - participação de Jq. Sr., sob o título de “Ainda uma resposta ao Ilmo. Sr. As.”;

${ }^{258}$ Veja Nota 259, para acompanhar a interferência de outros participantes. 
7. $N^{\circ} 937,26 / 3 / 1858$ - participação de Machado de Assis, sob o título de "Os Cegos" - (Encerramento da polêmica).

\section{A polêmica n'A Marmota: Machado e Jq. Sr.}

A primeira resposta à questão proposta por Paula Brito vem, em 26/2/1858, de Jq. Sr. ${ }^{259}$, que diante do abandono de outros adversários ${ }^{260}$, será, de fato, o grande antagonista machadiano ao longo da polêmica que se estenderá por cerca dois meses, transformando-a em duelo.

Ao lançar mão de um subtítulo para sua resposta - Resolução filosófica a Demócrito -, Jq. Sr. de pronto reconhece o caráter filosófico da questão. Embora faça apelo ao "filósofo que ri" e se declare "amigo de galhofar", zombando de filósofos e gracejando com o assunto, diz-se pouco "acostumado em manejar silogismos e espertezas da lógica" e insiste em dar mostras de erudição, algo corriqueiro (e necessário) àqueles que se expunham nos periódicos. Tanto é que se escora em referências:

Se a vida é, como diz Bichat ${ }^{261}$, a reunião dos fenômenos que triunfam da morte; se a vista, como diz Stahll ${ }^{262}$, é a melhor coisa da vida; segue-se concludentemente que a cegueira, isto é a morte da vista, é a aniquilação da melhor parte da vida.

O cego de nascença começa a vida sem essa aniquilação, isto é, não sofre essa subtração na sua fôrça vital, portanto êste argumento só serve para mostrar sofrimento no cego posterior ao nascimento, que a meu ver é o mais digno de pena.

\footnotetext{
${ }^{259}$ Sobre a identidade de Jd, Sr. ver a longa exposição em A juventude de Machado de Assis (MASSA, 1971: 190-192). Contudo, Machado parece conhecê-lo - cf. comentários e agradecimentos a Joaquim Serra, nas crônicas de 24/10/1864 e 7/3/1865 (Diário do Rio de Janeiro) e 5/1/1888 (Gazeta de Notícias). Por outro lado, Magalhães Jr. (2008: 88-89) considera estranho Massa questionar a identidade de Jd. Sr. e levanta uma série de indícios e provas da presença de Joaquim Serra no Rio de Janeiro à época em que se desenrolou a polêmica.

${ }^{260}$ Em 9/3/1858 a polêmica entre Jq. Sr. e Machado de Assis sofre leve interrupção devido às participações de Alcipe, a mulher-poeta, que publicava poesias n'A Marmota desde 1854, sob esse pseudônimo e A. (especula-se que A. seja Moreira de Azevedo); ambos concordaram com Jq. Sr.. A polêmica, de fato, tem fim com Machado de Assis, embora outros tenham publicado suas opiniões em números posteriores d'A Marmota, dando continuidade à discussão. São eles: $\mathrm{N}^{\text {os }} 939$, T. C. Castelo Branco, 943, M. A. Calasans Peixoto e 951, Antônio Manuel dos Reis. Todos foram unânimes em afirmar que a pior desgraça é ser cego por acidente.

${ }^{261}$ Marie François Xavier Bichat (1771-1802), considerado um dos fundadores da medicina moderna, foi também um dos precursores da fisiologia.

${ }^{262}$ Georg Ernest Stahl (1659-1734), médico alemão que se opunha às doutrinas materialistas de Boerhaave e um dos últimos teóricos do flogístico (phlogistique).
} 
Jq. Sr. constrói um texto sem qualquer pretensão. Malgrado as alusões, ao lançar mão deste ou daquele médico para sustentar sua opinião, elege o humor como divisa. De sua argumentação, o que surpreende é sua peripécia conclusiva: "Todavia eu preferiria antes ser cego do que ter bons olhos e não ver como o célebre astrônomo Lalande $^{263}$ que dizia: 'J'ai visité toute l'étendue du ciel, et n'y ai point vu Dieu!'” Surpreende, porque sinaliza toda a problemática presente na argumentação machadiana, aproximando-a de Diderot.

A polêmica, circunscrita a Machado e Jq. Sr., tem duração de um mês (26 de fevereiro a 26 de março de 1858), quando Machado, a única nota discordante (afirmou que o cego de nascença era o que experimentava a dor mais profunda) coloca fim à questão. O jovem cronista parece ter se preparado para o confronto, pois refuta os argumentos de Jq. Sr. de maneira radical: "O que diz nêle? [no artigo] Nada. Nem mesmo a razão sobre que o mesmo Sr. funda sua opinião."

Machado apresenta sua opinião de forma "clara e filosófica", do mesmo modo como definira a questão, porém desconstruindo os argumentos de seu adversário (5/3/1858):

O Sr. Jq. Sr. diz que, para o cego de nascença a vida começa sem a aniquilação da melhor parte da vida - a vista - e que portanto o cego por acidente, sofrendo a aniquilação, é o mais digno de lástima. A consequiência é errada, e está diametralmente oposta à única conclusão possível do princípio estabelecido. É pela razão mesma de que o cego de nascença não sofre a aniquilação da vista, que é o mais desgraçado. Ao nascer êle esbarra com a noite que o deve cercar durante a sua vida; esbarra com êsse caos para que nunca há de soar um Fiat. Como não ser desgraçado? Sem ter o gôzo do cego por desgraça que vê em parte pelos olhos do espírito, êle não pode fazer uma idéia exata dos objetos que lhe apresentais; e conseguintemente não pode compreender-vos, gozar um pouco do que gozais - pelo exercício dos outros sentidos ou faculdades.

Continua o mesmo senhor, dizendo que o cego de nascença fantasia um mundo à sua guisa, e identifica-se com êle, idealizando e colorindo as coisas melhor do que elas são.

Isto importa um erro psicológico. Não é possível ao cego em questão criar êsse mundo à sua guisa: e a razão é esta: _ _ A criação dêsse mundo espiritual só pode ser fantasiada pela imaginação e pelo raciocínio. Estas duas faculdades desenvolvem-se no

${ }^{263}$ Joseph Jérôme Lefrançois de Lalande (1732-1807), reputado astrônomo francês que participou de inúmeras polêmicas ao longo do século XVIII, contudo, a citação creditada a ele por Jq. Sr., não foi localizada. 
centro das idéias; as idéias são adquiridas pelos sentidos. Ora, sendo o cego de nascença totalmente estranho ao mundo físico, não pode receber idéias para povoar o seu mundo pela ausência do importante órgão da percepção visual: Como idealizar, colorir, e identificar-se com o seu mundo?

O cronista argumenta ainda que o cego por desgraça pode se beneficiar das lembranças que guarda no espírito e facilmente imaginar tudo que lhe narrarem, criando, assim, um mundo espiritual a partir das "pálidas reflexões das suas recordações". Em seguida, retoma Jq. Sr, para contradizê-lo: Jq. Sr. dissera em seu artigo que o cego de nascença tem um gozo - o desejo de ver a luz -, enquanto o cego por desgraça padece de uma dor - a saudade da luz:

\begin{abstract}
Concordamos que haja no cego por acidente essa saudade, modificada porém pela ciência que êle tem do mundo físico. O que, porém, não aceitamos, é que o desejo no cego de nascença seja um gôzo; nem mesmo em ninguém. O que há no cego de nascença é uma luta íntima, terrível, sangrenta, que abala o espírito, e fatiga as forças morais. Vivendo no meio de uma sociedade que a cada momento está fazendo a pintura de tôdas as coisas, de todos os objetos, o cego de nascença sente o desejo ardente e voraz de ver, de conhecer êsses objetos e essas coisas. _ Quem pode dizer que isto é um gôzo? Dai ao cego de nascença uma rosa, fazei-lhe aspirar o seu perfume; pensais que isto deve ser para êle um gôzo? Não! Aquêle perfume suave e delicado, como um bálsamo filtrado por um dos mais belos poros da natureza, deve inspirar-lhe ardentemente o desejo de ver a flor que o exala. Deve ser bela, dirá êle, a flor que contém em seu seio êste aroma que me embriaga o espírito e banha-me a alma na mais suave essência! Porém o coitado não pode ver, nem fazer dela a menor idéia. Como aquela alma deve estorcer-se naquele desejo, naquela luta!
\end{abstract}

Afora essas razões, Machado, ilustra a pior condição do cego de nascença ao destacar sua completa ignorância em relação ao mundo material:

Uma das provas mais eloqüentes, mais vivas, por isso que palpável, da existência de Deus, é o universo, o mundo físico, esta natureza que se desenrola aos olhos do homem, colorida e perfumada por uma mão suprema. A inteligência humana reconhece que êste desabrochar de flôres, êste reverdecer de campos, êste suceder contínuo de estações, dias e noites, êste existir de átomos, de insetos, que escapam à vista, e que nascem, vivem, movem-se, agitam-se, para o que é necessário haver músculos, pois sem músculos não há movimento, enfim êste mundo grande e infinitamente pequeno, que se 
manifesta no trovão e no imperceptível caminhar dos átomos, êste mundo harmônico orgânico, majestoso, admirável; tudo isto, dizíamos nós, reconhece a inteligência humana que deve ter uma origem, que não pode estar em si, porque seria um absurdo, que não pode ser obra do acaso que nada produz, mas que deve nascer de um Ente Supremo, infinito, eterno. Êste reconhecimento que importa um dos pontos capitais da filosofia, e a base da religião não pode ser operado senão pelas idéias recebidas pelos sentidos. Pode o cego de nascença sem uma só noção do mundo físico, esta grande manifestação da existência de Deus, fazer uma idéia exata da Divindade? Não o cremos.

E conclui:

E pois, mais uma vez está provado que é mais doloroso o estado do cego de nascença comparado ao cego por acidente, pois que êste tem uma idéia de tudo o que existe pelos olhos do espírito e da memória.

Embora Paula Brito peça "que não ocultem o nome do autor, do livro, ou do jornal" que venha a ser objeto de consulta dos colaboradores, ninguém o faz - sequer Machado. De maneira que ao fundar suas opiniões (com exceção de Buffon, citado à revelia, em mostra de franco eruditismo) o cronista sonega as fontes, desobrigando-se de citar, referenciar, aludir, etc.

Acompanhemos o desenrolar da polêmica, sobretudo com destaque para a construção da argumentação machadiana:

Em face de um adversário que a todo instante insiste em valorizar sua comicidade, Machado busca aquilo que é próprio de toda formulação discursiva: a dissimulação; muito provavelmente, uma estratégia visando preservar seu oponente por algum tempo, seja para dar mais fôlego à querela seja para vê-lo capitular posteriormente. Ao armar sua controvérsia, o jovem cronista usa do mesmo subterfúgio, ou seja, retoma a fala de Jq. Sr. sem, contudo, revelar aos leitores a origem da argumentação de seu adversário. Prefere refutar Jq. Sr. através das ideias empiristas proclamadas no Essai sur l'entendement humain (1689), no qual Locke defende que todo conhecimento provém de experiências com objetos externos, pela sensação, ou por operações intelectuais internas, pela reflexão. Adentrando ao campo da especulação, é provável que o jovem polemista tenha querido mostrar-se "atualizado" ao apregoar o sensualismo, frente às ideias inatas de Jq. Sr.-Descartes, um tanto ultrapassadas ${ }^{264}$.

\footnotetext{
${ }^{264}$ Em Méditations Métaphysiques (1641), Descartes sustenta a existência de um conhecimento legítimo apesar da existência de argumentos céticos contra a verdade e a certeza, apresenta o homem como tendo
} 
Embora a polêmica, no caso, pudesse se desenvolver a partir de uma retórica argumentativa (buscando legitimar uma conclusão a partir do enunciado proposto), seus desdobramentos remetem a discursos anteriores (discursos fontes ou discursos primeiros), instituindo um dialogismo intertextual. E, nota-se, ambos os adversários optaram por uma argumentação de acepção literária, em que o(s) discurso(s) abrange(m) outros discursos, fazendo do texto um portador polifônico, tal os enunciados que articula. Assim, tomemos a afirmação de Jq. Sr. em 26/2/1858:

\begin{abstract}
O cego de nascença idealiza as coisas colorindo-as melhor do que elas são, fantasia um mundo à sua guisa, identifica-se com êle, e portanto se visse a realidade, talvez essa desmerecesse à sua imaginação, e assim amasse mais a seu mundo.
\end{abstract}

Comparando-se a assertiva de Jq. Sr. e a reflexão cartesiana, tem-se revelada a origem de suas ideias, contudo, Machado evita trazê-la a público, e, em 5/3/1858, muito provavelmente por tratar-se de sua primeira "performance", usa de estratagema retórico: encara-o como vero contraditor ao evitar refutá-lo a partir de suas afirmações, preferindo impor-se através de uma "ação oratória", qual seja, confrontá-lo com suas ideias sensualistas. A artimanha produz resultado, tanto é que em 9/3/1858, Jq. Sr., não tão perspicaz quanto Machado, cai na armadilha e, faz exatamente o que o cronista evitou fazê-lo, ou seja, contestar a partir do discurso do outro. Jq. Sr., ao rejeitar as ideias sensualistas cogitadas por Machado, denuncia ele mesmo a "base" de seu arrazoado:

Quanto ao vosso sistema sôbre as idéias serem exclusivamente adquiridas pelos sentidos, e que apresentais como uma razão de impossibilidade para o cego de nascença criar um mundo ideal; só vos responderemos que a teoria de idéias inatas é altamente filosófica, e que neste caso a sua aplicação é muito sensata.

Ora, jovem, Machado já demonstra uma competência natural que combina capacidades enunciativas e interacionais e, no intuito de construir uma opinião autônoma, opõe-se ao seu interlocutor desqualificando sua fonte. Em 16/3/1858, num átimo, guilhotina Descartes:

uma substância essencialmente pensante (cogito), em oposição à substância material, o corpo, e sinaliza sua rejeição a toda forma de sensibilidade ao afirmar que as percepções sensíveis podem ser enganosas. 
Mais adiante o nosso ilustre adverso fala em idéias inatas. Abstemo-nos de discutir êste princípio de Descartes, que não admitimos; concordamos que hajam (sic) princípios e sentimentos inatos - idéias, nunca!

Ainda que considere a filosofia cartesiana inadequada para sustentar a opinião adversa, Machado não a rejeita sumariamente, pois tenciona continuar a peleja, tanto é que ao final da mesma crônica incita seu adversário a procurar "novas argumentações" e "vir de nôvo falar sôbre a matéria". Assim, Descartes, que sob a pena de Jq. Sr. serve como esteio de sua retórica argumentativa, em mãos machadianas, de ricochete, tem efeito contrário ao pretendido pelo adversário. Explica-se: Machado, ao afirmar que as ideias inatas em nada contribuem para elucidar a questão, sinaliza seu uso tão somente como peça de controvérsia, despindo-as de qualquer status conclusivo, corroborando Massa (1971: 188), quando afirma a esterilidade de muitos desses embates.

Assim, como toda argumentação pode ser definida como uma tentativa de modificar as representações do interlocutor; é claro que toda informação contribui para esse jogo e é, ela mesma, argumentativa nesse sentido (BENVENISTE, 1966: 242). Nessa lógica, Machado refuta Jq. Sr. ao destacar o caráter "reducionista" das ideias inatas (16/3/1858), levando-o a reformular seu ponto de vista (19/3/1858), sob o peso das ideias sensualistas que introduzira. Com isso Machado não só desqualifica Jq. Sr., como reorienta seu próprio discurso e dá um salto argumentativo que o leva até Diderot, através da problemática que envolve a polêmica desde os seus primórdios.

De fato, é como se Machado voltasse às origens, perpetuando o "núcleo" da questão, sem a qual a polêmica perderia sua força. A natureza como prova eloquente da existência de Deus, constitui-se no grande nó da questão depois de Diderot especular sobre os conceitos de Deus, do bem e do mal em um homem privado dos sentidos. Ao fazê-lo, Diderot demonstra que as ideias concernentes à existência de Deus e à moral não eram absolutas e sim relativas em conformidade à condição física e à percepção pelos sentidos.

"Pode o cego de nascença sem uma só noção do mundo físico, esta grande manifestação da existência de Deus, fazer uma idéia exata da Divindade? Não o cremos." Ao expressar sua dúvida Machado aproxima-se de Diderot que, para acreditar em Deus, precisa tocá-lo. Ambos ao deslocarem a compreensão da Divindade para o domínio dos sentidos nomeiam o percurso: materialismo. Tanto é que Voltaire, deísta, 
após ter lido a Lettre, escreve (1855: 516, Tome XI) a Diderot elogiando o texto, entretanto, protestando pelo modo como ali se nega a existência de Deus.

A filosofia de Diderot, fundada nos fatos e na experiência, recusa toda transcendência ${ }^{265}$, de maneira que ao excluir do universo a eficaz presença divina, liberando-a para além da razão, toda e qualquer explicação teológica que pretenda compreender o mundo, postula a impossibilidade das Lumières e perpetua dogmas que não resistem à comprovação científica, artilharia eficaz contra a perpetuação das superstições, do fanatismo e do despotismo teológico. Por essa razão, as centelhas materialistas presentes na Lettre foram exponencialmente ampliadas.

E é através da ficção, na Lettre, que isso se torna evidente: no confronto entre Saunderson, o matemático cego de nascença e o pastor Holmes. O ministro, hábil, começa por enumerar ao moribundo as maravilhas da natureza na tentativa de fazê-lo professar a fé divina. Saunderson, obstinado em seu ateísmo, contra-argumenta dizendo que o belo espetáculo enunciado pelo ministro é para aqueles que veem, e contesta: "Si vous voulez que je croie en Dieu, il faut que vous me le fassiez toucher." Astuto, o ministro pede ao cego que toque a si mesmo e lá encontrará a Divindade, numa retomada às ideias inatas cartesianas. Para Diderot, esse resgate constante, só demonstra que o argumento do ministro não se sustenta face às ideias racionalistas, portanto, tornase clara a impossibilidade (para o cego) material, portanto, física, estabelecer um senso moral e estético a partir de uma ideia abstrata de simetria e beleza naturais.

Ordem e simetria remetiam ao universo divino e sua origem, por isso é algo revelador que tais temas sejam abordados na Lettre. Trazê-los à discussão na condição de qualidade e ou convenções humanas, implica, obrigatoriamente, colocar em dúvida uma das principais provas da existência do Criador, ainda que na Lettre a linguagem apareça como base reflexiva da discussão sobre a beleza. Para Diderot, o cego aprende a falar e classifica como "belo" ou "feio" aquilo que ele toca segundo a sua experiência oratória e "interlocutiva", de modo que a natureza como prova eloquente da existência divina, não passa de um sofisma, porque incapaz de expressar a beleza àqueles desprovidos da visão. É nesse ponto que as ideias de Diderot e Machado se encontram.

\footnotetext{
${ }^{265}$ Sobre isso ver o artigo "Raison", da Encyclopédie: "Nulle proposition ne peut être reçue pour révélation divine, si elle est contradictoirement opposée à ce qui nous est connu, ou par une intuition immédiate, telles que sont les propositions évidentes par elles-mêmes, ou par des déductions évidentes de la raison, comme dans les démonstrations ; [...]."
} 


\section{Machado e Diderot: a fatura machadiana}

\subsection{A escuridão das trevas}

"Je me doutais bien, Madame..." "266 Na Lettre endereçada a tal senhora, Diderot menciona entre outras coisas, a visita que fizera a um cego em Puiseaux. Ao descrevêlo, destaca suas habilidades relatando, inclusive, sua destreza em manejar uma arma. Em um duelo, o cego atinge seu adversário, matando-o. Frente ao juiz, pergunta ao magistrado o que será feito dele. "Je vous jetterai dans un cul de basse-fosse", respondelhe o magistrado, ao que o cego prontamente retruca: “... il y a vingt-cinq ans que j'y suis". Ao final do relato, Diderot considera: "Nous sortons de la vie comme d'un spectacle enchanteur; l'aveugle en sort ainsi que d'un cachot : si nous avons à vivre plus de plaisir que lui, convenez qu'il a bien moins de regret à mourir. (2000: 34-35)"

Machado, por outro lado, ao questionar Jq. Sr. sustenta ser o cego de nascença o mais desgraçado exatamente porque "não sofre a aniquilação da vista" e "ao nascer esbarra com a noite que o deve cercar durante toda a vida".

Confrontando esses dois extratos, nota-se que Diderot e Machado valorizam unidades mínimas de significação para ressaltar a condição do cego de nascença. A escuridão, em Diderot, vem indiciada pela palavra cachot, cuja definição vem comumente acrescida das palavras obscure e sombre, atribuindo ausência parcial de luz à limitação do local.

Persistindo no cotejo dos textos, nota-se que a ausência de luz à qual é condenado o cego de nascença, em Diderot, vem "dissimulada", algo que estimula a interpretação. O texto machadiano (muito provavelmente por tratar-se do primeiro embate entre os adversários) não tende para subjetivo, donde a referência explícita à Luz: "Ao nascer êle esbarra com a noite que o deve cercar durante a sua vida; esbarra com êsse caos para que nunca há de soar um Fiat."

Ora, ainda que se esforce em ser explícito, Machado trilha os passos de Diderot, deixando ao leitor a completude do sentido. Veja-se: é evidente que o cronista ao introduzir a forma ativa subjuntiva do verbo latino fio (fiat), o faz como marca de

\footnotetext{
${ }^{266}$ A identidade dessa senhora jamais foi confirmada; especula-se que tenha sido Mme de Puisieux, amante de Diderot ou Mme de Prémontval. Considera-se também a possibilidade de uma interlocutora fictícia.
} 
erudição em substituição a palavra luz. Porém, ao fazê-lo, suprime justamente a parte substancial da expressão bíblica fiat lux. Assim, o que a primeira vista pode ter sido suprimido por tratar-se de uma obviedade, cotejado ao texto de Diderot, adquire nova dimensão, afinal, a locução latina está presente no início do Gênesis ${ }^{267}$, exatamente a primeira palavra pronunciada por Deus, quando da criação do mundo. Para o cego de nascença, contudo, não houve (há) luz. Por que teria Deus agido tão parcialmente, malgrado sua onisciência e imparcialidade? Afinal, não fora o homem criado à sua imagem e semelhança?

Se cachot, como núcleo do sintagma, transposto ao texto machadiano, equivale à palavra noite, esta, como unidade textual, remete ao discurso centralizador que versa sobre a cegueira. Não enxergar é estar predestinado à escuridão. Ademais, as trevas, às quais são condenados os cegos de nascença, figuram em outro trecho do texto de Diderot, na resposta de Saunderson, o matemático cego, ao ministro Holmes (2000: 59): “Eh! Monsieur, [...] laissez-là tout ce beau spectacle qui n'a jamais été fait pour moi. J'ai été condamné à passer ma vie dans les ténèbres [...]"

Assim, consoante ao que afirma Jenny (1979: 19), "estabelece-se entre duas palavras literárias, duas realizações de linguagens secundárias", ou seja, "dois sistemas de signos, cuja organização é da mesma natureza" se relacionam: também em Diderot, un cul de basse-fosse ou cachot, representam a escuridão a qual foi condenado o cego de nascença que, acrescida da ideia de aprisionamento, correspondente às limitações de suas ações e de seu universo, portanto, um condenado à "prisão". Em Machado, embora haja certa economia na escrita, o sentido se expande: a noite (cachot, basse-fosse), ao mesmo tempo em que dá conta da escuridão e limitação impostas ao cego, sugere a permanência da cegueira ${ }^{268}$, já que a noite vai cercá-lo "para a vida toda". Em ambos os casos, contudo, indicia-se ausência de crime e a pena injusta imposta pela divindade.

A problemática sobre a cegueira (o cego de nascença) detém o comando do sentido quando se cotejam os dois extratos textuais, pois, não obstante as modificações (carta/polêmica, peça argumentativa), a referência intertextual resiste como elemento paradigmático e, deslocada para a crônica, em novo contexto, divide-se: estala a leitura conduzindo o leitor à Lettre, além, é claro, de fundamentar as argumentações do

\footnotetext{
${ }^{267}$ A frase completa é: Fiat lux, et lux fuit. (Haja luz, e houve luz.)

${ }^{268}$ Em Diderot, ainda que remotamente, expõe-se a possibilidade de cura, através das cirurgias de catarata.
} 
cronista. Em qualquer um dos casos, rompe-se com o discurso monológico, através da alusão absorvida pelo texto centralizador que, no caso, é a razão de sua própria existência. Porém, enquanto prática intertextual, a alusão à cegueira (quase semântica) surge inteiramente como efeito de leitura: uma ocorrência de memória literária ligada aos sentidos.

\subsection{As "ideias adquiridas pelos sentidos"}

Ainda na primeira de suas respostas a Jq. Sr. (5/3/1858), Machado questiona: como pode um cego de nascença "idealizar, colorir e identificar-se com o mundo" se a “criação de um mundo espiritual só pode ser fantasiada pela imaginação e pelo raciocínio" e "essas faculdades desenvolvem-se no centro das idéias", que "são adquiridas pelo sentido"?

Ao reforçar seus argumentos, destaca a tortura vivida pelo cego de nascença em uma sociedade que, a todo instante, o incita a transpor uma barreira que lhe é fisicamente - impossível. Exemplos sensualistas ressaltam a intensa luta espiritual do cego de nascença $(5 / 3 / 1858)$ :

Dai ao cego de nascença uma rosa, fazei-lhe aspirar o seu perfume; pensais que isso deve ser para êle um gôzo? Não! Aquêle perfume suave e delicado, como o bálsamo filtrado por um dos mais belos poros da natureza, deve inspirar-lhe ardentemente um desejo de ver a flor que o exala. Deve ser bela, dirá êle, a flor que contém em seu seio êste aroma que me embriaga o espírito e banha-me a alma na mais suave essência!

Ora, Diderot, ao sustentar a impossibilidade de o cego de nascença fruir dessa "dádiva" encaminha suas ideias para o campo da percepção, faculdade de apreender através dos sentidos ou da mente, mas, sobretudo, de construir o conhecimento através das sensações físicas (na polêmica em questão, as sensações físicas estão intimamente ligadas à visão), de maneira a ressaltar a ignorância do cego em relação ao mundo físico:

[...] un aveugle [...] quand il dit cela est beau, il ne juge pas, il rapporte seulement le jugement de ceux qui voient", "la beauté pour un aveugle n'est qu'un mot" [e lamenta]: 
"Combien de choses admirables perdues pour eux! le seul bien qui les dédommage de cette perte, c'est d'avoir des idées du beau [...] (2000: 30-31).

Face ao cego desejoso de ver a flor, o lamento de Diderot ecoa em páginas machadianas e o cronista exclama: "Porém o coitado não pode ver, nem fazer dela a menor idéia. Como aquela alma deve estorcer-se naquele desejo, naquela luta!" Para não se deixar consumir pelo desejo de ver a flor, deve o cego recorrer a um interlocutor qualquer, ao homem. Sem a ajuda humana (o relato de um interlocutor), entenda-se, material, o cego de nascença é incapaz de conceber qualquer ideia do mundo, essa grande manifestação da existência de Deus.

Porém, antes de adentrar ao religioso (ou a irreligião), Machado habilmente recria o texto de Diderot, suprimindo exatamente algo que talvez pudesse garantir alguma munição a seu adversário: a apreensão das sensações pelo tato ${ }^{269}$. Ao contradizer Jq. Sr., que sustentara a ideia de o cego de nascença criar um mundo à sua maneira, idealizando e colorindo-o melhor que o mundo real, o cronista questiona:

Não é possível ao cego em questão criar êsse mundo à sua guisa: e a razão é esta: _ _ A criação dêsse mundo espiritual só pode ser fantasiada pela imaginação e pelo raciocínio. Estas duas faculdades desenvolvem-se no centro das idéias; as idéias são adquiridas pelos sentidos. Ora, sendo o cego de nascença totalmente estranho ao mundo físico, não pode receber idéias para povoar o seu mundo pela ausência do importante órgão da percepção visual: Como idealizar, colorir, e identificar-se com o seu mundo?

Ocorre que Diderot já se perguntara: "Comment un aveugle-né se forme-t-il des idées des figures?" ${ }^{270}$ Ao entrever a resposta, o francês trouxe de arrasto as ideias sensualistas tão em moda à época (o conhecimento - as ideias - provém de experiências com objetos externos, pela sensação, ou por operações intelectuais internas, pela reflexão):

Je crois que les mouvements de son corps [de l'aveugle-né], l'existence successive de sa main en plusieurs lieux, la sensation non interrompue d'un corps qui se passe entre ses

\footnotetext{
${ }^{269}$ Machado, em 16/3/1858, afirmaria: "Ora, o cego de nascença se bem que tenha idéias sensiveis do mundo tangível, não tem todavia, pela falta de órgão visual, os corpos e as imagens necessárias para a criação de seu mundo imaginário; logo não se dá no cego de nascença a idealização de um tal mundo." ${ }^{270} \mathrm{O}$ que Diderot nomeia figures, ao longo da polêmica Machado denomina objetos.
} 
doigts, lui donnent la notion [...] il a par des expériences réitérées du toucher, la mémoire des sensations éprouvées [...] et [peut] former des figures (2000:39-40).

Os textos primam pelo convencimento do interlocutor; em cada um deles, à sua maneira, o enunciador (que enxerga) joga com possibilidades retóricas "razoáveis", que pairam no mundo das ideias. Porém, se ambos acreditam que "as ideias são adquiridas pelos sentidos", algo difere entre os autores quanto à dinâmica de apreensão dessas ideias, a começar pela "confissão" (em Diderot) de que muito do que se diz, de fato, tem origem especulativa: "il ne se passe rien dans sa tête [de l'aveugle] d'analogue à ce qui se passe dans la nôtre: il n'imagine point [...] (2000: 40)".

Veja-se: Machado afirma que "a criação do mundo espiritual só pode ser fantasiada pela imaginação e pelo raciocínio", ao passo que o cego de nascença, em Diderot, “n'a mémoire que des sensations prises par le toucher, qu'il rapporte à différents points, lieux ou distances, et dont il compose des figures” (Idem). Ora, considerando-se o caráter capcioso do cronista, é de se supor que tenha ignorado propositadamente essa possibilidade no intuito de confundir seu adversário em meio a afluência retórica, por isso, ateve-se ao "órgão da percepção visual" indo de encontro à opinião de Diderot, que sugere o tato como importante "condutor" de transmissão de ideias, portanto, capaz de "povoar" o mundo do cego de nascença.

Machado questiona (ao tratar do cego de nascença): "Como idealizar, colorir, e identificar-se com o seu mundo?" Colorir não! Identificar-se? Talvez. Mas, diante dos argumentos de Diderot, idealizar torna-se algo bem provável. E nisto, embora sugira impossibilidade, ambos parecem estar de acordo (Não nos esqueçamos de que o cronista precisava relativizar ao máximo as opiniões de Jq. Sr.). Veja-se: Machado afirma que a criação de um mundo espiritual "só pode ser fantasiada pela imaginação e pelo raciocínio", os quais, "desenvolvem-se no centro das idéias" e estas, por sua vez, "são adquiridas pelos sentidos".

O "centro das idéias" referido por Machado, Diderot, ao tratar da(s) sensação(ões), denomina-o sens interne ${ }^{271}$ :

\footnotetext{
${ }^{271}$ No caso, sens interne, é um desenvolvimento do senso comum aristotélico. Locke, define-o a partir da seguinte reflexão: "though it be not sense, as having nothing to do with external objects, yet it is very like it and might properly enough be called internal sense (Essay, II, I, §4)" - In: Nota: 31 (DIDEROT, 2000: 176).
} 
Quoique la sensation soit indivisible par elle-même, elle occupe, si on peut se servir de ce terme, un espace étendu, auquel l'aveugle-né a la faculté d'ajouter ou de retrancher par la pensée, en grossissant ou diminuant la partie affectée. Il compose par ce moyen des points, des surfaces, des solides : il aura même un solide gros comme le globe terrestre, s'il suppose le bout du doigt gros comme le globe et occupé par la sensation en longueur, largeur et profondeur.

Je ne connais rien qui démontre mieux la réalité du sens interne que cette faculté faible en nous, mais forte dans les aveugles-nés, de sentir ou de se rappeler la sensation des corps, lors même qu'ils sont absents et qu'ils n'agissent plus sur eux. $(2000: 41)$

Nota-se que se ambos são unânimes quanto à existência de um "centro de idéias"/sens interne, diferem quanto ao sentido condutor dessas ideias (Machadovisão/Diderot-tato) e discordam quanto à idealização de um mundo espiritual, algo que Machado nega radicalmente. Diderot, por outro lado sequer menciona a visão, sustentando seus argumentos a partir do tato. O cego de nascença pode, portanto, idealizar "seu" mundo, retrabalhar pensamentos e ideias, fantasiar espaços, superfícies, sólidos, além de, com as pontas dos dedos, experimentar a sensação de distância, largura e profundidade. Assim, como afirma Diderot, "les sensations qu'il aura prises par le toucher, seront, pour ainsi dire, le moule de toutes ses idées (2000 : 42)”.

Desse modo, perfaz-se uma inter-relação dialógica, em que dois discursos (deslocados no tempo e pertencentes a línguas diferentes), justapostos, se entrelaçam simultaneamente. A assimilação intertextual na escrita machadiana articula-se à revelia da cronologia e sequer comporta modificação de sentido. Explica-se: o fio condutor das observações de Diderot é a "perception des rapports", sobretudo, em relação à estética: ordem, simetria e beleza. Ocorre que questões de ordem e simetria no universo, faziam parte de uma discussão que envolvia a origem divina, portanto, trazê-las para a alçada das convenções humanas é colocar em dúvida uma das mais importantes provas da existência do Criador, algo do qual nem Diderot e nem Machado escaparam.

\subsection{A natureza, "colorida e perfumada por uma mão suprema"}

Embora o mote proposto por Paula Brito nas páginas d'A Marmota sugerisse uma discussão em torno de um problema físico - e de óptica -, não demorou para que a 
polêmica tomasse outro rumo. Em linhas gerais, a questão estética foi inteiramente ignorada, porém, em razão de o cronista aludir às maravilhas da natureza (crença generalizada no século XVIII, e que se estendeu por boa parte do XIX), produziu-se um desvio intertextual que aproxima ainda mais a polêmica do texto francês. Veja-se:

Diderot:

Lorsqu'il [Saunderson] fut sur le point de mourir, on appela auprès de lui un ministre fort habile, M. Gervaise Holmes : ils eurent ensemble un entretien sur l'existence de Dieu, dont il nous reste quelques fragments que je vous traduirai de mon mieux, car ils en valent bien la peine. Le ministre commença par lui objecter les merveilles de la nature. $(2000: 59)$

Nota-se que Diderot suprime as "merveilles de la nature", as quais serão apreendidas pelo leitor a partir da resposta de Saunderson ao ministro. Contudo, se inserirmos o texto machadiano em meio à conversa dos dois, ter-se-á uma sequência lógica (e dialógica) entre textos. Veja-se: na sequência do entrecho acima se pode introduzir o fragmento do cronista:

Uma das provas mais eloqüentes, mais vivas, por isso que palpável, da existência de Deus, é o universo, o mundo físico, esta natureza que se desenrola aos olhos do homem, colorida e perfumada por uma mão suprema.

Ao que Saunderson responderia:

Eh! Monsieur, [...], laissez-là tout ce beau spectacle qui n'a jamais été fait pour moi. J'ai été condamné à passer ma vie dans les ténèbres, et vous me citez des prodiges que je n'entends point, et qui ne prouvent que pour vous et que pour ceux qui voient comme vous.(Idem)

Ocorre que, misturados os textos, abre-se o diálogo à maneira da polêmica, criando espaço para as ideias antitéticas. Assim, de um lado teríamos Diderot, Machado e Saunderson; de outro, o Ministro Holmes ${ }^{272}$ e Jq. Sr.. Explica-se: Diderot, em parágrafos anteriores já dissera que há "une peinture pour les aveugles; celle à qui leur propre peau servirait de toile" (2000: 58), destituindo assim a natureza de seu caráter (e

${ }^{272}$ De fato, os fictícios Saunderson e Holmes, colaboram com Diderot na enunciação das ideias. 
origem) divino, pois, não obstante a beleza do mundo físico, o cego consegue (através do tato) estimular seu sens interne e idealizar a pintura de seu mundo em sua própria pele (uma espécie de autossuficiência em relação ao divino, através da qual se pode perfeitamente privar de apreciar a natureza, e, consequentemente, passar sem Deus).

Machado, a princípio, parece contradizer Diderot ao trazer um argumento de clara insinuação cartesiana: "Uma das provas mais eloqüentes, mais vivas, por isso que mais palpável da existência de Deus, é o universo, o mundo físico, esta natureza [...]" Porém, logo à frente, nota-se que fizera apenas um desvio, pois, afinal proclama a autorregeneração da natureza:

A inteligência humana reconhece que êste desabrochar de flôres, êste reverdecer de campos, êste suceder contínuo de estações, dias e noites, êste existir de átomos, de insetos, que escapam à vista, e que nascem, vivem, movem-se, agitam-se, para o que é necessário haver músculos, pois sem músculos não há movimento [...]

Entretanto, o desvio é curto. Essa função nervosa descentralizada é descontínua, intermitente, e o cronista após breve recuo

[...] reconhece a inteligência humana que deve ter uma origem, que não pode estar em si, porque seria um absurdo, que não pode ser obra do acaso que nada produz, mas que deve nascer de um Ente Supremo, infinito, eterno.

Logo, porém, retoma sua argumentação e questiona:

Êste reconhecimento que importa um dos pontos capitais da filosofia, e a base da religião não pode ser operado senão pelas idéias recebidas pelos sentidos. Pode o cego de nascença sem uma só noção do mundo físico, esta grande manifestação da existência de Deus, fazer uma idéia exata da Divindade? Não o cremos.

Ora, esse arremedo cartesiano soa algo irônico, relativiza o "Ente Supremo" em sua "grande manifestação" e, ao fazê-lo, o cronista profana o sagrado com sua franqueza cínica, uma vez que joga com a ambivalência: de um lado o Poder Supremo, o Criador dos céus e da terra, de outro, a irrefutável fragilidade da supremacia divina: a "incapacidade" de esse Deus fazer com que o cego tenha a exata ideia de sua Divindade. Como ser onipresente se não se é reconhecível por uma parcela de suas criaturas? 
Percebe-se que Machado é sinuoso e constrói seu argumento de forma pendular; ora credita a Deus a criação do universo ora o depõe de sua hegemonia. Hesitação de um cronista em face de uma sociedade crédula e fervorosa? Independente do que se afirmar, o certo é que sua perplexidade encontra ecos no texto francês. Em Diderot, a possibilidade de uma função nervosa descentralizada (e aqui tomamo-la por algo em estreito contato com o "Ente Supremo") é constante:

Je ne craindrais point qu'un philosophe lui objectât que les nerfs sont les causes de nos sensations, et qu'ils partent tous du cerveau : quand ces deux propositions seraient aussi démontrées qu'elles le sont peu, surtout la première, il lui suffirait de se faire expliquer tout ce que les physiciens ont rêvé là-dessus, pour persister dans son sentiment. (2000 : 42)

Ora, considerando-se a suposição que Diderot fizera em parágrafo precedente ( $\mathrm{Si}$ jamais un philosophe aveugle et sourd de naissance fait un homme à l'imitation de celui de Descartes, j'ose [...] assurer [...], qu'il placera l'âme au bout de doigts ; car c'est de là qui viennent ses principales sensations et toutes ses connaissances. - 2000: 42), nota-se claramente a relativização da supremacia divina, mitigando o Deus de Descartes. Desse modo, não só a divindade é colocada em questão, haja vista o homem, criado à imagem e semelhança de Deus, apresentar discordância entre si no que se refere à disposição da alma, como também seus autores, que resvalam na descrença e no materialismo.

\subsection{Irreligião e materialismo}

Diderot sabia de antemão a extensão de suas reflexões. À sua destinatária, considera:

Je pourrais entrer là-dessus dans un détail qui vous amuserait sans doute; mais que certaines gens qui voient du crime à tout, ne manqueraient pas d'accuser d'irréligion ; comme s'il dépendait de moi de faire apercevoir aux aveugles les choses autrement qu'ils ne les aperçoivent. (2000: 39)

Contudo, mais à frente (através de Saunderson), destaca a ignorância do homem face ao desconhecido e não hesita em sugerir que se a natureza enquanto obra divina é um nó difícil de desatar, o próprio Deus, este, é um problema tão insolúvel quanto sua 
obra e que, por isso, mereça talvez um pouco mais de filosofia, ou ainda, ser deixado de lado:

Un phénomène est-il, à notre avis, au-dessus de l'homme ? nous disons aussitôt, c'est l'ouvrage d'un Dieu ; notre vanité ne se contente pas à moins : ne pourrions-nous pas mettre dans nos discours un peu moins d'orgueil et un peu plus de philosophie ? Si la nature nous offre un noeud difficile à délier, laissons-le pour ce qu'il est, et n'employons pas à le couper la main d'un Être qui devient ensuite pour nous un nouveau noeud plus indissoluble que le premier. (2000: 60)

Machado envereda pelo mesmo caminho de Diderot, porém, após ter sido incitado por Jq. Sr (9/3/1858):

Perguntais ainda se pode o cego de nascença, sem uma só noção do mundo físico, fazer uma idéia exata da divindade?! com efeito! é uma contingência muito mesquinha essa em [que] pondes as provas da existência de Deus!! é acabar com tôdas as idéias imateriais e em que se funda a crença dos espiritualistas sôbre a divindade! é reconhecer a Deus, sòmente em suas obras, e fazer dependente de acontecimentos físicos, uma idéia tôda dependente da alma!!...

Jq. Sr. inunda seu texto com interrogações e exclamações que dão conta de uma estupefação hiperbólica ao notar que a polêmica invadira o "sagrado" território da fé. Se no século XVIII, na França, Voltaire a todo instante bradejava seu bordão contra a religião, clamando às ideias: _ “Écrasez l'infâme!", no Rio de Janeiro do século XIX, o contexto não era tão diferente quanto à religiosidade. Assumir publicamente o ateísmo implicava certo patrulhamento e circunscrever o círculo de amizades. E, analisadas as referências pessoais ao longo da polêmica, ambos, Machado e Jq. Sr. se conheciam muito bem. Ao que parece, Jq. Sr. surpreende-se por descobrir o lado "materialista" de Machado através da imprensa e é por meio dela que demonstra todo seu espanto.

O fato é que Machado parece ter se incomodado com a pecha de materialista. Tanto é que, em 16/3/1858, embora afirme que Jq. Sr. ao refutar seus "argumentos, em vez de destruí-los, dá-lhes mais força" e dizer que seu adversário "como um náufrago, tem de agarrar-se aos destroços de seu próprio navio", vai logo à questão: 
O último tópico do artigo do Sr. Jq. Sr. é interessantíssimo. S. S. acusa-nos de materialista: e para prová-lo lança mão de um dos sofismas mais reprovados; atribui-nos uma opinião que não temos, dizendo que admitimos e reconhecemos Deus sòmente nas suas obras, nós que dissemos que uma das provas mais vivas, por isso que palpável da existência de Deus, era o mundo físico!

Contudo, ao restringir a existência de Deus à metafísica, Machado não só se aproxima do Deus "phénomène indissoluble" de Diderot, como ainda ridiculariza as ideias inatas e coloca Deus como peça de fabulação:

Contra a filosofia de todos os tempos êle [Jq. Sr.] só encontra provas da existência de Deus na ordem metafísica. Isto e a admissão de idéias inatas são um sacrifício heróico do espiritualismo que não podemos deixar de louvar. O que será então da fantasia caprichosa e romanesca dos poetas que reconhecem a mãe [mão] de Deus em tôdas as suas obras?

Embora não corresse o risco de receber à porta uma lettre de cachet, Machado rapidamente recua e revê inclusive, a parte de seu discurso referente às ideias inatas, que considerara um sofisma para, agora, provar sua cristandade. A natureza em seu esplendor que a princípio fora argumento para o cronista refutar Jq. Sr. e sustentar a impossibilidade de o cego por nascença crer na existência de Deus, diante da acusação de materialista, adquire outro sentido e serve como pretexto para o cronista - em perfeito estado de sua visão - apresentá-la como uma das provas da existência divina. Temeroso, sugere ainda existirem outras provas da existência divina, já que a natureza é apenas uma das provas!

Não satisfeito, procura desculpar-se com o leitor: "Ora, quem nos ler com atenção há de convencer-se da nossa inocência", não sem, é claro, alfinetar seu antagonista: "assim como quem ler os artigos de nosso adversário, reconhecera fàcilmente no seu autor, uma veneração fanática pelas doutrinas espiritualistas”. Ou seja, se eu peco pelo materialismo, meu adversário o faz pelo espiritualismo - doutrina mal vista à época pela Igreja. Na tentativa de equacionar a questão, Machado busca um meio termo, sinal de que jovem, já refletira sobre o ecletismo, algo fundamental no início do século XIX: "Nos não somos nem espiritualista puro, nem materialista; 
harmonizamos as doutrinas de ambas as escolas e seguimos assim em ecletismo com o qual nos damos às mil maravilhas.”

Quanto à enunciação, é clara a artimanha do jovem cronista ao se aproximar do leitor e partilhar com este sua opinião, dividindo assim a "heresia", pois, o "nós não somos", nós "harmonizamos", nós "seguimos" vem a calhar para o jovem que, percebese, não sedimentara ainda suas opiniões e que, embora, buscasse na filosofia a resposta para suas dúvidas, mostrava-se à deriva em meio a pontos de vistas que se contrapunham a cada nova linha.

\section{5. À guisa de conclusão}

Diante disso Jq. Sr. ganha força, cresce e sustenta a opinião de que o cego por desgraça é o mais infeliz (19/3/1858), além de contrapor seu primeiro artigo em tom humorístico à argumentação machadiana, que classifica de filosófica e erudita. De sua parte, nega que seja um "espírito aferrado à escola espiritualista", porém, sabendo que a retórica e a erudição (MAGALHÃES JR., 1957: 2) merecem destaque na sociedade de sua época e são objeto de elogios, admite o idealismo de Mallebranche, o panteísmo de Spinoza e curva-se "à fôrça da voz poderosa de Cousin". Como bem afirmara Massa (1971: 188), tais polêmicas em grande parte soavam estéreis, tanto é que Jq. Sr. diz que o colega enganou-se quando entendeu que o havia chamado de materialista e retoma seus argumentos acrescendo detalhes à medida que faz referências a Chateaubriand, Xenófanes e Camões.

$\mathrm{Na}$ outra ponta, Machado não se dá por vencido e afirma ter visto o "nosso adversário recuando passo a passo" até encontrar a "parede a que levou os nossos argumentos sensatos e consequentes". Por fim, agradece as palavras lisonjeiras de seu adversário, criticando o desânimo e a frieza que afirma ter encontrado em seus argumentos subsequentes, e encerra a polêmica não sem antes censurar as ideias "ultrapassadas" de seu rival que, "se não admitisse as idéias inatas de Descartes, admitiria sem dúvida a tábua rasa de Locke", e, "se não fôsse espiritualista puro, seria um materialista perfeito", talvez como Diderot (e ele, se tivesse ousado admitir).

Mas o que extrair do jovem polemista em nível textual? Seu discurso pauta-se, sobretudo, pela manutenção da tradicional dicotomia filosófico-religiosa, característica 
da crítica ética, uma vez que essa leitura (crítica) "é imperiosa para aqueles que vêem a literatura como transmissão de idéias e princípios, como responsáveis por uma ação direta sobre a sociedade" (PERRONE-MOISÉS, 1973: 43). Exatamente por isso não se pode crer que Machado já tivesse "pronto" seu próprio sistema de valores: prova disso é seu recuo frente à acusação de materialista.

Contudo, é flagrante sua presença de espírito ao questionar as posições adotadas por Jq. Sr., que considerou obsoletas e refutou como sofismas diante das ideias que defendeu. A crítica à posição adotada por Jq. Sr., traz um eco de crítica moral, pois, ao contestar seu adversário, Machado é categórico: “concordamos que hajam princípio e sentimentos inatos - idéias nunca!”. Dessa forma, dirige-se à obra cartesiana munido de um pensamento pré-concebido, de um significado já estabelecido a partir do qual exercerá sua crítica argumentativa, relativizando a obra de Descartes e desprezando sua linguagem referencial.

Percebe-se ao longo da polêmica que as relações do cronista com sua obra (peça argumentativa) não são unívocas e as fontes literário-filosóficas interessam na medida em que contribuem para o entendimento de sua postura e de suas ideias: ora Descartes e Locke são chamados porque auxiliam em sua expressão, ora porque, invertidos, contribuem para ocultar seu pensamento materialista e afastá-lo de Diderot (fonte primordial e inconfessada) que o coloca em situação defensiva em face de seu adversário.

Contudo, é preciso considerar que a polêmica só teve continuidade porque nasceu da permeabilidade entre obras e, dessas relações, constitui-se a correspondência entre o pensamento do jovem cronista e o materialismo de Diderot, cuja consonância aparece, inclusive, naquilo que há de mais perverso: o temor em professar uma ideia estranha ao contexto em que se está inserido (apesar de a polêmica ter sido objeto de discussões "universais" ao longo da circulação das ideias literárias). Tomada como fonte literária, em tese, asseguraria ao cronista certa apropriação ao pensamento materialista de Diderot sem qualquer prejuízo à sua figura de formador de opinião em ascensão na sociedade carioca.

Normalmente, as relações entre enunciados (anterior e atual) são responsáveis pela produção de sentidos. No caso da polêmica dos cegos, nota-se com clareza a limitação imposta pelo tema preexistente - a impossibilidade de o cego de nascença não 
poder fruir da natureza, negando-a como prova maior da existência de Deus. Ora, o tema, enquanto razão constitutiva da polêmica e influxo intertextual, embora seja campo fértil para muita argumentação teórica, impede que se acrescente algo realmente novo à questão. Em ponto pequeno (n'A Marmota), demora-se sobre as mesmas considerações teóricas: materialismo, acusação de irreligião, e o consequente impedimento da irrestrita liberdade de pensar.

\section{O BOTÃO QUE NÃO É DE DIDEROT!}

\section{As Origens de um "paradoxo"}

Tuer le mandarin! Quando, ao longo do século XIX, em meio à conversa, hora ou outra as misérias da vida vinham à tona e ditavam o rumo da prosa, de pronto, saia-se com o termo tuer le mandarin! Matar para enriquecer tem seus inconvenientes: demanda tempo e imaginação. Afora ponderar interesses, escolher a vítima, tomá-la de assalto, etc.; ato feito, o maior estorvo, talvez, seja prestar contas à sociedade.

Mas pensemos de outro modo. Imaginemos que esse crime possa ser cometido de modo prático, como quem toca uma campainha, estala os dedos ou pressiona um botão. E mais: seu autor não correrá jamais o risco de qualquer acusação ou delação, afinal, seu álibi é indelével. A vítima (alguém que nunca viu) o tornará milionário, morrerá subitamente em lugar muito distante, na China, por exemplo. Sabendo que talvez a vítima "deita[e]-se todas as noites na esperança da morte", pois idosa, padeça de alguma doença (e partirá sem dor), "tu que me lês e és um homem mortal, tocarás tu a campainha? (EÇA DE QUEIROZ, 1946: 301)" Eis a essência do "paradoxo" ou da lenda do mandarim. Mas como terá surgido?

Tem-se dessa maneira parte dos ingredientes do "paradoxo": a recompensa, a impunidade e fantástico. Mas e a origem desse raciocínio, que passou para a literatura? Acredita-se que tudo tenha começado na Lídia, e quem conta é Heródoto (COIMBRA MARTINS: 1967: 16): certo pastor, por nome Giges, encontra um anel e, após colocá-lo no dedo, ao girá-lo, nas vezes em que a pedra permanecia voltada para dentro, o pastor tornava-se invisível. Pedra para fora e o pastor voltava à vista. Tanto fez o pastor com

${ }^{273}$ Sobre o desenvolvimento do "paradoxo”, ver Coimbra Martins (1967: 7-266). 
seu anel mágico que ganhou ascendência sobre os outros pastores, estabeleceu contato com o rei, matou-o, casou-se com a rainha e assim nasceu a dinastia dos Mérmnades. Não se trata ainda do que mais tarde viria a ser conhecido como "paradoxo" do mandarim, afinal, a vítima é conhecida, mas aí estão a riqueza, a impunidade e o inverossímil.

Nessa esteira, o anel de Giges foi parar n'A República (Liv. II), de Platão, e tornou-se um apólogo moral. Depois continuou seu percurso em Cícero (De Finibus Bonorum et malorum - Liv. II, § 18), que já não menciona mais o anel, mas preserva o mote da história: a problemática da consciência moral e a punição. Tempos depois, Montaigne (2009: 423, Tome II) e La Bruyère (1836: 112) remexem na questão ressaltando a relação impunidade-virtude. Rousseau ${ }^{274}$, ao imbróglio acrescenta o olhar do "Ser Supremo", afastando o secreto do crime e destacando a obediência à consciência como noção moral.

Porém, anos antes, Diderot, que a exemplo de Rousseau criava símiles sugestivos para suas especulações morais, aproxima-se da fórmula do mandarim e, justamente na Lettre sur les aveugles (2000: 38) discorre sobre quase todos os elementos integrantes da fórmula: a morte do homem, a distância e a ausência de medo ou punição. A hipótese de Diderot, contudo, não trata do móbil do crime, o botão referido por Machado. ${ }^{275}$

Todavia, nem mesmo em Entretien d'un père avec ses enfants (1773) pode-se ligar Diderot ao "paradoxo". É preciso esperar o catolicismo estético-moral de Chateaubriand (que traz algo do deísmo sentimental de Rousseau) e sua "divinização" da consciência. Em Génie du Christianisme (1802), de fato, Chateaubriand dá origem ao "paradoxo", porém, nada do móbil do crime, o botão referido por Machado.

De qualquer modo o autor romântico (1845: 155), a exemplo de Rousseau, sustenta que o mal, inerente ao homem, repugna à consciência, independente do receio de punição. No entanto, tratando-se do "paradoxo", Chateaubriand foi além, urdiu o sofisma de maneira a aproximá-lo da fórmula tal qual a conhecemos hoje: uma vítima distante (um chinês), um crime que traz fortuna, impunidade para o criminoso - e até benefício para vítima (la mort est un bien pour lui)! O mandarim, este viria depois com

\footnotetext{
${ }^{274}$ Ver Discours sur l'origine et les fondements de l'inégalité parmi les hommes (2008: 161-162) e Nouvelle Héloüse (1868: 181).

${ }^{275}$ Outra aproximação de Diderot se dá em Entretien d'un père avec ses enfants (1869: 162-163, Tome I).
} 
Balzac, que em Le Père Goriot (1963: 226) promovera o até então simples chinês. Porém, o móbil, a facilidade de "pousser le bouton", só virá com Monnier e Martin (1855: 24), no vaudeville intitulado As-tu tué le mandarin?. E...

\section{2. ... o botão pode ser pressionado no Rio de Janeiro}

\subsection{A emblemática capital}

Trata-se de história de longa data: embora a chegada de D. João VI, em 1808, tivesse trazido mudanças, a cidade que recebera a família real portuguesa era singular. Ao longe, observada dos navios que se aproximavam, mostrava-se bucólica; uma vez em terra, a impressão que se tinha era outra. "A limpeza da cidade estava toda confiada aos urubus", consoante o historiador Oliveira Lima (1996: 78). ${ }^{276}$ Mas tudo mudou para melhor (ao menos para a elite branca) nessa cidade que triplicou de tamanho entre os anos de 1808 e 1822: saneamento, saúde, arquitetura, costumes, artes, etc.

Contudo, o que para alguns era digno de nota: "Nenhum porto colonial do mundo está tão bem localizado para o comércio geral quanto o do Rio de Janeiro. Ele [...] parece ter sido criado pela natureza para constituir o grande elo de união entre o comércio dessas [das] grandes regiões do globo" (MAWE, 1978: 82), para outros, expunha a vulnerabilidade e a inadequação da cidade para capital do Império do Brasil. A France Antarctique soava distante, mas é provável que a investida (1711) de Duclerc e DuGuay-Trouin ${ }^{277}$ ainda fizesse parte do imaginário dos habitantes da cidade, de modo que não se condenava só sua localização litorânea, sujeita à invasões, mas também sua inclinação à praça de comércio, responsável por atrair grande número de negociantes estrangeiros, vistos como "a pior sorte de população que ali pode[ia] entrar" (SOBRINHO, 1977: 89).

O fato é que desde muito cedo se pensou a capital num ponto central do país. Em 1877, Francisco Adolfo Varnhagen, Visconde de Porto Seguro, publica ${ }^{278}$ em Viena sua experiência pioneira no comando de uma expedição, cujo objetivo não era outro que a

\footnotetext{
${ }^{276}$ A coleta regular de lixo só seria iniciada em 1847 (NEEDELL, 1993: 46).

${ }^{277}$ Trata-se de Jean-François Duclerc ou du Clerc (-1711) e René Duguay-Trouin (1673-1736), corsários franceses que invadiram o Rio de Janeiro em 1711.

${ }^{278}$ Trata-se da monografia A questão da capital: marítima ou no interior?
} 
demarcação do local exato onde seria construída Brasília. O pioneirismo de Varnhagen e o desdobramento de suas iniciativas pontuam em 1892, a Missão Cruls, coordenada pelo engenheiro Louis Cruls ${ }^{279}$, em cumprimento ao Art. $3^{\circ}$ da primeira Constituição Republicana.

À época da publicação do chamado Relatório Cruls $(1896)^{280}$ a imprensa dedicou amplo espaço aos resultados da Missão, afirmando, sobretudo, que a transferência da capital era o "único meio de impedir que o Brasil inteiro fique [ficasse] reduzido à Rua do Ouvidor, e a própria rua a alguns quarteirões apenas". ${ }^{281}$ Machado publicaria na Gazeta de Notícias (7/6/1896) crônica que engrossava o coro dos intelectuais favoráveis à transferência da capital. Porém, em $1893^{282}$, o alcance de suas considerações vai além do geográfico: o cronista traz à luz a dinâmica da transferência da capital, intui certo jogo de interesses dos poderes constituídos, reflete sobre o fim da convivência da cidade com ônus de ser a capital federal e duvida da morte anunciada da "sua" Rua do Ouvidor:

A questão Capital está na ordem do dia. Tempo houve em que na República Argentina não se falou de outra coisa. Lá, porém, não se tratava de trocar a capital da província de Buenos Aires por outra, mas de tirar à cidade dêste nome o duplo caráter de capital de província e da República. Um dia resolveram fazer uma cidade nova, La Plata, que dizem ser magnífica, mas que custou naturalmente empréstimos grossos.

Entre nós, a questão é mais simples. Trata-se de mudar a capital do Rio de Janeiro para outra cidade que não fique sendo um prolongamento da rua do Ouvidor. Convém que o Estado não viva sujeito ao botão de Diderot, que matava um homem na China. A questão é escolher entre tantas cidades. A idéia legislativa até agora é Teresópolis; assim se votou ontem na Assembléia. Era a do finado capitalista Rodrigues, que escreveu artigos sôbre isso. Grande viveur, o Rodrigues! Em verdade, Teresópolis está mais livre de um assalto, é fresca, tem terras de sobra, onde se edifique para oficiar, para legislar e para dormir.

Campos quer também a capitalização. Reúne-se, discute, pede, insta. Vassouras não quer ficar atrás. Velha cidade de um município de café, julga-se com direito herdar de Niterói, e oferece dinheiros para auxiliar a administração. Petrópolis também quer

\footnotetext{
${ }^{279}$ O engenheiro belga, Louis Ferdinand Cruls (1848-1908) ficaria conhecido no Brasil por Luís Cruls.

${ }^{280}$ O Relatório Cruls teve várias edições. A mais recente é Relatório da Comissão Exploradora do Planalto Central do Brasil. Relatório Cruls. $4^{\mathrm{a}}$ ed. Brasília: Secretaria do Governo do Distrito Federal, 1984.

${ }^{281}$ Conforme reportagem publicada em 1896 no Correio Braziliense.

282 "A Semana”, Gazeta de Notícias, 22/1/1893.
} 
ser capital, e parece invocar algumas razões de elegância e de beleza; mas tem contra si não estar muito mais longe da rua do Ouvidor, e até mais perto, por dous caminhos. Também há quem indique Nova Friburgo; [...]

Quanto à capital da república, é matéria constitucional, e a comissão encarregada de escolher e delimitar a área já concluiu os seus trabalhos, ou está prestes a fazê-lo, segundo li esta semana. Telegrama de Uberaba diz que ali chegou o chefe, Luís Cruls.[...]

Na crônica, cujo mote não é outro que a transferência da capital, o cronista chama a atenção para a proximidade de Petropólis que, caso venha a ser escolhida, poderá confundir a geografia das identidades, qual seja, a cidade serrana concebida como protótipo de cidade europeia encravada nos trópicos reforçará os contrastes e exporá as fissuras e desordens sociais. Não bastasse isso, considerado o fisiologismo que rege as relações políticas, uma vez transferida a capital federal para outro lugar, perderá o estado do Rio que, mais tempo, menos tempo, será controlado à distância.

\subsection{E Machado altera o "paradoxo"}

"Convém que o Estado não viva sujeito ao botão de Diderot, que matava um homem na China." O sobreaviso é claro: afastada a máquina do poder, corre-se o risco de o Estado (e a cidade do Rio de Janeiro) caírem em decadência. Com isso, Machado entra no rol daqueles que subverteram (e adaptaram) o "paradoxo" do mandarim. Teria ele lido Entretien d'un père avec ses enfants (1773) ou teria lhe caído às mãos o Dictionnaire de la langue verte (1866), obras nas quais, ainda que enviezadamente, Diderot pode ser ligado ao "paradoxo"? Jamais o saberemos, mas o fato é que o cronista integra o elemento estrangeiro à sua escrita, alterando-o em sua estrutura.

Veja-se: assim que Monnier e Martin acrescentaram-lhe um móbil, configurouse o "paradoxo" tal como o conhecemos hoje, porém, ao alterá-lo, Machado sinaliza sua incompletude, perpetuando seu movimento ao longo da circulação das ideias:

\begin{tabular}{c|l|l}
\multicolumn{1}{c|}{ Estrutura } & \multicolumn{1}{|c}{ O “paradoxo" } & \multicolumn{1}{|c}{ Alterações machadianas } \\
\hline Recompensa/Riqueza & $\begin{array}{l}\text { Assegurada com a morte da } \\
\text { vítima. }\end{array}$ & $\begin{array}{l}\text { Não mencionada, mas intui-se a } \\
\text { evasão de riquezas para fora da } \\
\text { cidade (e do Estado) do Rio de }\end{array}$
\end{tabular}




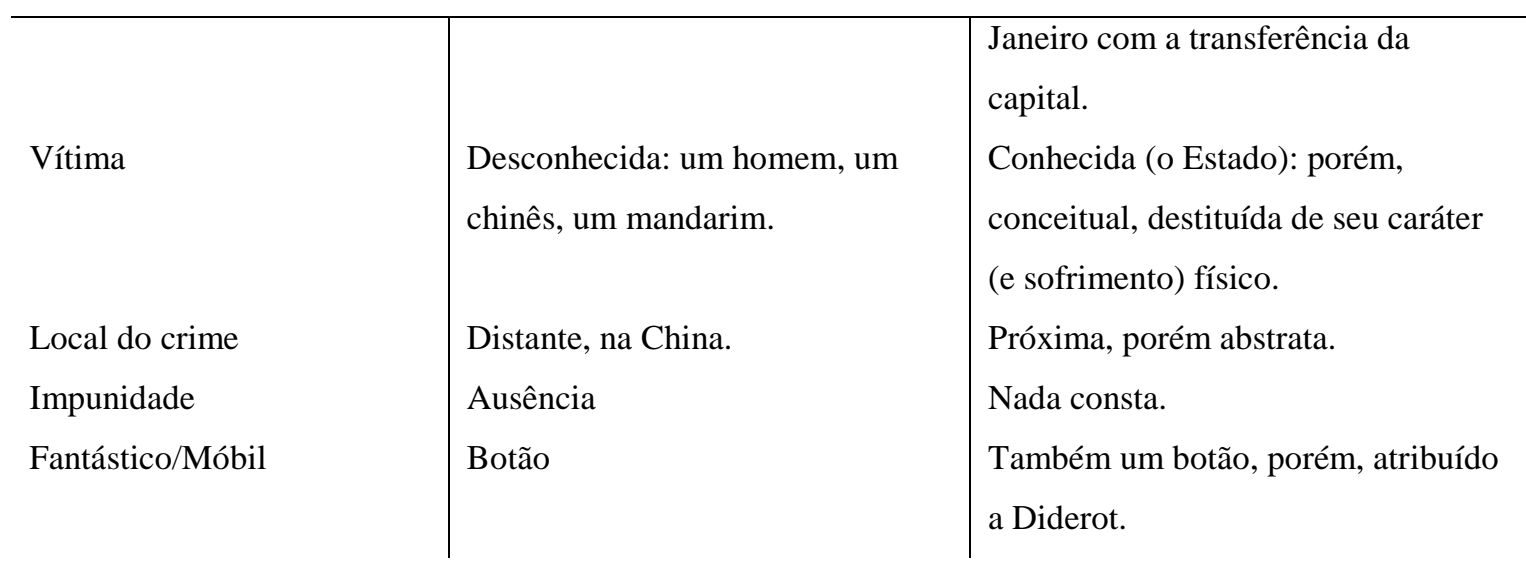

Assim, embora Machado se coloque favoravelmente à transferência da capital, a introdução de um elemento estrangeiro, corrompido em sua essência (uma vez que o cronista subtraiu a problemática envolvendo consciência individual e complexidade moral), mais uma vez nos leva à inversão, prática usual na escrita machadiana, que consente afirmar para negar (ou ao contrário). De fato, há o alerta sobre o controle à distância (e manipulação) da Federação contra o Estado, algo cuja extensão era desconhecida à época ${ }^{283}$, portanto, alvo de reflexão e visto com desconfiança.

Vale destacar ainda que o argumento do cronista adquire importância na medida em que, sob a monarquia, a proximidade do poder assegurava, de certa forma, que se pudesse prever a próxima cartada no jogo político-social, alternado entre conservadores e liberais. Contudo, fora as inferências públicas, permite-se arriscar (ainda que em caráter especulativo) o alcance do "botão de Diderot" em seu aspecto particular, nos moldes da coexistência em todos os eventos políticos das bandeiras públicas e particulares (concepção enunciada em Memórias póstumas de Brás Cubas - cap. IV). Machado, é sabido, mantinha-se próximo à arena do poder, onde figuras públicas, assumindo cunho de fontes, subterraneamente abasteciam-no de informações privilegiadas, de modo que também ele ver-se-ia "sujeito ao botão de Diderot" e, talvez, privado desse contexto.

Um ano depois, em 1894, o cronista voltaria a fazer alusão ao botão, corrompendo seu mecanismo a ponto de a vítima padecer na Noruega.

\footnotetext{
${ }^{283}$ Clamores anteriores aqueciam a questão. Segundo Needell (1993), “os paulistas, membros da força mais dinâmica das elites, consideravam a Monarquia centralizadora, uma instituição que favorecia as regiões mais antigas" (p. 28) e "viam na República uma redistribuição do poder mais favorável a seus interesses regionais" (p. 23), donde o parâmetro que talvez orientasse a elite urbana da Corte.
} 


\section{A Revolta da Armada e calor intenso: "bandeiras públicas" e "bandeiras particulares"}

À República Machado parece ter dispensado a mesma ambiguidade que rege sua escritura; passado o golpe que destituiu o Império, sua visão artística não sofreria qualquer mudança visível. Em seus romances e crônicas, o novo regime sempre é visto sob o crivo de um narrador satírico, irônico, às vezes brincalhão, que se expõe consoante às personagens.

Em Esaú e Jacó (1904), por exemplo, o barão de Santos, preocupado que o advento da República trouxesse a desordem pública e comprometesse seus negócios, ouve de Aires, o Conselheiro, que "nada se mudaria; o regímen, sim, era possível, mas também se muda de roupa sem trocar de pele" ${ }^{\text {284 }}$, ao passo que o velho Custódio, indeciso, aparece como paródia da crise no célebre episódio da troca da tabuleta ${ }^{285}$.

Sob crivo artístico, os problemas da jovem República permeiam parte das crônicas machadianas. Em 18/2/1894 ${ }^{286}$, embora já se considerasse vencida a Revolta da Armada $^{287}$, o cronista faz dos rumores da revolta o pano de fundo da sua crônica. Broquéis, dinamite, explosões, pólvora, etc., “que diabo!”, figuram como necessidade vital, onde a paz universal surge como a "dissolução final das cousas".

Deixando-se levar pela introdução, o leitor certamente será ludibriado pelo cronista. A crise política anunciada pelo belicismo do vocabulário, na condição de "bandeira pública", findo o parágrafo, é deixada de lado. Segue-se então o desfraldar da "bandeira particular" ao tratar seus comentários como "rabugens", especulando sobre a "dissolução final" imaginada e fantasiando o mundo sob a anarquia, numa guinada circular em que o futuro será o que já foi e "Adão e Eva dormirão as noites, passearão as tardes; [e] Caim e Abel escreverão um jornal sem ortografia nem sintaxe".

Na sequência, envereda-se ainda mais pelo particular: reafirma sua rabugice, reclama de mal estar, acredita-se doente e deseja meter-se na cama - ou na cova -, donde certa ironia consigo mesmo, seu estado físico; a razão, acredita, está no intenso calor

\footnotetext{
${ }^{284}$ Capítulo LXIV - "Paz!"

${ }^{285}$ Capítulos LXII - "Pare no D." e LXIII - "Tabuleta Nova"

286 "A Semana", Gazeta de Notícias.

${ }^{287}$ Rebelião promovida pelos oficiais da Marinha contra o presidente Floriano Peixoto em 1891 e 1893 (unidades encouraçadas da marinha trocaram tiros com fortes do Exército, no Rio de Janeiro, em 13 de setembro de 1893). Em março de 1894, Floriano considerou contida a rebelião.
} 
que abrasa a cidade. Certo é que o cronista vive um fevereiro atípico a ponto de, em oração, pedir a Deus que lhe conceda um pequeno estio, ainda que na condição de exceção, quando sai com uma dessas frases que, extraídas da crônica, caminham como verdadeiro adágio: “A exceção só é odiosa para os outros; em si mesma é necessária."

Por meio de um clichê (quente-inferno; subentendendo-se que o inferno seja quente), o cronista aprofunda a questão em situação antitética, opondo o calor obsedante do Rio de Janeiro ao frio mortal da Noruega, correspondência possível a partir da "desconstrução" do "paradoxo" do mandarim.

\section{1. "Eu bufo aqui e [...] morre alguém na Noruega"}

Veja-se o entrecho em que o intertexto, como alusão, integra-se à escrita machadiana:

A terra é quente. Lá mesmo haverá epidemias, que não sabemos, e um subobituário, mais numeroso que o obituário dêstes dias. [O cronista havia dito que talvez se metesse numa cova para escapar do calor.] É a nossa enfatuação de vivos que nos leva a crer que só há calamidades para nós; também os mortos terão as suas, acomodadas ao estado. Nem o purgatório significa outra cousa senão as doenças de que os mortos podem sarar e saram. O inferno é um hospício de incuráveis. Raros, bem raros, cinco por século, subirão logo para o céu.

O que me consola um pouco, é que em outras partes estão morrendo de frio. A certeza de que, quando eu bufo aqui e corro a comprar gêlo, morre alguém na Noruega, por havê-lo de graça, ajuda a suportar o calor. Não é preciso o botão de Diderot $^{288}$; não fica na alma essa sombra de sombra de remorso, que pode trazer a idéia de haver apunhalado diretamente, ainda que de longe, uma pessoa. A certeza basta, e sem interêsse pecuniário, note-se bem. É o povo que formulou, dizendo que o mal de muitos consôlo é. Expirai às mãos de vossa mãe, filhos da neve, enquanto os filhos do sol aqui morremos às mãos do nosso grande pai.

Dissolvido ao longo da escritura, o elemento estrangeiro indiciado pela expressão "botão de Diderot" em pouco altera a significação do fato comentado. O fator climático, embora responda por algumas mortes, não vem à tona em razão delas, mas sim pelo exponencial (e particular) incômodo que provoca ao cronista. Ademais, não

${ }^{288} \mathrm{Na}$ Gazeta de Notícias, talvez por falha de revisão, está grafado "balão". 
fosse a referência a Diderot, algo que possibilita recuperar parte da estrutura do "paradoxo", poder-se-ia afirmar que Machado se deixou levar por um enunciado sentencioso $^{289}$, repetido à exaustão pela cultura popular, dada a maneira como encerra seu pensamento.

De qualquer forma, partes do "paradoxo" antecedem a frase sentenciosa e surgem como desdobramento da memória, incitando o leitor através de seus indícios intertextuais. Assim, vemos que a partir de uma correspondência climática na qual ora morre-se de calor ora de frio, Machado dispensa o botão de Diderot, afasta da questão qualquer arrependimento e, ironicamente, abranda o remorso que acomete aqueles que apunhalam diretamente, "ainda que de longe". Veja-se como o cronista trabalha com a estrutura do "paradoxo":

\begin{tabular}{|c|c|c|}
\hline Estrutura & O "paradoxo" & Alterações machadianas \\
\hline Recompensa/Riqueza & $\begin{array}{l}\text { Assegurada com a morte da } \\
\text { vítima. }\end{array}$ & $\begin{array}{l}\text { Não há qualquer interesse } \\
\text { pecuniário, basta a certeza de que a } \\
\text { vítima morrerá. }\end{array}$ \\
\hline Vítima & $\begin{array}{l}\text { Desconhecida: um homem, um } \\
\text { chinês, um mandarim. }\end{array}$ & $\begin{array}{l}\text { Também desconhecida, porém, um } \\
\text { norueguês. Não se comenta sobre } \\
\text { qualquer sofrimento físico. }\end{array}$ \\
\hline Local do crime & Distante, na China. & Também distante, na Noruega. \\
\hline Impunidade & Ausência & $\begin{array}{l}\text { Não há sequer "sombra de sombra } \\
\text { de remorso". }\end{array}$ \\
\hline Fantástico/Móbil & Botão & $\begin{array}{l}\text { Substituição do botão por uma } \\
\text { bufada. }\end{array}$ \\
\hline
\end{tabular}

Embora o cronista promova mudanças em dois pontos essenciais (recompensa e impunidade) o "paradoxo" se mantém. Vejamos:

Ao longo da formulação do "paradoxo", a recompensa é o grande propulsor: Giges, ao matar o rei, não só se casou com a rainha como também herdou seus bens; Platão fala em "bens alheios"; Cícero menciona que "da morte tirarias proveito"; ao retomar Cícero, Montaigne (2009: 423, Tome II) relembra Sextilius Rufus que se apropriou de uma herança e Crassus e Hortensius envolvidos na produção de um

\footnotetext{
${ }^{289}$ É provável que a frase "é o povo que formulou, dizendo que o mal de muitos consôlo é", tenha sua raízes no provérbio latino "Quae mala cum multis patimur, leviora videntur" (Mal de muitos, consolo é.).
} 
testamento falso para "tirer quelque fruit". La Bruyère generaliza e afirma que os homens se veem como herdeiros uns dos outros; Rousseau alude aos "héretiers avides", Chateaubriand fala em fortuna, Balzac em "s'enrichir" e Monnier volta à questão da herança.

Ora, em Machado nem tudo é o que parece! Por trás de um aparente desinteresse pecuniário, esconde-se algo maior. A correspondência traçada pelo cronista estabelece o contraponto: bufa-se no Rio, morre-se na Noruega. Porém, uma vez que a analogia dáse em razão de um efeito climático, admite-se inferir uma hipotética lei natural de compensações, através da qual a natureza também estabelece similitudes: bufando, preserva-se a vida no Rio, mas à condição de que alguém morra na Noruega.

Talvez, por esse motivo, o cronista tenha afastado do "paradoxo" o remorso. Afastando-o, se junta àqueles que reforçam sua estrutura, tal qual Platão: "ninguém é justo por livre vontade; [...] não há moral que resista à garantia de impunidade". Para o cronista algum remorso existiria (e aqui viria em forma de punição) caso a vítima fosse apunhalada. Ainda assim, ao admiti-lo, estabelece nuances mitigando sua importância. A "sombra da sombra de remorso" e "a idéia de haver apunhalado diretamente, ainda que de longe, uma pessoa" despontam em forma de paródia à problemática da consciência individual (teorizada por Rousseau e Chateaubriand).

Machado, passa ao largo de toda a problemática, creditando à distância ("ainda que de longe") certa amenização dos efeitos da consciência e, ao fazê-lo, aproxima-se de Diderot (Entretien d'un père avec ses enfants) que afirmara:

On convint que peut-être la distance des lieux et du temps affaiblissaint plus au moins tous les sentiments, toutes les sortes de consciences, même celle du crime (1869: 162)

Pelo viés lexical também se entrevê a proximidade machadiana com o francês. A punição concebida pelo cronista reduz parodicamente a dimensão da consciência individual. Contudo, a "sombra de uma sombra de remorso" não perde sua forma original, ainda que à distância. De qualquer modo, o vocábulo escolhido por Machado aparece na Entretien, de Diderot, um dos poucos autores a tratar do remorso, essa inquietação da alma que atormenta o algoz tanto quanto a punição pública: 
Le remords naît peut-être moins de l'horreur de soi que de la crainte des autres ; moins de la honte de l'action que du blâme et du châtiment qui la suivraient s'il arrivait qu'on la découvrît. (1869: 163)

O fato é que ao parodiar a consciência moral, Machado apequena o remorso, adaptando o intertexto à sua escritura de modo a responder por um problema banal, distante do contexto francês setecentista. A "sombra de sombra de um remorso" faz com que o grito (do remorso) soe ao longe, e o eco, distante, mal incomoda.

No mais, o remorso em myse en abyme, assim como a vítima, apunhalada diretamente, mas ao longe, não se aplicam ao contexto do cronista, mas, ainda assim, na escritura, reforçam o caminhar do "paradoxo" ao longo da circulação das ideias. Nesse caminhar, o cronista providencia pequena mudança em relação ao móbil: o que para alguns fora um estalar de dedos, para outros um botão, no fevereiro escaldante do Rio de Janeiro, torna-se um punhal.

Desse modo, Machado integra à sua escritura um clichê de origem remota e, ao fazê-lo, associa seu discurso leve de folhetim a expoentes das Lumières, fazendo com que os elementos intertextuais apareçam como elo de "integração" entre as culturas francesa e brasileira.

\section{4. "Abitanti de Parigi..."}

"Abitanti de Parigi, è ora di riposar." ${ }^{, 290}$ A frase parece solta na crônica de 20/12/1896 ${ }^{291}$, porém, observada de perto, nota-se que não só articula as lembranças do cronista em um relato de cunho aparentemente policial, como também indicia traço característico da escrita machadiana: apropriar-se dos fatos sem observar suas fronteiras.

Interpretada sob perspectiva ficcional e associada a eventos históricos pontuais, a notícia surge na crônica como démarche para que o cronista desenvolva um dos principais traços de sua escrita: a relativização textual. Assim, com a notícia rompida em seus limites, instauram-se dois movimentos essenciais: em relação ao conteúdo, o

\footnotetext{
${ }^{290} \mathrm{Na}$ Gazeta de Noticias está grafado "Habitanti de Parigi è ora di riposar." Nas edições da Jackson e Aguilar, corrigiu-se a palavra habitante (abitante, em italiano), porém, não se corrigiu o verbo repousar, riposare, em língua italiana.

291 "A Semana", Gazeta de Notícias.
} 
fato é destituído de sua suposta "verdade"; tratando-se do viés estético, contudo, esse princípio promove maior uso de formas, tonalidades e inusitada expressividade, onde tudo é lido forma dúbia, num misto de seriedade e ironia.

Sob o eco dos "abitanti de Parigi" o cronista relembra a época em os que os habitantes do Rio de Janeiro obedeciam a um toque de recolher, marcado pelo sino da igreja de São Francisco de Paula, que soava às 10 horas da noite. "Ó tempos! Tempos!" E um cronista nostálgico encaminha suas lembranças de forma a sustentar a necessidade da polícia, "uma instituição necessária à ordem e à vida de uma cidade", afinal, reitera: "antes medíocre que nenhuma".

Figuras lendárias voltam às páginas da crônica, assim como as ações da polícia. Estas, consideradas providenciais, pois "poupava-se a vida à gente pacífica", naquela data, confundem as pessoas e são vistas de modo jocoso, de tal arte que a polícia não prendeu ninguém "porque os ladrões de dinamite não são como os de simples lenços pendurados às portas das lojas", "obrigados a furtar de dia, à vista do dono e dos passantes". A ironia que desqualifica as ações (e a competência) da polícia fica por conta do modo como o autor contrapõe as diferentes categorias de ladrões.

Ladrões de dinamites roubam à noite, às escondidas. Ladrões de lenços roubam durante o dia, à vista de todos, "correm, são perseguidos pelo clamor do público, e afinal pegados". Logo, questiona o cronista: que virtude move as pessoas que "perseguem o gatuno"? Disso, temos a démarche que nos levará ao "problema de Diderot".

\section{1. "O problema de Diderot"}

A reação do público face às diferentes categorias de ladrões influencia o olhar do cronista e resulta na reescritura do "paradoxo", promovendo, assim, a reativação de suas estruturas. A analogia com a matriz original se conserva em pormenor e a relação entre "paradoxo"/crônica dá-se por transposição, de maneira que o intertexto, adaptando-se à temática e absorvido pela escrita, degrada-se. Novamente, não fosse a referência a Diderot, perder-se-ia o elo intertextual e teríamos algo que, pela similitude, distinguirse-ia do original, oferecendo no máximo uma aproximação de conteúdo. Vejamos o entrecho da crônica: 
Eu, apesar do gôsto que tenho à psicologia, ainda não pude descobrir o móvel secreto das pessoas que perseguem neste caso a um gatuno. [Trata-se do ladrão que rouba à luz do dia, à vista do público.] É o simples impulso da virtude? É o desejo de perseguir um homem hábil que quer escapar à lei? Mistério insondável. A virtude é, decerto, um grande e nobre motivo, e se pudesse haver deliberação no ato, não há dúvida que ela seria o motivo único; mas, não se pode deliberar quando alguém furta um lenço e foge; o ato da corrida é imediato. Se os perseguidores fôssem outros lojistas, não há dúvida que, por aquêle seguro mútuo natural entre as pessoas interessadas, cada um trataria de capturar e fazer punir o que defraudou o vizinho, e pode amanhã vir defraudá-lo a êle. Mas, em geral, os perseguidores são pessoas que nada têm com aquilo. Nenhum dêles levaria nunca o lenço de ninguém; não contesto que um ou outro, pôsto em corredor escuro e solitário, diante de um relógio de ouro, regulando bem, longe dos homens, difîcilmente sairá sem o relógio no bôlso. É, por outra maneira, o problema de Diderot. Não vades crer que eu condeno a perseguição dos delinqüentes; ao contrário, aplaudo o espírito de solidariedade que deve prender o cidadão à autoridade e à lei; mas não falo em tese, falo em hipótese.

Desse modo o cronista introduz o que chama de "problema de Diderot", talvez porque o mecanismo, corrompido, emaranhou-se à sua escrita, sendo em parte mutilado. Embora desfigurado, evidencia fragmentos de um fundo literário que surge no texto como marca conciliatória de parte da memória que se acomoda a um enunciado estranho à sua origem e, mesmo ali, destaca-se como uma excitação de leitura, que preside a um ato de leitura ao de escrita, portanto, passível de reescritura.

Ainda assim, partes do "paradoxo" (recompensa, vítima, local do crime, impunidade e móbil) aceitaram ser reescritas. Por outro lado, ao tratar da recompensa o cronista introduz uma escala valorativa; um mesmo indivíduo pode ter sua moral (ou ética) dimensionada a partir da oportunidade e do valor do objeto:

Mas, em geral, os perseguidores são pessoas que nada têm com aquilo. Nenhum dêles levaria nunca o lenço de ninguém; não contesto que um ou outro, pôsto em corredor escuro e solitário, diante de um relógio de ouro, regulando bem, longe dos homens, difìcilmente sairá sem o relógio no bôlso.

A recompensa existe, contanto que o crime (roubo) compense, porque de alta monta. Desse modo, ecos de Diderot ressoam: na Lettre sur les aveugles (1749), ao 
tratar da punição, o filósofo francês também introduz a ideia de proporção, porém relacionada à distância e ao tamanho da vítima:

Si nous avons de la compassion pour un cheval qui souffre, et si nous écrasons une fourmi sans aucun scrupule, n'est-ce pas le même principe qui nous détermine ? (2000: 38)

O secreto do crime, garantia inexorável de impunidade, fica por conta do "corredor escuro e solitário", imagem criada pelo cronista para adequar o conceito a seu texto leve de folhetim.

“É, por outra maneira, o problema de Diderot." Sobretudo por esse arremate, efetua-se a integração do elemento intertextual ao texto folhetinesco. Embora destituído de sua "grandiosidade" filosófica, suscita a reflexão, inventaria em parte o pecúlio literário do cronista e responde pela máxima alencariana de que se deve observar o "tamanho da sociedade fluminense" (ALENCAR, 1997: 175). Nota-se, por fim, que a ablação surge como procedimento intertextual do cronista: a interposição do intertexto (e a mutilação de parte do "paradoxo") fez com que o fragmento escolhido se convertesse em texto. Desse modo, circunscrevendo-se ao caso específico, a fórmula sofre interrupções e alterações.

Assim, através da transposição parcial do "paradoxo" (e a referência a Diderot), um conceito que versa sobre a consciência individual, suas questões de cunho moral e ético, deixa as páginas dos tratados filosóficos e se transforma num arremedo. Parodiado, perde seus ares "plato-rousseaunianos", ganha a rua e provoca o leitor: afinal, que moral move os espíritos diante de uma lucrativa oportunidade no secreto de um "corredor escuro e silencioso"?

E, "em hipótese", o cronista faz suas cabriolas evocando o pensamento de Hamlet. Antes, porém, envereda pelo crime, comenta certo roubo de joias (e, mais uma vez, a estupidez policial), não sem antes citar verso da ópera-cômica de d'Halévy - Les Mousquetaires de la Reine (1846) e trecho de Colomba $(1840)^{292}$ de Mérimée, completando assim sua escritura mosaico, permeada de influxos franceses.

\footnotetext{
${ }^{292}$ Em 1840, o texto é publicado na Revue des Deux Mondes. Em 1841 teria sua primeira publicação em volume.
} 
Conclui-se, dessa forma, o périplo do "paradoxo" do mandarim: cruzando o Atlântico, deixa de lado seu ar sisudo e se enternece nas páginas da crônica sem, contudo, perder de todo suas raízes morais. Nos trópicos, parodiado e apequenado, envolve-se em questões políticas (a mudança da capital federal), climáticas e policiais. Ao longo da circulação das ideias literárias, em universo machadiano, a fórmula não só estofa a ironia do cronista no trato com a aridez da notícia, como distende a significação do(s) fato(s) comentado(s). Diderot, arrolado à revelia, ganha desse cronista um "botão" e um "problema", os quais, de certa forma, funcionam como móbil de integração entre as culturas francesa e brasileira. 


\section{OLHARES SOBRE O SÉCULO XVIII E ANALOGIAS DE LEITURAS NAS CRÔNICAS MACHADIANAS}

"O resultado da Revolução Francesa foi que a era de Balzac substituiu a era de Mme Dubarry."

(HOBSBAWM, 1989: 72)

\section{Na França do século XIX, diferentes "regards en arrière"}

Em Histoire de la littérature française, Pierre Kohler, ao iniciar o capítulo sobre o século XVIII, afirma que os modos e as ideias de uma nação não se renovam simultaneamente ao badalar dos sinos que anunciam o despertar de um novo século (1948: 19). Contudo, tratando-se do século XVIII, algo destoou da afirmação do crítico, pois em 1804 o Institut national junta ao concurso de eloquência um Tableau littéraire de la France au XVIII siècle, o que não só denota o desejo de considerar o século anterior como uma época já concluída, mas, sobretudo, coloca-o como algo distante e passível de novas interpretações. ${ }^{293}$

“Quel contraste! quel brusque passage!” exclama Hazard (1961: 7) ao partir do XVII para adentrar o XVIII. Largamente cosmopolita, cenário das grandes questões científicas e sociais, palco de polêmicas e discursos, ao longo do século XIX o Siècle des Lumières não só seria referenciado, incensado, sonhado, mas, sobretudo, rejeitado, vilipendiado. Ainda que o abismo da Revolução sinalize a ruptura entre dois mundos, o Século de Voltaire continuou presente na consciência e nos escritos do homem oitocentista.

O simples fato de se querer esquecê-lo é motivo para sua incessante reconstituição, razão pela qual o século XIX se constrói a partir de seu anterior imediato, rendendo-lhe tributo e mitificando-o à medida que se constitui. Contudo, sem deixar de ver a si mesmo como uma era livre de qualquer herança, por mais que o XIX tome consciência de sua singularidade e busque definir sua evolução, o XVIII se impõe

\footnotetext{
${ }^{293}$ Mortier (1972 : 13), que estudou as diferentes modalidades do concurso, afirmou: "l'idée de faire, au tournant d'un siècle, le bilan d'un centenaire est déjà un phénomène curieux et nouveau dont on ne trouve le précédent ni en 1700, ni auparavant. Il semble que la Révolution d'une part, l'idée de mouvement historique d'autre part [...], aient suscité cette soudaine prise de conscience. Neste estudo, Mortier discorre sobre uma fase capital na luta para se tentar proteger o legado das Lumières, diante da opinião católica e legitimista.
} 
como uma identidade específica ${ }^{294}$, de modo que, invariavelmente, ao homem oitocentista tornou-se impossível se desvincular de imagens herdadas e da autorrepresentação setecentista, enfim, de uma acumulação de escritos nos quais os imaginários se encontram.

Nessa perspectiva, diferentes discursos revisitados, uma vez questionados, contraditos e ou ratificados, elaboram o mito do século XVIII, ainda que ilusório, uma vez que dificilmente o presente oferece a "verdade" sobre o passado. Repensado por seu ulterior num processo de comparação, o século XVIII estimula e enriquece as reflexões de seu sucessor imediato, de tal arte que não só posições ideológicas, mas, sobretudo, significações estéticas e toda uma gama de representações artísticas, afora anseios, medos e arrependimentos vêm à tona assegurando a coesão desses dois mundos.

E não é por outra razão que os olhares do XIX asseguraram a permanência e continuidade do XVIII, principalmente nas artes: na pintura, o gosto dos artistas pelo Século de Voltaire é obsedante e na literatura, consoante Paul Bénichou (1992: 102), "la vogue du XVIII ${ }^{\mathrm{e}}$ siècle dans la littérature romantique, de sa légende galante, de ses marquises, de son bon sens ironique, est un fait général, connu depuis longtemps". 295 Contudo, essa atração (ou mesmo a repulsa) está ancorada em escolhas estéticas que caracterizam a literatura da época e é exatamente por isso que o XVIII ganha relevância e representação nas obras em prosa, de maneira que o interesse pelo passado vem à tona, sobretudo, em romances e ou estudos de caráter histórico.

Esse olhar admirativo que contagiou escritores, historiadores, crítica e público, exibindo um movimento cujo dinamismo trouxe em si o gérmen do cansaço, fenece logo depois, confirmando o caráter oscilatório dos olhares oitocentistas. Pouco antes, por exemplo, após o entusiasmo da Revolução e do Terror, imperaram os discursos contrarrevolucionários, o cansaço, a apatia e a indiferença.

Nesse contexto, a aurora do novo século, tomada pelo esgotamento, volta seu primeiro olhar para a complexidade do XVIII: um olhar crítico, enfadado, colérico violento! Ao refutar seu passado próximo, o XIX caricaturou e reduziu-o a estereótipos,

\footnotetext{
${ }^{294}$ Segundo R. Mortier (1969: 13), o século XVIII foi "le premier à s'être défini lui-même comme une entité spécifique, douée d'une volonté propre et tendant à réalisation d'objectifs clairement formulés".

${ }^{295}$ Seymour O. Simches, por exemplo, divide sua obra Le Romantisme et le goût esthéthique du XVIII ${ }^{e}$ siècle (1964) nos seguintes capítulos : 1. le retour du goût pour le XVIII ${ }^{\mathrm{e}}$ siècle ; 2 . le goût pour le XVIII ${ }^{\mathrm{e}}$ siècle dans l'art; 3. le goût pour le XVIII ${ }^{\mathrm{e}}$ siècle dans le mobilier et la mode; 4 . le goût pour le XVIII ${ }^{\mathrm{e}}$ siècle dans la poésie ; 5 . le goût pour le XVIII ${ }^{\mathrm{e}}$ siècle dans le théâtre et le roman.
} 
valendo-se de clichês. O Siècle de Lumières, de modo perifrástico, surgiu como codinome e ofereceu farto material para a Igreja e o Estado condená-lo sumariamente, uma vez que se considerou que nele geraram-se os gérmens da Revolução. Voltaire, Rousseau, Diderot, d'Holbalch tornaram-se sinônimos de subversivo e ateu, e, aliados à palavras como intelectual, racional e analítico, auxiliaram na interpretação do século XVIII.

Os contraditos se sucedem e o século XVIII continua em linha de mira. Diante disso, nesse começo de século, a herança das Lumières parece um fardo bastante pesado a carregar, mesmo para aqueles que nutrem certa simpatia pelo século dos filósofos, suas ideias libertárias e de tolerância. Mme de Staël, por exemplo, em De l'Allemagne (1813) mostra-se dividida e, se sustenta uma imagem positiva da primeira parte do século XVIII, deixa claro sua repulsa sobretudo à segunda metade quando, afirma, tudo se corrompe.

Porém, à luz das novas mudanças, o século XVIII deixa de ser odiado, haja vista não mais inflamar as multidões e incitar os espíritos. Agora, o olhar que se lança ao XVIII é um tanto enigmático, um misto de curiosidade e fascinação: busca-se ali o pitoresco, o espírito dos salões onde escritores se misturam à vida mundana, a noção do bem-viver, as festas e os princípios do prazer e da felicidade. Despertam também interesse as grandes personagens, as polêmicas, a libertinagem despreocupada, o teatro, a arte que ilustrara esse mundo nostálgico e sonhado, enfim, as cores de Watteau, Lancret e Greuze que demoviam o perfil pré-revolucionário e a aridez do século XVIII.

Embora se considere natural a negação de uma geração por outra que a sucede, esse fenômeno aplicado aos séculos XVIII e XIX não soa maniqueísta, pois há uma integração entre os dois séculos que se revigora incessantemente. Não por outra razão, em março de 1834, Victor Hugo afirma no prefácio de Littérature et philosophie mêlées:

C'est d'ailleurs peut-être la seule chose frappante de ce volume, à la composition duquel n'a été mêlé aucun arrangement artificiel, qu'il commence par le nom de Voltaire et finisse par le nom de Mirabeau. Cela montrerait, s'il en existait pas d'ailleurs beaucoup d'autres exemples à côté desquels celui-ci ne vaut pas la peine d'être compté, à quel point le dix-huitième siècle préoccupe le dix-neuvième. Voltaire, en effet, c'est le 
dix-huitième siècle système ; Mirabeau, c'est le dix-huitième siècle action. (1857: VIVII)

Logo, o século XVIII se intromete no XIX como inesgotável fonte nostálgica, da qual não escapam a literatura e a reflexão estética, cuja contemplação das impressões fugidias dos peintres galants, que coloriam um mundo pleno de aspirações e sonho, tornam-se uma constante. Mundo esse, que manteria correspondência com seu sucessor imediato, num misto de repulsa e atração até que sentimentos e ideias fossem depurados pelo tempo.

Contudo, diante de opiniões bastante díspares e a despeito de a repulsa às Lumières perderem fôlego como essência do romantismo, Voltaire, Rousseau, Montesquieu, etc. (conhecidos pelo espírito, a vivacidade e o talento) são frequentemente acusados de não terem sequer conhecido a verdadeira finalidade (e aspirações) da arte, afora terem se desviado dos caminhos da poesia, vista então como algo paralisado, fechado em si mesmo, distante do natural. Nessa perspectiva, o paulatino afastamento de autores como Rousseau e Voltaire faz com que as Lumières sejam interpretadas como antítese da poesia e da verdadeira inspiração.

O que no século XVIII fora motivo de admiração, e algo positivo, pois contribuíra para a vulgarização do conhecimento, torna-se contraproducente, negativo. A literatura concebida para o simples prazer do espírito e cantada nos salões soa como produto da futilidade e da superficialidade. Exemplo disso é o célebre Préface de Cromwell (1827), em que a literatura setecentista é vista como ocupação leviana, fruto de espíritos presunçosos e afetados. Consoante Hugo a literatura setecentista é um "régime littéraire comme l'ancien régime politique", uma vez que

Le dernier siècle pèse encore presque de tout point sur le nouveau. Il l'opprime notamment dans la critique. Vous trouvez, par exemple, des hommes vivants qui vous répètent cette définition du goût échappée à Voltaire : « Le goût n’est autre chose pour la poésie que ce qu'il est pour les ajustements des femmes. » Ainsi, le goût, c'est la coquetterie. Paroles remarquables qui peignent à merveille cette poésie fardée, mouchetée, poudrée, du dix-huitième siècle, cette littérature à paniers, à pompons et à falbalas. Elles offrent un admirable résumé d'une époque avec laquelle les plus hauts génies n'ont pu être en contact sans devenir petits, du moins par un côté, d'un temps où 
Montesquieu a pu et dû faire le Temple de Gnide, Voltaire le Temple du Goût, JeanJacques le Devin du Village. (HUGO, 1897: 315)

Hugo segue então com a proposta de uma crítica forte, cujas bases sólidas e profundas permitirão que escritores não mais sejam julgados a partir da consentaneidade às regras e gêneros, mas a partir dos princípios recorrentes da arte e de leis especiais de sua própria organização. Nessa lógica, a despeito da abundante literatura "industrial” do século XIX, entreve-se o tempo em que a literatura terá acesso a seu título de nobreza, privilegiará o culto do escritor e, séria, investida de dignidade, distanciar-se-á dos espíritos e da frivolidade dos salões setecentistas.

Desse modo, diante das expressões e ideias filosófico-religiosas que invadem a literatura do século XVIII, esta é vista como algo que acaba por provocar a asfixia do gênio literário, destituindo-o de imaginação e de poesia. Esse processo, uma sorte de auto-instrumentalização da literatura, tornava-a simples veículo de lutas pessoais e ideológicas. Assim, realiza-se um cenário em que se contrapõem a sociabilidade artificial do século XVIII ao íntimo e profundo do homem, revelando sua unidade com o mundo. Exatamente por isso, muitos se voltam às Lumières e a seus "mitos fundadores" à procura de um modo de escrever pós Robespierre e Bonaparte, mas essa não é a regra geral, já que outros tantos continuariam ainda a refutar as Lumières.

\section{Piscadelas setecentistas nas crônicas machadianas}

Tratando-se de Machado de Assis, há muito a crítica tem se debruçado sobre algumas ideias dominantes que percorrem seu pensamento e fluem nos subterrâneos de contos, crônicas e romances. Sistematizá-las a ponto de apresentá-las em um conjunto de concepções essencialmente machadiano não parece - até agora -, um esforço conclusivo, a despeito de considerarem-no mais filósofo que muitos de seus coetâneos.

Tão importante quanto refletir sobre uma "filosofia machadiana" e ou a [im]possibilidade de o homem de letras constituir um conjunto de valores, cuja singularidade de princípios abordasse problemas fundamentais à existência e ao conhecimento em suas mais diversas naturezas, irradiando, influindo e alterando outros sistemas filosóficos, parece ser entender o meio em que o artista vivia, ou seja, a 
condição de país periférico e suscetível, sobretudo, à filosofia e cultura francesas, dominantes à época.

É fato que Machado seduz pelo modo introspectivo como percorre os meandros da alma humana, em cujo percurso exibe não só vigor artístico, mas também uma constante "mania de filosofar" - que dantes incomodara Silvio Romero -, e O Alienista (1882) e Quincas Borba (1891) surgem como célebres exemplos dessa carpintaria. Não raro, Machado busca o princípio universal das coisas, sempre por vias humorísticas e irônicas, imprimindo um sentido lato à palavra filosofia, de modo a torná-la sinonímia de "forma de compreensão" e ou "súmula de significado" (REALE, 1982: 4).

Reale, ao tratar da recorrência da palavra "metafísica" na obra machadiana relembra de maneira providencial a assertiva de Machado na Teoria do Medalhão (2008: 275): "Nesse ramo de conhecimentos humanos tudo está achado, formulado, rotulado, encaixotado; é só prover os alforges da memória." E não foi outro o procedimento adotado por Machado ao longo de sua vida de cronista. Sempre que se via frente a um fato isolado, apropriava-se de suas particularidades como subterfúgio para discorrer sobre o sentido da vida, fazendo emergir uma densidade essencial - e filosófica -, a fim de compreender o drama da existência.

Nessa toada, e, sobretudo porque a crônica é um gênero borboleteante por excelência, as piscadelas do cronista suscitam correspondências e, desses liames, surgem Voltaire, Rousseau, Diderot, Schopenhauer, Montaigne, Pascal, etc. Mas, como nem só de filósofos vive a crônica, toda a literatura produzida por uma infinidade de escritores como Balzac, Stendhal, Chateaubriand e tantos outros invadem o espaço do folhetim e, não raro, servem de filtro para a filosofia.

A filosofia, sobretudo, é decantada através de romances oitocentistas: a erudição de tratados e teses, depurada, transforma-se em matéria de cultura popular, que por sua vez dá suporte à tramas, às vezes, de gosto duvidoso e adocicado. $\mathrm{O}$ próximo passo é a reprodução de muitas destas narrativas na célebre seção "folhetim", ao rez-de-chaussée das primeiras páginas dos jornais. Desse modo, disseminam-se entre o grande público preceitos, princípios, teses, teorias e tratados à guisa do bon sauvage rousseauniano e muitos outros.

Porém, isso não é uma especificidade oitocentista: basta lembrar o célebre Candide (1759), sátira voltairiana às doutrinas finalistas ideadas por Leibniz. Se no 
século XVIII, a cada vez que se ria de Pangloss em meio às peripécias de Candide e Cacambo, Leibniz e seu Essais de théodicée (1710) vinha à tona e sedimentava o imaginário popular, no Oitocentos é a expressão "no melhor dos mundos possíveis" que, vulgarizada, ganha foro proverbial e é reproduzida boca a boca, distendendo-se ao longo da circulação das ideias literárias até que Leibniz e a Théodicée, sequer sejam ligados ao axioma e ou lembrados.

Balzac, por exemplo, não só evoca os burgueses de Paris e a admiração destes por Molière, Voltaire e Rousseau, mas descreve seus salões abarrotados de móveis estilo rocaille, esculturas de Boule e porcelanas de Saxe. ${ }^{296}$ Machado volta-se a Balzac ora relembrando as anedotas de um jogador inveterado em suas tramas, ora a robustez de seu trabalho, ora "as aflições do pobre diabo, correndo abaixo e acima, à cata de dinheiro" 297 para pagar seus credores. Isto, claro, surge como testemunho das visitas do cronista ao grande romancista e indício de que assim como "mamou muito leite romântico, pode [muito bem ter metido] o dente [em muito] rosbife [setecentista]"298 via Balzac.

Os romances, embora constituíssem vigorosa fonte de [re]leitura, não se revelam exclusivos para o cronista machadiano, sobretudo pela importância do jornal ao longo de sua carreira jornalística. Os periódicos cariocas (e franceses) reproduziam à exaustão muita farelagem filosófica disseminada em artigos, críticas, comentários políticos, resenhas de livros e reportagens das mais diversas naturezas, vulgarizando tratados e doutrinas de denso eruditismo; o mesmo ocorria com personagens históricas e da vida mundana, cujas biografias eram esfaceladas, constituindo-se em pequenos cacos que hora ou outra completavam mosaicos de aventuras imaginadas em que essas figuras se sobressaíam pela presença de espírito - ou a falta dele.

Nesse contexto, os olhares lançados ao século XVIII e seus protagonistas na França são simplesmente replicados no Rio de Janeiro, em razão da reprodução de matérias jornalísticas, sobretudo do La Presse e do Le Siècle e de romances traduzidos e publicados em capítulos no espaço do folhetim. A cultura e a vida política francesa

\footnotetext{
${ }^{296}$ Em Histoire de la grandeur et de la décadence de César Biroteau (1837), no entanto, esses burgueses compram as obras, porém não as leem. Por outro lado, a maioria das personagens nobres da Comédie humaine transitam por ambientes luxuosos que preservam as marcas do estilo Louis XV, a exemplo da condessa Laginska em La Fausse maîtresse (1842) e de Madame d'Espard em L'Interdiction (1836). 297 "A Semana”, Gazeta de Notícias, 22/4/1894.

298 “A Semana”, Gazeta de Notícias, 25/12/1892.
} 
estão a tal ponto arraigadas ao que se produz e comenta no Brasil que os problemas locais sempre são trazidos à discussão amparados em acontecimentos, situações, estudos e personalidades europeias, sobretudo francesas. O Diário do Rio de Janeiro ${ }^{299}$ surge como exemplo ímpar desse intercâmbio de ideias e Robespierre, associado a Marat e outros revolucionários, reproduz em solo tupiniquim a mesma atração-repulsão experimentada pelos franceses ao refletirem sobre o século XVIII.

\subsection{Robespierre nas crônicas machadianas}

Na tarde do 10 Thermidor An II (28/7/1794), sob a aclamação da multidão, vinte e duas cabeças são colocadas em uma caixa de madeira e seus respectivos corpos amontoados em uma charrete, logo depois, cabeças e corpos são jogados na vala comum do cimetière des Errancis. Dentre elas, a de Robespierre, o "tyran", que teria inspirado um anônimo a produzir um epitáfio póstumo que traduz o sentimento deixado pelo revolucionário: "Passant, ne t'apitoie pas sur mon sort/ Si j'étais vivant, tu serais mort. ${ }^{, 300}$.

Antes que Robespierre entrasse para a literatura e o teatro, sob a pena de Charles Nodier, Balzac, Alexandre Dumas, Georges Sand, Julles Vallèrs, Anatole France, Büchner e outros ${ }^{301}$, uma imagem desfavorável, hostil e repugnante fora construída quase que concomitante à sua atuação no teatro da Revolução. Ainda sob o calor dos acontecimentos, Merlin publica Portrait de Robespierre, um opúsculo de 16 páginas, cujo intuito é refletir sobre sua personalidade. Ali, nada é favorável à imagem do revolucionário; até mesmo a menção a um escritor que teria dito "qu'il avoit le talent de la réfutation" (1795: 9-10) é descontruída.

\footnotetext{
${ }^{299}$ Privilegiou-se aqui o Diário do Rio de Janeiro, pelo fato de ali Machado ter estreado como jornalista profissional, no ano de 1860, a convite de Quintino Bocaiúva. Porém, a presença francesa é superabundante em todos os periódicos oitocentistas, sobretudo nos primeiros três quartos do século XIX. A partir de então, deixa de ser tão intensa e artigos não são reproduzidos à revelia, preenchendo páginas inteiras como era comum na primeira metade do século.

${ }^{300}$ Portier-Kaltenbach, Clémentine. «Robespierre, bourreau de la Vendée ? », émission L'Ombre d'un doute sur France 3, 23 janvier 2013, 1h8min55s, (http://www.youtube.com/watch?v=J526unuYPP8). Feller (1823: 301) traz a seguinte versão para o epitáfio: « Passant, ne pleure pas son sort,/ Car s'il vivait, tu serais mort. »

301 Após sua morte, Robespierre torna-se uma das personagens principais de numerosos dramas e tragédias: 49 peças entre 1791 e 1815, 37 entre 1815 e 1989. Na grande maioria, difunde-se uma imagem hostil e desfavorável, porém, em muitas, nota-se uma tentativa de reabilitação e a preocupação de imprimir um olhar enaltecedor à personagem.
} 
Como fariam muitos outros escritores ao longo do século XIX, Merlin traça o perfil de Robespierre comparando-o a Danton, Marat e Mirabeau, donde surge uma figura de espírito limitado, melancólico e irritadiço, portador de um humeur noire, algo que o autor considera ser próprio de tiranos levados ao furor pelo temor. Robespierre é apresentado como um ser ambicioso, tirânico, que não sabe distinguir o combate do extermínio total de seus inimigos, a anarquia da opressão e que não sabia "faire la guerre qu'à force d'hommes, opprimer qu'à force de tyrannie, et régir qu'à force d'argent" (1795: 3). Merlin sentencia (1795: 12-13): "Ce sont des évenemens étrangers aux combinaisons de Robespierre qui expliquent la fortune de cet homme si commun."

Por fim, depois de apresentá-lo como um déspota dominado pela inveja e o desejo de eliminar seus rivais de tribuna, subalterno em talento a Mirabeau, Condorcet, Lafayette, Brissot, Vergniaux, Chaumette, Merlin desafia seu leitor (1795: 14): "Construisez une machine humaine foible et lâche: animez-la de la passion de l'envie, placez-la dans les circonstances où s'est trouvé Robespierre, et vous recommencerez Robespierre."

As aparições tardias de Robespierre nas crônicas (todas no final do XIX) mantêm inalterada a aura negra colada ao tribuno, sempre ligada à aplicação de políticas repressivas, sobretudo entre os anos de 1793-1974 (La Terreur), qual seja, preservando a condição de fantoche do Terror. Contudo, suas aparições na Gazeta de Notícias, quando transita pelas "Balas de Estalo" e "A Semana", perdem em estatura, são carnavalizadas, tornam-se motivo de zombaria.

Em 9/12/1883 ${ }^{302}$, Machado discorre sobre a crise financeira que acomete a maçonaria a partir dos estatutos da Associação de Beneficência e Previsão do Grande Oriente do Brasil. Segundo o cronista, caiu-lhe às mãos um impresso ${ }^{303}$ da Associação, cujos estatutos sistematizam o intento de "levantar a maçonaria do abatimento em que se acha" e, apesar de considerá-los excelentes, vê ali imperfeições que podem ser retificadas, afinal, trata-se de "uma obra humana".

A ironia e jocosidade, de pronto, instalam-se desde a primeira frase (Com:. por uma sup:. grat:. Suponho que o leit:. não é maç:.), uma vez que o cronista reproduz a maneira codificada de os maçons publicarem comunicados em jornais: explica-se, a

\footnotetext{
302 "Balas de Estalo", Gazeta de Notícias.

${ }^{303}$ É provável que Machado, de fato, se refira ao Boletim do Grande Oriente do Brazil, jornal oficial da maçonaria que, a Gazeta de Notícias, por exemplo, acusa o recebimento na edição de 22/1/1883 (p.1).
} 
forma gráfica das palavras era subvertida, ora com a supressão das vogais finais ora de sílabas inteiras, mutilando-as. ${ }^{304}$ Logo depois, comenta uma metáfora em forma de enigma, que acredita tratar-se de um anfiguri (trecho literário burlesco, propositadamente ininteligível), confessa não compreendê-lo e, adiante, chega ao balanço semestral da tesouraria, deparando-se com o artigo XXX do estatuto, que dispõe sobre as contribuições:

Felizm:. apar:. o art. XXX, que é um verdad :. refrig :. Este artigo dá "ao contribuinte a liberd:. de pagar adiant:., e por tempo indeterminado, qualquer quant:. com dest:. à assoc:." Esta liberd:. de pagar adiant:. é uma das que a reação tem sempre combat:., por todos os modos. Ninguém ignora que a idade média é histor:. trag:. das tentativ :. dos contrib:. para conquistar esta liberd:. preciosa. Nem o cárcere, nem o suplício, coisa nenhuma deteve os heróis dessa luta de séculos. A revol:. de 89 alcançou por esse momento a vitór:. nessa parte ; mas Robespierre destruiu-a e Bonaparte acabou com ela inteiram :. restabelecendo os pagam:. vencidos. Falo de uma parte da Europa; no resto, em Portugal, por exemplo, e no Bras:. que era colon:. nunca um tal princípio triunfou.

Se, no romance, o uso da ironia e do humor como procedimentos literários contribuem para a criação de um mundo percebido ou concebido, evidenciando certa ousadia a ponto de ser lida como um estilo particular do romancista, na crônica, essa mesma ousadia marca a discordância entre o real e o ficcional, uma vez que os estatutos maçônicos são tomados pelo cronista como peça de ficção. Assim, humor e ironia ressaltam a impropriedade de se oferecer ao público "a liberdade de pagar adiantado e por tempo indeterminado qualquer quantia destinada à associação". O artifício usado pelos maçônicos choca pela subestimação do interlocutor e, tornando-se caricato, passa por ridículo.

O cronista, evidentemente, não acredita que alguém chancele tal investimento ilógico que, semelhante a um fundo de pensão, convoca supostos doadores a efetuarem contribuições antecipadas de qualquer quantia e a qualquer tempo, porém, recebendo a família, em caso de morte do contribuinte, uma parte proporcional da pensão com valor previamente estipulado: 5\$000. Receber em vida o dinheiro investido? Só "metade da

\footnotetext{
${ }^{304}$ Em 20/12/1883, a Gazeta de Notícias publica uma nota da maçonaria que se inicia da seguinte forma:

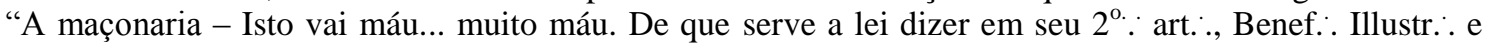
moral. . nada disto existe!!? [...]"
} 
pensão, provando, entre outras coisas, esta: 'indigência e perda de emprego, por sentença profana, não aprovada pela ordem maçônica"’!!!

Como prova do desarrazoado da proposta, o cronista volta-se à história e revelase grande ironista ao criticar a pretendida liberdade que a Associação permite ao contribuinte, uma vez que essa liberdade, de fato, quem goza é a própria maçonaria, exercendo o ofício de usurária, algo que, como bem esclarece, era interdito na Idade Média.

Ora, como o humor e a ironia não se dogmatizam, pelo contrário, flutuam, tomam direções diversas e não se cristalizam, o cronista critica a "esperteza" da usura maçônica e demonstra como o óbvio opera obliquamente. E, para ressaltar essa astúcia maçônica, traz à cena Robespierre, como personalidade dúbia, porém, anedótica, destituída de sua "identidade" histórica. Minimizado, funciona como símbolo e contribui para a instalação da galhofa, em razão da distância temporal e espacial.

Se por um lado, ligado à Revolução, o tribuno da Convenção pode ser confundido com os ideais de liberdade difundidos pelo movimento de $89^{305}$ (A revol:. de 89 alcançou por esse momento a vitór:. nessa parte;) por outro, sua imagem destruidora se impõe, neutralizando a anterior. E, por sua ligação uterina com a Revolução, Robespierre é aquele que deplora o usurário (ou instituições que trabalham com o dinheiro, como a Bolsa de valores), considerando-o especulador, uma vez que se passa por comerciante e não faz comércio.

Desse modo, o cronista reforça a imagem de Robespierre como ditador, cujos tentáculos, totalitários, ultrapassam os domínios da política e interferem nas transações comerciais, ditando regras e suprimindo a mesma liberdade de que ora usufrui a maçonaria, e a tal ponto que não só induz o contribuinte, mas o faz crer e se sentir livre ao "investir" na Associação. Mas tudo isso, puxado pela memória, ainda que evoque um fato histórico citado (A revol:. de 89...) e um de seus principais atores, na esfera da crônica mistura-se ao quotidiano desprovido de qualquer justificativa, com o intuito único da ridicularização e da galhofa. Assim, ditador ou não, Robespierre é tão símbolo quanto César atravessando o Rubicão, relativizados que foram pela poeira do tempo, de

\footnotetext{
${ }^{305}$ Vale lembrar que sob a égide de Robespierre (à época, chefe do Comité de salut public) foram assinados os decretos de 10/10/1793, decidindo que «le gouvernement sera révolutionnaire jusqu'à la paix" e o de 14 frimaire (4 de dezembro) organizando as instituições, quando todas as liberdades (de imprensa, de reunião e de "parole") foram suprimidas.
} 
modo que cem ou mil anos se equivalem na matéria do folhetim, cujo compromisso, de fato, é manter certa frivolidade, donde um símbolo facilitador para o público Robespierre.

Diferente não é a menção a Robespierre que surge na crônica de 26/9/1884 ${ }^{306}$, quando se comenta a campanha do Sr. Dr. Cunha Sales à câmara dos deputados. O candidato, caso seja eleito, não só abre mão dos subsídios que o cargo lhe confere como os destina em favor da emancipação dos escravos, configurando um gesto de dupla magnanimidade. Porém, tanta generosidade soa algo falso e o cronista entra pelo jocoso, associando-o a um compositor de polcas, o Sr. Sales Bastos:

Assim pudesse eu entender o título da nova polca do outro Sales, o Sr. Sales Bastos. Chama-se esta produção: $O$ Encarnado pegou fogo. Não posso perceber quem seja este Encarnado, que é por força um vulto público, talvez histórico, talvez universal - desde que o Sr. Bastos compôs uma polca, e não um enigma. Quem diabo será esse Encarnado? Supor que a polca é uma alegoria à morte de Robespierre, cujas opiniões eram efetivamente rubras, não me parece verossímil. Já imaginei se, entre os vestidos da célebre dançarina Taglioni ${ }^{307}$, algum era daquela cor, e se esse algum dia ardeu...

Tratando-se de Robespierre, vale recorrer a representações que sustentam o imaginário social, uma vez que nelas reside todo um simbolismo derivado de construções paulatinas que se associam a movimentos e práticas sociais. Apoiar-se em emblemas tem sido um exercício recorrente no campo das representações coletivas, de modo que ideias, ritos, modos de ação, imagens, etc. se articulam construindo e ou personificando um vulto político (ou uma cena, um quadro, etc.) desvalorizando, deslegitimando ou valorizando-o à medida que é associado a determinado símbolo (e sua significação).

Nessa perspectiva, as opiniões "efetivamente rubras" de Robespierre, de pronto, o condenam. A crônica, evidentemente, não oferece espaço para o horror, de modo que a cor rubra, de forma amena, introduz o leitor no teatro de ação em que Robespierre é tido como o grande mentor, o Terror. A cor vermelha (rubra para o cronista)

\footnotetext{
306 "Balas de Estalo", Gazeta de Notícias.

307 Marie Taglioni (1804-1884). A fama da "la Taglioni" espalhou-se por toda a Europa, onde se apresentou em praticamente todas as capitais. Em 1827, entra para o Ballet de l'Opéra e ao lado de JeanFrançois Coulon, torna-se sensação, sobretudo nas variações de o Sicilien.
} 
normalmente associada ao sangue, no contexto revolucionário, invariavelmente remete a Robespierre de modo a perpetuar a imagem do "jongleur sanguinaire [...] qui fit trembler tous les citoyens sous sa tyrannie" (MERLIN, 1795: 14). Se Robespierre ardeu ou não como o "encarnado que pegou fogo", fica por conta de um gracejo do cronista e, quando muito, a critério de um ou outro pensamento cristão.

Em 1/8/1885 ${ }^{308}$, ainda sob a insígnia do terror, Machado retoma Robespierre ao se deparar com notícias vindas de Sergipe:

\footnotetext{
O nosso velho sestro de dar às coisas nomes maiores que elas fez-me passar por uma dos diabos.

É o caso, que eu lia os jornais, muito sossegado da minha vida, quando dei com esta frase, de uma carta de Sergipe: "Estamos em pleno domínio de terror". Não quis ler mais nada. Os cabelos ficaram-me em pé. Mísero Sergipe! terror! Robespierre! guilhotina! lei dos suspeitos! Ah! não! nunca! Há de haver um brasileiro que...
}

Dito isto, o cronista entra em estado de alucinação: imagina possuir um carro, chama seu cocheiro e pede a ele que o leve à casa do ministro do império sob ameaça de fazer-lhe "saltar os miolos" com uma pistola, pois "trata-se da humanidade". No caminho, os cavalos em disparada, o carro em alta velocidade, medita sobre os "excessos da política", maldiz o terror, imagina "as prisões atulhadas de suspeitos", processos sumários, execuções sumaríssimas e os brados da multidão a cantar em coro aos supliciados.

Porém, num rasgo de humor e puro sarcasmo a canção entoada pela multidão não é a célebre "Çà ira, çà ira, çà ira,/ Les aristocrates à la lanterne", mas "Onde vai seu Pereira de Morais/ Se você vai, não volta mais". A pressa é indescritível e por mais que o cocheiro pusesse carro e cavalo a voar, o cronista, desvairado, sentindo-se imóvel, ergue-se, engata o gatilho e dispara no cocheiro. Ao som de um grito volta a si; tudo não passara de um delírio.

Ao prosseguir a leitura da carta de Sergipe, o cronista comprova que todo o terror não fora mais que duas demissões, uma remoção e uma reintegração. Ao constatar a hipérbole que a palavra traz em si, implora que não lhe preguem sustos iguais:

308 "Balas de Estalo", Gazeta de Notícias. 


\begin{abstract}
Mas, pelo amor de Deus, não me ponham o Terror em trocos miúdos. Robespierre, apesar de morto, é ainda um tutu muito aproveitável. Se lhe desconcertamos o esqueleto, e fazemos das tíbias umas vaquetas de tambor, reduzimos aquilo a uma caçoada. [...] Não estejamos a ver gigantes por toda a parte.
\end{abstract}

De fato, o sarcasmo diante do exagero que traz a notícia, dispara sua memória e todo o teatro da Revolução vem à tona, e esta por sua vez, relativizada, surge parodiada, afinal, acredita o cronista, "nunca! Há de haver um brasileiro que...”, confrontando o local com o universal. Nesse jogo (e numa retomada a Alencar), em ponto pequeno e comparações nem tão anódinas, é preciso respeitar o tamanho da sociedade [sergipana] e, de modo mais amplo, os traços, impulsos, temperamento e disposição do brasileiro.

Por isso, num espaço que comporta o drama, não o terror, não há de haver um Robespierre tupiniquim e aquele que tiver o furor de imaginá-lo arriscando entoar "Çà ira, çà ira", de fato, se sentirá mais genuíno e autêntico se cantar "Onde vai seu Pereira de Morais/ Se você vai, não volta mais".

A imagem de Robespierre associada ao sangue prossegue e, em 21/5/1893 ${ }^{309} \mathrm{o}$ cronista, tomado por reminiscências, relembra as chuvas do verão anterior, depois o calor, as doenças e o grande obituário. De súbito, recorda-se do tempo em que "era alegre" e a memória o leva aos constantes problemas da iluminação a gás ${ }^{310}$, quando o povo trouxera à luz o mote $O$ gás virou lamparina, um riso público em face da ineficiência do sistema.

De volta a uma semana cheia - e trapalhona para alguns -, perambula pela Rua do Ouvidor onde colhe algumas “invenções”. De boato em boato, é lá - afirma - que "há [...] um cunho de boa roda, que dá mais brilho ao exato, e faz parecer exato o inventado”. E, enquanto um grupo dá uma notícia e outro a repete de modo contrário, o cronista, entre ouvi-las e cotejá-las, colhe mais um boato:

\footnotetext{
309 “A Semana”, Gazeta de Notícias.

${ }^{310}$ A iluminação a gás foi introduzida na cidade do Rio de Janeiro em 1854 pelo Barão de Mauá, porém, simultâneo ao novo serviço, permanecia a iluminação a "azeite de peixe" (expressão da época), uma vez que a intensidade da luz exigida pelo contrato era insuficiente, o que ocasionava "falta absoluta de iluminação [mesmo nas ruas de maior trânsito] e em outras, situadas nos bairros suburbanos, [vinha] provocando reclamações dos particulares e até de algumas autoridades" (http://www.rjnet.com.br/rjiluminacaopublica.php - consulta em 22/10/2013, às 11h32m).
} 
Foi o que me aconteceu anteontem. Deram-me duas versões do que se passava na câmara dos deputados; segundo uns, não se estava passando nada; segundo outros, passava-se o diabo. Cheguei a ouvir citar o ano de 93, como sendo o primeiro aniversário secular do Terror. E diziam-me que, assim como há bodas de prata, bodas de ouro, bodas de diamante, havia também bodas de sangue, as bodas de sangue da liberdade: eram os cem anos da Convenção. Achei plausível; corri à câmara. Primeira decepção: não vi Robespierre. Discutia-se uma questão de votação, e a câmara resolvia continuar no dia seguinte, ontem, em comissão-geral. Eram quatro horas e meia da tarde; a sessão começara ao meio-dia.

Os boatos vêm da Rua do Ouvidor, a rua do pasmatório e, entre um e outro o cronista entabula a estrutura da crônica, cujo movimento oscila entre boato e verdade, Brasil/França, 1793/1893, opinião e contraopinião. “Às vezes perco uma verdade da rua da Quitanda por uma invenção da rua do Ouvidor", sinal de que nada é tão sério na esfera do folhetim. Assim, em meio às invenções e à boataria, elementos da história francesa misturam-se à crônica não só como marca da intimidade do cronista (e seu leitor) aos acontecimentos de ordem universal, mas, sobretudo, como constitutivos de relativização do dado local.

A partir deste arcabouço forjado à base de antitéticos, o cronista afasta a rigidez do relato, ressaltando a introdução do elemento cômico: "Primeira decepção: não vi Robespierre." Mitigado, o político francês surge desprovido de seriedade e, consoante Sareil (1984: 60-67), para quem uma das fontes privilegiadas do cômico textual consiste no recurso aos clichês que, tomados ao pé da letra ou não, forjam a intenção de produzir o riso, a menção ao tribuno instala a galhofa e a jocosidade na sessão da câmara.

Ironicamente, a ausência de Robespierre numa votação ágil e plena de bonomia, provoca sua protelação e ressalta, sobretudo, o fato de que ali nada requer uma solução imediata, tudo pode ser deixado para o dia seguinte, afinal, nada é assim tão importante. Nas entrelinhas: uma crítica irônica ao descomprometimento do legislativo. Diminuta em face da Convenção, a câmara, que padece da presença de Robespierre, perde importância.

E, diante de uma "semana pobre", uma vez que a crônica "comenta" (e "cria") o quotidiano da cidade, se nada de extraordinário acontece, nem por isso o cronista deixa de fazer referência a um marco da vida legislativa, qual seja, Robespierre, como dispositivo irônico. Todavia, ainda se pode entrever preservada a imagem do tribuno 
ligada à falta de liberdade e ao Terror, porém, como nesses textos nada é tão sério, decantado pela pena leve do cronista, o drama do próprio Robespierre perde em intensidade, e o máximo que provoca é a lembrança de modos, costumes, e discursos já extintos.

A crônica 5/5/1895 311 , longe dos fatos da semana, sugere um momento de elucubração, a divagação profunda de um cronista em busca de um epíteto para o século fluminense ainda não terminado. Os pensamentos o levam a Roma e Atenas e, diante dessas capitais universais, conclui que o século em cidades médias e mínimas deveria também ser reduzido, algo em torno de cinquenta ou vinte e cinco anos. Opta por cinquenta anos e revela a abstração em que se encontra, levado pelo pensar e a distração: "Puxei pela memória, achei, tirei, comparei, fiz, desfiz, sem positivamente chegar a resultado certo até ontem."

Dessa vez, confessa não ter querido saber dos boatos, nem dos fatos da semana, "nada, nada", e, depois de muito esforço consegue achar um nome para o "nosso século carioca": o "século dos jardins". A perífrase o leva às origens do homem, quando este teve o jardim como sua primeira morada. E, ao relembrar o Éden, que ficou na memória dos tempos, o cronista enreda o arcanjo Gabriel e o poeta Milton até que o homem se metesse a comprar e construir jardins.

Contudo, como não explicara o porquê de sua escolha, o cronista ironicamente a credita à elevação de sentimentos e à crescente e contraditória espiritualidade do carioca, que "ama as flores, embora reserve o direito de deitar as árvores abaixo" e, desse modo, comenta os jardins: o Passeio Público, o Jardim Botânico e, num lance sarcástico, o Jardim Lotérico, onde brotam o Camelo, o Burro, o Avestruz e o Leão. Ao relembrar o Passeio Público, comenta:

Nos primeiros tempos do Passeio Público ${ }^{312}$, o povo corria para ele, e o nome de Belas Noites, dado à rua das Marrecas, vinha de serem as noites de luar as escolhidas para as passeatas. Sabeis disso; sabeis também que o povo levava a guitarra, a viola, a cantiga, e provavelmente o namoro. O namoro devia ser inocente, como a viola e os costumes. Onde irão eles, costumes e instrumentos? Eram contemporâneos da revolução

\footnotetext{
311 “A Semana", Gazeta de Notícias.

${ }^{312}$ Localizado no bairro da Lapa (RJ), o Passeio Público foi inaugurado ainda no século XVIII (1783). Alterado em 1864 pelo arquiteto francês Auguste François Marie Glaziou, a pedido do Imperador D. Pedro II, o parque ganhou aleias curvas e sinuosas, lagos e pontos, bem ao estilo romântico.
} 
Francesa, foram com os discursos dela. Enquanto Robespierre caía na Convenção, ouvindo este grito: “Desgraçado! é o sangue de Danton que te afoga!”313, o nosso arruador cantava com a ternura na guitarra:

Vou-me embora, vou-me embora,

Que me dão para levar?

Saudades, penas e lágrimas

Eu levo para chorar.

Os tempos em que se namorava nas redondezas do Passeio Público são recordados pelo cronista, que ao dividir suas reminiscências com o leitor, relembra os instrumentos levados pelo povo. Tratando-se de um parque do século XVIII - e já em terreno especulativo -, o cronista, ao lamentar o desparecimento de costumes e instrumentos, promove um desvio que curiosamente determina a extinção deles à época da Revolução, quando ainda eram contemporâneos.

Ao insistir no contraste, o cronista associa o declínio dos instrumentos musicais à queda de Robespierre na Convenção e, mais uma vez, na esfera da crônica, o líder revolucionário vem na contramão das liberdades, reforçando seu caráter sombrio e dissimulado, sobretudo, ao associá-lo à célebre frase que o responsabiliza pela morte de Danton. E, graças à liberdade da crônica, o tempo cronológico é subvertido, de modo que o dito pronunciado no 9 thermidor, sentenciando a queda de Robespierre na Convenção, surge simultâneo à cançoneta entoada pelo arruador no Passeio Público.

A contraposição se intensifica como apoio textual à medida que se leva em conta o o fato de que na França revolucionária os políticos se entredevoravam, ao passo que, segundo o cronista, no Brasil colonial a vida social era bem diferente, donde os instrumentos musicais e a cantoria pública. No mais, a antropofagia política expressa pela queda de Robespierre é matéria de cultura popular disseminada à exaustão, portanto, memória palatável, de fácil entendimento público, apto a apreender o efeito contrastante presumido pelo cronista. Logo, a aparição de Robespierre surge como

\footnotetext{
313 Após a proscrição dos girondins e a morte de Danton, Robespierre volta-se contra o que sobrara dos partidários de Danton; com o intuito de eliminá-los ou bani-los, cria uma lista que inclui, inclusive, o nome de inúmeros de seus partidários, provocando uma violenta disputa entre ele e Billaud, que tinha influência na Convenção e não quis lhe abandonar as vítimas. Diante de um perigo iminente, até os mais tímidos tomam coragem e se unem aos partidários de Danton, e para escapar de novas perseguições conspiram contra Robespierre. Esse complot irrompe em 27/7/1794 (9 thermidor de l'an 2), e quando Robespierre sobe à tribuna sua voz é sufocada por gritos de "À bas le tyran!", de modo que ele não se fazia ouvir. «Un mot, disait-il, écumant de rage, un mot, président des assassins !... » «C'est le sang de Danton qui l'étouffe », cria encore une autre voix. (FELLER, 1823: 300)»
} 
simples artefato histórico da retórica machadiana e termo de oposição entre o ardor do momento histórico francês e certa bonomia dos costumes brasileiros.

Inexpressivo como orador, porém, considerado uma das encarnações do espírito revolucionário, Robespierre recebeu o epíteto de "l’incorruptible défenseur du peuple", contudo, em sua grande maioria, seu nome aparece ligado a perífrases como "l'incorruptible ami du peuple qu'on accable", "superbe oppresseur ennemi redoutable", "personnage fameux dans les fastes sanglans de la révolution française", "despote sanguinaire et égorgeur de curés et des Vendéens", "ditacteur", etc., e é dessa forma que o cronista se refere ao tribuno, na crônica de 1/3/1896

La République manque de femmes ${ }^{315}$, disse consigo a nova capital, e cuidou de lhe dar esta costela. Talvez o dito do republicano francês não caiba aqui inteiramente. As instituições francesas, quaisquer que sejam, precisam de mulheres. A própria revolução, salvo a ditadura de Robespierre, não as dispensou de todo. A Suíça, Esparta e outros Estados de instituições mais ou menos parecidas, dispensam mulheres. A razão penso ser que a sociedade francesa não vai sem conversação, e os franceses não acreditam que haja conversação sem damas.

Ninguém há que aprecie mais as mulheres do que nós; mas aqui é difícil vê-las juntas sem fazê-las dançar ou dançar com elas. Uma só que seja, podemos dizer-lhe coisas bonitas, enquanto não ouvimos uma valsa; em ouvindo a valsa, deitamos-lhe o braço à roda da cintura e fazemos dois ou três giros.

Embora díspares, os contextos se aproximam na crônica machadiana: na França, a república que se instala com a queda do Ancien Régime por meio da Revolução; no Brasil, a troca de regimes com a Proclamação. Não se faz referência a Versailles, mas Petrópolis, insígnia do Império, é comparada a Baias ${ }^{316}$, cidade de recreio da antiga Roma. A aproximação contém certo exagero, porém, introduz parte da história da “Cidade Imperial”, que após 15 de novembro passou por um "estupor que a deixou lesa de ambos os lados".

A resistência das cidades e o fato de Petrópolis ter se tornado a capital do Estado em razão de um "sentimento de elegância muito respeitável”, antecedem comentário do

\footnotetext{
314 “A Semana”, Gazeta de Notícias.

${ }^{315}$ Em La République, conditions de la régénération de la France (1872 : 173), Edgard Quinet, pergunta : "Que serait une république, une démocratie à laquelle manquerait le génie de la femme ? »

${ }^{316}$ De fato, as Baias eram uma área de lazer junto ao mar, ao sul da Vila de Luculo, em Nápoles. Para os romanos, Baias era sinônimo, de luxo e perdição.
} 
cronista de que felizmente a cidade "não tem qualquer vocação administrativa nem política". Ignorando o próprio governador e os discursos da Assembleia, Petrópolis conseguiu voltar ao que era antes, palco das figuras - e das mulheres do Império.

O desvio até Robespierre é explicado linhas acima pelo cronista: "A minha memória compõe-se de muitas alcovas meio escuras e poucas salas claras; às vezes, para achar uma coisa, desço ao porão com lanterna." Desse modo, ao elogiar a leveza que retornou à cidade, o dito de Edgar Quinet vem à luz e as mulheres são elevadas à condição de protagonistas que personalizam o lado humano e gentil das repúblicas, algo que resgata a influência delas nas sociedades dos antigos regimes.

É de se supor que as "poucas salas claras" da memória do cronista tenham lhe trazido à frente figuras como a Pompadour, a Maintenon e tantas outras que abrilhantaram os grandes salões, em contraponto à austeridade republicana. A objeção às mulheres na ditadura de Robespierre foi motivo de questionamentos (MERLIN, 1795: 4): 'Il est faux qu'il ait eu l'honneur d'aimer les femmes; au contraire, il leur a fait l'honneur de les haïr."

Merlin ainda comenta a perseguição de Robespierre contra as mulheres:

\footnotetext{
“Il se déchaîna contre les femmes célèbres par l'esprit ou la figure ; contre les femmes vertueuses, parce qu'elles étoient respectées ; contre les courtisannes, parce qu'elles étoient l'objet de quelques empressemens, il se déchaîna sur les morts dont on rappeloit encore les noms, dont on lisoit les écrits ; il proscrivit la mémoire de ceux dont il avoit proscrit la tête. (1975: 7)"
}

Desse modo, mais uma vez no âmbito da crônica há reprodução (e o fortalecimento) de uma imagem de Robespierre veiculada na França e solidificada ao longo do século XIX. Contudo, vale ressaltar que o cronista isolou a figura do tribuno revolucionário e, em se tratando da Revolução, afirma: esta "não as dispensou de todo". Ainda assim, é provável que ao lançar mão de sua lanterna para iluminar o porão da memória, lá tenha encontrado Marie Le Masson Le Golft e Louise de Kéralio, duas escritoras, cuja entrada para Academia de Arras tivera o apoio de Robespierre em fevereiro de $1787 .^{317}$

\footnotetext{
${ }^{317}$ Eleito para a Académie royale de Belles-Lettres d'Arras em 15/11/1783, Robespierre, em 4/2/1786, foi nomeado diretor por unanimidade. Ao desempenhar seu novo papel, afirmava compartilhar a visão cartesiana sobre igualdade de gênero e dizia estar ansioso para promover a diversidade dentro de
} 
Por outro lado, afirmava-se que Robespierre era misógino e teria, por exemplo, repelido todos os avanços de Mlle Duplay, que lhe fizera a corte por muito tempo (GAUTHEROT, 1912: 408). Mas a crônica, se escava os porões à busca de informação, filtra, depura o obscuro, e não traz à luz nada mais que o ridente e prazeiroso. Por isso, uma vez mais Robespierre surge como símbolo ligado a uma questão civilizacional, qual seja, a vida mundana dos salões - eruditos ou não.

Nesse contexto, em meio a artefatos históricos, o cronista privilegia a figura feminina: esta, vista no espaço público da política - e do lar (os salões), encanta sobretudo, e, volátil, proporciona espetáculos à medida que marca os passos, movimentando-se ao ritmo da valsa. Nas festas, imprime graça à arte de governar; nos salões, revela-se anfitriã e exime habilidades artísticas; independente, espalha galanteria com a mesma facilidade com que desliza pelos salões numa dança contínua. A mulher assemelha-se em leveza à crônica, razão pela qual o cronista a retoma como ideia retórica ao afirmar, ironicamente, que "não é exatamente de mulheres que a República precisa: é de pares para os seus cavalheiros". Afinal, "ninguém há que aprecie mais as mulheres que nós; mas aqui é difícil vê-las juntas sem fazê-las dançar e dançar com elas".

Ainda sob o efeito da galanteria produzida pelas mulheres nas cortes, em contraponto à aridez republicana no trato e no protocolo, o cronista comenta a visita dos czares russos a França. Em 6/10/1896, a Gazeta de Notícias (p. 1, Telegrammas - Pariz) noticia:

\footnotetext{
Cherburgo, 5

O czar e a czarina desembarcaram do seu yacht ás 3 horas da tarde, [...].

É indescriptivel o regosijo popular.

- Ao desembarcar no arsenal os soberanos russos foram recebidos pelo Sr. Felix Faure, presidente da Republica, cercado de seus ministros, dos presidentes da câmara dos deputados e do senado, das auctoridades da cidade e das casas civil e militar do chefe do Estado.

O Sr. Felix Faure beijou a mão da czarina e estendeu a mão ao czar, que a conservou affectuosamente apertada durante a expressão dos votos pelas boas vindas, aos quaes o
}

sociedades científicas. Sobre isso ver (GAUTHIER, 2007: 189-191) o prefácio à «Réponse de Maximilien de Robespierre, avocat du Parlement et directeur de l"Académie, au discours de Mlle Kéralio ». 
czar Nicoláo respondeu manifestando o prazer immenso de ter podido finalmente realisar o projecto ha longo tempo formado, de visitar a França.

Contudo, se os jornais franceses relatam uma recepção acalorada e "as ovações de que [...] foram alvo os soberanos por parte da multidão" (Gazeta, 8/10/1896, p. 1), nem tudo parece ter saído a contento, pois na mesma data e página é publicado o seguinte telegrama de Roma:

Roma, 7

As folhas italianas registram as manifestações que estão sendo feitas em França aos imperadores da Russia, não deixando, porém, na sua maioria de fazer transparecer o máo humor.

As intrigas da "corte" republicana francesa, por um momento, parecem ter desviado a atenção do cronista dos fatos locais, já que inicia sua "Semana" de $11 / 1 / 1896^{318}$ tratando exatamente da questão do beijo recebido pela tzarina. No centro da questão, a gentileza e a galanteria próprias das cortes e do sexo feminino.

Adequando-se ao gênero que manipula semanalmente, o cronista atém-se ao fútil, e como se estivesse escrevendo diretamente à tzarina, evita adentrar o problema ideológico que o gesto representa (a república curvando-se à monarquia), informando-a simplesmente de que em relação ao beijo, "uns acharam que, para republicano, o ato foi de vilania; outros que, para francês, foi galantaria". Desse modo, volta-se para os costumes das cortes, considerando que a democracia pode muito bem abraçar esse tipo de graça e, mais uma vez, dirige-se à tzarina:

Olha, tzarina, houve tempo em que nessa mesma França, cujo chefe te beijou a mão, se fazia grande cabedal de tratar por tu uns aos outros, para continuar Robespierre e os seus terríveis companheiros. Então um poeta falou em verso, como é uso dêles, e concluiu por êste, que faz casar a política e as maneiras: Appelons-nous MONSIEUR et soyons CITOYEN ${ }^{319}$.

Ao tratar da cortesia e das boas maneiras francesas o cronista traz Robespierre e seus terríveis companheiros, perpetuando a ideia do terror ligada ao tribuno. Amena,

\footnotetext{
318 "A Semana", Gazeta de Notícias.

${ }^{319}$ Frase atribuída ao poeta François Guillaume Jean Stanislas ANDRIEUX.
} 
minimizada, parodiada, ora satirizada, ironizada às vezes, a imagem de um legalista é difundida na esfera da crônica em consonância ao olhar que o XIX francês lançava às personalidades setecentistas, sobretudo, aquelas envolvidas na Revolução.

Nesse contexto, em que fábulas, anacronismos e outros atalhos se juntam para construir uma imagem, Robespierre dificilmente poderá contar com uma reflexão que esclareça mais profundamente as conexões políticas das quais fizera parte, sobretudo porque, consoante Alencar, a crônica é borboleteante, não pode - e não deve -, demorarse em assuntos áridos e ásperos. Diante disso, sobra a reprodução sintética, clara e perfeitamente acessível de retratos temáticos (o Terror, a Revolução) e pessoais - tal o de Robespierre -, que surgem, não raro, como simples caricaturas que desacreditam este ou aquele ponto de vista, relativizando a ação do homem a serviço de seu tempo, suas lutas e sua atuação política. Fora de contexto, resiste o tirânico e sanguinário Robespierre que, ao lado de Saint-Just, sobreviveu como responsável pela violência durante o Terror.

\subsection{Miscelânea: Buffon, Chénier... e os Luíses da França.}

O século XVIII, "data de tantas liberdades" 320 , é fonte de comentários, ideias, associações, e várias são as personalidades que marcam presença na esfera dos folhetins que Machado produzia para os diferentes órgãos da imprensa carioca. Nem todas, evidentemente, foram alvo de interesse como Voltaire, Rousseau e Diderot, mas por mérito, influência ou fatuidade, muitas surgem nos textos machadianos.

No século XVIII francês, quando as ameaças do espírito teológico, o gosto pelo fantástico e a importância por interesses morais ocupavam o pensamento humano, não obstante a vitória do método experimental e suas posições conquistadas (malgrado alguns recuos), até mesmo pessoas de elevado conhecimento hostilizaram e se indignaram contra as teorias de Buffon.

Quando não se surpreendiam com seu estilo, filósofos e naturalistas contestavam seus métodos e, pode-se dizer que contras estes, Buffon não teve a ajuda sequer de religiosos e metafísicos, comumente contrários à filosofia. Os partidários da ortodoxia se multiplicaram e fizeram frente para desacreditar suas obras, seus artigos e seus

320 “Ao Acaso", Diário do Rio de Janeiro, 25/4/1865. 
estudos. Contudo, embora muitos acreditassem que esses avanços históricos devessem (ou poderiam) ficar restritos aos círculos restritos dos savants e colecionadores, Buffon, com L'Histoire générale, naturelle et particulière (1749) ${ }^{321}$, alcança reconhecimento desde o início de sua publicação e sua popularidade aumenta dia-a-dia e de forma unânime entre o público médio, tornando-se tão célebre quanto Voltaire e Rousseau. Esse trio representativo das Lumières seria alterado mais tarde, com a substituição de Buffon por Diderot.

Nas crônicas machadianas, no entanto, Buffon aparece rapidamente em dois textos da juventude, e depois, tardiamente, em 1894. Primeiro, em 5/3/1858 ${ }^{322}$, na polêmica dos cegos (tratada aqui no capítulo sobre Diderot) quando o cronista refuta seu adversário Jq. Sr.. Ao encerrar seu texto e talvez porque conhecesse seu oponente, não querendo ferir as suscetibilidades, recorre a Buffon: "Aguardamo-lo. Entretanto, fique certo de uma verdade: nós não ferimos personalidades, mas sim argumentos: mesmo apesar da frase de Buffon: _ O estilo é o homem.",323

Do raciocínio de Buffon, o cronista reproduz justamente a parte que se transformara em adágio no intuito de dissociar o homem da ideia. Contudo, fosse Jq. Sr. um homem curioso, certamente constataria que a tutela de Buffon o colocava em desvantagem em relação a seu rival, uma vez que o francês insiste que "le style ne peut donc ni s'enlever, ni se transporter, ni s'altérer: s'il est élevé, noble, sublime, l'auteur sera également admiré dans tous le temps; car il n'y a que la vérité qui soit durable et même éternelle. (BUFFON, 1818: 604)"

Desse modo, ainda que furtivamente, o cronista não só impõe a imagem que tem de si mesmo, mas também aquilo que espera para si no futuro. Sem emitir qualquer opinião sobre o naturalista, é de se crer que o tenha alta conta, pois assim como buscou sua tutela para essa questão particular, também, ironicamente o fez quando criticou um espécime curioso que denominou "fanqueiro literário":

A Buffon escapou êsse animal interessante; nem Cuvier lhe encontrou osso ou fibra perdidos em terra antediluviana. ${ }^{324}$

\footnotetext{
${ }^{321}$ Compreendendo um total de 36 volumes, os sete últimos volumes serão editados em 1789 .

${ }^{322}$ A Marmota, pp. 1-2.

${ }^{323} \mathrm{O}$ intertexto, consta no discurso que Buffon pronunciou na Académie Française, em 25/8/1733, dia de sua recepção (BUFFON, 1818: 604): "Ces choses sont hors de l'homme, le style est l'homme même."

324 “Aquarelas - Os fanqueiros literários”, O Espelho, 11/9/1859.
} 
Ao comentar a caráter desse "prosador novato", desprovido de talento, excessivo em vaidades, volúvel, cujas "odes e discursos parvamente retumbantes" orientam-se ao sabor das aspirações e do interesse comercial, o cronista ressalta o fato de que Buffon o tenha deixado de lado e, como "nem Cuvier lhe encontrou osso ou fibra perdidos em terra antediluviana", transfere a seu "leitor curioso" o encargo de investigá-lo. Buffon, no caso, contribui para traduzir o pensamento do cronista, que relativiza esse novo tipo enquanto homem, comparando-o aos animais, no sentido proposto pelo grande naturalista, em que a natureza é vista como um todo ao qual cada animal pertence, constituindo-se este num pequeno fragmento do todo.

Por fim, uma pilhéria, cuja graça vem da tentativa de autores imprimirem credibilidade e lastro científico a obras de cunho especulativo, os já procurados livros de autoajuda abarrotados de respostas fáceis para problemas pessoais complicados, em geral, repletos de afirmações pseudocientíficas. Em 24/6/1894 ${ }^{325}$, em meio a muitos assuntos o cronista desliza os dedos à escolha de um deles quando ouve um espectro a gritar “São João, sortes de São João!”; à procura do espectro, encontra-o com uma série de folhetinhos a distribuir as "boas sortes" de São João.

Após seus “devaneios", a memória o transporta para anos atrás e passa a rememorar as antigas festas de São João, depois, chama seu leitor para a noite de 24 de junho de 1841 e dá com olhos em uma folha antiga que quase se desfaz de tanto velha, embora preserve os anúncios de "livros de sorte". Em seguida, demora-se em alguns desses anúncios, quando passa a comentar o último deles:

Eis agora o Oráculo das senhoras, conselheiro oculto, diz o subtítulo, e acrescenta: "respondendo de um modo infalível a tôdas as questões sobre as épocas e acontecimentos mais importantes da vida, confirmado pela opinião de filósofos e fisiologistas mais célebres, Descartes, Buffon, Lavater, Gall e Spurzheim”.

Quem não ia pela fé, ia pela ciência, e, à fôrça do Batista ou de Descartes, agarravam-se pelas orelhas os segredos mais recônditos do futuro, para trazê-los ao clarão das velas, porque ainda não havia gás.

Desse modo, por via indireta, uma vez mais Buffon surge nos textos machadianos, como referência de autoridade, ligado ao eruditismo e a um conhecimento

325 “A Semana”, Gazeta de Notícias. 
específico, de maneira a tutelar a argumentação do cronista. Diante da unanimidade de Buffon no mundo das ciências setecentistas, suas teorias sobre a formação do universo e sobre a evolução da terra, não só o colocaram como figura participante do espírito das Lumières, como fizeram com que fosse condenado pela Igreja, porém, diante da fé do naturalista, a Igreja (e a Sorbonne) deixam de persegui-lo, algo que o afasta de grandes polêmicas, perpetuando a imagem positiva de grande cientista, que é reproduzida pelo cronista.

Num outro extremo, longe das ciências, acha-se o poeta André Chénier: figura do helenismo na França, a partir de 1787 a poesia de Chénier traz ingredientes filosóficos e satíricos que estimulam o cenário político-ideológico pré-revolucionário, ainda que sua situação precária o obrigue a conter sua combatividade. Quando, a partir de 1791 condena os excessos da Revolução no Journal de Paris, referindo-se particularmente a Robespierre e Marat, caí em desgraça.

Porém, o olhar compreensivo que receberá de seus ulteriores dá-se pelo fato de os românticos reconhecerem no poeta uma manifestação do amor à natureza que vai além da expressão dos sentimentos pessoais. Isso fez com que fosse admirado pelos escritores do XIX como um dos "precursores" do romantismo, exatamente pelo contraste que oferece com os poetas de seu tempo. Chénier, visto como o irmão mais velho dos novos poetas, de fato, é considerado pelos românticos como se pertencesse ao XIX. Dele, e de Mathurin Regnier, Sainte-Beuve (1966: 798) diz 'qu'ils sont un peu en dehors de leurs époques chronologiques".

Chénier tem aparição isolada em um texto machadiano de $1859^{326}$, na segunda parte de suas "Aquarelas", quando trata do "parasita literário". Comparando-o ao fanqueiro literário, afirma que este não "mira o resultado pecuniário", a imprensa é a mesa onde se senta "com tôda a sem-cerimônia". No caso, a crítica recai sobre aqueles que publicam uma enxurrada de prosa e verso nos jornais, veículo que curiosamente o cronista chama de "mesa intelectual", muito provavelmente porque à época era assídua a presença de escritores e intelectuais nos periódicos.

O parasita literário, que não se contenta apenas com o jornal, invade os livros derramando versos "em harpas selvagens como um tamoio" ou, se é prosa, amontoando as frases “descabeladas entre si, segundo a opinião do autor", e, por fim, vai ao teatro,

\footnotetext{
${ }^{326}$ O Espelho, 9/10/1859.
} 
onde recita tal qual "um bardo em um festim". O que surpreende o cronista, em soma, é que esse tipo de parasita, "vampiro da paciência humana", não só encontra leitores, mas também coleciona simpatias e aplausos!

Porém, seu menosprezo por esses escritores medíocres é evidente a ponto de criticar aqueles que os aplaudem: "Há quem lhes faça crer que alguma coisa lhes rumina na cabeça como a André Chénier; êles, a quem já não faltava vontade de crer, aceitam, como princípio evidente, essa solução do impossível, que a parvoíce lhe dá de boa vontade."

Assim, Chénier sustenta a crítica machadiana em face da banalidade e da insuficiência de qualidade que se instalam entre as publicações da época. O poeta surge das entrelinhas como artista talentoso, cuja obra reveladora escapa à parvoíce e induz à reflexão, em oposição aos coetâneos do cronista, de maneira que se consolida a imagem favorável do poeta reverenciado pelos românticos franceses.

À guisa de conclusão, surgem Louis XV e Louis XVI: ambos deixaram imagens que entraram para a história através (e numa esfera) de excessiva fabulação, suscitando pensamentos muito diferentes de acordo com o ponto de vista sob o qual se coloca o escritor. Robert Darnton (1991: 213) mostra a que ponto a opinião pública era hostil a Louis XV. À época, livros, panfletos, canções, gazetas e rumores disseminavam a imagem de um rei adúltero e envolvido em improváveis orgias.

Mais tarde, passados os primeiros medos da Revolução, tem início um olhar diferente sobre a época de Louis XV, algo como o anúncio da decadência da nobreza que se fazia pressentir. No início do XIX, historiadores e escritores passaram a identificar os sinais de decrepitude que marcaram a vida política e social no Ancien Régime que envelhecia e, curiosamente, o tédio que prefigura a inquietude romântica, contribui para evocar imagens que ilustram essa decadência ${ }^{327}$ que antecede a Revolução.

É nessa perspectiva que escritores como Barbey d'Aurevilly (1892: 104) comentam a "volupté funèbre" de Madame du Deffand e André Bellesort (1941: 117), o tédio e "la mélancolie âpre et sombre" como característica da marquesa que muitos experimentariam no século seguinte. Esse mesmo tédio, os Goncourt o veem como um mal que é próprio ao século XVIII e que o corroía silenciosamente; não se trata do

\footnotetext{
${ }^{327}$ Esta reflexão, evidentemente, não se refere ao decadentismo que marca os vinte últimos anos do século XIX francês.
} 
spleen romântico, mas de uma tristeza decadente, originada de um cansaço profundo e de um esgotamento físico que atende todas as classes sociais e que acaba por se incarnar em Louis $\mathrm{XV}^{328}$, que os Goncourt transformam em herói "fin de siècle" (1860: 216).

Contudo, nas crônicas, toda essa reflexão passa ao largo e o que surge é um Louis XV sinonímia de marca temporal, apequenado a ponto de uma futilidade prevalecer à ideia de grande monarca, tal qual o desejo do cronista, que ao morrer espera deixar a seus sobreviventes um legado que lhes desperte a atenção: "os cabelos à Luís XV" ${ }^{329}$ O monarca francês aparece ainda nas "Balas de Estalo",330, num indício de que seu nome poderia alavancar a venda de um livro de Alfredo do Vale Cabral, já que à época eram comuns obras que continham anedotas, historietas "secretas", romances inconfessados, enfim, fofocas das cortes e nobreza desparecidas, especialmente a francesa, de maneira que o cronista especula na provável confusão, esperança de Cabral:

\footnotetext{
O Cabral ${ }^{331}$, que imaginou enriquecer quando publicou as Memórias de Drummond, está nas mesmas condições pecuniárias que dantes. Note-se que ele contava que o nome Drummond, puramente francês, fizesse crer em anedotas de Luís XIV ou $\mathbf{X V}$; mas foi esbulhado das esperanças. Uma das folhas denunciou que se tratava da independência do Brasil e do primeiro reinado, e ninguém caiu na esparrela.
}

Da mesma forma surgem Louis XVI ao lado de Mirabeau (veja crônica no capítulo 1, p. ), Louis XI, Louis XIV e Louis XVIII marcando a presença da realeza francesa no folhetim. Também expressivos, Lesage, Crébillon, Vestris (dançarino e coreógrafo), Marmontel, Champcenetz, Destouches, Chamfort e outros, aparecem concomitante a Beaumarchais; este, figura emblemática das Lumières, surge nas crônicas sempre ligado à música ${ }^{332}$ e sua não menos célebre fórmula: "tout finit par des chansons" ${ }^{, 33}$, que o cronista adapta à medida que se serve do intertexto, de modo que no Brasil ora acaba em óperas, operetas ou polcas.

\footnotetext{
328 "Louis XV, en effet, est le grand exemple de l'ennui, comme il en est la grande victime.", "Mais l'homme qui est derrière le roi, l'homme qui le monarque trahit si bien, l'homme dans Louis XV est un abîme d'ennui. L'ennui le possède véritablement. (GONCOURT, 1860 : 216-217)"

329 "História de Quinze Dias", Ilustração Brazileira, 15/11/1876.

${ }^{330}$ Gazeta de Notícias, 25/11/1884.

${ }^{331}$ Pesquisador e bibliófilo, Alfredo do Vale Cabral foi organizador da seção de manuscritos da Biblioteca Nacional.

${ }^{332}$ A célebre Le Mariage de Figaro (1778).

${ }^{333}$ Le mariage de Figaro, Ato V, Cena XI (BEAUMARCHAIS, 1785: 135).
} 
Dessa forma, fragmentos do século XIX marcam presença na crônica machadiana e, na quase totalidade, reproduzem e consolidam os olhares previamente lançados em solo francês, confirmando uma recepção não desinteressada, mas de total absorção, condição comum no XIX de países periféricos habituados a assimilar influxos externos. No mais, ressalta-se a condição singular do Rio de Janeiro, cidade que se pretendia a símile de Paris nos trópicos: visivelmente afrancesada, ali a cultura gálica se impunha, porém, não como algo sem contestação, mas como possibilidade de a capital ombrear-se a Paris.

Por fim, vale destacar que, voluntariamente - ou não -, o folhetim preservou nos trópicos a imagem de um século XVIII analítico, caracterizado por uma literatura árida e uma filosofia tão "perigosa" quanto libertadora. E, se a crônica, leve e gaiteira, ocupase do lado obscuro, trazendo à cena Robespierre, só o faz por galhofa; no mais, quando reserva aos Luíses papel de coadjuvantes no "rez-de-chaussée" da primeira página, também o faz, porque zombeteira, gosta de pirracear. 


\section{DE BORBOLETAS E COLIBRIS EM SOBREVOO, UM MEL TODO MACHADIANO}

Um colibri, uma borboleta, uma abelha? De fato, quem ou o que quer que seja não vem ao caso. Para o cronista-folhetinista, o que importa, efetivamente, é adejar, pairar sobre um assunto e outro, esvoaçar novamente, pousar, e depois lançar-se uma vez mais num voo leve, batendo as asas por entre as flores miúdas à procura do mel. A metáfora vem de longa data: Montaigne, que afirmou não estudar os livros, mas apenas folheá-los, ao tratar da leitura e da memória, traz de arrasto a imagem que um dia fora de Sêneca e Plutarco: "Les abeilles pillotent deçà delà les fleurs, mais elles en font après leur miel, qui est tout leur. (2009: 321, Tome I)"

Alencar, em Ao Correr da Pena ${ }^{334}$, ao refletir sobre o folhetinista, evoca a condição do escritor comparando-o a "uma espécie de colibri a esvoaçar em ziguezague, e a sugar, como o mel das flores, a graça, o sal e o espírito que deve necessariamente descobrir no fato o mais comezinho" e, ao burilar a imagem romântica, faz-do escritor colibri "uma borboleta que quebrou a crisálida para ostentar o brilho fascinador de suas cores", nas vezes em que lança o pensamento sobre o papel, livre como o espaço.

É provável que Machado tenha se valido da metáfora via Alencar, pois alguns anos depois traz à luz suas "Aquarelas"335 e, ao ponderar sobre a aclimatação do folhetinista, "produto" eminentemente francês, afirma: "O folhetinista, na sociedade, ocupa o lugar do colibri na esfera vegetal; salta, esvoaça, brinca, tremula, paira e espaneja-se sôbre todos os caules suculentos, sôbre tôdas as seivas vigorosas. Todo o mundo lhe pertence; até mesmo a política."

Se o cronista salta aqui e acolá à procura da "arraia-miúda", lapidando-a, para dela extrair a essência a partir da qual refletirá sobre os desconcertos do mundo e as vicissitudes do "barro humano", o movimento que o leitor se vê "obrigado" a perfazer não é muito diferente. Um sobrevoo pelo conjunto das crônicas machadianas obriga-o a saltar de um assunto a outro num vai-e-vem constante, ao sabor da imaginação do cronista, até que se complete a visão panorâmica desenhada ao longo dos quarenta anos que escrevinhou para as diversas folhas cariocas.

\footnotetext{
${ }^{334}$ Correio Mercantil, 24/9/1854, p. 1.

${ }^{335}$ O Espelho, 30/10/1859.
} 
Sob essa perspectiva os textos reproduzem o pulsar da vida no Rio de Janeiro oitocentista. Submetida à percepção artística do cronista, a notícia, pontuada pela aridez da contingência, ganha verniz literário e, "fíccionalizada", surge enternecida no espaço do folhetim. No princípio, um cronista "duro", apegado às referências e citações, reproduzindo e ou adaptando-as impecável e corretamente; depois, livre das amarras, dá livre curso a seu pensamento, subjugando-as ao seu texto, volatilizando e integrando-as ao elemento local, de maneira a agregar sentidos e tutelar a fala de um interlocutor relativista e desconfiado, não só empenhado em relativizar o discurso oficial, mas sempre à busca do oculto nas entrelinhas e do escondido sob as aparências.

O diálogo intertextual conjugado à acrobacia humorística do cronista garante jocosidade e literariedade ao texto. Aforismos, por exemplo, justapostos a fatos e discursos desprendidos da notícia e comumente filtrados pela percepção crítica e lúdica do cronista, não só contribuem para ampliar a esfera da crônica, fazendo-a emergir do rés-do-chão da primeira página, mas cumprem com o propósito de ridicularizar, fazer rir e, sobretudo, reforçar a hilaridade da situação comentada, perfazendo, a seu modo, o vigor crítico, tornando-o insinuado, controverso e, não raro, ambíguo. No mais, fustigam o leitor, estimulando-o a [re]leitura para além do folhetim, qual seja, das obras ali citadas e referenciadas.

Nessa toada, "o melhor dos mundos possíveis", axioma leibniziano já popularizado ao longo da circulação das ideias literárias, integra-se à crônica e ridiculariza a vida nos trópicos, criticando-a sub-repticiamente, na medida em que é justaposto à problemática das companhias de bonde que gozam desse paraíso panglossiano, uma vez que jamais indenizam suas vítimas de atropelamento. Nesse jogo, em que fatores como a amenidade do quotidiano, a fabulação e a intromissão do intertexto entram em ebulição, conta muito a participação do leitor culto machadiano, apto a acompanhar o movimento da crônica, principalmente a partir dos desvios provocados pelas referências e citações, que, em parte, guardam traços do texto de origem.

As crônicas, muitas vezes - e inadvertidamente -, classificadas como “documentos", portanto, material histórico sujeito ao "estilo bárbaro próprio do ofício" 336 , para o cronista é "confeito literário" 337 , matéria de "tom ameno e fácil, frase

336 “A Semana”, Gazeta de Notícias, 12/6/1892. 
ligeira e chistosa" ${ }^{338}$, enfim, "prato de pouca ou nenhuma resistência, simples môlho branco" 339 . É nesse contexto que os atores políticos e acontecimentos político-sociais passam pelo crivo do artista. E é também sob essa perspectiva que o século XVIII adentra o folhetim, pois, consoante Bosi (2006: 64) os desconcertos do mundo "não se localizavam só nesta ou naquela nação nem seriam apanágio deste ou daquele povo".

Desse modo, uma vez que vilania, hipocrisia, vaidade, incoerências e interesses pontuais campeiam por todo o planeta, esse cronista pintor de homens, na conjunção do imaginário com o real, não hesita em fantasiar e, para isso, vale-se da ferramenta intertextual para imprimir traço carnavalesco a seu texto.

Se é para “imitar alguém, imita Mirabeau!", de maneira que o anedótico sobressai em meio à aridez e o insólito da notícia, e o histórico, amiúde nas páginas do folhetim, adquire tonalidade ficcional, confirmando-se como presença puramente parodística. Não por outra razão, Bosi (2006: 63) insiste na mediação moral e estilística, a que o cronista submete as impressões do quotidiano convertendo-as em juízos de valor, de modo "que o historiador que recolha da escrita machadiana só o puro documento da época arrisca-se a perder a dimensão mesma do seu sentido encurtando o alcance da interpretação".

Não obstante visar a identificação dos autores franceses do século XVIII presentes nas crônicas machadianas, este trabalho deteve-se, antes, na manufatura do cronista às voltas com um gênero que lhe permite observar o "barro humano", suas ações e escolhas, analisando-as de modo ambíguo. Ao relativizar fatos e comportamentos, o "nosso" pintor de homens chama ao diálogo seu leitor ideal, mostra a pantomima que é a vida e ri nas entrelinhas. Dessa forma, fundamenta a práxis da inversão tutelada pela ironia, em que amiúde destaca as desigualdades, absurdos e impropriedades entre o ser e o parecer, pontuados, sobretudo, pelas oposições entre o real e o fictício.

Ao revestir episódios sociais e históricos de uma indumentária galhofeira, Machado faz com que a História resvale, em termos de sentido em proveito de uma visão matizada, na qual, das vicissitudes, emergem certos valores humanos. Nessa perspectiva, surge o artista que amplia a relação entre o restrito do comezinho e a

\footnotetext{
${ }^{337}$ O Espelho, 30/10/1859.

338 “Ao Acaso", Diário do Rio de Janeiro, 12/6/1864.

339 "A Semana", Gazeta de Notícias, 1/1/1894.
} 
notícia, fazendo da crônica espaço de entretenimento, onde a "veracidade" histórica é subjugada à fantasia, de maneira que o espelhamento da coisa miúda, de fato, afasta a ideia de se creditar ao gênero status documental - algo tratado no capítulo sobre a cosmovisão artístico-literária machadiana.

Mergulhado na galofilia, o cronista pareceu não se deixar sufocar e dali extraiu matéria para pensar o quotidiano via folhetim. Nessa toada, o século XVIII francês vem à luz como um ruptor de ideias, estilhaçando o pensamento, a estabilidade e as certezas do espírito clássico, e abrindo território para que os homens expandissem seus horizontes, interessassem pela diversidade do mundo, tomassem gosto pelas viagens e elevassem a ciência a um patamar jamais visto; vulgarizando-a e deitando o saber à rua, afastando-o das universidades e de entre os clérigos, onde jazeu o conhecimento até o fim da Idade Média.

Machado, "le fils qui a tout examiné, qui a tout mis en question", inegavelmente um admirador das ideias das Lumières, aproxima-se de Voltaire e, nas vezes em que sua pena deita sobre a página citações e referências ao francês, a ironia salta das entrelinhas como principal traço de sua escrita, tornando-a ambígua e relativista, de maneira que o intertexto voltairiano revela-se esteio para uma crítica que se constrói a partir de ideias anteriores. Ora como estratégia retórica ora ferramenta no jogo irônico entre o ser e o parecer, Voltaire contribui para a expressão do cronista, o chiste e o jocoso da crônica.

Rousseau perde a aura de grande filósofo, torna-se puro clichê e se materializa nas páginas do folhetim, de onde emergem temas e princípios criados por ele e decantados pela cultura popular como "o homem natural", "a doutrina de Rousseau", o "Estado social de Rousseau", etc. Adaptados, esses lugares-comuns integram-se ao novo texto operando não só uma transposição de ordem estética, uma vez que são submetidos ao senso artístico do cronista, mas trazendo em si tal vigor conteudístico que cooperam para o ônus crítico disseminado por entre as fissuras irônicas de um texto construído à força da graça e da jocosidade.

Nessa esfera, os autores setecentistas ampliam o universo de significação das crônicas, contribuindo para a sedimentação da integração Brasil-França. Arlequins, vestem-se de várias cores à medida que circulam pelo folhetim (e jornalismo) brasileiro, propiciando o resgate de temas presentes no prosaísmo cultural que circunda o cronista 
e o leitor. Este, sobretudo, beneficia-se com uma melhor compreensão da realidade flagrada pelo relato.

Diderot (assim como Voltaire e Rousseau), numa época em que não só a literatura brasileira, mas também o jornalismo e as rodas de conversa permitiam-se inundar de galicismos, teorias, autores, histórias e personagens franceses para construir seus próprios alicerces ou dar continuidade ao rumo da prosa, surge na imprensa e dá forma a um traço peculiar francês - as polêmicas. Como eco a ressoar nos trópicos, a "polêmica dos cegos" movimenta por alguns meses as páginas d'A Marmota, redimensionando questões sobre a percepção dos sentidos, irreligião, materialismo e a natureza como evidência e expressão máxima da existência divina.

Em ponto pequeno e subordinada à pena do cronista, a polêmica traz à cena carioca muito do espírito francês setecentista, reproduzindo a dúvida que reinava em todas as esferas, de maneira que participar, desencadear e ou dar continuidade a controvérsias intelectuais era também contribuir com uma fatura própria, qual seja, inscrever-se no concerto das nações ditas civilizadas, concorrendo (não obstante o evidente descompasso) para a divulgação das ideias do século em que a razão tornou-se uma audácia crítica.

Porém, o século XVIII é fértil e o cronista nutre por ele confessada atração: simultâneo aos grandes expoentes das Lumières vicejam nos folhetins seus coadjuvantes e uma enormidade de outros atores que lhe dão forma, cor e animação, materializando o espetáculo setecentista.

Dessa forma, por meio de um tom galhofeiro que predomina sobre quaisquer outros elementos textuais, Machado não só faz da linguagem a grande personagem de seus relatos semanais, mas da crônica um gênero destinado por excelência ao entretenimento. Como sabemos, ao lançar mão do fato, adiciona uma intromissão intertextual qualquer, provocando o desdobramento da notícia e promovendo a decantação cultural que populariza autores exponenciais como Voltaire, Rousseau e Diderot. A artimanha, analisada em detalhes ao longo deste estudo, não só surge como uma característica particular da recepção da cultura francesa, como comprova a hipótese do gênero como desbastador da erudição, fazendo desses grandes autores companheiros literários compreensíveis para o leitor, sem deixar de consignar uma das possibilidades de recepção da cultura francesa, paralela e nem sempre coincidente em relação a 
tratados e livros dos cursos universitários jurídicos, onde muitos desses autores tinham grande aceitação.

Trata-se, conforme sabemos, de um tipo de recepção que se caracteriza pela larga circulação dos periódicos, muito mais presentes na vida brasileira que a erudição de livros. Não se pode esquecer, entretanto, que a atividade jornalística de Machado ia de par com a vida do parlamento e com os próprios estudos filosóficos e jurídicos que culminariam com a República. Como se percebe, os caminhos da recepção da cultura mais uma vez se mostram complexos e ligados às necessidades dos grupos que dela se apropriam.

Acrescentando a ironia como tempero necessário à vida brasileira, em várias dimensões e matizes, Machado soube articular de modo eficaz e singular a presença francesa do setecentos ao espetáculo que, como cronista, podia contemplar no Brasil do século XIX, fazendo com que o leiamos até hoje com inescapável prazer e proveito. 


\section{BIBLIOGRAFIA}

\section{MACHADO DE ASSIS}

ASSIS, Machado de. Obra completa em quatro volumes. Rio de Janeiro: Editora Nova Aguilar, 2008.

Obras Completas, Crítica Literária. Vol. 29. Rio de Janeiro: W. M. Jackson, 1952. Obras Completas, Crônicas. Vols. 22 a 28. Rio de Janeiro: W. M. Jackson, 1952.

BOSI, Alfredo. Brás Cubas em três versões: estudos machadianos. São Paulo: Companhia das Letras, 2006.

. "Machado de Assis". In: História concisa da Literatura Brasileira. São Paulo: Editora Cultrix, 1994.

Ática, 1999.

"Uma figura machadiana". In: Machado de Assis: o enigma do olhar. São Paulo:

BRAYNER, Sonia. "Metamorfose machadianas - O Laboratório Ficcional". In: Machado de Assis - Alfredo Bosi... /et al./; participação especial de Antonio Candido... /et al./. Coleção escritores brasileiros: antologia e estudos. São Paulo: Ática, 1982.

CANDIDO, Antonio. "Esquema de Machado de Assis", In: Vários Escritos. São Paulo: Livraria Duas Cidades, 1977.

CORÇÃO, Gustavo. "Machado de Assis cronista". In: Machado de Assis - Obra Completa. Vol. III. Rio de Janeiro: Cia. José Aguilar Editôra, 1973.

COUTINHO, Afrânio. Machado de Assis na Literatura Brasileira. Rio de Janeiro: Livraria São José, 1960.

FACIOLI, Valentim. "A Fraude e a Garofinha: a crônica de Machado de Assis". In: CRUZ JÚNIOR, Dilson Ferreira da. Estratégias e máscaras de um fingidor: a crônica de Machado de Assis. São Paulo: Nankin Editorial; Humanitas FFLCH/USP, 2002.

FAORO, Raymundo. Machado de Assis: a pirâmide e o trapézio. $4^{\mathrm{a}}$ ed. rev. São Paulo: Globo, 2010.

GLEDSON, John. Bons Dias! - Machado de Assis: introdução e notas: John Gledson. Campinas: Editora da UNICAMP, 2008.

. Machado de Assis: ficção e história. Tradução: Sônia Coutinho. São Paulo: Editora

Paz e Terra, 2003.

GOMES, Eugênio. Machado de Assis. Rio de Janeiro: Livraria São José, 1958.

GRIECO, Agrippino. Machado de Assis. Rio de Janeiro: Livraria José Olympio, 1959.

MAGALHÃES JR., Raimundo. Machado de Assis: vida e obra. Aprendizado Vol. I. Rio de Janeiro: Record, 2008.

1957.

Machado de Assis desconhecido. Rio de Janeiro: Editôra Civilização Brasileira,

MAGRI, Dirceu. Aspectos da presença de Voltaire nas crônicas machadianas. 2009. 367f. Dissertação (Mestrado em Letras) - Faculdade de Filosofia, Letras e Ciências Humanas FFLCH, Universidade de São Paulo, São Paulo.

MASSA, Jean-Michel. A juventude de Machado de Assis. Rio de Janeiro: Editôra Civilização Brasileira, 1971.

MEYER, Augusto. Machado de Assis: 1935-1958. Rio de Janeiro: José Olympio; ABL, 2008. À sombra da estante: ensaios. Rio de Janeiro: Editôra J. Olympio, 1947.

MIGUEL-PEREIRA, Lúcia. Machado de Assis: estudo crítico e biográfico. $6^{\mathrm{a}}$ ed. Belo Horizonte: Editora Itatiaia; São Paulo: Edusp, 1988. 
PAIVA DE LUCA, Heloísa Helena. Propósito e Fantasia: a presença francesa nas crônicas machadianas. 1996. 211f. Dissertação (Mestrado em Letras) - Faculdade de Filosofia, Letras e Ciências Humanas - FFLCH, Universidade de São Paulo, São Paulo.

Balas de Estalo, de Machado de Assis/Heloisa Helena Paiva de Luca (Org.). São Paulo: Annablume, 1998.

PASSOS, Gilberto Pinheiro. A poética do legado: a presença francesa em Memórias póstumas de Brás Cubas. São Paulo: Annablume, 1996. [1]

. As sugestões do Conselheiro: A França em Machado de Assis - Esaú e Jacó e Memorial de Aires. São Paulo: Editora Ática, 1996. [2]

. O Napoleão de Botafogo: presença francesa em Quincas Borba de Machado de Assis. Coleção Parcours. São Paulo: Annablume, 2000.

. Miragem Gálica: presença da França na Revista da Sociedade Filomática. São Paulo: Instituto de Cooperação Interinstitucional-INTER: Coordenação de Aperfeiçoamento de Pessoal de Nível Superior-CAPES, 1991.

REALE. Miguel. A filosofia na obra de Machado de Assis: com uma "Antologia filosófica de Machado de Assis". São Paulo: Pioneira, 1982.

SÁ REGO, Enylton José de. O calundu e a panacéia: Machado de Assis, a sátira menipéia e a tradição luciânica. Rio de Janeiro: Forense Universitária, 1989.

SCHWARZ, Roberto. Ao vencedor as batatas: forma literária e processo social nos inícios do romance brasileiro. São Paulo: Duas Cidades; Ed. 34, 2003.

SEVCENKO, Nicolau. "A ficção capciosa e a história traída". In: Machado de Assis: ficção e história. Tradução: Sônia Coutinho. São Paulo: Editora Paz e Terra, 2003.

SONTAG, Susan. "Vidas póstumas: o caso de Machado de Assis". In: Questão de ênfase: ensaios. São Paulo: Companhia das Letras, 2005.

\section{FICÇÃO EM PORTUGUÊS}

ALENCAR, José de. Nota de Josè de Alencar. In: Senhora. São Paulo: Klick Editora, 1997.

EÇA DE QUEIROZ, José Maria de. Obras de Eça de Queiroz: A cidade e as serras; $O$ Mandarim. Vol. 3. Porto: Lello \& Irmãos Editores, 1946.

MENDES, Murilo. A idade do serrote. Rio de Janeiro: Record, 2003.

PESSOA, Fernando (BERNARDO SOARES). Livro do desassossego. São Paulo: Montecristo Editora Ltda., 2012.

\section{GERAL}

ANNAES DO PARLAMENTO BRAZILEIRO. Câmara dos Srs. Deputados. Segundo Anno da Undecima Legislatura. Sessão de 1862. Tomo I. Rio de Janeiro: Typographia Imperial e Constitucional de J. Villeneuve \& C., 1862.

BADINTER. Elisabeth. As paixões intelectuais. Desejo de glória: 1735-1751. Vol. I. Tradução de Clóvis Marques. Rio de Janeiro: Civilização Brasileira, 2007.

. As paixões intelectuais. Vontade de poder: 1762-1778. Vol. III. Tradução de Clóvis

Marques. Rio de Janeiro: Civilização Brasileira, 2009.

BROCA, Brito. Letras Francesas. Comissão Estadual de Literatura. Coleção textos e documentos. Secretaria da Cultura, Esportes e Turismo. São Paulo: Imprensa Oficial do Estado, 1969.

CANDIDO, Antonio et al. "O francês como instrumento de desenvolvimento". In: $O$ francês instrumental, a experiência na Universidade de São Paulo. São Paulo: Hemus, 1977.

CHAUÍ, Marilena de Souza. "Três em uma (Considerações sobre o Cândido de Voltaire). In: Da realidade sem mistérios ao mistério do mundo: Espinosa, Voltaire, Merleau-Ponty. $2^{\mathrm{a}}$ ed. São Paulo: Editora Brasiliense, 1981. 
COIMBRA MARTINS, António. Ensaios Queirosianos. Lisboa: Publicações Europa-América, 1967.

FREIRE, Junqueira. Elementos de Rhetorica Nacional. Rio de Janeiro: Eduardo \& Henrique Laemmert, 1869.

GALVÃO DE SOUZA, José Pedro. Introdução à História do Direito Político Brasileiro. $2^{\mathrm{a}}$ ed. Coleção Direito e Cultura, Vol 11. São Paulo: Ed. Saraiva, 1962.

GOMES, Laurentino. 1808: como uma rainha louca, um príncipe medroso e uma corte corrupta enganaram Napoleão e mudaram a história de Portugal e do Brasil. São Paulo: Editora Planeta do Brasil, 2007.

HOBSBAWN, Eric J. A Era das revoluções: Europa 1789-1848. Tradução de Maria Tereza Lopes Teixeira e Marcos Penchel. $7^{\text {a }}$ edição. Rio de Janeiro: Paz e Terra, 1989.

KANT, Immanuel. Crítica da faculdade de julgar. In: NOGUERA, Mónica Herrera. O juízo do gosto como fundamento de interpretação da beleza natural e artística na 'Crítica da faculdade de julgar' de Immanuel Kant. 2006. 169f. Dissertação (Mestrado em Filosofia) - Pós-Graduação em Filosofia, Filosofia Transcendental e Hermenêutica - Universidade Federal de Santa Maria, Rio Grande do Sul.

LIMA, Manuel de Oliveira. D. João VI no Brasil (1808). $3^{\text {a }}$ ed. Rio de Janeiro: Topbooks, 1996. MAWE, John. Viagens ao interior do Brasil. Belo Horizonte: Itatiaia; São Paulo: Edusp, 1978.

MOTA, M. A. Rezende. Sílvio Romero: dilemas e combates no Brasil da virada do século XX. Rio de Janeiro: FGV Editora, 2000.

NEEDELL, Jeffrey D. Belle Époque Tropical: Sociedade e cultura de elite no Rio de Janeiro na virada do século. Tradução de Celso Nogueira. São Paulo: Companhia das Letras, 1993.

NIZZA DA SILVA, Maria Beatriz. Cultura e sociedade do Rio de Janeiro (1808-1821). São Paulo: Companhia Editora Nacional, 1978.

SAMÓSATA, Luciano de. Diálogo dos mortos. Tradução de notas de Henrique G. Muracco. São Paulo: Palas Athena; Editora da Universidade de São Paulo, 2007.

SCHOPENHAUER, Arthur. Metafísica do amor, metafísica da morte. Tradução de Jair Barboza. São Paulo: Martins Fontes, 2000 - (Clássicos).

SOBRINHO, Barbosa Lima. Antologia do Correio Braziliense. Rio de Janeiro: Editora Cátedra, 1977.

SOUZA, Laura de Mello e. O diabo e a terra de Santa Cruz: feitiçaria e religiosidade popular no Brasil colonial. São Paulo: Cia. das Letras, 1995.

\section{TEORIA}

BAKHTIN, Mikhail Mikhailovitch. Problemas da poética de Dostoiévski. Tradução de Paulo Bezerra. $4^{\mathrm{a}}$ ed. Rio de Janeiro: Forense Universitária, 2008.

Fontes, 2003.

Estética da criação verbal. Tradução de Paulo Bezerra. $4^{\mathrm{a}}$. ed. São Paulo: Martins

BEZERRA, Paulo. "Prefácio". In: BAKHTIN, Mikhail Mikhailovitch. Problemas da poética de Dostoiévski. Trad. De Paulo Bezerra. 4a ed. Rio de Janeiro: Forense Universitária, 2008.

CANDIDO, Antonio. "A Personagem de Romance". In: A Personagem de Ficção. 9a ed. São Paulo: Perspectiva, 1992.

DÄLLENBACH, Lucien. "Intertexto e autotexto". In: Poétique: Revista de teoria e análise literárias - Intertextualidades. Coimbra: Livraria Almedina, 1979.

JENNY, Laurent. "A estratégia da forma". In: Poétique: Revista de teoria e análise literárias Intertextualidades. Coimbra: Livraria Almedina, 1979.

PERRONE-MOISÉS, Leyla. Falência da Crítica. São Paulo: Editora Perspectiva, 1973.

\section{PERIÓDICOS NACIONAIS}


A Marmota

Correio Mercantil

Diário de Notícias

Diário do Rio de Janeiro

Folha

Gazeta de Notícias

O Globo

O Paiz

Revista Illustrada

The Rio News

\section{OBRAS EM FRANCÊS}

\section{FICÇ̃̃O EM FRANCÊS}

* Exceto Diderot, Rousseau e Voltaire, cujas obras foram agrupadas em "Geral".

BALZAC, Honoré de. Le Père Goriot. Paris : Éditions Garnier Frères, 1963.

BEAUMARCHAIS, Caron de. La Folle journée, ou Le mariage de Figaro. Paris : (s/editora), 1785.

CHATEAUBRIAND, François-René de. Le Génie du christianisme. In : Oeuvres complètes. Tome III. Paris : Libraire d'Adolphe Delahays, s/d.

Génie du christianisme: suivi de la défense du génie du christianisme et de la lettre a

M. de Fontanes. Tome I. Paris : Librairie de Firmin Didot Frères, 1845.

COMETTANT, Oscar. Trois ans aux Étas-Unis. Paris : Pagnerre, Libraire-Éditeur, 1858.

DUMAS, Alexandre. "Une âme à naître ». In : Oeuvres complètes d'Alexandre Dumas. Paris : Michel Lévy Frères, Éditeurs, 1868.

HUGO, Victor. Lucrêce Borgia. Drame. Bruxelles : Louis Hauman et C ${ }^{\text {ie }}$, Libraires, 1833.

MEILHAC, Henri; HALÉVY, Ludovic; OFFENBACH, Jacques (musique). La Grandeduchesse de Gérolstein: opéra-bouffe en trois actes, quatre tableaux. Paris: Michel Lévy Frères, Libraires Éditeurs, 1867.

MOLIÈRE. Oeuvres de J.B. Poquelin de Molière. Tome V. Paris : Didot, Pierre ; Didot, Firmin, 1799.

MONNIER, Albert; MARTIN, Édouard. As-tu tué le mandarin?. Lagny: Imprimerie de Vialat, s.d. (1855).

MUSSET. Oeuvres Completes. Paris: Aux Éditions du Seuil, Tome I, 1963.

. La Confession d'un enfant du siècle. Paris : Charpentier, Libraire Éditeur, 1840.

STERNE, Laurence. La vie et les opinions de Tristam Shandy. Traduites de l'anglois de Stern, par M. Frénais. Seconde partie. Neuchâtel : De l'Imprim. de la Société Typographique, 1777.

\section{GERAL}

ANDRAU, Paule. Diderot: Jacques le Fataliste et son maître. Paris : Éditons Bréal, 2006.

BARBEY D'AUREVILLY, Jules. Les oeuvres et les hommes : littérature épistolaire. Vol. XIII. Paris : Alphonse Lemerre, Éditeur, 1892.

BARRÈRE, Jean-Jacques; ROCHE, Christian. Le Bêtisier des philosophes. Paris : Éditions du Seuil, 1997.

BARTHES, Roland. Sade, Fourier, Loyola. Paris : Éditions du Seuil, 1971.

. Le Plaisir du texte. Paris : Seuil, 1973.

BELLESORT, André. Dix-huitième siècle et romantisme. Paris : Librairie Arthème-Fayard, 1941. 
BÉNICHOU, Paul. L'École du désenchantement: Sainte-Beuve, Nodier, Musset, Nerval, Gautier. Paris : NRF Gallimard, 1992.

BENVENISTE, Mikhail. Problèmes de linguistique générale. Paris : Gallimard, 1966.

BILLAUD-VARENNE, Jacques-Nicolas. Principes régénérateurs du systême social. Introduction et notes par Françoise Brunel. Préface de Michel Vovelle. Paris : Publications de la Sorbonne, 1992.

BUFFON, George Louis Leclerc de. Oeuvres complètes de Buffon. Tome V. Paris, Rapet \& Ce., 1818.

CAILlOIS, Roger; SKALLAGRIMSON, Egili. Art Poétique: suivi de traductions de la Vagasameyi Samhita (XXIIII,46-62). Paris : Gallimard, 1958.

CAMBACÉRÈS, Étienne-François. Sermons de L'Abbé de Cambacérès, prédicateur du Roi, Chanoine E Archidiacre de l'Église de Montpellier. Paris : Chez J. G. Mérigot le jeune, Libraire, 1787.

CONSTANT, Benjamin. Oeuvres complètes. Bibliothèque de la Pléiade. Paris : Gallimard, 1957.

DARNTON, Robert. Édition et sédition: 1'univers de la littérature clandestine au XVIII ${ }^{\mathrm{e}}$ siècle. Paris: Gallimard, 1991.

DELON, Michel. Le savoir-vivre libertin. Paris : Hachette Littératures, Collection Pluriel, 2000. DESAN, Philippe. Montaigne : les formes du monde et de l'esprit. Paris : PUPS - Presse de l'Université Paris-Sorbonne, 2008.

DIDEROT. Lettre sur aveugles à l'usage de ceux qui voient; Lettre sur les sourds et muets à l'usage de ceux qui entendent et qui parlent. Paris : GF Flammarion, 2000. . Jacques le Fataliste et son maître. Paris : Pocket, 1989.

$\overline{1869 .}$

Romans et contes de Diderot. Tome I. Paris : Librairie de la Bibliothèque Nationale, Laffont, 1994.

Le Neveu de Rameau. Diderot Oeuvres Tome II - Contes. Paris : Édition Robert

D'HOEFER (direction). Nouvelle biographie générale: depuis les temps les plus reculés jusqu'à nos jours. Tome XXXV. Paris : Firmin Didot Frères, Fils et $C^{\text {ie }}$, Éditeurs, MDCCCLXI (1866).

D’ORMESSON, Jean. Une autre histoire de la littérature française. Tome II. Paris : NiL Éditions, 1997.

GALAND, David. Montesquieu: Lettres persanes. Paris: Éditons du Bréal, 2003.

GAUTHIER, Florence. «Présentation et notes» pour le onzième volume de Oeuvres de Maximilien Robespierre. Tome XI. Compléments : 1784-1794. Paris : SER (Société des études robespierristes), 2007.

GENETTE, Gérad. Palimpsestes: la littérature au second degré. Paris : Éditions du Seuil, 1982.

GIDE, André. Journal 1889-1933. Paris: Gallimard-Pléiade, 1948.

GODIN, Christian. La Totalité. Vol. 4. La totalité réalisée : Les arts et la littérature. Seyssel : Les Éditions Champ Vallon, 1997.

GONCOURT, Edmond de; GONCOURT, Jules de. Les Maîtresses de Louis XV. Tome I. Paris : Firmin Didot Frères, Fils et $C^{\text {ie }}, 1860$.

GOUHIER, Henri. Les Méditations métaphysiques de Jean-Jacques Rousseau. Paris : J. Vrin, 1970.

GUIZOT, François. Mémoires pour servir à l'histoire de mon temps. Vol. I. Paris: M. Lévy, 1858.

HAZARD, Paul. La Crise de conscience européenne: 1680-1715. Paris : Fayard, 1961.

La pensée européenne au XVIII ìme siècle. Collection Pluriel $\mathrm{n}^{\circ} 25$. Paris : Fayard,

1963.

HOBSON, Simon; HARVEY, Marian. «Le 'Problème Molyneux'». In : Lettre sur aveugles à l'usage de ceux qui voient; Lettre sur les sourds et muets à l'usage de ceux qui entendent et qui parlent. Paris : GF Flammarion, 2000. 
HORACE. Épîtres. Expliquées littéralement, traduites en français et annotées par M. Em. Taillefert. Paris : Hachette et $\mathrm{C}^{\mathrm{ie}}, 1846$.

HUGO, Adèle. Victor Hugo raconté par un témoin de sa vie. Tome I. Paris: Librairie Internationale ; Bruxelles, Leipzig et Livourne: A. Lacroix, Verboeckhoven et Cie. Éditeurs, 1867.

HUGO, Victor. Littérature et philosophie mêlées. Oeuvres complètes. Paris: Alexandre Houssiaux, Libraire Éditeur, 1857.

. La préface de Cromwell. Introduction et notes de Maurice Anatole Souriau. Paris : Société française d'imprimerie et de libraire, 1897.

JARRY, André. Afred de Vigny: Étapes et sens du geste littéraire : lecture psychanalitique. Tome I. Genève : Librairie Droz, 1998.

KOHLER, Pierre. Histoire de la littérature française. Le XVIII ${ }^{\mathrm{e}}$ siècle et la première moitié du $\mathrm{XIX}^{\mathrm{e}}$ siècle. Vol. II. Lausanne : Librairie Payot, 1948.

LA BRUYÈRE. Les Caractères de La Bruyère : suivis des caractères de Théophraste. Paris : Librairie d'Abel Ledoux, 1836.

LA HARPE, Jean-François de. «Éloge de Voltaire». In: Oeuvres de Voltaire. Tome I. Introductions: BEUCHOT, Adrien Jean Quentin; LA HARPE, Jean-François de (Éloge de Voltaire par M. de La Harpe de L'Académie Française); MIGER, Pierre-Auguste-Marie. Paris : Firmin-Didot Frères, Libraires ; Léfèvre, 1834.

LAUNAY, Michel ; MAILHOS, George. Introduction à la vie Littéraire du XVIIIe siècle. Paris : Bordas, 1968.

LEPAPE, Pierre. Voltaire le conquérant. Paris : Éditions du Seuil, 1994.

Diderot. Paris : Flammarion, 1991.

LOCKE, John. Essai sur l'entendement humain. Traduction par Pierre Coste. Les Classiques de la Philosophie. Paris : Librairie Générale Française, 2009.

LOTTERIE, Florence. "Le discours historique: une laïcisation ambiguë". In : Histoire de la France littéraire: Classicismes : $\mathrm{XVII}^{\mathrm{e}}-\mathrm{XVIII}^{\mathrm{e}}$ siècle. Tome II. Publié sous la direction de Michel Prigent. Volume dirigé par Jean-Charles Darmon et Michel Delon. Paris : PUF, 2006.

MALLARMÉ, Stéphane. «Crise de vers » In :Oeuvres complètes. Ed. par Henri Mondor et G. Jean-Aubry. «Bibliothèque de La Pléiade ». Paris : Gallimard, 1945.

.Oeuvres complètes. Bibliothèque de la Pléiade. Paris : Gallimard, 1975.

MARIVAUX. Oeuvres choisies. Vol. 2. Paris : Librarie de L. Hachette et $C^{\text {ie }}, 1868$.

MAUZI, Robert. «La Parodie romanesque dans Jacques le Fataliste »In : Diderot Studies VI. Vol. 12. Genève : Librairie Droz, 1964.

MERLIN, Antoine Christophe. Portrait de Robespierre. Paris : rue de la Loi, n ${ }^{\circ} 1232,1795$.

MONTAIGNE. Essais. Tome I. Paris: Éditions Gallimard, 2009.

. Essais. Tome II. Paris: Éditions Gallimard, 2009.

Essais. Tome III. Paris: Éditions Gallimard, 2009.

MORTIER, Roland. "Le Tableau littéraire de la France au XVIII siècle » : un épisode de la «guerre philosophique» à l'Académie française sous l'Empire, 1804-1810. Volume 55 de l'Académie royale de langue et de littérature françaises de Belgique. [Publications diverses]. Bruxelles : Palais des Académies, 1972. . "Lumière' et 'Lumières', histoire d'une image et d'une idée au XVII ${ }^{\mathrm{e}}$ et au XVIIIe siècle ». In : Clartés et ombres au siècle des Lumières : études sur le XVIII ${ }^{\mathrm{e}}$ siècle. Genève : Librairie Droz, 1969.

«Unité ou scission au siècle de Lumières ». In : Clartés et ombres au siècle des Lumières : études sur le XVIII ${ }^{\mathrm{e}}$ siècle. Genève : Librairie Droz, 1969.

PASCAL, Blaise. «Pensées nouvelles». In. COUSIN, Victor. Études sur Pascal. V édition. Paris : Didier et $\mathrm{C}^{\text {ie }}$, Libraires-Éditeurs, 1837.

POMEAU, René. Voltaire en son temps. Tome I. Paris : Fayard ; Voltaire Foundation, 1995.

POTELET, Hélène. Mémento de littérature française. Paris : Hatier, 1990.

POUJOULAT, M. Histoire de la Révolution Française I. $4^{\mathrm{eme}}$ Édition. Tours : Alfred Mame et Fils, Éditeur, 1866. 
PYAT, Félix. «Les Artistes ». In : Nouveau tableau de Paris au XIX ${ }^{e}$ siècle. Paris : Librairie de Mme Charles-Béchet, 1834.

QUINET, Edgard. La République : conditions de la régénération de la France. Paris : E. Dentu, Libraire-Éditeur, 1872.

RIOU, Daniel. "Le Roman: héritage et inventions". In : Histoire de la France Littéraire. Dirigé par Jean-Charles Darmon et Michel Delon. Paris : PUF, 2006.

ROUSSEAU, Jean-Jacques. Du Contrat Social. Paris : Chez Mourer et Pinparé, 1797.

Oeuvres complètes de J. J. Rousseau: Philosophie et Politique. Vol. V. Paris : Chez

P. Dupont, Libraire-Éditeur, 1823.

. Les Confessions. Édition critique établie, présentée et annotée par Jacques Voisine.

Paris : Classiques Garnier, 2011.

Discours sur l'origine et les fondements de l'inégalité parmi les hommes. Paris : Flammarion, 2008.

Oeuvres Complètes de J.-J. Rousseau, avec ces notes historiques. Tome Deuxième. Paris : Chez Furne, Libraire, Éditeur, 1835.

Oeuvres Complètes de J.-J. Rousseau, avec des notes historiques. Tome II. La

Nouvelle Héloïse, Émile, Lettre à M. de Beaumont. Paris : Chez Firmin Didot Frères, Fils et $\mathrm{C}^{\mathrm{ie}}$, Libraires, 1868.

SAINTE-BEUVE, Charles-Augustin. Chateaubriand et son groupe littéraire sous l'Empire. Vol. 1. Paris : Garnier Frères, 1861.

Oeuvres: Premiers lundis ; Portraits littéraires (début)-t-2. Portrais littéraires (fin);

Portraits de femmes. Vol. 1. Paris : Gallimard, 1966.

SAINT-JUST. Oeuvres de Saint-Just : represéntant du peuple à la Convention nationale. Paris : Prévot, Libraire-Éditeur, 1834.

SAMOYAULT, Tiphaine. L'intertextualité : mémoire de la littérature. (Littérature 128). Paris : Armand Colin, 2005.

SAREIL, Jean. L'écriture comique. Paris : P.U.F., 1984.

SARTRE, Jean-Paul. Qu'est-ce que littérature ?. Paris : Gallimard, 2011

SAUCLIÈRES, Roisselet de. Histoire de la Révolution Française, précédée d'un aperçu historique sur les règnes de Louis XV et de Louis XVI et suivie du procès de Louis XVI tiré des séances de la convention nationale. Seconde Édition. Tome Premier. Paris : Adolphe Delahays, Libraire-Éditeur, 1860.

SCHAERER, René. Citado In : Poétique de l'ironie. Paris : Éditions du Seuil, 2001.

SCHNEIDER, Michel. Voleurs de mots : essai sur le plagiat, la psychanalyse et la pensée. Paris : Gallimard, 1985.

SCHOENTJES, Pierre. Poétique de l'ironie. Paris : Éditions du Seuil, 2001.

STAROBINSKI, Jean. «Le fusil à deux coups de Voltaire ». In : Le Remède dans le mal: critique et légitimation de l'artifice à l'âge des Lumières. Paris : Gallimard, 1989.

STERNHELL, Zeev. Les anti-Lumières. Paris : Gallimard, 2010.

TODOROV, Tzvetan. La Littérature en péril. Paris : Flammarion, 2007.

L'Esprit des Lumières. Paris : Éditions Robert Lafont, 2006.

TROUVÉ, Alain. «De L'intertexte à l'arrière-texte». In : Approches interdisciplinaires de la lecture $n^{\circ} 5$ : Intertexte et arrière-texte : les coulisses du littéraire. Collection dirigée par MarieMadeleine Gladieu et Alain Trouvé. Séminaire 2009-2010. Paris : Épure - Éditions et Presses Universitaires de Reims, 2010.

VANDEUL, Marie-Andélique de. Diderot, mon père. Strasbourg : Éditions Circé, 1992.

VAN TIEGHEM, Paul. Le Romantisme dans la littérature européenne. Paris : Albin Michel, 1969.

VIGNY, Alfred de. Le Maure de Venise : Othello. Traduite de Shakespeare en vers français. Paris : Chez Levasseur, Libraire ; Urbain Canel, Libraire, 1830.

VOLTAIRE. Candide ou l'Optimisme. Paris : Pocket, 1989.

. Oeuvres complètes de Voltaire: Essai sur les moeurs. Annales de l'Empire. Tome III.

Paris: Chez Furne, Libraire-Éditeur, 1835. 
Oeuvres complètes de Voltaire. Mélanges II. Tome XXIII. Paris : Garnier Frères, Libraires-Éditeurs, 1879.

Oeuvres complètes de Voltaire. Théâtre II. Tome III. Paris: Garnier Frères, Libraires-Éditeurs, 1877.

Oeuvres complètes de Voltaire. Théâtre V. Tome VI. Paris: Garnier Frères, Libraires-Éditeurs, 1877.

Oeuvres complètes de Voltaire. Poésie : La Henriade, Poème de Fontenoy, Odes et

Stances, etc. Tome VIII. Paris : Garnier Frères, Libraires-Éditeurs, 1877.

. Oeuvres complètes de Voltaire. Discours en vers sur l'homme, poèmes, épîtres.

Tome X. Paris : Chez mme Ve. H. PERRONNEAU Imprimeur-Libraire ; CERIOUX aîné, Libraire, 1817.

Oeuvres complètes. Correspondance générale. Tome VIII. Paris: Armand-Aubrée, Éditeur, 1830.

. Oeuvres complètes. Correspondance avec les souverains. Tome III. Paris : P. Pourrat Frères, Éditeurs, 1839.

- Voltaire à Ferney, sa correspondance avec la duchesse de Saxe-Gotha. Recueillies

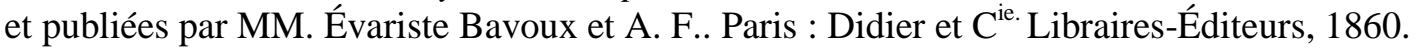
Oeuvres complètes de Voltaire. Essai sur les moeurs. Tome XI. Paris : Garnier Frères, Libraires-Éditeurs, 1878.

Oeuvres complètes de Voltaire. Romans. Tome XXI. Paris: Garnier Frères, Libraires-Éditeurs, 1879.

Oeuvres complètes de Voltaire. Études et documents biographiques. Tome I. Paris :

Garnier Frères, Libraires-Éditeurs, 1883.

. Oeuvres complètes de Voltaire. Mélanges V. Tome XXVI. Paris : Garnier Frères, Libraires-Éditeurs, 1879.

Éditeurs. 1855.

Oeuvres Complètes: Correspondances. V. 1. Paris: Librairie de Firmin Difot Frères,

Libraire, 1817.

Oeuvres complètes de Voltaire. Poésie. Vol. III, partie 2. Paris : Chez Th. Desoer,

WEINRICH, Harald. Conscience linquistique et lectures littéraires. Paris : Ed. de la Maison des sciences de l'homme, 1989.

\section{DICIONÁRIOS/ENCICLOPÉDIAS :}

ACADÉMIE FRANÇAISE. Dictionnaire de L'Académie Françoise. Tome Second L-Z. $4^{\mathrm{eme}}$ édition. Paris : Chez la veuve de Bernard Brunet, 1762.

Dictionnaire européen des Lumières. Direction de Michel Delon. Paris : P.U.F., 1997.

DIDEROT; D'ALEMBERT. Encyclopédie, ou dictionnaire raisonné des sciences, des arts et des métiers, par une Société des gens de lettres. Tome V. Paris : Briasson ; David l'ainé ; Le Breton ; Durand, 1755.

. Encyclopédie, ou dictionnaire raisonné des sciences, des arts et des métiers, par une Société des gens de lettres. Tome XI. Paris : Briasson ; David l'ainé ; Le Breton ; Durand, 1765. . Encyclopédie, ou dictionnaire raisonné des sciences, des arts et des métiers, par une

Société des gens de lettres. Tome XVI. Paris : Briasson; David l'ainé ; Le Breton ; Durand, 1765.

FELLER, François Xavier de. Dictionnaire historique, ou histoire abrégée des hommes qui se sont fait un nom par le génie, les talents, les vertus, les erreurs: depuis le commencement du monde jusqu'à nos jours...Tome XI. Paris : Chez Méquignon Fils Ainé, Libraire, 1823.

\section{PERIÓDICOS FRANCESES}


GAUTHEROT, Gustave. Robespierre. In : Revue d'histoire de l'Église de France. Tome 3. $\mathrm{N}^{\mathrm{o}}$ 16, pp. 397-420, 1912.

GOLliAU, Catherine. «La faut à Voltaire». In: Le Point Hors-série: Les textes fondamentaux. $\mathrm{N}^{\mathrm{o}} 26$. Paris : Le Point, mars-avril 2010.

DELON, Michel. «Rivaux pour toujours ». In : Le Point Références. $\mathrm{N}^{0}$ 39. Paris : Le Point, mai-juin 2012.

Revue des Deux Mondes. XXXII ${ }^{\mathrm{e}}$ Année. Seconde Période. Tome XXXIII. Paris: Bureau de la Revue des Deux Mondes, 1862.

Journal des Savants

Le Figaro Chroniqueur

La Revue des Deux Mondes

\section{OBRAS EM INGLÊS}

BULWER, Sir Henry Lylton. Historical Characters: Talleyrand, Cobbett, Mackintosh, Canning. Leipzig: Bernhard Tauchnitz, Vol. I. 1868.

FRIEDRICH, Hugo. Montaigne. Edited and with an introduction by Philippe Desan. Translated by Dawn Eng. California: University of California Press, 1991.

HUME, David. The history of England from the invasion of Julius Caesar, to the Revolution in 1688. Vol. 1. London: Christie \& Son; Baldwin \& Co.; Sharpe \& Son; Akerman; Smith \& Co. .., 1819.

SHAKESPEARE. Chefs-d'oeuvre de Shakespeare: Othello, Hamlet et Macbeth. La traduction française en regard. Paris : Belin-Mandar, 1837.

\section{OBRAS EM ESPANHOL}

BORGES, Jorge Luis. Ficciones. Buenos Aires: Emecé, 1956.

TITO LÍVIO. Decadas de Tito Lívio, príncipe de la historia romana. Vol. I. Editor: Arnaldo Brikman. Tradução: Pedro de Veja. Madrid: Editora en la Imprensa Real, 1793.

\section{OBRAS EM ITALIANO}

CALVINO, Italo. Perchè leggere i classici. Mondadori Editore: Milano, 2012.

\section{SITES CONSULTADOS}

http://www.revistadehistoria.com.br/secao/entrevista/sidney-chalhoub. www.voltaire-integral.com/Html/01/17Hugo.html. http://www.youtube.com/watch?v=J526unuYPP8 (L'Ombre d'un doute : Robespierre, bourreau de la Vendée ?).

http://www.rjnet.com.br/rjiluminacaopublica.php - consulta em 22/10/2013 